Jisela Aparecida Santanna Greco

\title{
AVALIAÇÃO DA INFLUÊNCIA DE ALGUNS FATORES NAS PROPRIEDADES MECÂNICAS DE MISTURAS ASFÁLTICAS DENSAS, À LUZ DA TÉCNICA DE PLANEJAMENTO E ANÁLISE DE EXPERIMENTOS FATORIAIS FRACIONÁRIOS ASSIMÉTRICOS
}

Tese apresentada à Escola de Engenharia de São Carlos da Universidade de São Paulo, como parte dos requisitos para a obtenção do Título de Doutor em Engenharia de Transportes.

Orientador: Prof. Dr. Glauco Tulio Pessa Fabbri

São Carlos 
Dedico este trabalho a minha mãe, Neusa Rosa Santanna (in memoriam) 


\section{AGRADECIMENTOS}

A Deus;

Ao meu querido marido Marcelo Greco, pelo carinho, pelo companheirismo, pelo incentivo, pela paciência inabalável e pelo incansável apoio nos momentos mais difíceis;

Ao meu orientador, Prof. Dr. Glauco Tulio Pessa Fabbri, pelos ensinamentos, pela compreensão, pela amizade, pela colaboração e por ter me guiado com sua experiência;

A Antonio Carlos Gigante, técnico responsável pelo Departamento de Estradas do Departamento de Transportes da EESC-USP, pela colaboração e por ter tornado possível a concretização desta pesquisa;

Aos técnicos do Laboratório de Estrada do Departamento de Transportes da EESC-USP, Paulo Toyama e João D. Pereira Filho, pela grande ajuda no preparo do material e na execução dos ensaios, e pela amizade;

A André Naleto Mugayar, Paulo Cesar Lopes Lemes e Antonio Carlos Gigante, pela realização em conjunto da parte experimental e pela eficiência dos dias de trabalho laboratorial compartilhados;

Aos professores do Departamento de Transportes da EESC-USP, pelo suporte a mim oferecido para realização deste trabalho;

Ao Prof. Dr. Manoel Henrique Alba Sória, pelas valiosas sugestões;

À Heloísa Morgado Belo, pela prontidão com que sempre me ajudou e em especial pela ajuda com os textos em inglês; 
Aos funcionários do STT, Heloísa, Elizabeth, Sueli, Magaly, Lílian, Carlos, Sr. Vicente e Sr. Nelson, pela colaboração e apoio;

Ao Conselho Nacional de Desenvolvimento Científico e Tecnológico - CNPq, pela bolsa de estudo concedida;

À pedreira Bandeirantes e à Continental Asfaltos, pelo fornecimento dos materiais utilizados nesta pesquisa;

À Ana Paula Furlan, pelo companheirismo, pela amizade e pela colaboração com a parte experimental deste trabalho;

À Claudia Scoton Antonio Marques, pela amizade de tantos anos e por estar sempre ao meu lado, me dando forças para continuar nos momentos mais difíceis;

Aos colegas de laboratório, Lilian, Ana, Ana Flávia, Caio, Coutinho, Adalberto, Carlos, Claudio Taira, Claudio Dubeux e a todos que contribuíram para a realização deste trabalho;

Aos colegas do Departamento de Transportes da EESC-USP, pela convivência e apoio na luta do dia a dia;

Ao meu sogro Pedro Greco e a minha sogra Jurema Fróes Greco, pela compreensão, pelo carinho e pelo apoio que sempre me deram;

A minha irmã Renata Aparecida Santanna, pela dedicação, pelo apoio, pelo carinho e pela amizade incondicional e

Ao meu pai, Lauro Carvalho Santanna Filho, pelos ensinamentos, pela compreensão, por ter caminhado comigo durante toda a minha vida e por ter sido sempre um exemplo para mim. 


\section{RESUMO}

SANTANNA-GRECO, J.A. (2004). Avaliação da influência de alguns fatores nas propriedades mecânicas de misturas asfálticas densas, à luz da técnica de planejamento e análise de experimentos fatoriais fracionários assimétricos. $340 \mathrm{p}$. Tese (Doutorado) - Escola de Engenharia de São Carlos, Universidade de São Paulo, São Carlos, 2004.

Trata-se de uma investigação sobre a influência de alguns fatores no comportamento mecânico de misturas asfálticas densas quanto à estabilidade e à flexibilidade. Foram testados três tipos de ligantes, asfalto convencional, modificado com 4,5\% de SBS e modificado com $20 \%$ de borracha reciclada de pneu; duas distribuições granulométricas do agregado, centros das faixas B e C do DNER (1997); quatro teores de ligante, escolhidos com base nos valores de volumes de vazios e espessuras de película almejados; três condições de envelhecimento a longo prazo, mistura não envelhecida, envelhecida em estufa ventilada a $85^{\circ} \mathrm{C}$ por 5 dias e envelhecida por exposição ao tempo por 4 meses; e duas condições de envelhecimento a curto prazo, mistura não envelhecida e envelhecida em estufa ventilada a $135^{\circ} \mathrm{C}$ por 4 horas. A técnica de planejamento e análise de experimentos fatoriais fracionários assimétricos foi utilizada para a consideração simultânea dos fatores citados. O comportamento mecânico das misturas foi avaliado através dos ensaios de resistência à tração, módulo de resiliência e fluência por compressão uniaxial estática e dinâmica. A análise de variância dos resultados permitiu a identificação dos fatores com influência significativa nas respostas dos ensaios. O modo como cada fator interferiu nas propriedades apresentadas pelas misturas foi estabelecido através da construção de modelos estatísticos de comportamento. Os resultados mostraram que a adição de modificadores ao asfalto melhora a resistência das misturas à fadiga e à deformação permanente. Os processos de envelhecimento aumentaram os módulos de resiliência das misturas mas diminuíram sua capacidade de recuperação elástica, o que significa queda de resistência à fadiga. Por outro lado, a resistência a deformações permanentes das misturas, inclusive daquelas compostas por asfaltos modificados, aumentou com o envelhecimento.

Palavras-chave: misturas asfálticas; asfaltos modificados; envelhecimento; módulo de resiliência; deformação permanente; experimentos fatoriais fracionários 


\section{ABSTRACT}

SANTANNA-GRECO, J.A. (2004). Influence evaluation of some factors in the mechanical properties of binder mixtures using design and analysis of asymmetric fractional factorial experiments technique. 340 p. Ph.D. Thesis - Escola de Engenharia de São Carlos, Universidade de São Paulo, São Carlos, 2004.

This work deals with the influence of some factors in the mechanical behavior of asphalt mixtures stability and flexibility. Three types of binders were tested, conventional one, modified with $4,5 \%$ of SBS and modified with $20 \%$ of recycled tire rubber. Two aggregate gradations were tested, center of B and C gradations of DNER (1997). Four binder contents were chosen based on the air voids and film thickness. Three types of long-term aging were tested, not aged, aged in a forced-draft oven for 5 days at $85^{\circ} \mathrm{C}$ and aged through weather exposition for the period of 4 months. Two types of short-term aging were tested; not aged and aged in a forced-draft oven for 4 hours at $135^{\circ} \mathrm{C}$. The technique of design and analysis of asymmetric fractional factorial experiments was used for the simultaneous analysis of the factors. The mechanical behavior of the mixtures was evaluated based on indirect tensile strength test, resilient modulus test and static and dynamic creep tests. The results of the analysis of variance allowed the identification of factors with significant influence in the answers. The influence of the factors in the mixtures properties was established through statistical models of behavior. The results showed that modified binders improves the mixtures resistance in relation to fatigue and to permanent deformation. The aging processes increased the resilient modulus of the mixtures, but also decreased its capacity of elastic return, resulting in a lost of fatigue resistance. On the other hand, the permanent deformation resistance of the aging mixtures increased, including the mixtures with modified binders cases.

Keywords: asphalt mixtures; modified binders; aging; resilient modulus; permanent deformation; fractional factorial designs 


\section{LISTA DE ILUSTRAÇÕES}

FIGURA 2.1 - Escolha da fração do experimento $2^{4-1}$ a ser utilizada 34

FIGURA 4.1 - Representação esquemática do logaritmo da taxa de fluência em função da. tensão de fluência (Little et al., 1993).

FIGURA 4.2 - Curva representativa dos estágios de fluência (Mohamed e Yue, 1994).

FIGURA 4.3 - Gráficos típicos de tensão e deformação em função do tempo de carregamento, em ensaios de módulo complexo.

(FONSECA*, 1995 apud TONIAL, 2001)

FIGURA 5.1 - Faixa B do DNER (1997), zona de restrição Superpave para diâmetro nominal máximo de $25 \mathrm{~mm}$ e curva granulométrica adotada.

FIGURA 5.2 - Faixa $C$ do DNER (1997), zona de restrição Superpave para diâmetro. nominal máximo de $12,5 \mathrm{~mm}$ e curva granulométrica adotada

FIGURA 5.3 - Curvas granulométricas adotadas, correspondentes aos centros. das faixas $B$ e $C$ do DNER (1997)

FIGURA 5.4 - Vista geral dos corpos de prova submetidos ao processo de. envelhecimento por exposição ao tempo.

FIGURA 5.5 - Detalhe dos corpos de prova submetidos ao processo de envelhecimento por exposição ao tempo.

FIGURA 5.6 - Escolha de $1 / 4$ do experimento fatorial $4 \times 3^{2} \times 2^{2}$, que corresponde à fração do experimento testada em laboratório.....

FIGURA 5.7 - Curva viscosidade Saybolt-Furol $\times$ temperatura para o asfalto convencional.

FIGURA 5.8 - Curva viscosidade Saybolt-Furol $\times$ temperatura para o asfalto modificado com $4,5 \%$ do polímero SBS.

FIGURA 5.9 - Curva viscosidade Saybolt-Furol $\times$ temperatura para o asfalto modificado com $20 \%$ de borracha.

FIGURA 5.10 - Prensa pneumática utilizada nos ensaios de fluência por compressão uniaxial estática.

FIGURA 5.11 - Visão geral da aparelhagem utilizada no ensaio de fluência por compressão uniaxial estática

FIGURA 5.12 - Exemplo da tela do programa computacional desenvolvido em LabView, obtida ao final do ensaio de creep estático 
FIGURA 5.13 - Exemplo da tela do programa computacional desenvolvido em LabView, obtida ao final do ensaio de creep dinâmico 160

FIGURA 5.14 - Detalhe dos ciclos de carregamento aplicados no ensaio de creep dinâmico..161

FIGURA 5.15 - Detalhe de um ciclo de carregamento do ensaio de creep dinâmico.

FIGURA 5.16 - Curva de deformação versus tempo, para um ciclo de carregamento...163

FIGURA 5.17 - Suporte utilizado para acomodação do corpo de prova no ensaio de. módulo de resiliência por compressão diametral dinâmica.............................164

FIGURA 5.18 - Corpo de prova com suporte para fixação do LVDT. 165

FIGURA 5.19 - Corpo de prova acomodado no suporte utilizado para aplicação da. carga, e suporte utilizado para fixação do LVDT.

FIGURA 5.20 - Exemplo da tela do programa computacional desenvolvido em LabView, para o ensaio de módulo de resiliência.

FIGURA 5.21 - Exemplo da tela do programa computacional desenvolvido em LabView, obtida ao final do ensaio de resistência à tração por. compressão diametral.

FIGURA 6.1 - Valores de resistência à tração em função do teor de ligante asfáltico, para agregado com distribuição granulométrica correspondente ao...... centro da faixa $\mathrm{B}$.

FIGURA 6.2 - Valores de resistência à tração em função do teor de ligante, para agregado com distribuição granulométrica correspondente ao centro da faixa $\mathrm{C}$.

FIGURA 6.3 - Valores de resistência à tração em função do volume de vazios, para agregado.... com distribuição granulométrica correspondente ao centro da faixa B.

FIGURA 6.4 - Valores de resistência à tração em função do volume de vazios, para agregado.... com distribuição granulométrica correspondente ao centro da faixa $\mathrm{C}$.

FIGURA 6.5 - Pontos experimentais e modelos de comportamento referentes ao MR total. em função do teor de ligante e da condição de envelhecimento a longo prazo,...... para a faixa granulométrica B, considerando-se confiança de $99 \%$.

FIGURA 6.6 - Pontos experimentais e modelos de comportamento referentes ao MR total. em função do teor de ligante e da condição de envelhecimento a longo prazo,..... para a faixa granulométrica C, considerando-se confiança de $99 \%$. 179

FIGURA 6.7 - Pontos experimentais e modelos de comportamento referentes ao MR total.... em função do teor de ligante, do tipo de ligante e da condição de...... envelhecimento a longo prazo, para a faixa granulométrica B, considerando-se... confiança de $95 \%$. 180

FIGURA 6.8 - Pontos experimentais e modelos de comportamento referentes ao MR total em função do teor de ligante, do tipo de ligante e da condição de envelhecimento a longo prazo, para a faixa granulométrica $\mathrm{C}$, considerando-se... 
confiança de $95 \%$.

FIGURA 6.9 - Pontos experimentais e modelos de comportamento referentes ao MR.

instantâneo em função do teor de ligante e da condição de envelhecimento.

a longo prazo, para a faixa granulométrica $\mathrm{B}$, considerando-se.

confiança de $99 \%$

FIGURA 6.10 - Pontos experimentais e modelos de comportamento referentes ao MR

instantâneo em função do teor de ligante e da condição de envelhecimento.

a longo prazo, para a faixa granulométrica $\mathrm{C}$, considerando-se.

confiança de $99 \%$.

FIGURA 6.11 - Pontos experimentais e modelos de comportamento referentes ao MR

instantâneo em função do teor de ligante e da condição de envelhecimento

a longo prazo, para a faixa granulométrica B, considerando-se.

confiança de $95 \%$.

FIGURA 6.12 - Pontos experimentais e modelos de comportamento referentes ao MR

instantâneo em função do teor de ligante e da condição de envelhecimento.

a longo prazo, para a faixa granulométrica $\mathrm{C}$, considerando-se.

confiança de $95 \%$.

FIGURA 6.13 - Pontos experimentais e modelos de comportamento referentes ao MR total. em função do volume de vazios e da condição de envelhecimento a longo. prazo, para a faixa granulométrica $\mathrm{B}$, considerando-se níveis de.

confiança de $99 \%$ ou $95 \%$.

FIGURA 6.14 - Pontos experimentais e modelos de comportamento referentes ao MR total em função do volume de vazios e da condição de envelhecimento a longo. prazo, para a faixa granulométrica $\mathrm{C}$, considerando-se níveis de. confiança de $99 \%$ ou $95 \%$.

FIGURA 6.15 - Pontos experimentais e modelos de comportamento referentes ao MR instantâneo em função do volume de vazios e da condição de envelhecimento.... a longo prazo, para a faixa granulométrica $\mathrm{B}$, considerando-se. níveis de confiança de $99 \%$ ou $95 \%$.

FIGURA 6.16 - Pontos experimentais e modelos de comportamento referentes ao MR instantâneo em função do volume de vazios e da condição de envelhecimento.... a longo prazo, para a faixa granulométrica $\mathrm{C}$, considerando-se. níveis de confiança de $99 \%$ ou $95 \%$.

FIGURA 6.17 - Variação do módulo de resiliência total em função da condição de envelhecimento a longo prazo e da distribuição granulométrica do. agregado. 
FIGURA 6.18 - Variação do módulo de resiliência instantâneo em função da condição. de envelhecimento a longo prazo e da distribuição granulométrica...... do agregado. 188

FIGURA 6.19 - Pontos experimentais e modelos de comportamento referentes à deformação..... total em função do teor de ligante, para a faixa granulométrica $\mathrm{B}$ considerando-se confiança de $95 \%$

FIGURA 6.20 - Pontos experimentais e modelos de comportamento referentes à deformação..... total em função do teor de ligante, para a faixa granulométrica $\mathrm{C}$ considerando-se confiança de $95 \%$

FIGURA 6.21 - Pontos experimentais e modelos de comportamento referentes à deformação..... total em função do volume de vazios, para a faixa granulométrica $\mathrm{B}$, considerando-se confiança de $95 \%$

FIGURA 6.22 - Pontos experimentais e modelos de comportamento referentes à deformação..... total em função do volume de vazios, para a faixa granulométrica $\mathrm{C}$, considerando-se confiança de $95 \%$

FIGURA 6.23 - Pontos experimentais e modelos de comportamento referentes à deformação..... recuperável em função do teor de ligante e das condições de envelhecimento a... curto e longo prazos, para a faixa granulométrica $\mathrm{B}$, considerando-se. confiança de $95 \%$.

FIGURA 6.24 - Pontos experimentais e modelos de comportamento referentes à deformação..... recuperável em função do teor de ligante e das condições de envelhecimento a... curto e longo prazos, para a faixa granulométrica $\mathrm{C}$, considerando-se. confiança de $95 \%$.

FIGURA 6.25 - Pontos experimentais e modelos de comportamento referentes à deformação..... recuperável em função do volume de vazios e das condições de. envelhecimento a curto e longo prazos, para a faixa granulométrica $\mathrm{B}$, considerando-se confiança de $95 \%$

FIGURA 6.26 - Pontos experimentais e modelos de comportamento referentes à deformação..... recuperável em função do volume de vazios e das condições de. envelhecimento a curto e longo prazos, para a faixa granulométrica $\mathrm{C}$, considerando-se confiança de $95 \%$

FIGURA 6.27 - Variação da deformação recuperável em função das condições de. envelhecimento a curto e longo prazos, para misturas com agregados. da faixa $\mathrm{B}$

FIGURA 6.28 - Variação da deformação recuperável em função das condições de. envelhecimento a curto e longo prazos, para misturas com agregados da faixa $\mathrm{C}$. 
FIGURA 6.29 - Pontos experimentais referentes à deformação não recuperável em função do.... teor de ligante, para a faixa granulométrica $\mathrm{B}$, considerando-se. confiança de $95 \%$. 203

FIGURA 6.30 - Pontos experimentais referentes à deformação não recuperável em função do.... teor de ligante, para a faixa granulométrica $\mathrm{C}$, considerando-se. confiança de $95 \%$.

FIGURA 6.31 - Pontos experimentais referentes à deformação não recuperável em função do.... volume de vazios, para a faixa granulométrica $\mathrm{B}$, considerando-se. confiança de $95 \%$

FIGURA 6.32 - Pontos experimentais referentes à deformação não recuperável em função do.... volume de vazios, para a faixa granulométrica $\mathrm{C}$, considerando-se confiança de $95 \%$....

FIGURA 6.33 - Pontos experimentais e modelos de comportamento referentes à recuperação..... em função do teor de ligante e das condições de envelhecimento a curto e longo prazos, para a faixa granulométrica $\mathrm{B}$, considerando-se confiança de $95 \%$.

FIGURA 6.34 - Pontos experimentais e modelos de comportamento referentes à recuperação..... em função do teor de ligante e das condições de envelhecimento a curto e longo prazos, para a faixa granulométrica $\mathrm{C}$, considerando-se. confiança de $95 \%$. 206

FIGURA 6.35 - Pontos experimentais e modelos de comportamento referentes à recuperação..... em função do volume de vazios e das condições de envelhecimento a curto e...... longo prazos, para a faixa granulométrica $\mathrm{B}$, considerando-se. confiança de $95 \%$.

FIGURA 6.36 - Pontos experimentais e modelos de comportamento referentes à recuperação..... em função do volume de vazios e das condições de envelhecimento a curto e....... longo prazos, para a faixa granulométrica $\mathrm{C}$, considerando-se. confiança de $95 \%$. 207

FIGURA 6.37 - Pontos experimentais e modelos de comportamento referentes ao módulo de fluência em função do teor de ligante e da condição de envelhecimento. a longo prazo, para a faixa granulométrica $\mathrm{B}$, considerando-se. confiança de $95 \%$. .208

FIGURA 6.38 - Pontos experimentais e modelos de comportamento referentes ao módulo. de fluência em função do teor de ligante e da condição de envelhecimento. a longo prazo, para a faixa granulométrica $\mathrm{C}$, considerando-se. confiança de $95 \%$. 
FIGURA 6.39 - Pontos experimentais e modelos de comportamento referentes ao módulo. de fluência em função do volume de vazios e da condição de envelhecimento..... a longo prazo, para a faixa granulométrica $\mathrm{B}$, considerando-se.

confiança de $95 \%$.

FIGURA 6.40 - Pontos experimentais e modelos de comportamento referentes ao módulo de fluência em função do volume de vazios e da condição de envelhecimento..... a longo prazo, para a faixa granulométrica $\mathrm{C}$, considerando-se. confiança de $95 \%$.

FIGURA 6.41 - Variação do módulo de fluência do ensaio de creep estático em função. da condição de envelhecimento a longo prazo.

FIGURA 6.42 - Pontos experimentais referentes ao módulo de fluência após recuperação. em função do teor de ligante, para a faixa granulométrica B, considerando-se confiança de $95 \%$

FIGURA 6.43 - Pontos experimentais referentes ao módulo de fluência após recuperação. em função do teor de ligante, para a faixa granulométrica $\mathrm{C}$, considerando-se confiança de $95 \%$

FIGURA 6.44 - Pontos experimentais referentes ao módulo de fluência após recuperação. em função do volume de vazios, para a faixa granulométrica $\mathrm{B}$ considerando-se confiança de $95 \%$

FIGURA 6.45 - Pontos experimentais referentes ao módulo de fluência após recuperação em função do volume de vazios, para a faixa granulométrica $\mathrm{C}$, considerando-se confiança de $95 \%$

FIGURA 6.46 - Pontos experimentais e modelos de comportamento referentes à inclinação....... da curva de fluência em função do teor de ligante, do tipo de ligante e da. condição de envelhecimento a longo prazo, para a faixa granulométrica $B$ considerando-se confiança de $95 \%$

FIGURA 6.47 - Pontos experimentais e modelos de comportamento referentes à inclinação....... da curva de fluência em função do teor de ligante, do tipo de ligante e da..... condição de envelhecimento a longo prazo, para a faixa granulométrica $\mathrm{C}$,.... considerando-se confiança de $95 \%$

FIGURA 6.48 - Pontos experimentais e modelos de comportamento referentes à inclinação........ da curva de fluência em função do volume de vazios e do tipo de ligante, para a faixa granulométrica B, considerando-se confiança de $95 \%$.

FIGURA 6.49 - Pontos experimentais e modelos de comportamento referentes à inclinação. da curva de fluência em função do volume de vazios e do tipo de ligante, para a faixa granulométrica $C$, considerando-se confiança de $95 \%$. 
FIGURA 6.50 - Variação da inclinação da curva de fluência do ensaio de creep estático em....... função do tipo de ligante e da condição de envelhecimento a longo prazo......215

FIGURA 6.51 - Pontos experimentais e modelos de comportamento referentes à. deformação total em função do teor de ligante, do tipo de ligante e da. condição de envelhecimento a longo prazo, para misturas da faixa B e sem. envelhecimento a curto prazo, considerando-se níveis de. confiança de $99 \%$ ou $95 \%$.

FIGURA 6.52 - Pontos experimentais e modelos de comportamento referentes à. deformação total em função do teor de ligante, do tipo de ligante e da. condição de envelhecimento a longo prazo, para misturas da faixa $\mathrm{C}$ e sem envelhecimento a curto prazo, considerando-se níveis de confiança de $99 \%$ ou $95 \%$

FIGURA 6.53 - Pontos experimentais e modelos de comportamento referentes à. deformação total em função do teor de ligante, do tipo de ligante e da. condição de envelhecimento a longo prazo, para misturas da faixa B. envelhecidas a curto prazo por 4 horas, considerando-se níveis de. confiança de $99 \%$ ou $95 \%$. .221

FIGURA 6.54 - Pontos experimentais e modelos de comportamento referentes à. deformação total em função do teor de ligante, do tipo de ligante e da...... condição de envelhecimento a longo prazo, para misturas da faixa $\mathrm{C}$. envelhecidas a curto prazo por 4 horas, considerando-se níveis de. confiança de $99 \%$ ou $95 \%$.

FIGURA 6.55 - Modelos de comportamento referentes à deformação total em. função do volume de vazios, para misturas compostas por asfalto. convencional e por agregados da faixa $\mathrm{B}$, considerando-se. níveis de confiança de $99 \%$ ou $95 \%$.

FIGURA 6.56 - Modelos de comportamento referentes à deformação total em função do volume de vazios, para misturas compostas por asfalto. convencional e por agregados da faixa $\mathrm{C}$, considerando-se. níveis de confiança de $99 \%$ ou $95 \%$.

FIGURA 6.57 - Modelos de comportamento referentes à deformação total em função. do volume de vazios, para misturas compostas por asfalto modificado. com polímero e por agregados da faixa $\mathrm{B}$, considerando-se. níveis de confiança de $99 \%$ ou $95 \%$.

FIGURA 6.58 - Modelos de comportamento referentes à deformação total em função do volume de vazios, para misturas compostas por asfalto modificado com polímero e por agregados da faixa $\mathrm{C}$, considerando-se. 
níveis de confiança de $99 \%$ ou $95 \%$.

FIGURA 6.59 - Modelos de comportamento referentes à deformação total em função.

do volume de vazios, para misturas compostas por asfalto modificado

com borracha e por agregados da faixa $\mathrm{B}$, considerando-se

níveis de confiança de $99 \%$ ou $95 \%$.

FIGURA 6.60 - Modelos de comportamento referentes à deformação total em função.

do volume de vazios, para misturas compostas por asfalto modificado.

com borracha e por agregados da faixa $\mathrm{C}$, considerando-se.

níveis de confiança de $99 \%$ ou $95 \%$.

FIGURA 6.61 - Variação da deformação total do ensaio de creep dinâmico em função do. tipo de ligante e da condição de envelhecimento a longo prazo, para.

agregados da faixa $\mathrm{B}$ e misturas não envelhecidas a curto prazo.

FIGURA 6.62 - Variação da deformação total do ensaio de creep dinâmico em função do. tipo de ligante e da condição de envelhecimento a longo prazo, para. agregados da faixa B e misturas envelhecidas a curto prazo por $4 \mathrm{~h}$ em estufa ventilada.

FIGURA 6.63 - Variação da deformação total do ensaio de creep dinâmico em função do. tipo de ligante e da condição de envelhecimento a longo prazo, para. agregados da faixa $\mathrm{C}$ e misturas não envelhecidas a curto prazo.

FIGURA 6.64 - Variação da deformação total do ensaio de creep dinâmico em função do. tipo de ligante e da condição de envelhecimento a longo prazo, para. agregados da faixa $\mathrm{C}$ e misturas envelhecidas a curto prazo por $4 \mathrm{~h}$ em estufa ventilada.

FIGURA 6.65 - Pontos experimentais e modelos de comportamento referentes ao módulo. de fluência em função do teor e tipo de ligante, e da condição de envelhecimento a longo prazo, para a faixa granulométrica $\mathrm{B}$, considerando-se níveis de confiança de $99 \%$ ou $95 \%$ .228

FIGURA 6.66 - Pontos experimentais e modelos de comportamento referentes ao módulo. de fluência em função do teor e tipo de ligante, e da condição de envelhecimento a longo prazo, para a faixa granulométrica $\mathrm{C}$ considerando-se níveis de confiança de $99 \%$ ou $95 \%$

FIGURA 6.67 - Pontos experimentais e modelos de comportamento referentes ao módulo de fluência em função do volume de vazios, do tipo de ligante e da condição...... de envelhecimento a longo prazo, para a faixa granulométrica $\mathrm{B}$, considerando-se níveis de confiança de $99 \%$ ou $95 \%$ 
FIGURA 6.68 - Pontos experimentais e modelos de comportamento referentes ao módulo........ de fluência em função do volume de vazios, do tipo de ligante e da condição...... de envelhecimento a longo prazo, para a faixa granulométrica $\mathrm{C}$,

considerando-se níveis de confiança de $99 \%$ ou $95 \%$

FIGURA 6.69 - Variação do módulo de fluência do ensaio de creep dinâmico em função do.... tipo de ligante e da condição de envelhecimento a longo prazo, para..... agregados da faixa $B$

FIGURA 6.70 - Variação do módulo de fluência do ensaio de creep dinâmico em função do.... tipo de ligante e da condição de envelhecimento a longo prazo, para. agregados da faixa $\mathrm{C}$ .230

FIGURA 6.71 - Pontos experimentais e modelos de comportamento referentes à.. inclinação da curva de fluência em função do tipo de ligante e da condição de.... envelhecimento a curto prazo, para a faixa granulométrica $\mathrm{B}$, considerando-se confiança de $99 \%$

FIGURA 6.72 - Pontos experimentais e modelos de comportamento referentes à.. inclinação da curva de fluência em função do tipo de ligante e da condição de.... envelhecimento a curto prazo, para a faixa granulométrica $\mathrm{B}$, considerando-se confiança de $95 \%$ .232

FIGURA 6.73 - Pontos experimentais e modelos de comportamento referentes à.. inclinação da curva de fluência em função do tipo de ligante e da condição de.... envelhecimento a curto prazo, para a faixa granulométrica $\mathrm{C}$, considerando-se confiança de $99 \%$

FIGURA 6.74 - Pontos experimentais e modelos de comportamento referentes à. inclinação da curva de fluência em função do tipo de ligante e da condição de.... envelhecimento a curto prazo, para a faixa granulométrica $\mathrm{C}$, considerando-se confiança de $95 \%$

FIGURA 6.75 - Pontos experimentais e modelos de comportamento referentes à. inclinação da curva de fluência em função do volume de vazios, do tipo de. ligante e da condição de envelhecimento a curto prazo, para a faixa.. granulométrica B, considerando-se níveis de confiança de $99 \%$ ou $95 \%$

FIGURA 6.76 - Pontos experimentais e modelos de comportamento referentes à. inclinação da curva de fluência em função do volume de vazios, do tipo de. ligante e da condição de envelhecimento a curto prazo, para a faixa. granulométrica C, considerando-se níveis de confiança de $99 \%$ ou $95 \%$ .234

FIGURA 6.77 - Variação da inclinação da curva de fluência do ensaio de creep dinâmico em função do tipo de ligante e da distribuição granulométrica do agregado...235 


\section{LISTA DE TABELAS}

TABELA 2.1 - Representação de um experimento fatorial em dois níveis. com dois fatores.

TABELA 2.2 - Notações e organização dos dados para aplicação do método

ANOVA (GARCIA-DIAZ \& PHILLIPS, 1995).

TABELA 2.3 - Quadro de análise de variância (ANOVA)

TABELA 2.4 - Quadro de análise de variância (ANOVA) para experimentos. fatoriais em dois níveis.

TABELA 2.5 - Arranjo do experimento fatorial completo $2^{3}$.

TABELA 2.6 - Arranjo do experimento fatorial fracionário $2^{4-1}$ .33

TABELA 2.7 - Arranjo do experimento fatorial completo $2^{4}$. . .36

TABELA 2.8 - Transformação do fator $A$ com três níveis de variação em dois. fatores $X 2$ e $X 3$ de dois níveis

TABELA 2.9 - Transformação do fator $B$ com quatro níveis de variação em dois. fatores $X 4$ e $X 5$ de dois níveis

TABELA 2.10 - Arranjo do experimento fatorial $2^{5}$

TABELA 2.11 - Análise de variância do planejamento fatorial com três fatores, em dois, três e quatro níveis.

TABELA 3.1 - Trechos experimentais construídos no Brasil, utilizando asfalto..... modificado com polímeros (DNER*, 1998 apud. AMARAL, 2000, p.35).

TABELA 3.2 - Principais polímeros utilizados como modificadores de asfalto. .64

TABELA 3.3 - Autores que avaliaram e aprovaram o desempenho de misturas asfalto-borracha.

TABELA 3.4 - Principais polímeros utilizados como modificadores de asfalto. .64

TABELA 4.1 - Fatores que interferem no desempenho de misturas asfálticas quanto à deformação permanente.

TABELA 4.2 - Critério subjetivo para avaliação da deformação permanente de. misturas asfálticas.

TABELA 4.3 - Avaliação de alguns ensaios empregados para a determinação da. suscetibilidade de misturas asfálticas a deformações permanentes. 86 
TABELA 4.4 - Critérios para avaliação do módulo de fluência obtido a partir do ensaio de fluência por compressão uniaxial estática.

TABELA 4.5 - Limites para a deformação após 1 hora de ensaio de fluência e para a..... inclinação da curva de fluência no estágio secundário (Little et al., 1993)...102

TABELA 4.6 - Critérios para o módulo de fluência após 1 hora de carregamento.

(Little et al., 1993)

TABELA 4.7 - Condições do ensaio de fluência por compressão uniaxial estática adotadas por alguns autores.

TABELA 4.8 - Condições do ensaio de fluência por compressão uniaxial dinâmica adotadas por alguns autores.

TABELA 4.9 - Fatores com influência na rigidez e na vida de fadiga de misturas asfálticas..112

TABELA 4.10 - Faixas de variação do módulo de resiliência, obtidas. por Pinto e Preussler (1980).

TABELA 4.11 - Relações MR/ $\sigma_{R}$ encontradas em estudos realizados a $25^{\circ} \mathrm{C}$.

TABELA 5.1 - Características físicas do asfalto convencional.

TABELA 5.2 - Características físicas do asfalto modificado com 4,5\% do polímero SBS.

TABELA 5.3 - Características físicas do asfalto modificado com $20 \%$ de borracha. reciclada de pneu.

TABELA 5.4 - Limites das faixas granulométricas $B$ e $C$ do DNER (1997). e curvas granulométricas adotadas

TABELA 5.5 - Variáveis independentes ou fatores do experimento fatorial fracionário.

TABELA 5.6 - Transformação do fator $A$ com quatro níveis de variação em dois fatores de dois níveis, $X 1$ e $X 2$.

TABELA 5.7 - Transformação do fator $B$ com três níveis de variação em dois fatores. de dois níveis, $X 3$ e $X 4$.

TABELA 5.8 - Representação parcial do arranjo do experimento fatorial completo $2^{6}$.. 140

TABELA 5.9 - Relação das linhas replicadas do arranjo experimental $2^{6}$...... .141

TABELA 5.10 - Arranjo parcial do experimento fatorial fracionário $2^{8-2}$........... .142

TABELA 5.11 - Padrões de acoplamento para o experimento fracionário $1 / 44 \times 3^{2} \times 2^{2}$ 144

TABELA 5.12 - Identificação dos teores de ligante de acordo com a faixa granulométrica considerada.

TABELA 5.13 - Descrição das condições experimentais a serem simuladas em laboratório.

TABELA 5.14 - Especificações do ensaio de abrasão Los Angeles para as graduações

B, C e D (DNER, 1998). 148

TABELA 5.15 - Resultados do ensaio de abrasão Los Angeles 148 
TABELA 5.16 - Temperaturas de mistura e compactação para o asfalto convencional. e para os asfaltos modificados.

TABELA 5.17 - Volumes de vazios obtidos através das dosagens Marshall, realizadas para as seis misturas.

TABELA 5.18 - Espessuras de película em função dos teores de ligante, para.

a graduação B

TABELA 5.19 - Espessuras de película em função dos teores de ligante, para.....

a graduação $\mathrm{C}$

TABELA 5.20 - Escolha dos teores de ligante para misturas compostas por. agregados da faixa $\mathrm{B}$.

TABELA 5.21 - Escolha dos teores de ligante para misturas compostas por agregados da faixa $\mathrm{C}$.

TABELA 6.1 - Equações polinomiais para o fator quantitativo $A$.

TABELA 6.2 - Equações polinomiais correspondentes aos fatores qualitativos.

$B, C, X 7$ e $X 8$.

TABELA 6.3 - Resumo da análise de variância realizada com os resultados do ensaio. de módulo de resiliência , considerando-se o fator $A$ (teor de ligante). quantitativo

TABELA 6.4 - Resumo da análise de variância realizada com os resultados do ensaio. de módulo de resiliência , considerando-se o fator $A$ (volume de vazios) qualitativo

TABELA 6.5 - Resumo dos modelos de regressão múltipla determinados através da análise do experimento fatorial fracionário assimétrico $1 / 4\left(4 \times 3^{2} \times 2^{2}\right)$, considerando-se o fator $A$ quantitativo, representando o teor de ligante nas misturas.

TABELA 6.6 - Resumo dos modelos de regressão múltipla determinados através da análise. do experimento fatorial fracionário assimétrico $1 / 4\left(4 \times 3^{2} \times 2^{2}\right)$, para níveis...... de confiança de 99 ou 95\%, considerando-se o fator $A$ qualitativo, representando o volume de vazios nas misturas. 185

TABELA 6.7 - Classificação qualitativa dos valores de MR em função dos níveis do fator $B$.

TABELA 6.8 - Classificação qualitativa dos valores de MR em função dos níveis do fator $C$.

TABELA 6.9 - Classificação qualitativa dos valores de MR em função dos níveis do fator $X 7$

TABELA 6.10 - Resultados médios de resistência à tração e módulo de resiliência, e relações $M R / \sigma_{R}$ 
TABELA 6.11 - Resumo da análise de variância realizada com os resultados do ensaio de. creep estático, considerando-se o fator $A$ (teor de ligante) quantitativo. e confiança de $95 \%$

TABELA 6.12 - Resumo da análise de variância realizada com os resultados do ensaio. creep estático, considerando-se o fator $A$ (volume de vazios) qualitativo e confiança de $95 \%$

TABELA 6.13 - Modelos de regressão múltipla determinados através da análise do. experimento fatorial fracionário assimétrico $1 / 4\left(4 \times 3^{2} \times 2^{2}\right)$, considerando-se... o fator $A$ quantitativo, representando o teor de ligante nas misturas.

TABELA 6.14 - Modelos de regressão múltipla determinados através da análise do. experimento fatorial fracionário assimétrico $1 / 4\left(4 \times 3^{2} \times 2^{2}\right)$, considerando-se... o fator $A$ qualitativo, representando o volume de vazios nas misturas. 194

TABELA 6.15 - Classificação qualitativa das respostas do ensaio de creep estático. em função dos níveis do fator $B$.

TABELA 6.16 - Classificação qualitativa das respostas do ensaio de creep estático. em função dos níveis do fator $C$.

TABELA 6.17 - Classificação qualitativa das respostas do ensaio de creep estático. em função dos níveis do fator $X 7$

TABELA 6.18 - Classificação qualitativa das respostas do ensaio de creep estático. em função dos níveis do fator $X 8$

TABELA 6.19 - Resumo da análise de variância realizada com os resultados do ensaio de creep dinâmico, considerando-se o fator $A$ (teor de ligante) quantitativo e confiança de $99 \%$

TABELA 6.20 - Resumo da análise de variância realizada com os resultados do ensaio de creep dinâmico, considerando-se o fator $A$ (teor de ligante) quantitativo. e confiança de $95 \%$

TABELA 6.21 - Resumo da análise de variância realizada com os resultados do ensaio. creep dinâmico, considerando-se o fator $A$ (volume de vazios) qualitativo e confiança de $95 \%$

TABELA 6.22 - Modelos de regressão múltipla determinados através da análise do. experimento fatorial fracionário assimétrico $1 / 4\left(4 \times 3^{2} \times 2^{2}\right)$, considerando-se..... o fator $A$ quantitativo, representando o teor de ligante nas misturas. .218

TABELA 6.23 - Modelos de regressão múltipla determinados através da análise do experimento fatorial fracionário assimétrico $1 / 4\left(4 \times 3^{2} \times 2^{2}\right)$, considerando-se..... o fator $A$ qualitativo, representando o volume de vazios nas misturas. .219 
TABELA 6.24 - Classificação qualitativa dos respostas do ensaio de creep dinâmico em. função dos níveis do fator $B$.

TABELA 6.25 - Classificação qualitativa dos respostas do ensaio de creep dinâmico em função dos níveis do fator $C$.

TABELA 6.26 - Classificação qualitativa dos respostas do ensaio de creep dinâmico em. função dos níveis do fator $X 7$......

TABELA 6.27 - Classificação qualitativa dos respostas do ensaio de creep dinâmico em. função dos níveis do fator $X 8$. 


\section{LISTA DE ABREVIATURAS E SIGLAS}

\begin{tabular}{ll} 
AAPT & Association of Asphalt Paving Technologists \\
AASHTO & American Association of State Highway and Transportation Officials \\
AMD & Análise Mecânica Dinâmica \\
ANOVA & Análise de Variância \\
asf. borr. & asfalto modificado com borracha \\
asf. conv. & asfalto convencional CAP 20 \\
asf. pol. & asfalto modificado com polímero \\
ASTM & American Society for Testing and Materials \\
B.R.P. & borracha reciclada de pneu \\
CAP & cimento asfáltico de petróleo \\
CONAMA & Conselho Nacional do Meio Ambiente \\
DNER & Departamento Nacional de Estradas de Rodagem \\
EESC-USP & Escola de Engenharia de São Carlos - Universidade de São Paulo \\
ESALs & solicitações equivalentes do eixo padrão \\
EVA & ethylene vinyl acetate (polímero) \\
GPC & Gel Permeation Chromatography \\
LPO & low-pressure oxidation \\
LTOA & long-term oven aging \\
LVDT & linear variable differential transformer \\
MR & módulo de resiliência \\
POB & Pressure Oxidation Bomb \\
RBV & relação betume vazios \\
RTFOT & Rolling Thin Film Oven Test \\
SBR & styrene butadiene rubber (polímero) \\
SBS & styrene butadiene styrene (polímero) \\
SHRP & Strategic Highway Research Program \\
SUPERPAVE & \\
& Suprior Performing Asphalt Pavements \\
\hline
\end{tabular}




\section{LISTA DE SÍMBOLOS}

$\alpha$

$\Delta \sigma$

$\varepsilon_{0}$

$\varepsilon_{\mathrm{p}}$

$\varepsilon_{\mathrm{qu}}$

$\varepsilon_{\mathrm{rt}}$

$\varepsilon_{\mathrm{vp}}$

$\phi$

$\eta$

$\mu$

$\sigma$

$\sigma_{0}$

$\sigma_{\text {contato }}$

$\sigma_{\mathrm{R}}$

$\sigma_{t}$

$\sigma_{\mathrm{x}}$

$\sigma_{\mathrm{y}}$

$\omega$

A

B

c

C

$\mathrm{CCl}_{4}$

$\mathrm{CO}_{2}$

$\mathrm{C}_{\mathrm{m}}$

$\mathrm{C}_{\mathrm{n}, \mathrm{p}}$

$\mathrm{E}^{*} \quad$ módulo complexo

$E_{i} \quad$ efeito principal do fator $X_{i}$

nível de significância tração)

deformação permanente

deformação elástica total

deformação visco-plástica

viscosidade do asfalto

tensão de tração

tensão de tração

tensão de compressão

tetracloreto de carbono

dióxido de carbono diferença algébrica entre as tensões vertical (de compressão) e horizontal (de

amplitude máxima da deformação específica

deformação determinada pelo ensaio de compressão não confinada

ângulo de fase (ângulo de defasagem entre $\varepsilon_{0}$ e $\sigma_{0}$ )

efeito comum ou média da população; coeficiente de Poisson

tensão aplicada através do carregamento

amplitude máxima da tensão

pressão de contato dos pneus

tensão de ruptura de tração

freqüência angular de carga

letra utilizada para identificação de fatores

letra utilizada para identificação de fatores

número da condição experimental ou tratamento

letra utilizada para identificação de fatores

fator de correção da Shell para o efeito dinâmico

combinação linear entre $n$ fatores tomados $p$ a $p$ 


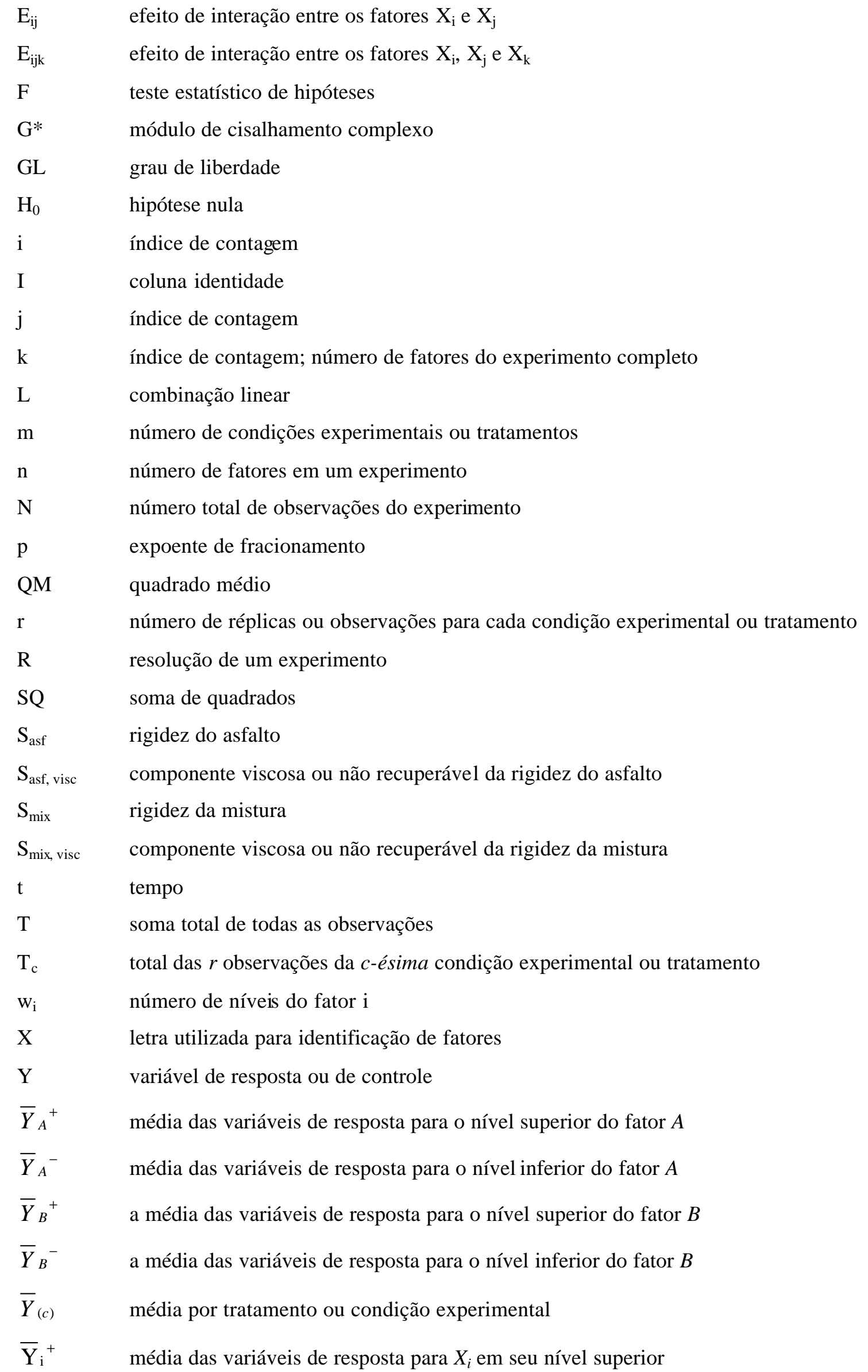


$\overline{\mathrm{Y}}_{\mathrm{i}}{ }^{-} \quad$ média das variáveis de resposta para $X_{i}$ em seu nível inferior

$\bar{Y}_{c(i+)}{ }^{j+} \quad$ resposta média para a situação em que o fator $X_{i}$ encontra-se em seu nível superior, mantendo-se $X_{j}$ também em seu nível superior

$\bar{Y}_{c(i-)}{ }^{j+} \quad$ resposta média para a situação em que o fator $X_{i}$ encontra-se em seu nível inferior, mantendo-se $X_{j}$ em seu nível superior

$\bar{Y}_{c(i+)}{ }^{j-} \quad$ resposta média para a situação em que o fator $X_{i}$ encontra-se em seu nível superior, mantendo-se $X_{j}$ em seu nível inferior

$\bar{Y}_{c(i-)}{ }^{j-} \quad$ resposta média para a situação em que o fator $X_{i}$ encontra-se em seu nível inferior, mantendo-se $X_{j}$ também em seu nível inferior

$\mathrm{Z}$ fator de distribuição da tensão de compressão. 


\section{SUMÁRIO}

RESUMO iv

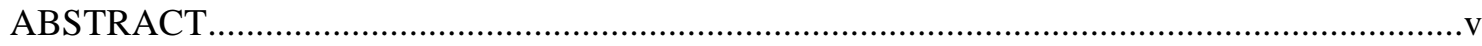

LISTA DE ILUSTRAÇÕES.............................................................................................

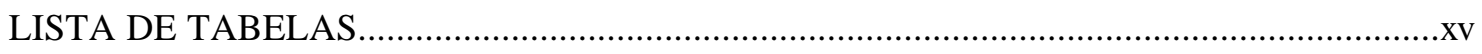

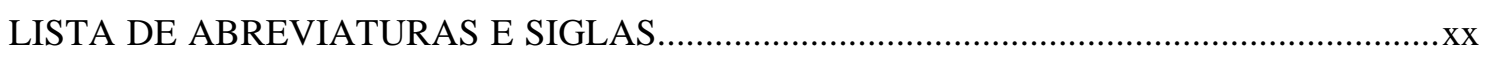

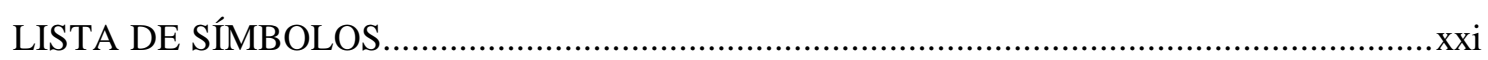

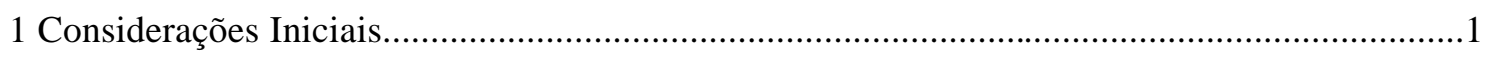

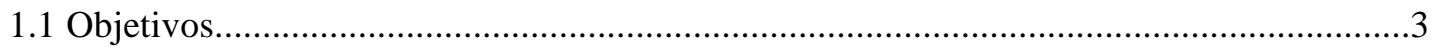

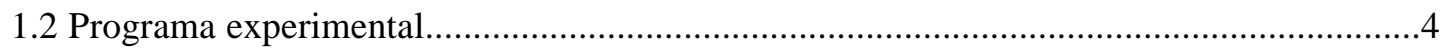

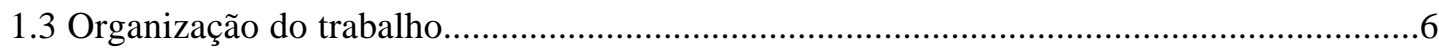

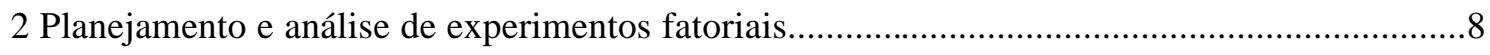

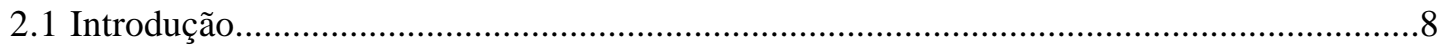

2.2 Planejamento estatístico de experimentos fatoriais........................................................

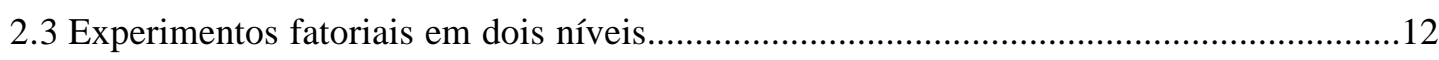

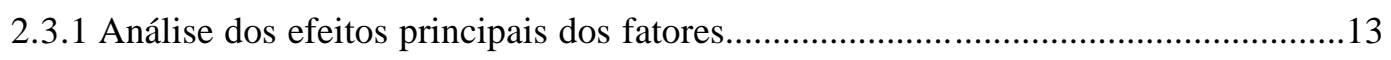

2.3.2 Análise dos efeitos de interação entre os fatores.....................................................17

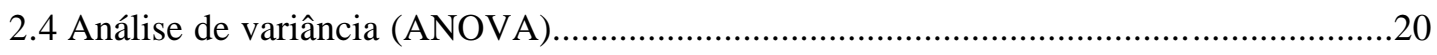

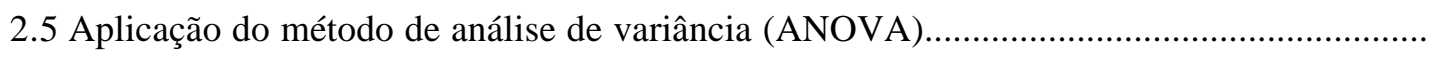

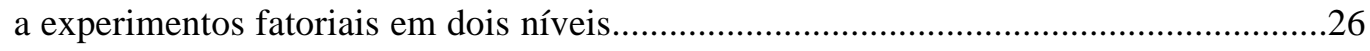

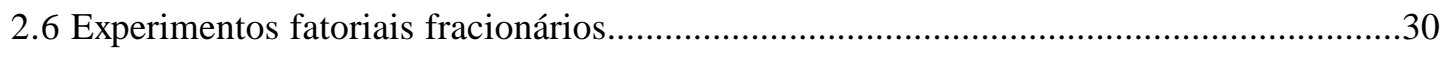

2.6.1 Montagem de experimentos fatoriais fracionários em dois níveis............................31

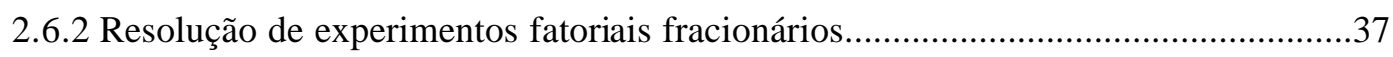

2.6.3 Análise de variância de experimentos fatoriais fracionários......................................38

2.7 Experimentos fatoriais com fatores em níveis variados....................................................38

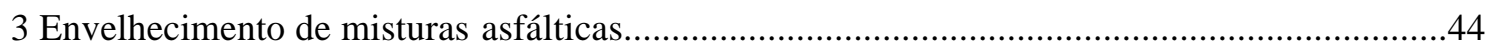

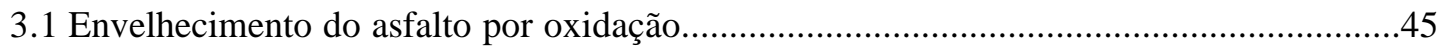

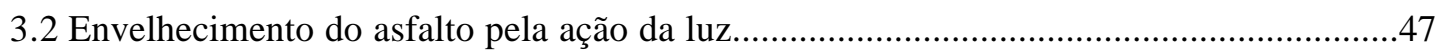

3.3 Envelhecimento do asfalto por perda de componentes oleosos.........................................48

3.4 Simulação em laboratório do envelhecimento de misturas asfálticas................................48

3.5 Testes utilizados para avaliação dos efeitos do envelhecimento de misturas asfálticas...54 
3.6 Problemas relacionados aos processos de extração e recuperação do ligante.

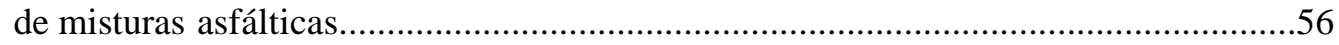

3.7 Envelhecimento de asfaltos modificados.......................................................................61

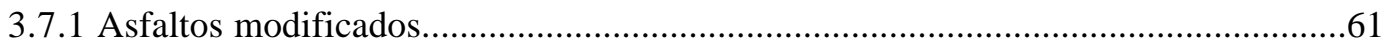

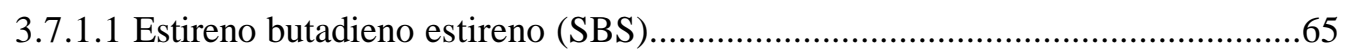

3.7.1.2 Borracha estireno butadieno (SBR) ........................................................65

3.7.1.3 Etileno acetato de vinila (EVA) ......................................................................66

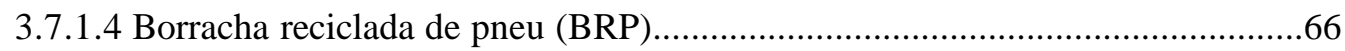

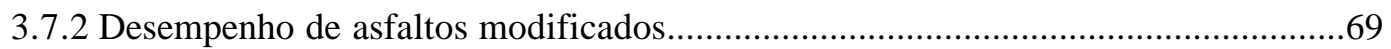

3.7.3 Comportamento de asfaltos modificados quanto ao envelhecimento........................75

4 Avaliação em laboratório do desempenho de misturas asfálticas quanto

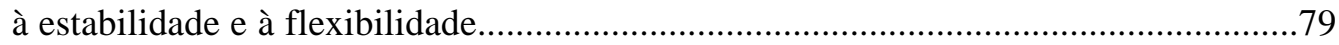

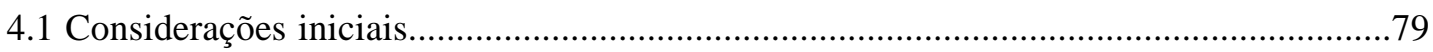

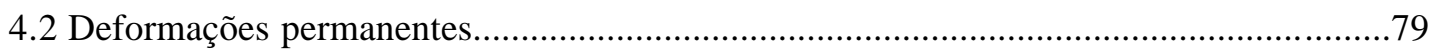

4.2.1 Métodos para previsão de deformações permanentes em laboratório..........................82

4.2.2 Tensões no ensaio de fluência por compressão uniaxial...........................................95

4.2.3 Ensaio de fluência por compressão uniaxial estática................................................99

4.2.4 Ensaio de fluência por compressão uniaxial dinâmica.............................................104

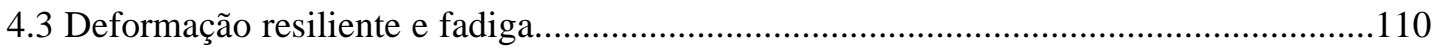

4.3.1 Ensaio de módulo de resiliência por compressão diametral dinâmica....................116

4.3.2 Aplicações do ensaio de módulo de resiliência por compressão.

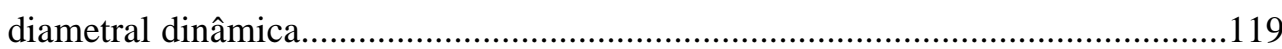

4.3.3 Ensaio de módulo complexo dinâmico por compressão uniaxial............................124

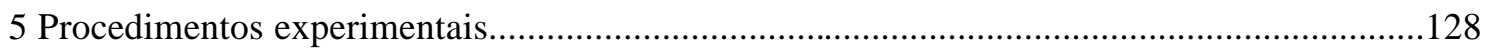

5.1 Variações ou níveis dos fatores selecionados para estudo..............................................129

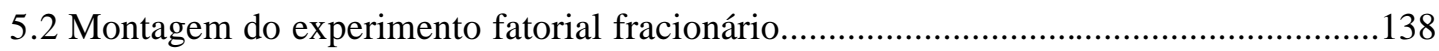

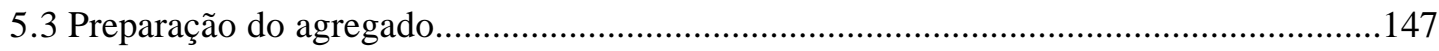

5.3.1 Ensaio de abrasão Los Angeles........................................................................147

5.3.2 Densidade real dos grãos.............................................................................148

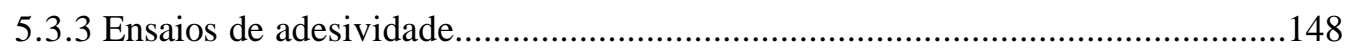

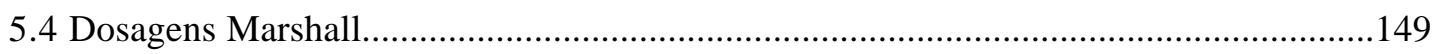

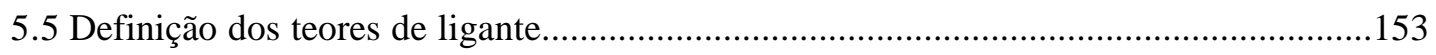

5.6 Verificação das modificações sofridas pelo asfalto envelhecido.....................................155

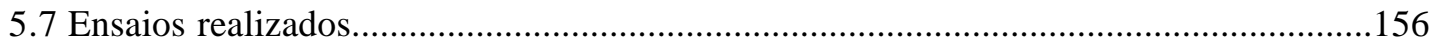

5.7.1 Ensaio de fluência por compressão uniaxial estática (creep estático).....................156

5.7.2 Ensaio de fluência por compressão uniaxial dinâmica (creep dinâmico)................159

5.7.3 Ensaio de módulo de resiliência por compressão diametral dinâmica.....................162 
5.7.4 Ensaio de resistência à tração por compressão diametral estática...........................166

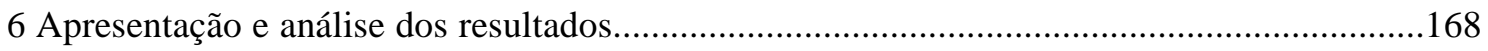

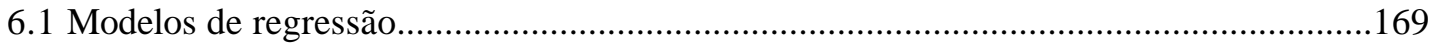

6.2 Resultados do ensaio de resistência à tração por compressão diametral..........................173

6.3 Resultados do ensaio de módulo de resiliência...............................................................176

6.3.1 Análise de variância (ANOVA) realizada com os resultados do. ensaio de módulo de resiliência.

6.3.2 Apresentação gráfica e modelagem dos resultados do ensaio de. módulo de resiliência

6.4 Resultados do ensaio de fluência por compressão uniaxial estática

6.4.1 Análise de variância (ANOVA) realizada com os resultados do ensaio de. creep estático.

6.4.2 Apresentação gráfica e modelagem dos resultados do ensaio de. creep estático.

6.5 Resultados do ensaio de fluência por compressão uniaxial dinâmica

6.5.1 Análise de variância (ANOVA) realizada com os resultados do ensaio de creep dinâmico

6.5.2 Apresentação gráfica e modelagem dos resultados do ensaio. de creep dinâmico.

7 Considerações finais. .238

7.1 Ensaio de módulo de resiliência. .240

7.2 Ensaio de fluência por compressão uniaxial estática. .242

7.3 Ensaio de fluência por compressão uniaxial dinâmica. .244

7.4 Comentários finais. .246

7.5 Sugestões para pesquisas futuras. .249

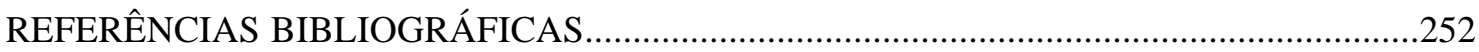

Apêndice $\mathrm{A}$ - Tabelas relativas à montagem do experimento fatorial........................................265

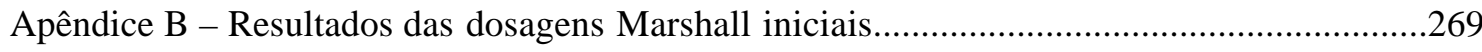

Apêndice C - Definição dos teores de ligante em função das espessuras de película................282

Apêndice D - Apresentação dos dados......................................................................289

Apêndice E - Apresentação dos dados em forma de matrizes fatoriais.......................................315

Apêndice F - Tabelas de análise de variância.............................................................................329 


\section{CONSIDERAÇÕES INICIAIS}

As rodovias constituem-se no principal meio de transporte brasileiro, sendo que a grande maioria das rodovias pavimentadas no Brasil têm revestimento asfáltico. Dessa forma, esforços no sentido da melhoria da qualidade dos pavimentos asfálticos contribuem para que se caminhe no sentido do aumento da segurança e de maior economia no transporte em estradas pavimentadas.

Um dos principais fatores que afetam a qualidade dos revestimentos asfálticos é a deterioração causada por aumentos do volume diário médio de veículos de carga, das cargas por eixo e da pressão dos pneus. A redução de custos decorrente do aumento da carga transportada por cada caminhão individualmente está se refletindo no aumento das dimensões dos caminhões. Consequentemente, os projetos de infra-estrutura de rodovias devem prever solicitações severas, buscando a construção de pavimentos cada vez mais resistentes, para que não ocorram degradações como deformações permanentes, trincas e perda de material da superfície de rolamento, em curtos períodos de tempo.

O pavimento é uma estrutura de múltiplas camadas sujeita ao tráfego e às condições climáticas. Uma vez que o asfalto apresenta características termoplásticas, a temperatura de serviço altera a resposta mecânica do revestimento asfáltico submetido à ação das cargas provenientes do tráfego.

No Brasil, a predominância de clima quente torna os revestimentos asfálticos mais suscetíveis a deformações permanentes significativas, que podem ser identificadas pela 
formação de depressões longitudinais ao longo das trilhas de rodagem, geralmente acompanhadas por elevações laterais. Deformações permanentes ocorrem devido à ação combinada de densificação e deformação por cisalhamento dos materiais constituintes das diversas camadas do pavimento, incluindo o subleito (COELHO e SÓRIA, 1995). O processo de densificação ocorre com diminuição de volume do material e a deformação por cisalhamento, com deslocamento de material, sem variação de volume.

Dentre os fatores que influem na ocorrência de deformação permanente originária da camada de concreto asfáltico destacam-se as características do agregado (textura superficial, granulometria, forma e tamanho), a rigidez da mistura asfáltica na temperatura em que a propensão a deformações permanentes está sendo avaliada, a quantidade de ligante, o volume de vazios na mistura, o volume de vazios no agregado mineral, o método de compactação, a temperatura de serviço e as condições de tráfego (COELHO e SÓRIA, 1995; MOMM e DOMINGUES, 1996; MOTTA et al., 1996).

Além da deformação permanente ou plástica, o desempenho do pavimento também pode ser afetado pela deformação elástica ou resiliente, associada às trincas de fadiga.

A fadiga é uma forma de ruptura resultante da repetição de cargas, originárias tanto do tráfego como das mudanças de temperatura. Em condições normais, a camada de concreto asfáltico tende a voltar a sua posição original após o término do carregamento, recuperando parte considerável da deformação sofrida. Entretanto, quando ocorrem deformações cíclicas sob cargas repetidas, o concreto asfáltico sofre o fenômeno de fadiga.

A maioria das pesquisas sustenta que o processo de ruptura por fadiga inicia-se devido a trincas geradas por deformações longitudinais na superfície inferior da camada asfáltica, que crescem em direção à superfície. Por outro lado, algumas pesquisas salientam que, para espessuras elevadas do revestimento asfáltico, as trincas iniciam-se na superfície, progredindo em direção à parte inferior da camada asfáltica (CASTELL e PINTADO, 1999). Segundo Hsu e Tseng (1996), as tensões térmicas constituem-se em outro fator que leva as trincas decorrentes do processo de fadiga a se iniciarem na superfície do revestimento. 
Uma vez que existam trincas na superfície, a água da chuva pode infiltrar-se até a camada de base, provocando deteriorações tanto da base como do subleito, acelerando o processo de ruptura do pavimento, com redução drástica de sua vida útil.

Dentre os fatores que influem na resistência do revestimento à fadiga incluem-se a espessura do revestimento, o módulo de resiliência, o coeficiente de Poisson, o volume de vazios na mistura, as características de forma do agregado e a granulometria da mistura (BALADI, 1989; HSU e TSENG, 1996; SOUSA et al., 1998).

Além de oferecerem resistência à fadiga e à deformação permanente, os revestimentos asfálticos devem também resistir ao envelhecimento e à abrasão. Dentre os fatores que interferem e afetam o envelhecimento da mistura asfáltica incluem-se a presença de oxigênio, a radiação ultravioleta, as variações de temperatura, a umidade, a precipitação pluviométrica, o tempo de envelhecimento, o grau de compactação da mistura, o tipo de asfalto, a suscetibilidade do asfalto à temperatura, o tipo do agregado e a espessura da película asfáltica. Com o envelhecimento as misturas asfálticas tornam-se mais frágeis, ficando mais sujeitas a fissuras e a desagregação.

\subsection{Objetivos}

O desempenho e a durabilidade dos revestimentos asfálticos podem ser melhorados através de escolhas adequadas dos materiais utilizados e dos métodos construtivos adotados. Dessa forma, o objetivo dessa pesquisa é identificar os principais fatores que influenciam o comportamento de misturas asfálticas densas quanto à estabilidade e à flexibilidade, avaliando-se a significância de cada fator, seu modo de atuação e as relações de interdependência entre os fatores.

Para isso foram utilizados experimentos fatoriais, que consistem de estratégia experimental onde os fatores interferentes em um processo são variados simultaneamente. O efeito dessa variação simultânea pode ser avaliado através da determinação dos efeitos principais e dos efeitos de interação entre os fatores, sendo que o efeito principal de um fator corresponde ao valor médio do gradiente de mudança da resposta produzido pela mudança no nível do fator, mantendo-se os demais fatores 
constantes (CARPINETTI, 2000), e os efeitos de interação entre os fatores medem o grau de dependência entre os fatores.

\subsection{Programa experimental}

O programa de pesquisa aqui apresentado faz parte de um programa experimental conjunto, que além do presente trabalho inclui também mais três pesquisas de mestrado, desenvolvidas pelos pós-graduandos Antonio Carlos Gigante, André Naleto Mugayar e Paulo Cesar Lopes Lemes, do Departamento de Transportes da EESC-USP.

As quatro pesquisas relacionam-se ao estudo dos fatores influentes no comportamento de misturas asfálticas densas. Foram estudados seis tipos de misturas, resultantes da combinação de três tipos de ligantes com duas distribuições granulométricas. Os ligantes utilizados foram um asfalto convencional (CAP 20), um asfalto modificado com polímero (CAP 20 modificado com 4,5\% do polímero SBS - estireno butadieno estireno) e um asfalto modificado com borracha (CAP 20 modificado com $20 \%$ de BRP - borracha reciclada de pneu). As distribuições granulométricas adotadas correspondem aos centros das faixas $B$ e $C$ do DNER (1997).

Para cada mistura asfáltica foi realizada uma dosagem Marshall, a partir da qual foram definidos os teores de ligante nos quais a referida mistura teria seu comportamento avaliado. A definição desses teores se balizou pelos valores de espessura de película asfáltica e volume de vazios que seriam testados. Foram definidos cinco teores, dos quais quatro fazem parte do desenvolvimento da pesquisa aqui apresentada.

O comportamento das misturas asfálticas em relação à fadiga foi avaliado através da propriedade mecânica módulo de resiliência. A suscetibilidade dessas misturas à deformação permanente foi avaliada através da realização dos ensaios de fluência por compressão uniaxial estática e dinâmica (ou ensaios de creep estático e dinâmico).

O envelhecimento a curto prazo sofrido pelas misturas asfálticas, que corresponde ao envelhecimento ocorrido nas fases de mistura em usina e construção do revestimento, foi simulado em laboratório, seguindo-se as especificações da AASHTO (2001). O 
comportamento das misturas asfálticas foi avaliado em duas condições, logo após o processo de misturação, que corresponde à condição da mistura não envelhecida, e após 4 horas de envelhecimento em estufa de circulação de ar forçada a $135^{\circ} \mathrm{C}$.

O envelhecimento a longo prazo, sofrido durante a vida útil do pavimento, foi simulado através de dois procedimentos distintos. Em um dos procedimentos seguiram-se as especificações da AASHTO (2001), segundo as quais os corpos do prova devem permanecer em estufa de circulação de ar forçada a $85^{\circ} \mathrm{C}$ por cinco dias, processo que equivale a um envelhecimento que ocorreria durante 7 a 10 anos de vida útil do pavimento. $\mathrm{O}$ outro procedimento consistiu em expor os corpos de prova às condições climáticas por 4 meses, acomodando-os em suportes ligeiramente inclinados, colocados no telhado. Essa última estratégia de simulação de envelhecimento a longo prazo já foi utilizada por Garrick (1995).

Uma vez que a base de estudo foi a mesma para as quatro pesquisas, grande parte do programa experimental desenvolvido em laboratório foi realizada em conjunto, num sistema de cooperação mútua, onde destacaram-se as vantagens de uma produção em série.

Foram realizadas em conjunto todas as etapas de preparação do material utilizado, que incluíram o peneiramento do agregado para separação deste em intervalos granulométricos especificados pelas curvas granulométricas adotadas; a lavagem do agregado, para retirada do pó e das impurezas, com posterior secagem em estufa; a pesagem em proporções adequadas do agregado previamente separado em peneiras, para composição das curvas granulométricas adotadas; as dosagens Marshall iniciais, realizadas para definição dos teores utilizados e as moldagens de todos os corpos de prova utilizados nas pesquisas.

Além disso, algumas misturas foram submetidas aos mesmos ensaios em mais de uma pesquisa. Nesses casos, também esses ensaios foram realizados em conjunto. Houve também reaproveitamento de alguns corpos de prova moldados com misturas não envelhecidas, que após ensaiados foram submetidos aos processos de envelhecimento a longo prazo. 


\subsection{Organização do trabalho}

Este trabalho é composto por 7 capítulos. No Capítulo 2 apresenta-se uma visão geral da técnica de planejamento e análise de experimentos fatoriais, incluindo-se a exposição da técnica de fracionamento de experimentos utilizada nesta pesquisa.

O Capítulo 3 trata dos processos de envelhecimento a curto e longo prazos sofridos por misturas asfálticas. São expostas as principais causas do envelhecimento, bem como os fatores interferentes nos processos de envelhecimento. Nesse capítulo foi incluída uma revisão sobre misturas compostas por asfaltos modificados, destacando-se a melhora nas propriedades mecânicas das misturas decorrente da adição de modificadores ao asfalto, relatada em diversas pesquisas. Foram apresentados também os resultados de algumas pesquisas que têm procurado estabelecer o modo como a adição de modificadores ao asfalto pode interferir nos processos de envelhecimento sofridos pelas misturas.

No Capítulo 4 são apresentados os mecanismos de deterioração de revestimentos asfálticos relacionados à fadiga e à deformação permanente. São apresentados ensaios laboratoriais para medida da resistência das misturas às deformações permanentes, com destaque aos ensaios de creep estático e dinâmico, e ensaios laboratoriais para medida da resistência das misturas à deformação elástica, com destaque para o ensaio de módulo de resiliência.

No Capítulo 5 são descritos os materiais utilizados para a realização desta pesquisa, a montagem do experimento fatorial, com os acoplamentos de efeitos necessários para o seu fracionamento, e os ensaios utilizados para avaliação das propriedades mecânicas das misturas, a saber, ensaio de resistência à tração por compressão diametral estática, ensaio de módulo de resiliência por compressão diametral dinâmica, ensaio de fluência por compressão uniaxial estática (creep estático) e ensaio de fluência por compressão uniaxial dinâmica (creep dinâmico).

No Capítulo 6 são apresentados os resultados dos ensaios e as análises de variância dos mesmos, através da qual foi possível a identificação dos fatores influentes em cada propriedade analisada e a construção de modelos estatísticos de comportamento, que 
auxiliaram a visualização da variação das respostas apresentadas pelas misturas em função da variação dos fatores tipo e teor de ligante, distribuição granulométrica do agregado e condições de envelhecimento a curto e longo prazos.

No Capítulo 7 encontram-se as constatações decorrentes do experimento realizado, bem como algumas generalizações acerca do comportamento de misturas asfálticas quanto à estabilidade e à flexibilidade, baseadas dos resultados obtidos através dos ensaios laboratoriais realizados. A experiência obtida com este trabalho motivou também algumas sugestões e recomendações para trabalhos futuros. 


\section{PLANEJAMENTO E ANÁLISE DE EXPERIMENTOS FATORIAIS}

Introduzem-se técnicas de planejamento e análise de experimentos fatoriais, com o objetivo de se adquirir ferramentas para a avaliação dos efeitos de se variar simultaneamente todas as variáveis envolvidas no experimento em estudo, realizando-se o mínimo número de ensaios.

Uma revisão bibliográfica sobre técnicas de planejamento e análise de experimentos fatoriais é apresentada, na qual incluem-se experimentos fatoriais com todos os fatores apresentando apenas dois níveis de variação, que consiste em uma classe especial de experimentos, destacada pela simplicidade de planejamento e análise; experimentos fatoriais fracionários com fatores em dois níveis de variação; experimentos fatoriais com fatores em níveis variados, denominados experimentos assimétricos e experimentos fatoriais fracionários com fatores em níveis variados.

\subsection{Introdução}

O planejamento de experimentos é uma técnica utilizada para se definir os tipos e as quantidades dos dados coletados durante a realização de determinado experimento, bem como as condições de coleta, visando a maior precisão estatística possível na resposta, com o menor custo. 
Em pesquisas básicas e tecnológicas, técnicas de planejamento de experimentos conduzidos no esquema fatorial têm sido cada vez mais aplicadas. A grande vantagem de sua utilização é o teste de várias hipóteses em um mesmo experimento, incluindo a possibilidade de obtenção de conclusões mais amplas face ao estudo simultâneo de vários fatores.

Segundo Namboodiri et al. (1975), o planejamento de experimentos possui como principais vantagens a diminuição do número de ensaios em estudos de um número considerável de fatores e a detecção de interações entre os fatores.

Para se realizar um planejamento fatorial, escolhem-se as variáveis independentes a serem estudadas e os valores em que essas variáveis serão testadas, denominados níveis. A seguir efetuam-se experimentos para todas as combinações possíveis dos níveis selecionados para as variáveis ou fatores em estudo. Esses experimentos são utilizados para pesquisar não somente diferenças nas respostas provenientes de variações nos níveis dos fatores, denominadas de efeitos principais, mas também o modo como a escolha do nível de determinado fator interfere nos efeitos dos demais fatores, que consistem nos efeitos de interação entre os fatores.

Como cada fator pode possuir vários níveis de variação e como o número de condições experimentais a serem testadas em um experimento fatorial é dado por todas as combinações possíveis dos diversos níveis dos fatores ou variáveis que o constituem, a realização do experimento completo pode tornar-se impraticável.

Surge então a necessidade do fracionamento do experimento, que permite que as informações desejadas sejam obtidas realizando-se apenas uma fração do experimento total, com base na redundância existente quando muitos fatores são introduzidos. Através da aplicação da técnica de planejamento e análise de experimentos fatoriais fracionários, o número de condições experimentais necessárias à obtenção da resposta desejada pode ser reduzido, fazendo-se uso do sistema de acoplamento de efeitos, que baseia-se na consideração de que interações de alta ordem podem ser desconsideradas. Dessa forma o experimentador pode reduzir o tempo de pesquisa, sem ser obrigado a limitar o número de fatores a serem testados ou o número de níveis por fator, como ocorre no método clássico de experimentação (MARGOLIN, 1968). 
Uma vez obtidos os dados segue-se a análise dos mesmos, realizada com a finalidade de se concluir sobre o grau de influência que a variação dos níveis dos fatores ou variáveis de entrada possui na variação da resposta ou variável de saída. Para isso são utilizadas técnicas estatísticas, como o quadro de análise de variância (ANOVA). A significância dos efeitos de interação entre os fatores também é determinada através da análise de variância.

\subsection{Planejamento estatístico de experimentos fatoriais}

Experimentos são testes onde são feitas variações propositais nas variáveis de entrada ou de controle de um processo, com o objetivo de se observar e identificar as razões de variação da resposta ou variável de saída. Experimentos fatoriais são aqueles que consideram todas as combinações possíveis dos diversos níveis dos fatores ou variáveis que o constituem, sendo que os níveis de um fator correspondem aos valores que este fator pode assumir durante a experimentação.

O efeito dessa variação simultânea dos fatores pode ser avaliado através da determinação dos efeitos principais e dos efeitos de interação entre os fatores. $\mathrm{O}$ efeito principal de um fator corresponde ao valor médio do gradiente de mudança de resposta produzido pela mudança no nível do fator, mantendo-se os demais fatores constantes (CARPINETTI, 2000).

Além dos efeitos principais, podem ser determinados os efeitos de interação entre os fatores, que medem o grau de dependência entre os fatores. Existe interação entre dois ou mais fatores de um experimento se o efeito da variação de um fator depende dos níveis em que são considerados os outros fatores (MONTGOMERY, 1997).

Dessa forma, a interação entre dois fatores $A$ e $B$ mede o erro cometido estimando-se o efeito principal apenas de $A$, como se esta fosse uma variável independente de $B$ (BOX et al., 1978).

O número total de tratamentos ou condições experimentais em um experimento fatorial depende do número de fatores e do número de níveis em que cada fator é considerado. 
Sejam $n$ o número de fatores e $w_{i}$ o número de níveis do fator $i$. O número de condições experimentais $m$ é dado pela eq. (2.1).

$$
m=w_{1} \times w_{2} \times w_{3} \times \ldots \times w_{n}
$$

Os dados associados ao planejamento do experimento fatorial com $n$ fatores podem ser dispostos em um tabela com $m$ linhas. Se cada condição experimental tiver $r$ réplicas ou observações, o número total de observações necessário para a análise de todos os efeitos envolvidos no experimento será igual a $N$, conforme eq. (2.2).

$$
N=r \times w_{1} \times w_{2} \times w_{3} \times \ldots \times w_{n}
$$

Os experimentos devem ser realizados seguindo-se os princípios básicos da experimentação, que são aleatoriedade da ordem dos ensaios, com o objetivo de minimizar os efeitos de interferências tendenciosas, como por exemplo o efeito da variação da temperatura ao longo do dia (PIRATELLI FILHO, 1997); repetição, realizada para se estimar a variabilidade existente dentro de uma mesma condição experimental; e divisão da unidade experimental em blocos, dentro dos quais as condições experimentais são mais homogêneas que as condições do experimento completo.

A aleatoriedade da ordem da experimentação pode ser obtida selecionando-se aleatoriamente a condição experimental a ser testada, toda vez que for ser realizada uma observação. Se a condição experimental sorteada já tiver sido testada, descarta-se o sorteio e repete-se o processo até que todas as observações sejam coletadas.

A inclusão de réplicas, ou repetições do experimento, aponta a variabilidade decorrente de fontes de variação não controladas, como mudanças em condições de testes e erros de medidas, permitindo a obtenção de uma estimativa do erro experimental (PLACKETT e BURMAN, 1946). A estimativa dessa variabilidade experimental não controlada pode ser feita através de desvios padrões amostrais de testes repetidos. 


\subsection{Experimentos fatoriais em dois níveis}

Um caso particular do planejamento de experimentos fatoriais é aquele onde todos os fatores são considerados em apenas dois níveis, que podem indicar dois valores numéricos para fatores quantitativos ou duas possibilidades de escolha, para fatores qualitativos. Sendo $n$ o número de fatores, o número de combinações ou condições experimentais será $2^{n}$.

As definições utilizadas no planejamento de experimentos fatoriais em dois níveis são:

$n=$ número de fatores;

$r=$ número de réplicas para cada condição experimental;

$w=$ número de níveis dos fatores $=2$;

$m=2^{n}=$ número de tratamentos ou condições experimentais;

$c=$ número do tratamento ou condição experimental;

$N=r 2^{n}=$ número total de observações;

$Y=$ variável de resposta ou de controle;

$T_{c}=$ total das $r$ observações da $c$-ésima condição experimental ou tratamento;

$\bar{Y}_{(c)}=\frac{T_{(c)}}{r}=$ média por tratamento ou condição experimental.

A montagem do arranjo de experimentos fatoriais em dois níveis pode ser realizada com relativa simplicidade. Representando-se o nível inferior dos fatores pelo sinal menos ( - ) e o nível superior pelo sinal mais $(+$ ), segue-se um procedimento sistemático que se resume nos seguintes passos:

- para o fator $1(X 1)$, escreve-se uma coluna com sinais alternando em grupos de $2^{0}=1$, ou seja, alternando seguidamente: -+-+-+-+ ;

- para o fator $2(X 2)$, escreve-se uma coluna com sinais alternando em grupos de $2^{1}=2$, ou seja, em pares: --++--++ ;

- para o fator $3(X 3)$, escreve-se uma coluna com sinais alternando em grupos de $2^{2}=4$, ou seja, em grupos de quatro: ----++++ ;

- para o fator $4(X 4)$, escreve-se uma coluna com sinais alternando em grupos de $2^{(4-1)}=8$, ou seja, em grupos de oito; 
- para o fator $n(X n)$, escreve-se uma coluna de sinais alternando em grupos de $2^{(\mathrm{n}-1)}$, ou seja, escreve-se $2^{(\mathrm{n}-1)}$ vezes o nível inferior $(-)$, seguidos de $2^{(\mathrm{n}-1)}$ vezes o nível superior $(+)$.

Essa forma de arranjo do experimento garante que as colunas sejam ortogonais entre si, ou seja, garante que seus efeitos sejam independentes (PLACKETT, 1946).

\subsubsection{Análise dos efeitos principais dos fatores}

No planejamento de experimentos fatoriais em dois níveis, o efeito principal de um fator é definido como a diferença entre as médias da variável de resposta ou de controle para os dois níveis do fator considerado.

Seja um experimento fatorial em dois níveis, inferior $(-)$ e superior $(+)$, com dois fatores, $A$ e $B$. Considere-se a representação indicada na Tabela 2.1.

Tabela 2.1 - Representação de um experimento fatorial em dois níveis com dois fatores

\begin{tabular}{ccccc}
\hline \multicolumn{2}{c}{ níveis } & \multicolumn{2}{c}{ representação } & variável de \\
fator A & fator B & $\mathrm{A}$ & $\mathrm{B}$ & resposta \\
\hline inferior & inferior & - & - & $\bar{Y}_{11}$ \\
superior & inferior & + & - & $\bar{Y}_{21}$ \\
inferior & superior & - & + & $\bar{Y}_{12}$ \\
superior & superior & + & + & $\bar{Y}_{22}$ \\
\hline
\end{tabular}

Onde

$\bar{Y}_{11}$ é a reposta média, ou seja, é a soma das observações dividida pelo número de réplicas, para a situação em que os fatores $A$ e $B$ são tomados em seu nível inferior;

$\bar{Y}_{12}$ é a resposta média, ou seja, é a soma das observações dividida pelo número de réplicas, para a situação em que o fator $A$ é tomado em seu nível inferior e o fator $B$, em seu nível superior;

$\bar{Y}_{21}$ é a resposta média, ou seja, é a soma das observações dividida pelo número de réplicas, para a situação em que o fator $A$ é tomado em seu nível superior e o fator $B$, em seu nível inferior; 
$\bar{Y}_{22}$ é a reposta média, ou seja, é a soma das observações dividida pelo número de réplicas, para a situação em que os fatores $A$ e $B$ são tomados em seu nível superior.

O efeito principal de $A, E_{A}$, é dado por:

$$
\begin{gathered}
\mathrm{E}_{\mathrm{A}}=\overline{\mathrm{Y}}_{\mathrm{A}}^{+}-\overline{\mathrm{Y}}_{\mathrm{A}}^{-} \\
E_{\mathrm{A}}=\frac{1}{2}\left(-\bar{Y}_{11}-\bar{Y}_{12}+\bar{Y}_{21}+\bar{Y}_{22}\right)
\end{gathered}
$$

Sendo

$\bar{Y}_{A}{ }^{+}$a média das variáveis de resposta para o nível superior do fator $A$;

$\bar{Y}_{A}{ }^{-}$a média das variáveis de resposta para o nível inferior do fator $A$.

O efeito principal de $B, E_{B}$, é dado por:

$$
\begin{gathered}
\mathrm{E}_{\mathrm{B}}=\overline{\mathrm{Y}}_{\mathrm{B}}^{+}-\overline{\mathrm{Y}}_{\mathrm{B}}^{-} \\
E_{B}=\frac{1}{2}\left(-\bar{Y}_{11}+\bar{Y}_{12}-\bar{Y}_{21}+\bar{Y}_{22}\right)
\end{gathered}
$$

Sendo

$\bar{Y}_{B}{ }^{+}$a média das variáveis de resposta para o nível superior do fator $B$;

$\bar{Y}_{B}{ }^{-}$a média das variáveis de resposta para o nível inferior do fator $B$.

O efeito da interação entre dois fatores é definido como a metade da diferença entre os efeitos de um fator nos dois níveis do segundo fator, ou seja

$$
E_{A B}=\frac{E_{A}{ }^{B+}-E_{A}{ }^{B-}}{2}
$$

Onde

$E_{A B}$ é o efeito da interação entre os fatores $A$ e $B$; 
$E_{A}{ }^{B+}$ é o efeito do fator $A$ mantendo-se o fator $B$ em seu nível superior;

$E_{A}{ }^{B-}$ é o efeito do fator $A$ mantendo-se o fator $B$ em seu nível inferior.

De forma semelhante, o efeito da interação entre três fatores $(A, B$ e $C)$ é definido como metade da diferença entre os efeitos das interações entre dois fatores nos dois níveis do terceiro fator.

$$
E_{A B C}=\frac{E_{A B}{ }^{C+}-E_{A B}{ }^{C-}}{2}
$$

Onde

$E_{A B C}$ é o efeito da interação entre os fatores $A, B$ e $C$;

$E_{A B}{ }^{C+}$ é o efeito da interação entre os fatores $A$ e $B$, mantendo-se o fator $C$ em seu nível superior;

$E_{A B}{ }^{C-}$ é o efeito da interação entre os fatores $A$ e $B$, mantendo-se o fator $C$ em seu nível inferior.

Considerando-se um experimento com $i$ fatores, o número de observações associadas ao nível inferior ( - ) do fator $X_{i}$ é $\frac{1}{2} r 2^{n}$, o que significa que $2^{n-1}$ condições experimentais encontram-se associadas ao nível inferior desse fator. Da mesma forma, o número de observações associadas ao nível superior $(+)$ do fator $X_{i}$ é $\frac{1}{2} r 2^{n}$, que equivalem a $2^{n-1}$ condições experimentais.

Sejam,

$T_{i}^{+}=$soma das $r 2^{n-1}$ observações correspondentes às $2^{n-1}$ condições experimentais com $X_{i}$ em seu nível superior, ou seja $X_{i}=+1$;

$T_{i}^{-}=$soma das $r 2^{n-1}$ observações correspondentes às $2^{n-1}$ condições experimentais com $X_{i}$ em seu nível inferior, ou seja $X_{i}=-1$. 
O efeito principal do fator $X_{i}$ é estimado pela diferença entre duas médias, a média da variável de resposta para $X_{i}$ em seu nível superior (eq. 2.7) e a média da variável de resposta para $X_{i}$ em seu nível inferior (eq. 2.8).

$$
\begin{aligned}
& \bar{Y}_{i}^{+}=\frac{T_{i}^{+}}{r 2^{n-1}} \\
& \bar{Y}_{i}^{-}=\frac{T_{i}^{-}}{r 2^{n-1}}
\end{aligned}
$$

Sendo $E_{i}$ o efeito principal do fator $X_{i}$, temos

$$
E_{i}=\frac{1}{r 2^{n-1}}\left(T_{i}^{+}-T_{i}^{-}\right)
$$

Considerando-se as seguintes definições

$R_{i l}=$ região formada pelas observações das condições experimentais correspondentes ao nível superior $(+)$ do fator $X_{i}$, ou seja, $X_{i}=+1$;

$R_{i 2}=$ região formada pelas observações das condições experimentais correspondentes ao nível inferior ( - ) do fator $X_{i}$, ou seja, $X_{i}=-1$,

temos

$$
\begin{aligned}
& T_{i}^{+}=\sum_{c \in R_{i 1}} T_{(c)} \\
& T_{i}^{-}=\sum_{c \in R_{i 2}} T_{(c)}
\end{aligned}
$$

Dessa forma

$$
E_{i}=\frac{1}{2^{n-1}} \sum_{c \in R_{i 1} \cup R_{i 2}} a_{(c)} \frac{T_{(c)}}{r}
$$

Ou seja,

$$
E_{i}=\frac{1}{2^{n-1}} \sum_{c \in R_{i 1} \cup R_{i 2}} a_{(c)} \bar{Y}_{(c)}
$$

onde

$$
\begin{aligned}
& a_{(c)}=+1, \text { para } c \in \mathrm{R}_{\mathrm{i} 1} \\
& a_{(c)}=-1, \text { para } \mathrm{c} \in \mathrm{R}_{\mathrm{i} 2} \mathrm{e} \\
& \sum a_{(c)}=0
\end{aligned}
$$


De acordo com as definições apresentadas e acrescentando-se a definição da eq. (2.14), o efeito principal dos fatores pode ser expresso pela eq. (2.15).

$$
\begin{gathered}
L_{i}=\sum_{c \in R_{i 1} \cup R_{i 2}} a_{(c)} \bar{Y}_{(c)} \\
E_{i}=\frac{L_{i}}{2^{n-1}}
\end{gathered}
$$

A combinação linear apresentada na eq. (2.14) é definida como um contraste, pois $\sum_{c} a_{(c)}=0$, ou seja, o número de condições experimentais ocorrentes no nível superior é igual ao número de condições experimentais ocorrentes no nível inferior do fator $X_{i}$.

\subsubsection{Análise dos efeitos de interação entre os fatores}

Considerem-se dois fatores $X_{i}$ e $X_{j}$, cada qual em dois níveis, inferior (- ) e superior $(+)$. Seja $L_{j}=\sum_{c} b_{(c)} \bar{Y}_{(c)}$ um contraste pertencente ao efeito principal do fator $X_{j}$.

O efeito condicional do fator $X_{j}$ quando $X_{i}=+1\left(E_{j}\left(X_{i}^{+}\right)\right)$pode ser estimado por $2^{n-1}$ linhas em contraste, pertencentes à região $R_{i l}$.

$$
E_{j}\left(X_{i}^{+}\right)=\frac{\sum_{c \in R_{i 1}} b_{(c)} \bar{Y}_{(c)}}{2^{n-2}}
$$

De forma similar, o efeito condicional do fator $X_{j}$ dado quando $X_{i}=-1\left(E_{j}\left(X_{i}^{-}\right)\right)$pode ser estimado por $2^{n-1}$ linhas em contraste, pertencentes à região $R_{i 2}$.

$$
E_{j}\left(X_{i}^{-}\right)=\frac{\sum_{c \in R_{i 2}} b_{(c)} \bar{Y}_{(c)}}{2^{n-2}}
$$

O efeito da interação entre os fatores $X_{i}$ e $X_{j}\left(E_{i j}\right)$ é definido como a diferença média entre os efeitos condicionais dados pelas eq. (2.16) e (2.17). 


$$
\begin{gathered}
E_{i j}=\frac{E_{j}\left(X_{i}^{+}\right)-E_{j}\left(X_{i}^{-}\right)}{2} \\
E_{i j}=\frac{\sum_{c \in R_{i 1}} b_{(c)} \bar{Y}_{(c)}-\sum_{c \in R_{i 2}} b_{(c)} \bar{Y}_{(c)}}{2^{n-1}}
\end{gathered}
$$

Seja $R_{i l}$ a união de dois conjuntos de condições experimentais,

$$
\begin{aligned}
& S_{i j}^{++}=\left\{c \mid X_{i}=+1, X_{j}=+1\right\} e \\
& S_{i j}{ }^{+-}=\left\{c \mid X_{i}=+1, X_{j}=-1\right\}
\end{aligned}
$$

e $R_{i 2}$, por sua vez, a união de

$$
\begin{aligned}
& \mathrm{S}_{\mathrm{ij}}{ }^{-}=\left\{\mathrm{c} \mid \mathrm{X}_{\mathrm{i}}=-1, \mathrm{X}_{\mathrm{j}}=+1\right\} \mathrm{e} \\
& \mathrm{S}_{\mathrm{ij}}{ }^{-}=\left\{\mathrm{c} \mid \mathrm{X}_{\mathrm{i}}=-1, \mathrm{X}_{\mathrm{j}}=-1\right\}
\end{aligned}
$$

Pode-se escrever

$$
\begin{gathered}
E_{i j}=\frac{1}{2^{n-1}}\left(\sum_{c \in S_{i j}^{++}} b_{(c)} \bar{Y}_{(c)}+\sum_{c \in S_{i j}^{+}} b_{(c)} \bar{Y}_{(c)}-\sum_{c \in S_{i j}^{+}} b_{(c)} \bar{Y}_{(c)}-\sum_{c \in S_{i j}^{-}} b_{(c)} \bar{Y}_{(c)}\right) \\
E_{i j}=\frac{1}{2^{n-1}}\left(\sum_{c \in S_{i^{+}}^{+}} \bar{Y}_{(c)}-\sum_{c \in S_{i^{+}}^{+}} \bar{Y}_{(c)}-\sum_{c \in S_{i^{+}}^{+}} \bar{Y}_{(c)}+\sum_{c \in S_{i j}^{-}} \bar{Y}_{(c)}\right)
\end{gathered}
$$

Seja $L_{i}$ um contraste pertencente ao efeito principal do fator $X_{i}$, e seja $L_{i}$ ortogonal a $L_{j}$.

$$
\begin{aligned}
L_{i} & =\sum_{c} a_{(c)} \bar{Y}_{(c)} \\
L_{j} & =\sum_{c} b_{(c)} \bar{Y}_{(c)}
\end{aligned}
$$

Sendo $a_{(c)}=-1$ ou $+1, b_{(c)}=-1$ ou $+1, \sum_{c} a_{(c)}=0, \sum_{c} b_{(c)}=0$ e $\sum_{c} a_{(c)} b_{(c)}=0$ 
Pode-se notar que

$$
\begin{array}{lll}
a_{(c)} b_{(c)}=+1 & \text { para } & c \in S_{i j}^{++} \\
a_{(c)} b_{(c)}=-1 & \text { para } & c \in S_{i j}^{+-} \\
a_{(c)} b_{(c)}=-1 & \text { para } & c \in S_{i j}^{++} \\
a_{(c)} b_{(c)}=+1 & \text { para } & c \in S_{i j}^{--}
\end{array}
$$

Dessa forma o contraste $L_{i j}$, escrito conforme eq. (2.22), pertence ao efeito de interação entre os fatores $X_{\mathrm{i}}$ e $\mathrm{X}_{\mathrm{j}}$, que pode ser expresso pela eq.(2.23).

$$
\begin{gathered}
L_{i j}=\sum_{c \in S_{i j}^{++}} \bar{Y}_{(c)}-\sum_{c \in S_{i j}^{+-}} \bar{Y}_{(c)}-\sum_{c \in S_{i j}^{-+}} \bar{Y}_{(c)}+\sum_{c \in S_{i j}^{--}} \bar{Y}_{(c)} \\
E_{i j}=\frac{L_{i j}}{2^{n-1}}
\end{gathered}
$$

O efeito da interação entre três fatores $X_{i}, X_{j}$ e $X_{k}$, denominado de $E_{i j k}$, é definido como a média da diferença entre os efeitos das interações condicionais $E_{i j}\left(X_{k}^{+}\right)$e $E_{i j}\left(X_{k}^{-}\right)$, seguindo-se procedimento semelhante ao utilizado para obtenção do efeito da interação entre dois fatores.

$$
\begin{gathered}
E_{i j k}=\frac{E_{i j}\left(X_{k}^{+}\right)-E_{i j}\left(X_{k}^{-}\right)}{2} \\
E_{i j k}=\frac{L_{i j k}}{2^{n-1}}
\end{gathered}
$$

Apenas a observação dos efeitos principais e dos efeitos de interação entre os fatores pode não ser conclusiva para se determinar se esses efeitos são ou não significativos. Um estudo mais rigoroso sobre a significância dos efeitos principais e de interação entre os fatores é fornecido pelo método de análise de variância (ANOVA). 


\subsection{Análise de variância (ANOVA)}

A análise de variância (ANOVA) consiste em uma técnica estatística para comparação simultânea de várias médias, provenientes de amostras distintas. O método ANOVA permite a verificação da hipótese nula em que o efeito sob consideração é significativo em termos do teste estatístico $F$.

O propósito básico de um teste de significância é comparar uma estimativa do efeito de um tratamento ou amostra com a estimativa do erro aleatório. Considerando-se que o erro aleatório é desprezível, é possível através dessa comparação estabelecer se o efeito do tratamento em questão é ou não significativo. Para isso faz-se uso do teste de hipótese.

Um teste de hipótese estatístico, como por exemplo o teste $F$ das variâncias amostrais, é um critério que conduz à decisão de se aceitar ou rejeitar a hipótese em consideração, a partir de valores experimentais obtidos das amostras.

Como as conclusões derivadas de testes de hipótese baseiam-se em curvas de distribuição de probabilidades, dois tipos de erros podem ser cometidos, denominados erro do tipo I e erro do tipo II.

O erro do tipo I ocorre quando aceita-se a hipótese inicial $H_{0}$ quando esta é falsa. A probabilidade de se cometer um erro desse tipo pode ser controlada pela seleção da confiança estatística desejada na realização do teste de hipóteses. Dessa forma, se a confiança escolhida for de $99 \%$, a probabilidade de se aceitar uma hipótese falsa é de $1 \%$, que é igual ao nível de significância do teste, denominado de $\alpha$.

A rejeição de $H_{0}$ quando esta é uma hipótese verdadeira é conhecida como erro do tipo II. A probabilidade de se cometer um erro desse tipo depende do tamanho da amostra, do desvio padrão amostral e da magnitude da diferença entre médias necessária para se aceitar a hipótese nula, segundo a qual as médias são diferentes. Amostras muito pequenas podem levar a um erro do tipo II, principalmente quando a diferença observada entre as médias for muito pequena. 
A validade de testes estatísticos de significância depende da existência de réplicas, pois estas fornecem uma estimativa do erro aleatório e tornam possível o uso de tabelas de significância, construídas sob a consideração de que os erros são independentes.

No método ANOVA considera-se que qualquer observação aleatória possui três componentes, o efeito comum, o efeito do tratamento e o erro aleatório. $\mathrm{O}$ efeito comum é um valor constante presente em todas as observações. $\mathrm{O}$ efeito do tratamento consiste de uma parcela fixa ou aleatória, que varia de acordo com a condição experimental considerada. Quanto ao erro, trata-se de uma quantidade aleatória não previsível, cujo valor esperado é zero.

O modelo matemático que descreve a origem da variação em cada uma das observações tomadas aleatoriamente de uma população dividida em $k$ tratamentos é dado pela eq. (2.25).

$$
Y_{i j}=\mu+\tau_{j}+\varepsilon_{i j}
$$

onde

$Y_{i j}=i$-ésima observação aleatória do $j$-ésimo tratamento;

$\mu=$ efeito comum ou média da população;

$\tau_{j}=$ efeito devido ao tratamento $j$;

$\varepsilon_{i j}=$ erro aleatório na $i$-ésima observação do j-ésimo tratamento.

Sendo $\mu_{j}$ a média do tratamento $j$, o efeito do tratamento $j\left(\tau_{j}\right)$ é dado pela diferença entre a média do tratamento $j$ e a média da população, de acordo com a eq. (2.26), e o erro aleatório na $i$-ésima observação do j-ésimo tratamento é dado pela diferença entre o valor da observação e a média do tratamento ao qual pertence a observação em questão, conforme eq.(2.27).

$$
\begin{aligned}
& \tau_{j}=\mu_{j}-\mu \\
& \varepsilon_{i j}=Y_{i j}-\mu_{j}
\end{aligned}
$$


A Tabela 2.2 resume as notações e o formato utilizado para organização dos dados necessários à aplicação do método de análise de variância ANOVA (GARCIA-DIAZ e PHILLIPS, 1995).

Tabela 2.2 - Notações e organização dos dados para aplicação do método ANOVA (GARCIADIAZ e PHILLIPS, 1995)

\begin{tabular}{rcccccc}
\hline & \multicolumn{5}{c}{ tratamentos } \\
& $\mathrm{j}=1$ & $\mathrm{j}=2$ & $\mathrm{j}=3 \ldots$ & $\mathrm{j}$ & $\ldots \mathrm{j}=\mathrm{m}-1$ & $\mathrm{j}=\mathrm{m}$ \\
\cline { 2 - 7 } & $\mathrm{Y}_{11}$ & $\mathrm{Y}_{12}$ & $\mathrm{Y}_{13}$ & $\mathrm{Y}_{1 \mathrm{j}}$ & $\mathrm{Y}_{1, \mathrm{~m}-1}$ & $\mathrm{Y}_{1 \mathrm{~m}}$ \\
& $\mathrm{Y}_{21}$ & $\mathrm{Y}_{22}$ & $\mathrm{Y}_{23}$ & $\mathrm{Y}_{2 \mathrm{j}}$ & $\mathrm{Y}_{2, \mathrm{~m}-1}$ & $\mathrm{Y}_{2 \mathrm{~m}}$ \\
& $\vdots$ & $\vdots$ & $\vdots$ & $\vdots$ & $\vdots$ & $\vdots$ \\
& $Y_{r_{1}, 1}$ & $Y_{r_{2}, 2}$ & $Y_{r_{3}, 3}$ & $Y_{r_{j}, j}$ & $Y_{r_{m-1}, m-1}$ & $Y_{r_{m}, m}$ \\
total & $\mathrm{T}_{1}$ & $\mathrm{~T}_{2}$ & $\mathrm{~T}_{3}$ & $\mathrm{~T}_{\mathrm{j}}$ & $\mathrm{T}_{\mathrm{m}-1}$ & $\mathrm{~T}_{\mathrm{m}}$ \\
tamanho da amostra & $\mathrm{r}_{1}$ & $\mathrm{r}_{2}$ & $\mathrm{r}_{3}$ & $\mathrm{r}_{\mathrm{j}}$ & $\mathrm{r}_{\mathrm{m}-1}$ & $\mathrm{r}_{\mathrm{m}}$ \\
média amostral & $\bar{Y}_{1}$ & $\bar{Y}_{2}$ & $\bar{Y}_{3}$ & $\bar{Y}_{j}$ & $\bar{Y}_{m-1}$ & $\bar{Y}_{m}$ \\
\hline
\end{tabular}

Sejam as definições,

$$
\begin{aligned}
& \text { total geral }=T=\sum_{j=1}^{m} T_{j} \\
& \text { número total de observações }=N=\sum_{j=1}^{m} r_{j} \\
& \text { média total }=\bar{Y}=\frac{T}{N}
\end{aligned}
$$

O desvio total $Y_{i j}-\mu$ (eq. 2.31) pode ser dividido em duas parcelas, o desvio da média do tratamento $j$ em relação à média total da população, ou seja, $\tau_{j}$, e o desvio da $i$-ésima observação do j-ésimo tratamento em relação à média do tratamento correspondente, denominado de $\varepsilon_{i j}$.

$$
Y_{i j}-\mu=\tau_{j}+\varepsilon_{i j}
$$

Como os parâmetros populacionais não são conhecidos, utilizam-se os valores amostrais estimados de acordo com as definições apresentadas nas eq. (2.28), (2.29) e (2.30) para obtenção do desvio total, que dessa forma pode ser expresso por

$$
Y_{i j}-\bar{Y}=\left(\bar{Y}_{j}-\bar{Y}\right)+\left(Y_{i j}-\bar{Y}_{j}\right)
$$


Para levar em consideração apenas a magnitude da variação independentemente do sinal algébrico, calculam-se os quadrados das diferenças, conforme eq. (2.33).

$$
\left(Y_{i j}-\bar{Y}\right)^{2}=\left(\bar{Y}_{j}-\bar{Y}\right)^{2}+\left(Y_{i j}-\bar{Y}_{j}\right)^{2}+2\left(\bar{Y}_{j}-\bar{Y}\right)\left(Y_{i j}-\bar{Y}_{j}\right)
$$

Somando-se em $i$ e $j$, tem-se

$$
\begin{aligned}
\sum_{j} \sum_{i}\left(Y_{i j}-\bar{Y}\right)^{2}= & \sum_{j} \sum_{i}\left(\bar{Y}_{j}-\bar{Y}\right)^{2}+\sum_{j} \sum_{i}\left(Y_{i j}-\bar{Y}_{j}\right)^{2}+ \\
& +\sum_{j} \sum_{i} 2\left(\bar{Y}_{j}-\bar{Y}\right)\left(Y_{i j}-\bar{Y}_{j}\right)
\end{aligned}
$$

O último termo da eq. (2.34) é nulo, como pode ser visto pela eq.(2.35).

$$
\begin{aligned}
\sum_{j} \sum_{i}\left(\bar{Y}_{j}-\bar{Y}\right)\left(Y_{i j}-\bar{Y}_{j}\right) & =\sum_{j}\left(\bar{Y}_{j}-\bar{Y}\right) \sum_{i}\left(Y_{i j}-\bar{Y}_{j}\right) \\
& =\sum_{j}\left(\bar{Y}_{j}-\bar{Y}\right)\left(r_{j} \bar{Y}_{j}-r_{j} \bar{Y}_{j}\right)=0
\end{aligned}
$$

Definindo-se as seguintes somas de quadrados,

$$
\begin{aligned}
& S Q_{\text {total }}=\sum_{j} \sum_{i}\left(Y_{i j}-\bar{Y}\right)^{2} \\
& S Q_{\text {tratamento }}=\sum_{j}\left(\bar{Y}_{j}-\bar{Y}\right)^{2} \\
& S Q_{\text {erro }}=\sum_{j} \sum_{i}\left(Y_{i j}-\bar{Y}_{j}\right)^{2}
\end{aligned}
$$

pode-se escrever a equação fundamental da análise de variância (eq. 2.39).

$$
S Q_{\text {total }}=S Q_{\text {trataments }}+S Q_{\text {erro }}
$$

Introduzem-se então três estatísticas adicionais, denominadas de quadrados médios, definidas como o quociente entre cada soma de quadrados e seu respectivo grau de 
liberdade $(G L)$. O número de graus de liberdade consiste em uma medida da independência dos valores utilizados para determinação de uma estatística.

$$
\begin{gathered}
Q M_{\text {total }}=\frac{S Q_{\text {total }}}{N-1} \\
Q M_{\text {tratamento }}=\frac{S Q_{\text {tratamentos }}}{m-1} \\
Q M_{\text {erro }}=\frac{S Q_{\text {erro }}}{N-m}
\end{gathered}
$$

O quadrado médio total $\left(Q M_{\text {total }}\right)$ representa a variância total dos dados. O número de graus de liberdade total $\left(G L_{\text {total }}\right)$ é calculado pelo número total de observações menos um, $N$ - 1 , em virtude da restrição imposta pelo cálculo da média total $(\bar{Y})$, que implica na perda de um grau de liberdade.

Da mesma forma, os quadrados médios $Q M_{\text {tratamentos }}$ e $Q M_{\text {erro }}$ representam estimativas das variâncias entre tratamentos e dentro de cada tratamento, respectivamente, obtidas dividindo-se as somas de quadrados pelos respectivos números de graus de liberdade. Como o objetivo é comparar as variâncias entre tratamentos, o quadrado médio que representa a variação dentro do tratamento ou amostra é chamado de erro experimental.

O número de graus de liberdade entre tratamentos, ou entre amostras, é igual ao número de tratamentos menos um $\left(G L_{\text {tratamentos }}=m-1\right)$ e o número de graus de liberdade dentro de cada tratamento, ou dentro de cada amostra, é igual ao número de tratamentos vezes o número de réplicas por tratamento menos um, ou seja $G L_{\text {erro }}=m \times(r-1)$. O número de graus de liberdade dentro do tratamento ou amostra pode também ser calculado pela diferença entre o número de graus de liberdade total $\left(G L_{\text {total }}=N-1\right)$ e o número de graus de liberdade entre tratamentos $\left(G L_{\text {tratamentos }}=m-1\right)$, obtendo-se dessa forma $G L_{\text {erro }}=N$ $m$.

A comparação das variâncias entre tratamentos é feita comparando-se valores de quadrados médios, admitindo-se uma hipótese inicial $H_{0}$ de que as médias dos tratamentos ou amostras são diferentes $\left(H_{0} \neq \overline{Y_{1}} \neq \overline{Y_{2}} \neq \ldots \neq \overline{Y_{m}}\right)$. Se o quadrado médio 
entre tratamentos apresentar valor bem superior ao quadrado médio dentro dos tratamentos, a hipótese de pesquisa, segundo a qual as médias comparadas são iguais, poderá ser rejeitada, confirmando-se a hipótese nula $\mathrm{H}_{0}$.

Essa comparação deverá ser feita com rigor matemático, fundamentando-se na teoria da probabilidade (CARPINETTI, 2000). A estatística utilizada para testar diferenças entre médias é a "estatística $F$ ", determinada pela razão entre dois quadrados médios ou duas variâncias, conforme eq. (2.43), na qual $v_{l}$ representa o grau de liberdade do quadrado médio $1(Q M 1)$ e $\mathrm{v}_{2}$, o grau de liberdade do quadrado médio 2 (QM2).

$$
F_{v_{1}, v_{2}}=\frac{Q M_{1}}{Q M_{2}}
$$

O teste $F$ de Snedecor baseia-se na comparação do valor de $F$ calculado a partir dos resultados observados (eq. 2.44) com valores de $F$ tabelados, obtidos a partir de uma distribuição de probabilidades da razão entre variâncias de duas amostras, extraídas aleatoriamente de uma mesma população com distribuição normal. São tabelados valores de $F$ em função do nível de significância e dos graus de liberdade das variâncias do numerador e do denominador $\left(v_{l}\right.$ e $v_{2}$, respectivamente). O nível de significância $\alpha$ é igual a um menos o nível de confiança adotado. Níveis de significância usualmente aceitos são $\alpha=0,01 ; 0,05$ ou 0,1 , correspondentes a níveis de confiança ou probabilidades de 99\%, 95\% e 90\%, respectivamente (PIRATELLI FILHO, 1997). Dessa forma, o valor de $F$ tabelado é representado na forma $F_{\alpha, v l, v 2}$, sendo denominado de valor crítico de $F$.

$$
F_{m-1, N-m}=\frac{Q M_{\text {trataments }}}{Q M_{\text {erro }}}
$$

Se o valor de $F$ calculado for maior do que o valor tabelado, pode-se afirmar com uma confiança de [(1 - $\alpha) 100] \%$ que as médias são diferentes e portanto aceita-se a hipótese nula. 
O resumo dos resultados da análise de variância geralmente mostra-se no formato apresentado na Tabela 2.3.

Tabela 2.3 - Quadro de análise de variância (ANOVA)

\begin{tabular}{ccccc}
\hline fonte de variação & $\begin{array}{c}\text { graus de } \\
\text { liberdade } \\
(\mathrm{GL})\end{array}$ & $\begin{array}{c}\text { soma de } \\
\text { quadrados } \\
(\mathrm{SQ})\end{array}$ & $\begin{array}{c}\text { quadrado médio } \\
(\mathrm{QM})\end{array}$ & $\begin{array}{c}\text { razão entre QM } \\
(\mathrm{F})\end{array}$ \\
\hline $\begin{array}{c}\text { variação entre } \\
\text { tratamentos }\end{array}$ & $m-1$ & $\mathrm{SQ}_{\text {trat }}$ & $Q M_{\text {trat }}=\frac{S Q_{\text {trat }}}{(m-1)}$ & $F=\frac{Q M_{\text {trat }}}{Q M_{\text {erro }}}$ \\
\hline $\begin{array}{c}\text { variação dentro } \\
\text { de cada } \\
\text { tratamento } \\
\text { (erro) }\end{array}$ & $\begin{array}{c}N-m \\
\text { ou } \\
m \times(r-1)\end{array}$ & $\mathrm{SQ}_{\text {erro }}$ & $Q M_{\text {erro }}=\frac{S Q_{\text {erro }}}{(N-m)}$ & \\
\hline variação total & $N-1$ & $\mathrm{SQ}_{\text {total }}$ & & \\
\hline
\end{tabular}

Para que os resultados obtidos da análise de variância sejam válidos, é necessário que os dados apresentem distribuição normal e que as variâncias dentro das amostras sejam aproximadamente iguais. Além disso as variáveis devem ser aleatórias.

\subsection{Aplicação do método de análise de variância (ANOVA) a experimentos fatoriais em dois níveis}

Uma vez determinados os efeitos principais e os efeitos de interação entre os fatores de um experimento fatorial em dois níveis, deve-se procurar responder estatisticamente se esses efeitos são ou não significativos. Para isso pode-se utilizar o método de análise de variância ANOVA.

O objetivo da análise de variância é calcular uma estimativa da variância entre tratamentos e uma estimativa da variância dentro dos tratamentos e em seguida comparar a razão entre essas variâncias com um valor apropriado da estatística $F$, função dos graus de liberdade entre tratamentos e dentro dos tratamentos e do nível de significância adotado.

Seja $E$ uma estimativa do efeito a ser testado e $L$, o contraste ortogonal relacionado a esse efeito. De acordo com as eq. (2.14), (2.15), (2.23) e (2.24), temos 


$$
E=\frac{L}{2^{n-1}}
$$

onde

$$
L=\sum_{c=1}^{m} a_{(c)} \bar{Y}_{(c)}
$$

lembrando que

$$
\begin{aligned}
& m=2^{n}=\text { número total de condições experimentais e } \\
& a_{(c)}=+1 \mathrm{ou}-1 .
\end{aligned}
$$

Conforme demonstrado por Garcia-Diaz e Phillips (1995), a soma dos quadrados do contraste $L\left(S Q_{L}\right)$ é

$$
\begin{gathered}
S Q_{L}=L^{2}\left(\sum_{c} \frac{a_{(c)}^{2}}{r}\right)^{-1} \\
S Q_{L}=\frac{r L^{2}}{2^{n}}
\end{gathered}
$$

Como o número de condições experimentais é igual a $2^{n}$, o número de contrastes mutuamente ortogonais é igual a $2^{n}-1$, cada contraste representando um efeito principal ou um efeito de interação.

Considerando-se um experimento com $n$ fatores, o número de efeitos principais e de efeitos de interação entre fatores será dado por,

$$
\begin{aligned}
n & =\text { número de efeitos principais; } \\
\left(\begin{array}{l}
n \\
2
\end{array}\right) & =C_{n, 2}=\frac{n !}{2 !(n-2) !}=\text { número de interações entre dois fatores = combinação }
\end{aligned}
$$
linear entre $n$ fatores tomados dois a dois;

$\left(\begin{array}{l}n \\ 3\end{array}\right)=C_{n, 3}=\frac{n !}{3 !(n-3) !}=$ número de interações entre três fatores; 


$$
\begin{aligned}
& \left(\begin{array}{l}
n \\
p
\end{array}\right)=C_{n, p}=\frac{n !}{p !(n-p) !}=\text { número de interações entre } p \text { fatores; } \\
& \vdots \\
& \left(\begin{array}{l}
n \\
n
\end{array}\right)=C_{n, n}=\frac{n !}{n !(n-n) !}=1=\text { número de interações entre } n \text { fatores }
\end{aligned}
$$

Cada efeito possui um grau de liberdade. O número total de graus de liberdade é dado por $r 2^{n}-1$. Dessa forma, o grau de liberdade do erro é igual a $r 2^{n}-1-\left(2^{n}-1\right)=2^{n}(r-1)$, o que significa que o experimento deve ter pelo menos duas réplicas $(r \geq 2)$ para que possam ser analisados os efeitos de interação entre os fatores.

A soma dos quadrados do erro aleatório pode ser expressa pela eq.(2.47).

$$
S Q_{\text {erro }}=S Q_{\text {total }}-\sum_{i} S Q_{i}-\sum_{i j} S Q_{i j}-\cdots, S Q_{12 \ldots n}
$$

onde

$S Q_{i}$ é a soma dos quadrados relativa ao fator $X_{i}$;

$S Q_{i j}$ é a soma dos quadrados relativa à interação entre os fatores $X_{i}$ e $X_{j}$;

$S Q_{12 \ldots n}$ é a soma dos quadrados relativa à interação entre os fatores $X_{1}, X_{2} \ldots X_{n}$ e

$S Q_{\text {total }}$ é a soma dos quadrados total.

A soma dos quadrados total pode ser obtida pela eq. (2.48).

$$
S Q_{\text {total }}=\sum_{c=1}^{m} \sum_{k=1}^{r} Y_{c k}^{2}-\frac{T^{2}}{N}
$$

onde

$Y_{c k}=k$-ésima observação da $c$-ésima condição experimental;

$m=2^{n}=$ número de condições experimentais;

$T=$ soma total de todas as observações;

$N=$ número total de observações $=r 2^{n}$. 
Seja $S Q^{*}$ a soma dos quadrados de todas as observações (eq. 2.49) e $G$ o termo de correção (eq.2.50). A soma dos quadrados total pode ser expressa em função de $S Q^{*}$ e $G$ através da eq. (2.51).

$$
\begin{aligned}
S Q^{*} & =\sum_{c=1}^{m} \sum_{k=1}^{r} Y_{c k}^{2} \\
G & =\frac{T^{2}}{N} \\
S Q_{\text {total }} & =S Q^{*}-G
\end{aligned}
$$

A soma dos quadrados dos tratamentos ( $S Q_{\text {tratamentos }}$ ) é dada pela eq.(2.52) e inclui a soma dos quadrados dos efeitos principais dos fatores e dos efeitos de interação entre os fatores.

$$
S Q_{\text {tratamneto }}=\sum_{i=1}^{n} S Q_{i}+\sum_{i=1}^{n} \sum_{j=1}^{n} S Q_{i j}+\ldots S Q_{12 \ldots n}
$$

Os quadrados médios para o caso de experimentos fatoriais em dois níveis tornam-se

$$
\begin{gathered}
Q M_{\text {total }}=\frac{S Q_{\text {total }}}{G L_{\text {total }}}=\frac{S Q_{\text {total }}}{r 2^{n}-1} \\
Q M_{\text {tratamento }}=\frac{S Q_{\text {tratamento }}}{2^{n}-1} \\
Q M_{\text {erro }}=\frac{S Q_{\text {erro }}}{2^{n}(r-1)}
\end{gathered}
$$

onde

$Q M_{\text {total }}$ é o quadrado médio total;

$Q M_{\text {tratamentos }}$ é o quadrado médio dos tratamentos e

$Q M_{\text {erro }}$ é o quadrado médio do erro. 
Para testar se um efeito é significativo, o valor de $F=\frac{M Q_{L}}{M Q_{\text {erro }}}$ deve ser comparado com um valor crítico $F_{1-\alpha(1, v)}$, sendo $v$ o grau de liberdade do erro e $\alpha$ o nível de significância.

Se $F_{\text {calculado }}>F_{\text {tabelado, aceita-se a hipótese nula, concluindo-se que o tratamento }}$ considerado possui efeito significativo no resultado final.

Na Tabela 2.4 é apresentado um modelo geral do quadro de análise de variância para experimentos fatoriais em dois níveis.

Tabela 2.4 - Quadro de análise de variância (ANOVA) para experimentos fatoriais em dois níveis

\begin{tabular}{ccccc}
\hline $\begin{array}{c}\text { fonte de } \\
\text { variação }\end{array}$ & $\begin{array}{c}\text { graus de } \\
\text { liberdade } \\
(\mathrm{GL})\end{array}$ & $\begin{array}{c}\text { soma de } \\
\text { quadrados } \\
(\mathrm{SQ})\end{array}$ & quadrado médio $(\mathrm{QM})$ & $\begin{array}{c}\text { razão entre QM } \\
(\mathrm{F})\end{array}$ \\
\hline $\begin{array}{c}\text { variação entre } \\
\text { tratamentos }\end{array}$ & $2^{\mathrm{n}}-1$ & $\mathrm{SQ}_{\text {trat }}$ & $Q M_{\text {trat }}=\frac{S Q_{\text {trat }}}{\left(2^{n}-1\right)}$ & $F=\frac{Q M_{\text {trat }}}{Q M_{\text {erro }}}$ \\
\hline $\begin{array}{c}\text { variação } \\
\text { dentro de cada } \\
\text { tratamento } \\
\text { ou erro }\end{array}$ & $2^{\mathrm{n}}(\mathrm{r}-1)$ & $\mathrm{SQ}_{\text {erro }}$ & $Q M_{\text {erro }}=\frac{S Q_{\text {erro }}}{\left(2^{n}(r-1)\right)}$ & \\
\hline variação total & $\mathrm{r}^{\mathrm{n}}-1$ & $\mathrm{SQ}_{\text {total }}$ & & \\
\hline
\end{tabular}

\subsection{Experimentos fatoriais fracionários}

Experimentos que buscam estudar a influência de diversos fatores no comportamento de determinada variável aumentam geometricamente com o aumento do número de fatores considerados. Como geralmente se faz necessário testar um número razoavelmente grande de fatores para se proceder a uma investigação sobre quais são os fatores interferentes em determinada resposta de um processo, o referido experimento pode tornar-se impraticável.

Em muitos casos, entretanto, as informações desejadas podem ser obtidas realizando-se apenas uma fração do experimento total, em virtude da redundância existente quando 
muitos fatores são introduzidos em um experimento. Essa redundância origina-se em efeitos desprezíveis, tanto principais como de interação.

Efeitos principais desprezíveis aparecem quando são introduzidos no experimento fatores que não possuem influência na variável de resposta. Por outro lado, observa-se que os efeitos de interação entre os fatores tendem a obedecer a uma certa hierarquia em termos de magnitude absoluta, sendo que os efeitos principais dos fatores geralmente apresentam valores maiores que os efeitos de interação entre dois fatores, que por sua vez tendem a apresentar valores superiores aos efeitos de interação entre três fatores, e assim sucessivamente (BOX et al, 1978). Dessa forma, interações de alta ordem, por exemplo, interações entre quatro fatores, tendem a se tornar desprezíveis, podendo ser desconsideradas.

O planejamento fatorial fracionário baseia-se na exploração dessa redundância, fazendo uso do sistema de confundimento ("confounding"), ou acoplamento, para diminuir o número de ensaios em um experimento. Nesse sistema os efeitos das variáveis de entrada ou fatores encontram-se acoplados, podendo-se realizar apenas uma fração do experimento, com base na consideração de que interações de alta ordem podem ser desconsideradas.

Após a análise dos dados obtidos com a fração escolhida do experimento, pode-se optar pela introdução de frações complementares, podendo-se mesmo vir a realizar o experimento completo, embora na maioria dos casos isso não seja necessário.

\subsubsection{Montagem de experimentos fatoriais fracionários em dois níveis}

A notação que representa experimentos fatoriais fracionários é $w^{k-p}$, sendo $w$ o número de níveis dos fatores, $k$ o número de fatores e $p$ o expoente de fracionamento. Experimentos fracionários com fatores em dois níveis são designados por $2^{k-p}$, sendo que será realizada uma fração de $2^{-p}$ do experimento completo $2^{k}$.

Considere-se um experimento fatorial envolvendo $k$ fatores, todos com dois níveis de variação. $\mathrm{O}$ experimento fatorial completo envolveria $2^{k}$ condições experimentais ou 
tratamentos e através da realização desse experimento poderiam ser determinados $2^{k}-1$ efeitos, nos quais estariam incluídos efeitos de interação de alta ordem.

Optando-se por realizar um experimento fracionário, pode-se diminuir o número de condições experimentais a serem testadas para $2^{k-p}$, correspondentes a uma fração de $1 / 2^{p}$ do experimento completo. Essa redução do experimento implica na conseqüente redução do número de efeitos que podem ser determinados. Realizando-se uma fração de $1 / 2^{p}$ do experimento completo, poderão ser determinados $2^{(k-p)}-1$ efeitos, nos quais haverá a presença de acoplamento, com confundimento de efeitos principais com efeitos de interação entre fatores, e de efeitos de interação entre si (ACHCAR, 1995).

Um experimento fatorial fracionário é montado construindo-se um experimento fatorial completo para $k-p$ fatores, ou seja, construindo-se um experimento $2^{k-p}$, e posteriormente acoplando-se os efeitos principais dos $p$ fatores não utilizados para montagem do experimento a alguns dos efeitos de interação entre os $k$ - $p$ fatores. Dessa forma cada um dos $p$ fatores será adicionado ao experimento sem que ocorra aumento do número de condições experimentais a serem testadas, fazendo seus níveis coincidirem com uma das colunas de sinais representativas das interações entre os $k-p$ fatores. Em decorrência do fracionamento, os efeitos das interações utilizadas para introdução dos $p$ fatores estarão confundidos com os efeitos principais desses $p$ fatores.

A título de ilustração, considere-se um experimento fatorial em dois níveis com quatro fatores, $k=4$, que realizado completo requereria 16 condições experimentais. Suponha que se queira testar apenas 8 condições experimentais, através de um experimento fatorial fracionado em $1 / 2$, ou seja, através de um experimento $2^{4-1}$.

A notação $2^{4-1}$ significa que o experimento acomoda quatro fatores ou variáveis, mas que apenas $2^{4-1}=2^{3}=8$ condições experimentais serão testadas. A escolha das condições experimentais a serem testadas é feita construindo-se inicialmente um experimento fatorial completo com $k$ - $p$ variáveis, ou seja, para o exemplo em questão deve-se construir um experimento fatorial completo $2^{3}$, com três variáveis $X 1, X 2$ e $X 3$, cujo arranjo experimental encontra-se apresentado na Tabela 2.5. Posteriormente introduz-se a quarta variável, fazendo seus níveis coincidirem com uma coluna de interação entre os fatores já utilizados para a montagem do experimento. 
Tabela 2.5 - Arranjo do experimento fatorial completo $2^{3}$

\begin{tabular}{|c|c|c|c|c|c|c|c|}
\hline \multirow{2}{*}{$\begin{array}{c}\text { condições } \\
\text { experimentais }\end{array}$} & \multicolumn{7}{|c|}{$\begin{array}{c}\text { fatores } \\
\text { efeitos principais e de interação }\end{array}$} \\
\hline & $\mathrm{X} 1$ & $\mathrm{X} 2$ & $\mathrm{X} 3$ & $\mathrm{X} 1 \mathrm{X} 2$ & X1X3 & $\mathrm{X} 2 \mathrm{X} 3$ & $\mathrm{X} 1 \mathrm{X} 2 \mathrm{X} 3$ \\
\hline 1 & - & - & - & + & + & + & - \\
\hline 2 & + & - & - & - & - & + & + \\
\hline 3 & - & + & - & - & + & - & + \\
\hline 4 & + & + & - & + & - & - & - \\
\hline 5 & - & - & + & + & - & - & + \\
\hline 6 & + & - & + & - & + & - & - \\
\hline 7 & - & + & + & - & - & + & - \\
\hline 8 & + & + & + & + & + & + & + \\
\hline
\end{tabular}

No caso de experimentos fatoriais fracionados em 1/2, a escolha da fração a ser utilizada é feita considerando-se como gerador a interação de maior ordem, ou seja, a interação entre as $k$ - $p$ variáveis. No caso deve-se escolher como gerador do fator $X 4$ a interação entre os fatores $X 1, X 2$ e $X 3$, designada por $X 1 X 2 X 3$. O arranjo do experimento fatorial fracionário $2^{4-1}$ encontra-se apresentado na Tabela 2.6, onde por facilidade de representação foi eliminada a letra $X$ da designação dos fatores e de suas interações. Dessa forma o fator $X 1$ é designado apenas por 1 , a interação entre os fatores $X 1, X 2$ e $X 3$ é designada apenas por 123 , e assim por diante.

Tabela 2.6 - Arranjo do experimento fatorial fracionário $2^{4-1}$

\begin{tabular}{|c|c|c|c|c|c|c|c|c|c|c|c|c|c|}
\hline \multirow{2}{*}{$\begin{array}{l}\text { cond. } \\
\text { exp. }\end{array}$} & \multicolumn{11}{|c|}{$\begin{array}{c}\text { fatores } \\
\text { efeitos principais e de interação }\end{array}$} & \multirow[b]{2}{*}{134} & \multirow[b]{2}{*}{234} \\
\hline & 1 & 2 & 3 & 12 & 13 & 23 & $123=4$ & 14 & 24 & 34 & 124 & & \\
\hline 1 & - & - & - & + & + & + & - & + & + & + & - & - & - \\
\hline 2 & + & - & - & - & - & + & + & + & - & - & - & - & + \\
\hline 3 & - & + & - & - & + & - & + & - & + & - & - & + & - \\
\hline 4 & + & + & - & + & - & - & - & - & - & + & - & + & + \\
\hline 5 & - & - & + & + & - & - & + & - & - & + & + & - & - \\
\hline 6 & + & - & + & - & + & - & - & - & + & - & + & - & + \\
\hline 7 & - & + & + & - & - & + & - & + & - & - & + & + & - \\
\hline 8 & + & + & + & + & + & + & + & + & + & + & + & + & + \\
\hline
\end{tabular}

Pode-se observar na Tabela 2.6 que a coluna de sinais correspondente à interação entre os fatores $X 1 X 2 X 3$ foi utilizada para definir os níveis da variável $X 4$. Através desse procedimento foi escolhida uma fração adequada do experimento completo $2^{4}$, correspondente à metade das condições experimentais, conforme pode ser verificado pela Figura 2.1, na qual as condições experimentais a serem utilizadas foram destacadas por asteriscos. 


\begin{tabular}{|c|c|c|c|c|c|}
\cline { 3 - 6 } \multicolumn{2}{c|}{} & \multicolumn{2}{c|}{$\mathrm{X} 1(-)$} & \multicolumn{2}{c|}{ X1 (+) } \\
\cline { 2 - 6 } \multicolumn{2}{c|}{} & $\mathrm{X} 2(-)$ & $\mathrm{X} 2(+)$ & $\mathrm{X} 2(-)$ & $\mathrm{X} 2(+)$ \\
\hline \multirow{3}{*}{$\mathrm{X} 3(-)$} & $\mathrm{X} 4(-)$ & $*$ & & & $*$ \\
\cline { 2 - 6 } & $\mathrm{X} 4(+)$ & & $*$ & $*$ & \\
\hline \multirow{2}{*}{$\mathrm{X} 3(+)$} & $\mathrm{X} 4(-)$ & & $*$ & $*$ & \\
\cline { 2 - 6 } & $\mathrm{X} 4(+)$ & $*$ & & & $*$ \\
\hline
\end{tabular}

Figura 2.1 - Escolha da fração do experimento $2^{4-1}$ a ser utilizada

A utilização de experimentos fatoriais fracionários diminui o número de condições experimentais a serem testadas mas em contrapartida o número de efeitos que podem ser estudados também diminui. No exemplo em questão, com o experimento completo poderiam ser determinados $2^{4}-1=15$ efeitos, sendo quatro efeitos principais e onze efeitos de interações entre os fatores. Realizando-se o experimento fracionado em $1 / 2,0$ número de efeitos independentes que podem ser estimados cai para $2^{4-1}-1=7$, significando uma perda de material para análise.

Isso ocorre devido ao acoplamento de efeitos existente em experimentos fatoriais fracionários. Como exemplo pode-se observar que as colunas 12 e 34 da Tabela 2.6 são idênticas, resultado do confundimento ou acoplamento dos efeitos de interação dos fatores $X 1$ e $X 2$ e dos fatores $X 3$ e X4. As interações 12 e 34 são denominadas sinônimos.

Utiliza-se o símbolo $L_{12}$ para designar a função linear das observações pertencentes ao efeito de interação entre os fatores $X 1$ e $X 2$ e $L_{34}$ para designar a função linear das observações pertencentes ao efeito de interação entre os fatores $X 3$ e $X 4$. Sendo $L_{12}=$ $L_{34}$, indica-se $L_{12} \rightarrow 12+34$, notação que representa o padrão de "confundimento" ou padrão de acoplamento dos efeitos das interações entre esses fatores.

Os padrões de acoplamento, que definem os efeitos que estarão acoplados, são determinados pela relação definidora do experimento fatorial fracionário, que por sua vez é obtida a partir dos geradores e de suas multiplicações dois a dois, três a três e assim por diante, incluindo todas as combinações possíveis. 
As relações geradoras de um experimento fatorial fracionário $2^{k-p}$ são aquelas que associam os níveis das $p$ variáveis às interações das $k$ - $p$ variáveis utilizadas para a montagem do experimento.

No caso do exemplo dado, a relação geradora do experimento fatorial fracionado em 1/2 é

$$
X 4=X 1 X 2 X 3
$$

Multiplicando-se ambos os lados da eq.(2.56) pela coluna de sinais da variável $X 4$, obtém-se

$$
\begin{aligned}
X 4 \times X 4 & =X 1 X 2 X 3 \times X 4 \\
X 4^{2} & =X 1 X 2 X 3 X 4
\end{aligned}
$$

Como a multiplicação de colunas com elementos idênticos fornece uma coluna de sinais positivos, designada por $I$, o padrão de acoplamento resulta em

$$
I=X 1 X 2 \times 3 \times 4
$$

A relação expressa pela eq.(2.59) é denominada gerador do experimento. A combinação $X 1 X 2 X 3 X 4$ é referida como "palavra". Experimentos fracionados em $1 \frac{1}{2}$ possuem apenas um gerador e consequentemente a relação definidora do experimento confunde-se com a relação geradora. Em geral um experimento $2^{k-p}$ é produzido por $p$ geradores e possui uma relação definidora com $2^{p}-1$ palavras.

A relação definidora, que inclui os geradores e todas as outras palavras que podem ser obtidas multiplicando-se os geradores entre si, constitui a base de determinação dos padrões de acoplamento ou padrões de sobreposição. A regra prática consiste em multiplicar-se ambos os membros da relação definidora pela coluna do efeito cujos sinônimos ou padrões de acoplamento se desejam determinar. Ou seja, para se encontrar os padrões de acoplamento de determinado efeito, todas as palavras da relação definidora devem ser multiplicadas pelo referido efeito. 
No exemplo em questão, a relação definidora é $I=X 1 X 2 X 3 X 4$. Multiplicando-se ambos os membros dessa relação por $X 1$ obtém-se $X 1=X 1^{2} X 2 X 3 X 4$, ou seja, $X 1=X 2 X 3 X 4$, o que significa que o efeito de $X 1$ confunde-se com o efeito da interação entre os fatores $X 2 X 3 X 4$. De forma semelhante podem ser obtidos os demais padrões de acoplamento, que devem ser destacados e apresentados em um quadro, quando se realiza o planejamento de um experimento fatorial fracionário.

A técnica de fracionamento de experimentos também pode ser utilizada para introduzir novos fatores em determinado experimento, sem aumentar o número de condições experimentais a serem testadas. Por exemplo, o planejamento do experimento fatorial completo com quatro fatores apresentado na Tabela 2.7 poderia ser transformado em um planejamento fatorial fracionário de resolução $V$, com cinco fatores. Para isso bastaria incluir no experimento um quinto fator em dois níveis $X 5$, confundindo-se o efeito de $X 5$ com o efeito da interação entre os fatores $X 1 X 2 X 3 X 4$.

Tabela 2.7 - Arranjo do experimento fatorial completo $2^{4}$

\begin{tabular}{|c|c|c|c|c|c|c|c|c|c|c|c|c|c|c|c|}
\hline \multirow{2}{*}{$\begin{array}{l}\text { cond } \\
\text { exp }\end{array}$} & \multicolumn{15}{|c|}{ efeitos dos fatores e de suas interações } \\
\hline & $\mathrm{X} 1$ & $\mathrm{X} 2$ & $\mathrm{X} 3$ & $\mathrm{X} 4$ & 12 & 13 & 14 & 23 & 24 & 34 & 123 & 124 & 134 & 234 & 1234 \\
\hline 1 & - & - & - & - & + & + & + & + & + & + & - & - & - & - & + \\
\hline 2 & + & - & - & - & - & - & - & + & + & + & + & + & + & - & - \\
\hline 3 & - & + & - & - & - & + & + & - & - & + & + & + & - & + & - \\
\hline 4 & + & + & - & - & + & - & - & - & - & + & - & - & + & + & + \\
\hline 5 & - & - & + & - & + & - & + & - & + & - & + & - & + & + & - \\
\hline 6 & + & - & + & - & - & + & - & - & + & - & - & + & - & + & + \\
\hline 7 & - & + & + & - & - & - & + & + & - & - & - & + & + & - & + \\
\hline 8 & + & + & + & - & + & + & - & + & - & - & + & - & - & - & - \\
\hline 9 & - & - & - & + & + & + & - & + & - & - & - & + & + & + & - \\
\hline 10 & + & - & - & + & - & - & + & + & - & - & + & - & - & + & + \\
\hline 11 & - & + & - & + & - & + & - & - & + & - & + & - & + & - & + \\
\hline 12 & + & + & - & + & + & - & + & - & + & - & - & + & - & - & - \\
\hline 13 & - & - & + & + & + & - & - & - & - & + & + & + & - & - & + \\
\hline 14 & + & - & + & + & - & + & + & - & - & + & - & - & + & - & - \\
\hline 15 & - & + & + & + & - & - & - & + & + & + & - & - & - & + & - \\
\hline 16 & + & + & + & + & + & + & + & + & + & + & + & + & + & + & + \\
\hline
\end{tabular}

Dessa forma, o planejamento da Tabela 2.7 pode representar diversos tipos de planejamentos fatoriais fracionários, bastando para isso confundir os efeitos de interação entre os fatores utilizados com os efeitos de novos fatores. 


\subsubsection{Resolução de experimentos fatoriais fracionários}

Experimentos fatoriais fracionários possuem a desvantagem do acoplamento de efeitos, que aumenta com o aumento do grau de fracionamento.

O grau de fracionamento de um experimento é representado pela sua resolução, sendo inversamente proporcional a essa, ou seja, quanto maior a resolução de um experimento menor é o grau de fracionamento e consequentemente menor é o acoplamento de efeitos.

Por exemplo, seja um experimento fatorial em dois níveis com cinco fatores, fracionado em $1 \frac{2}{2}$. Fazendo-se com que o nível de um dos fatores seja função dos níveis dos demais fatores, tem-se um experimento de resolução $V$, o que significa que o efeito principal dos fatores é confundido com o efeito de interação entre quatro fatores e o efeito de interação entre dois fatores é confundido com o efeito de interação entre três fatores.

Um experimento com quatro fatores em dois níveis, fracionado em 1/2, com relação definidora $I=X 1 X 2 X 3 X 4$, possui resolução $I V$, o que significa que efeitos principais dos fatores são confundidos com efeitos de interação entre três fatores e efeitos de interação entre dois fatores são confundidos entre si.

Quanto maior for o fracionamento do arranjo fatorial, menor será o poder de resolução do experimento (PIRATELLI FILHO, 1997).

A notação utilizada para designar a resolução do experimento é uma letra apropriada em algarismo romano anexada como subscrito. Por exemplo, um experimento fatorial fracionário em dois níveis, com resolução $V$, é indicado por $2_{V}^{k-p}$.

Em geral, a resolução de um experimento fracionário em dois níveis é igual ao comprimento da palavra mais curta da relação definidora (BOX et al, 1978). Sendo $R$ a resolução de um experimento, isso significa que nenhum efeito de interação entre $p$ fatores é confundido com efeitos de interação entre menos de $R$ - $p$ fatores. 


\subsubsection{Análise de variância de experimentos fatoriais fracionários}

Experimentos fatoriais fracionários $2^{k-p}$ podem ser analisados da mesma forma que experimentos completos $2^{n}$, substituindo-se $n$ por $k$-p nas equações de análise. Procedendo-se dessa forma, as equações para obtenção das combinações lineares $(L)$, dos efeitos $(E)$ e das somas dos quadrados $(S Q)$ tornam-se

$$
\begin{aligned}
& L=\sum \frac{a_{(c)} T_{(c)}}{r} \\
& E=\frac{L}{2^{k-p-1}} \\
& S Q_{L}=\frac{r L^{2}}{2^{k-p}}
\end{aligned}
$$

sendo

$r$ = número de réplicas para cada condição experimental;

$c=$ número do tratamento ou condição experimental;

$T_{(c)}=$ total das $r$ observações da $c$-ésima condição experimental ou tratamento;

$E=$ efeitos principais ou de interação entre os fatores;

$L=$ combinação linear das observações pertencentes ao efeito a ser determinado;

$a_{(c)}=+1$ ou -1 , conforme o nível do fator; $\sum a_{(c)}=0$;

$S Q_{L}=$ soma dos quadrados para o efeito considerado;

$p=$ expoente de fracionamento;

$k=$ número de fatores.

\subsection{Experimentos fatoriais fracionários com fatores em níveis variados}

Em algumas situações ocorre a necessidade de se introduzir em um experimento fatores que possuem mais de dois níveis de variação. Isso acontece geralmente quando o experimento engloba fatores quantitativos e qualitativos, havendo a possibilidade dos fatores qualitativos possuírem três ou quatro níveis diferentes (WANG e WU, 1991). 
Experimentos onde os fatores não ocorrem todos no mesmo nível são denominados experimentos fatoriais assimétricos (ADDELMAN, 1962a; ADDELMAN, 1962b).

Para que o planejamento e a análise de experimentos com fatores em níveis variados possam ser realizados com relativa simplicidade e funcionalidade, convém acomodar os fatores com mais de dois níveis de variação em planejamentos fatoriais em dois níveis $2^{n}$. Com esse objetivo, utiliza-se o artifício de transformação de fatores com três ou quatro níveis em dois fatores com dois níveis de variação (CHENG, 1989; MONTGOMERY, 1997).

Como exemplo ilustrativo do procedimento a ser seguido, seja um experimento fatorial com três fatores $X 1, A$ e $B$, tendo o fator $X 1$ dois níveis de variação, o fator $A$ três níveis e o fator $B$ quatro níveis.

A transformação do fator $A$, com três níveis de variação, em dois fatores $X 2$ e $X 3$ de dois níveis é feita de acordo com a associação de níveis apresentada na Tabela 2.8, conforme sugerido por Grove e Davis (1991) e Montgomery (1997). A transformação do fator $B$, com quatro níveis de variação, em dois fatores $X 4$ e $X 5$ de dois níveis é feita de acordo com a associação apresentada na Tabela 2.9, seguindo sugestão de Mason et al. (1989) e Montgomery (1997).

Tabela 2.8 - Transformação do fator $A$ com três níveis de variação em dois fatores $X 2$ e $X 3$ de dois níveis

\begin{tabular}{ccc}
\hline \multicolumn{2}{l}{ fatores em dois níveis } & fator em três níveis \\
$X 2$ & $X 3$ & $A$ \\
\hline- & - & nível 0 \\
+ & - & nível 1 \\
- & + & nível 1 \\
+ & + & nível 2 \\
\hline
\end{tabular}

Tabela 2.9 - Transformação do fator $B$ com quatro níveis de variação em dois fatores $X 4$ e $X 5$ de dois níveis

\begin{tabular}{ccc}
\hline \multicolumn{2}{c}{ fatores em dois níveis } & fator em quatro níveis \\
$X 4$ & $X 5$ & $B$ \\
\hline- & - & nível 0 \\
+ & - & nível 1 \\
- & + & nível 2 \\
+ & + & nível 3 \\
\hline
\end{tabular}


Dessa forma, o experimento fatorial $2 \times 3 \times 4$ pode ser acomodado em um experimento com cinco fatores em dois níveis, $2^{5}$. Pode-se notar que o experimento $2 \times 3 \times 4$ envolve 24 condições experimentais, enquanto que o experimento $2^{5}$ envolve 32 condições experimentais. As 8 condições experimentais adicionais que aparecem com a utilização do artifício de transformação de variáveis na verdade são réplicas referentes ao nível intermediário da variável em três níveis, acrescentadas apenas para facilitar a análise dos dados. Ou seja, em laboratório continuariam a ser testadas 24 condições experimentais.

$\mathrm{O}$ arranjo do planejamento fatorial em dois níveis $2^{5}$ é apresentado na Tabela 2.10, na qual encontram-se as cinco colunas de sinais correspondentes aos efeitos principais dos fatores, as dez colunas de sinais correspondentes aos efeitos de interação entre dois fatores, seis colunas referentes à interação entre três fatores, uma coluna referente à interação entre quatro fatores e a coluna correspondente à interação entre os cinco fatores. Dos trinta e um efeitos que podem ser obtidos a partir de um experimento $2^{5}$ deixaram de ser incluídos na Tabela 2.10 quatro efeitos de interação entre três fatores e quatro efeitos de interação entre quatro fatores, redução realizada para melhor visualização dos dados apresentados.

O cálculo do efeito principal do fator X1 deve ser feito considerando-se apenas as linhas da Tabela 2.10 nas quais o fator $A$ encontra-se nos níveis mais baixo (nível 0) e mais alto (nível 2), desconsiderando-se as linhas correspondentes ao nível intermediário do fator $A$ (nível 1). Dessa forma o efeito principal de $X 1$ deve ser calculado com as linhas $1,2,7,8,9,10,15,16,17,18,23,24,25,26,31$ e 32 da Tabela 2.10. A mesma regra é válida para cálculo dos efeitos de $X 4, X 5, X 4 X 5, X 1 X 4, X 1 X 5$ e $X 1 X 4 X 5$. Os demais efeitos principais e de interação devem ser calculados considerando-se todas as condições experimentais envolvidas no experimento. 
Tabela 2.10 - Arranjo do planejamento fatorial $2^{5}$

\begin{tabular}{|c|c|c|c|c|c|c|c|c|c|c|c|c|c|c|c|c|c|c|c|c|c|c|c|}
\hline \multirow{3}{*}{$\begin{array}{l}\text { cond } \\
\text { exp }\end{array}$} & \multicolumn{23}{|c|}{ efeitos dos fatores e de suas interações } \\
\hline & \multirow[b]{2}{*}{$\mathrm{X} 1$} & \multicolumn{3}{|c|}{ A } & \multicolumn{3}{|c|}{$\mathrm{B}$} & \multicolumn{3}{|c|}{$\mathrm{X} 1 \mathrm{~A}$} & \multicolumn{3}{|c|}{$\mathrm{X} 1 \mathrm{~B}$} & \multicolumn{9}{|c|}{ interação entre os fatores $\mathrm{A}$ e B } & \multirow[b]{2}{*}{12345} \\
\hline & & $\mathrm{X} 2$ & $\overline{X 3}$ & 23 & $\mathrm{X} 4$ & $\mathrm{x} 5$ & 45 & 12 & 13 & $\overline{123}$ & 14 & 15 & 145 & 24 & 25 & 245 & 34 & 35 & 345 & 234 & 235 & 2345 & \\
\hline 1 & - & - & - & + & - & - & + & + & + & - & + & + & - & + & + & - & + & + & - & - & - & + & - \\
\hline 2 & + & - & - & + & - & - & + & - & - & + & - & - & + & + & + & - & + & + & - & - & - & + & + \\
\hline *3 & - & + & - & - & - & - & + & - & + & + & + & + & - & - & - & + & + & + & - & + & + & - & + \\
\hline${ }^{*} 4$ & + & + & - & - & - & - & + & + & - & - & - & - & + & - & - & + & + & + & - & + & + & - & - \\
\hline${ }^{*} 5$ & - & - & + & - & - & - & + & + & - & + & + & + & - & + & + & - & - & - & + & + & + & - & + \\
\hline${ }^{*} 6$ & + & - & + & - & - & - & + & - & + & - & - & - & + & + & + & - & - & - & + & + & + & - & - \\
\hline 7 & - & + & + & + & - & - & + & - & - & - & + & + & - & - & - & + & - & - & + & - & - & + & - \\
\hline 8 & + & + & + & + & - & - & + & + & + & + & - & - & + & - & - & + & - & - & + & - & - & + & + \\
\hline 9 & - & - & - & + & + & - & - & + & + & - & - & + & + & - & + & + & - & + & + & + & - & - & + \\
\hline 10 & + & - & - & + & + & - & - & - & - & + & + & - & - & - & + & + & - & + & + & + & - & - & - \\
\hline${ }^{*} 11$ & - & + & - & - & + & - & - & - & + & + & - & + & + & + & - & - & - & + & + & - & + & + & - \\
\hline${ }^{*} 12$ & + & + & - & - & + & - & - & + & - & - & + & - & - & + & - & - & - & + & + & - & + & + & + \\
\hline${ }^{*} 13$ & - & - & + & - & + & - & - & + & - & + & - & + & + & - & + & + & + & - & - & - & + & + & - \\
\hline${ }^{*} 14$ & + & - & + & - & + & - & - & - & + & - & + & - & - & - & + & + & + & - & - & - & + & + & + \\
\hline 15 & - & + & + & + & + & - & - & - & - & - & - & + & + & + & - & - & + & - & - & + & - & - & + \\
\hline 16 & + & + & + & + & + & - & - & + & + & + & + & - & - & + & - & - & + & - & - & + & - & - & - \\
\hline 17 & - & - & - & + & - & + & - & + & + & - & + & - & + & + & - & + & + & - & + & - & + & - & + \\
\hline 18 & + & - & - & + & - & + & - & - & - & + & - & + & - & + & - & + & + & - & + & - & + & - & - \\
\hline${ }^{*} 19$ & - & + & - & - & - & + & - & - & + & + & + & - & + & - & + & - & + & - & + & + & - & + & - \\
\hline${ }^{*} 20$ & + & + & - & - & - & + & - & + & - & - & - & + & - & - & + & - & + & - & + & + & - & + & + \\
\hline${ }^{*} 21$ & - & - & + & - & - & + & - & + & - & + & + & - & + & + & - & + & - & + & - & + & - & + & - \\
\hline *22 & + & - & + & - & - & + & - & - & + & - & - & + & - & + & - & + & - & + & - & + & - & + & + \\
\hline 23 & - & + & + & + & - & + & - & - & - & - & + & - & + & - & + & - & - & + & - & - & + & - & + \\
\hline 24 & + & + & + & + & - & + & - & + & + & + & - & + & - & - & + & - & - & + & - & - & + & - & - \\
\hline 25 & - & - & - & + & + & + & + & + & + & - & - & - & - & - & - & - & - & - & - & + & + & + & - \\
\hline 26 & + & - & - & + & + & + & + & - & - & + & + & + & + & - & - & - & - & - & - & + & + & + & + \\
\hline *27 & - & + & - & - & + & + & + & - & + & + & - & - & - & + & + & + & - & - & - & - & - & - & + \\
\hline${ }^{*} 28$ & + & + & - & - & + & + & + & + & - & - & + & + & + & + & + & + & - & - & - & - & - & - & - \\
\hline *29 & - & - & + & - & + & + & + & + & - & + & - & - & - & - & - & - & + & + & + & - & - & - & + \\
\hline${ }^{*} 30$ & + & - & + & - & + & + & + & - & + & - & + & + & + & - & - & - & + & + & + & - & - & - & - \\
\hline 31 & - & + & + & + & + & + & + & - & - & - & - & - & - & + & + & + & + & + & + & + & + & + & - \\
\hline 32 & + & + & + & + & + & + & + & + & + & + & + & + & + & + & + & + & + & + & + & + & + & + & + \\
\hline
\end{tabular}

obs.: por facilidade de representação utilizou-se a notação 12 para indicar o efeito de interação entre os fatores $X 1$ e $X 2,13$ para indicar o efeito de interação entre os fatores $X 1$ e $X 3$, e assim sucessivamente.

O fator $A$, com três níveis de variação, possui dois graus de liberdade, podendo-se considerá-lo dividido em duas componentes, linear $\left(A_{L}\right)$ e quadrática $\left(A_{Q}\right)$, cada componente com um grau de liberdade (MARGOLIN, 1967; BOX et al., 1971). O efeito linear de $A$ é obtido a partir da soma de dois efeitos, calculados com as colunas de sinais $X 2$ e $X 3$.

O efeito da interação entre os fatores $X 1$ e $A$ deve ser calculado somando-se o efeito de interação entre $X 1$ e $A_{L}$ com o efeito de interação entre $X 1$ e $A_{Q}$, sendo que o efeito de 
interação entre $X 1$ e $A_{L}$ também deve ser calculado pela soma dos efeitos de duas colunas de interação, $X 1 X 2$ e $X 1 X 3$. Deve-se observar que as linhas 3 e 5 são réplicas uma da outra, equivalendo a um grau de liberdade quando utilizadas para estimativa do erro. Outras linhas ou condições experimentais que se encontram replicadas são 4 e 6 ; 11 e $13 ; 12$ e $14 ; 19$ e $21 ; 20$ e 22; 27 e $29 ; 28$ e 30 . No total são oito graus de liberdade que podem ser utilizados para estimativa do erro. A variância média desses oito pares de linhas poderia ser utilizada como o quadrado médio do erro, com oito graus de liberdade. O resumo da análise de variância do experimento encontra-se apresentado na Tabela 2.11 .

O efeito do fator $B$, com quatro níveis de variação, equivale à soma dos efeitos de $X 4$, $X 5$ e X4X5, mutuamente ortogonais, correspondendo aos três graus de liberdade do fator $B$. Em geral, o grau de liberdade do efeito principal de um fator é igual ao número de níveis do referido fator menos um, e o grau de liberdade do efeito de interação entre fatores é igual à multiplicação dos graus de liberdade dos efeitos principais dos fatores considerados na interação.

O exemplo utilizado refere-se a um experimento completo, mas o artifício de transformação de fatores de três ou quatro níveis em fatores de dois níveis também pode ser aplicado a planejamentos de experimentos fatoriais fracionários (ADDELMAN, 1962b).

O planejamento do experimento fatorial completo apresentado na Tabela 2.10 poderia ser transformado em um planejamento fatorial fracionário de resolução $I V$, com cinco fatores, sendo um fator com três níveis de variação, um com quatro níveis de variação e três fatores com dois níveis de variação. Para isso bastaria incluir no experimento dois fatores de dois níveis $X 6$ e $X 7$, confundindo-se o efeito de $X 6$ com o efeito da interação entre os fatores $X 2 X 3 X 4$, e o efeito de $X 7$ com o efeito da interação entre os fatores X2X4X5.

Dessa forma, o planejamento da Tabela 2.10 pode representar diversos tipos de planejamentos fatoriais fracionários, bastando para isso confundir os efeitos de interação entre os fatores utilizados com os efeitos de novos fatores. Cabe ressaltar que as colunas de sinais correspondentes às interações $X 2 X 3$ e $X 4 X 5$ não podem ser 
utilizadas para a introdução de novas variáveis, uma vez que correspondem aos efeitos quadráticos dos fatores $A$ e $B$, respectivamente (MONTGOMERY, 1997).

Tabela 2.11 - Análise de variância do planejamento fatorial com três fatores, em dois, três e quatro níveis

fonte de variação

$\begin{array}{ccc}\text { graus de } & \text { soma de quadrados } & \text { quadrado médio } \\ \text { liberdade } & (\mathrm{SQ}) & (\mathrm{QM})\end{array}$

(GL)

\begin{tabular}{|c|c|c|c|}
\hline $\mathrm{X} 1$ & 1 & $\mathrm{SQ}_{\mathrm{X} 1}$ & $\mathrm{QM}_{\mathrm{X} 1}$ \\
\hline $\begin{array}{l}A\left(A_{L}+A_{Q}\right) \\
A=X 2+X 3+X 2 X 3\end{array}$ & 2 & $\begin{aligned} \mathrm{SQ}_{\mathrm{A}}= & \mathrm{SQ}_{\mathrm{X} 2}+\mathrm{SQ}_{\mathrm{X} 3}+ \\
& \mathrm{SQ}_{\mathrm{X} 2 \mathrm{X} 3}\end{aligned}$ & $\mathrm{QM}_{\mathrm{A}}$ \\
\hline $\mathrm{B}=\mathrm{X} 4+\mathrm{X} 5+\mathrm{X} 4 \mathrm{X} 5$ & 3 & $\begin{array}{c}\mathrm{SQ}_{\mathrm{B}}=\mathrm{SQ}_{\mathrm{X} 4}+\mathrm{SQ}_{\mathrm{X} 5}+ \\
\mathrm{SQ}_{\mathrm{X} 4 \mathrm{X} 5}\end{array}$ & $\mathrm{QM}_{\mathrm{B}}$ \\
\hline $\begin{array}{l}X 1 \times A=\left(X 1 \times A_{L}+X 1 \times A_{Q}\right) \\
X 1 \times A=X 1 X 2+X 1 X 3+X 1 X 2 X 3\end{array}$ & 2 & $\begin{array}{l}\mathrm{SQ}_{\mathrm{X} 1 \mathrm{~A}}=\mathrm{SQ}_{\mathrm{X} 1 \mathrm{X} 2}+ \\
\mathrm{SQ}_{\mathrm{X} 1 \mathrm{X} 3}+\mathrm{SQ}_{\mathrm{X} 1 \mathrm{X} 2 \mathrm{X} 3}\end{array}$ & $\mathrm{QM}_{\mathrm{X} 1 \mathrm{~A}}$ \\
\hline $\mathrm{X} 1 \times \mathrm{B}=\mathrm{X} 1 \mathrm{X} 4+\mathrm{X} 1 \mathrm{X} 5+\mathrm{X} 1 \mathrm{X} 4 \mathrm{X} 5$ & 3 & $\begin{array}{l}\mathrm{SQ}_{\mathrm{X} 1 \mathrm{~B}}=\mathrm{SQ}_{\mathrm{X} 1 \mathrm{X} 4}+ \\
\mathrm{SQ}_{\mathrm{X} 1 \mathrm{X} 5}+\mathrm{SQ}_{\mathrm{X} 1 \mathrm{X} 4 \mathrm{X} 5}\end{array}$ & $\mathrm{QM}_{\mathrm{X} 1 \mathrm{~B}}$ \\
\hline $\begin{array}{l}\mathrm{A} \times \mathrm{B}=\mathrm{X} 2 \mathrm{X} 4+\mathrm{X} 2 \mathrm{X} 5+\mathrm{X} 2 \mathrm{X} 4 \mathrm{X} 5+ \\
\mathrm{X} 3 \mathrm{X} 4+\mathrm{X} 3 \mathrm{X} 5+\mathrm{X} 3 \mathrm{X} 4 \mathrm{X} 5+\mathrm{X} 2 \mathrm{X} 3 \mathrm{X} 4+ \\
\mathrm{X} 2 \mathrm{X} 3 \mathrm{X} 5+\mathrm{X} 2 \mathrm{X} 3 \mathrm{X} 4 \mathrm{X} 5\end{array}$ & 6 & $\mathrm{SQ}_{\mathrm{AB}}$ & $\mathrm{QM}_{\mathrm{A} \mathrm{B}}$ \\
\hline $\begin{array}{l}\mathrm{X} 1 \times \mathrm{A} \times \mathrm{B}=\mathrm{X} 1 \mathrm{X} 2 \mathrm{X} 4+\mathrm{X} 1 \mathrm{X} 2 \mathrm{X} 5+ \\
\mathrm{X} 1 \mathrm{X} 2 \mathrm{X} 4 \mathrm{X} 5+\mathrm{X} 1 \mathrm{X} 3 \mathrm{X} 4+\mathrm{X} 1 \mathrm{X} 3 \mathrm{X} 5+ \\
\mathrm{X} 1 \mathrm{X} 3 \mathrm{X} 4 \mathrm{X} 5+\mathrm{X} 1 \mathrm{X} 2 \mathrm{X} 3 \mathrm{X} 4+\mathrm{X} 1 \mathrm{X} 2 \mathrm{X} 3 \mathrm{X} 5 \\
+\mathrm{X} 1 \mathrm{X} 2 \mathrm{X} 3 \mathrm{X} 4 \mathrm{X} 5\end{array}$ & 6 & $\mathrm{SQ}_{\mathrm{X} 1 \mathrm{~A} \mathrm{~B}}$ & $\mathrm{QM}_{\mathrm{X} 1 \text { A B }}$ \\
\hline erro & 8 & $\mathrm{SQ}_{\text {erro }}$ & $\mathrm{QM}_{\text {erro }}$ \\
\hline variação total & 31 & $\mathrm{SQ}_{\text {total }}$ & \\
\hline
\end{tabular}




\section{ENVELHECIMENTO DE MISTURAS ASFÁLTICAS}

Misturas asfálticas, quando expostas às condições ambientais, sofrem modificações em suas propriedades, tornando-se mais rígidas, mais frágeis e apresentando maior suscetibilidade à desagregação e consequentemente aos efeitos da umidade. Essas modificações são denominadas envelhecimento.

O envelhecimento de misturas asfálticas durante sua vida útil ocorre em duas etapas principais. Durante a fase de mistura dos materiais em usina e posterior construção do pavimento ocorre o processo inicial de envelhecimento, denominado envelhecimento a curto prazo, com perda de componentes voláteis e oxidação do asfalto enquanto a mistura está quente. Uma vez construído o pavimento, a mistura asfáltica ficará exposta às condições climáticas do local, sofrendo o que se denomina envelhecimento a longo prazo.

Dentre as causas do envelhecimento das misturas asfálticas destacam-se a oxidação do asfalto pela reação com o oxigênio da atmosfera; a ação da luz, principalmente da faixa ultravioleta de radiação; e a perda de componentes oleosos do asfalto por absorção por agregado poroso.

O processo de envelhecimento é afetado por fatores como temperatura, radiação solar, umidade, precipitação pluviométrica, tempo de envelhecimento, grau de compactação da mistura (representado pela permeabilidade ou pelo índice de vazios), tipo de asfalto, 
suscetibilidade do asfalto à temperatura, tipo do agregado e espessura da película asfáltica (ou teor de asfalto na mistura). Porém, o modo como cada um desses fatores interfere no envelhecimento sofrido pelo asfalto ainda não se encontra totalmente elucidado. Um melhor entendimento dos fatores influentes nos processos de envelhecimento é essencial para a obtenção de pavimentos asfálticos mais duráveis e resistentes.

\subsection{Envelhecimento do asfalto por oxidação}

Uma das principais causas do envelhecimento de misturas asfálticas é a oxidação sofrida pelo asfalto. Com a oxidação, ou seja, reação das moléculas de asfalto com o oxigênio da atmosfera, ocorre o aumento da viscosidade devido ao aumento das forças de interação molecular, resultante da introdução de oxigênio, uma vez que este possui natureza polar. Entretanto, embora o aumento da viscosidade esteja relacionado com a quantidade de oxidação ocorrida, a resposta do asfalto em termos de mudança de viscosidade não depende apenas da quantidade de produtos de oxidação formados, mas também da origem ou composição do asfalto em questão.

Segundo Petersen (1990), as mudanças nas propriedades físicas do asfalto em virtude da oxidação parecem ser governadas pelo estado de dispersão dos componentes reativos do asfalto, ou seja, parecem depender da capacidade apresentada pela fase solvente do asfalto de manter os componentes polares dispersos durante a oxidação, reduzindo seu efeito no aumento da viscosidade.

Para explicar o mecanismo do processo de oxidação, Petersen (1990) propõe um modelo microestrutural de envelhecimento, mostrando que a cinética do envelhecimento é governada em grande parte por fatores físico-químicos e não simplesmente por reações químicas. Nesse modelo, as moléculas polares se associam para formar microestruturas. Quanto maior o grau de associação, menor a mobilidade dos componentes moleculares e consequentemente menor a capacidade de reação com o oxigênio disponível. 
A influência da temperatura no grau de associação da microestrutura molecular mostrou-se muito significativa no estudo realizado por Petersen (1990). No processo de envelhecimento ocorrido a baixas temperaturas, ou seja, em temperaturas de serviço do pavimento, a taxa de aumento de viscosidade diminui significativamente conforme aumenta o tempo de envelhecimento, o que não acontece nas temperaturas elevadas dos testes acelerados de envelhecimento.

No processo de envelhecimento ocorrido em temperaturas de serviço do pavimento, conforme as moléculas mais reativas (moléculas de asfalteno e moléculas polares aromáticas) se oxidam e se tornam polares, rapidamente se imobilizam em virtude da aglomeração, decorrente da baixa energia térmica do sistema.

Consequentemente, a capacidade das moléculas reagirem com o oxigênio torna-se altamente reduzida, sendo que a taxa de aumento da viscosidade com o tempo de envelhecimento diminui hiperbolicamente, conforme aumenta o tempo de envelhecimento.

Por outro lado, quando o envelhecimento se dá em altas temperaturas, as moléculas mais reativas (aromáticas polares e asfaltenos), mesmo oxidadas, não ficam significativamente imobilizadas em virtude da alta energia térmica do sistema. Desassociadas, essas moléculas continuam produzindo oxidação. Por isso o aumento da viscosidade com o tempo de oxidação, em condições de temperatura elevada, é uma relação praticamente linear.

Petersen (1990) concluiu que os testes de envelhecimento acelerado realizados em temperaturas elevadas geralmente não são indicadores satisfatórios das características de envelhecimento do pavimento no campo. Estudos laboratoriais e de campo sobre envelhecimento de asfalto têm mostrado que o endurecimento do asfalto segue um modelo consistente no qual a taxa de endurecimento é inicialmente bastante elevada, mas decresce progressivamente até que não haja mais endurecimento com o tempo. Essa situação corresponde ao envelhecimento ocorrido em baixas temperaturas (GARRICK, 1995). 
Petersen et al. (1993) constataram que o processo de envelhecimento do asfalto depende da temperatura máxima de serviço do pavimento, função do clima da região, principalmente quando forem utilizados asfaltos com microestrutura molecular altamente associada, ou seja, asfaltos cuja fase solvente possua baixa capacidade de dispersão. Isso porque o processo de envelhecimento desse tipo de asfalto depende fundamentalmente da temperatura de envelhecimento. Em baixas temperaturas as moléculas se encontram imobilizadas devido ao alto grau de associação molecular, o que fisicamente dificulta a oxidação. Por outro lado, em altas temperaturas as moléculas adquirem mobilidade devido à dissociação da microestrutura molecular ocasionada pela alta energia térmica do sistema, tornando possível a ocorrência de oxidação.

Se por um lado a quantidade de aglomeração molecular depende sensivelmente da temperatura do pavimento quando são utilizados asfaltos com baixo grau de dispersão molecular, por outro, em asfaltos com elevada capacidade de manter os componentes polares dispersos, a quantidade de aglomeração molecular será baixa para uma vasta faixa de temperatura, incluindo temperaturas de serviço baixas e altas. Dessa forma a temperatura de envelhecimento influencia principalmente o mecanismo de oxidação de asfaltos com alto grau de associação molecular.

\subsection{Envelhecimento do asfalto pela ação da luz}

Dentre os diversos fatores que afetam o envelhecimento de misturas asfálticas inclui-se a radiação solar. A componente ultravioleta da radiação afeta apenas uma fina camada de ligante da superfície do pavimento, enquanto que a componente infravermelha da radiação aumenta a temperatura média do pavimento, conforme é absorvida (VERHASSELT e CHOQUET, 1993). Bell (1989) relatam diversos estudos nos quais os efeitos da radiação infravermelha foram comparados aos efeitos da radiação ultravioleta, identificando a radiação ultravioleta como a mais danosa em termos de envelhecimento. Além disso, os efeitos da radiação ultravioleta são mais intensos em películas asfálticas com espessuras mais finas.

Button (1996) demonstrou, através da teoria de propagação de ondas de luz, que a radiação ultravioleta quimicamente ativa atinge apenas cerca de dois micrômetros da 
película asfáltica. Entretanto, a ação da radiação ultravioleta sobre o asfalto provoca a formação de compostos solúveis em água. Dessa forma, o ciclo natural das condições climáticas, com chuvas alternadas por sol, pode ter um efeito erosivo sobre o topo da camada de revestimento asfáltico exposta diretamente à luz solar.

Embora o efeito do endurecimento do asfalto provocado pela radiação ultravioleta atinja diretamente apenas uma finíssima película da superfície do revestimento, esse endurecimento pode dar início à formação de trincas térmicas, que em conjunto com a foto-oxidação do asfalto e com a conseqüente formação dos compostos solúveis em água, geram um processo de erosão do revestimento.

\subsection{Envelhecimento do asfalto por perda de componentes oleosos}

O envelhecimento do asfalto por absorção dos componentes oleosos pelo agregado é um fator tanto mais significativo quanto mais voláteis forem os asfaltos que compõem as misturas, e mais porosos forem os agregados (BELL, 1989).

Kemp e Sherman (1984) estudaram a durabilidade de misturas asfálticas através de um programa de ensaios no qual foram testados três tipos de asfalto, dois tipos de agregado, três intervalos de volumes de vazios e quatro condições climáticas. Foram avaliados agregados de dois tipos, agregados com baixa absorção e agregados porosos, com alta absorção. Kemp e Sherman (1984) verificaram que a porosidade do agregado tem efeito significativo na taxa de oxidação sofrida pelo ligante asfáltico em regiões de clima quente. Agregados mais porosos podem absorver os componentes oleosos do asfalto, resultando no envelhecimento da película asfáltica que permanece na superfície.

\subsection{Simulação em laboratório do envelhecimento de misturas asfálticas}

Nos últimos anos, a intensificação do tráfego nas rodovias tem salientado a necessidade do desenvolvimento e aplicação de testes que possam garantir um desempenho 
adequado dos materiais a serem utilizados na construção de pavimentos, a fim de que estes apresentem as características requeridas de durabilidade e resistência.

Em geral, o envelhecimento exerce efeito negativo no desempenho de pavimentos, exceto quanto ao aspecto de formação de trilhas de roda (FINN, 1990), visto que o envelhecimento resulta em endurecimento da mistura asfáltica, o que melhora a distribuição do carregamento, tornando o pavimento mais resistente à deformação permanente. Nos demais aspectos, o endurecimento das misturas asfálticas causado pelo envelhecimento piora o desempenho dos pavimentos, uma vez que ocasiona misturas mais quebradiças, diminuindo a resistência aos efeitos da água e da umidade, o que diminui sua durabilidade (BELL et al., 1990).

Para avaliação da suscetibilidade das misturas asfálticas ao envelhecimento, os processos de envelhecimento a curto e longo prazos devem ser simulados em laboratório através de procedimentos simples, que possam ser utilizados como testes rotineiros de controle das condições das misturas asfálticas a serem utilizadas na construção de pavimentos. Além disso, as características das misturas envelhecidas em laboratório devem ser similares às apresentadas por misturas envelhecidas no campo.

Entretanto, os testes acelerados de envelhecimento a longo prazo em geral não são capazes de simular o envelhecimento ocorrido no campo, uma vez que são realizados em temperaturas muito elevadas, ou seja, muito acima das temperaturas observadas em condições de serviço do pavimento (VERHASSELT e CHOQUET, 1993). Dessa forma, esses testes não são capazes de prever o desempenho real dos pavimentos, uma vez que o mecanismo de envelhecimento a baixas temperaturas é diferente do mecanismo de envelhecimento em temperaturas elevadas. Verhasselt e Choquet (1993) sugerem que as temperaturas dos testes acelerados de envelhecimento a longo prazo variem entre $70^{\circ} \mathrm{e}$ $95^{\circ} \mathrm{C}$.

Considerando-se os diversos fatores que têm influência no processo de envelhecimento de um pavimento em serviço, percebe-se que a simulação desse envelhecimento em laboratório é uma tarefa praticamente impossível. Entretanto, essa simulação torna-se possível simplificando-se o processo através da consideração de que a maioria dos 
fatores interferentes permanecerão constantes, escolhendo-se apenas alguns para serem avaliados.

Diversos autores têm realizado estudos para desenvolvimento de procedimentos padrões que simulem em laboratório o envelhecimento de misturas asfálticas sofrido em campo. Kimet al. (1987) envelheceram misturas asfálticas em laboratório utilizando para isso um método de oxidação por pressão, denominado de POB (pressure oxidation bomb), no qual o asfalto ou a mistura asfáltica são colocados em um recipiente hermeticamente fechado, onde são submetidos a oxigênio puro a uma pressão de 100 psi $(689,5 \mathrm{KPa})$ a $60^{\circ} \mathrm{C}$ por períodos de mais de cinco dias. $\mathrm{O}$ envelhecimento da mistura asfáltica nessas condições mostrou-se equivalente ao envelhecimento ocorrido no campo, em um pavimento com cinco a dez anos de serviço.

Os resultados encontrados por Kim et al. (1987) mostraram que a taxa de envelhecimento é função do índice de vazios ou permeabilidade da mistura asfáltica, e das propriedades do asfalto. A permeabilidade interfere no tempo que o oxigênio leva para penetrar na mistura e reagir com o ligante asfáltico.

Bell et al. (1990) iniciaram um estudo para simulação do envelhecimento de misturas asfálticas em laboratório. Os resultados desse estudo foram apresentados com mais detalhes por Bell et al. (1991).

Para simular o envelhecimento a curto prazo, Bell et al. (1991) testaram dois métodos, o método de envelhecimento em estufa com circulação de ar forçada e o método de envelhecimento com tempo de mistura estendido. O envelhecimento em estufa com circulação de ar forçada foi realizado por períodos de $0 \mathrm{~h}$ (sem envelhecimento), $6 \mathrm{~h}$ e 15 horas, nas temperaturas de $135^{\circ}$ e $163^{\circ} \mathrm{C}$. O envelhecimento com tempo de mistura estendido foi realizado com a utilização do teste RTFO (rolling thin film oven) modificado pela introdução de um anexo que permitisse que a mistura solta fosse espalhada, estendendo o tempo de mistura pelos períodos de 0 (sem envelhecimento), 10,120 e 360 minutos, nas temperaturas de $135^{\circ}$ e $163^{\circ} \mathrm{C}$. O envelhecimento a curto prazo foi simulado com condicionamento da mistura solta, ou seja, não compactada. 
O envelhecimento a longo prazo foi simulado por Bell et al. (1991) de três formas, em uma estufa com circulação de ar forçada (LTOA - long-term oven aging), em um recipiente de oxidação por pressão e em uma célula de teste triaxial (LPO - lowpressure oxidation). Em todos os métodos, foi realizado o condicionamento de amostras compactadas.

No envelhecimento em estufa com circulação de ar forçada, as amostras compactadas foram pré-condicionadas por dois dias nas temperaturas de $40^{\circ}$ e $60^{\circ}$, para garantia de sua estabilidade. Após o período de pré-condicionamento, as amostras foram submetidas a temperatura de $107^{\circ} \mathrm{C}$ pelos períodos de 0,2 e 7 dias, sendo que o período de 0 dia corresponde à condição da mistura sem envelhecimento.

No processo de envelhecimento com oxidação por pressão, com introdução de oxigênio ou ar comprimido, as amostras compactadas foram expostas a condições específicas de temperatura e pressão pelos períodos de 0,2 e 7 dias. Foram utilizadas temperaturas de $25^{\circ}$ e $60^{\circ} \mathrm{C}$, e pressões de $100 \mathrm{psi}(689,5 \mathrm{KPa})$ e $300 \mathrm{psi}(2068,5 \mathrm{KPa})$.

O envelhecimento em célula triaxial foi realizado com condicionamento das amostras enquanto estas eram posicionadas em uma célula de teste triaxial, onde o módulo resiliente poderia ser determinado em qualquer etapa do processo de condicionamento. Foi utilizado um fluxo de $4 \mathrm{ft}^{3} / \mathrm{h}\left(0,113 \mathrm{~m}^{3} / \mathrm{h}\right)$ de oxigênio ou ar comprimido passando pelas amostras, nas condições de 50 psi $(344,75 \mathrm{KPa})$ de pressão e temperaturas de $25^{\circ}$ e $60^{\circ} \mathrm{C}$.

Nos três procedimentos de envelhecimento a longo prazo utilizados por Bell et al. (1991), foram determinadas as características das amostras antes e após o envelhecimento. O estado de envelhecimento das misturas asfálticas foi medido através da razão entre dois módulos, o módulo resiliente medido após o processo de simulação de envelhecimento e o módulo resiliente medido antes do processo de simulação de envelhecimento, com um aumento dessa razão entre módulos significando um aumento do envelhecimento. 
Bell et al. (1991) concluíram que o tempo de envelhecimento e a temperatura interferem significativamente em todos os métodos de simulação de envelhecimento utilizados, tendo encontrado que o envelhecimento das misturas asfálticas aumenta com o aumento da temperatura de condicionamento das amostras e com o tempo de exposição das amostras às condições de condicionamento.

Outros resultados obtidos por Bell et al. (1991) referem-se ao índice de vazios das misturas asfálticas, cujo aumento mostrou ocasionar aumento do envelhecimento, e à permeabilidade, que aumentou com o envelhecimento.

Através de uma revisão da literatura referente à relação entre testes de envelhecimento de misturas asfálticas em laboratório e o desempenho dessas misturas em campo, Bell (1990) constatou que em campo ocorre um aumento hiperbólico da viscosidade com o aumento do tempo de envelhecimento, observando que conforme o tempo de envelhecimento aumenta, diminui a taxa de aumento da viscosidade.

Essa constatação confirmou-se no estudo realizado por Bell et al. (1991), onde ficou evidenciado que o mecanismo de oxidação a altas temperaturas é diferente do mecanismo de oxidação a baixas temperaturas. Segundo esses autores, as altas temperaturas em que são realizados os testes de envelhecimento acelerado (por volta de $100^{\circ} \mathrm{C}$ ) não são representativas das condições de campo, produzindo módulos resilientes muito elevados, cerca de $50 \%$ maiores do que os módulos de amostras retiradas do pavimento em serviço. Dessa forma, Bell et al. (1991) recomendam que os métodos de simulação de envelhecimento a longo prazo utilizem-se de temperaturas mais baixas, em torno de $85^{\circ} \mathrm{C}$.

Sosnovske et al. (1993) realizaram um estudo complementar ao realizado por Bell et al. (1991). Para simular o envelhecimento a curto prazo utilizaram a estufa de circulação de ar forçada, à temperatura de $135^{\circ} \mathrm{C}$ pelo período de 4 horas. A simulação do envelhecimento a longo prazo foi realizada por dois métodos, oxidação a baixa pressão (LPO - low-pressure oxidation), nas temperaturas de $60^{\circ}$ e $85^{\circ} \mathrm{C}$ pelo período de cinco dias, e envelhecimento em estufa com circulação de ar forçada (LTOA - long-term oven 
aging), realizado nas temperaturas de $85^{\circ}$ e $100^{\circ} \mathrm{C}$, pelos períodos de cinco e dois dias, respectivamente.

Os resultados obtidos por Sosnovske et al. (1993) mostraram que a suscetibilidade das misturas asfálticas ao envelhecimento depende dos tipos de asfalto e agregado utilizados, bem como da adesão entre ambos. Segundo esses autores, quanto maior a adesão entre o asfalto e o agregado utilizados, maior a resistência ao envelhecimento apresentada pela mistura asfáltica. Dessa forma, ficou evidenciada a necessidade da adoção de testes para avaliação do envelhecimento de misturas asfalto-agregado, pois testes de envelhecimento realizados apenas com o ligante não são suficientes, uma vez que o mesmo asfalto pode apresentar diferentes níveis de suscetibilidade ao envelhecimento, dependendo do tipo de agregado utilizado na mistura. De acordo com Sosnovske et al. (1993), o envelhecimento de misturas asfalto-agregado parece estar relacionado com a interação química entre o agregado e o asfalto.

Garrick (1995) examinou um estudo conduzido em Whiting, Indiana, no final da década de 1960. Nesse estudo foi utilizado o método Marshall para moldagem de corpos de prova em laboratório, que foram deixados para envelhecer numa prateleira ou suporte colocado no telhado. Foram testados 10 tipos de asfalto, com diferentes procedências, tendo sido moldados 8 corpos de prova para cada tipo de asfalto. Foram ensaiados dois corpos de prova para cada período de envelhecimento, sendo que os períodos de envelhecimento utilizados foram 1 dia, 230 dias, 345 dias e 730 dias. O agregado utilizado na mistura asfáltica foi pedra britada. Segundo Garrick (1995), asfaltos apresentando as mesmas propriedades reológicas tendem a apresentar durabilidade semelhante.

Kemp e Sherman (1984) estudaram o efeito do envelhecimento a longo prazo no desempenho de misturas asfálticas expondo corpos de prova moldados em laboratório ao tempo, em quatro condições climáticas. Os corpos de prova foram envelhecidos pelos períodos de 1, 2 e 4 anos. Foram testadas misturas compostas por três tipos de ligantes e dois tipos de agregados, porosos e não porosos. A compactação foi realizada de modo que fossem obtidas misturas com três diferentes volumes de vazios. Os resultados obtidos mostraram que 24 meses de envelhecimento ao tempo dos corpos de prova equivalem a 32 meses de envelhecimento do revestimento do pavimento em 
serviço. Os fatores com maior influência nos processos de envelhecimento das misturas foram a temperatura do ar, o volume de vazios nas misturas e a porosidade do agregado, sendo que o último fator citado teve influência significativa em regiões de clima quente. Temperaturas mais elevadas, volumes de vazios maiores e agregados com maior porosidade corresponderam a uma maior oxidação sofrida pelo ligante asfáltico.

Huff e Vallerga (1981), estudando o comportamento de asfaltos modificados com borracha, envelheceram corpos de prova moldados com asfalto modificado. O envelhecimento foi realizado por exposição dos corpos de prova ao tempo, deixando-os expostos a luz solar, pelo período de dois anos. Os resultados mostraram que a razão entre a viscosidade do ligante após o envelhecimento e a viscosidade do ligante antes do envelhecimento diminuiu quando foram utilizados óleos extensores nas misturas do cimento asfáltico com a borracha.

\subsection{Testes utilizados para avaliação dos efeitos do envelhecimento de misturas asfálticas}

De acordo com Bell (1989), vários testes têm sido utilizados para avaliação dos efeitos do envelhecimento sofrido por misturas asfálticas. Dentre eles destacam-se o ensaio de módulo de resiliência, ensaios de fadiga, ensaios de fluência ou ensaios de creep, o ensaio de resistência à tração e o ensaio de módulo complexo ou módulo dinâmico.

Bell (1989) menciona ainda que a tendência geral observada nas pesquisas por ele consultadas é que o envelhecimento das misturas asfálticas provoca o aumento do módulo de resiliência e da vida de fadiga, quando os ensaios são realizados à tensão controlada. O prolongamento da vida de fadiga com o envelhecimento pode ser explicado pelo fato dos ensaios serem realizados a tensão constante. Como a tensão de ruptura por tração diminui em virtude das amostras tornarem-se mais quebradiças e menos flexíveis com o envelhecimento, os ensaios de fadiga de misturas envelhecidas são realizados com tensões menores, o que acarreta o aumento da vida de fadiga das mesmas. 
Kim et al. (1987) realizaram testes de módulo de resiliência e fadiga para medida das propriedades de corpos de prova moldados em laboratório e de amostras retiradas do pavimento, antes e após o envelhecimento. Foi utilizada a razão entre o módulo de resiliência após o envelhecimento e o módulo de resiliência antes do envelhecimento, para avaliação do efeito desse processo nas misturas. Essa razão mostrou-se superior a um para quase todas as amostras ensaiadas, indicando aumento do módulo de resiliência com o envelhecimento. Apesar dos ensaios de fadiga terem sido realizados a tensão constante, a resistência à fadiga diminuiu com o aumento do tempo de envelhecimento.

Sosnovske et al. (1993) avaliaram os efeitos do envelhecimento através dos ensaios de módulo de resiliência por compressão diametral e módulo de resiliência por compressão triaxial, realizados a $25^{\circ} \mathrm{C}$. Uma vez coletados todos os dados, as amostras foram submetidas a testes de resistência à tração, com monitoramento constante do carregamento e da deformação até a ruptura. Algumas amostras foram submetidas ao teste de módulo dinâmico, nas temperaturas de $0^{\circ}, 25^{\circ}$ e $40^{\circ} \mathrm{C}$, com freqüências variando de 15 a 0,01 Hz. Os resultados obtidos mostraram aumento do módulo de resiliência com o envelhecimento das misturas.

AbWahab et al. (1993) utilizaram os testes de análise mecânica dinâmica, módulo resiliente por compressão diametral, módulo resiliente triaxial e resistência à tração indireta para avaliação e quantificação do envelhecimento sofrido por misturas asfálticas. Segundo esses autores, testes de módulo resiliente diametral e triaxial determinam apenas a resposta elástica das misturas. Testes de análise mecânica dinâmica (AMD), além de determinarem a resposta elástica, determinam também a resposta viscosa e o ângulo de fase, que parecem ser indicadores mais significativos do desempenho das misturas.

AbWahab et al. (1993) obtiveram módulos complexos maiores, tanto para misturas envelhecidas a curto prazo como para misturas envelhecidas a longo prazo, quando comparados com os módulos das misturas não envelhecidas. O parâmetro ângulo de fase, obtido através do ensaio de módulo complexo, diminuiu com o envelhecimento das misturas. A curva de variação do ângulo de fase mostrou ser um bom indicador do aumento de viscosidade com o envelhecimento. A taxa de envelhecimento foi obtida de 
duas formas, dividindo-se o módulo complexo de misturas envelhecidas pelo módulo complexo de misturas não envelhecidas, e dividindo-se o módulo de resiliência de misturas envelhecidas pelo módulo de resiliência de misturas não envelhecidas. As taxas obtidas por ambos os métodos foram semelhantes.

\subsection{Problemas relacionados aos processos de extração e recuperação do ligante de misturas asfálticas}

As consequiências do envelhecimento podem ser verificadas por medidas das propriedades físicas do ligante antes e após o envelhecimento, através da realização dos ensaios tradicionais de viscosidade, penetração, ponto de amolecimento e ductilidade, ou através de parâmetros utilizados mais recentemente, como o parâmetro $G^{*} \operatorname{sen} \delta$, obtido em reômetros de cisalhamento, e que representa a deformação não recuperável do ligante. Esses testes devem ser realizados diretamente com o ligante, que deve ser extraído e recuperado das misturas asfálticas. O envelhecimento provoca aumento do ponto de amolecimento, da viscosidade e do parâmetro $G^{*} \operatorname{sen} \delta$, e diminuição da penetração e da ductilidade.

O processo de extração pode ser facilmente realizado fazendo-se uso de um solvente, e a recuperação do asfalto diluído nesse solvente teoricamente deveria ser um processo de fácil execução por evaporação do solvente volátil, uma vez que em casos normais existe uma grande diferença entre os pontos de ebulição do solvente e do asfalto. Entretanto esse processo não é tão simples quanto poderia parecer.

Dentre os problemas encontrados no processo de extração e recuperação de asfaltos destacam-se:

- $\quad$ extração incompleta e não uniforme do asfalto aderido ao agregado;

- $\quad$ envelhecimento do asfalto devido ao contato deste com o solvente;

- permanência de solvente residual no asfalto recuperado, distorcendo as propriedades físicas do ligante a serem medidas;

- perda de voláteis durante o processo de recuperação. 
Processos de extração e recuperação do asfalto somente têm significado se o asfalto recuperado apresentar as mesmas propriedades físicas que apresentaria caso não houvesse passado por tais processos. Por exemplo, quando se pretendem avaliar as condições do ligante de um pavimento em serviço, o asfalto recuperado de uma amostra do pavimento deve apresentar propriedades físicas, como viscosidade, muito próximas das propriedades físicas do ligante in situ. Isso é essencial para que os testes realizados com o ligante tenham significado com respeito ao desempenho do pavimento. Entretanto os métodos em uso de extração e recuperação de asfalto mostram-se pouco precisos e ineficazes.

Atualmente os métodos de extração mais utilizados são o método de centrifugação (ASTM D-2172, método A, da ASTM, 1995b) e o método de refluxo (ASTM D-2172, método B, da ASTM, 1995b). O método de extração a vácuo (ASTM D-2172, método C, da ASTM, 1995b) não tem sido muito utilizado (BURR et al., 1993).

Os problemas associados ao processo de extração englobam extração incompleta do asfalto aderido ao agregado, com o agravante de que o asfalto que permanece aderido ao agregado possui composição diferente do asfalto removido, e reações químicas sofridas pelo asfalto enquanto em solução, muitas vezes denominadas de envelhecimento do asfalto devido ao solvente. Essas reações alteram as propriedades do asfalto, provocando mudanças de caráter coloidal em sua natureza (BROOME, 1949). Em geral, as taxas de reação aumentam exponencialmente com a temperatura e com o tempo de exposição do asfalto ao solvente.

Embora as reações sofridas pelo asfalto quando no estado dissolvido também ocorram em temperatura ambiente, em temperaturas de ensaio de extração de asfalto por refluxo sua taxa de ocorrência é maior. Dessa forma, há reservas quanto à utilização do método de refluxo para obtenção de asfaltos cujas propriedades forem ser analisadas, uma vez que métodos de refluxo expõem o asfalto a solventes em temperaturas elevadas por longos períodos de tempo (BURR et al., 1991).

Outras variáveis influentes no processo de extração são a concentração de asfalto na solução e o tipo de solvente utilizado. O efeito da concentração de asfalto ainda não está completamente elucidado. Sabe-se entretanto que em concentrações altas o processo de 
endurecimento do asfalto devido ao solvente parece dominar, enquanto que em concentrações muito baixas, abaixo de $0,15 \mathrm{~g} / \mathrm{ml}$, predomina o processo de amolecimento, que se acentua com a diminuição da concentração de asfalto e com o aumento da temperatura.

Durante o amolecimento devido ao solvente são formados produtos com pesos moleculares menores, ocasionando menores viscosidades. Dentro de faixas de temperatura de trabalho, existem limites de concentração de asfalto acima dos quais parece não ocorrer amolecimento do asfalto.

A influência do tipo de solvente no envelhecimento do asfalto tem sido estudada por diversos autores. Abson e Burton (1960) testaram vários solventes clorados e concluíram que alguns induzem a envelhecimento acentuado. O solvente mais ofensivo ao asfalto foi o tetracloreto de carbono $\left(\mathrm{CCl}_{4}\right)$. O solvente 1,1,1-tricloroetano também mostrou causar envelhecimento acentuado. Noureldin e Manke (1978) constataram envelhecimento do asfalto quando em contato com o solvente tricloroetileno em processos de extração a quente.

Geralmente, o melhor modo de evitar endurecimento devido ao solvente é utilizar métodos de extração a frio e completar o processo de recuperação o mais rapidamente possível, de acordo com sugestão da ASTM (BURR et al., 1991).

Os solventes mais eficientes para extração do asfalto segundo Burr et al. (1993) são o tricloroetileno com adição de $15 \%$ de etanol e piridina. O solvente mais seguro segundo esses autores é o tolueno com $15 \%$ de etanol.

Collins-Garcia et al. (2000) procuraram determinar um solvente mais inofensivo ao meio ambiente e à saúde, que pudesse substituir a maioria dos solventes clorados utilizados atualmente nos processos de extração e recuperação de asfalto. O solvente estudado foi o bromato de propila, que não possui em sua composição nenhum solvente clorado, e dessa forma não é considerado cancerígeno. Esse solvente mostrou-se adequado à finalidade em questão, podendo substituir o tricloroetileno sem modificações dos métodos de ensaio atuais. Além disso o bromato de propila poderia ser reciclado e reutilizado nos processos de extração e recuperação de ligante. 
Burr et al. (1991) estudaram a influência das variáveis presença de oxigênio e presença de luz no envelhecimento do asfalto dissolvido. Constataram que o envelhecimento aumenta com a presença de oxigênio e, independentemente da presença de oxigênio, a presença de luz mostrou acelerar o processo de envelhecimento. Observaram também que as mudanças químicas sofridas pelo asfalto devido à exposição ao solvente dependem do tipo de asfalto considerado.

A recuperação do asfalto diluído geralmente é realizada através do método Abson (ASTM D-1856, da ASTM, 1995a) ou do método do Rotavapor (ASTM D-5404, da ASTM, 1993), igualmente utilizados.

No método Abson a solução de solvente e asfalto obtida de um processo anterior de extração é destilada sob condições prescritas, fazendo-se uso do gás dióxido de carbono $\left(\mathrm{CO}_{2}\right)$ nas etapas finais da destilação, para aumentar a eficácia do processo de remoção do solvente e para evitar que a solução espume.

No método do Rotavapor, a recuperação do asfalto é realizada com a utilização de uma aparelhagem rotativa para evaporação, desenvolvida com a finalidade de minimizar as modificações das propriedades físicas do ligante durante o processo de recuperação. A aparelhagem utilizada nesse método inclui um recipiente giratório para destilação, que possibilita o aumento da área superficial de asfalto exposta, com conseqüente aumento da taxa de remoção do solvente. São também utilizados os recursos de se submeter a solução a vácuo parcial e a um fluxo de gás nitrogênio ou dióxido de carbono, com a mesma finalidade de aumentar a eficácia do processo de remoção do solvente.

Tanto o método Abson como o método do Rotavapor apresentam o problema de remoção incompleta do solvente, em virtude do tempo de destilação e das temperaturas utilizadas no processo serem insuficientes. Essa deficiência não pode ser ignorada, uma vez que mesmo concentrações baixas de solvente no asfalto (em torno de 0,2 \%) são suficientes para distorcer significativamente as propriedades físicas do asfalto.

Com o objetivo de avaliar o desempenho dos métodos de recuperação de asfalto existentes, Burr et al. (1990) estudaram o problema da remoção incompleta do solvente, pois embora este seja aparentemente um problema simples, tem afetado o resultado de 
muitas pesquisas. Foram realizadas recuperações pelos métodos Abson e Rotavapor a várias temperaturas e com vários tamanhos de amostras, numa vasta faixa de viscosidade.

Para detecção de solvente residual no asfalto recuperado, Burr et al. (1990) utilizaram o método de análise de cromatografia de permeação de gel (GPC) e constataram a presença de solvente residual no asfalto recuperado por ambos os métodos, indicada por endurecimento negativo do asfalto, ou seja, amolecimento. A presença de solvente residual ocasiona viscosidades menores do que os valores reais. Analisando a influencia da viscosidade e do tamanho da amostra, constataram que viscosidades altas e amostras grandes de asfalto impedem uma taxa elevada de remoção do solvente.

Procurando estabelecer novas condições que garantissem a remoção completa de solvente, estudaram o efeito do aumento do tempo de recuperação e da temperatura de recuperação nas condições do asfalto. Observaram que essas modificações podem diminuir a concentração de solvente residual, mas em contrapartida acentuam o problema de envelhecimento devido à exposição ao solvente.

Com o objetivo de superar as deficiências dos métodos de extração em uso, Burr et al. (1993) desenvolveram um procedimento integrado de extração e recuperação de asfalto, no qual propuseram um novo método de extração, e para recuperação do asfalto utilizaram o método do Rotavapor.

No método proposto por Burr et al. (1993) a extração é realizada em um tambor giratório onde o solvente e a amostra da mistura asfáltica são mantidos em contato. $\mathrm{O}$ material extraído é filtrado a vácuo em diversas etapas, sendo então transferido para o evaporador rotatório onde o solvente é destilado, também a vácuo. Os processos de mistura, filtração e destilação se repetem por várias lavagens, para extração do asfalto fortemente adsorvido/absorvido pelo agregado.

Após a destilação da terceira lavagem, o frasco de recuperação é removido e colocado à parte. Este frasco contém cerca de $90 \%$ do asfalto da amostra e sua remoção das condições em que é feita a recuperação ajuda a prevenir o envelhecimento do asfalto. Um outro frasco de recuperação é adaptado ao evaporador rotatório para as lavagens 
subseqüentes. Após a recuperação final, o asfalto em ambos os frascos é misturado em solução. Os agregados finos remanescentes são centrifugados. Para recuperação final do asfalto é utilizado o método do Rotavapor.

Embora o método de extração proposto por Burr et al. (1993) tenha se mostrado melhor que os métodos em uso, o processo de recuperação do asfalto acarreta os problemas já mencionados. Dentre os principais problemas encontrados destaca-se a remoção incompleta de solvente do asfalto recuperado.

\subsection{Envelhecimento de asfaltos modificados}

\subsubsection{Asfaltos modificados}

Melhorias na qualidade dos materiais utilizados para a construção de revestimentos asfálticos têm sido obtidas com a utilização de misturas asfálticas compostas por ligantes modificados com polímero ou com borracha.

A adição de modificadores ao asfalto vem de longa data. A primeira patente de asfalto modificado pela adição de borracha natural foi obtida em 1823 pelo inglês T. Hancock, para a fabricação de material impermeabilizante para embarcações de madeira (ISACSSON e LU, 1995; ZANZOTTO e KENNEPOHL, 1996). Ainda segundo Zanzotto e Kennepohl (1996), a primeira patente de uma mistura de material betuminoso com borracha natural, destinada à construção de estradas, foi obtida em 1844 por E.E Cassell. Em 1902 foi construída a primeira estrada utilizando asfalto modificado com borracha natural, em Cannes, França. Após a Segunda Guerra Mundial passaram a ser utilizados também polímeros sintéticos como modificadores do asfalto.

Desde então vêm sendo realizados paralelamente estudos sobre a adição de borracha natural e de polímeros sintéticos ao asfalto. O objetivo dessas pesquisas é a melhoria das propriedades dos ligantes, a fim de que apresentem maior adesão aos agregados, maior resistência ao envelhecimento e menor suscetibilidade térmica em faixas de temperatura de serviço dos pavimentos. Como resultado, buscam-se pavimentos mais resistentes à fadiga e à deformação permanente (LING et al., 1997). 
A adição de modificadores ao asfalto para fins de pavimentação intensificou-se por volta de 1970, nos Estados Unidos e na Europa. No Brasil, o uso de ligantes modificados em rodovias começou a ser testado somente por volta de 1990. Em 1997 já eram comercializados asfaltos modificados pelo polímero SBS (estireno butadieno estireno), pela companhia Ipiranga Asfaltos S.A.. A PETROBRAS iniciou a comercialização de asfaltos modificados por SBS e por SBR (borracha estireno butadieno) em 1998 (LEITE, 1999).

Antes disso já haviam sido realizados alguns trechos experimentais, mas sem o monitoramento adequado. De acordo com o DNER* (1998, apud AMARAL, 2000, p.35), asfaltos modificados com polímero começaram a ser estudados no Brasil em 1968 e desde então vários trechos experimentais têm sido construídos, conforme resumo apresentado na Tabela 3.1.

Tabela 3.1 - Trechos experimentais construídos no Brasil, utilizando asfaltos modificados com polímeros (DNER*, 1998 apud AMARAL, 2000, p.35)

\begin{tabular}{ccc}
\hline polímero & local do trecho experimental & ano \\
\hline látex & ruas internas da Petroflex & 1969 \\
\hline látex & Belford Roxo & 1976 \\
\hline asfalto-epoxi & Ponte Rio-Niterói & década de 1970 \\
\hline asfalto-epoxi & Via Dutra & década de 1970 \\
\hline lama asfáltica com SBR & Ponte Rio-Niterói & 1982 \\
\hline látex & rodovia Rio-Petrópolis & 1983 \\
\hline latex & RJ-104 (Rio de Janeiro) & 1983 \\
\hline SBR & juntas de dilatação - Aeroporto Santos Dumont & 1984 \\
\hline SBR & pistas auxiliares do Aeroporto Internacional do \\
& Rio de Janeiro & 1984 \\
\hline SBS e EVA & Rua Leopoldo Bulhões \\
\hline SBS (Betuflex) & Rodovia dos Bandeirantes \\
\hline SBS & PE-75 (Pernambuco) & 1990 \\
\hline SBS & PE-74 (Pernambuco) & 1992 \\
\hline SBS & $\begin{array}{c}\text { Autódromo internacional Nélson Piquet, na } \\
\text { cidade do Rio de Janeiro }\end{array}$ & 1993 \\
\hline SBS & Autódromo de Jacarepaguá, Fórmula I, na \\
cidade do Rio de Janeiro & 1995 \\
\hline SBS & Autódromo de Jacarepaguá, Fórmula Indy, na \\
cidade do Rio de Janeiro & 1995 \\
\hline
\end{tabular}

* DNER (1998). Pesquisa de asfaltos modificados por polímeros - Relatório final. Tomo I e II. Departamento Nacional de Estradas de Rodagem. Rio de Janeiro apud AMARAL, S.C. (2000). Estudos de misturas asfálticas densas com agregados do estado do Pará, utilizando asfalto convencional (CAP40) e asfalto modificado com polímero SBS (BETUFLEX B 65/60). São Carlos. Dissertação (Mestrado) Escola de Engenharia de São Carlos, Universidade de São Paulo. 147 p. 
Além do SBS e do SBR, outros polímeros podem ser adicionados ao asfalto. O grupo de polímeros termoplásticos normalmente utilizados como modificadores de CAP consiste de copolímeros em bloco de estireno butadieno (SB), estireno butadieno estireno (SBS), estireno isopreno estireno (SIS), estireno etileno butadieno estireno (SEBS) e acrilonitrila butadieno estireno (ABS). Também são utilizados polietileno de baixa densidade (LDPE), etileno acetato de vinila (EVA) e etileno propilenodieno (EPDM). Para se comportar como elastômero, o SB requer a adição de enxofre, assim como os três últimos copolímeros citados.

O grupo de borrachas sintéticas e naturais que usualmente requerem agente de ligações cruzadas para a formação de uma rede contínua consiste de homopolímeros como a borracha natural (NR), o polibutadieno (PBD), o poliisopreno (PI) e os copolímeros randômicos de borracha butadieno estireno.

Os homopolímeros são polímeros formados por apenas um tipo de monômero, e os copolímeros apresentam em sua estrutura pelo menos dois tipos de monômeros diferentes, sendo que monômeros são as unidades formadoras das macromoléculas de polímeros.

Os principais polímeros utilizados como modificadores de asfalto, de acordo com Leite (1999), encontram-se apresentados na Tabela 3.2. Outros modificadores adicionados ao asfalto são aceleradores de vulcanização, como o enxofre, utilizados para aumentar a resistência ao envelhecimento, melhoradores de adesividade, utilizados para evitar problemas de desagregação, e antioxidantes, também utilizados para aumento da resitência do ligante ao envelhecimento.

Bahia et al. (1998), baseados em estudos realizados por diversos autores, mencionam que existe um grande número de modificadores adicionados a asfaltos para fins rodoviários. Citam 55 modificadores, agrupados em 17 classes genéricas. Dentre esses, procuraram identificar os mais utilizados, realizando uma pesquisa onde órgãos rodoviários dos Estados Unidos e do Canadá foram questionados sobre quais modificadores utilizam e para qual finalidade. Concluíram que os polímeros mais utilizados pertencem à classe dos elastômeros, que quando adicionados ao asfalto produzem ligantes conhecidos como asfaltos elastoméricos. 
No estudo realizado por Bahia et al. (1998) destacou-se o polímero elastômero SBS, que foi o mais citado pelos órgãos consultados. Seu uso tem como finalidade, de acordo com os órgão consultados por Bahia et al. (1998), o aumento da resistência dos pavimentos a deformações permanentes e fadiga, a diminuição dos efeitos danosos causados pela umidade e pelas baixas temperaturas e o aumento da resistência ao envelhecimento. Também foram muito citados os polímeros SBR e borracha de pneus descartados moída, pertencentes ao grupo dos elastômeros, e o polímero EVA, pertencente ao grupo dos plastômeros.

Tabela 3.2 - Principais polímeros utilizados como modificadores de asfalto

\begin{tabular}{ccc}
\hline polímero & fabricante & nome comercial \\
\hline borracha moída de pneu & GRF 80 & Rouse Rubber \\
\hline borracha moída de pneu & IGR & Baker \\
\hline borracha moída de pneu & Envirotire, Inc & Pluaride II \\
\hline copolímeros de etileno & DuPont & Elvaloy \\
\hline copolímeros de etileno & ARE, Inc & Starflex \\
\hline copolímeros de etileno & ARE, Inc & Modiflex \\
\hline copolímeros de etileno & Exxon Chemical & Polybilt \\
\hline copolímeros em blocos estirênicos & Dexco Polymers & Vector \\
\hline copolímeros em blocos estirênicos & Shell & Kraton \\
\hline EPDM & Huls & Vestoplast \\
\hline EVA & DuPont & Elvax \\
\hline LDPE & Adv. Asphalt Tech. & Novophalt \\
\hline PE funcionalizado & Eastman & Finaprene \\
\hline poliamina (melhorador de adesão) & Morton Int & Pave Bond \\
\hline polibutadieno (melhorador de adesão) & Goodyear & UP-5000 \\
\hline policloropreno látex & DuPont & Neoprene \\
\hline SBR & Goodyear & UP-70, UP7289,... \\
\hline SBR & Rub-R-road & R-504, R-550 \\
\hline SBR & BASF & Butonal \\
\hline SBS & Ergon & Sealo-flex \\
\hline SBS & FINA & - \\
\hline
\end{tabular}

Fonte: Leite (1999)

Cabe mencionar que elastômeros e plastômeros são os dois tipos principais de polímeros industriais utilizados como modificadores de asfalto. Asfaltos modificados com polímeros do tipo plastômero geram misturas asfálticas com maior módulo de rigidez e maior estabilidade. Por outro lado, polímeros do tipo elastômero acrescentam elasticidade ao asfalto, tornando os pavimentos mais flexíveis. 


\subsubsection{Estireno butadieno estireno (SBS)}

SBS são copolímeros em bloco de estireno e butadieno. Possuem as características dos elastômeros termoplásticos, ou seja, são materiais que escoam livremente quando aquecidos, mas que apresentam resistência mecânica elevada e propriedade de resiliência, quando em temperatura ambiente. Esse comportamento se deve à morfologia do polímero SBS, que decorre da incompatibilidade entre os blocos de estireno e dieno, resultando em uma matriz de dieno em que domínios de poliestireno estão dispersos. Esses domínios atuam como centros de ancoragem de força. Além disso, o copolímero SBS, por apresentar escoamento elevado, não eleva muito a viscosidade do asfalto ao qual é misturado (LEITE, 1999).

Dessa forma, em temperaturas elevadas, superiores ao ponto de amolecimento do CAP puro, o SBS, com domínios estirênicos ainda sólidos, forma uma malha que envolve o ligante fluido e mantém a consistência da mistura, evitando que esta apresente fluxo viscoso. Por outro lado, em temperaturas muito baixas, nas quais o CAP puro teria comportamento vítreo e trincaria, o copolímero SBS confere elasticidade à mistura. Ou seja, a adição do copolímero SBS ao CAP puro eleva o ponto de amolecimento do ligante resultante, e diminui seu ponto de ruptura Fraass. Isso significa aumento do intervalo de plasticidade e diminuição da suscetibilidade térmica (TAIRA, 2001).

\subsubsection{Borracha estireno butadieno (SBR)}

SBR são copolímeros com arranjo aleatório de estireno e butadieno, obtidos principalmente por processo de polimerização em emulsão. Por serem do tipo elastômero, resistem bem a temperaturas elevadas e apresentam propriedades elásticas que lembram a borracha. Apresentam também boa compatibilidade com o asfalto. Embora tenham baixa resistência mecânica, suas propriedades podem ser melhoradas com a vulcanização, que é conseguida pela reação com enxofre ou peróxidos (LEITE, 1999). 


\subsubsection{Etileno acetato de vinila (EVA)}

O EVA é um copolímero plastômero de etileno e acetato de vinila. A porcentagem de acetato de vinila na composição desse copolímero pode variar, podendo ser baixa ou atingir cerca de 50\% (LEITE, 1999). Dessa forma variam também as propriedades apresentadas, que podem se assemelhar às propriedades do polímero termoplástico polietileno de baixa densidade, que amolece de forma reversível pela ação do calor, endurecendo novamente quando resfriado, ou podem se assemelhar às propriedades dos polímeros elastômeros, que apresentam maior resistência a temperaturas elevadas do que os polímeros termoplásticos, e também recuperam seu estado original quando resfriados.

A redução do teor de acetato de vinila aumenta o módulo de rigidez desses polímeros e a temperatura de amolecimento, e diminui a temperatura de fragilidade. Esse polímero é classificado como um termoplástico plastômero, pois escoa irreversivelmente quando submetido a uma tensão cisalhante, uma vez que não possui reticulação como o SBR, ou microdomínios, como o SBS.

\subsubsection{Borracha reciclada de pneu (BRP)}

A utilização de refugos de pneus na composição de misturas asfálticas, tanto como modificadores do asfalto como em substituição ao agregado, além de melhorar suas propriedades também contribui para a preservação do meio ambiente.

Segundo Bertollo (2002), o emprego de borracha moída de pneus na construção de pavimentos asfálticos surgiu como uma alternativa tecnicamente viável para a reciclagem desse tipo de resíduo. No estudo conduzido por Bertollo (2002), ensaios de solubilização e lixiviação mostraram que a incorporação da borracha em misturas asfálticas tornou-a um material inerte. Além disso a mistura asfáltica resultante não teve seu desempenho comprometido e, ao contrário, apresentou melhora em algumas propriedades. 
Entretanto, os processos para incorporação de borracha moída de pneus em misturas asfálticas não foram desenvolvidos por razões ambientais, mas sim econômicas, ligadas ao alto custo dos polímeros (HEITZMAN, 1992).

A borracha de pneu é um composto de borracha natural com borracha sintética e pode ser utilizado não apenas como modificador do asfalto, mas também como agregados em misturas asfálticas. Esses dois métodos de incorporação são denominados processo úmido e processo seco, respectivamente.

No processo úmido, a borracha moída em partículas finas é misturada ao cimento asfáltico aquecido, produzindo um novo tipo de ligante, denominado asfalto-borracha. No processo seco, partículas maiores de borracha substituem parte do agregado mineral e a mistura asfáltica resultante é denominada concreto asfáltico modificado pela adição de borracha. $\mathrm{O}$ asfalto borracha pode ser utilizado em concretos asfálticos usinados a quente e em tratamentos superficiais. Já o agregado-borracha deve ser utilizado somente em concretos asfálticos usinados a quente.

Tentativas de utilização da borracha de pneus como material de pavimentação, para melhoria das propriedades elásticas dos cimentos asfálticos, vem sendo feitas desde 1920, mas foi somente no início da década de 1940 que seu uso tornou-se oficial, quando a U.S. Rubber Reclaiming Company introduziu no mercado um produto de material asfáltico e borracha desvulcanizada reciclada, denominado Ramflex (FAXINA, 2002).

Em 1963, o engenheiro Charles McDonald utilizou asfalto modificado com borracha na manutenção de pavimentos asfálticos dos Estados Unidos. Desde então vários trechos experimentais foram construídos e as experiências realizadas revelaram aumento da durabilidade dos pavimentos, da resistência à derrapagem, da resistência à fadiga e às deformações permanentes (LEITE, 1999). Cabe ressaltar que os teores de borracha adicionados ao asfalto variam de $5 \%$ a $30 \%$, nos estados da Flórida, Arizona e Califórnia.

No Brasil, pesquisas sobre o emprego de borracha de pneus descartados em pavimentação asfáltica iniciaram-se em 1990. Em 1999 entrou em vigor a resolução 
n²58 do Conselho Nacional do Meio Ambiente (CONAMA). Ficou estabelecido que a partir de janeiro de 2002 as indústrias de pneumáticos e importadores deveriam se responsabilizar pela coleta e pelo destino final dos pneus inservíveis. Essa resolução tem contribuído para a intensificação de pesquisas sobre o uso da borracha de pneus descartados como material em pavimentação, assim com em outras áreas (FAXINA, 2002; BERTOLLO, 2002).

Embora os custos iniciais de misturas empregando asfalto borracha sejam superiores aos custos de misturas asfálticas convencionais, pavimentos empregando asfalto-borracha podem ter a espessura da camada de revestimento reduzida e sua vida útil prolongada. Além disso, não pode deixar de ser considerado o ganho ambiental.

O elevado consumo de pneus, decorrente do desenvolvimento da indústria automobilística, gerou a preocupação de se encontrar um destino adequado para os pneus descartados. Se forem simplesmente abandonados, os pneus podem servir como local para procriação de mosquitos e outros vetores de doenças, além de representarem um risco constante de incêndio, que, quando ocorre, contamina a atmosfera com uma fumaça altamente tóxica e libera um óleo que se infiltra e contamina o lençol freático. A disposição em aterros sanitários também é problemática, pois os pneus dificultam a compactação. Uma solução seria triturar os pneus antes de depositá-los nos aterros, mas a trituração é um processo caro (ODA, 2000).

Dessa forma, a utilização da borracha dos pneus como material em pavimentação surgiu como umas das soluções para o problema ambiental gerado pelos pneus descartados. Conclui-se assim que a avaliação das vantagens do emprego de borracha moída de pneus em pavimentos asfálticos não deve se restringir a uma comparação direta de custos entre asfaltos modificados com borracha e asfaltos convencionais, pois a vantagem principal de sua utilização encontra-se nos benefícios ambientais.

Sabe-se que as temperaturas de mistura do asfalto-borracha com o agregados e a temperatura de lançamento da mistura na pista geralmente são mais elevadas do que no caso de misturas convencionais, e a compactação deve ser realizada enquanto a mistura ainda não perdeu muito calor, pois a viscosidade do ligante asfalto-borracha aumenta rapidamente (ZAMAN et al., 1995). 
Entretanto, embora haja uma maior dificuldade em se produzir e aplicar asfaltos com borracha moída de pneu, quando comparados com asfaltos convencionais, misturas com asfalto-borracha têm apresentado desempenho superior, conforme resultados de diversas pesquisas realizadas nas décadas de 1970, 1980 e 1990 (ODA, 2000). Algumas dessas pesquisas estão relacionadas na Tabela 3.3.

Tabela 3.3 - Autores que avaliaram e aprovaram o desempenho de misturas asfalto-borracha

\begin{tabular}{ccc}
\hline pesquisadores & ano & forma de avaliação \\
\hline Morris e McDonald & 1976 & campo \\
\hline Coetzee e Monismith & 1979 & estudo computacional \\
\hline Huff e Vallerga & 1981 & campo e laboratório \\
\hline Esch & 1982 & campo e laboratório \\
\hline Jimenez & 1982 & laboratório \\
\hline Stephens & 1982 & campo \\
\hline Chehovits e Manning & 1984 & campo \\
\hline Jimenez e Meier, Jr & 1985 & laboratório \\
\hline Shuler et al. & 1985 & campo \\
\hline Roberts e Lytton & 1987 & laboratório \\
\hline Takallou e Hicks & 1988 & campo e laboratório \\
\hline Salter e Mat & 1990 & laboratório \\
\hline Heitzman & 1992 & histórico de aplicação \\
\hline Krutz e Stroup-Gardiner & 1992 & laboratório \\
\hline Zaman et al. & 1995 & laboratório \\
\hline Liang e Lee & 1996 & laboratório \\
\hline Madapatti et al. & 1996 & laboratório \\
\hline Oda & 2000 & laboratório \\
\hline Bertollo & 2002 & laboratório \\
\hline Faxina & 2002 & laboratório \\
\hline & &
\end{tabular}

\subsubsection{Desempenho de asfaltos modificados}

Diversos estudos vêm sendo realizados com o objetivo de avaliar o desempenho de misturas compostas por asfaltos modificados. Estudos realizados em pistas experimentais têm demonstrado o melhor desempenho de misturas asfálticas compostas por ligantes modificados por polímeros, especialmente no que se refere à deformação permanente e à fadiga.

No estudo realizado por Khosla (1991), o comportamento de misturas com asfaltos modificados por polímeros foi avaliado através dos ensaios de módulo de resiliência, fadiga e fluência por compressão uniaxial estática. Os resultados mostraram que asfaltos modificados conferem às misturas módulos de resiliência maiores em temperaturas 
elevadas e não afetam os valores de módulos de resiliência em baixas temperaturas. Além disso, misturas com asfaltos modificados mostram-se mais resistentes à ruptura por fadiga em baixas temperaturas e mais resistentes a deformações permanentes em temperaturas elevadas.

Srivastava et al. (1992) mencionam que na cidade de Alkmaar, Holanda, um trecho de uma rodovia com tráfego pesado e intenso foi revestido com mistura composta por asfalto modificado pelo polímero SBS e tem apresentado desempenho excelente. O referido trecho anteriormente era construído utilizando asfaltos convencionais e apresentava uma vida útil de no máximo oito meses. Após ter sido construído com asfalto modificado pelo polímero SBS teve seu comportamento observado por dez anos de serviço e ao longo desse período não apresentou nenhum sinal de formação de trilhas de roda, corrugações ou trincas por fadiga.

Para comprovarem o excelente desempenho de asfaltos modificados pelo polímero SBS, Srivastava et al. (1992) construíram um trecho experimental de $300 \mathrm{~m}$ em uma rodovia da Austrália. Para a construção do trecho, foram removidos os $9 \mathrm{~cm}$ superiores do pavimento existente, substituindo-os por $9 \mathrm{~cm}$ de mistura com asfalto modificado com SBS. O custo do recapeamento utilizando asfalto modificado com SBS foi similar ao custo de $15 \mathrm{~cm}$ de mistura com asfalto convencional. Observando o comportamento desse trecho, verificaram que as deformações permanentes sofridas foram baixas, assim como a ocorrência de trincas por fadiga. Dessa forma comprovaram o bom desempenho de misturas com asfaltos modificados por SBS, acrescentando que sua aplicação é economicamente viável.

Misturas com asfalto modificado por copolímeros compostos por blocos de estireno foram aplicadas em trechos experimentais do município de Perry, em Kentucky, Estados Unidos. Fleckenstein et al. (1992) avaliaram o desempenho dessas misturas através do monitoramento dos trechos experimentais, e também através de ensaios de laboratório. Foram realizados ensaios de estabilidade Marshall, módulo de resiliência, resistência à tração e ensaios para avaliação da suscetibilidade aos danos por umidade. Os ensaios de módulo de resiliência foram realizados nas temperaturas de 0,25 e $40^{\circ} \mathrm{C}$. Tanto os ensaios de estabilidade Marshalll como os ensaios de módulo de resiliência indicaram que os asfaltos modificados com polímeros conferem às misturas menor 
suscetibilidade a deformações permanentes. Esse resultado foi confirmado pelo monitoramento dos trechos experimentais. Observações visuais dos trechos pelo período de dois anos não indicaram quaisquer sinais de danos severos nos pavimentos.

Ainda segundo Fleckenstein et al. (1992), a utilização de asfaltos modificados com polímero eleva o custo inicial dos pavimentos em 30 a $40 \%$. Para verificar se os benefícios decorrentes da utilização de asfaltos modificados compensam o aumento de custo, os autores sugeriram que o monitoramento dos trechos experimentais continuasse por um período mais longo.

Ponniah e Kennepohl (1996) realizaram um estudo onde duas pistas experimentais foram construídas na cidade de Ontário, Canadá, para verificação do comportamento de asfaltos modificados com diferentes tipos de polímero. Medidas de profundidade de trilhas de roda realizadas entre 5 e 7 anos após a construção das pistas experimentais mostraram a maior resistência à deformação permanente de misturas compostas por asfaltos modificados. Realizando uma análise de custo/benefício, na qual a eficiência do ligante utilizado foi avaliada em termos de vida útil do pavimento, medida como o tempo de serviço decorrido até que o pavimento apresentasse profundidades de trilhas de roda iguais ou superiores a $19 \mathrm{~mm}$, verificaram que o uso de asfaltos modificados é viável desde que o custo do ligante modificado seja no máximo o dobro do custo do ligante convencional.

Gowda et al. (1996) verificaram que misturas com asfalto convencional apresentaram deformação permanente maior que a apresentada por misturas compostas por asfalto modificado com borracha, e concluíram que a adição de borracha pode reduzir o potencial de formação de trilhas de roda em revestimentos asfálticos.

Segundo Liang e Lee (1996), asfaltos modificados parecem apresentar melhor resistência à deformação permanente do que asfaltos convencionais em virtude da maior resposta elástica apresentada pelos primeiros.

Diversos autores têm observado, experimentalmente, a redução de deformações permanentes em misturas asfálticas, em consequiência da adição de polímeros aos asfaltos. Dentre eles podem ser citados Valkering et al. (1990), que estudaram a 
resistência a deformação permanente apresentada por misturas asfálticas compostas por ligantes modificados pelo copolímero estireno butadieno estireno (SBS). Foram testadas diversas concentrações do polímero no ligante, sendo que a máxima concentração testada foi de 7\%. O polímero foi adicionado ao ligante antes da produção da mistura asfáltica. $O$ ensaio para verificação da suscetibilidade da mistura a deformação permanente foi realizado em pistas experimentais do laboratório da Shell, em Amsterdam, a $50^{\circ} \mathrm{C}$.

No Brasil, o estudo controlado de trechos experimentais construídos com asfalto modificado iniciou-se por volta de 1990. De acordo com Ramos et al. (1996), no decorrer do ano de 1990 o Instituto de Pesquisas Rodoviárias do Departamento Nacional de Estradas de Rodagem promoveu, em conjunto com o Departamento Geral de Vias Urbanas da Secretaria de Obras do Município do Rio de Janeiro, a construção de trechos experimentais utilizando asfaltos modificados com polímeros na Rua Leopoldo Bulhões. Os trechos foram monitorados ao longo de seis anos, com a retirada de corpos de prova e a determinação do módulo de resiliência, além de análises deflectométricas e levantamentos visuais dos trechos. O trecho construído com a utilização do polímero SBS apresentou desempenho muito melhor que o apresentado pelos trechos construídos com asfalto convencional e modificado com EVA.

Em agosto de 1996 os trechos foram destruídos por motivo de obras de restauração da drenagem e da pavimentação da Rua Leopoldo Bulhões. Nessa época, o trecho construído com asfalto modificado com SBS apresentava a superfície de rolamento em estado perfeito, sem trincas ou fissuras, e a deflexão característica manteve seu valor. Já os trechos construídos com asfalto convencional e modificado com EVA apresentavam trincas do tipo couro de crocodilo, buracos e deformações.

Ramos et al. (1996) descrevem também a reforma do autódromo Nélson Piquet, na cidade do Rio de Janeiro, realizada em 1995. Nessa obra, o revestimento asfáltico da pista teve sua camada de rolamento composta por asfalto modificado pelo polímero SBS, e a pintura de ligação entre a camada de regularização e a de rolamento foi executada com emulsão modificada com látex de SBR. Através do controle de desempenho, realizado até 1996, verificou-se a ocorrência de alguns problemas de ondulações e pequenos desníveis de juntas. Mas esses defeitos foram decorrentes da 
execução e não do emprego de asfaltos modificados. O desempenho da pista foi considerado bom, especialmente quanto à adesão e à coesão proporcionadas pelo emprego de asfaltos modificados. Havia uma grande preocupação em relação ao desprendimento dos agregados, quando submetidos a elevados esforços. No entanto, nenhum deslocamento foi verificado.

Freitas (1996) comparou o comportamento de asfaltos modificados com EVA com o comportamento de asfaltos convencionais e verificou que a adição do polímero EVA propicia aumento da consistência em temperaturas elevadas, o que se traduz em maior resistência à deformação permanente; maior flexibilidade em baixas temperaturas; menor suscetibilidade térmica, com conseqüente aumento do intervalo de plasticidade; maior ductilidade, o que torna as misturas mais resistentes à fadiga e aumento da coesão em uma faixa de temperatura ampliada, particularmente nas temperaturas de serviço dos pavimentos.

Motta et al. (1996), através da análise de resultados de ensaios de fluência por compressão uniaxial dinâmica, observaram que existe um teor ótimo de polímero a ser utilizado, que no caso do estudo analisado pelos autores foi em torno de 5\% de SBS, pois misturas com ligantes modificados pela adição de 5\% de SBS apresentaram as menores deformações, inclusive menores que as deformações apresentadas por misturas com ligante modificado pela adição de $7 \%$ de SBS. Verificou-se assim que o ensaio de creep dinâmico é capaz de diferenciar o comportamento de misturas compostas por ligantes modificados.

Amaral (2000) avaliou as vantagens e desvantagens de se utilizar asfalto modificado com o polímero SBS em misturas densas com seixo rolado como agregado graúdo. Os ensaios utilizados para avaliação do comportamento das misturas foram ensaios Marshall, ensaio de fluência por compressão uniaxial estática à $40^{\circ} \mathrm{C}$, ensaio de resistência à tração por compressão diametral a $25^{\circ} \mathrm{C}$ e ensaio de módulo de resiliência por compressão diametral dinâmica, realizado também à $25^{\circ} \mathrm{C}$. Os resultados dos ensaios Marshall e de resistência à tração acusaram um melhor desempenho das misturas com asfalto modificado, assim como as relações entre o módulo de resiliência e a resistência à tração. Os resultados do ensaio de fluência por compressão uniaxial 
estática ora apontaram as misturas com asfalto modificado como tendo melhor comportamento quanto à deformação permanente, ora o contrário.

No estudo realizado por Oda (2000), asfaltos modificados com borracha mostraram-se mais resistentes ao acúmulo de deformação permanente e ao aparecimento de trincas por fadiga. $\mathrm{O}$ efeito dos fatores teor e granulometria da borracha, temperatura de mistura e tempo de reação foram avaliados através de ensaios tradicionais de caracterização de ligantes asfálticos e também através de ensaios do Método Superpave.

Taira (2001) avaliou o desempenho de misturas asfálticas densas utilizando um ligante convencional CAP20 e o mesmo ligante modificado com o polímero SBS, através dos ensaios Marshall, fluência por compressão uniaxial estática e dinâmica, resistência à tração por compressão diametral e módulo de resiliência por compressão diametral dinâmica. Os ensaio de fluência por compressão uniaxial estática e os ensaios de módulo de resiliência não distinguiram claramente o efeito da adição de polímeros em misturas asfálticas, ao contrário dos ensaios de fluência dinâmica, que identificaram o melhor comportamento das misturas com asfalto modificado, assim como os ensaios de estabilidade Marshall.

Bertollo (2002) estudou o comportamento de misturas agregado-borracha e avaliou o efeito produzido pelo teor e pela granulometria da borracha reciclada de pneumáticos sobre as propriedades das misturas asfálticas densas. Misturas compostas por partículas de borracha utilizadas em substituição a parte dos agregados pétreos tiveram seu desempenho comparado ao de misturas de controle, sem borracha. A avaliação das propriedades mecânicas das misturas foi realizada através do ensaio de compressão diametral dinâmico, utilizado para determinação do módulo de resiliência, ensaio de resistência à tração por compressão diametral e ensaio de afundamento em trilha de roda, em equipamento simulador de tráfego em laboratório.

No estudo realizado por Bertollo (2002), os resultados dos ensaios de trilha de roda indicaram que a incorporação de borracha na granulometria fina melhora o desempenho das misturas em termos de resistência à deformação permanente, quando comparada à mistura de controle. Quanto ao módulo de resiliência e à resistência à tração, os valores apresentados pelas misturas modificadas com borracha foram menores que os 
apresentados pelas misturas de controle. No entanto a redução do módulo de resiliência ocasionada pela adição de borracha não foi proporcional à redução da resistência à tração, o que, segundo Bertollo (2002), sugere maior flexibilidade e resistência à fadiga das misturas modificadas.

Faxina (2002) avaliou o desempenho de três misturas asfálticas do tipo concreto asfáltico usinado a quente, duas empregando diferentes teores de borracha moída e óleo de xisto (CAP $40+12 \%$ de borracha $+10 \%$ de óleo de xisto e CAP $40+20 \%$ de borracha $+15 \%$ de óleo de xisto), e uma convencional. Foram realizados ensaios de resistência à tração, módulo de resiliência e fluência por compressão uniaxial estática. Faxina (2002) concluiu ser viável a execução de trechos experimentais empregando as duas misturas modificadas testadas.

\subsubsection{Comportamento de asfaltos modificados quanto ao envelhecimento}

Liang e Lee (1996) estudaram o envelhecimento de misturas asfálticas com ligante modificado por borracha utilizando os métodos de envelhecimento propostos por Von Quintus et al. (1991). No envelhecimento a curto prazo, os corpos de prova compactados foram colocados em uma estufa com ventilação forçada à temperatura de $135^{\circ} \mathrm{C}$ por oito horas. Para simulação do envelhecimento a longo prazo, as amostras compactadas inicialmente foram aquecidas à $60^{\circ} \mathrm{C}$ na estufa com ventilação forçada pelo período de dois dias, ficando então submetidas a uma temperatura de aproximadamente $107^{\circ} \mathrm{C}$ pelo período adicional de 5 dias. Também foi simulado o envelhecimento a curto prazo apenas do ligante, através do ensaio TFOT (thin film oven test), realizado de acordo com a norma ASTM D1754.

A avaliação do envelhecimento a curto prazo sofrido pelo ligante modificado foi realizada por Liang e Lee (1996) através do ensaio de cisalhamento dinâmico, realizado com o reômetro de cisalhamento dinâmico. Foram medidos o módulo complexo cisalhante $\left(\mathrm{G}^{*}\right)$ e o ângulo de fase $\delta$. Através desse ensaio podem ser caracterizados os comportamentos viscoso e elástico do ligante. O módulo complexo cisalhante $\left(\mathrm{G}^{*}\right)$, que em valor absoluto é definido como a razão entre a tensão cisalhante máxima $\left(\tau_{\max }\right)$ e a deformação cisalhante máxima $\left(\gamma_{\max }\right)$, é a medida da resistência total do material aos 
esforços cisalhantes repetidos. O ângulo de fase $(\delta)$ define a defasagem entre a tensão aplicada e a deformação sofrida, e é um indicador da relação entre as deformações recuperável e não recuperável.

De acordo com os resultados obtidos por Liang e Lee (1996), quanto menor o tamanho das partículas de borracha utilizadas para modificação do ligante e quanto maior a quantidade de borracha utilizada, maior o aumento da viscosidade. Quanto à resposta do ligante ao envelhecimento a curto prazo, observaram que asfaltos modificados por borracha apresentaram aumentos de viscosidade superiores aos apresentados por asfaltos convencionais.

Asfaltos modificados com borracha apresentaram maiores valores de módulo complexo cisalhante, que aumentou com o aumento da porcentagem de borracha adicionada ao ligante. Além disso, o envelhecimento a curto prazo aumentou o módulo complexo cisalhante, tanto de asfaltos modificados como de asfaltos convencionais. Entretanto o aumento do módulo complexo cisalhante com o envelhecimento foi maior para asfaltos modificados com borracha.

O comportamento das misturas asfalto-agregado avaliadas por Liang e Lee (1996) quanto ao envelhecimento, foi semelhante ao comportamento dos ligantes. Em geral, os processos de envelhecimento a curto e longo prazos exerceram efeitos mais significativos em misturas com asfalto modificado do que em misturas com asfalto convencional. Reforçando essa conclusão, misturas com asfalto modificado por borracha apresentaram maiores aumentos do módulo de resiliência, decorrente do envelhecimento, do que misturas com asfalto convencional.

Leite (1999) submeteu um asfalto modificado com o polímero SBS ao processo de envelhecimento em estufa RTFOT (rolling thin film oven test) e verificou que as propriedades reológicas, tais como ponto de amolecimento, penetração e módulo complexo, pioraram devido à redução de peso molecular e à quebra de cadeias nas insaturações presentes no butadieno do copolímero SBS.

Para verificação da redução do peso molecular do copolímero SBS quando submetido ao efeito do calor e do ar, amostras antes e após o envelhecimento foram avaliadas no 
cromatógrafo por permeação em gel. Os resultados indicaram que a degradação do SBS aumenta após o efeito do calor e do ar, e esse aumento é proporcional ao aumento do teor de diluente. Ou seja, a aromaticidade, vista como favorável para compatibilização dos asfaltos modificados com SBS, deve ser limitada, pois favorece a quebra de ligações insaturadas.

De acordo com Leite (1999), o modo como o polímero é incorporado ao ligante, ou seja, o tipo de agitação, o tempo de mistura e até mesmo o teor de SBS, tem efeito na suscetibilidade ao envelhecimento. Ainda segundo a autora, a reticulação com enxofre consiste em um modo de reverter parte das insaturações do butadieno em ligações covalentes simples, cruzadas com enxofre, e dessa forma tornar o asfalto modificado com o copolímero SBS mais resistente à presença de calor e ar.

Morilha Jr e Trichês (2003) avaliaram em laboratório a resistência ao envelhecimento de nove ligantes, três convencionais e sete modificados por polímeros, sendo que dos sete, três foram modificados pelo polímero SBS, um por EVA e dois por borracha moída de pneus. Os ligantes convencionais utilizados foram CAP 20, CAP 40 e CAP 7 fluxado a partir de um CAP 40. A análise do envelhecimento sofrido pelos ligantes baseou-se nos resultados dos ensaios de perda de massa, penetração, ponto de amolecimento, recuperação elástica e viscosidade dinâmica a 135,155 e $175^{\circ} \mathrm{C}$.

De acordo com os resultados obtidos por Morilha Jr e Trichês (2003), os asfaltos modificados por SBS, independentemente do teor de polímero utilizado, não apresentaram boa resistência ao envelhecimento. Por outro lado, os asfaltos modificados com EVA apresentaram aumento da recuperação elástica com o envelhecimento, possivelmente devido a não existência de ligações duplas em suas moléculas. Os dois ligantes com borracha moída de pneus também apresentaram aumento significativo de recuperação elástica após os processos de envelhecimento. Segundo os autores isso provavelmente ocorreu em virtude do aquecimento proporcionar uma maior interação entre as moléculas de borracha e de asfalto, o que pode dar continuidade ao processo de fusão, melhorando consequentemente a recuperação elástica. Os autores sugerem ainda que esse fenômeno também deve ocorrer durante a usinagem, proporcionando misturas asfálticas mais flexíveis, mesmo após a oxidação que ocorre em todo o processo de produção e aplicação da massa asfáltica. 
Coplantz et al. (1993) relatam o estudo realizado por J.L. Goodrich, em 1988, onde cinco tipos de ligantes, três convencionais e dois modificados com polímeros, foram submetidos a processos de envelhecimento em laboratório. Através dos resultados obtidos pôde-se concluir que a modificação com polímero não reduz a oxidação sofrida pelo ligante. Entretanto, analisando os resultados de um estudo realizado em pistas experimentais da Califórnia, Coplantz et al. (1993) constataram que misturas compostas por asfalto modificado com polímeros apresentam maior resistência ao envelhecimento. Os trechos experimentais foram construídos na Rodovia 98, município Imperial, próximo a Ocotillo, e na rodovia Interestadual 40, município de São Bernardino, próximo a Needles. Nesse estudo foi utilizado asfalto modificado com o polímero SBS.

Raad e Saboundjian (2001) estudaram a influência do envelhecimento ocorrido em campo na resistência à fadiga de misturas asfálticas convencionais e de misturas com asfalto-borracha. Concluíram que o envelhecimento é prejudicial para misturas convencionais, reduzindo sua vida de fadiga, e benéfico para misturas com asfaltoborracha, que tiveram sua vida de fadiga prolongada com o envelhecimento.

Verificou-se assim a ausência de consenso quanto à influência da adição de modificadores nos processos de envelhecimento sofridos pelas misturas asfálticas. Dessa forma, embora as propriedades mecânicas de misturas compostas por asfalto modificado com polímeros estejam sendo estudadas por inúmeras pesquisas, a mudança de seu comportamento ao longo do tempo, também denominada envelhecimento, ainda precisa ser melhor investigada (Mouillet et al, 2003). 


\title{
4 AVALIAÇÃO EM LABORATÓRIO DO DESEMPENHO DE MISTURAS ASFÁLTICAS QUANTO À ESTABILIDADE E À FLEXIBILIDADE
}

\subsection{Considerações iniciais}

\begin{abstract}
A avaliação do desempenho estrutural de pavimentos flexíveis deve considerar deformações elásticas ou resilientes e deformações plásticas ou permanentes. A deformação elástica ou resiliente é ocasionada pela repetição das cargas, que gera as trincas de fadiga. A deformação plástica ou permanente pode ser observada nos afundamentos das trilhas de roda, ocasionados por dois tipos distintos de solicitações, a compressão e o cisalhamento. Os esforços de compressão geram a densificação dos materiais constituintes das camadas dos pavimentos e os esforços cisalhantes, movimentos laterais de uma ou mais camadas. Dessa forma, a avaliação de misturas asfálticas em laboratório deve englobar tanto ensaios que meçam a deformação elástica, relacionada à flexibilidade das misturas, como ensaios que meçam a deformação permanente, relacionada à estabilidade das misturas.
\end{abstract}

\subsection{Deformações permanentes}

Deformações permanentes são afundamentos ou depressões longitudinais nas trilhas de roda, em conseqüência da consolidação dos materiais constituintes das camadas do 
pavimento e também de movimentos laterais de uma ou mais camadas, devido à ação de cargas repetitivas do tráfego (HENSLEY e LEAHY, 1989; LAI e HUFFERD, 1976 e ANANI et al., 1990).

A deformação permanente ocasionada pelo afundamento das camadas de base, sub-base ou subleito geralmente ocorre quando o pavimento é submetido a cargas superiores àquelas para as quais foi projetado, ou quando ocorreram falhas de compactação durante o processo de sua construção. Esse tipo de deformação gera trincas de tração na parte inferior da camada de revestimento.

Embora todas as camadas de um pavimento possam ter influência nas deformações permanentes das trilhas de roda, esse trabalho restringiu-se às deformações permanentes da camada de revestimento asfáltico.

Brown e Cross (1989), em trabalho realizado para avaliação da deformação permanente em campo e em laboratório, constataram que a parcela mais significativa da deformação permanente nos cinco pavimentos por eles estudados ocorreu entre 7 e $10 \mathrm{~cm}$ da superfície dos pavimentos. Al-Abdul Wahhab et al. (1995) também observaram a ocorrência de deformações permanentes nos $10 \mathrm{~cm}$ superiores das camadas de concreto asfálico das onze principais rodovias da Arábia Saudita. De acordo com Anani et al. (1990), resultados semelhantes têm sido encontrados em diversos estudos.

Hofstra e Klomp* (1972 apud SOUSA et al.,1991, p.10) também encontraram maiores deformações permanentes na parte superior da camada de revestimento. Segundo esses autores, esse comportamento é esperado, pois com o aumento da profundidade aumenta a resistência à deformação permanente por movimentação plástica e diminuem os esforços cisalhantes. Sousa et al. (1991) e Mohamed e Yue (1994) mencionam que a maior parte da deformação permanente de um pavimento deve-se a esforços cisalhantes que ocorrem na parte superior da camada de concreto asfáltico.

* HOFSTRA, A. e KLOMP, A.J.G. (1972). Permanent deformation of flexible pavements under simulated road traffic conditions, Proceedings, Third International Confrence on the Structural Design of Asphalt Pavements. London, v.1, p.613-621 apud SOUSA, J.B.; CRAUS, J.; MONISMITH, C.L. (1991). Summary report on permanent deformation in asphalt concrete. Publicação SHRP-A/IR-91-104 do Strategic Highway Research Program. National Research Council. Washington, D.C. 120p. 
São muitos os fatores que interferem na ocorrência de deformações permanentes, podendo-se citar o volume de tráfego pesado, a pressão de enchimento dos pneus, a temperatura de serviço do pavimento, as práticas construtivas e os fatores internos, relacionados às características das camadas do pavimento. Dentre os últimos podem-se citar as espessuras das camadas do pavimento e as propriedades dos materiais que as constituem (ANANI et al., 1990).

Sousa et al. (1991) apresentaram um resumo dos principais fatores que podem afetar o desempenho de misturas asfálticas quanto à deformação permanente. Esse resumo encontra-se reproduzido na Tabela 4.1 .

Tabela 4.1 - Fatores que interferem no desempenho de misturas asfálticas quanto à deformação permanente

\begin{tabular}{|c|c|c|c|}
\hline & fator & variação do fator & $\begin{array}{l}\text { efeito na resistência à } \\
\text { deformação permanente }\end{array}$ \\
\hline agregado & $\begin{array}{l}\text { - textura superficial } \\
\text { - granulometria } \\
\text { - forma } \\
\text { - tamanho }\end{array}$ & $\begin{array}{l}\text { - lisa para rugosa } \\
\text { - aberta para contínua } \\
\text { - redonda para angulosa } \\
\text { - aumento do tamanho } \\
\quad \text { máximo } \\
\end{array}$ & $\begin{array}{l}\text { - aumento } \\
\text { - aumento } \\
\text { - aumento } \\
\text { - aumento }\end{array}$ \\
\hline ligante & - rigide $^{\mathrm{a}}$ & - aumento & - aumento \\
\hline mistura & $\begin{array}{l}\text { - quantidade de ligante } \\
\text { - volume de vazios }{ }^{\text {b }} \\
\text { - vazios no agregado mineral } \\
\text { - método de compactação }\end{array}$ & $\begin{array}{l}\text { - aumento } \\
\text { - aumento } \\
\text { - aumento }\end{array}$ & $\begin{array}{l}\text { - redução } \\
\text { - redução } \\
\text { - redução } \\
\text { d }\end{array}$ \\
\hline $\begin{array}{l}\text { condições } \\
\text { de ensaio }\end{array}$ & $\begin{array}{l}\text { - temperatura } \\
\text { - estado de } \\
\text { tensão/deformação } \\
\text { - repetição do carregamento } \\
\text { - água }\end{array}$ & $\begin{array}{l}\text { - aumento } \\
\text { - aumento da pressão de } \\
\text { contato dos pneus } \\
\text { - aumento } \\
\text { - seco para molhado }\end{array}$ & $\begin{array}{l}\text { - redução } \\
\text { - redução } \\
\text { - redução } \\
\text { - redução se a mistura } \\
\quad \text { for sensível à água }\end{array}$ \\
\hline
\end{tabular}

a - refere-se à rigidez na temperatura em que a suscetibilidade a deformações permanentes está sendo avaliada. Modificadores podem ser adicionados ao ligante para aumentar sua rigidez em temperaturas críticas, reduzindo assim a propensão a deformações permanentes;

$\mathrm{b}$ - quando o volume de vazios é inferior a 3\%, a suscetibilidade a deformações permanentes aumenta;

$\mathrm{c}$ - questiona-se atualmente se valores muito baixos de VAM (por exemplo inferiores a 10\%) devem ser evitados;

d - o método de compactação, em campo ou em laboratório, pode influenciar na estrutura do material e consequentemente em sua suscetibilidade a deformações permanentes.

Fonte: Sousa et al. (1991)

Ainda segundo Sousa et al. (1991), misturas asfálticas com elevados teores de ligante e poucos vazios, volume de vazios inferior a $4 \%$, estão sujeitas a deformações permanentes por movimentação plástica, que se caracteriza por afundamento no centro das trilhas de roda, acompanhado por pequenas elevações laterais. Isso porque a redução 
do volume de vazios em conseqüência do aumento do teor de ligante indica que os espaços vazios estão preenchidos com ligante, o que faz com que este se torne praticamente um lubrificante entre as partículas de agregado. A suscetibilidade a deformações permanentes de misturas com essas características se agrava em temperaturas elevadas, quando o ligante asfáltico passa a facilitar ainda mais as deformações por cisalhamento.

Por outro lado, volumes de vazios da mistura compactada superiores a $8 \%$ tornam a camada de revestimento sujeita à consolidação nas trilhas de roda, que nesse caso aparece como uma depressão sem o surgimento de elevações laterais.

O resumo apresentado por Sousa et al. (1991) e reproduzido na Tabela 4.1, sobre os fatores influentes na suscetibilidade de misturas asfálticas a deformações permanentes, é corroborado por diversas pesquisas, como por exemplo Oteng-Seifah e Manke (1976), que investigaram a ocorrência de deformação permanente em pavimentos flexíveis de alta qualidade; Al-Abdul Wahhab et al. (1995), que verificaram a influência do volume de vazios, da porcentagem de vazios no agregado mineral, da ação das cargas do tráfego e da temperatura; Coelho (1996), que estudou o efeito da granulometria das misturas e da temperatura e Merighi (1999), que avaliou o efeito da temperatura, da distribuição granulométria, do tempo de carregamento e da magnitude do carregamento.

\subsubsection{Métodos para previsão de deformações permanentes em laboratório}

A estabilidade estrutural de uma mistura asfáltica está relacionada à resistência à deformação permanente apresentada pela camada de concreto asfáltico do pavimento em condições de serviço. Surge assim a necessidade de se avaliar as condições das misturas em laboratório, através de testes que permitam a previsão do comportamento dessas misturas quanto à deformação permanente, quando utilizadas como camada de revestimento de pavimentos reais, sujeitos às solicitações do tráfego e às condições climáticas.

A previsão das deformações permanentes de um pavimento envolve o desenvolvimento de métodos de análise ou modelos de previsão, que permitam a estimativa das tensões, 
deformações e deslocamentos que ocorrerão nas diversas camadas em conseqüência do carregamento aplicado, e também o desenvolvimento de métodos de ensaio em laboratório que permitam uma caracterização realística dos materiais constituintes dessas camadas. É através dos ensaios que são determinados os parâmetros básicos, utilizados para a calibração dos modelos teóricos de previsão de comportamento. Os ensaios de laboratório, por sua vez, devem ser validados por comparações de resultados com ensaios realizados em pistas experimentais.

Os métodos de análise das tensões, deformações e deslocamentos que ocorrem na estrutura de um pavimento podem basear-se na teoria elástica linear ou não-linear aplicada a um sistema em camadas ou podem considerar comportamento visco-elástico das camadas, com variação do comportamento dos materiais em função do tempo de carregamento. Realizando-se a análise visco-elástica das camadas, as propriedades dos materiais podem ser definidas em termos de modelos resultantes de um número finito de elementos de Maxwell e Kelvin, que podem ser combinados em diversos arranjos, de modo a se obter uma melhor representação do comportamento dos materiais.

Sousa et al. (1991) apresentaram uma série de modelos de previsão de deformações permanentes, que podem ser divididos em três categorias, equações de regressão empíricas, leis de deformações plásticas e equações funcionais diretamente baseadas em resultados de ensaios de laboratório.

De qualquer forma, independentemente do método de análise e do modelo de comportamento utilizados, ensaios laboratoriais se fazem sempre necessários para a caracterização dos materiais. O objetivo dos ensaios de laboratório é reproduzir, o mais fielmente possível, as condições reais de um pavimento, incluindo o estado de tensões, as condições de temperatura e umidade, e a composição geral do material a ser ensaiado.

Os métodos de avaliação tradicionais, como o método Marshall para misturas asfálticas, são empíricos e possuem aplicação limitada, sendo que seus critérios não se estendem a qualquer tipo de mistura. Como solução para estimativa em laboratório das deformações ocorridas em campo, foram desenvolvidos os ensaios de trilhas de roda, nos quais uma 
roda com carga constante move-se em uma trilha de roda única, em temperatura controlada.

Al-Abdul Wahhab et al. (1995) propuseram um critério para a avaliação da resistência de misturas asfálticas a deformações permanentes, baseado nos resultados dos ensaios de trilha de roda, estabilidade Hveem e módulo de resiliência. Esse critério encontra-se apresentado na Tabela 4.2.

Tabela 4.2 - Critério subjetivo para avaliação da deformação permanente de misturas asfálticas

\begin{tabular}{cccccc}
\hline $\begin{array}{c}\text { resistência à } \\
\text { deformação } \\
\text { permanente }\end{array}$ & $\begin{array}{c}\text { profundidade da } \\
\text { deformação permanente } \\
\text { no ensaio de trilhas de } \\
\text { roda (mm/10000ciclos) }\end{array}$ & ou & $\begin{array}{c}\text { estabilidade } \\
\text { Hveem } \\
(\%)\end{array}$ & $\begin{array}{c}\text { MR } \\
25^{\circ} \mathrm{C} \\
(\mathrm{MPa})\end{array}$ \\
\hline muito boa & $<2,0$ & ou & $>47$ & e & $>3300$ \\
\hline boa & $2,0-3,5$ & ou & $43-47$ & e & $3000-3300$ \\
\hline regular & $3,5-5,0$ & ou & $37-43$ & e & $2600-3000$ \\
\hline baixa & $>5,0$ & ou & $<37$ & e & $<2400$ \\
\hline
\end{tabular}

De acordo com Al-Abdul Wahhab et al. (1995), a resistência à deformação permanente pode ser avaliada de forma subjetiva em laboratório, determinando-se o módulo de resiliência das amostras e em seguida a estabilidade Hveem.

No Brasil, segundo Merighi (1999), houve um grande avanço em termos de adequação laboratorial para medida de deformações permanentes com a aquisição do equipamento francês simulador de tráfego tipo tracking test pelo laboratório LTP-EPUSP.

Bernucci et al. (1996) estudaram a potencialidade de desenvolvimento de deformação permanente em concretos asfálticos usinados a quente, em função da variação do teor de ligante utilizado nas misturas. Os ensaios foram realizados no equipamento simulador de tráfego, que testa duas placas de misturas asfálticas compactadas de cada vez. De acordo com Bernucci et al. (1996), o equipamento é munido de rodas pneumáticas, cuja pressão do pneu e carga no eixo são controláveis. A solicitação no ensaio é feita pela passagem repetida da roda do equipamento sobre a placa de mistura asfáltica compactada, em ciclos de ida e retorno da roda de $1 \mathrm{~Hz}$, em temperaturas controladas que podem variar de $20^{\circ} \mathrm{C}$ a $60^{\circ} \mathrm{C}$. $\mathrm{O}$ afundamento na trilha de roda é medido em diversos pontos, após números previamente determinados de solicitações. 
Buscando métodos de ensaio mais simplificados para a avaliação da deformação permanente sofrida por misturas asfálticas, pesquisadores da Shell desenvolveram o ensaio de fluência por compressão uniaxial, ou ensaio de creep. Experimentos laboratoriais conduzidos por diversos autores têm demonstrado que esse ensaio é capaz de diferenciar comportamentos de misturas de concreto asfáltico quanto à deformação permanente.

Um resumo dos resultados encontrados por alguns autores, que procuraram identificar métodos de ensaios adequados para a determinação da suscetibilidade de misturas asfálticas a deformações permanentes, é apresentado na Tabela 4.3.

Pode-se observar pelo resumo apresentado na Tabela 4.3 que o ensaio de fluência por compressão uniaxial surgiu como uma forma de simular em laboratório a deformação permanente ocorrida em campo. Uma das razões para a difusão de seu uso é a relativa simplicidade de sua execução.

Hills (1973) forneceu as bases teóricas para o ensaio de creep estático, propondo modelos teóricos para a deformação sofrida por misturas asfálticas, consideradas por Hills (1973) como sistemas formados por partículas de agregado mineral envoltas por películas de ligante asfáltico, com vazios entre as partículas de agregado.

Para a construção dos modelos foi adotada a hipótese de que as deformações são consequiência do deslocamento relativo entre as partículas de agregado, ou seja, da deformação cisalhante que ocorre no ligante asfáltico. Considerou-se também que, para um nível constante de tensão, a velocidade relativa de deslocamento entre duas partículas de agregado depende da espessura da película asfáltica que separa essas partículas e que, quando uma mistura é submetida a uma força de compressão, a força normal que atua entre duas partículas adjacentes irá comprimir o ligante para os vazios existentes na mistura. Dessa forma, a deformação cisalhante diminui ao longo do ensaio. 
Tabela 4.3 - Avaliação de alguns ensaios empregados para a determinação da suscetibilidade de misturas asfálticas a deformações permanentes

\begin{tabular}{|c|c|c|c|}
\hline & $\begin{array}{l}\text { ensaios } \\
\text { avaliados }\end{array}$ & $\begin{array}{c}\text { avaliação dos } \\
\text { ensaios }\end{array}$ & $\begin{array}{c}\text { modo de avaliação } \\
\text { empregado }\end{array}$ \\
\hline $\begin{array}{l}\text { Van de Loo } \\
\text { (1974) }\end{array}$ & $\begin{array}{l}\text { - creep estático } \\
\text { - ensaios Marshall }\end{array}$ & $\begin{array}{l}\text { - adequado } \\
\text { - não adequados }\end{array}$ & $\begin{array}{l}\text { comparação com resultados } \\
\text { do ensaio de trilha de roda }\end{array}$ \\
\hline $\begin{array}{c}\text { Thrower* } \\
\text { (1978 apud } \\
\text { SOUSA et al., } \\
1991, \text { p.70) }\end{array}$ & $\begin{array}{l}\text { - fluência por compressão } \\
\text { triaxial }\end{array}$ & - não adequado & $\begin{array}{l}\text { estado de tensões da camada } \\
\text { de revestimento não pode seı } \\
\text { reproduzido por esse ensaio, } \\
\text { pois o cisalhamento nessa } \\
\text { camada é elevado }\end{array}$ \\
\hline $\begin{array}{l}\text { Brown e Cross } \\
\text { (1989) }\end{array}$ & $\begin{array}{l}\text { - módulo de resiliência } \\
\text { - ensaio de tração indireta } \\
\text { - fluência Marshall }\end{array}$ & $\begin{array}{l}\text { - não adequado } \\
\text { - não adequado } \\
\text { - adequado }\end{array}$ & $\begin{array}{c}\text { comparação com } \\
\text { comportamento da mistura } \\
\text { quando utilizada como } \\
\text { camada de revestimento }\end{array}$ \\
\hline $\begin{array}{l}\text { Anani et al. } \\
\text { (1990) }\end{array}$ & $\begin{array}{l}\text { - módulo de resiliência } \\
\text { - VAM } \\
\text { - estabilidade Hveem } \\
\text { - estabilidade Marshall } \\
\text { - fluência Marshall } \\
\end{array}$ & $\begin{array}{l}\text { - adequado } \\
\text { - adequado } \\
\text { - indefinido } \\
\text { - indefinido } \\
\text { - indefinido } \\
\end{array}$ & $\begin{array}{c}\text { comparação com } \\
\text { comportamento da mistura } \\
\text { quando utilizada como } \\
\text { camada de revestimento em } \\
\text { pavimentos reais }\end{array}$ \\
\hline $\begin{array}{l}\text { Sousa et al. } \\
\quad(1991)\end{array}$ & $\begin{array}{l}\text { - creep estático } \\
\text { - creep dinâmico } \\
\text { - ensaio de trilha de roda } \\
\text { - cisalhamento direto } \\
\text { - cisalhamento por torção } \\
\text { - fluência por compressão } \\
\text { triaxial } \\
\text { - fluência por compressão } \\
\text { diametral }\end{array}$ & $\begin{array}{l}\text { - adequado } \\
\text { - adequado } \\
\text { - adequado } \\
\text { - adequado } \\
\text { - adequado } \\
\text { - adequado } \\
\text { - não adequado }\end{array}$ & $\begin{array}{l}\text { comparação com resultados } \\
\text { de pistas experimentais }\end{array}$ \\
\hline $\begin{array}{l}\text { Merighi } \\
\text { (1999) }\end{array}$ & $\begin{array}{l}\text { - creep dinâmico } \\
\text { - ensaio de trilha de roda }\end{array}$ & $\begin{array}{l}\text { - resultados } \\
\text { compatíveis } \\
\text { - resultados } \\
\text { compatíveis } \\
\end{array}$ & $\begin{array}{c}\text { comparação dos resultados } \\
\text { do ensaio de creep dinâmico } \\
\text { com os resultados do ensaio } \\
\text { de trilha de roda }\end{array}$ \\
\hline $\begin{array}{l}\text { Coelho } \\
(1996) \\
\end{array}$ & $\begin{array}{l}\text { - creep estático } \\
\text { - ensaio Marshall }\end{array}$ & $\begin{array}{l}\text { - adequado } \\
\text { - não adequado }\end{array}$ & $\begin{array}{l}\text { comparação com resultados } \\
\text { de ensaios de trilha de roda }\end{array}$ \\
\hline $\begin{array}{c}\text { Al-Abdul } \\
\text { Wahhab et al. } \\
\text { (1995) }\end{array}$ & $\begin{array}{c}\text { - ensaio de trilha de roda } \\
+ \\
\text { módulo de resiliência }\end{array}$ & - adequados & $\begin{array}{c}\text { comparação com } \\
\text { comportamento da mistura } \\
\text { quando utilizada como } \\
\text { camada de revestimento }\end{array}$ \\
\hline
\end{tabular}

Observações:

creep estático = ensaio de fluência por compressão uniaxial estática;

creep dinâmico = ensaio de fluência por compressão uniaxial dinâmica;

módulo de resiliência = parâmetro obtido através do ensaio de compressão diametral dinâmica

\footnotetext{
* THROWER, E.N. (1978). Stress invariants and mechanical testing of pavement materials. Report 810. Transport and Road Research Laboratory. Great Britain apud SOUSA, J.B.; CRAUS, J.; MONISMITH, C.L. (1991). Summary report on permanent deformation in asphalt concrete. Publicação SHRP-A/IR-91104 do Strategic Highway Research Program. National Research Council. Washington, D.C. 120p.
} 
Para a montagem dos modelos, Hills (1973) considerou comportamento viscoelástico do material e proporcionalidade entre as tensões e deformações. Foram montados três modelos de deformação, através do isolamento de um par de partículas de agregado mineral, separadas por uma película de ligante asfáltico.

No primeiro modelo, a espessura da película asfáltica é considerada constante. Usando a equação de Newton para fluido viscoso, o deslocamento tangencial relativo depende dos fatores geométricos e é diretamente proporcional à tensão aplicada e ao tempo de carregamento, e inversamente proporcional à viscosidade do ligante. Sendo a deformação da mistura proporcional ao deslocamento do modelo, a deformação permanente da mistura é proporcional à deformação permanente do ligante betuminoso. Plotando-se a deformação da mistura em função da deformação do ligante em escala log-log segundo esse modelo de deformações, o resultado será uma linha reta com inclinação constante.

O segundo modelo considera que a tensão de compressão aplicada ao par de partículas de agregado faz com que a espessura da película de ligante diminua, em virtude do escoamento deste. Nesse modelo, inicialmente a deformação da mistura é igual à deformação do ligante e, após um certo tempo de carregamento, a deformação da mistura torna-se proporcional à raiz quadrada da deformação do ligante, o que significa diminuição da taxa de deformação ao longo do ensaio.

O terceiro modelo proposto por Hills (1973) considera pontos de contato entre partículas de agregado mineral adjacentes. Nesse caso a taxa de deformação é inversamente proporcional à área nominal de contato por unidade de volume da mistura, que por sua vez aumenta com o aumento da deformação ocorrida no ligante. A curva da deformação da mistura versus a deformação do ligante betuminoso tem inclinação igual ao inverso do logaritmo neperiano da deformação do ligante, ou seja, a inclinação da curva diminui com o aumento da deformação do ligante.

Segundo Coelho (1996), o uso do ensaio de fluência por compressão uniaxial para medida das características de misturas asfálticas passou a ser largamente empregado a partir da década de 1970, ganhando força com as pesquisas realizadas no laboratório da Companhia Shell (“Koninklijke/Shell-Laboratorium”) de Amsterdã, na Holanda. 
Conforme mencionado por Mahboub (1990), pesquisadores da Shell caracterizaram a suscetibilidade de misturas asfálticas a deformações permanentes através do ensaio de fluência por compressão uniaxial (creep test), estabelecendo um vínculo empírico entre as propriedades reológicas do asfalto e o comportamento viscoelastoplástico do concreto asfáltico.

O método da Shell* (1978, apud MAHBOUB, 1990, p.148) permite a estimativa das deformações permanentes nas trilhas de roda a partir do módulo de rigidez da mistura asfáltica, obtido por sua vez em função do módulo de rigidez do asfalto, através do ensaio de fluência por compressão uniaxial.

Van der Poel (1954) mediu valores de rigidez do asfalto através de uma série de ensaios estáticos e dinâmicos, que forneceram resultados similares. Dessa forma o ensaio de creep estático foi considerado adequado para estimar valores de rigidez.

A equação estabelecida originalmente pela Shell para a previsão do potencial de formação de trilhas de roda foi

$$
h=H C_{m} Z \frac{\sigma_{\text {contato }}}{S_{m i x}}
$$

\section{Onde}

$\mathrm{h}=$ profundidade da trilha de roda;

$\mathrm{H}=$ espessura da camada asfáltica;

$\mathrm{C}_{\mathrm{m}}=$ fator de correção da Shell para o efeito dinâmico;

$\mathrm{Z}=$ fator de distribuição da tensão de compressão;

$\sigma_{\text {contato }}=$ pressão de contato dos pneus;

$\mathrm{S}_{\mathrm{mix}}=$ rigidez da mistura.

* SHELl PAVEMENT DESIGN MANUAL (1978). Shell Petroleum Co. London, England. apud MAHBOUB, K. (1990). Asphalt concrete creep as related to rutting. Journal of Materials in Civil Engineering. v.2, n.3, p.147-163. 
O fator Z foi determinado por Van de Loo (1976) através do programa computacional; BISAR, considerando o pavimento como uma camada única, composta por material elástico. Van de Loo (1976) montou gráficos de variação do fator Z em função da razão entre o raio da área de contato do carregamento e a espessura da camada de concreto asfáltico.

A premissa básica do método da Shell é que as deformações desenvolvidas em um pavimento asfáltico estão relacionadas às deformações que ocorrem em um ensaio de creep realizado em laboratório (MAHBOUB, 1990).

A partir dessa consideração pesquisadores da Shell montaram curvas de comportamento que relacionam a rigidez da mistura asfáltica $\left(S_{\text {mix }}\right)$ com a rigidez do asfalto $\left(S_{\text {asf }}\right)$, utilizando para isso o ensaio de creep estático.

De acordo com Van de Loo (1978), a relação entre a rigidez da mistura $\left(S_{\text {mix }}\right)$ e a rigidez do asfalto $\left(\mathrm{S}_{\mathrm{asf}}\right)$, obtida através do ensaio de creep estático, é igual à relação entre a componente viscosa da rigidez da mistura $\left(S_{\text {mix, visc }}\right)$, responsável pela deformação permanente, e a componente viscosa ou não recuperável da rigidez do asfalto $\left(S_{\text {asf, visc }}\right)$.

Dessa forma, para o cálculo da deformação permanente através da eq. (4.1), o valor de $S_{\text {mix }}$ a ser utilizado na verdade é a componente viscosa da rigidez da mistura $\left(S_{\text {mix, visc }}\right)$, obtida a partir das curvas de comportamento montadas pelos pesquisadores da Shell, que relacionam $S_{\text {mix }}$ com $S_{\text {asf }}$, sendo que $S_{\text {asf }}=S_{\text {asf, visc, cujo valor pode ser calculado }}$ pela eq. (4.2).

$$
S_{a s f}=\frac{3 \eta}{N t}
$$

Onde

$\mathrm{N}$ = número de aplicações de carga;

$\mathrm{t}=$ tempo de um ciclo de carregamento (s);

$\eta=$ viscosidade do asfalto $\left(\mathrm{Ns} / \mathrm{m}^{2}\right)$. 
Mahboub (1990) levantou três empecilhos ao uso dessa equação. Segundo esse autor, na eq. (4.1) o parâmetro de rigidez $\mathrm{S}_{\mathrm{mix}}$ é um parâmetro pseudo-elástico e é usado no formato da lei de Hooke, da seguinte forma

$$
\text { deformação }=\frac{\text { tens } \tilde{a} o=\left(Z \times \sigma_{\text {contato }}\right)}{\text { rigidez }=S_{\text {mix }}}
$$

Entretanto, esse formato é válido apenas para deformações elásticas, ou seja, recuperáveis, e dessa forma não deveria utilizar o parâmetro de rigidez total, $S_{\text {mix }}$, que representa a combinação das respostas elástica, plástica, viscoelástica e viscoplástica.

Além disso, o fator de correção para efeitos dinâmicos, $\mathrm{C}_{\mathrm{m}}$, que na equação da Shell (eq. 4.1) varia de 1 a 2, atua como um fator de majoração. Porém, em materiais viscoelásticos, carregamentos dinâmicos causam deformações menores que carregamentos estáticos.

Esse fenômeno foi melhor explicado por Kinder* (1986 apud MAHBOUB, 1990, p.148), cujos dados sugerem que carregamentos estáticos possuem efeitos mais danosos ao concreto asfáltico do que carregamentos dinâmicos.

Segundo Van de Loo (1978), a equação da Shell incorporou o fator de majoração $C_{m}$ em virtude de discrepâncias observadas entre os valores de profundidade de trilhas de roda previstos por essa equação e os observados em campo. Ainda segundo esse autor, a causa dessa discrepância está na extrapolação linear simples das medidas de rigidez realizadas em laboratório para as condições de campo, o que não é adequado.

Por último, Mahboub (1990) menciona a consideração da linearidade na equação da Shell e observa que a acumulação da deformação permanente não é linearmente proporcional ao nível de tensão.

* KINDER, D.F. (1986). A study of both the viscoelastic and permanent deformation properties of a New South Wales asphalt. 13 $3^{\text {th }}$ Australian Road Reseach Board. New South Wales, Australia. p.1-11 apud MAHBOUB, K. (1990). Asphalt concrete creep as related to rutting. Journal of Materials in Civil Engineering. v.2, n.3, p.147-163. 
A relação entre a variável independente tensão e a variável dependente deformação permanente possui a forma log-linear, com inclinação aproximadamente igual a 1,61, para misturas convencionais de concreto asfáltico. Khedr (1986) exemplifica mostrando que, quando o nível de tensão aumenta de $\sigma$ para $2 \sigma$, ocorre um aumento correspondente na deformação viscoplástica acumulada de $\varepsilon_{\mathrm{vp}}$ para $3 \varepsilon_{\mathrm{vp}}$.

Dessa forma, Mahboub (1990) propôs uma expressão para a previsão da deformação permanente, através de modificações da equação original da Shell. Seu método de previsão baseia-se no ensaio de creep estático.

O procedimento proposto por Mahboub (1990) permite que as características viscoplásticas medidas em laboratório sejam normalizadas em função das condições de tensão utilizadas em laboratório. Dessa forma é possível transformar os parâmetros medidos em laboratório nos respectivos parâmetros encontrados nos pavimentos em serviço, onde tensões superiores às de laboratório são encontradas. $\mathrm{O}$ resultado desse procedimento foi o desenvolvimento de um parâmetro denominado componente viscoplástico da rigidez da mistura.

O modelo de deformação original da Shell considera uma relação linear entre a tensão e a deformação plástica acumulada, sendo que na verdade esta relação não é linear. A equação modificada da Shell, proposta por Mahboub (1990), leva em conta a plasticidade e a não linearidade, da seguinte forma

$$
h=H\left[\frac{z \sigma_{\text {contato }}}{\sigma_{l a b}}\right]^{1,61} \varepsilon_{v p}(t)
$$

\section{Onde}

$\mathrm{h}=$ profundidade da trilha de roda;

$\mathrm{H}=$ espessura da camada asfáltica;

$\sigma_{\text {contato }}=$ pressão de contato dos pneus;

$\sigma_{\text {lab }}=$ tensão utilizada no ensaio de creep estático, em laboratório;

$\mathrm{z}=$ fator de distribuição da tensão de compressão;

$\varepsilon_{v p}(t)=$ deformação viscoplástica em função do tempo. 
A razão entre $z \sigma_{\text {contato }}$ e $\sigma_{l a b}$ é elevada à potência de 1,61 , para que sejam consideradas as não linearidades envolvidas nas deformações viscoplásticas acumuladas.

Segundo Mahboub (1990), várias pesquisas têm sugerido a expressão da deformação permanente acumulada em função do tempo de carregamento ou do número de ciclos de carregamento, através de funções potência.

Kenis (1976) propôs o modelo apresentado na eq. (4.5) e Pearl (1983), o modelo apresentado na eq. (4.6).

$$
\begin{gathered}
\varepsilon_{v p}=a t^{b} \\
\varepsilon_{v p}=a(\boldsymbol{\sigma}) t^{b}
\end{gathered}
$$

Onde

$\mathrm{t}=$ tempo de aplicação do carregamento;

$\sigma=$ tensão aplicada através do carregamento;

$\varepsilon_{\mathrm{vp}}=$ deformação viscoplástica;

$\mathrm{a}$ e $\mathrm{b}=$ constantes de regressão.

Em ambas as equações, o coeficiente $a$ é função da tensão aplicada no ensaio de fluência e da rigidez da mistura. $\mathrm{O}$ expoente $b$ representa a taxa em que a deformação permanente é acumulada em função do tempo, em um ensaio de creep estático. Para misturas de concreto asfáltico, o expoente $b$ não apresenta grandes variações, estando entre 0,17 e 0,25 (PERL et al., 1983; LAI e ANDERSON, 1973).

Tseng e Lytton* (1986 apud SOUSA et al, 1991) expressaram a deformação permanente ocasionada por carregamento repetitivo através de um modelo exponencial baseado em três parâmetros, conforme eq. (4.7)

\footnotetext{
* TSENG, K.H. e LYTTON, R.L. (1986). Prediction of permanent deformation in flexible pavement materials. STP 1016. American Society of Testing and Materials. p.154-172 apud SOUSA, J.B.; CRAUS, J.; MONISMITH, C.L. (1991). Summary report on permanent deformation in asphalt concrete. Publicação SHRP-A/IR-91-104 do Strategic Highway Research Program. National Research Council. Washington, D.C. 120p.
} 


$$
\varepsilon_{a}=\varepsilon_{0} \exp \left[-\left(\frac{\rho}{N}\right)^{\beta}\right]
$$

Onde

$\varepsilon_{\mathrm{a}}=$ deformação permanente;

$\mathrm{N}$ = número de ciclos de carregamento;

$\varepsilon_{0}, \rho, \beta=$ parâmetros de regressão

Embora a eq. (4.7) forneça uma ferramenta mais realística para a determinação de deformações permanentes do que as eq. (4.4, 4.5 e 4.6), esse modelo requer a realização de ensaios de creep dinâmico, ao invés de ensaios de creep estático. Comparações entre ensaios estáticos e dinâmicos têm sido realizadas por diversas pesquisas.

Van de Loo (1974) procurou correlacionar a deformação permanente que ocorre em ensaios de trilha de roda em laboratório com a deformação permanente medida no ensaio de creep estático. As diferenças encontradas entre as respostas foram atribuídas ao fato do ensaio de trilhas de roda ser confinado e dinâmico e o ensaio de creep estático, não confinado e estático.

Para avaliar a diferença entre carregamentos estáticos e dinâmicos, Van de Loo (1974) realizou ensaios não confinados, com carregamento contínuo e com carregamento repetitivo, encontrando valores de deformação permanente sempre maiores quando o carregamento adotado foi repetitivo, ou seja, dinâmico. A partir desse resultado inicial, foi realizada uma investigação mais minuciosa, na qual a temperatura utilizada foi de $20^{\circ} \mathrm{C}$, e a tensão de ensaio, $0,2 \mathrm{MPa}$. O ensaio foi realizado de duas formas, com carregamento ininterrupto por $17 \mathrm{~h}$ ou com carregamento repetitivo com durações de $1 \mathrm{~h}$, $10 \mathrm{~min}$ ou $1 \mathrm{~min}$, sendo que entre dois carregamentos consecutivos os corpos de prova foram submetidos a períodos de repouso. O carregamento repetitivo foi realizado até que a deformação total atingida fosse de 4,5\%. Em ambos os ensaios foram utilizados corpos de prova com dimensões de $60 \times 60 \times 200 \mathrm{~mm}$.

Os resultados demonstraram que o módulo de fluência da mistura, calculado pela razão entre a tensão aplicada e a deformação sofrida, diminuiu a medida que a duração da 
aplicação de carga também diminuiu, ou seja, o módulo de fluência diminuiu a medida que o número de aplicações de carga aumentou. Destacaram-se assim as diferenças entre ensaios estáticos e dinâmicos.

Ressalta-se entretanto que Van de Loo (1974) realizou os ensaios de creep estático e dinâmico em temperatura muito baixa $\left(20^{\circ} \mathrm{C}\right)$, não correspondente às temperaturas de serviço dos pavimentos no Brasil. Em temperaturas mais elevadas, como por exemplo temperatura de $40^{\circ} \mathrm{C}$, na qual geralmente são realizados os ensaios de creep, os efeitos danosos do carregamento estático são mais pronunciados. Para endossar essa observação cita-se Mahboub (1990), que comparou carregamentos estáticos e dinâmicos e constatou maior suscetibilidade de materiais viscoelásticos a deformações permanentes quando submetidos a carregamentos estáticos.

Van de Loo (1974) menciona também ensaios realizados para testar o princípio de superposição de efeitos, segundo o qual a deformação permanente no ensaio de creep dinâmico seria função apenas do tempo de carregamento acumulado. Os resultados dos testes mostraram que esse princípio é válido somente para ensaios realizados apenas com o ligante betuminoso, mas não para ensaios realizados com misturas asfálticas. Conclui-se assim que o efeito dinâmico deve estar relacionado com o contato entre as partículas de agregado da mistura.

Independentemente de serem estáticos ou dinâmicos, o uso de ensaios de fluência por compressão uniaxial para a avaliação da suscetibilidade de misturas asfálticas a deformações permanentes parece ser consenso entre os pesquisadores.

Little et al. (1993) variaram as características de misturas asfálticas e estudaram a influência que essa variação teve nos parâmetros do ensaio de fluência por compressão uniaxial. Verificaram que as características das misturas que possuem maior influência na inclinação da curva de fluência no estágio estável e na deformação permanente após 1 hora de carregamento são, em ordem de influência, o volume de vazios da mistura, o tipo de agregado, o nível de tensão utilizado no ensaio, a temperatura de ensaio, o tipo de asfalto e o teor de asfalto utilizado na mistura. 
Little et al. (1993) concluíram que o ensaio de fluência por compressão uniaxial estática mostrou-se muito sensível a variações nas características das misturas, sendo adequado para avaliação do comportamento de misturas asfálticas quanto à deformação permanente. Essa conclusão é corroborada por Lai e Hufferd (1976), Sousa et al. (1991) e Mohamed e Yue (1994).

Sá e Motta (1996) empregaram os ensaios de creep estático e dinâmico para avaliação do potencial de resistência a deformações permanentes apresentado por misturas asfálticas e constataram que este mostrou-se dependente do teor de ligante, da faixa granulométrica, da temperatura e do nível de tensão aplicada.

Para Motta et al. (1996), os ensaios de fluência por compressão uniaxial estática e dinâmica estão entre os mais utilizados internacionalmente para avaliação da suscetibilidade de misturas asfálticas a deformações permanentes, com uma tendência maior para uso do ensaio de compressão dinâmica, uma vez que os parâmetros fornecidos por esse ensaio se correlacionam melhor com os resultados dos simuladores de tráfego.

\subsubsection{Tensões no ensaio de fluência por compressão uniaxial}

Van de Loo (1974) inicialmente realizaram o ensaio de fluência por compressão uniaxial estática com tensões de ensaio realísticas, calculadas tendo por base pressões de enchimento de pneus de 0,7 MPa, que correspondem a tensões médias de 0,5 MPa no interior da camada de concreto asfáltico, calculadas com o programa computacional BISTRO (PEUTZ et al., 1968). Utilizando esse nível de tensões, não obtiveram concordância entre as deformações do ensaio de creep estático e as deformações dos ensaios de trilhas de roda. Realizando o ensaio de creep estático com níveis de tensão inferiores, em torno de $0,1 \mathrm{MPa}$, os resultados obtidos foram concordantes com os resultados dos ensaios de trilha de rodas.

De acordo com Van de Loo (1974), embora os ensaios de trilha de roda sejam realizados com tensões elevadas, o tempo de aplicação da carga é tão curto que as 
deformações permanentes se mantêm no limite do comportamento linear, com taxa de deformação constante, independente da tensão aplicada. Dessa forma, o ensaio de creep também deve ser realizado na faixa linear de comportamento, que corresponde a baixas tensões.

Para Little et al. (1993), entretanto, os ensaios de fluência por compressão uniaxial devem ser realizados em temperaturas realísticas e em níveis de tensão próximos às tensões ocorridas em pavimentos em serviço.

Conforme exposto por Little et al (1993), traçando-se uma curva do logaritmo da taxa de fluência em função da tensão de fluência, Figura 4.1, observa-se que esta é formada por três estágios. No primeiro estágio, correspondente à fase de baixas tensões, a forma da curva é compatível com a função seno hiperbólica e o aumento da taxa de fluência é pequeno e de pouca importância prática. Na região intermediária da curva existe uma relação praticamente linear entre o logaritmo da taxa de fluência e a tensão de fluência. No último estágio da curva, quando as tensões se aproximam da tensão de ruptura do material, a taxa de fluência aumenta exponencialmente com a tensão de fluência.

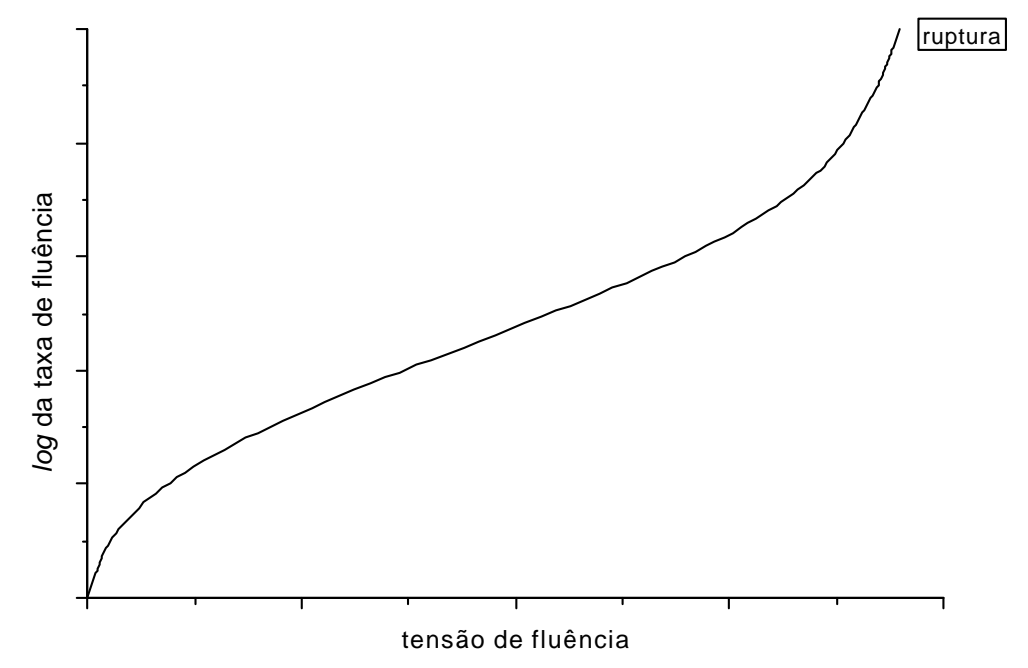

Figura 4.1 - Representação esquemática do logaritmo da taxa de fluência em função da tensão de fluência (Little et al., 1993)

Dessa forma, se no campo o pavimento é submetido a tensões próximas da tensão de ruptura do material, considerações de comportamento linear não são apropriadas. Little et al. (1993) concluem portanto que a realização de testes de laboratório a baixas tensões para posterior substituição pelas altas tensões ocorridas em campo, com base no 
princípio da superposição linear viscoelástica, é um procedimento incorreto, devendo-se realizar os testes laboratoriais com tensões realísticas.

Os estágios de fluência podem também ser visualizados traçando-se curvas de deformação versus tempo de carregamento, para o ensaio realizado com carregamento estático, ou curvas de deformação axial permanente acumulada versus número de ciclos de carregamento, para o ensaio realizado com carregamento repetitivo. Observando-se a curva de fluência obtida, Figura 4.2, pode-se perceber que esta é formada por três estágios, geralmente denominados estágios primário, secundário e terciário.

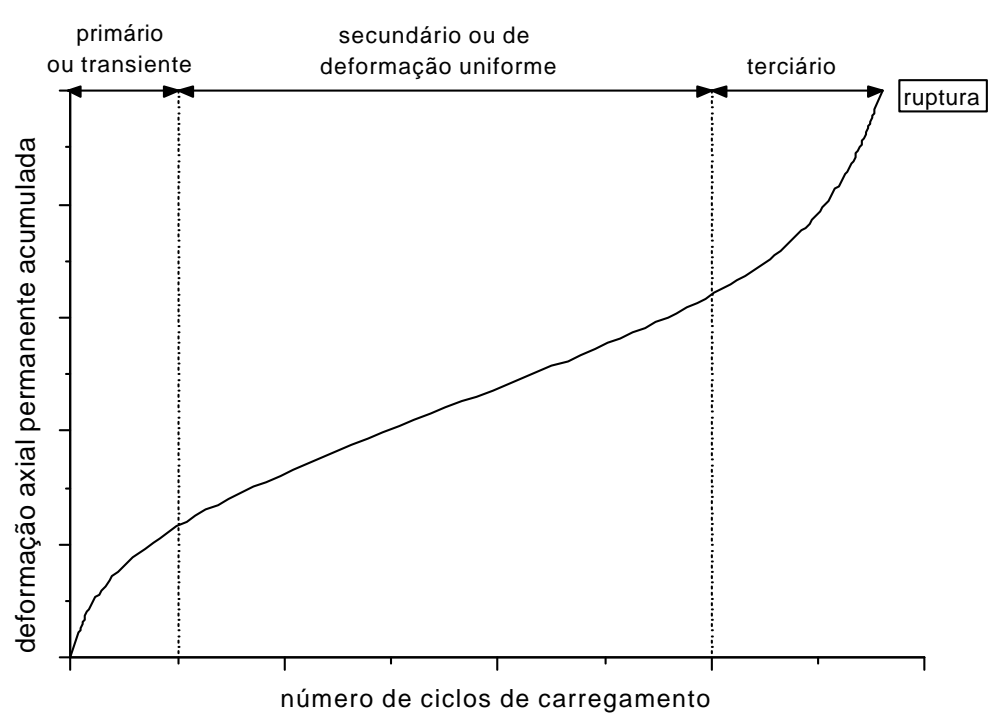

Figura 4.2 - Curva representativa dos estágios de fluência (Mohamed e Yue, 1994)

No estágio primário a inclinação inicial da curva de fluência é bastante elevada, ou seja, a taxa de deformação com o tempo de carregamento é elevada, uma vez que ocorrem grandes deformações em um curto período de carregamento. Logo em seguida a inclinação da curva decai rapidamente.

De acordo com Mohamed e Yue (1994), a alta taxa de deformação inicial se deve à concentração de tensão nos pontos elevados da superfície do corpo de prova, que geralmente é irregular. Outra possível causa é a densificação do corpo de prova, resultante da redução do volume de vazios. Ainda segundo esses autores, a redução drástica da taxa de aumento de deformação que é observada em seguida se deve a mudanças na microestrutura da mistura de concreto asfáltico, com reorientação das 
partículas de agregado e conseqüente densificação da mistura, que se torna mais resistente à deformação.

O estágio secundário de deformação pode ser identificado pela taxa constante de aumento de deformação, ou seja, a curva de fluência apresenta inclinação constante. Nessa fase, os agregados já se encontram acomodados para o nível de energia adotado no ensaio e a deformação permanente ocorrida deve-se principalmente à fluência por cisalhamento. Quanto maior a inclinação da curva de fluência nesse estágio, maior a suscetibilidade da mistura à deformação permanente (MOHAMED e YUE, 1994).

No estágio terciário ou estágio de ruptura, a deformação volta a crescer rapidamente, até a ruptura do corpo de prova. Dentre as prováveis causas de ruptura podem ser citadas a fadiga do material, no caso de ensaios dinâmicos; a utilização de misturas não homogêneas para a moldagem dos corpos de prova; a excentricidade da placa de carregamento e o ensaio de copos de prova com superfícies inclinadas. Embora as correlações entre os testes de fluência realizados em laboratório e o desempenho dos pavimentos em campo sejam precárias, para Little et al. (1993) parece evidente que misturas estáveis não devem apresentar o terceiro estágio de fluência, se ensaiadas em laboratório sob condições de tensão e temperatura que simulem as condições encontradas em campo.

Mahboub e Little* (1988 apud LITTLE et al., 1993, p.54) desenvolveram fatores de correção que mostram que a tensão vertical de compressão que ocorre dentro da camada de concreto asfáltco geralmente varia entre 65 e $86 \%$ da tensão média de contato entre o pneu e a superfície do pavimento.

* MAHBOUB, K. e LITTLE, D.N. (1988). Improve asphalt concrete mixture design. Research Report 2474-1F. Texas Transportation Institute apud LITTLE, D.N.; BUTTON, J.W e YOUSSEF, H. (1993). Development of criteria to evaluate uniaxial creep data and asphalt concrete permanent deformation potential. Transportation Research Record, 1417, p.54. 
Os cálculos de distribuição de tensões verticais realizados por Von Quintus et al. (1991) basearam-se na teoria linear elástica. Roberts et al.* (1986 apud UTTLE et al., 1993, p.54) utilizaram o programa computacional ILLI-PAVE para análise estrutural de pavimentos, e fizeram considerações mais realísticas sobre o estado de distribuição de tensões. Concluíram que tensões de ensaio variando entre 0,345 e 0,414 MPa refletem de forma mais apropriada a realidade dos pavimentos em serviço.

Dessa forma, embora alguns autores recomendem tensões de ensaio variando entre 0,0345 e 0,138 MPa, para que se trabalhe na região viscoelástica linear, a fim de que possa ser utilizada a teoria viscoelástica linear para análise das tensões e deformações que ocorrem nos pavimentos, essas tensões são muito inferiores às tensões ocorridas em campo. Como o concreto asfáltico não responde de forma linear viscoelástica quando as tensões se aproximam das tensões de ruptura, o mais sensato seria utilizar tensões de ensaio próximas às tensões ocorridas em campo.

\subsubsection{Ensaio de fluência por compressão uniaxial estática}

O ensaio de fluência por compressão uniaxial estática, ou ensaio de creep estático, foi desenvolvido para determinação da estabilidade mecânica de misturas, sendo capaz de estimar a suscetibilidade dos pavimentos à formação de trilhas de roda.

Esse ensaio consiste na aplicação de uma carga de compressão uniaxial constante sobre um corpo de prova de concreto asfáltico, com formato cilíndrico e extremidades planas, paralelas e lubrificadas. O corpo de prova é posicionado entre duas placas metálicas, uma fixa e outra móvel, sendo que a carga de compressão é aplicada sobre a placa móvel.

* ROBERTS, F.L.; TIELKING, J.T.; MIDDLETON, D.; LYTTON, R.L. e TSENG, K.H. (1988). Effects of tire pressure on flexible pavements. Report 372-1F. Texas Transportation Institute, p.223-235 apud LITTLE, D.N.; BUTTON, J.W e YOUSSEF, H. (1993). Development of criteria to evaluate uniaxial creep data and asphalt concrete permanent deformation potential. Transportation Research Record, 1417, p.54. 
A deformação axial do corpo de prova é medida em função do tempo de carregamento, através de extensômetros localizados em lados opostos do corpo de prova. Durante o ensaio a temperatura é controlada e mantida constante. Geralmente o ensaio é realizado com 1 hora de aplicação de carga. O equipamento utilizado no ensaio pode ser observado nas Figuras 5.10 e 5.11 do Capítulo 5 deste trabalho.

Os resultados do ensaio de creep estático, quando expressos em termos de deformação específica, são independentes da forma do corpo de prova, desde que as superfícies deste sejam planas, paralelas e bem lubrificadas. A lubrificação é necessária para que a distribuição de tensões normais seja uniforme e para evitar o aparecimento de tensões de cisalhamento devido a uma vinculação lateral do corpo de prova.

A partir do momento em que o ensaio de fluência por compressão uniaxial estática passou a ser largamente utilizado para estimativa do comportamento de misturas asfálticas, diversos autores têm estabelecido critérios para avaliação da deformação permanente, com base em parâmetros determinados através desse ensaio.

Alguns critérios para avaliação baseados no módulo de fluência, definido por Van de Loo (1974) como a relação entre a tensão aplicada e a deformação relativa sofrida pelo corpo de prova, foram resumidos por Little et al. (1993) e encontram-se apresentados na Tabela 4.4.

Little et al. (1993) estabeleceram critérios para avaliação do comportamento de misturas asfálticas quanto a deformação permanente, a partir de dados fornecidos pelo Instituto de Transportes do Texas. Na Tabela 4.5 são apresentados critérios para os parâmetros deformação total após 1 hora de ensaio e inclinação da curva de fluência no estágio secundário, ou seja, trecho da curva deformação $\times$ tempo de carregamento com inclinação constante. Esses critérios foram estabelecidos com o objetivo de reduzir o potencial de deformação permanente apresentado pelas misturas. 
Tabela 4.4 - Critérios para avaliação do módulo de fluência obtido a partir do ensaio de fluência por compressão uniaxial estática

\begin{tabular}{cccccc}
\hline critério & $\begin{array}{c}\text { tempo } \\
\text { de } \\
\text { carreg } \\
(\mathrm{min})\end{array}$ & $\begin{array}{c}\text { temp. } \\
\text { do } \\
\text { ensaio } \\
\left({ }^{\circ} \mathrm{C}\right)\end{array}$ & $\begin{array}{c}\text { nível de } \\
\text { tensão } \\
(\mathrm{MPa})\end{array}$ & $\begin{array}{c}\text { mód. de } \\
\text { fluência } \\
\text { mínimo } \\
(\mathrm{MPa})\end{array}$ & \\
\hline Von Quintus et al. (1991) & 60 & 40 & $\begin{array}{c}0,345 \text { a } \\
0,414\end{array}$ & 68,9 & $\begin{array}{c}\text { - concreto asfáltico sobre } \\
\text { base rígida } \\
\text { - superfície de uma } \\
\text { camada de concreto } \\
\text { asfáltico espessa }\end{array}$ \\
& & & & 55,1 & $\begin{array}{c}\text { revestimento asfáltico } \\
\text { superficial }\end{array}$ \\
\hline $\begin{array}{c}\text { Viljoen e Meadows *(1981 } \\
\text { apud LITTLE et al., 1993) }\end{array}$ & 100 & 40 & 0,207 & 82,7 & \\
\hline Khedr (1986) & 60 & 40 & 0,207 & 137,9 & \\
\hline $\begin{array}{c}\text { Kronfuss et al. ** (1984 } \\
\text { apud LITTLE et al., 1993) }\end{array}$ & 60 & 40 & 0,103 & 20,7 & $\begin{array}{c}\text { intensidade de tráfego } \\
\text { baixa }\end{array}$ \\
& & & & $20,7-31,0$ & $\begin{array}{c}\text { intensidade de tráfego } \\
\text { moderada }\end{array}$ \\
& & & & $31,0-45,3$ & $\begin{array}{c}\text { intensidade de tráfego } \\
\text { alta }\end{array}$ \\
\hline Sousa et al. (1991) & 60 & 40 & 0,207 & 69 & \\
\hline
\end{tabular}

Little et al. (1993) mencionam que embora ensaios com carregamento cíclico sejam mais realísticos e predigam melhor a suscetibilidade de misturas asfálticas à deformações permanentes, o ensaio de fluência por compressão uniaxial estática também pode ser utilizado para tal fim, com a vantagem de requerer equipamento mais simples para a sua realização.

\footnotetext{
* VILJOEN, A.W. e MEADOWS, K. (1981). The creep test - A mix design tool to rank asphalt mixes in terms of their resistance to permanent deformation under heavy traffic. National Institute of Road Research. Pretoria, South Africa apud LITTLE, D.N.; BUTTON, J.W e YOUSSEF, H. (1993). Development of criteria to evaluate uniaxial creep data and asphalt concrete permanent deformation potential. Transportation Research Record, 1417, p.54.

** KRONFUSS, R.; KRZEMIEN, R.; NIEVELT, G.; PUTZ, P.. (1984). Verformungsfestigkjeit von asphalten ermittlung in kriechtest, bundesministerium fur bauten and technik. Strassenforschung. Heft 240. Wien, Austria apud LITTLE, D.N.; BUTTON, J.W e YOUSSEF, H. (1993). Development of criteria to evaluate uniaxial creep data and asphalt concrete permanent deformation potential. Transportation Research Record, 1417, p.54.
} 
Tabela 4.5 - Limites para a deformação após 1 hora de ensaio de fluência e para a inclinação da curva de fluência no estágio secundário (Little et al., 1993)

\begin{tabular}{c|c|c|c|c|c|c}
\hline $\begin{array}{c}\text { deformação } \\
\text { total após 1h } \\
\text { de ensaio } \\
(\%)\end{array}$ & \multicolumn{7}{c}{ inclinação da curva de fluência no estágio secundário } \\
\cline { 2 - 7 } & $<0,17$ & $<0,20$ & $<0,25$ & $<0,30$ & $<0,35$ & $<0,40$ \\
\hline$<0,25$ & $\mathrm{IV}^{2}$ & $\mathrm{IV}^{2}$ & $\mathrm{IV}^{2}$ & $\mathrm{IV}^{2}$ & $\mathrm{IV}^{2}$ & $\mathrm{III}^{2}$ \\
\hline$<0,40$ & $\mathrm{IV}^{2}$ & $\mathrm{IV}^{2}$ & $\mathrm{IV}^{2}$ & $\mathrm{III}^{2}$ & $\mathrm{III}^{2}$ & $\mathrm{III}^{2}$ \\
\hline$<0,50$ & $\mathrm{IV}^{2}$ & $\mathrm{IV}^{2}$ & $\mathrm{III}^{2}$ & $\mathrm{III}^{2}$ & $\mathrm{III}^{2}$ & $\mathrm{II}$ \\
\hline$<0,80$ & $\mathrm{III}^{2}$ & $\mathrm{III}^{2}$ & $\mathrm{II}$ & $\mathrm{II}$ & $\mathrm{II}$ & $\mathrm{II}$ \\
\hline$<1,0$ & $\mathrm{I}$ & $\mathrm{I}$ & $\mathrm{I}$ & $\mathrm{I}$ & $\mathrm{I}^{1}$ & \\
\hline$<1,2$ & $\mathrm{I}^{1}$ & $\mathrm{I}$ & $\mathrm{I}$ & & & \\
\hline
\end{tabular}

1 - deve apresentar também deformação permanente $<0,8 \%$, aos 1800 s de carregamento

2 - deve também seguir o critério: $\varepsilon_{p}<0,5 \varepsilon_{q u}+\varepsilon_{r t}$

Onde

I - intensidade de tráfego baixa : $<10^{5}$ ESALs

II - intensidade de tráfego baixa : entre $10^{5}$ e $5 \times 10^{5}$ ESALs

III - intensidade de tráfego baixa : entre $5 \times 10^{5}$ e $10^{6}$ ESALs

IV - intensidade de tráfego baixa : > $10^{6}$ ESALs

ESALs - solicitações equivalentes do eixo padrão de 8,2 t.

Ainda segundo Little et al. (1993), no caso de se utilizar o ensaio estático, a avaliação da mistura deve respeitar o critério segundo o qual a soma da deformação permanente $\left(\varepsilon_{\mathrm{p}}\right)$, medida após $3600 \mathrm{~s}$ de carregamento no ensaio de fluência estática, com a deformação elástica total $\left(\varepsilon_{\mathrm{rt}}\right)$, medida durante o ensaio de módulo de resiliência uniaxial (ASTM D 3497), não deve exceder $50 \%$ da deformação $\left(\varepsilon_{\text {qu }}\right)$ determinada pelo ensaio de compressão não confinada (AASHTO T 167), ou seja

$$
\varepsilon_{p}<0,5 \varepsilon_{q u}+\varepsilon_{r t}
$$

A deformação recuperável total $\left(\varepsilon_{\mathrm{rt}}\right)$ deve ser medida em um ensaio com frequiência de aplicação de carga de 1 ciclo por segundo, com 0,1s de aplicação de carga e 0,9s de repouso ou recuperação.

Embora essa avaliação requeira a realização do ensaio de módulo de resiliência uniaxial, que consiste em um ensaio dinâmico, o número de aplicações de carga nesse 
caso é bem menor do que o número de aplicações em um ensaio de fluência por compressão uniaxial dinâmica.

Com base nos dados da Tabela 4.5, Little et al. (1993) concluíram que a inclinação máxima do estágio secundário da curva de fluência em escala log-log, para um ensaio com duração de 3600 s, é 0,25 . Estabeleceram também que o valor limite para a deformação total, em ensaios representando as condições de campo, é 0,203 mm/mm.

Os critérios relativos ao módulo de fluência após 1 hora de carregamento, estabelecidos por Little et al. (1993) para limitar a suscetibilidade das misturas a deformações permanentes, são apresentados na Tabela 4.6, na qual a intensidade do tráfego aparece conforme notação utilizada na tabela anterior (Tabela 4.5).

Tabela 4.6 - Critérios para o módulo de fluência após 1 hora de carregamento (Little et al., 1993)

\begin{tabular}{|c|c|c|c|c|}
\hline \multirow{2}{*}{$\begin{array}{c}\text { resistência a } \\
\text { deformação } \\
\text { permanente }\end{array}$} & \multirow{2}{*}{$\begin{array}{c}\text { intensidade do } \\
\text { tráfego }\end{array}$} & \multicolumn{3}{|c|}{$\begin{array}{c}\text { módulo de fluência mínimo (MPa) para o ensaio de } \\
\text { fluência por compressão uniaxial estática }\end{array}$} \\
\cline { 3 - 5 } & & $0,207 \mathrm{MPa}$ & $0,354 \mathrm{MPa}$ & $0,483 \mathrm{MPa}$ \\
\hline \multirow{2}{*}{$\begin{array}{c}\text { elevada } \\
\text { resistência a } \\
\text { deformação } \\
\text { permanente }\end{array}$} & IV & 103,4 & 120,7 & 155,1 \\
\cline { 2 - 5 } & III & 48,3 & 69,0 & 96,5 \\
\cline { 2 - 5 } & II & 34,5 & 44,8 & 60,3 \\
\hline $\begin{array}{c}\text { moderada } \\
\text { resistência a } \\
\text { deformação } \\
\text { permanente }\end{array}$ & I & 20,7 & 27,6 & 41,4 \\
\cline { 2 - 5 } & IV & 51,7 & 69,0 & 96,5 \\
\cline { 2 - 5 } & III & 34,5 & 50,0 & 69,0 \\
\hline
\end{tabular}

Caso o ligante fosse considerado de forma isolada, o módulo de fluência calculado com base na deformação total seria tão adequado quanto o módulo de fluência calculado com base na deformação não recuperável, uma vez que para as altas temperaturas utilizadas nos testes de fluência e considerando-se 3600s de aplicação de carga, a parcela elástica da deformação do ligante mostra-se muito pequena se comparada à parcela viscosa.

Entretanto, quando são ensaiadas misturas asfálticas, o efeito da matriz de agregado na resiliência ou recuperação da mistura deve ser considerado. Segundo Little et al. (1993), a forma mais simples de se considerar tal efeito é através da realização de um ensaio de recuperação logo após o ensaio de fluência. 
Tanto a deformação total como a deformação não recuperável são funções do tempo de carregamento, da temperatura, do estado de tensões, do tipo de mistura e de outros parâmetros, como as condições de carregamento.

Segundo Little et al. (1993), o período de 1 hora geralmente adotado para o ensaio de fluência por compressão uniaxial estática deve-se ao fato desse tempo ser longo o suficiente para se verificar a ocorrência de ruptura, e curto o suficiente para que seja executável.

Sá e Motta (1996) prolongaram o tempo de carregamento no ensaio de creep estático, realizado com tensão de $0,1 \mathrm{MPa}$, para além de 1 hora, e constataram que após 1 hora de carregamento as deformações ocorrem muito lentamente, com tendência de estabilização. Dessa forma concluíram que ao fim de 1 hora de aplicação de carga já se manifestou a maior parte da deformação, sendo este um tempo conveniente para o ensaio de fluência.

Embora as especificações do ensaio de fluência estática varie de acordo com a pesquisa realizada, Motta et al. (1996) identificaram tendências predominantes em relação a alguns aspectos, tais como a realização de ensaios axiais, o emprego de temperaturas elevadas e a utilização de tempos de ensaios relativamente curtos. Condições de ensaio adotadas por alguns autores são apresentadas na Tabela 4.7.

\subsubsection{Ensaio de fluência por compressão uniaxial dinâmica}

O ensaio de fluência por compressão uniaxial dinâmica (creep dinâmico) consiste na aplicação de pulsos de cargas de compressão uniaxiais ao corpo de prova, a uma determinada freqüência, com intervalos sem carregamento entre as aplicações de carga. A deformação do corpo de prova é obtida em função do número de ciclos de carregamento.

Assim como no ensaio de creep estático, não existe uma padronização para a realização do ensaio de creep dinâmico. Condições de ensaio utilizadas em algumas pesquisas são apresentadas na Tabela 4.8 . 
Tabela 4.7 - Condições do ensaio de fluência por compressão uniaxial estática adotadas por alguns autores

\begin{tabular}{|c|c|c|c|c|c|c|}
\hline autor & $\begin{array}{c}\text { tipo de } \\
\text { compactação }\end{array}$ & $\begin{array}{l}\text { dime } \\
\text { média } \\
\text { cps }(\end{array}$ & $\begin{array}{l}\text { isões } \\
\text { s dos } \\
\mathrm{mm} \text { ) }\end{array}$ & $\begin{array}{l}\text { temp. } \\
\left({ }^{\circ} \mathrm{C}\right)\end{array}$ & $\begin{array}{l}\text { tempo de } \\
\text { carrega- } \\
\text { mento }\end{array}$ & $\begin{array}{l}\text { tensão ensaio } \\
\quad(\mathrm{MPa})\end{array}$ \\
\hline & & $\phi$ & $\mathrm{h}$ & & & \\
\hline Lai e Anderson (1973) & amassamento & 50,8 & 76,2 & 24,4 & $\begin{array}{c}1 / 6 \\
10 / 6 \\
100 / 6\end{array}$ & $\begin{array}{c}0,07 ; 0,21 \\
0,34\end{array}$ \\
\hline $\begin{array}{l}\text { Viljoen e Meadows* } \\
\text { (1981 apud LITTLE et } \\
\text { al., 1993) }\end{array}$ & & & & 40 & 100 & 0,207 \\
\hline Bissada (1983) & Marshall & 101,6 & 63,5 & 40 & 60 & 0,1 \\
\hline Perl et al. (1983) & $\begin{array}{l}\text { compactador } \\
\text { vibratório }\end{array}$ & 50,8 & 101,6 & 25 & 60 & $\begin{array}{c}0,1 ; 0,2 ; 0,4 ; \\
0,8\end{array}$ \\
\hline $\begin{array}{c}\text { Kronfuss et al.** } \\
\text { (1984 apud LITTLE et } \\
\text { al., 1993) }\end{array}$ & & & & 40 & 60 & 0,103 \\
\hline $\begin{array}{c}\text { Xu e Zhu } * * *(1984 \\
\text { apud Sá e Motta, 1996) }\end{array}$ & amassamento & 101,6 & 100 & $\begin{array}{l}20 ; 30 \\
40 \text { e } 50\end{array}$ & 90 & 0,2 \\
\hline $\begin{array}{l}\text { Krutz e Stroup- } \\
\text { Gardiner (1990) }\end{array}$ & Marshall & 101,6 & 63,5 & 25 & 60 & 0,1 \\
\hline Tayebali et al. (1991) & amassamento & 101,6 & 203 & 40 e 60 & 60 & 0,$1 ; 0,2$ \\
\hline $\begin{array}{c}\text { Von Quintus et al. } \\
\text { (1991) }\end{array}$ & & & & 40 & 60 & 0,345 a 0,414 \\
\hline Sousa et al. (1991) & vários & 203,2 & 101,6 & 40 e 60 & 60 & 0,$104 ; 0,207$ \\
\hline Hopman et al. (1992) & $\begin{array}{c}\text { Marshall; } \\
\text { compactador } \\
\text { giratório e } \\
\text { vibratório }\end{array}$ & 60 & 100 & 40 & 60 & 0,1 \\
\hline Little et al (1993) & & & & 40 & 60 & 0,345 a 0,414 \\
\hline Motta et al. (1996) & Marshall & 101,6 & 63,5 & 25 e 40 & 60 & 0,1 \\
\hline Coelho (1996) & Marshall & 101,6 & 63,5 & 40 & 60 & 0,4 \\
\hline Silveira (1999) & Marshall & 101,6 & 63,5 & 40 & 60 & 0,05 \\
\hline Foretti (1999) & Marshall & 101,6 & 63,5 & 40 & 60 & 0,4 \\
\hline Amaral (2000) & Marshall & 101,6 & 63,5 & 40 & 60 & 0,1 \\
\hline Taira (2001) & Marshall & 101,6 & 63,5 & 40 & 60 & 0,$1 ; 0,4 ; 0,7$ \\
\hline Faxina (2002) & Marshall & 101,6 & 63,5 & 40 & 60 & 0,4 e 0,7 \\
\hline
\end{tabular}

* VILJOEN, A.W. e MEADOWS, K. (1981). The creep test - A mix design tool to rank asphalt mixes in terms of their resistance to permanent deformation under heavy traffic. National Institute of Road Research. Pretoria, South Africa apud LITTLE, D.N.; BUTTON, J.W e YOUSSEF, H. (1993). Development of criteria to evaluate uniaxial creep data and asphalt concrete permanent deformation potential. Transportation Research Record, 1417, p.54.

** KRONFUSS, R.; KRZEMIEN, R.; NIEVELT, G.; PUTZ, P.. (1984). Verformungsfestigkjeit von asphalten ermittlung in kriechtest, bundesministerium fur bauten and technik. Strassenforschung. Heft 240. Wien, Austria apud LITTLE, D.N.; BUTTON, J.W e YOUSSEF, H. (1993). Development of criteria to evaluate uniaxial creep data and asphalt concrete permanent deformation potential. Transportation Research Record, 1417, p.54.

*** XU, S.; ZHU, Z. (1984). Prediction and control of rutting in asphalt pavements. The $4^{\text {th }}$ International Conference on the Bearing Capacity of Roads and Airfields. v.1, p.17-21 apud Sá, M.F.P.; MOTTA, L.M.G. (1996). Utilização de ensaios de creep estático e dinâmico para caracterização de misturas asfálticas. $13^{\circ}$ Encontro de Asfalto-IBP, p.91-115. 
Tabela 4.8 - Condições do ensaio de fluência por compressão uniaxial dinâmica adotadas por alguns autores

\begin{tabular}{|c|c|c|c|c|c|c|c|}
\hline \multirow[t]{2}{*}{ autor } & \multirow[t]{2}{*}{$\begin{array}{c}\text { tipo de } \\
\text { compactação }\end{array}$} & \multicolumn{2}{|c|}{$\begin{array}{l}\text { dimensões do } \\
\text { cp (mm) }\end{array}$} & \multirow[t]{2}{*}{$\begin{array}{l}\text { temp. } \\
\left({ }^{\circ} \mathrm{C}\right)\end{array}$} & \multirow[t]{2}{*}{$\begin{array}{l}\text { número de } \\
\text { ciclos }\end{array}$} & \multirow[t]{2}{*}{$\begin{array}{l}\text { duração de cada } \\
\text { ciclo (s) }\end{array}$} & \multirow{2}{*}{$\begin{array}{l}\text { tensão } \\
\text { ensaio } \\
\text { (MPa) }\end{array}$} \\
\hline & & $\phi$ & $\mathrm{h}$ & & & & \\
\hline (1) & amassamento & 50,8 & 76,2 & 24,4 & $\begin{array}{c}8 \text { ciclos por } \\
\text { tensão }+100 \\
\text { ciclos } \\
(0,28 \mathrm{MPa}) \\
\end{array}$ & $\begin{array}{l}4 \mathrm{~min} \text { por ciclo } \\
1 \mathrm{~min} \text { com carga } \\
3 \mathrm{~min} \text { sem carga }\end{array}$ & $\begin{array}{c}0,07 ; 0,14 ; \\
0,21 ; 0,28 \\
0,34\end{array}$ \\
\hline (2) & $\begin{array}{l}\text { compactador } \\
\text { giratório }\end{array}$ & 50,8 & 101,6 & 25 & 20 & $\begin{array}{l}2 \mathrm{~min} \text { por ciclo } \\
1 \mathrm{~min} \text { com carga } \\
1 \mathrm{~min} \text { sem carga }\end{array}$ & $\begin{array}{c}0,1 ; 0,2 ; \\
0,4 ; 0,8\end{array}$ \\
\hline (3) & amassamento & 101,6 & 100 & 40 & 45000 & 0,2 s por ciclo & 0,2 \\
\hline (4) & & 101,6 & 203,2 & $\begin{array}{l}26,7 \\
37,8 \\
48,9 \\
\end{array}$ & 10000 & $\begin{array}{c}0,5 \mathrm{~s} \text { por ciclo } \\
0,1 \mathrm{~s} \text { com carga } \\
0,4 \mathrm{~s} \text { sem carga }\end{array}$ & $\begin{array}{c}0,205 ; \\
0,278 ; \\
0,341 ; 0,415 \\
\end{array}$ \\
\hline (5) & tipo rolo & 100 & 140 & $\begin{array}{c}25 ; 30 \\
35 ; 40 \\
45 ; \text { e } 50\end{array}$ & & 0,1 s por ciclo & 0,3 \\
\hline (6) & tipo rolo & 100 & 60 & 40 e 50 & 1800 & $\begin{array}{c}2 \text { s por ciclo } \\
0,2 \text { s com carga } \\
1,8 \text { s sem carga }\end{array}$ & 0,1 \\
\hline (7) & $\begin{array}{l}\text { Marshall; } \\
\text { compactador } \\
\text { giratório e } \\
\text { vibratório }\end{array}$ & 100 & 60 & 40 & 2000 & $\begin{array}{c}2 \mathrm{~s} \text { por ciclo } \\
0,2 \mathrm{~s} \text { com carga } \\
1,8 \mathrm{~s} \text { sem carga }\end{array}$ & 0,1 \\
\hline (8) & $\begin{array}{l}\text { amostras } \\
\text { extraídas do } \\
\text { campo; } \\
\text { compactador } \\
\text { giratório } \\
\end{array}$ & & $\begin{array}{c}40 \mathrm{a} \\
80\end{array}$ & 25 e 40 & 5000 & $\begin{array}{c}2 \text { s por ciclo } \\
0,2 \text { s com carga } \\
1,8 \text { s sem carga }\end{array}$ & 0,69 \\
\hline (9) & Marshall & 101,6 & 63,5 & 25 e 40 & 3600 & $\begin{array}{c}\text { 1s por ciclo } \\
0,1 \text { s com carga } \\
0,9 \text { s sem carga }\end{array}$ & 0,1 \\
\hline (10) & Marshall & 101 & 62 & 45 & & $\begin{array}{c}1 \text { s por ciclo } \\
0,1 \mathrm{~s} \text { com carga } \\
0,9 \mathrm{~s} \text { sem carga }\end{array}$ & 0,1 \\
\hline (11) & Marshall & 101,6 & 63,5 & 40 & 5000 & $\begin{array}{c}\text { 1s por ciclo } \\
0,2 \mathrm{~s} \text { com carga } \\
0,8 \mathrm{~s} \text { sem carga }\end{array}$ & 0,1 \\
\hline (12) & Marshall & 101,6 & 63,5 & 40 & 5000 & $\begin{array}{c}2 \text { s por ciclo } \\
0,2 \text { s com carga } \\
1,8 \text { s sem carga }\end{array}$ & 0,1 \\
\hline $\begin{array}{l}\text { (1) Lai } \\
\text { (2) Perl } \\
\text { (3) Xu, } \\
\text { (4) Khe } \\
\text { (5) Eck } \\
\text { (6) Val }\end{array}$ & $\begin{array}{l}\text { Anderson (1973 } \\
\text { et al. (1983) } \\
\text { S.; Zhu, Z. *(198 } \\
\text { dr (1986) } \\
\text { mann (1989) } \\
\text { kering et al. (1990 }\end{array}$ & 4 apud $\mathrm{s}$ & Á e MOT & TA, 1996) & & $\begin{array}{l}\text { (7) Hopman et al } \\
\text { (8) Mohamed e Y } \\
\text { (9) Motta et al. (19 } \\
\text { (10) Ceratti et al. } \\
\text { (11) Silveira (199) } \\
\text { (12) Taira (2001) }\end{array}$ & $\begin{array}{l}\text { 1992) } \\
\text { le (1994) } \\
96) \\
1996) \\
\text { ) }\end{array}$ \\
\hline
\end{tabular}

* XU, S.; ZHU, Z. (1984). Prediction and control of rutting in asphalt pavements. The $4^{\text {th }}$ International Conference on the Bearing Capacity of Roads and Airfields. v.1, p.17-21 apud SÁ, M.F.P.; MOTTA, L.M.G. (1996). Utilização de ensaios de creep estático e dinâmico para caracterização de misturas asfálticas. $13^{\circ}$ Encontro de Asfalto-IBP, p.91-115. 
Souza e Soares (2002) salientam que os equipamentos pneumáticos geralmente utilizados no Brasil para aplicação do carregamento necessitam de um intervalo de tempo para que a carga almejada seja atingida. Dessa forma os pulsos de carga não são retangulares, conforme idealizado para o ensaio de creep dinâmico, mas sim possuem forma aproximadamente semi-senoidal.

Mohamed e Yue (1994) utilizaram o ensaio de fluência por compressão uniaxial dinâmica para avaliar a suscetibilidade de misturas asfálticas a deformações permanentes. Para cada mistura foi encontrada uma taxa constante de deformação permanente acumulada, que segundo os autores pode ser utilizada como critério para avaliação do potencial de deformação permanente do concreto asfáltico.

Mohamed e Yue (1994) estudaram ainda a influência dos fatores altura do corpo de prova, nível de tensão utilizada, energia de compactação, relação entre a compactação realizada em laboratório e a compactação ocorrida em campo e temperaturas de serviço, na suscetibilidade das misturas a deformação permanente.

A altura do corpo de prova não mostrou influência na deformação permanente acumulada sofrida, ao contrário da energia de compactação, pois ficou demonstrado pelo estudo realizado que uma compactação inadequada tem como conseqüência a redução da resistência à deformação permanente. Aumentando a temperatura de ensaio de 25 para $40^{\circ} \mathrm{C}$, a inclinação da curva de fluência no estágio secundário aumentou cerca de dez vezes, em virtude do aumento da fluência por cisalhamento, decorrente da diminuição da viscosidade do asfalto.

Um outro efeito observado com o aumento da temperatura de ensaio foi a redução do número de ciclos necessários para a transição do estágio de fluência secundário para o estágio terciário, que diminuiu em 10 vezes com o aumento da temperatura de 25 para $40^{\circ} \mathrm{C}$. A deformação permanente acumulada aumentou com o aumento da carga aplicada, e diminuiu consideravelmente com o aumento da energia de compactação dos corpos de prova. Amostras extraídas de pavimentos apresentaram curvas de fluência com inclinação no estágio secundário semelhante à inclinação apresentada pela curva de fluência de corpos de prova moldados em laboratório 
Ulmgren (1996) propôs uma modificação ao ensaio de creep dinâmico, sugerindo que a placa de carregamento, geralmente com diâmetro ligeiramente superior ao diâmetro do corpo de prova, tenha diâmetro inferior ao diâmetro do corpo de prova. Para isso propôs que o diâmetro do corpo de prova fosse aumentado de $100 \mathrm{~mm}$ para $150 \mathrm{~mm}$, mantendo-se o diâmetro da placa de carregamento em 100 mm, ou reduzindo-o para $50 \mathrm{~mm}$. Segundo Ulmgren (1996), essa modificação faz com que a estabilidade da mistura seja decorrente principalmente de forças de coesão, e não do atrito entre as partículas de agregado, como ocorre quando o diâmetro da placa de carregamento é igual ou superior ao diâmetro do corpo de prova.

A modificação proposta por Ulmgren (1996) é uma forma simplificada de confinar lateralmente o corpo de prova. Os resultados obtidos através dos ensaios de creep dinâmico modificados apresentaram boa correlação com ensaios de trilha de roda.

Tayebali et al. (1992) e Corté et al. (1993) também obtiveram boas correlações entre a suscetibilidade a deformações permanentes determinada através do ensaio de creep dinâmico com a suscetibilidade determinada através de ensaios de trilhas de roda.

De acordo com Taira (2001), parece haver um tendência mundial em se adotar ensaio dinâmicos ao invés de estáticos, principalmente quando se trata da avaliação da resistência à deformação permanente de misturas compostas por asfaltos modificados com polímero.

Segundo Valkering et al. (1990), o aumento de estabilidade devido ao uso de ligante modificado com polímero não é detectado pelo ensaio de creep estático, uma vez que este é muito simplificado e não consegue distinguir os distintos comportamentos reológicos dos ligantes com e sem polímero.

Supondo que a deficiência do ensaio de creep estático para avaliar o comportamento de misturas compostas por asfalto modificado por polímero talvez estivesse relacionada com a capacidade de recuperação da deformação após retirada do carregamento, Valkering et al. (1990) realizaram um ensaio com carregamentos repetitivos intercalados por períodos de recuperação. As características dos corpos de prova e do carregamento foram as mesmas utilizadas no ensaio de creep estático. As faces dos 
corpos de prova foram tratadas com grafite, para minimizar a fricção com as placas de carregamento.

Foi arbitrado um tempo de carregamento de $0,2 \mathrm{~s}$ e foram testados ciclos de carregamento de 1,2 e 4 s, para avaliação da influência do período de recuperação. Como não foi identificada uma diferença sistemática na influência dos tempos de recuperação testados, foi adotado um ciclo de carregamento de $2 \mathrm{~s}$. Valkering et al. (1990) observaram que a adição do polímero SBS ao asfalto provocou uma redução de 45 a $90 \%$ na taxa de deformação permanente e reduziu a deformação por um fator de 2 a 5 .

Concluíram que o ensaio de creep dinâmico é adequado para avaliação das propriedades de misturas com asfalto modificado por polímeros. Suas conclusões são baseadas em comparações de resultados do ensaio de creep com resultados de ensaios de trilhas de roda.

Estudos conduzidos por Oliveira e Motta (1996) e analisados por Motta et al. (1996) mostraram que o uso do polímero SBS em várias proporções não alterou significativamente os resultados do ensaio de fluência por compressão uniaxial estática. Ou seja, misturas asfálticas compostas pelo asfalto convencional CAP 40 apresentaram comportamento semelhante ao apresentado por misturas compostas por asfalto modificado com o polímero SBS, quando analisadas através do ensaio de creep estático.

Analisando-se o comportamento das misturas através do ensaio de creep dinâmico, entretanto, Motta et al. (1996) não apenas encontraram diferenças significativas como também verificaram a existência de um teor ótimo de polímero a ser utilizado, que no caso do estudo realizado por esses autores foi em torno de 5\% de SBS. Isso porque misturas com ligantes modificados pela adição de 5\% de SBS apresentaram as menores deformações, menores inclusive do que as deformações apresentadas por misturas com ligante modificado pela adição de $7 \%$ de SBS.

Dessa forma conclui-se que o ensaio de creep estático é adequado para avaliação da suscetibilidade a deformações permanentes de misturas compostas por asfalto convencional, mas não detecta as modificações nas propriedades reológicas do asfalto 
provocadas pela adição de polímeros. Isso porque ensaios estáticos não permitem que os materiais se comportem elasticamente, e dessa forma subestimam a resistência à deformação plástica dos asfaltos modificados (IBP, 1996).

O ensaio de creep dinâmico, por outro lado, tem se mostrado capaz de avaliar a suscetibilidade a deformações permanentes não somente de misturas compostas por asfaltos convencionais mas também de misturas compostas por asfaltos modificados, o que tem sido demonstrado pela boa correlação dos parâmetros obtidos por esse ensaio com resultados de simuladores de tráfego, conforme estudos anteriormente citados neste Capítulo (TAYEBALI et al., 1992; CORTÉ et al., 1993; VALKERING et al., 1990 e MOTTA et al., 1996).

\subsection{Deformações resilientes e fadiga}

A deformação elástica ou resiliente ocasionada pela repetição das cargas do tráfego pode levar o revestimento asfáltico à fadiga, que se evidencia na forma de trincamentos. A resistência à fadiga de uma mistura asfáltica, ou flexibilidade, pode ser definida como a capacidade de resistir a esforços repetitivos de flexão, sem se romper. A fadiga pode ocorrer mesmo quando são aplicados carregamentos repetitivos bem menores do que a carga de ruptura estática do material (YODER e WITCZAK, 1975).

A vida de fadiga de um revestimento asfáltico, ou seja, o número de solicitações necessárias para que ocorra um grau de trincamento considerado crítico, depende de vários fatores, relacionados com as características do tráfego, com as características próprias do pavimento e com as condições climáticas.

A estrutura de todo o pavimento, ou seja, os módulos elásticos e as relações entre os módulos das diversas camadas, bem como as espessuras dessas camadas, exercem influência na resistência do revestimento asfáltico à fadiga (TONIAL, 2001). Em pavimentos espessos e projetados para resistir a carregamentos elevados, a rigidez da mistura asfáltica da camada de revestimento deve ser alta. Por outro lado, em pavimentos delgados e projetados para tráfego leve, a mistura asfáltica da camada de 
revestimento deve ser o mais flexível possível, composta por exemplo por asfalto com baixa rigidez e agregado com graduação aberta.

Deformações excessivas do subleito e das camadas inferiores ao revestimento asfáltico aumentam a probabilidade da ocorrência de fadiga. Problemas de drenagem do subleito, por exemplo, podem acelerar o processo de fadiga do revestimento, pois este é submetido a elevadas deformações quando as camadas subjacentes são enfraquecidas pelo excesso de umidade (BERTOLLO, 2002).

A temperatura de serviço do pavimento consiste em um fator com grande influência na flexibilidade da camada asfáltica, uma vez que o asfalto é um material termossensível. Temperaturas elevadas aumentam a flexibilidade e temperaturas mais baixas tornam a camada asfáltica mais rígida e com maior tendência a se tornar quebradiça. Com a diminuição da temperatura, as tensões de tração que se desenvolvem na base do revestimento asfáltico aumentam.

Embora sejam muitos os fatores com influência na vida de fadiga de um pavimento, nesse trabalho foram considerados apenas os fatores relacionados às características das misturas asfálticas. Dentre esses, a viscosidade do ligante, o teor de ligante, a distribuição granulométrica do agregado e o volume de vazios são os principais fatores com influência na resistência à fadiga da mistura.

Volumes de vazios elevados geralmente correspondem a baixa resistência à fadiga. A graduação do agregado também afeta a vida de fadiga da mistura. Bertollo (2002) menciona que graduações contínuas são recomendadas para uso em pavimentos espessos, com o objetivo de aumentar a rigidez da mistura. Agregados com graduação descontínua são recomendados para pavimentos delgados, buscando-se a diminuição da rigidez da mistura.

Embora em menor grau, o formato das partículas de agregado, a angularidade e a textura superficial também afetam a vida de fadiga, que se prolonga quando são utilizadas partículas angulares com textura superficial rugosa. A redução da quantidade de fíler também contribui para tal fim, pois o uso em excesso desse material pode enrijecer as misturas e facilitar a ocorrência de trincamentos por fadiga. 
Tangella et al. (1990) ressaltam que, para misturas com distribuição granulométrica contínua, os dois principais fatores interferentes na resistência à fadiga são o teor de ligante e o volume de vazios, sendo que o tipo de agregado parece ter menor influência. Dessa forma concluem que para aumentar a resistência à fadiga, as misturas devem incorporar a maior quantidade de ligante possível, respeitando-se os limites da estabilidade.

Tangella et al. (1990) apresentaram um resumo da influência desses fatores, reproduzido na Tabela 4.9. Pode-se observar que em ensaios com tensão controlada, aumentos na rigidez da mistura correspondem a aumentos na vida de fadiga. Em ensaios com deformação controlada, entretanto, o efeito pode ser reverso. Por exemplo, aumentos da viscosidade do ligante correspondem a respectivos aumentos na rigidez da mistura e diminuição da vida de fadiga em ensaios com deformação controlada.

Tabela 4.9 - Fatores com influência na rigidez e na vida de fadiga de misturas asfálticas

\begin{tabular}{ccccc}
\hline fator & $\begin{array}{c}\text { variação do } \\
\text { fator }\end{array}$ & rigidez & $\begin{array}{c}\text { vida de fadiga em } \\
\text { ensaios com tensão } \\
\text { controlada }\end{array}$ & $\begin{array}{c}\text { vida de fadiga em } \\
\text { ensaios com } \\
\text { deformação } \\
\text { controlada }\end{array}$ \\
\cline { 3 - 5 } & aumento & aumento & aumento & diminuição \\
\hline $\begin{array}{c}\text { viscosidade do } \\
\text { ligante }\end{array}$ & aumento & aumento & aumento & aumento \\
\hline $\begin{array}{c}\text { teor de ligante } \\
\text { distribuição } \\
\text { granulométrica do } \\
\text { agregado }\end{array}$ & $\begin{array}{c}\text { aberta para } \\
\text { contínua }\end{array}$ & aumento & aumento & diminuição \\
\hline volume de vazios & diminuição & aumento & aumento & aumento \\
\hline Fonte: Tangella et al. (1990) & & &
\end{tabular}

Roberts et al. (1991), baseados nos resultados de numerosos ensaios, sugerem que em camadas de revestimento delgadas, que irão contribuir pouco com a resistência à flexão da estrutura do pavimento, sejam empregadas misturas com baixa rigidez e que a resistência à fadiga nesse caso seja avaliada através de ensaios com deformação controlada. Por outro lado, em camadas de revestimento espessas, que contribuam significativamente para a rigidez do pavimento, devem ser empregadas misturas mais rígidas e a avaliação da resistência à fadiga deve ser feita através de ensaios com tensão controlada. Embora a definição de camadas delgadas e espessas não seja clara, Maupin (1972) sugere que sejam consideradas delgadas as camadas com menos de 7,5 cm, e espessas as camadas com mais de $12,7 \mathrm{~cm}$. 
No laboratório, as características de fadiga de misturas asfálticas são medidas através dos ensaios de flexão em vigas, de torção em amostras cilíndricas, de tração uniaxial, de tração indireta por compressão diametral dinâmica e ensaios em amostras trapezoidais.

De acordo com Motta e Pinto (1994), o ensaio de tração indireta por compressão diametral dinâmica, normatizado para obtenção do módulo de resiliência pelo método de ensaio DNER-ME 133/94 (DNER, 1994a), é o mais utilizado no Brasil para avaliação da resistência à fadiga, em razão da simplicidade de sua execução e da facilidade de obtenção dos corpos de prova cilíndricos, que podem ser moldados pelo método Marshall ou extraídos por sonda rotativa.

Ainda segundo Motta e Pinto (1994), outro ensaio também utilizado no Brasil é o de flexão alternada, no qual vigotas de misturas asfálticas são submetidas a duas cargas simétricas em relação ao centro da vigota, o que produz um estado de tração uniforme na parte central da mesma, entre os dois pontos de carga.

Tanto no ensaio de tração indireta por compressão diametral como no ensaio de flexão alternada são aplicados carregamentos cíclicos sob regime de tensão controlada ou deformação controlada. O comportamento dos materiais quanto à fadiga pode ser descrito por relações do tipo

$$
\begin{aligned}
& N=K_{1}\left(\frac{1}{\sigma}\right)^{n 1} \\
& N=K_{2}\left(\frac{1}{\varepsilon}\right)^{n 2} \\
& N=K_{3}\left(\frac{1}{\Delta \sigma}\right)^{n 3}
\end{aligned}
$$

Onde

$\mathrm{N}$ = vida de fadiga expressa em números de solicitações da carga;

$\sigma=$ tensão de tração repetida;

$\varepsilon=$ deformação de tração repetida;

$\Delta \sigma=$ diferença algébrica entre as tensões vertical (de compressão) e horizontal (de tração), no centro da amostra; 
$\mathrm{K}_{1}, \mathrm{n}_{1}, \mathrm{~K}_{2}, \mathrm{n}_{2}, \mathrm{~K}_{3}, \mathrm{n}_{3}=$ parâmetros de fadiga determinados experimentalmente.

A determinação da vida de fadiga faz-se necessária para o dimensionamento racional de pavimentos, assim como a determinação do módulo de resiliência dos materiais (Motta e Pinto, 1994).

Os métodos utilizados para o projeto de pavimentos flexíveis podem ser classificados em duas categorias, procedimentos empíricos ou semi-empíricos e procedimentos analíticos ou teóricos.

Os procedimentos empíricos ou semi-empíricos baseiam-se em conhecimentos adquiridos e acumulados ao longo de anos de experiência na prática da construção e observação de pavimentos. O objetivo primordial do dimensionamento realizado por esses métodos é evitar a ruptura total do pavimento. Dessa forma, o principal esforço considerado é a tensão vertical máxima atuante no topo do subleito.

Para que os métodos empíricos ou semi empíricos possam ser utilizados, devem ser respeitadas as condições para as quais esses métodos foram desenvolvidos, incluindo condições climáticas e ambientais, condições de tráfego, condições específicas do solo, dos materiais naturais e dos materiais constituintes das camadas do pavimento. Quando essas condições são modificadas, impõe-se a necessidade do desenvolvimento de outro método que se adapte às novas condições, através de tentativa e erro.

Os métodos de projeto analíticos ou teóricos baseiam-se na análise de tensões e deformações produzidas pelo tráfego, para que não sejam ultrapassados os limites de resistência ao cisalhamento das camadas e o limite de resistência à fadiga do revestimento.

Os critérios utilizados podem se referir à deformação vertical no topo do subleito, que ocasiona a formação de trilhas de roda, ou à tensão horizontal que se desenvolve na superfície inferior do revestimento asfalto, responsável pela ocorrência de ruptura por fadiga. Atualmente, com as grandes velocidades e o aumento crescente do volume de tráfego, o conforto dos usuários tornou-se uma característica fundamental, levando os 
pavimentos a serem dimensionados considerando-se as deflexões verticais, de modo que essas não ultrapassem os limites aceitáveis.

O dimensionamento racional de um pavimento através dos métodos mecanísticos requer que se conheça o comportamento dos materiais que constituem as diversas camadas, quando solicitados dinamicamente. Nesse método é utilizado o módulo de resiliência ou módulo de elasticidade dinâmico dos materiais, que permite a quantificação das tensões e deformações em qualquer ponto do pavimento, ocasionadas pela aplicação de cargas.

Estudos mais recentes sobre projeto de pavimentos flexíveis incluem a aplicação de programas computacionais. Dentre os programas computacionais para cálculo de tensões e deformações que possuem como dado de entrada o módulo de resiliência destacam-se os programas CHEV, ELSYM5, FEPAVE e RIOPAVE.

Os programas CHEV e ELSYM5 baseiam-se na teoria de sistemas elásticos em camadas e os programas FEPAVE e RIOPAVE, no método dos elementos finitos. O programa RIOPAVE foi desenvolvido por Aedo et al. (1996), para análise tridimensional linear e não linear de pavimentos. Esse programa permite que se considere módulos variáveis e dependentes do estado de tensão.

Nesse trabalho, a determinação do módulo de resiliência das misturas asfálticas foi realizada através do ensaio de tração indireta por compressão diametral dinâmica. Esse ensaio simula o comportamento mecânico do revestimento asfáltico na região onde ocorrem as deformações específicas de tração, responsáveis pela fadiga da camada e consequentemente pela vida de serviço da estrutura (Pinto e Preussler, 1980).

Maupin (1972), em estudo realizado com quatro tipos de misturas asfálticas, preparadas e testadas em laboratório, encontrou boa correlação entre a vida de fadiga e a rigidez da mistura, obtida através do ensaio de tração indireta.

De acordo com Maupin (1972), o ensaio de tração indireta possui como vantagens a simplicidade de sua execução, o fato de serem utilizados corpos de prova moldados pelo método Marshall, a pequena influência das irregularidades superficiais nos resultados e o baixo coeficiente de variação dos resultados do ensaio. 
Os problemas desse ensaio estão relacionados com a teoria de cálculo das deformações, pois são considerados materiais elásticos e aplicação de uma linha de carregamento, e no entanto sabe-se que o concreto asfáltico é um material visco-elástico para a maioria das temperaturas ambientes e o carregamento é aplicado não em uma linha, mas sim distribuído em um friso. Para Maupin (1972), entretanto, os problemas do ensaio não são graves, e as vantagens superam as desvantagens.

\subsubsection{Ensaio de módulo de resiliência por compressão diametral dinâmica}

O módulo de resiliência de um material corresponde ao módulo de elasticidade determinado através de ensaios laboratoriais que simulem as condições de campo, incluindo a aplicação de carregamentos repetidos. Materiais submetidos a carregamentos dinâmicos de curta duração, que gerem tensões inferiores à tensão de plastificação, se comportam de forma aproximadamente elástica, mas não necessariamente linear. A esse parâmetro elástico denomina-se módulo de resiliência (PINTO e PREUSSLER, 1980). De acordo com Medina (1988), a palavra "resiliência" foi adotada por Hveem, no lugar de elasticidade, por serem os deslocamentos nos pavimentos muito maiores que os de vários sólidos elásticos, como o vidro, o concreto e o aço.

O módulo de resiliência é definido analiticamente pela expressão

$$
M r=\frac{\sigma}{\Delta}
$$

Onde

MR = módulo de deformação resiliente;

$\sigma=$ tensão aplicada dinamicamente;

$\Delta=$ deformação específica resiliente para um determinado número de aplicações da tensão.

Segundo Medina(1988), Schmidt (1972), pesquisador da Chevron Asphalt Company, foi quem primeiro divulgou a utilização do ensaio de compressão diametral dinâmica para a determinação do módulo resiliente de misturas asfálticas. Dessa forma o "ensaio brasileiro" foi aplicado a misturas asfálticas, 30 anos após sua criação. 
O ensaio de tração indireta ou de compressão diametral, conhecido como "ensaio brasileiro", foi desenvolvido por Professor Fernando Luiz Lobo B. Carneiro para determinação da resistência à tração do concreto em corpos de prova cilíndricos, através de solicitação estática. Simultaneamente e de forma independente, Tsunéo Akasawa chegou ao mesmo método de ensaio. Atualmente esse ensaio têm sido utilizado internacionalmente para a determinação do módulo de elasticidade dinâmico de misturas asfálticas.

O ensaio de tração indireta com carregamento repetido consiste em se submeter uma amostra cilíndrica a uma carga de compressão vertical, aplicada dinamicamente e distribuída ao longo de duas geratrizes diametralmente opostas, medindo-se as deformações resilientes ao longo do diâmetro horizontal, perpendicular à carga aplicada.

Frocht* (1948 apud SCHMIDT, 1972, p.22) demonstrou que as tensões que ocorrem no plano diametral horizontal, perpendicular à carga $F$ aplicada verticalmente no ensaio de tração indireta, são uniformes e podem ser calculadas pelas seguintes expressões

$$
\begin{gathered}
\sigma_{x}=\frac{2 F}{\pi t d}\left(\frac{d^{2}-4 x^{2}}{d^{2}+4 x^{2}}\right)^{2} \\
\sigma_{y}=\frac{-2 F}{\pi t d}\left(\frac{4 d^{4}}{\left(d^{2}+4 x^{2}\right)^{2}}-1\right)
\end{gathered}
$$

Onde

$\mathrm{F}=$ carga aplicada verticalmente, na direção do eixo y;

$\mathrm{t}=$ altura da amostra;

d = diâmetro da amostra;

$\mathrm{x}=$ abscissa do ponto considerado, ou seja, coordenada horizontal;

$\sigma_{\mathrm{x}}=$ tensão de tração;

$\sigma_{\mathrm{y}}=$ tensão de compressão.

* FROCHT, M.M. (1948). Photoelasticity. v.2. John Wiley and Sons, New York apud SCHMIDT, R.J. (1972). A practical method for measuring the resilient modulus of asphalt-treated mixes. Highway Research Record. 404, p.22-32. 
As expressões para as tensões que ocorrem no plano diametral vertical, conforme apresentado por Pinto e Preussler (1980), são

$$
\begin{gathered}
\sigma_{x}=\frac{2 F}{\pi t d} \\
\sigma_{y}=\frac{-2 F}{\pi t d}\left(\frac{2 d}{d-2 y}+\frac{2 d}{d+2 y}-1\right)
\end{gathered}
$$

Onde y é ordenada do ponto considerado, ou seja, é a coordenada vertical do ponto, e os demais parâmetros seguem as definições anteriores.

O carregamento aplicado no ensaio de tração indireta produz níveis de tensões de tração relativamente uniformes ao longo do plano diametral vertical, que podem ser calculados pela expressão

$$
\sigma_{t}=\frac{2 F}{\pi d t}
$$

Onde $\sigma_{t}$ é a tensão de tração e os parâmetros $F, d$ e $t$ seguem as definições anteriores. Independentemente de pequenas variações na configuração do carregamento, a expressão da eq. (4.17) é sempre válida para fornecer a tensão de tração no centro da amostra. Quando a carga vertical $F$ atinge o valor máximo de ruptura do corpo de prova, $\sigma_{t}$ corresponde à resistência à tração do material ensaiado.

Considerando-se estado plano de tensões e comportamento elástico, a expressão para a deformação $\varepsilon_{\mathrm{x}}$ no diâmetro horizontal é

$$
\varepsilon_{x}=\frac{1}{E}\left[\sigma_{x}-\mu\left(\sigma_{y}+\sigma_{z}^{0}\right)\right]
$$

Onde $\mu$ é o coeficiente de Poisson e $E$, o módulo de elasticidade.

Substituindo-se as expressões das eq. (4.13) e (4.14) na expressão da eq. (4.18), tem-se 


$$
\varepsilon_{x}=\frac{2 F}{E \pi t d}\left[\frac{\left(4 d^{4} v-16 d^{2} x^{2}\right)}{\left(d^{2}+4 x^{2}\right)^{2}}+(1-v)\right]
$$

A deformação total $\Delta$ no diâmetro horizontal é obtida pela integração da expressão acima, no intervalo $(-\mathrm{d} / 2 ; \mathrm{d} / 2)$

$$
\begin{gathered}
\Delta=\int_{-d / 2}^{d / 2} \varepsilon_{x} d x \\
\Delta=\frac{F}{t E}\left[\left(\frac{4}{\pi}\right)+\mu-1\right]
\end{gathered}
$$

Simplificando-se a expressão acima pode-se obter o módulo de elasticidade em função da carga aplicada, da deformação total, do coeficiente de Poisson e da altura do corpo de prova, conforme eq. (4.21).

$$
E=\frac{F}{t \Delta}(\mu+0,2732)
$$

Ou seja, conhecendo-se a deformação total no diâmetro horizontal, pode-se calcular o módulo de elasticidade. No caso de misturas asfálticas, que possuem comportamento viscoelástico, a eq. (4.21) permite o cálculo do módulo de resiliência, desde que o tempo de carregamento seja curto o suficiente para minimizar o comportamento viscoso da mistura asfáltica.

\subsubsection{Aplicações do ensaio de módulo de resiliência por compressão diametral dinâmica}

De acordo com Preussler e Pinto (1982), desde 1977 vêm sendo realizadas tentativas de se incorporar resultados de estudos sobre as características resilientes de solos e o comportamento à fadiga de misturas betuminosas, em procedimentos de projeto de pavimentos. Esses estudos envolveram a análise de estruturas de pavimentos que apresentaram situações críticas de comportamento, não explicadas pelos procedimentos 
usuais de análise. Procurou-se então um método racional de dimensionamento de pavimentos novos e de reforços de pavimentos existentes, através do cálculo das tensões e deformações que ocorrem na estrutura do pavimento. A determinação do módulo de resiliência de misturas asfálticas tornou-se assim uma necessidade.

Pinto e Preussler (1980) apresentaram um relatório fornecendo informações preliminares sobre módulos de resiliência de misturas asfálticas, projetadas no Laboratório de Pesquisas do Instituto de Pesquisas Rodoviárias. Foram ensaiadas misturas com dois tipos de ligante asfáltico, CAP 50/60 e CAP 85/100, três distribuições granulométricas, correspondentes às faixas A, B e C do DNER, para concretos asfálticos utilizados como binder e como camada de rolamento.

O módulo de resiliência das misturas foi determinado através do ensaio de compressão diametral dinâmica, realizado a $25^{\circ} \mathrm{C}$, com 200 aplicações da carga, a uma frequiência de 60 solicitações por minuto, com tempo de duração da carga de 0,14 s. Os ensaios foram conduzidos sob tensão controlada, tendo sido escolhida a menor tensão de tração capaz de provocar na amostra uma deformação mensurável.

O estudo conduzido por Pinto e Preussler (1980) não detectou influência direta da faixa granulométrica nos valores de módulo de resiliência das misturas. Entretanto constatouse que, quanto maior o teor ótimo da mistura, maior a resistência à tração. Dessa forma os maiores valores de resistência à tração foram obtidos para a faixa granulométrica $\mathrm{C}$, pois o teor ótimo de ligante obtido para essa faixa foi superior aos obtidos para as faixas A e B, em misturas utilizando ambos os tipos de ligante. Ou seja, a resistência à tração foi maior em misturas mais ricas em asfalto, nas condições em que foi realizado o estudo.

A influência da viscosidade do ligante asfáltico na rigidez das misturas foi direta, uma vez que os valores de módulo de resiliência e resistência à tração foram maiores para o ligante betuminoso com maior viscosidade, no caso o CAP 50/60.

Pinto e Preussler (1980) identificaram faixas de variação do módulo de resiliência das misturas, apresentadas na Tabela 4.10. 
Tabela 4.10 - Faixas de variação do módulo de resiliência, obtidas por Pinto e Preussler (1980)

\begin{tabular}{ccccc}
\hline ligante & & \multicolumn{3}{c}{ módulo de resiliência $(\mathrm{MPa})$} \\
\hline \multirow{3}{*}{ CAP 50/60 } & capa & 2700 & até & 4300 \\
& binder & 2700 & até & 4900 \\
\hline \multirow{2}{*}{ CAP 85/100 } & capa & 1900 & até & 3000 \\
& binder & 2200 & até & 3000 \\
\hline
\end{tabular}

Embora no estudo conduzido por Pinto e Preussler (1980) a variação do volume de vazios não tenha apresentado influência significativa nos valores de módulo de resiliência, os autores mencionam que misturas muito abertas podem afetar significativamente a vida de serviço de revestimentos asfálticos, pois podem acelerar o processo de oxidação do ligante asfáltico.

Preussler e Pinto (1982) propuseram um método para projeto de reforço de pavimentos flexíveis, considerando a resiliência dos materiais. Nesse estudo mencionam que corpos de prova submetidos ao ensaio de compressão diametral por carregamento repetido realizado em temperaturas superiores a $40^{\circ} \mathrm{C}$ apresentam ruptura plástica, com excessivas deformações permanentes de tração. Dessa forma, para essas condições não pode ser observado o comportamento à fadiga das misturas asfálticas. Os autores adotaram temperaturas de ensaio inferiores a $30^{\circ} \mathrm{C}$.

Métodos racionais de dimensionamento de pavimentos vêm substituindo os métodos empíricos. Nesses métodos as propriedades dos materiais são caracterizadas pelo módulo de resiliência. Dentre os métodos de dimensionamento baseados na resiliência dos materiais destaca-se o método da AASHTO (1993).

Motta e Medina (1991) propuseram um roteiro para dimensionamento racional de pavimentos que pressupõe a dosagem de misturas asfálticas de modo que as mesmas apresentem valores previamente especificados de módulo de resiliência, de acordo com a temperatura média prevista para o revestimento no trecho considerado. 
Motta* (1991, apud BEZERRA NETO, 2004, p.42) apresentou um método mecanístico de dimensionamento de pavimentos flexíveis, consolidando os estudos sobre a Mecânica dos Pavimentos desenvolvidos na COPPE/UFRJ desde a década de 1970. Nesse método a análise mecanística é efetuada utilizando-se o programa computacional FEPAVE, modificado pela introdução de novos critérios. Esse programa adota um modelo elástico linear para o revestimento asfáltico e um modelo elástico não-linear para as camadas subjacentes. As tensões e deformações são verificadas e comparadas com critérios de aceitação pré-estabelecidos, que podem se referir à deflexão máxima admissível na superfície; à diferença de tensões no revestimento; à tensão vertical admissível no topo do subleito; e a tensão e deformação de tração na fibra inferior do revestimento.

Segundo Motta et al. (1993), o dimensionamento com base na mecânica dos pavimentos compatibiliza as espessuras das camadas com os módulos de resiliência de todas as camadas, uma vez que o estado de tensões desenvolvido será função desses parâmetros, assim como a vida de fadiga do pavimento.

Ao contrário do obtido por Pinto e Preussler (1980), Motta** (1998 apud AMARAL, 2000, p.79), em estudo realizado para estimativa do módulo de resiliência de misturas asfálticas, encontrou variação do módulo de resiliência com a granulometria da mistura e com a viscosidade do ligante, mas não com o teor de ligante. Nesse estudo o módulo de resiliência mostrou-se maior para misturas com agregados pertencentes a faixas granulométricas mais grossas, ou seja, com partículas de diâmetros maiores, e para misturas com ligantes apresentando as maiores viscosidades.

\footnotetext{
* MOTTA, L.M.G. (1991). Método de dimensionamento de pavimentos flexíveis; critérios de confiabilidade e ensaios de cargas repetidas. Tese (Doutorado) - COPPE/UFRJ. Rio de Janeiro. apud BEZERRA NETO, R.S.. (2004). Análise comparativa de pavimentos dimensionados através dos métodos empírico do DNER e mecanístico e proposta de um catálogo simplificado de pavimentos para a região de campo grande (MS). 169p. Dissertação (Mestrado) - Escola de Engenharia de São Carlos, Universidade de São Paulo, São Carlos. 2004.

** MOTTA, L.M.G. (1998). Contribuição para a estimativa do módulo resiliente de misturas asfálticas. $14^{\circ}$ Encontro de Asfalto, p.30-39 apud AMARAL, S.C. (2000). Estudos de misturas asfálticas densas com agregados do estado do Pará, utilizando asfalto convencional (CAP-40) e asfalto modificado com polímero SBS (BETUFLEX B 65/60). São Carlos. Dissertação (Mestrado) - Escola de Engenharia de São Carlos, Universidade de São Paulo. 147 p.
} 
Como nem sempre equipamentos para realização de ensaios dinâmicos encontram-se disponíveis em laboratórios de pavimentação, têm sido estabelecidas correlações entre o módulo de resiliência $(M R)$ e a tensão de ruptura de tração $\left(\sigma_{R}\right)$, que pode ser determinada adaptando-se uma prensa Marshall para a realização do ensaio de resistência à tração por compressão diametral estática. Além disso a relação $M R / \sigma_{R}$ é um indicativo da capacidade de recuperação elástica das misturas asfálticas e de sua resistência ao trincamento por tração. Relações $M R / \sigma_{R}$ encontradas em alguns estudos são apresentadas na Tabela 4.11 .

Tabela 4.11 - Relações MR/ $\sigma_{\mathrm{R}}$ encontradas em estudos realizados a $25^{\circ} \mathrm{C}$

\begin{tabular}{ccc}
\hline estudo & tipo de ligante & relação $M R / \sigma_{R}$ \\
\hline Pinto (1991) & asfalto convencional & $M R=6461 \sigma_{R}$ \\
\hline Motta e Pinto (1994) & asfalto convencional & $M R=343+4028 \sigma_{R}$ \\
\hline procedimento de reforço & asfalto convencional & $M R=5000 \sigma_{R}$ \\
DNER PRO 269/94 & & \\
(DNER, 1994f) & & \\
\hline Motta* (1998 apud & asfalto modificado & $M R=3000$ a 3500 $\sigma_{R}$ \\
AMARAL, 2000, p.80) & & \\
\hline
\end{tabular}

As condições em que são conduzidos os ensaios de módulo de resiliência por compressão diametral dinâmica variam conforme a especificação adotada.

A ASTM (1982) recomenda que a carga aplicada seja tal que induza tensões de tração $\left(\sigma_{t}\right)$ entre $10 \%$ a $50 \%$ da resistência à tração determinada no ensaio de compressão diametral estático $\left(\sigma_{\mathrm{R}}\right)$. Os ensaios devem ser realizados em três temperaturas, 5, 25 e $40^{\circ} \mathrm{C}$, e em uma ou mais freqüências de carregamento, que podem ser de 0,$33 ; 0,5$ ou 1,0 Hz, para cada temperatura. O tempo de carregamento pode variar de 0,1 a $0,4 \mathrm{~s}$, recomendando-se duração de 0,1 s. Cada ensaio deve ter a duração de 4 minutos.

\footnotetext{
* MOTTA, L.M.G. (1998). Contribuição para a estimativa do módulo resiliente de misturas asfálticas. $14^{\circ}$ Encontro de Asfalto, p.30-39 apud AMARAL, S.C. (2000). Estudos de misturas asfálticas densas com agregados do estado do Pará, utilizando asfalto convencional (CAP-40) e asfalto modificado com polímero SBS (BETUFLEX B 65/60). São Carlos. Dissertação (Mestrado) - Escola de Engenharia de São Carlos, Universidade de São Paulo. 147 p.
} 
Antes deve ser realizado o pré-condicionamento do corpo de prova, aplicando-se ciclos de carregamento até que a deformação resiliente torne-se estável, o que geralmente significa a aplicação de 50 a 200 ciclos de carregamento. Cada corpo de prova deve ser ensaiado em duas direções, separadas por $90^{\circ}$.

A ASHTO (1994) recomenda a aplicação de cargas correspondentes a tensões de tração $\left(\sigma_{t}\right)$ inferiores a 30, 15 e 5\% da tensão de tração determinada no ensaio de compressão diametral estático $\left(\sigma_{\mathrm{R}}\right)$ realizado a $25^{\circ}$, para ensaios de módulo de resiliência realizados a 5,25 e $40^{\circ} \mathrm{C}$, respectivamente. São indicados ciclos de carregamento de $1 \mathrm{~s}$, com $0,1 \mathrm{~s}$ de aplicação de carga. Antes de cada ensaio deve ser realizado o pré-condicionamento do corpo de prova, aplicando-se ciclos de carregamento até que as deformações horizontais se estabilizem e pareçam uniformes. O número de ciclos de carregamento aplicados no pré-condicionamento depende da temperatura de ensaio e geralmente varia entre 50 a 150 ciclos, para ensaios realizados a $5^{\circ} \mathrm{C} ; 50$ a 100 ciclos, para ensaios realizados a $25^{\circ} \mathrm{C}$; e entre 20 e 50 ciclos, para ensaios realizados a $40^{\circ} \mathrm{C}$. Após a fase de pré-condicionamento, o ensaio deve ser realizado aplicando-se no mínimo 30 ciclos de carregamento. O módulo de resiliência deve ser calculado com os últimos 5 ciclos.

Segundo o DNER (1994a), o ensaio de módulo de resiliência deve ser realizado aplicando-se uma carga vertical diametralmente ao corpo de prova, que produza uma tensão de tração $\left(\sigma_{t}\right)$ inferior a $30 \%$ da resistência à tração determinada no ensaio de compressão diametral estático $\left(\sigma_{\mathrm{R}}\right)$. Quando a temperatura não for especificada, $\mathrm{o}$ ensaio deverá ser realizado a $30^{\circ} \mathrm{C} \pm 1^{\circ} \mathrm{C}$. A frequiência de aplicação de carga é de 1,0 $\mathrm{Hz}$, com duração de 0,1 s. Devem ser aplicados 500 ciclos de carregamento. Antes do ensaio deve ser realizado o pré-condicionamento do corpo de prova, que consiste na aplicação de 200 ciclos de carregamento.

\subsubsection{Ensaio de módulo complexo dinâmico por compressão uniaxial}

Outro método utilizado para a avaliação da resiliência de misturas asfálticas é a determinação do módulo complexo, que engloba não apenas a resposta elástica, mas também a resposta viscosa (GOODRICH, 1991). 
As misturas asfálticas não se comportam como materiais elásticos lineares, pois sua resistência varia com a temperatura, com a velocidade de aplicação de carga, com a magnitude da carga aplicada e com a configuração do carregamento. Quando materiais asfálticos são submetidos a um nível constante de tensão, a deformação depende do tempo de aplicação da carga.

Dessa forma, em geral as misturas asfálticas apresentam um comportamento viscoelástico e, quando um corpo de prova de material viscoelástico é submetido a carregamentos repetitivos com lei de carregamento senoidal, a deformação é defasada da tensão, conforme pode ser observado na Figura 4.3 (MOMM e DOMINGUES, 1996).

Através de análises baseadas no módulo complexo, o comportamento viscoelástico linear de misturas asfálticas pode ser caracterizado pelo método da superposição tempotemperatura, ou seja, é realizada a superposição das respostas do material que são dependentes do tempo de carregamento, com as respostas dependentes da temperatura de ensaio.

O ensaio de módulo complexo dinâmico por compressão axial encontra-se normatizado pela ASTM D3497-79 e consiste na aplicação de cargas verticais senoidais em corpos de prova cilíndricos não confinados, em determinadas temperatura e frequiência, medindo-se as deformações axiais sofridas, geralmente através de transdutores do tipo LVDT. Os corpos de prova ensaiados devem ter uma relação entre a altura e o diâmetro de 2 para 1, para minimizar o efeito do atrito nas faces da amostra. $\mathrm{O}$ diâmetro mínimo é de $10 \mathrm{~cm}$ e corpos de prova moldados em laboratório devem ter diâmetro no mínimo quatro vezes superior ao diâmetro nominal máximo do agregado na mistura. 


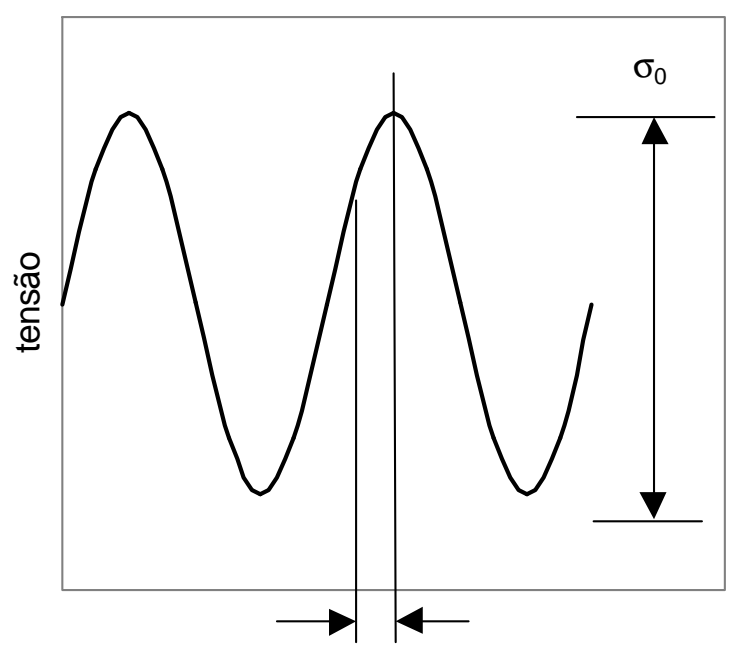

defasagem de tempo $=\phi / \varpi$

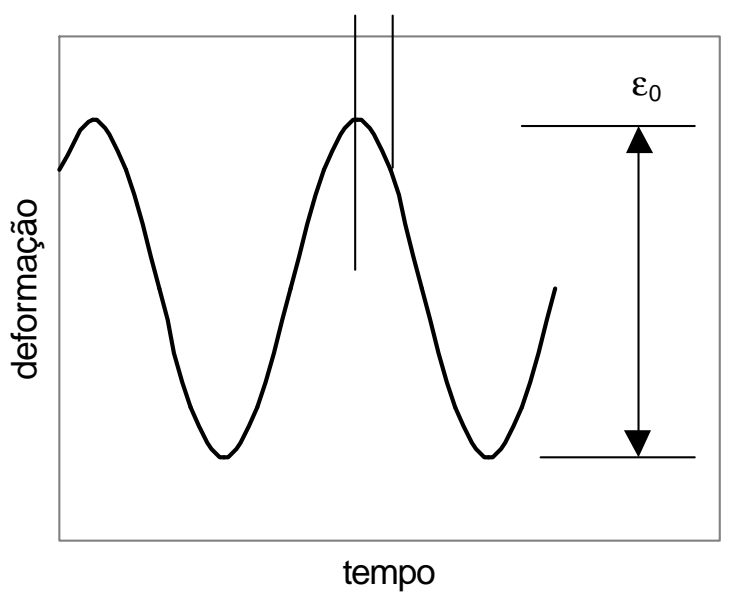

Figura 4.3 - Gráficos típicos de tensão e deformação em função do tempo de carregamento, em ensaios de módulo complexo (FONSECA*, 1995 apud TONIAL, 2001)

O ensaio de módulo complexo dinâmico foi desenvolvido para medir as propriedades viscoelásticas lineares de materiais de pavimentação. O módulo complexo é definido por

$$
E^{*}=\frac{\sigma_{0} \operatorname{sen} w t}{\varepsilon_{0} \operatorname{sen}(w t-\phi)}
$$

* FONSECA, O.F. (1985). Development of a time dependent model for the dynamic modulus of asphalt mixes. Ph.D. dissertation, University of Maryland, Maryland apud TONIAL, I.A. (2001). Influência do envelhecimento do revestimento asfáltico na vida de fadiga de pavimentos. Rio de Janeiro. Dissertação (Mestrado) - Universidade Federal do Rio de Janeiro. 
Onde

$$
\begin{aligned}
& \sigma_{0}=\text { amplitude máxima da tensão; } \\
& \varepsilon_{0}=\text { amplitude máxima da deformação específica; } \\
& \omega=\text { freqüência angular de carga em radianos por segundo; } \\
& \mathrm{t}=\text { tempo em segundos; } \\
& \phi=\text { ângulo de fase (ângulo de defasagem entre } \varepsilon_{0} \text { e } \sigma_{0} \text { ). }
\end{aligned}
$$

Por definição o módulo complexo E* é composto por uma parte real e por uma parte imaginária, podendo ser escrito da seguinte forma

$$
\begin{gathered}
E^{*}=\frac{\sigma_{0}}{\varepsilon_{0}} \cos \phi+i \frac{\sigma_{0}}{\varepsilon_{0}} \operatorname{sen} \phi \\
E^{\prime}=\left(\frac{\sigma_{0}}{\varepsilon_{0}}\right) \cos \phi \Rightarrow E^{\prime}=\left|E^{*}\right| \cos \phi \Rightarrow \text { módulo conservativo } \\
E^{\prime \prime}=\left(\frac{\sigma_{0}}{\varepsilon_{0}}\right) \operatorname{sen} \phi \Rightarrow E^{\prime \prime}=\left|E^{*}\right| \operatorname{sen} \phi \Rightarrow \text { módulo dissipativo }
\end{gathered}
$$

Ou seja

$$
E^{*}=E^{\prime}+i E^{\prime \prime}
$$

A parcela real do módulo complexo para um material elástico $(\phi=0)$ é chamada de módulo dinâmico. O módulo dinâmico é igual ao valor absoluto do módulo complexo, sendo expresso pela relação entre a tensão dinâmica máxima induzida $\left(\sigma_{0}\right)$ e a deformação específica máxima recuperável $\left(\varepsilon_{0}\right)$, conforme eq. (4.27).

$$
E(\text { dinâmico })=|E *|=\frac{\sigma_{0}}{\varepsilon_{0}}
$$

Embora o módulo dinâmico ou absoluto ignore a frequiência da aplicação de carga e a defasagem entre a tensão e a deformação, esse módulo tem sido usado como base para o desenvolvimento de modelos de caracterização da resposta tensão-deformação específica de misturas asfálticas, incorporados em métodos de dimensionamento de pavimentos flexíveis, como o método da AASHTO (1993). 


\section{PROCEDIMENTOS EXPERIMENTAIS}

O desempenho das misturas asfálticas utilizadas na construção de pavimentos flexíveis é afetado por diversos fatores, que incluem as características físicas dos materiais que as compõem; a dosagem desses materiais; a duração e as condições de temperatura dos processos de mistura em usina, transporte, espalhamento e compactação da camada asfáltica; o grau de compactação da mistura; e as condições ambientais do local onde o pavimento construído permanecerá em serviço.

Dentre os fatores citados foram selecionados para estudo:

- o tipo do ligante asfáltico;

- a distribuição granulométrica do agregado;

- a espessura da película asfáltica;

- o índice de vazios da mistura asfalto agregado compactada;

- o envelhecimento da mistura a curto prazo e

- o envelhecimento da mistura a longo prazo.

A influência da variação desses fatores no comportamento das misturas asfálticas quanto à estabilidade e à flexibilidade foi avaliada através da montagem de um programa experimental, utilizando-se a técnica de planejamento e análise de experimentos fatoriais. Dessa forma foram feitas variações propositais nas variáveis de entrada ou fatores influentes, com o objetivo de se identificar as razões da variação das respostas ou variáveis de saída, medidas através dos ensaios laboratoriais de módulo de 
resiliência por compressão diametral dinâmica e fluências por compressão uniaxial estática e dinâmica. A significância do efeito da variação de cada fator e dos efeitos de interação entre os fatores na variação dos parâmetros de ensaio foi estimada através do método de análise de variância (ANOVA).

\subsection{Variações ou níveis dos fatores selecionados para estudo}

As variações dos fatores selecionados para estudo são denominadas níveis dos fatores. O fator tipo de ligante asfáltico foi testado em três níveis. Foram selecionados para teste um asfalto convencional (CAP 20), um asfalto modificado com polímero (CAP 20 modificado com 4,5\% do polímero SBS - estireno butadieno estireno) e um asfalto modificado com borracha (CAP 20 modificado com 20\% de BRP - borracha reciclada de pneu), todos fornecidos pela Continental Asfaltos. A base de preparação dos asfaltos modificados foi o mesmo asfalto convencional selecionado para teste nessa pesquisa. As características físicas dos asfaltos convencional, modificado com polímero e modificado com borracha encontram-se apresentadas nas Tabelas 5.1, 5.2 e 5.3, respectivamente.

Tabela 5.1 - Características físicas do asfalto convencional

\begin{tabular}{lc}
\hline Ensaio & resultado \\
\hline Penetração, $25^{\circ} \mathrm{C}, 100 \mathrm{~g}, 5 \mathrm{~s}$ & $54\left(10^{-1} \mathrm{~mm}\right)$ \\
Ponto de amolecimento & $48^{\circ} \mathrm{C}$ \\
Índice de susceptibilidade térmica & $-1,534$ \\
Viscosidade Saybolt Furol a $135^{\circ} \mathrm{C}$ & $189 \mathrm{~s}$ \\
Viscosidade Saybolt Furol a $177^{\circ} \mathrm{C}$ & $30 \mathrm{~s}$ \\
Viscosidade absoluta a $60^{\circ} \mathrm{C}$ (poise) & $2102 \mathrm{p}$ \\
Solubilidade em tricloroetileno $(\%$ massa) & $99,5 \%$ \\
Ductilidade a $25^{\circ} \mathrm{C}$ & $96 \mathrm{~cm}$ \\
Ponto de fulgor & $256^{\circ} \mathrm{C}$ \\
\hline
\end{tabular}

Tabela 5.2 - Características físicas do asfalto modificado com 4,5\% do polímero SBS

\begin{tabular}{lc}
\hline Ensaio & resultado \\
\hline Penetração, $25^{\circ} \mathrm{C}, 100 \mathrm{~g}, 5 \mathrm{~s}$ & $47\left(10^{-1} \mathrm{~mm}\right)$ \\
Ponto de amolecimento & $67,5^{\circ} \mathrm{C}$ \\
Îndice de susceptibilidade térmica & 2,262 \\
Viscosidade Saybolt Furol a $135^{\circ} \mathrm{C}$ & $402 \mathrm{~s}$ \\
Viscosidade Saybolt Furol a $177^{\circ} \mathrm{C}$ & $68 \mathrm{~s}$ \\
Ponto de fulgor & $278^{\circ} \mathrm{C}$ \\
\hline
\end{tabular}


Tabela 5.3 - Características físicas do asfalto modificado com $20 \%$ de borracha reciclada de pneu

\begin{tabular}{lc}
\hline Ensaio & resultado \\
\hline Penetração, $25^{\circ} \mathrm{C}, 100 \mathrm{~g}, 5 \mathrm{~s}$ & $1\left(10^{-1} \mathrm{~mm}\right)$ \\
Ponto de amolecimento & $104^{\circ} \mathrm{C}$ \\
Índice de susceptibilidade térmica & 0,576 \\
Viscosidade Saybolt Furol a $135^{\circ} \mathrm{C}$ & -- \\
Viscosidade Saybolt Furol a $177^{\circ} \mathrm{C}$ & $840 \mathrm{~s}$ \\
Viscosidade Saybolt Furol a $185^{\circ} \mathrm{C}$ & $98 \mathrm{~s}$ \\
Ponto de fulgor & $241^{\circ} \mathrm{C}$ \\
\hline
\end{tabular}

Foram utilizadas duas curvas granulométricas, correspondentes aos centros das faixas $B$ e $C$ do DNER(1997). Os limites das faixas granulométricas utilizadas e as curvas granulométricas adotadas encontram-se apresentados na Tabela 5.4 e podem ser visualizados nas Figuras 5.1 e 5.2, onde encontram-se representadas as faixas $B$ e $C$, respectivamente. Pode-se observar por essas figuras que as curvas adotadas passam acima das respectivas zonas de restrição da especificação Superpave.

Tabela 5.4-Limites das faixas granulométricas $B$ e $C$ do DNER (1997) e curvas granulométricas adotadas

\begin{tabular}{|c|c|c|c|c|c|}
\hline \multirow{2}{*}{\multicolumn{2}{|c|}{ peneira de malha quadrada }} & \multicolumn{4}{|c|}{ porcentagem passada (\%) } \\
\hline & & \multicolumn{2}{|c|}{ faixas granulométricas } & \multicolumn{2}{|c|}{ curvas adotadas } \\
\hline discriminação & $\begin{array}{l}\text { abertura } \\
(\mathrm{mm})\end{array}$ & $B$ & $C$ & $\begin{array}{c}\text { centro da faixa } \\
B \\
\end{array}$ & $\begin{array}{c}\text { centro da faixa } \\
C\end{array}$ \\
\hline $2 "$ & 50,8 & - & - & - & - \\
\hline $11 / 2 "$ & 38,1 & 100 & - & 100 & - \\
\hline $1 "$ & 25,4 & $95-100$ & - & 100 & - \\
\hline $3 / 4 "$ & 19,1 & $80-100$ & 100 & 90 & 100 \\
\hline $1 / 2 "$ & 12,7 & - & $85-100$ & 74 & 93 \\
\hline $3 / 8 "$ & 9,5 & $45-80$ & $75-100$ & 63 & 87 \\
\hline$n^{\circ} 4$ & 4,8 & $28-60$ & $50-85$ & 44 & 67 \\
\hline $\mathrm{n}^{\circ} 10$ & 2,0 & $20-45$ & $30-75$ & 33 & 53 \\
\hline$n^{\circ} 40$ & 0,42 & $10-32$ & $15-40$ & 21 & 27 \\
\hline $\mathrm{n}^{\circ} 80$ & 0,18 & $8-20$ & $8-30$ & 14 & 19 \\
\hline$n^{\circ} 200$ & 0,074 & $3-8$ & $5-10$ & 5 & 7 \\
\hline
\end{tabular}

Para obtenção da curva média da faixa $B$ do DNER (1997) foi realizada uma interpolação gráfica entre as peneiras de aberturas 19,1 e 9,5 mm, para determinação da porcentagem de material passado pela peneira de abertura $12,7 \mathrm{~mm}$, uma vez que não consta nenhuma especificação referente a essa peneira. Procedendo-se dessa forma adotou-se $74 \%$ de material passado pela peneira de abertura $12,7 \mathrm{~mm}$. 


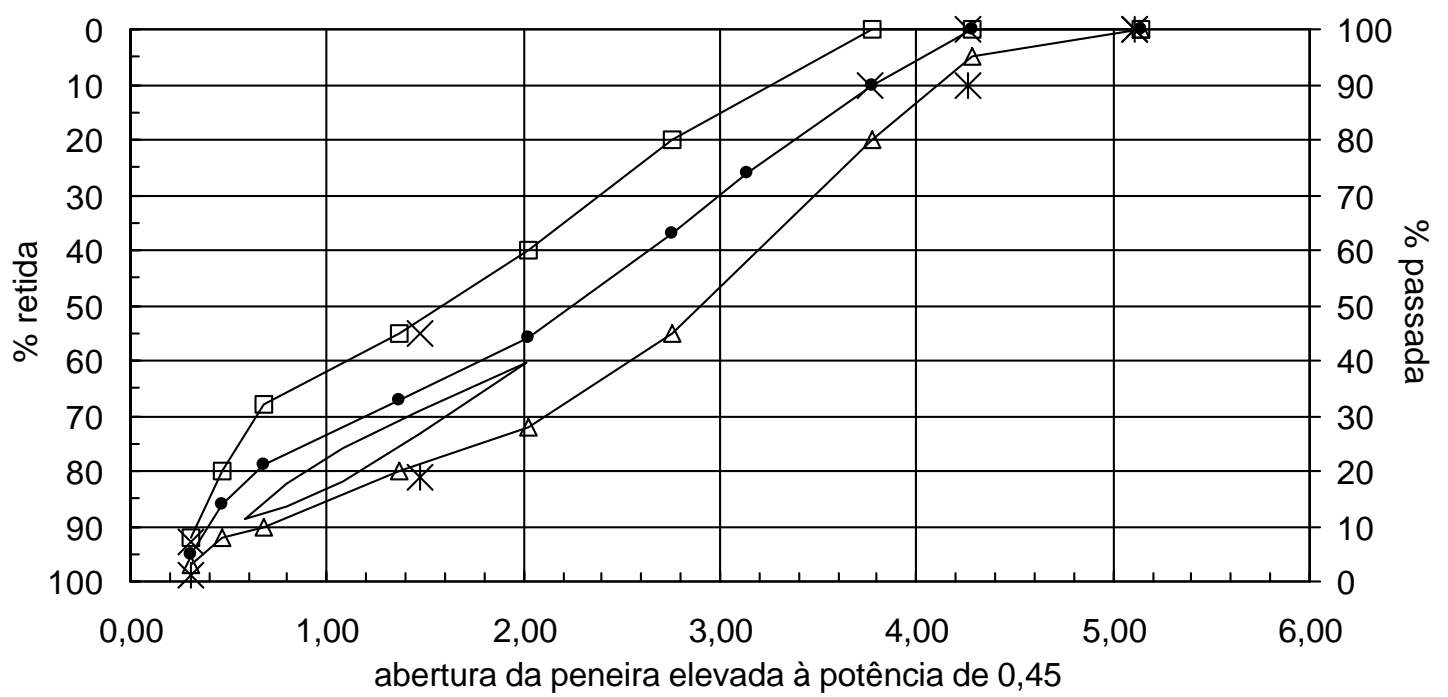

\begin{tabular}{|ll|}
\hline$\triangle$ limite inferior & $\square$ limite superior \\
$\rightarrow-$ curva adotada & zona de restrição Superpave \\
* pontos de controle Superpave - limite inferior & $\times \quad$ pontos de controle Superpave - limite superior \\
\hline
\end{tabular}

a) Curva granulométrica em diagrama de potência 0,45 (conforme especificação Superpave)

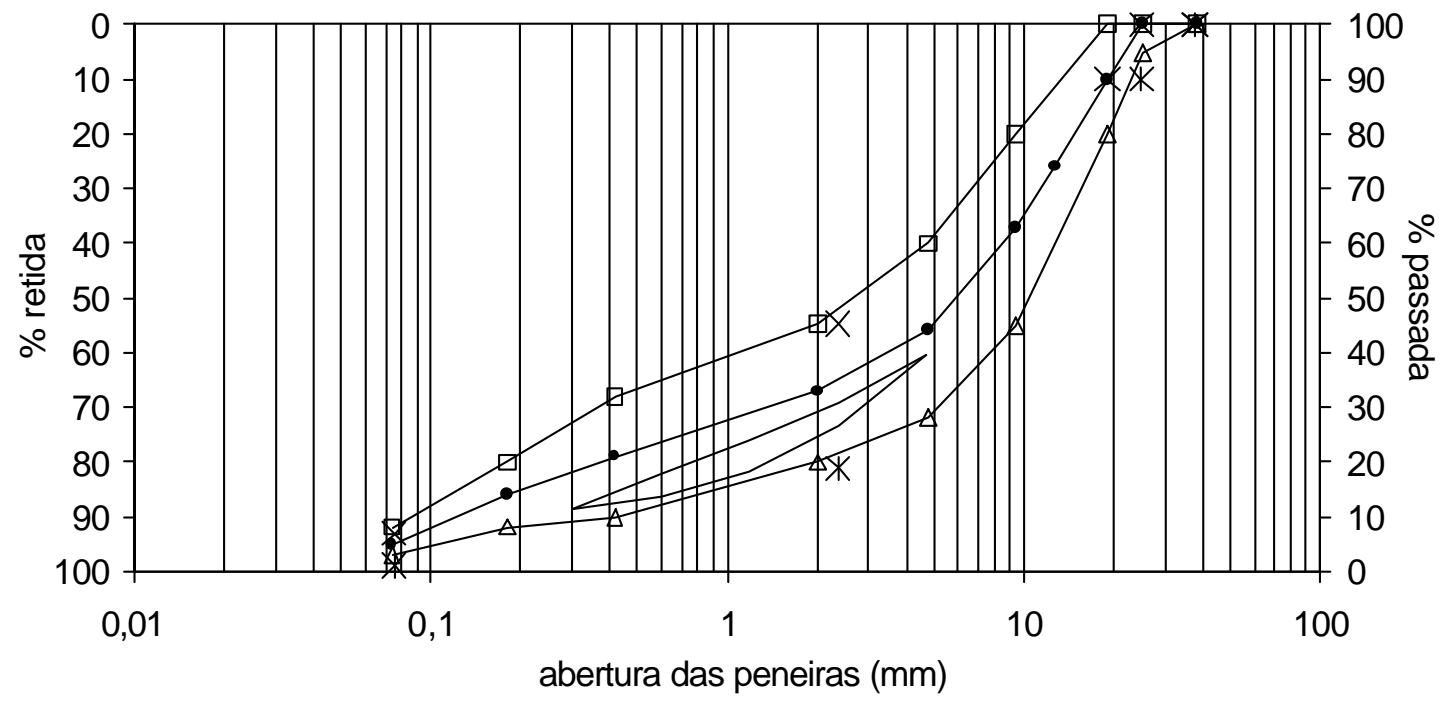

\begin{tabular}{|c|c|}
\hline $\begin{array}{l}\triangle \text { limite inferior } \\
\longrightarrow \text { c curva adotada } \\
* \text { pontos de controle Superpave - limite inferior }\end{array}$ & $\begin{array}{ll}\square & \text { limite superior } \\
& \text { zona de restrição Superpave } \\
\times & \text { pontos de controle Superpave - limite superior }\end{array}$ \\
\hline
\end{tabular}

b) Curva granulométrica em escala logarítmica

Figura 5.1 - Faixa $B$ do DNER (1997), zona de restrição Superpave para diâmetro nominal máximo de $25 \mathrm{~mm}$ e curva granulométrica adotada 


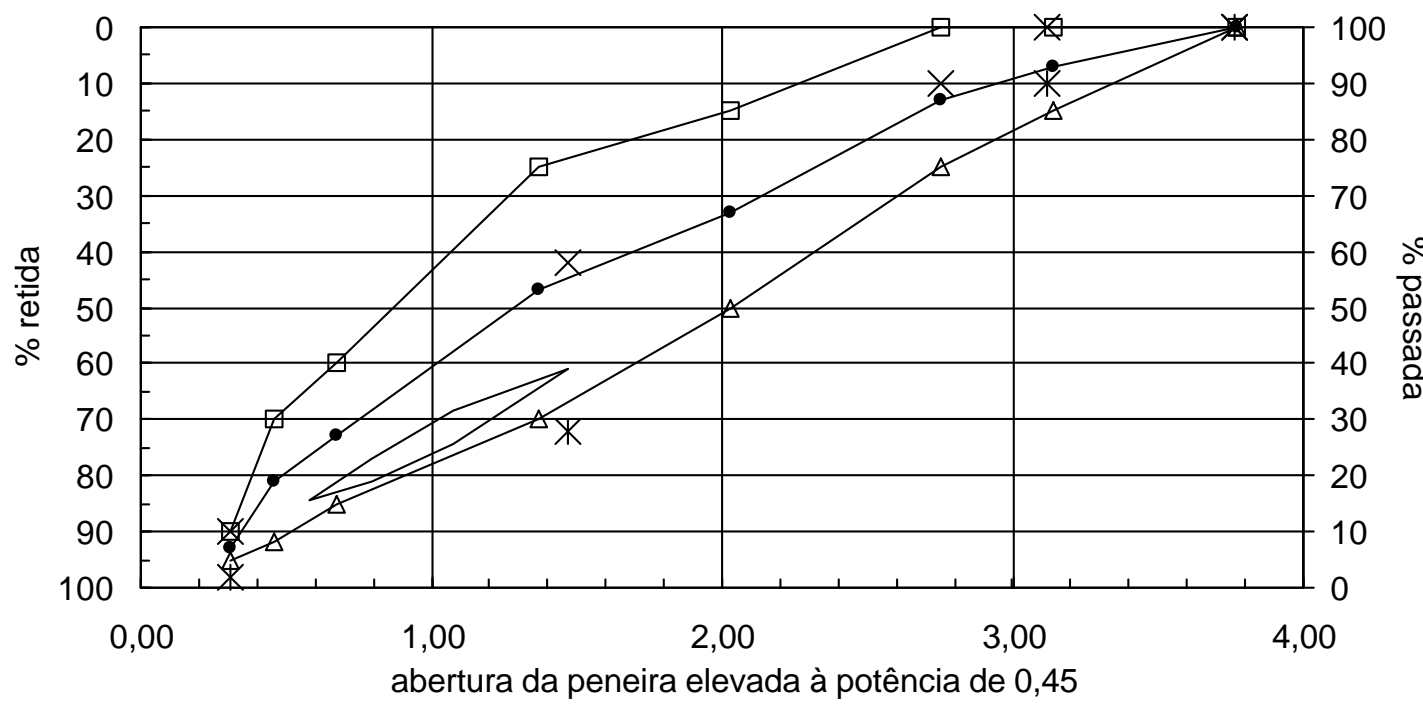

\begin{tabular}{|ll|}
\hline$\triangle$ limite inferior & $\square$ limite superior \\
$\rightarrow-$ curva adotada & zona de restrição Superpave \\
$* \quad$ pontos de controle Superpave - limite inferior & $\times \quad$ pontos de controle Superpave - limite superior \\
\hline
\end{tabular}

a) Curva granulométrica em diagrama de potência 0,45 (conforme especificação Superpave)
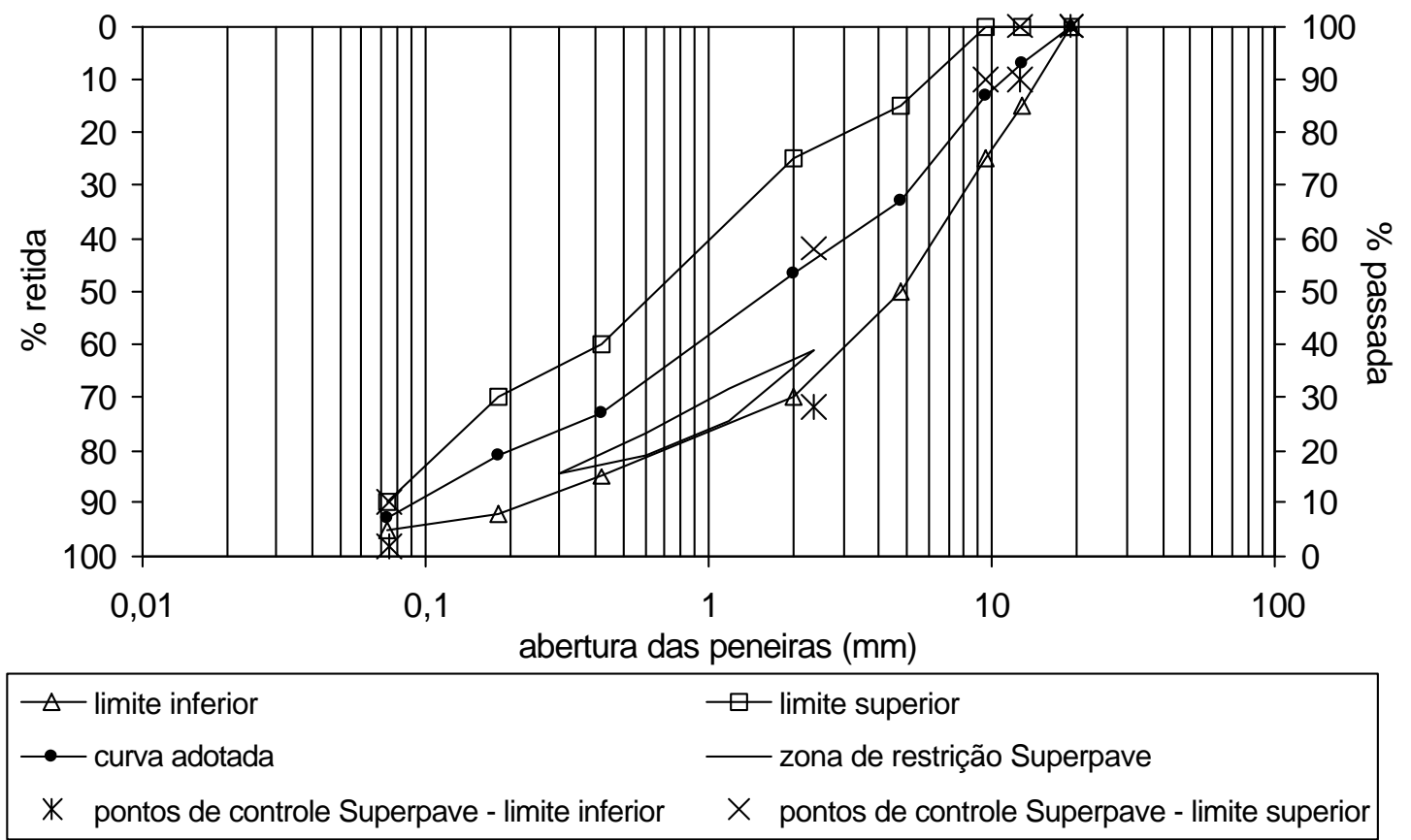

b) Curva granulométrica em escala logarítmica

Figura 5.2 - Faixa $C$ do DNER (1997), zona de restrição Superpave para diâmetro nominal máximo de 12,5 mm e curva granulométrica adotada

Adotou-se também $100 \%$ de material passando pela peneira de abertura $25,4 \mathrm{~mm}$, ao invés dos 97,5\% obtidos pela média entre os limites especificados para a faixa $B$. Essa escolha guiou-se por questões práticas de moldagem dos corpos de prova, pois caso fosse adotada a porcentagem de $97,5 \%$ de material passando pela peneira de abertura 
$25,4 \mathrm{~mm}$, ficariam retidos $2,5 \%$ de material nessa peneira, o que para um corpo de prova de $1200 \mathrm{~g}$ corresponderia a menos de $30 \mathrm{~g}$. Essa quantidade em muitos casos é inferior ao peso de cada brita retida na peneira $25,4 \mathrm{~mm}$, o que inviabilizaria a moldagem dos corpos de prova.

Deve-se observar que todo o agregado utilizado foi fornecido pela pedreira Bandeirantes, localizada na zona rural do município de São Carlos, estado de São Paulo, na estrada do $29 \mathrm{SN}$, e consiste de pedra britada, do tipo basáltico.

As curvas granulométricas adotadas correspondentes aos centros das faixas $B$ e $C$ do DNER (1997) encontram-se apresentadas na Figura 5.3.

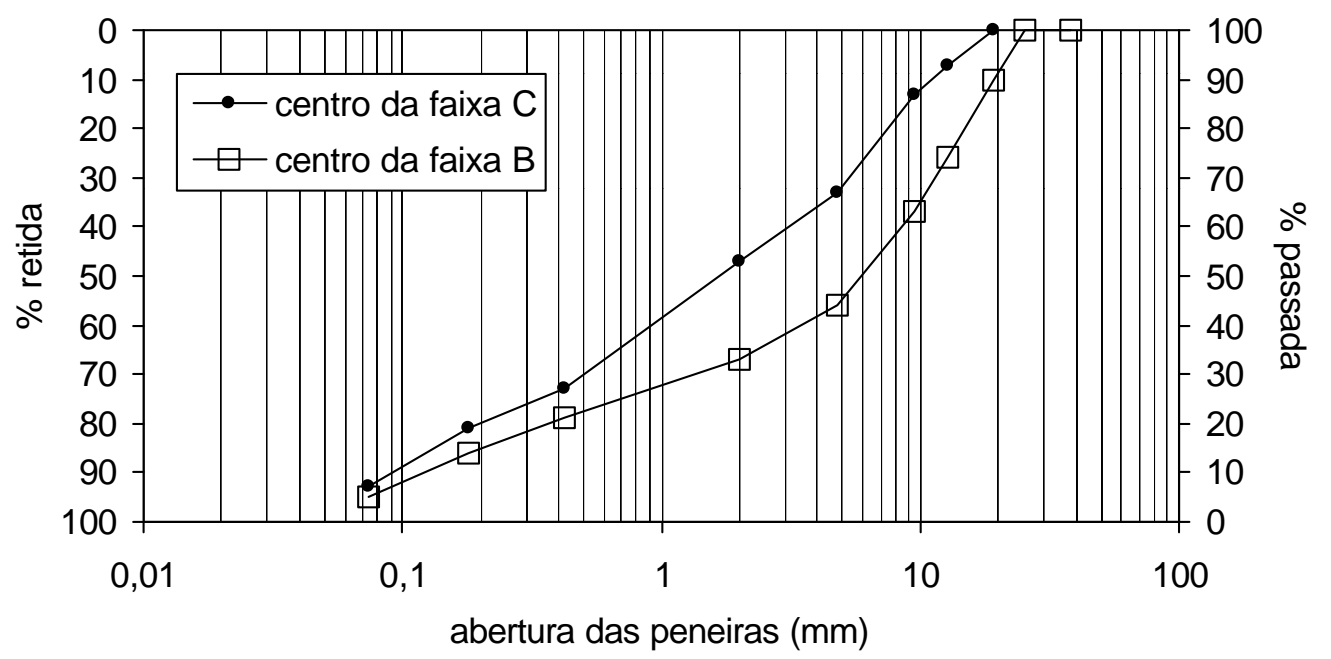

Figura 5.3 - Curvas granulométricas adotadas, correspondentes aos centros das faixas $B$ e $C$ do DNER (1997)

Como foi utilizado apenas um método de compactação e apenas uma energia de compactação, teoricamente os fatores espessura da película asfáltica e volume de vazios da mistura asfalto agregado compactada encontram-se vinculados, sendo determinados pelo teor de ligante utilizado.

De acordo com a literatura, misturas asfálticas com espessuras de película variando de 6 a $8 \mu \mathrm{m}$ apresentam desempenho mais adequado (KANDHAL e CHAKRABORTY, 1996; KANDHAL et al., 1998). Para teste dessa indicação foram adotados três teores de ligante, fornecendo três espessuras de película, a primeira próxima ao limite inferior da faixa recomendada pela literatura, a segunda correspondente ao centro da faixa e a 
terceira, próxima ao limite superior da faixa de espessura recomendada. Dessa forma foram adotados teores que fornecessem espessuras de película em torno de 6,7 e $8 \mu \mathrm{m}$.

Ainda segundo a literatura, valores de volume de vazios mais indicados variam entre $3 \%$ e 5\%, recomendando-se volumes de vazios em torno de $4 \%$. A influência do volume de vazios no desempenho de misturas asfálticas foi avaliada testando-se teores de ligante correspondentes a volumes de vazios em torno dos limites de $3 \%$ e $5 \%$, e em torno do valor médio de $4 \%$.

Os teores de ligante correspondentes aos volumes de vazios de 3\%, 4\% e 5\% foram determinados a partir de seis dosagens Marshall iniciais, correspondentes à combinação dos três tipos de asfalto com as duas distribuições granulométricas adotadas.

Foram utilizados quatro teores de asfalto, cuja escolha foi guiada pelos resultados das dosagens Marshall e pelos valores de espessura de película e volume de vazios almejados. Detalhes sobre a escolha dos teores de ligante utilizados são apresentados posteriormente nesse capítulo.

Um dos principais fatores de deterioração de misturas asfálticas é o envelhecimento, ocorrido em duas etapas distintas. Durante a fase de mistura em usina, armazenagem, transporte, espalhamento e compactação se dá o envelhecimento inicial da mistura, denominado de envelhecimento a curto prazo. Uma vez construído o pavimento, a mistura asfáltica estará exposta às condições ambientais, sofrendo o que se denomina de envelhecimento a longo prazo.

Ambos os processos de envelhecimento foram simulados em laboratório, sob condições específicas, seguindo-se as especificações da AASHTO (2001). O processo de envelhecimento a curto prazo foi avaliado coletando-se amostras da mistura asfáltica em dois momentos, logo após o processo de mistura e após um período de quatro horas de condicionamento da mistura solta em estufa de circulação de ar forçada, a $135^{\circ} \mathrm{C}$.

De acordo com os procedimentos de simulação de envelhecimento a curto prazo especificados pela AASHTO (2001), a mistura solta (não compactada) foi disposta em 
um recipiente e espalhada, formando uma camada com espessura variando entre 25 a 50 mm. A mistura foi revolvida a cada $60 \pm 5$ minutos, para que as condições de envelhecimento fossem uniformes.

O envelhecimento a longo prazo da mistura compactada foi avaliado medindo-se suas propriedades em três momentos, logo após a compactação, ou seja, sem envelhecimento; após envelhecimento acelerado em estufa de circulação de ar forçada; e após quatro meses de envelhecimento por exposição ao tempo das amostras compactadas. Os métodos de envelhecimento utilizados foram escolhidos por serem os mais viáveis perante as condições de pesquisa disponíveis.

Segundo especificações da AASHTO (2001), o envelhecimento a longo prazo acelerado foi realizado com condicionamento das amostras compactadas em estufa de circulação de ar forçada pelo período de 5 dias, a $85^{\circ} \mathrm{C}$. Esse processo simula o envelhecimento sofrido por misturas asfálticas durante 7 a 10 anos de serviço. Os corpos de prova foram compactados de acordo com o método Marshall. Após o período de envelhecimento, a estufa foi desligada e os corpos de prova permaneceram em temperatura ambiente por no mínimo $16 \pm 1 \mathrm{~h}$, antes de serem removidos.

O envelhecimento das amostras compactadas por exposição ao tempo foi realizado ao ar livre, acomodando-se os corpos de prova devidamente identificados sobre uma superfície lisa ligeiramente inclinada, para evitar o acúmulo de água. Semanalmente os corpos de prova foram invertidos e girados em $90^{\circ}$, para que os efeitos da exposição à radiação solar fossem sofridos uniformemente, em toda a superfície dos corpos de prova.

Conforme ilustrado nas Figuras 5.4 e 5.5, os corpos de prova foram colocados sobre bandejas metálicas invertidas, apoiadas em um dos lados por pedaços de madeira, para que ficassem inclinadas. Essas bandejas invertidas foram colocadas sobre a laje da caixa d'água do departamento de Transportes da EESC-USP, o que permitiu que os corpos de prova ficassem expostos aos efeitos do sol e das intempéries pelo período de quatro meses. 


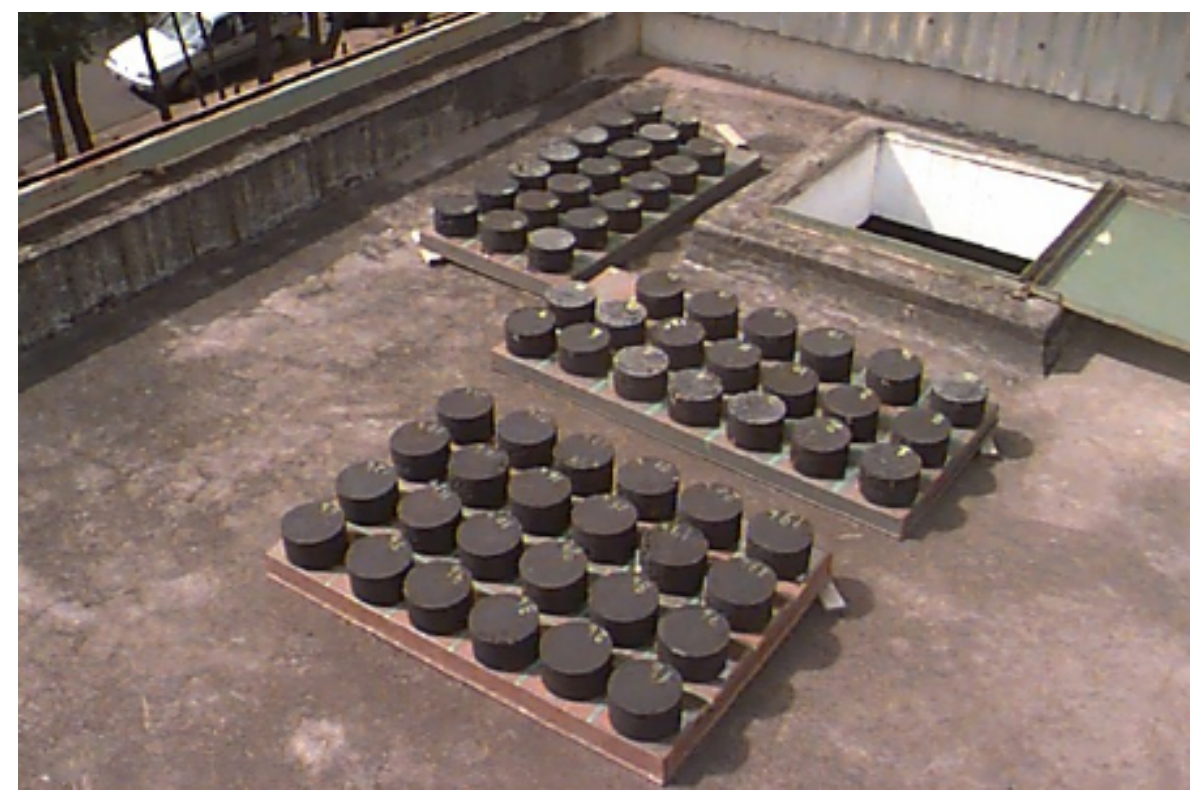

Figura 5.4 - Vista geral dos corpos de prova submetidos ao processo de envelhecimento por exposição ao tempo

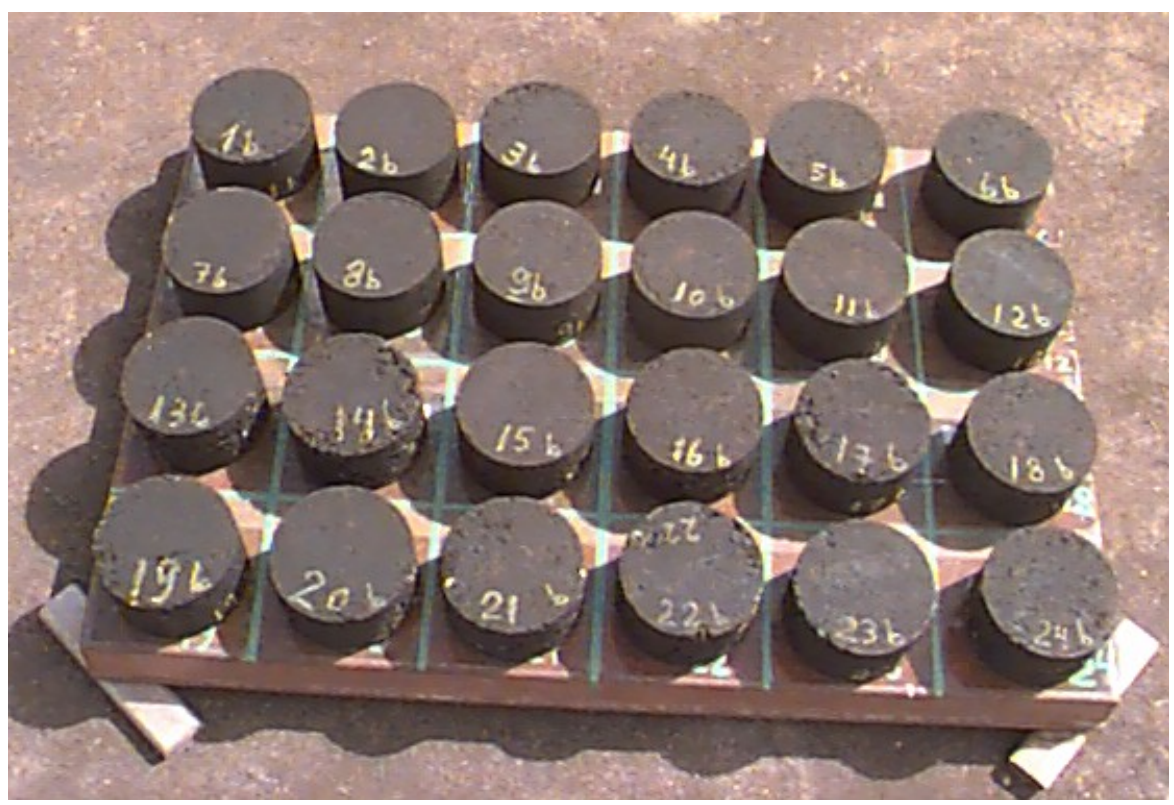

Figura 5.5 - Detalhe dos corpos de prova submetidos ao processo de envelhecimento por exposição ao tempo

Resumindo, os fatores distribuição granulométrica do agregado e período de envelhecimento a curto prazo foram testados em dois níveis. Foram utilizados quatro teores de ligante, o que significa que os fatores espessura da película asfáltica e índice de vazios foram considerados em quatro níveis. As variáveis tipo de ligante e condição de envelhecimento a longo prazo foram testadas em três níveis. Os fatores selecionados para estudo com seus respectivos níveis de ocorrência encontram-se apresentados na Tabela 5.5. 
Tabela 5.5 - Variáveis independentes ou fatores do experimento fatorial fracionário

\begin{tabular}{lcc}
\hline \multicolumn{1}{c}{ fatores } & $\begin{array}{c}\text { designação dos } \\
\text { fatores }\end{array}$ & $\begin{array}{c}\text { níveis dos } \\
\text { fatores }\end{array}$ \\
\hline teor de ligante & $A(X 1+X 2)$ & 4 \\
condição de envelhecimento a longo prazo & $B(X 3+X 4)$ & 3 \\
tipo de ligante & $C(X 5+X 6)$ & 3 \\
distribuição granulométrica & $X 7$ & 2 \\
condição de envelhecimento a curto prazo & $X 8$ & 2 \\
\hline
\end{tabular}

O número de condições experimentais para o experimento completo, ou seja, o número de combinações entre os níveis dos fatores selecionados é dado por $4 \times 3 \times 3 \times 2 \times 2=144$ condições experimentais. Moldando-se cinco corpos de prova por condição experimental, sendo um destinado ao ensaio de resistência à tração por compressão diametral, dois destinados ao ensaio de módulo de resiliência por compressão diametral dinâmica e os outros dois destinados aos ensaios de fluência por compressão uniaxial estática e dinâmica, seriam necessários 720 corpos de prova para o experimento completo, o que tornaria sua execução impraticável. Para solução desse problema optou-se por fracionar o experimento.

Deve-se observar que os ensaios de módulo de resiliência e de fluência foram realizados com três réplicas. Para que isso fosse possível com a moldagem de apenas cinco corpos de prova por condição experimental, houve reutilização de corpos de prova. Dessa forma foram submetidos ao ensaio de módulo de resiliência os dois corpos de prova moldados especialmente para tal fim e também um dos corpos de prova moldados para os ensaios de fluência. Esse último foi submetido ao ensaio de módulo de resiliência somente após ter sido submetido aos ensaios de fluência.

O mesmo esquema de reutilização de corpos de prova foi utilizado para obtenção de três réplicas para os ensaios de fluência, que foram realizados com os dois corpos de prova destinados a esse fim e também com um corpo de prova escolhido entre os dois corpos de prova destinados ao ensaio de módulo de resiliência, sendo que esse último somente foi ensaiado à fluência após já ter sido submetido ao ensaio de módulo de resiliência. 


\subsection{Montagem do experimento fatorial fracionário}

A utilização da técnica de fracionamento de experimentos permite que as respostas para as questões investigadas sejam obtidas com a realização de apenas uma fração do experimento, explorando-se a redundância existente quando são considerados muitos fatores em um experimento. Essa redundância pode estar presente no número excessivo de interações entre os fatores ou no número excessivo de fatores considerados. $\mathrm{O}$ experimento fatorial fracionário foi montado considerando-se uma fração de 1/4 do experimento completo, resultando em 36 condições experimentais a serem testadas em laboratório, que equivalem à moldagem de 180 corpos de prova, considerando-se 5 corpos de prova por condição experimental.

Como trata-se de um experimento fatorial assimétrico, com fatores ocorrendo em dois, três e quatro níveis, cada fator com mais de dois níveis de variação foi transformado em dois fatores de dois níveis, para acomodação do experimento fatorial assimétrico em um experimento fatorial em dois níveis.

A associação de níveis utilizada para transformação do fator $A$, com quatro níveis, em dois fatores de dois níveis $X 1$ e $X 2$ é apresentada na Tabela 5.6. A regra seguida para transformação do fator $B$, com três níveis de variação, em dois fatores de dois níveis $X 3$ e X4 pode ser observada na Tabela 5.7. O fator $C$, também em três níveis, foi transformado em dois fatores de dois níveis $X 5$ e $X 6$, seguindo-se a mesma regra de associação apresentada na Tabela 5.7.

Utilizando-se esse artifício de transformação de níveis de variáveis, o experimento fatorial fracionário assimétrico $1 / 44 \times 3^{2} \times 2^{2}$ foi acomodado em um experimento fatorial fracionário em dois níveis $2^{8-2}$, que apresenta como vantagem maior simplicidade de planejamento e análise.

Para montagem do experimento fatorial fracionário e escolha das 36 condições experimentais que seriam testadas em laboratório procedeu-se do seguinte modo. Inicialmente construiu-se um experimento fatorial completo com as variáveis $A, B$ e $C$, representando-se cada uma dessas variáveis por duas variáveis em dois níveis. Dessa 
forma foi construído um experimento fatorial completo em dois níveis, com as variáveis $X 1, X 2, X 3, X 4, X 5$ e $X 6$.

Tabela 5.6 - Transformação do fator $A$ com quatro níveis de variação em dois fatores de dois níveis, $X 1$ e $X 2$

\begin{tabular}{ccc}
\hline \multicolumn{2}{c}{ fatores em dois níveis } & fator em quatro níveis \\
$X 1$ & $X 2$ & $A$ \\
\hline- & - & nível 0 (faixa B $-4,0 \%$; faixa $\mathrm{C}-5,0 \%$ ) \\
+ & - & nível 1 (faixa B $-4,5 \%$; faixa C $-5,5 \%$ ) \\
- & + & nível 2 (faixa B $-5,0 \%$; faixa C $-6,0 \%$ ) \\
+ & + & nível 3 (faixa B $-5,5 \%$; faixa $\mathrm{C}-6,5 \%$ ) \\
\hline
\end{tabular}

Tabela 5.7 - Transformação do fator $B$ com três níveis de variação em dois fatores de dois níveis, $X 3$ e $X 4$

\begin{tabular}{ccl}
\multicolumn{2}{c}{ fatores em dois níveis } & \multicolumn{1}{c}{ fator em três níveis } \\
$X 3$ & $X 4$ & \multicolumn{1}{c}{$B$} \\
\hline- & - & nível 0 (sem envelhecimento) \\
+ & - & nível 1 (envelhecimento em estufa ) \\
- & + & nível 1 (envelhecimento em estufa) \\
+ & + & nível 2 (envelhecimento por exposição ao tempo) \\
\hline
\end{tabular}

Parte do arranjo do experimento fatorial completo $2^{6}$ encontra-se apresentado na Tabela 5.8, na qual foram incluídas algumas interações entre os fatores. Não foram apresentadas todas as interações por clareza de visualização. Pelo mesmo motivo não foram apresentadas as linhas correspondentes a todas as condições experimentais. Desse modo foram omitidas as linhas da Tabela 5.8 correspondentes às condições experimentais 17 a 48. Entretanto, a partir do arranjo experimental parcialmente apresentado pode-se inferir o arranjo total do experimento, integralmente apresentado no Apêndice A.

Observando-se a Tabela 5.8 pode-se notar que em virtude do artifício de transformação das variáveis de três níveis em duas variáveis de dois níveis, o número de linhas representativas das condições experimentais aumentou de 36 para 64. Entretanto as 28 linhas acrescentadas ao arranjo do experimento na verdade são réplicas. Dessa forma, o número de condições experimentais que efetivamente foram testadas em laboratório continuou sendo 36. As réplicas foram acrescentadas ao arranjo do experimento apenas com finalidade de simplificação das análises dos resultados. 
Tabela 5.8 - Representação parcial do arranjo do experimento fatorial completo $2^{6}$

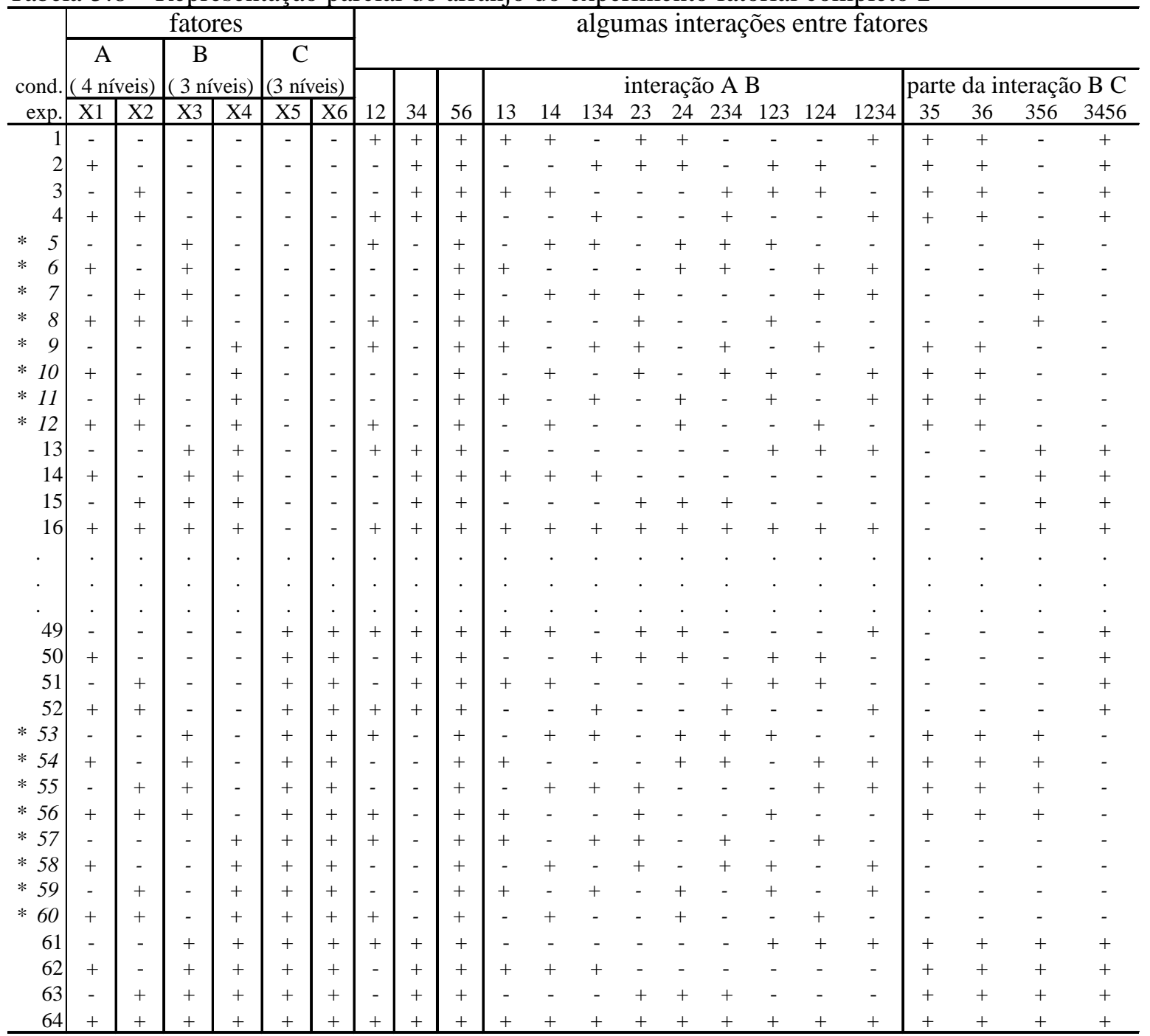

obs.: por facilidade de representação utilizou-se a notação 12 para indicar o efeito de interação entre os fatores $X 1$ e $X 2,13$ para indicar o efeito de interação entre os fatores $X 1$ e $X 3$, e assim sucessivamente.

As linhas que se encontram replicadas são relacionadas na Tabela 5.9. Algumas delas podem ser observadas na Tabela 5.8, destacadas por asteriscos. As linhas replicadas foram utilizadas apenas para cálculo dos efeitos relacionados aos fatores em três níveis $B$ e $C$, pois correspondem às condições experimentais para as quais tais fatores encontram-se em seu nível intermediário (nível 1).

Os efeitos principais dos fatores em dois e quatro níveis e os efeitos de interação entre tais fatores foram calculados com as linhas 1 a 8,13 a 20,29 a 32,49 a 56 , e 61 a 64 , ou seja, para cálculo desses efeitos não foram consideradas as linhas 21 a 24, que correspondem às condições experimentais para as quais ambos os fatores em três níveis 
encontram-se em seu nível intermediário, tampouco as linhas 9 a 12, 25 a 28, 33 a 48 e 57 a 60, que são réplicas introduzidas especificamente para cálculo dos efeitos dos fatores em três níveis.

Tabela 5.9 - Relação das linhas replicadas no arranjo experimental $2^{6}$ condições experimentais replicadas

\begin{tabular}{c|c}
\hline 5 e 9 & $23 ; 27 ; 39$ e 43 \\
6 e 10 & $24 ; 28 ; 40$ e 44 \\
7 e 11 & 29 e 45 \\
8 e 12 & 30 e 46 \\
17 e 33 & 31 e 47 \\
18 e 34 & 32 e 48 \\
19 e 35 & 53 e 57 \\
20 e 36 & 54 e 58 \\
$21 ; 25 ; 37$ e 41 & 55 e 59 \\
$22 ; 26 ; 38$ e 42 & 56 e 60 \\
\hline
\end{tabular}

Até esse ponto foi construído um experimento fatorial completo, considerando-se apenas os fatores teor de ligante (fator $A$ ), condição de envelhecimento a longo prazo (fator $B$ ) e tipo de asfalto (fator $C$ ). Os fatores distribuição granulométrica (fator $X 7$ ) e condição de envelhecimento a curto prazo (fator $X 8$ ) ainda não foram considerados no experimento.

A introdução desses fatores ao experimento será feita fazendo seus níveis coincidirem com colunas de interação entre fatores já utilizados para a montagem do experimento $2^{6}$. Para gerador do fator $X 7$ foi escolhida a coluna de interação entre os fatores $X 1, X 2, X 3$ e $X 4$, ou seja, os níveis do fator $X 7$ coincidirão com os níveis da coluna de interação entre os fatores $X 1, X 2, X 3$ e $X 4$. O fator $X 8$ terá como gerador a interação entre os fatores $X 3, X 4, X 5$ e $X 6$, ou seja, os níveis do fator $X 8$ coincidirão com os níveis da coluna de interação entre os fatores $X 3, X 4, X 5$ e $X 6$. Esses geradores foram escolhidos de modo que o experimento fatorial fracionário tivesse a maior resolução possível, considerando-se a limitação de 36 condições experimentais a serem testadas. Foi obtido dessa forma o arranjo do experimento fatorial fracionário $2^{8-2}$, parcialmente apresentado na Tabela 5.10.

Nessa tabela podem ser encontradas as colunas de sinais correspondentes aos níveis dos fatores $A, B, C, X 7$ e $X 8$, e as colunas de sinais correspondentes à interação $A C$. As demais colunas de sinais e as linhas 17 a 48 foram omitidas por motivos de facilidade de 
visualização. As linhas correspondentes ao nível intermediário das variáveis em três níveis $B$ e $C$ foram destacadas por asteriscos. O arranjo completo do experimento fatorial fracionário $2^{8-2}$ encontra-se apresentado no Apêndice A.

Tabela 5.10 - Arranjo parcial do experimento fatorial fracionário $2^{8-2}$

\begin{tabular}{|c|c|c|c|c|c|c|c|c|c|c|c|c|c|c|c|c|c|}
\hline \multirow{4}{*}{$\begin{array}{r}\text { cond. } \\
\text { exp. }\end{array}$} & \multicolumn{8}{|c|}{ fatores } & \multirow{2}{*}{\multicolumn{9}{|c|}{ interações entre fatores }} \\
\hline & \multirow{2}{*}{\multicolumn{2}{|c|}{$\begin{array}{c}\text { A } \\
\text { (4 níveis) }\end{array}$}} & \multirow{2}{*}{\multicolumn{2}{|c|}{$\begin{array}{c}\mathrm{B} \\
\text { (3 níveis) }\end{array}$}} & \multirow{2}{*}{\multicolumn{2}{|c|}{$\begin{array}{c}\mathrm{C} \\
\text { (3 níveis) }\end{array}$}} & \multirow[b]{3}{*}{$\mathrm{X} 7$} & \multirow[b]{3}{*}{$\mathrm{X} 8$} & & & & & & & & & \\
\hline & & & & & & & & & \multicolumn{9}{|c|}{ interação A C } \\
\hline & $\mathrm{X} 1$ & $\mathrm{X} 2$ & $\mathrm{X} 3$ & $\mathrm{X} 4$ & $\mathrm{X} 5$ & $\mathrm{X} 6$ & & & 15 & 16 & 156 & 25 & 26 & 256 & 125 & 126 & 1256 \\
\hline 1 & - & - & - & - & - & - & + & + & + & + & - & + & + & - & - & - & + \\
\hline 2 & + & - & - & - & - & - & - & + & - & - & + & + & + & - & + & + & - \\
\hline 3 & - & + & - & - & - & - & - & + & + & + & - & - & - & + & + & + & - \\
\hline 4 & + & + & - & - & - & - & + & + & - & - & + & - & - & + & - & - & + \\
\hline 5 & - & - & + & - & - & - & - & - & + & + & - & + & + & - & - & - & + \\
\hline$* 6$ & + & - & + & - & - & - & + & - & - & - & + & + & + & - & + & + & - \\
\hline$* 7$ & - & + & + & - & - & - & + & - & + & + & - & - & - & + & + & + & - \\
\hline * 8 & + & + & + & - & - & - & - & - & - & - & + & - & - & + & - & - & + \\
\hline$* 9$ & - & - & - & + & - & - & - & - & + & + & - & + & + & - & - & - & + \\
\hline$* 10$ & + & - & - & + & - & - & + & - & - & - & + & + & + & - & + & + & - \\
\hline$* 11$ & - & + & - & + & - & - & + & - & + & + & - & - & - & + & + & + & - \\
\hline$* 12$ & + & + & - & + & - & - & - & - & - & - & + & - & - & + & - & - & + \\
\hline 13 & - & - & + & + & - & - & + & + & + & + & - & + & + & - & - & - & + \\
\hline 14 & + & - & + & + & - & - & - & + & - & - & + & + & + & - & + & + & - \\
\hline 15 & - & + & + & + & - & - & - & + & + & + & - & - & - & + & + & + & - \\
\hline 16 & + & + & + & + & - & - & + & + & - & - & + & - & - & + & - & - & + \\
\hline & . & . & . & . & . & . & $\cdot$ & . & . & . & . & . & . & . & . & . & $\cdot$ \\
\hline & . & . & . & . & . & . & . & . & . & . & . & . & . & . & . & . & . \\
\hline & . & . & . & . & . & . & . & . & . & . & . & . & . & . & . & . & . \\
\hline 49 & - & - & - & - & + & + & + & + & - & - & - & - & - & - & + & + & + \\
\hline 50 & + & - & - & - & + & + & - & + & + & + & + & - & - & - & - & - & - \\
\hline 51 & - & + & - & - & + & + & - & + & - & - & - & + & + & + & - & - & - \\
\hline 52 & + & + & - & - & + & + & + & + & + & + & + & + & + & + & + & + & + \\
\hline$* 53$ & - & - & + & - & + & + & - & - & - & - & - & - & - & - & + & + & + \\
\hline$* 54$ & + & - & + & - & + & + & + & - & + & + & + & - & - & - & - & - & - \\
\hline$* 55$ & - & + & + & - & + & + & + & - & - & - & - & + & + & + & - & - & - \\
\hline$* 56$ & + & + & + & - & + & + & - & - & + & + & + & + & + & + & + & + & + \\
\hline$* 57$ & - & - & - & + & + & + & - & - & - & - & - & - & - & - & + & + & + \\
\hline$* 58$ & + & - & - & + & + & + & + & - & + & + & + & - & - & - & - & - & - \\
\hline$* 59$ & - & + & - & + & + & + & + & - & - & - & - & + & + & + & - & - & - \\
\hline$* 60$ & + & + & - & + & + & + & - & - & + & + & + & + & + & + & + & + & + \\
\hline 61 & - & - & + & + & + & + & + & + & - & - & - & - & - & - & + & + & + \\
\hline 62 & + & - & + & + & + & + & - & + & + & + & + & - & - & - & - & - & - \\
\hline 63 & - & + & + & + & + & + & - & + & - & - & - & + & + & + & - & - & - \\
\hline 64 & + & + & + & + & + & + & + & + & + & + & + & + & + & + & + & + & + \\
\hline
\end{tabular}

Por facilidade de representação foi eliminada a letra $X$ da designação dos fatores e de suas interações na Tabela 5.10. Dessa forma o fator $X 1$ encontra-se indicado apenas por 1, a interação entre os fatores $X 1$ e $X 5$ encontra-se indicada apenas por 15, e assim sucessivamente. 
As relações geradoras do experimento fatorial fracionário $2^{8-2}$ são

$$
\begin{aligned}
& X 7=X 1 X 2 X 3 X 4 \Rightarrow I=X 1 X 2 X 3 X 4 X 7 \\
& X 8=X 3 X 4 X 5 X 6 \Rightarrow I=X 3 X 4 X 5 X 6 X 8
\end{aligned}
$$

A relação definidora, que inclui os geradores e todas as palavras obtidas multiplicandose os geradores entre si, encontra-se apresentada na eq. (5.3).

$$
I=X 1 X 2 X 3 X 4 X 7=X 3 X 4 X 5 X 6 X 8=X 1 X 2 X 5 X 6 X 7 X 8
$$

Caso se tratasse de um experimento em dois níveis, este possuiria resolução $V$ (cinco), o que significaria que o efeito principal dos fatores seria confundido com o efeito de interação entre quatro fatores, o efeito de interação entre dois fatores seria confundido com o efeito de interação entre três fatores, e assim sucessivamente.

Entretanto, o experimento assimétrico $4 \times 3^{2} \times 2^{2}$ em questão, com relação definidora $I=A B X 7=B C X 8=A C X 7 X 8$, possui resolução $I I I$ (MASON et al., 1989), com efeitos principais confundindo-se com efeitos de interação entre dois fatores.

Como trata-se de um experimento fatorial fracionário que foi reduzido a $1 / 4$ do experimento completo, haverá acoplamento ou "confundimento" de alguns efeitos. Os padrões de acoplamento são determinados a partir da relação definidora do experimento. Para isso, todas as palavras da relação definidora devem ser multiplicadas pelo fator ou interação entre fatores cujo padrão de acoplamento se deseja determinar.

Por exemplo, os efeitos acoplados ao efeito de $A$ podem ser determinados multiplicando-se ambos os membros da relação definidora $I=A B X 7=B C X 8=A C X 7 X 8$ por $A$. Procedendo-se dessa forma obtém-se

$$
A=B X 7=A B C X 8=C X 7 X 8
$$


Os demais padrões de acoplamento podem ser obtidos de forma semelhante. $\mathrm{Na}$ Tabela 5.11 encontram-se apresentados os padrões de acoplamento para os efeitos principais dos fatores e para os efeitos de interação entre dois fatores.

Tabela 5.11 - Padrões de acoplamento para o experimento fracionário 1/4 $4 \times 3^{2} \times 2^{2}$

padrões de acoplamento

$$
\begin{array}{lc}
\mathrm{A}=\mathrm{BX} 7=\mathrm{ABCX} 8=\mathrm{CX} 7 \mathrm{X} 8 & \mathrm{AX} 8=\mathrm{BX} 7 \mathrm{X} 8=\mathrm{ABC}=\mathrm{CX} 7 \\
\mathrm{~B}=\mathrm{AX} 7=\mathrm{CX} 8=\mathrm{ABCX} 7 \mathrm{X} 8 & \mathrm{BC}=\mathrm{ACX} 7=\mathrm{X} 8=\mathrm{ABX} 7 \mathrm{X} 8 \\
\mathrm{C}=\mathrm{ABCX} 7=\mathrm{BX} 8=\mathrm{AX} 7 \mathrm{X} 8 & \mathrm{BX} 7=\mathrm{A}=\mathrm{CX} 7 \mathrm{X} 8=\mathrm{ABCX} 8 \\
\mathrm{X} 7=\mathrm{AB}=\mathrm{BCX} 7 \mathrm{X} 8=\mathrm{ACX} 8 & \mathrm{BX} 8=\mathrm{AX} 7 \mathrm{X} 8=\mathrm{C}=\mathrm{ABCX} 7 \\
\mathrm{X} 8=\mathrm{ABX} 7 \mathrm{X} 8=\mathrm{BC}=\mathrm{ACX} 7 & \mathrm{CX} 7=\mathrm{ABC}=\mathrm{BX} 7 \mathrm{X} 8=\mathrm{AX} 8 \\
\mathrm{AB}=\mathrm{X} 7=\mathrm{ACX} 8=\mathrm{BCX} 7 \mathrm{C} 8 & \mathrm{CX} 8=\mathrm{ABCX} 7 \mathrm{X} 8=\mathrm{B}=\mathrm{AX} 7 \\
\mathrm{AC}=\mathrm{BCX} 7=\mathrm{ABX} 8=\mathrm{X} 7 \times 8 & \mathrm{X} 7 \mathrm{~A} 8=\mathrm{ABX} 8=\mathrm{BCX} 7=\mathrm{AC} \\
\mathrm{AX} 7=\mathrm{B}=\mathrm{ABCX} 7 \mathrm{C} 8=\mathrm{CX} 8 &
\end{array}
$$

Apresenta-se na Tabela 5.13 um resumo dos níveis em que ocorrerão os fatores, para cada uma das 36 condições experimentais testadas. A identificação de cada condição experimental foi feita mantendo-se os números de identificação utilizados no planejamento em dois níveis. Os níveis do fator $A$, teor de ligante, variam de acordo com a faixa granulométrica correspondente à condição experimental em questão, de acordo com a Tabela 5.12.

Tabela 5.12 - Identificação dos teores de ligante de acordo com a faixa granulométrica considerada

teores de ligante para as respectivas faixas granulométricas

\begin{tabular}{ccc}
\hline $\begin{array}{c}\text { níveis da variável A } \\
\text { (teor de ligante) }\end{array}$ & centro da faixa B & centro da faixa C \\
\hline 0 & $4,0 \%$ & $5,0 \%$ \\
\hline 1 & $4,5 \%$ & $5,5 \%$ \\
\hline 2 & $5,0 \%$ & $6,0 \%$ \\
\hline 3 & $5,5 \%$ & $6,5 \%$ \\
\hline
\end{tabular}


Tabela 5.13 - Descrição das condições experimentais simuladas em laboratório

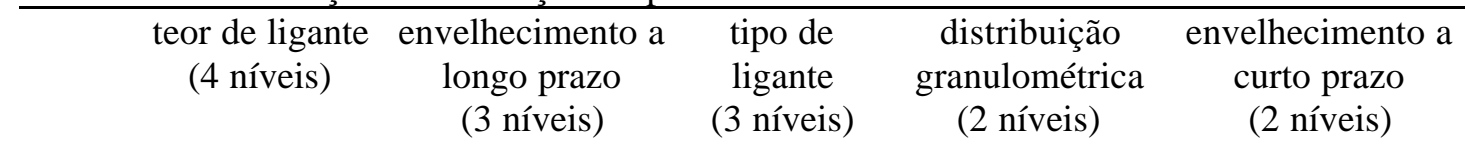

cond.

\begin{tabular}{|c|c|c|c|c|c|}
\hline exp. & A & B & $\mathrm{C}$ & $\mathrm{X} 7$ & X8 \\
\hline 1 & 0 & sem env. & conv. & $\mathrm{C}$ & 4 horas \\
\hline 2 & 1 & sem env. & conv. & B & 4 horas \\
\hline 3 & 2 & sem env. & conv. & B & 4 horas \\
\hline 4 & 3 & sem env. & conv. & $\mathrm{C}$ & 4 horas \\
\hline 5 & 0 & estufa & conv. & B & sem env. \\
\hline 6 & 1 & estufa & conv. & $\mathrm{C}$ & sem env. \\
\hline 7 & 2 & estufa & conv. & $\mathrm{C}$ & sem env. \\
\hline 8 & 3 & estufa & conv. & B & sem env. \\
\hline 13 & 0 & tempo & conv. & $\mathrm{C}$ & 4 horas \\
\hline 14 & 1 & tempo & conv. & B & 4 horas \\
\hline 15 & 2 & tempo & conv. & B & 4 horas \\
\hline 16 & 3 & tempo & conv. & $\mathrm{C}$ & 4 horas \\
\hline 17 & 0 & sem env. & pol. & $\mathrm{C}$ & sem env. \\
\hline 18 & 1 & sem env. & pol. & B & sem env. \\
\hline 19 & 2 & sem env. & pol. & B & sem env. \\
\hline 20 & 3 & sem env. & pol. & $\mathrm{C}$ & sem env. \\
\hline 21 & 0 & estufa & pol. & B & 4 horas \\
\hline 22 & 1 & estufa & pol. & $\mathrm{C}$ & 4 horas \\
\hline 23 & 2 & estufa & pol. & $\mathrm{C}$ & 4 horas \\
\hline 24 & 3 & estufa & pol. & B & 4 horas \\
\hline 29 & 0 & tempo & pol. & $\mathrm{C}$ & sem env. \\
\hline 30 & 1 & tempo & pol. & B & sem env. \\
\hline 31 & 2 & tempo & pol. & B & sem env. \\
\hline 32 & 3 & tempo & pol. & $\mathrm{C}$ & sem env. \\
\hline 49 & 0 & sem env. & bor. & $\mathrm{C}$ & 4 horas \\
\hline 50 & 1 & sem env. & bor. & B & 4 horas \\
\hline 51 & 2 & sem env. & bor. & B & 4 horas \\
\hline 52 & 3 & sem env. & bor. & $\mathrm{C}$ & 4 horas \\
\hline 53 & 0 & estufa & bor. & B & sem env. \\
\hline 54 & 1 & estufa & bor. & $\mathrm{C}$ & sem env. \\
\hline 55 & 2 & estufa & bor. & $\mathrm{C}$ & sem env. \\
\hline 56 & 3 & estufa & bor. & B & sem env. \\
\hline 61 & 0 & tempo & bor. & $\mathrm{C}$ & 4 horas \\
\hline 62 & 1 & tempo & bor. & B & 4 horas \\
\hline 63 & 2 & tempo & bor. & B & 4 horas \\
\hline 64 & 3 & tempo & bor. & $\mathrm{C}$ & 4 horas \\
\hline
\end{tabular}


A escolha da fração de $1 / 4$ do experimento fatorial $4 \times 3^{2} \times 2^{2}$ encontra-se representada na Figura 5.6, na qual as condições experimentais a serem utilizadas foram destacadas em cinza e identificadas pelos respectivos números.

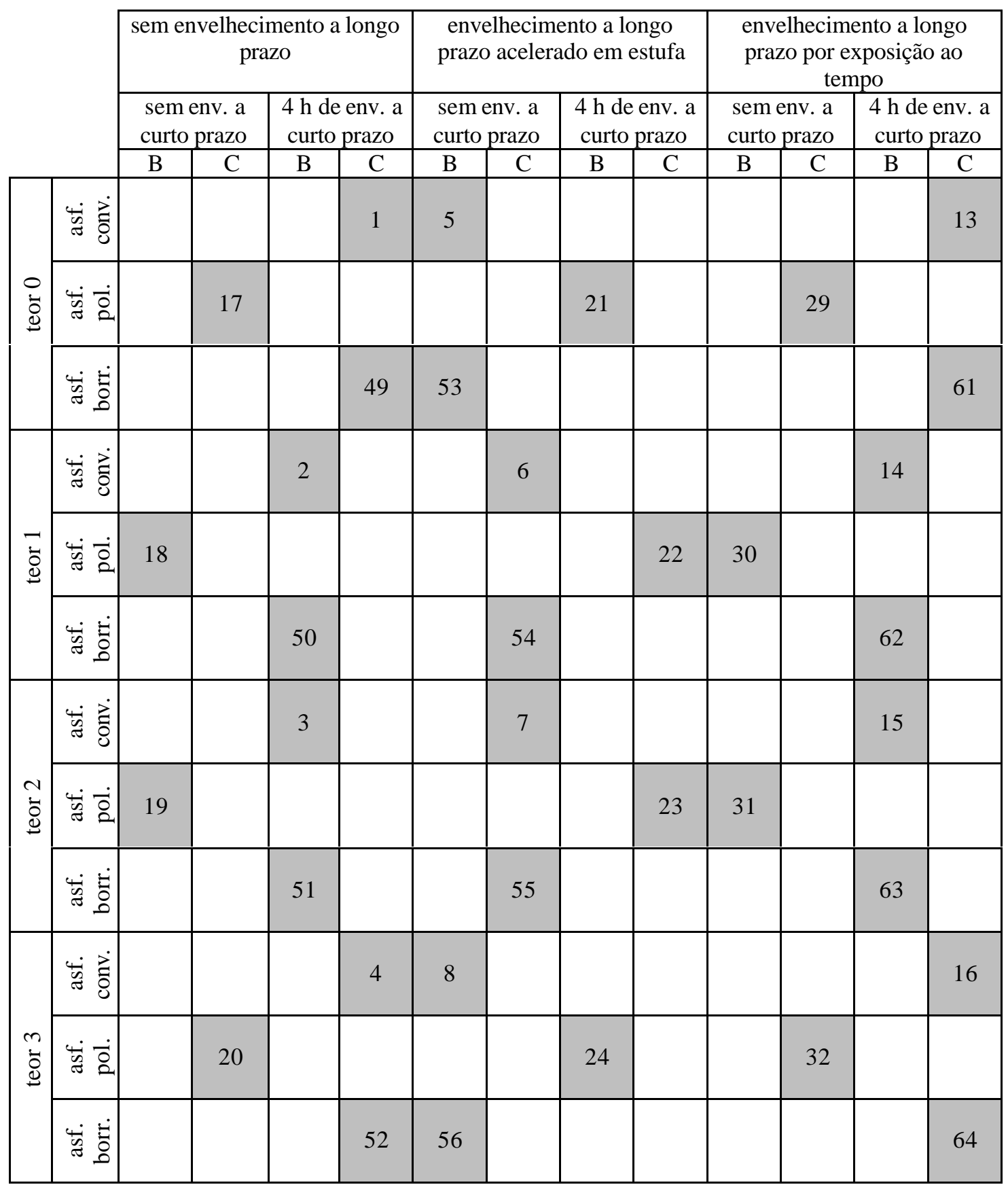

Figura 5.6-Escolha de $1 / 4$ do experimento fatorial $4 \times 3^{2} \times 2^{2}$, que corresponde à fração do experimento testada em laboratório 


\subsection{Preparação do agregado}

Inicialmente o agregado pétreo de natureza basáltica fornecido pela pedreira Bandeirantes foi colocado em bandejas e levado à estufa por no mínimo 12 horas, para secagem. Depois de seco, o agregado foi retirado da estufa e deixado em temperatura ambiente, para que resfriasse. Em seguida realizou-se o peneiramento manual do mesmo, para separação do material em faixas granulométricas, previamente definidas pelas curvas granulométricas adotadas. As seguintes aberturas de peneira foram utilizadas: $38,1 \mathrm{~mm} ; 25,4 \mathrm{~mm} ; 19,1 \mathrm{~mm} ; 12,7 \mathrm{~mm} ; 9,52 \mathrm{~mm} ; 4,76 \mathrm{~mm} ; 2,0 \mathrm{~mm}$; $0,42 \mathrm{~mm} ; 0,177 \mathrm{~mm}$ e $0,074 \mathrm{~mm}$.

O material separado foi lavado em água corrente, em peneira de malha $0,177 \mathrm{~mm}$, para remoção do pó de pedra aderido em sua superfície. Somente foram lavados os agregados com diâmetros superiores a $0,42 \mathrm{~mm}$. Em seguida o material lavado foi seco em estufa.

Uma vez realizada a separação do agregado nas peneiras especificadas, foi possível a montagem das curvas granulométricas adotadas, pesando-se a quantidade necessária de cada fração. A composição de agregados necessária para a moldagem de cada corpo de prova foi armazenada individualmente em sacos plásticos.

Os agregados foram submetidos aos ensaios de densidade real dos grãos, adesividade de agregados graúdos e miúdos ao ligante betuminoso convencional e abrasão Los Angeles.

\subsubsection{Ensaio de abrasão Los Angeles}

O ensaio de abrasão Los Angeles, que seguiu a especificação DNER-ME 35/98 (DNER, 1998), foi realizado em três graduações, B, C e D. As especificações para cada graduação são apresentadas na Tabela 5.14. 
Tabela 5.14 - Especificações do ensaio de abrasão Los Angeles para as graduações B, C e D (DNER, 1998)

\begin{tabular}{cccc}
\hline graduação & massa de material $(\mathrm{g})$ & intervalo granulométrico $(\mathrm{mm})$ & $\begin{array}{c}\text { número de esferas } \\
\text { de aço }\end{array}$ \\
\hline & $2500 \pm 50$ & $12,7<\phi<19,1$ & 11 \\
\hline $\mathrm{B}$ & $2500 \pm 50$ & $9,52<\phi<12,7$ & 8 \\
\hline $\mathrm{C}$ & $2500 \pm 50$ & $6,35<\phi<9,52$ & 6 \\
\hline $\mathrm{D}$ & $2500 \pm 50$ & $4,76<\phi<6,35$ & \\
\hline
\end{tabular}

Para cada graduação o material foi separado por peneiramento manual, pesado, colocado no tambor, juntamente com as esferas de aço correspondentes, e submetido a uma rotação de $33 \mathrm{rpm}$. Terminado o ensaio, o material foi lavado em uma peneira de 2,00 mm e colocado para secar em estufa, para posteriormente ser pesado, obtendo-se o percentual perdido por desgaste.

Foram realizados ensaios com três amostras de cada graduação. Os resultados obtidos encontram-se apresentados na Tabela 5.15, onde pode-se observar que os valores de desgaste foram sempre inferiores a $40 \%$, atendendo dessa forma à especificação do DNER, que estabelece desgaste igual ou inferior a $40 \%$.

Tabela 5.15 - Resultados do ensaio de abrasão Los Angeles

\begin{tabular}{ccccc}
\cline { 2 - 5 } graduação & \multicolumn{4}{c}{ desgaste $(\%)$} \\
amostra 1 & amostra 2 & amostra 3 & média \\
\hline B & 21,30 & 21,38 & 21,28 & 21,32 \\
C & 23,98 & 24,34 & 24,40 & 24,24 \\
D & 29,04 & 28,66 & 27,90 & 28,53 \\
\hline
\end{tabular}

\subsubsection{Densidade real dos grãos}

A massa específica dos sólidos foi determinada de acordo com as especificações DNER-ME 84/95 (DNER, 1994e), fornecendo como resultado 2,872 g/cm³.

\subsubsection{Ensaios de adesividade}

Os ensaios de adesividade do agregado graúdo ao ligante betuminoso ou ensaio RRL modificado foi realizado de acordo com a especificação DNER-ME 78/94 (DNER, 
1994c) e forneceu como resultado adesividade não satisfatória. O ensaio de adesividade do agregado miúdo ao ligante betuminoso ou ensaio de Riedel Weber foi realizado de acordo com a especificação DNER-ME 79/94 (DNER, 1994d) e forneceu como resultado adesividade má.

\subsection{Dosagens Marshall}

Os teores de ligante utilizados nessa pesquisa foram definidos com base nas espessuras de película e nos volumes de vazios almejados, sendo que os últimos foram determinados a partir do procedimento de dosagem Marshall. O ensaio Marshall foi utilizado pois, apesar de suas limitações, constitui-se ainda em um dos métodos mais utilizados no Brasil e no mundo para dosagem e controle das características físicas e mecânicas de misturas asfálticas para pavimentação (COELHO e SÓRIA, 1994).

As dosagens Marshall foram realizadas de acordo com a NBR 12891/93 (ABNT, 1993). Os corpos de prova foram moldados com o compactador Marshall, com energia de compactação de 75 golpes por face, recomendada para pressão de enchimento de pneu de 0,7 a 1,4 MPa.

A temperatura de mistura foi determinada para cada um dos ligantes utilizados, a partir da curva viscosidade $\times$ temperatura do material. Segundo as especificações DNER-ES 313/97 (DNER, 1997), o ligante deve ser aplicado a uma temperatura que corresponda à viscosidade Saybolt-Furol entre 75 e 150 segundos, recomendando-se a faixa de viscosidade entre 85 e 95 segundos. Além disso, a temperatura do ligante não deve ser inferior a $107^{\circ} \mathrm{C}$ e nem superior a $177^{\circ} \mathrm{C}$. Segundo a NBR 12891/1993 (ABNT, 1993), o ligante deve ser aplicado a uma temperatura que corresponda a $85 \pm 10 \mathrm{~s}$ de viscosidade Saybolt-Furol, faixa utilizada nas moldagens realizadas nesse trabalho.

Ainda segundo as especificações DNER-ES 313/97 (DNER, 1997), a temperatura dos agregados deve estar de $10^{\circ} \mathrm{C}$ a $15^{\circ} \mathrm{C}$ acima da temperatura do ligante. A temperatura da mistura na hora da compactação deve ser aquela na qual o ligante apresenta uma 
viscosidade Saybolt-Furol de $140 \pm 15 \mathrm{~s}$, faixa também especificada pela NBR 12891/1993 (ABNT, 1993).

Com as características dos ligantes, apresentadas nas Tabelas 5.1, 5.2 e 5.3, foram construídas as curvas viscosidade $\times$ temperatura para os ligantes convencional, modificado com $4,5 \%$ do polímero S.B.S e modificado com $20 \%$ de borracha. Essas curvas encontram-se apresentadas nas Figuras 5.7, 5.8 e 5.9, respectivamente.

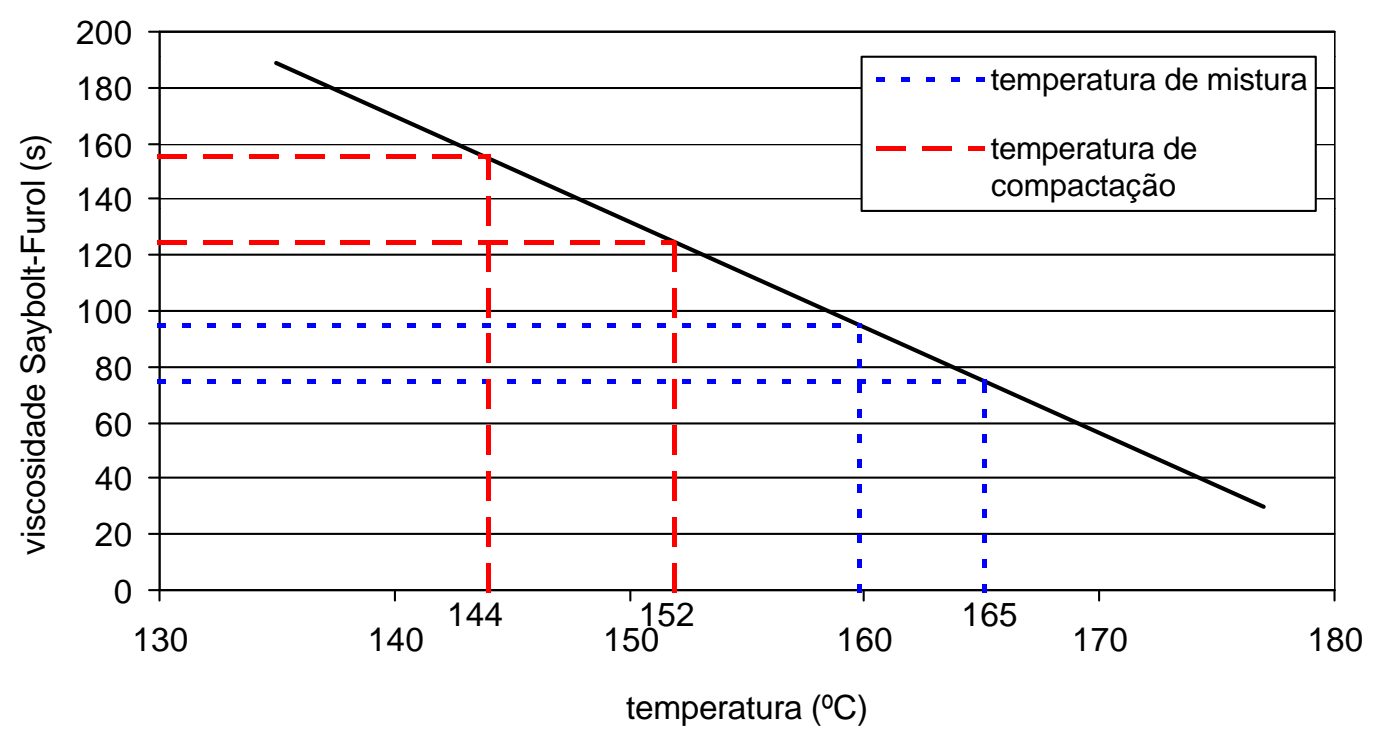

Figura 5.7 - Curva viscosidade Saybolt-Furol $\times$ temperatura para o asfalto convencional

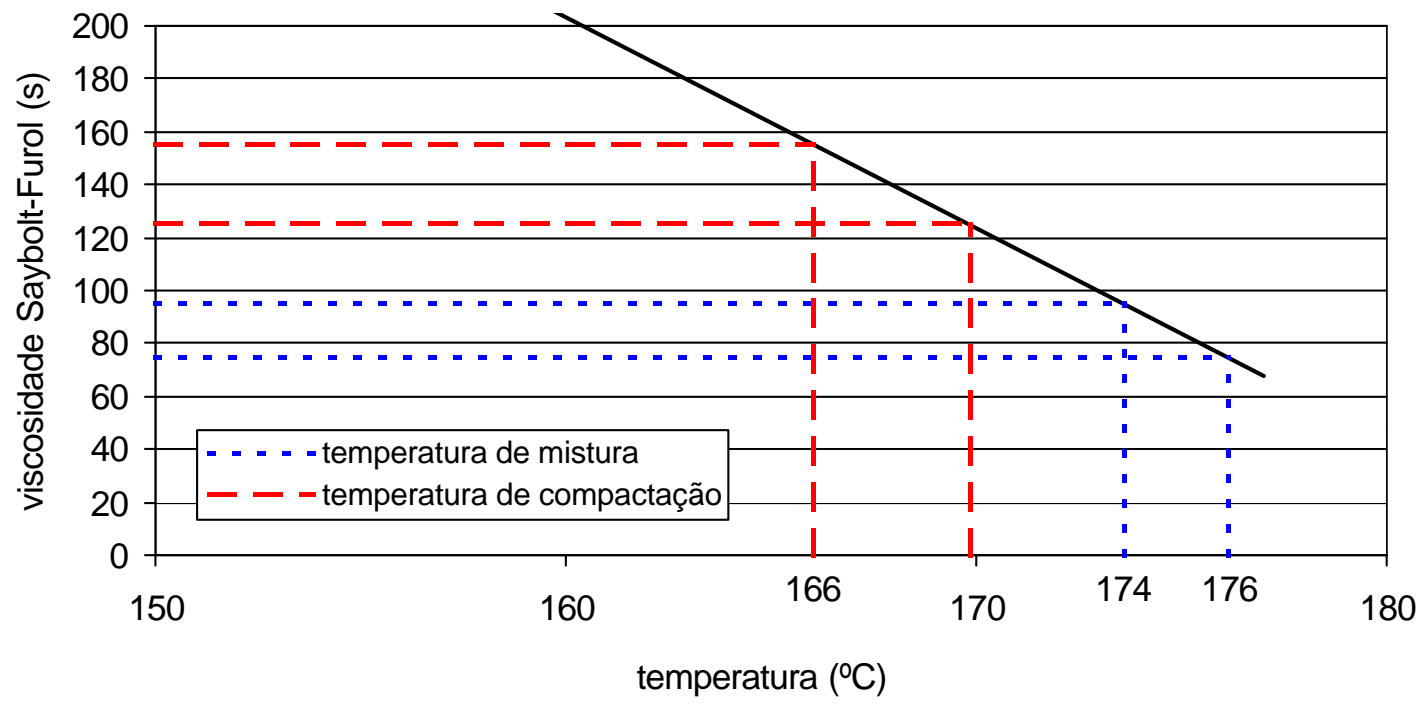

Figura 5.8 - Curva viscosidade Saybolt-Furol $\times$ temperatura para o asfalto modificado com $4,5 \%$ do polímero SBS 


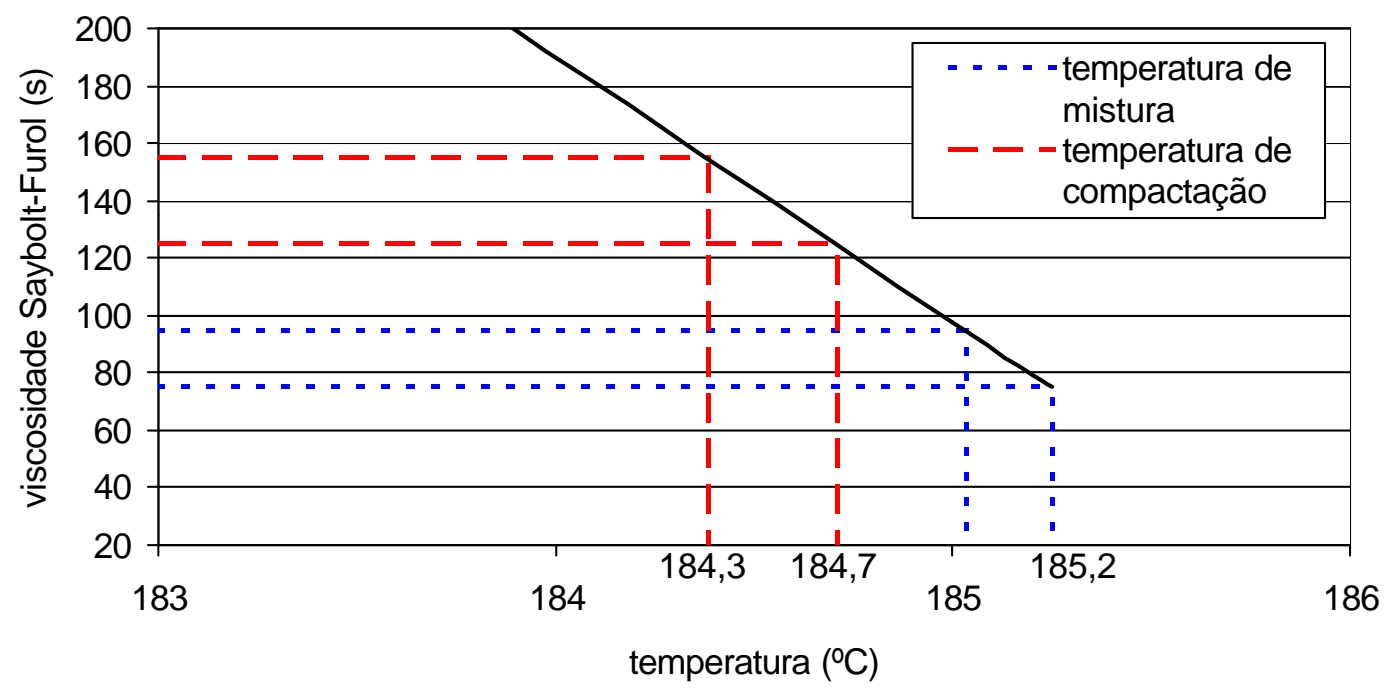

Figura 5.9 - Curva viscosidade Saybolt-Furol $\times$ temperatura para o asfalto modificado com $20 \%$ de borracha

A partir das curvas de viscosidade de cada material foram determinadas as respectivas faixas de temperatura para mistura do ligante com o agregado e de compactação dos corpos de prova. Um resumo das faixas de temperatura obtidas é apresentado na Tabela 5.16.

Tabela 5.16 - Temperaturas de mistura e compactação para o asfalto convencional e para os asfaltos modificados

\begin{tabular}{|c|c|c|}
\hline \multirow[b]{2}{*}{ ligante } & \multicolumn{2}{|c|}{ temperatura } \\
\hline & de mistura & de compactação \\
\hline asfalto convencional (CAP 20) & $160^{\circ} \mathrm{C}-165^{\circ} \mathrm{C}$ & $144^{\circ} \mathrm{C}-152^{\circ} \mathrm{C}$ \\
\hline asfalto modificado com $4,5 \%$ de SBS & $174^{\circ} \mathrm{C}-176^{\circ} \mathrm{C}$ & $166^{\circ} \mathrm{C}-170^{\circ} \mathrm{C}$ \\
\hline asfalto modificado com $20 \%$ de BRP & em torno de $185^{\circ} \mathrm{C}$ & em torno de $184,5^{\circ} \mathrm{C}$ \\
\hline
\end{tabular}

Embora haja uma especificação diferenciada para asfaltos modificados com polímero, DNER-ES 385/99 (DNER, 1999), que estabelece temperaturas de aquecimento do ligante e de compactação da mistura em função do teor de polímero no asfalto, nessa pesquisa optou-se por trabalhar em uma mesma faixa de viscosidade para os três tipos de ligante. Dessa forma as temperaturas de mistura e compactação dos asfaltos modificados foram determinadas de modo que esses atingissem as mesmas faixas de viscosidade especificadas para o asfalto convencional.

O processo de mistura do ligante com o agregado foi realizado em uma betoneira, o que tornou possível a preparação de material suficiente para a moldagem de vários corpos 
de prova simultaneamente. A quantidade de material misturada variou de 12 a 27 corpos de prova, sendo que sempre foi adicionada uma quantidade extra de material, equivalente a um ou dois corpos de prova, para compensar perdas de massa asfáltica na betoneira. $\mathrm{O}$ aquecimento da betoneira foi realizado externamente, com maçarico a gás.

Uma vez realizada a mistura, a massa asfáltica resultante foi revolvida e separada em bandejas metálicas. A quantidade de material reservada para a moldagem dos corpos de prova sem envelhecimento a curto prazo foi levada à uma estufa, onde permaneceu por 45 minutos em temperatura de compactação. Em seguida foi realizada a moldagem dos corpos de prova.

A outra parte da massa asfáltica foi envelhecida a curto prazo, permanecendo 4 horas em estufa ventilada, à $135^{\circ} \mathrm{C}$. Após esse período deu-se a transferência do material já envelhecido para uma estufa não ventilada, onde permaneceu por 45 minutos para que atingisse a temperatura especificada para a compactação.

Deve-se observar que, como foi necessário manter a mistura envelhecida a curto prazo por 45 min em estufa não ventilada, para que esta recuperasse a temperatura de compactação, seguiu-se o mesmo procedimento no caso de misturas não envelhecidas, para uniformização das condições de moldagem. Além disso, com esse procedimento conseguiu-se uma maior homogeneização da mistura.

Após a moldagem dos corpos de prova os mesmos permaneceram em seus moldes cilíndricos, em temperatura ambiente, até que resfriassem. Esse cuidado teve por objetivo evitar a deformação dos corpos de prova ao serem extraídos de seus moldes.

Através do ensaio Marshall foram obtidos o volume de vazios não preenchidos (\%), a relação betume vazio (RBV em \%), a densidade aparente $\left(\mathrm{g} / \mathrm{cm}^{3}\right)$, a estabilidade, que corresponde à carga de ruptura $(\mathrm{N})$, e a fluência, que corresponde à deformação sofrida pelo corpo de prova até a ruptura $(\mathrm{mm})$. Os resultados obtidos encontram-se apresentados no Apêndice B. 


\subsection{Definição dos teores de ligante}

Os quatro teores de ligante utilizados nessa pesquisa foram determinados por superposição dos teores correspondentes aos volumes de vazios de 3, 4 e 5\%, com os teores correspondentes às espessuras de película de 6,7 e $8 \mu \mathrm{m}$.

Os teores correspondentes aos volumes de vazios de 3, 4 e 5\% foram determinados a partir dos resultados das dosagens Marshall, apresentados no Apêndice B e resumidos na Tabela 5.17.

Tabela 5.17 - Volumes de vazios obtidos através das dosagens Marshall, realizadas para as seis misturas

\begin{tabular}{cccc} 
& \multicolumn{3}{c}{$\mathrm{Vv}(\%)$ - graduação B } \\
\cline { 2 - 4 } teor $(\%)$ & asf. conv. & mod. pol. & mod. bor. \\
\hline 4,0 & 6,93 & 6,94 & 7,16 \\
4,5 & 5,33 & 5,27 & 5,24 \\
5,0 & 3,81 & 3,74 & 3,78 \\
5,5 & 3,40 & 3,49 & 3,38 \\
6,0 & 3,23 & 3,14 & 3,28 \\
\hline \multicolumn{4}{c}{$\mathrm{Vv}(\%)$ - graduação C } \\
teor $(\%)$ & asf. conv. & mod. pol. & mod. bor. \\
\hline 4,5 & 6,26 & 6,33 & 6,95 \\
5,0 & 5,22 & 5,17 & 5,21 \\
5,5 & 3,98 & 3,92 & 4,05 \\
6,0 & 3,56 & 3,34 & 3,85 \\
6,5 & 3,04 & 2,79 & 3,74 \\
\hline
\end{tabular}

As espessuras de película foram determinadas em função dos teores de ligante, de acordo com o procedimento apresentado no Apêndice C. Os resultados obtidos encontram-se resumidos nas Tabelas 5.18 e 5.19, para as graduações B e C, respectivamente. Os cálculos foram os mesmos para os três tipos de ligante, pois as densidades dos asfaltos convencional e modificado com polímero são iguais $\left(1,024 \mathrm{~g} / \mathrm{cm}^{3}\right)$, e a densidade do asfalto modificado com borracha é muito próxima à densidade dos dois primeiros, sendo igual à $1,022 \mathrm{~g} / \mathrm{cm}^{3}$. 
Tabela 5.18 - Espessuras de película em função dos teores de ligante, para a graduação B espessura $\mid$ teor de ligante por 1 teor aproximado de película peso total da mistura de ligante

\begin{tabular}{c|l|l}
$(\mu \mathrm{m})$ & $(\%)$ & $(\%)$ \\
\hline 6 & 3,85 & 4,0 \\
7 & 4,46 & 4,5 \\
8 & 5,07 & 5,0 \\
9 & 5,67 & \\
10 & 6,26 & \\
\hline
\end{tabular}

Tabela 5.19 - Espessuras de película em função dos teores de ligante, para a graduação C espessura teor de ligante por 1 teor aproximado

\begin{tabular}{c|c|l}
$\begin{array}{c}\text { de película } \\
(\mu \mathrm{m})\end{array}$ & $\begin{array}{c}\text { peso total da mistura } \\
(\%)\end{array}$ & $\begin{array}{l}\text { de ligante } \\
(\%)\end{array}$ \\
\hline 6 & 5,21 & 5,0 \\
7 & 6,03 & 6,0 \\
8 & 6,83 & 6,5 \\
9 & 7,62 & \\
10 & 8,39 & \\
\hline
\end{tabular}

A superposição dos teores correspondentes a volumes de vazios de 3, 4 e $5 \%$ com os teores correspondentes a espessuras de película de 6, 7 e $8 \mu \mathrm{m}$ encontra-se esquematizada nas Tabelas 5.20 e 5.21, para misturas compostas por agregados das faixas B e C, respectivamente. Nessas tabelas são apresentados valores aproximados dos teores de ligante que deveriam ser utilizados para obtenção dos volumes de vazios e das espessuras de película desejados. Os teores de ligante foram obtidos considerando-se os dados referentes aos volumes de vazios dos três tipos de ligante, convencional, modificado com polímero e modificado com borracha. Entre parênteses foram apresentados os valores reais de volumes de vazios e espessuras de película para cada teor.

Tabela 5.20 - Escolha dos teores de ligante para misturas compostas por agregados da faixa B

\begin{tabular}{lcccc}
\hline volume de vazios $(\%)$ & \multicolumn{5}{c}{$5 \%$} & $4 \%$ & $3 \%$ \\
\cline { 2 - 5 } & & $(5,28 \%)$ & $(3,78 \%)$ & $(3,42 \%)$ \\
\hline espessura de película $(\mu \mathrm{m})$ & $6 \mu \mathrm{m}$ & $7 \mu \mathrm{m}$ & $8 \mu \mathrm{m}$ & - \\
& $(6,24 \mu \mathrm{m})$ & $(7,06 \mu \mathrm{m})$ & $(7,88 \mu \mathrm{m})$ & \\
\hline teor de ligante adotado $(\%)$ & $4,0 \%$ & $4,5 \%$ & $5,0 \%$ & $5,5 \%$ \\
\hline
\end{tabular}


Tabela 5.21 - Escolha dos teores de ligante para misturas compostas por agregados da faixa C

\begin{tabular}{lcccc}
\hline volume de vazios $(\%)$ & $\begin{array}{c}5 \% \\
(5,20 \%)\end{array}$ & $\begin{array}{c}4 \% \\
(3,98 \%)\end{array}$ & & $\begin{array}{c}3 \% \\
(3,19 \%)\end{array}$ \\
\hline espessura de película $(\mu \mathrm{m})$ & $6 \mu \mathrm{m}$ & - & $7 \mu \mathrm{m}$ & $8 \mu \mathrm{m}$ \\
& $(5,74 \mu \mathrm{m})$ & & $(6,97 \mu \mathrm{m})$ & $(7,59 \mu \mathrm{m})$ \\
\hline teor de ligante adotado $(\%)$ & $5,0 \%$ & $5,5 \%$ & $6,0 \%$ & $6,5 \%$ \\
\hline
\end{tabular}

\subsection{Verificação das modificações sofridas pelo asfalto envelhecido}

A verificação das modificações sofridas pelo ligante das misturas asfálticas envelhecidas foi feita indiretamente através dos ensaios creep estático e dinâmico, resistência à tração por compressão diametral e módulo de resiliência por compressão diametral dinâmica.

Além dos ensaios para avaliação das propriedades mecânicas dos concretos asfálticos, o ideal seria analisar as conseqüências do envelhecimento realizando-se também medidas das propriedades físicas do ligante antes e após os períodos de envelhecimento considerados, através da realização de ensaios de viscosidade, penetração, ponto de amolecimento e ductilidade. Para tanto seriam necessários testes realizados diretamente com o ligante, que deveria ser extraído e recuperado das misturas asfálticas.

O processo de extração poderia ser facilmente realizado fazendo-se uso de um solvente, e a recuperação do asfalto diluído nesse solvente aparentemente deveria ser um processo de fácil execução por evaporação do solvente volátil, uma vez que em casos normais existe uma grande diferença entre os pontos de ebulição do solvente e do asfalto. Entretanto esse processo não é tão simples quanto poderia parecer.

Dentre os problemas encontrados no processo de extração e recuperação de asfaltos destacam-se:

- $\quad$ extração incompleta e não-uniforme do asfalto aderido ao agregado;

- $\quad$ envelhecimento do asfalto devido ao contato deste com o solvente; 
- permanência de solvente residual no asfalto recuperado, distorcendo as propriedades físicas do ligante a serem medidas;

- $\quad$ perda de voláteis durante o processo de recuperação.

Processos de extração e recuperação do asfalto somente teriam significado se o asfalto recuperado apresentasse as mesmas propriedades físicas que apresentaria caso não houvesse passado por tais processos. Por exemplo, quando se pretendem avaliar as condições do ligante de um pavimento em serviço, o asfalto recuperado de uma amostra do pavimento deve apresentar propriedades físicas, como viscosidade, muito próximas das propriedades físicas do ligante in situ. Isso é essencial para que os testes realizados com o ligante tenham significado com respeito ao desempenho do pavimento. Entretanto os métodos em uso de extração e recuperação de asfalto mostram-se pouco precisos e ineficazes.

Tendo em vista as dificuldades relatadas no item 3.6 do Capítulo 3, para execução dos processos de extração e recuperação do ligante asfáltico, optou-se pela avaliação indireta de seu envelhecimento, através de ensaios realizados com o concreto asfáltico, medindo-se suas propriedades mecânicas.

\subsection{Ensaios realizados}

As propriedades mecânicas dos concretos asfálticos obtidos a partir de misturas preparadas a quente foram medidas através dos ensaios de fluência por compressão uniaxial (creep test) estática e dinâmica, resistência à tração por compressão diametral e módulo de resiliência por compressão diametral dinâmica, todos realizados com corpos de prova moldados pelo método Marshall.

\subsubsection{Ensaio de fluência por compressão uniaxial estática (creep estático)}

O ensaio de fluência por compressão uniaxial estática consistiu na aplicação contínua de uma carga de compressão estática em corpos de prova cilíndricos, moldados pelo 
método Marshall. $\mathrm{O}$ ensaio foi realizado a $40^{\circ} \mathrm{C}$ e teve a duração de 1 hora mais 15 minutos de recuperação.

A carga de compressão de 0,4 MPa, recomendada por Little et al. (1993) por representar a tensão média no centro de uma camada asfáltica de pavimentos em serviço, foi aplicada através de uma prensa pneumática, apresentada na Figura 5.10. A carga aplicada e os deslocamentos axiais sofridos pelo corpo de prova foram medidos e registrados eletronicamente por dois medidores tipo LVDT (linear variable differential transducers). O deslocamento axial sofrido pelo corpo de prova foi calculado pela média aritmética das leituras dos dois LVDT's. Uma visão geral da aparelhagem utilizada no ensaio é apresentada na Figura 5.11, onde podem ser observados a prensa pneumática colocada no interior de uma caixa de madeira utilizada para controle da temperatura de ensaio, os indicadores digitais de deslocamento e tensão e o computador utilizado para controle do ensaio.

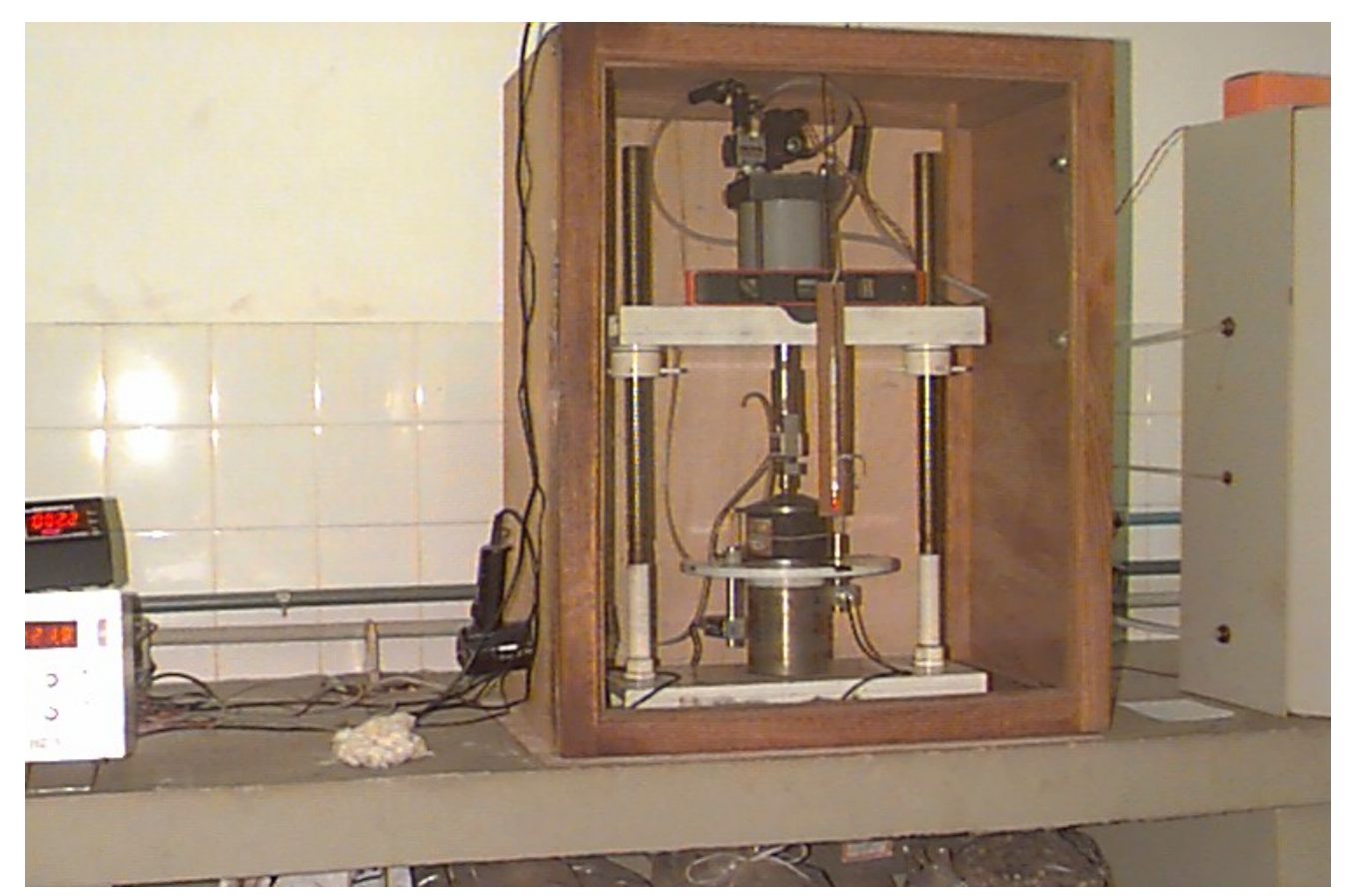

Figura 5.10 - Prensa pneumática utilizada nos ensaios de fluência por compressão uniaxial estática 


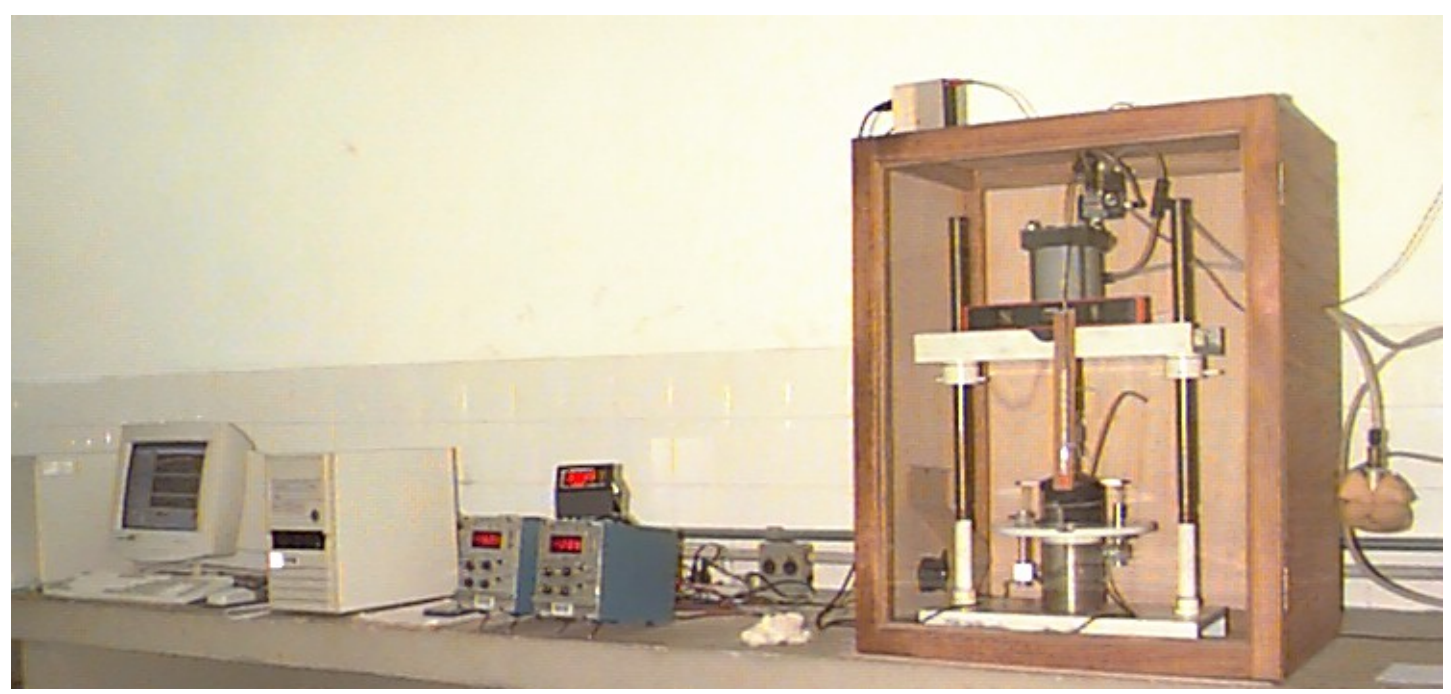

Figura 5.11 - Visão geral da aparelhagem utilizada no ensaio de fluência por compressão uniaxial estática

Os ensaios foram gerenciados por um programa computacional desenvolvido em LabView. Com esse programa foi realizado o controle da prensa pneumática e foram feitas as leituras, ao longo do tempo, dos deslocamentos axiais, por intermédio dos dois LVDT's, e da carga aplicada, através da célula de carga. Os dados foram gravados em disco, em formato texto. Um exemplo da tela do programa, ao final de um ensaio de fluência por compressão uniaxial estática, é apresentado na Figura 5.12, onde podem ser observadas as curvas de fluência obtidas pelos registros de deslocamentos axiais feitos pelos dois LVDT`s e a variação da carga aplicada ao longo do ensaio.

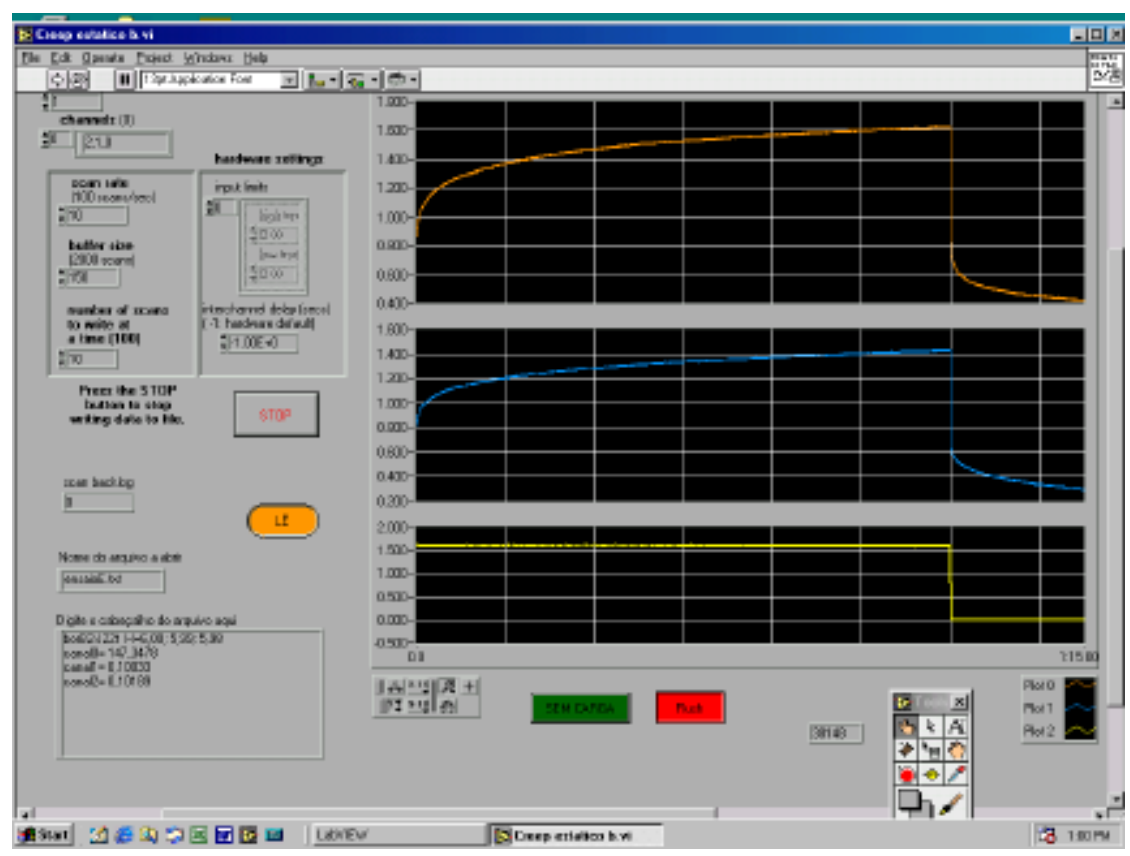

Figura 5.12 - Exemplo da tela do programa computacional desenvolvido em LabView, obtida ao final do ensaio de creep estático 
Para realização dos ensaios, inicialmente os corpos de prova tiveram suas faces lixadas, para regularização da superfície de aplicação de carga. Foram então revestidos com um filme plástico e levados a uma estufa com temperatura regulada em $40^{\circ} \mathrm{C}$, onde permaneceram por no mínimo 10 horas, para que na ocasião do ensaio a temperatura estivesse estabilizada e fosse homogênea em todo o corpo de prova, inclusive em seu interior. Antes de ser ensaiado, cada corpo de prova foi desembrulhado e teve suas faces lubrificadas com vaselina.

O pré-condicionamento do corpo de prova foi realizado com aplicação da carga de ensaio por 5 minutos, seguida por um período de descanso ou recuperação, também de 5 minutos. Em seguida realizou-se o ensaio, com aplicação da carga de ensaio por 60 minutos, seguida por um período de recuperação de 15 minutos.

As deslocamentos axiais sofridos pelo corpo de prova são medidos durante todo o ensaio, incluindo o período de recuperação. Com os resultados obtidos podem ser traçadas as curvas de fluência do material, ou curvas de deformação axial em função do tempo.

\subsubsection{Ensaio de fluência por compressão uniaxial dinâmica (creep dinâmico)}

O ensaio de fluência por compressão uniaxial dinâmica consistiu na aplicação repetitiva de cargas de compressão de curta duração em corpos de prova cilíndricos, moldados pelo método Marshall. Foram aplicados 5000 ciclos de carregamento, cada ciclo com duração de $1 \mathrm{~s}$, sendo $0,1 \mathrm{~s}$ de aplicação de carga e $0,9 \mathrm{~s}$ de recuperação. A carga utilizada foi de $0,4 \mathrm{MPa}$. $\mathrm{O}$ ensaio foi realizado a $40^{\circ} \mathrm{C}$. Antes de serem ensaiados, os corpos de prova passaram por uma fase de pré-condicionamento, na qual foram aplicados 200 ciclos de carregamento, com a mesma carga e a mesma temperatura utilizadas no ensaio.

A aparelhagem de ensaio, a forma de aquisição dos dados e a preparação dos corpos de prova, incluindo o condicionamento térmico dos mesmos por no mínimo 10 horas à 
$40^{\circ} \mathrm{C}$, foram realizados conforme descrição apresentada no item anterior, para o ensaio de creep estático.

Um exemplo da tela do programa computacional em LabView, obtida ao final do ensaio de creep dinâmico, é apresentado na Figura 5.13, onde podem ser observadas as duas curvas do deslocamento axial sofrido pelo corpo de prova ao longo do tempo, e a curva de variação do carregamento aplicado ao longo do ensaio. Um detalhe dessas curvas é apresentado na Figura 5.14. Na Figura 5.15 é apresentado em detalhe um ciclo de carregamento.

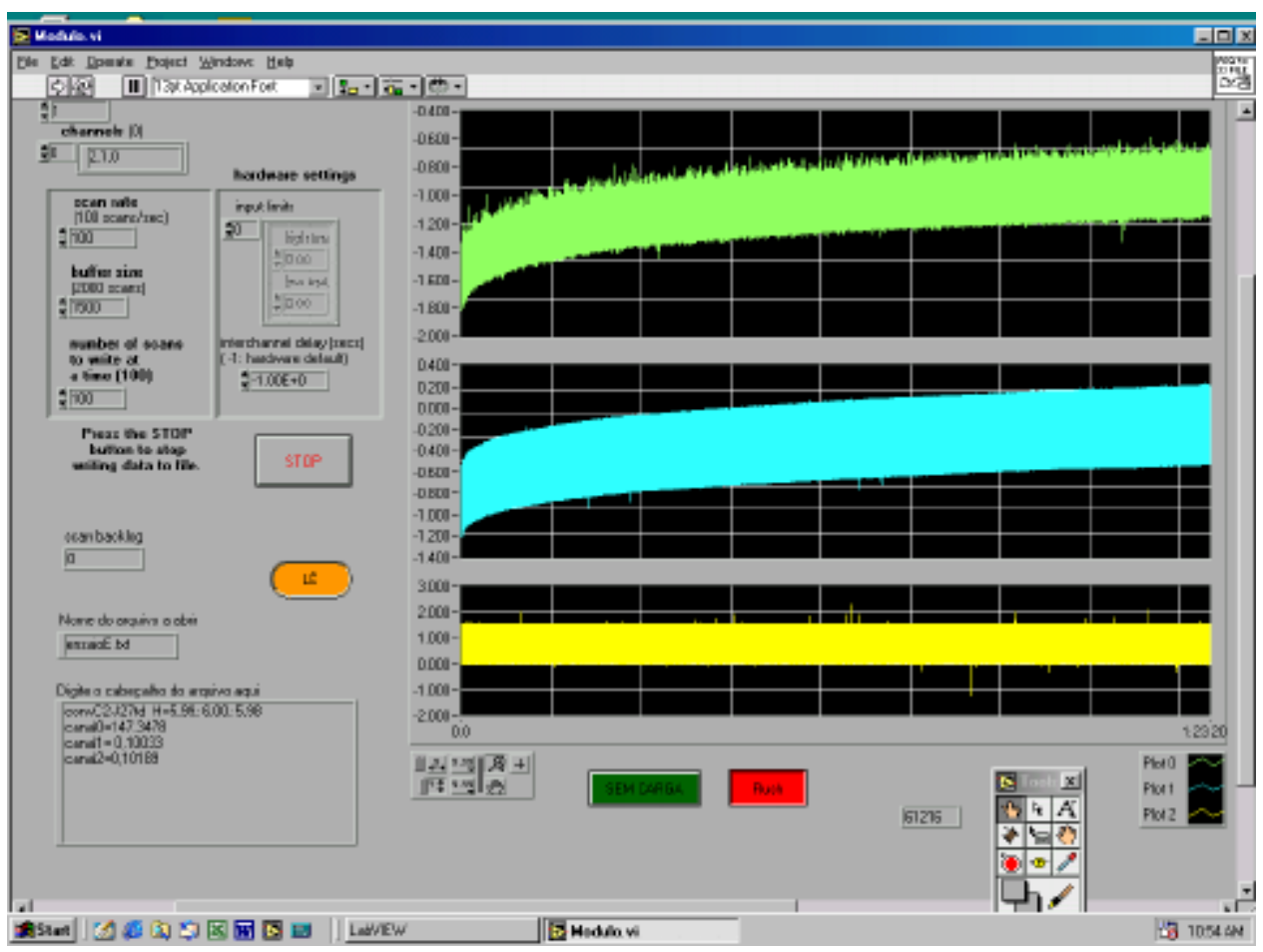

Figura 5.13 - Exemplo da tela do programa computacional desenvolvido em LabView, obtida ao final do ensaio de creep dinâmico 


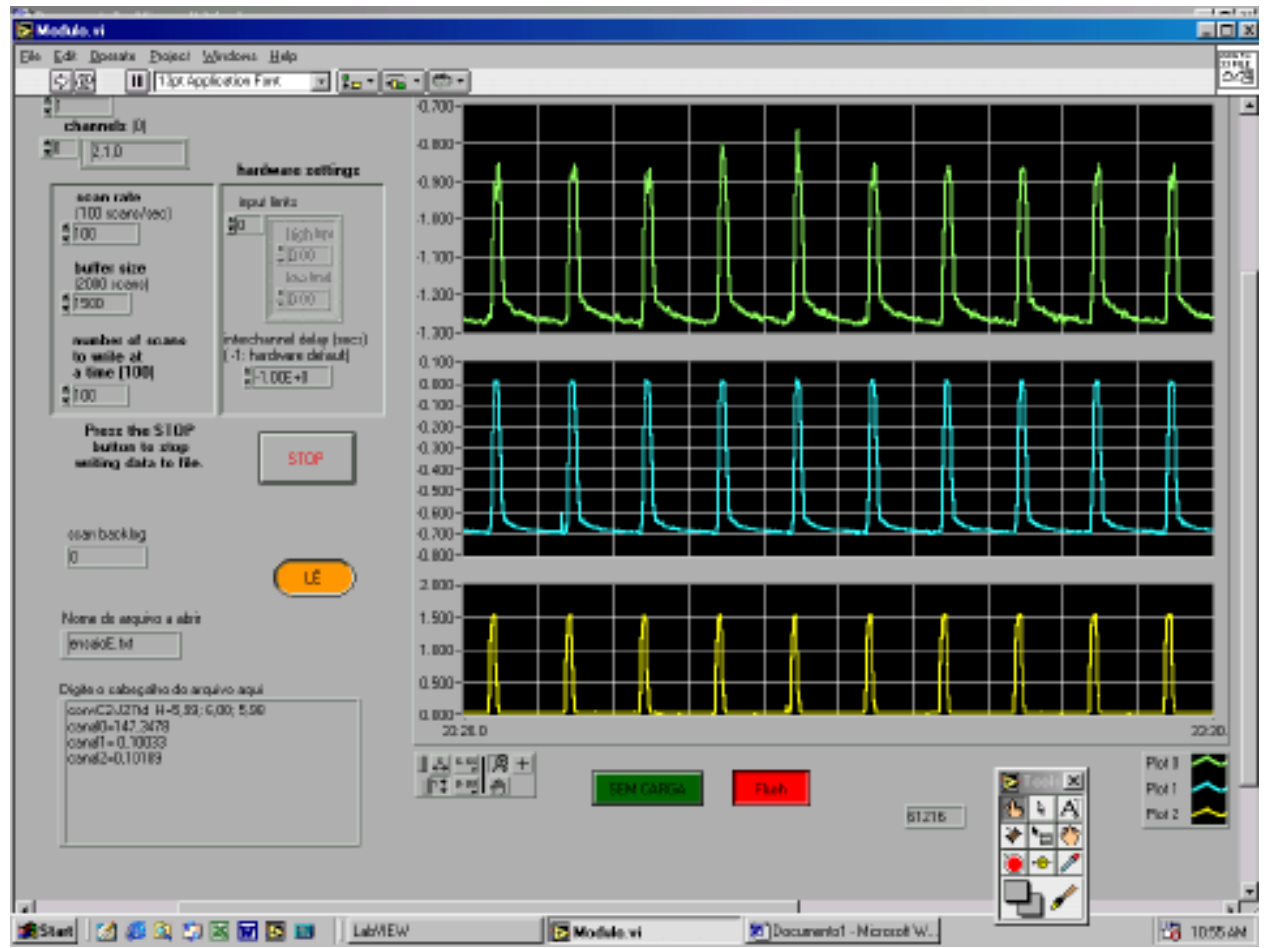

Figura 5.14 - Detalhe dos ciclos de carregamento aplicados no ensaio de creep dinâmico

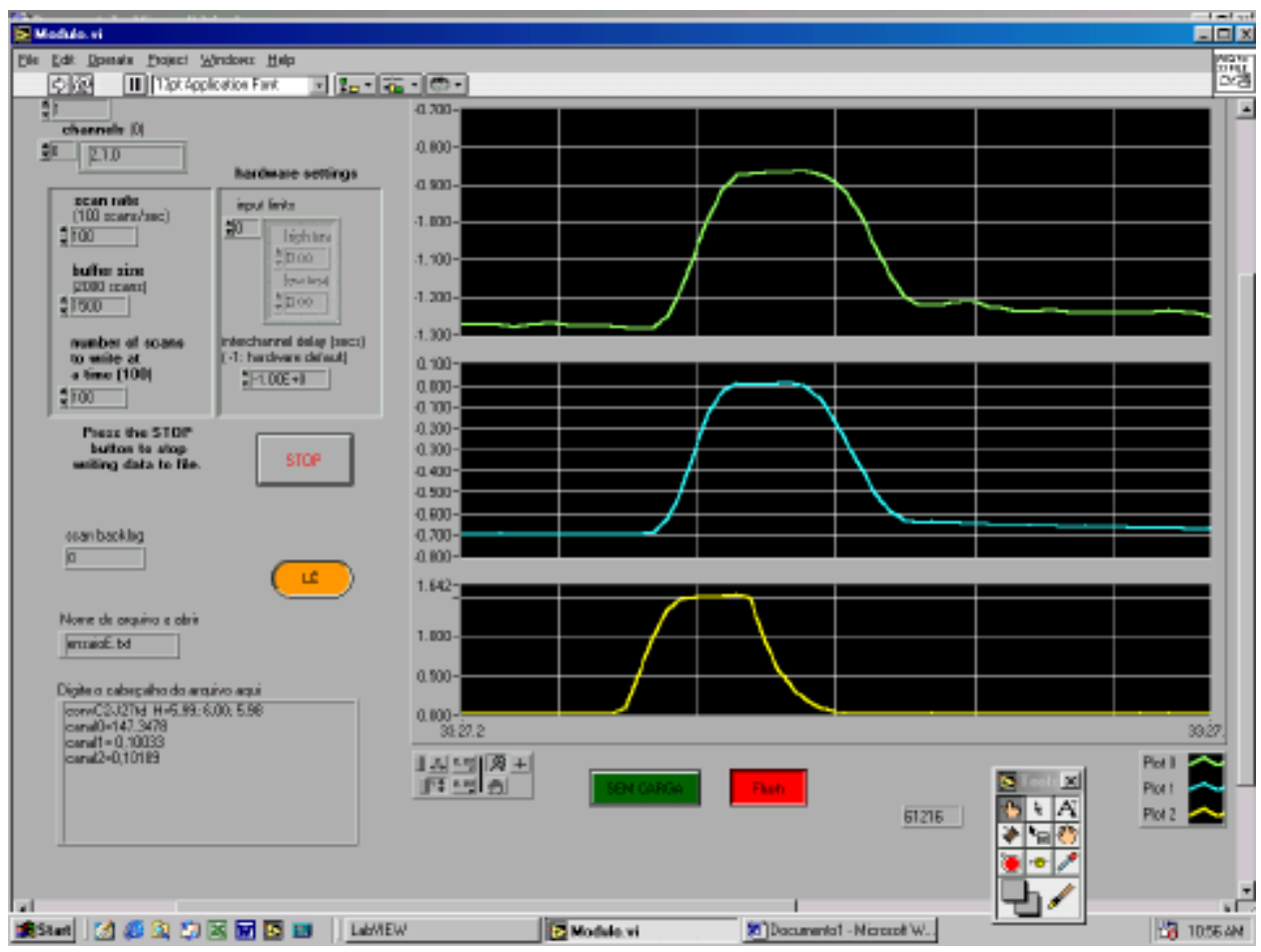

Figura 5.15 - Detalhe de um ciclo de carregamento do ensaio de creep dinâmico 


\subsubsection{Ensaio de módulo de resiliência por compressão diametral dinâmica}

O módulo de resiliência das misturas asfálticas foi obtido através do ensaio de compressão diametral dinâmica, ou ensaio de tração indireta, realizado de acordo com o método de ensaio DNER-ME 138/94 (DNER, 1994a). Os valores de módulo foram calculados por

$$
M R=\frac{F}{100 \Delta H}(0,9976 \mu+0,2692)
$$

Onde

- MR é o módulo de resiliência, em MPa;

- F é a carga vertical repetida aplicada diametralmente ao corpo de prova, em $\mathrm{N}$;

- $\Delta$ é o deslocamento (correspondente à deformação elástica ou resiliente sofrida pelo corpo de prova, em direção perpendicular à aplicação da carga), em cm;

- H é a altura do corpo de prova, em cm;

$-\mu$ é o coeficiente de Poisson.

Foi adotado um coeficiente de Poisson de 0,35.

A norma da AASHTO (1994) para determinação do módulo de resiliência de misturas asfálticas (AASHTO TP31-94) menciona dois tipos de módulo de resiliência, o módulo de resiliência total (MR total) e o módulo de resiliência instantâneo (MR inst.), ambos determinados com base na curva deformação versus tempo de cada ciclo de carregamento, esquematizada na Figura 5.16.

O módulo de resiliência instantâneo é calculado com a deformação recuperada instantaneamente na fase de descarregamento do ciclo, não incluindo a deformação recuperada durante o período de descanso ou recuperação, ou seja, período em que a deformação é recuperada ao longo do tempo. Essa deformação, denominada deformação instantânea $\left(\Delta_{\text {inst. }}\right)$, é dada pela diferença entre a deformação máxima atingida pelo corpo de prova no referido ciclo e a deformação na base do trecho de descarregamento da curva de deformação. O ponto da curva no qual essa última deformação é 
considerada é determinado gerando-se uma linha vertical a partir da interseção de duas retas de regressão e estendendo-a até que intercepte a curva de deformação.

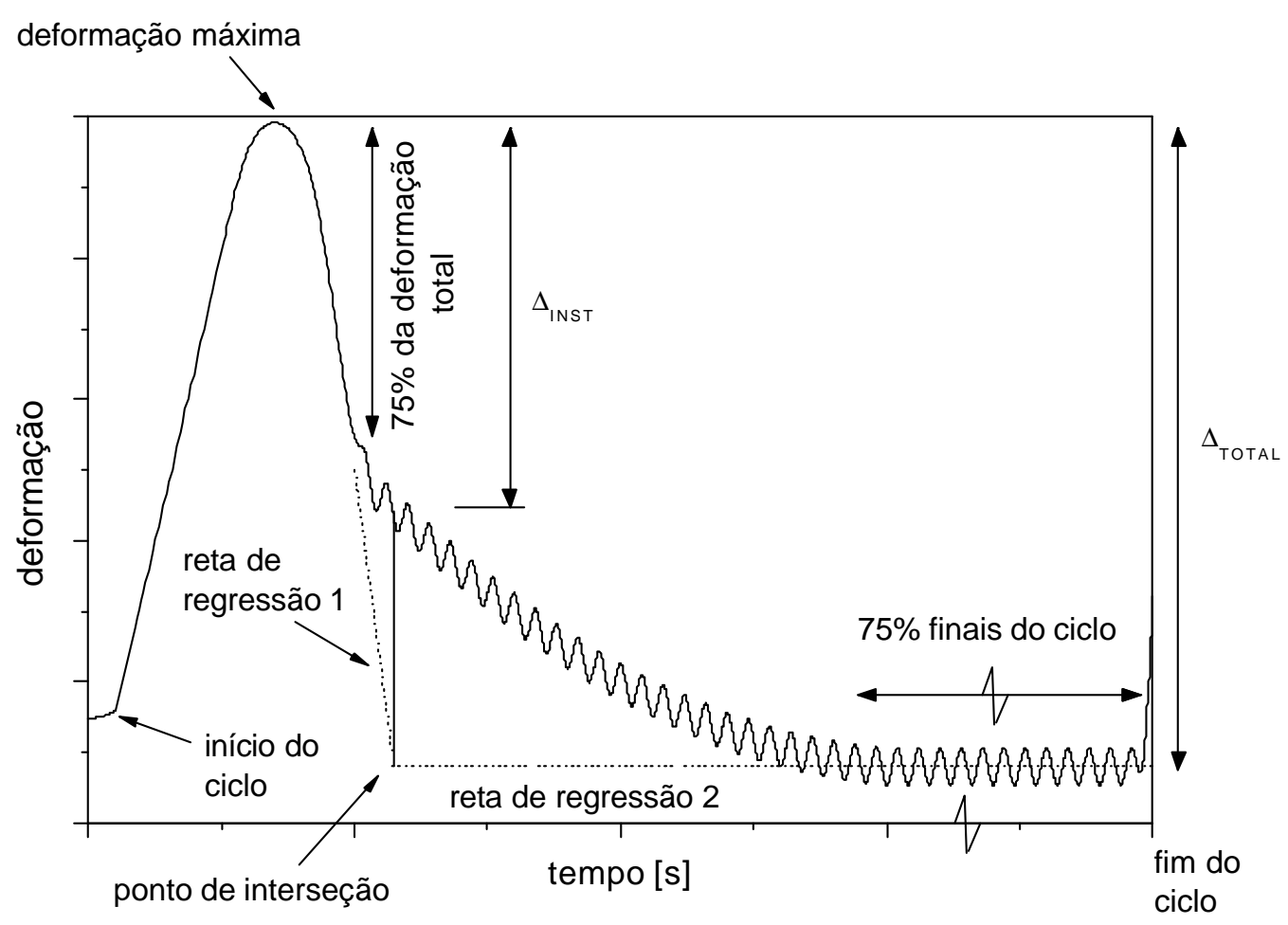

Fonte: AASHTO (1994) - AASHTO TP31-94

Figura 5.16 - Curva de deformação versus tempo, para um ciclo de carregamento

Uma das retas de regressão (reta 1) acima mencionadas é na verdade uma extensão da parte linear do trecho de descarregamento da curva de deformação e baseia-se em todos os pontos localizados após o pico da curva e antes da recuperação de $75 \%$ da deformação máxima sofrida. A outra reta de regressão (reta 2) baseia-se nos pontos correspondentes aos últimos $0,75 \mathrm{~s}$ do ciclo. Essas duas retas são estendidas e interceptam-se em um ponto, a partir do qual é traçada a linha vertical que por sua vez interceptará a curva de deformação.

O módulo de resiliência total é calculado a partir da deformação resiliente total $\left(\Delta_{\text {Total }}\right)$, que inclui tanto a deformação que é recuperada instantaneamente como a deformação recuperada durante a fase do ciclo em que o corpo de prova permanece sem carregamento, ou seja, em descanso. A deformação total é definida como a diferença entre a deformação máxima do ciclo de carregamento e a deformação final, determinada pela média dos valores de deformação dos últimos $75 \%$ do ciclo. 
O ensaio foi realizado a $25^{\circ} \mathrm{C}$, com aplicação de 500 ciclos de carregamento. A duração de cada ciclo foi de $1 \mathrm{~s}$, com $0,1 \mathrm{~s}$ de aplicação de carga e $0,9 \mathrm{~s}$ de recuperação. Antes de cada ensaio foi realizado um pré-condicionamento do corpo de prova, que consistiu na aplicação de 200 ciclos de carregamento, com a mesma carga e na mesma temperatura em que foram realizados os ensaios.

A magnitude da carga aplicada foi definida a partir da resistência à tração do corpo de prova, determinada no ensaio de resistência à tração por compressão diametral, realizado previamente. Foi aplicada a menor carga vertical que permitisse a leitura dos deslocamentos sofridos, e que gerasse uma tensão de tração $\left(\sigma_{t}\right)$ igual ou inferior à $30 \%$ da resistência à tração por compressão diametral estática $\left(\sigma_{R}\right)$, determinada através do método de ensaio DNER-ME 138/94 (DNER, 1994b).

A prensa pneumática utilizada para aplicação do carregamento foi a mesma utilizada nos ensaios de creep (Figura 5.10). O suporte utilizado para acomodação do corpo de prova encontra-se apresentado na Figura 5.17, e na Figura 5.18 pode ser visto também o suporte para fixação do LVDT que registrou os deslocamentos horizontais. Uma vista do conjunto montado com um corpo de prova é apresentado na Figura 5.19.

O controle do carregamento e aquisição dos dados foram realizados por um programa computacional desenvolvido em LabView. Um exemplo da tela do programa é apresentado na Figura 5.20, onde podem ser observados três ciclos de carregamento.

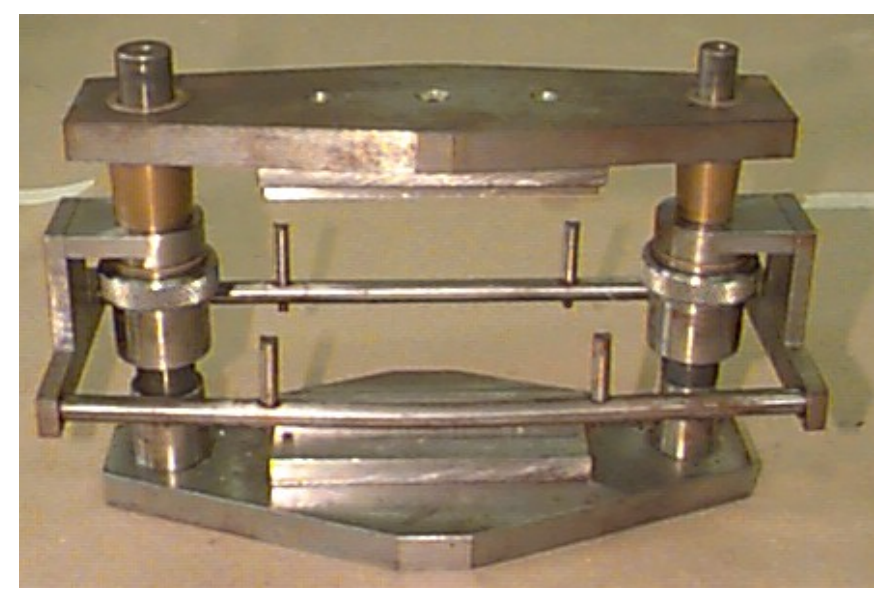

Figura 5.17 - Suporte utilizado para acomodação do corpo de prova no ensaio de módulo de resiliência por compressão diametral dinâmica 


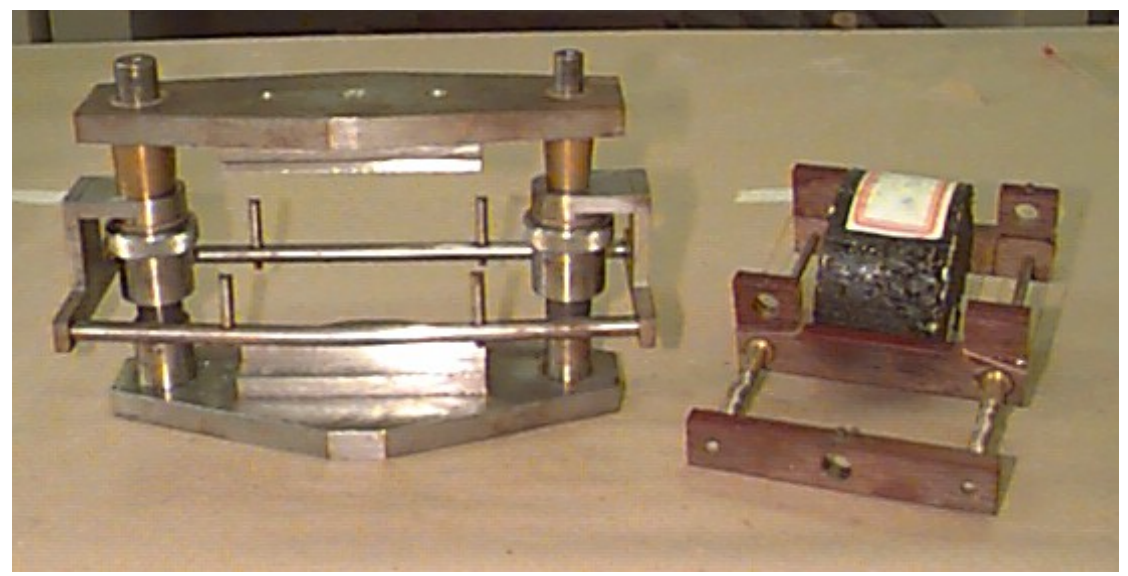

Figura 5.18 - Corpo de prova com suporte para fixação do LVDT

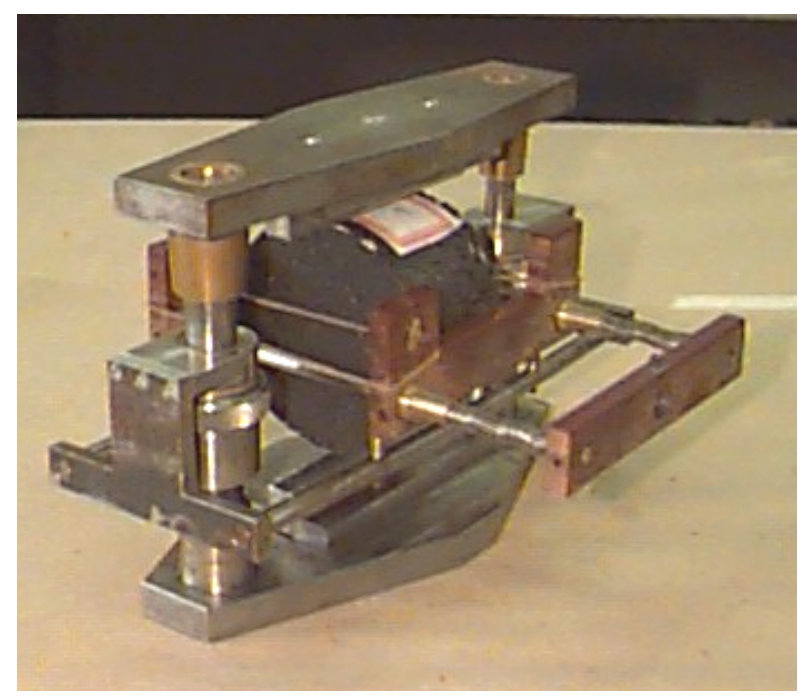

Figura 5.19 - Corpo de prova acomodado no suporte utilizado para aplicação da carga, e suporte utilizado para fixação do LVDT

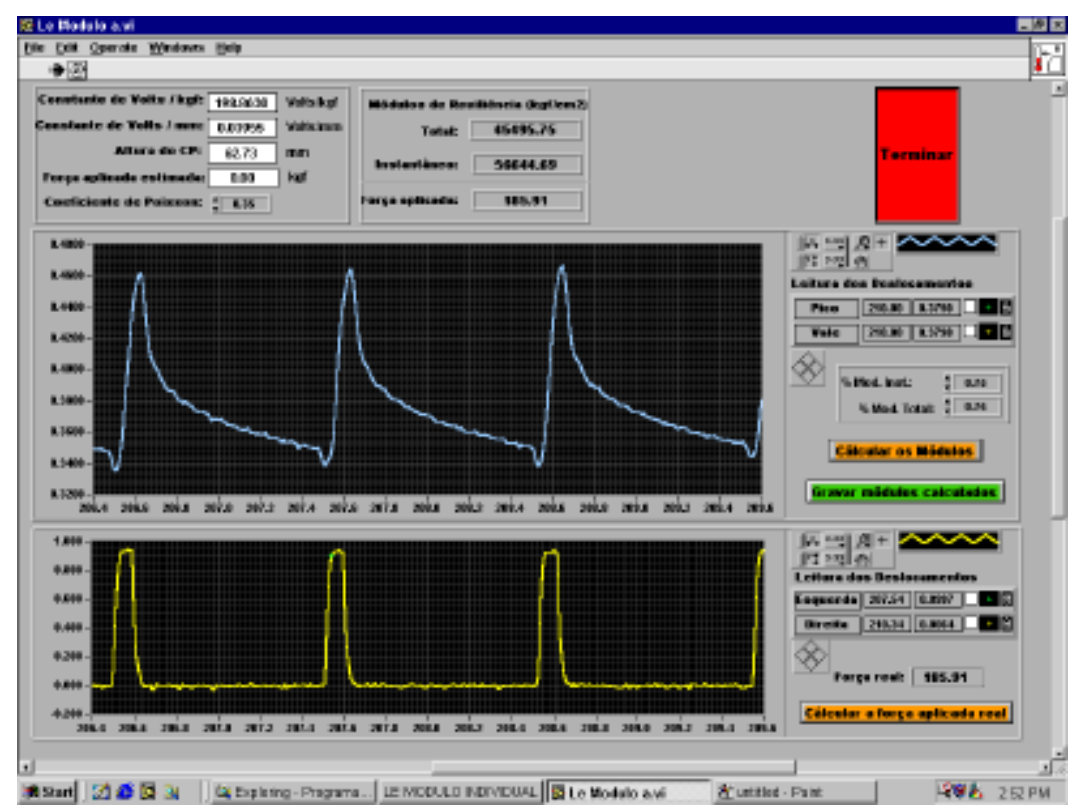

Figura 5.20 - Exemplo da tela do programa computacional desenvolvido em LabView, para o ensaio de módulo de resiliência 
Para cálculo do módulo de resiliência foram utilizados todos os ciclos, determinando-se o módulo de resiliência médio para o ensaio. Os cálculos foram realizados com a utilização de um programa desenvolvido em LabView, versão 6.0 para Windows, pelo Prof. Dr. Glauco Tulio Pessa Fabbri.

Cada corpo de prova foi ensaiado em duas direções, separadas entre si por cerca de $90^{\circ}$. O valor final do módulo de resiliência de cada corpo de prova foi calculado pela média entre os módulos obtidos em cada direção.

\subsubsection{Ensaio de resistência à tração por compressão diametral estática}

O ensaio de resistência à tração por compressão diametral estática foi realizado de acordo com o método de ensaio DNER-ME 138/94 (DNER, 1994b), com o objetivo de determinação da carga máxima aplicada no ensaio de módulo de resiliência por compressão diametral dinâmica. $\mathrm{O}$ ensaio foi realizado à $25^{\circ} \mathrm{C}$.

Nesse ensaio, corpos de prova cilíndricos, moldados de acordo com o método Marshall, foram submetidos a uma carga de compressão diametral estática, aplicada com aumento progressivo de sua magnitude, até a ruptura do corpo de prova.

A resistência à tração foi determinada de acordo com a expressão

$$
\sigma_{R}=\frac{2 F}{100 \pi d h}
$$

Onde

$$
\begin{aligned}
& \sigma_{\mathrm{R}}=\text { resistência à tração }(\mathrm{MPa}) ; \\
& \mathrm{F}=\text { carga de ruptura }(\mathrm{N}) ; \\
& \mathrm{d}=\text { diâmetro médio do corpo de prova }(\mathrm{cm}) ; \\
& \mathrm{h}=\text { altura do corpo de prova }(\mathrm{cm}) .
\end{aligned}
$$

A aquisição dos dados foi realizada através de um programa computacional desenvolvido em LabView. Um exemplo da tela obtida ao final do ensaio é apresentado 
na Figura 5.21, onde pode ser observada a variação da carga aplicada ao longo do ensaio.

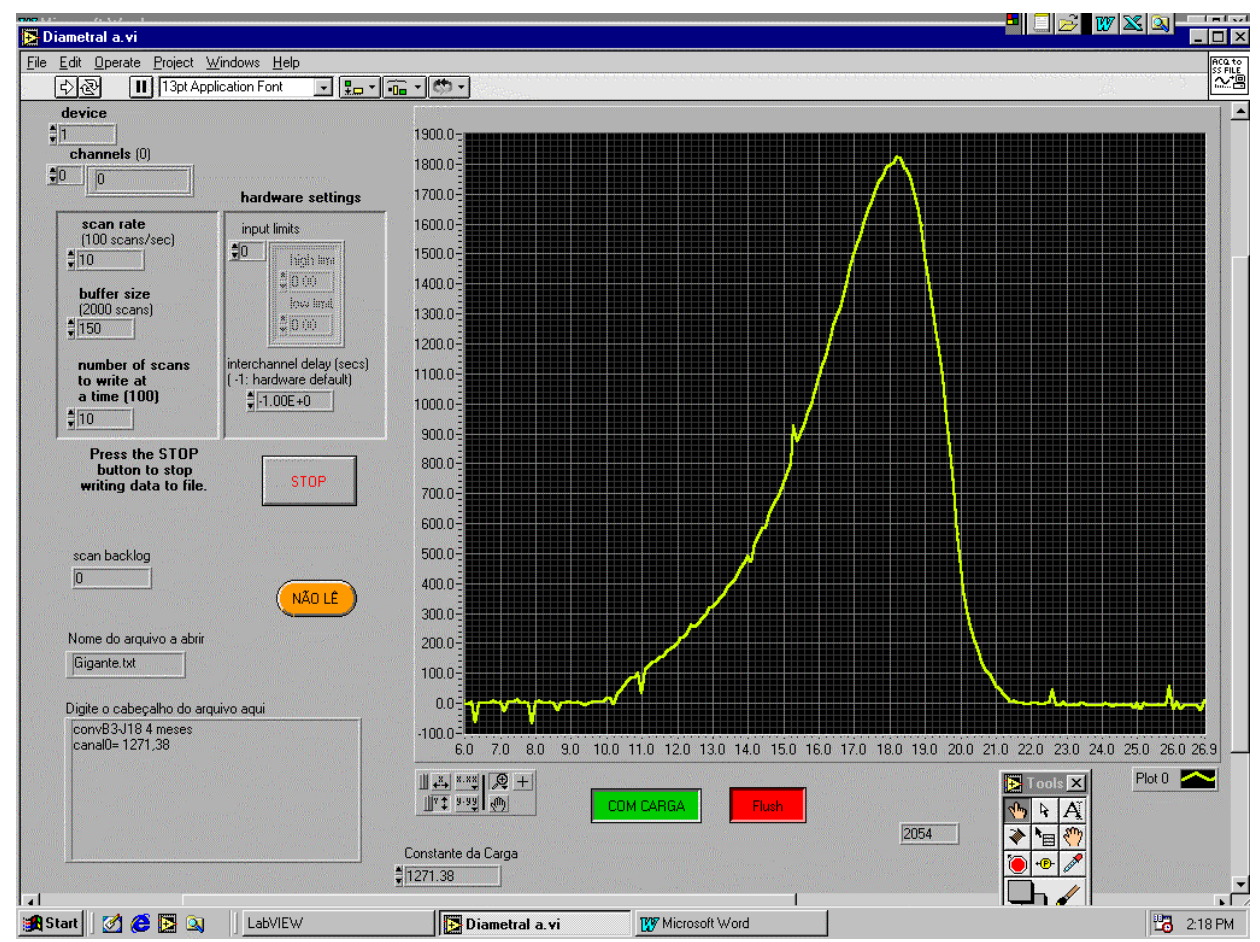

Figura 5.21 - Exemplo da tela do programa computacional desenvolvido em LabView, obtida ao final do ensaio de resistência à tração por compressão diametral 


\section{APRESENTAÇÃO E ANÁLISE DOS RESULTADOS}

São apresentados e analisados os resultados dos ensaios realizados para avaliação das propriedades mecânicas das misturas. Inicialmente é feita uma rápida exposição do procedimento adotado para a construção de modelos estatísticos de comportamento, apresentando-se em seguida os resultados obtidos experimentalmente através dos ensaios de resistência à tração por compressão diametral estática, módulo de resiliência por compressão diametral dinâmica e fluência por compressão uniaxial estática e dinâmica.

Os resultados dos ensaios são apresentados graficamente, em função do teor de ligante e do volume de vazios. Não foram construídos gráficos em função da variação da espessura de película, pois esta é função direta do teor de ligante. Dessa forma, as análises do comportamento das misturas realizadas em função do teor de ligante valem também para a espessura de película. Nos gráficos foram incluídos os modelos estatísticos de comportamento das variáveis de resposta, quando foi possível estabelecêlos. Também são apresentadas no presente capítulo as análises de variância dos resultados obtidos.

Embora os ensaios de módulo de resiliência e de fluência estática e dinâmica tenham sido realizados com três corpos de prova para cada uma das 36 condições experimentais que compõem o experimento fatorial fracionário, a análise do experimento foi conduzida considerando-se apenas duas observações por condição experimental. Para 
isso, o experimento original com três observações por condição experimental foi filtrado, eliminando-se a observação com maior desvio em relação à resposta média da condição experimental considerada. Essa medida foi adotada como uma forma paliativa de diminuição do erro experimental.

\subsection{Modelos de regressão}

O modelo de regressão múltipla para o experimento fatorial fracionário assimétrico com cinco fatores, designados por $A, B, C, X 7$ e $X 8$, é apresentado em sua forma geral através da seguinte expressão

$$
\begin{aligned}
& Y=\alpha_{0}+\alpha_{A l} P_{l}(A)+\alpha_{A q} P_{q}(A)+\alpha_{B} P(B)+\alpha_{C} P(C)+\alpha_{X 7} P(X 7)+\alpha_{X 8} P(X 8)+ \\
& +\alpha_{A l C} P_{l}(A) P(C)+\alpha_{A q C} P_{q}(A) P(C)+\alpha_{A l X 8} P_{l}(A) P(X 8)+\alpha_{A q X 8} P_{q}(A) P(X 8)
\end{aligned}
$$

Onde

$Y=$ variável dependente ou variável de resposta;

$A, B, C, X 7$ e $X 8=$ fatores ou variáveis independentes;

$A=$ teor de ligante asfáltico na mistura (diretamente relacionado ao volume de vazios e à espessura da película asfáltica revestindo o agregado);

$B=$ condição de envelhecimento da mistura a longo prazo;

$C=$ tipo de ligante asfáltico utilizado na mistura;

$X 7$ = distribuição granulométrica do agregado utilizado na mistura;

$X 8$ = condição de envelhecimento da mistura a curto prazo;

$\alpha_{0}=\bar{Y}=$ média total de todas as observações;

$\alpha_{A l}=$ coeficiente correspondente ao fator $A$, termo linear;

$\alpha_{A q}=$ coeficiente correspondente ao fator $A$, termo quadrático;

$\alpha_{B}=$ coeficiente correspondente ao fator $B$, termo linear;

$\alpha_{C}=$ coeficiente correspondente ao fator $C$, termo linear;

$\alpha_{X 7}=$ coeficiente correspondente ao fator $X 7$, termo linear;

$\alpha_{X 8}=$ coeficiente correspondente ao fator $X 8$, termo linear;

$\alpha_{A l C}=$ coeficiente correspondente à interação $A_{l} C$;

$\alpha_{A q C}=$ coeficiente correspondente à interação $A_{q} C$; 
$\alpha_{A l X 8}=$ coeficiente correspondente à interação $A_{l} X 8$;

$\alpha_{A q X 8}=$ coeficiente correspondente à interação $A_{q} X 8$;

$P_{l}(A)=$ equação polinomial linear correspondente ao fator $A$;

$P_{q}(A)=$ equação polinomial quadrática correspondente ao fator $A$;

$P(B)=$ equação polinomial correspondente ao fator $B$;

$P(C)=$ equação polinomial correspondente ao fator $C$;

$P(X 7)=$ equação polinomial correspondente ao fator $X 7 \mathrm{e}$

$P(X 8)=$ equação polinomial correspondente ao fator $X 8$.

Pode-se observar que fazem parte do modelo apenas os efeitos principais dos fatores e os efeitos das interações entre os fatores $A$ e $C$, e $A$ e $X 8$. As demais interações não foram incluídas por terem seus efeitos acoplados aos efeitos citados, em decorrência do fracionamento do experimento.

As equações polinomiais lineares e quadráticas de um fator quantitativo $x$ podem ser expressas em sua forma geral pelas eq. (6.2) e (6.3).

$$
\begin{gathered}
P_{l}(x)=\lambda_{l}\left[\frac{(x-\bar{x})}{d}\right] \\
P_{q}(x)=\lambda_{q}\left[\left(\frac{x-\bar{x}}{d}\right)^{2}-\left(\frac{a^{2}-1}{12}\right)\right]
\end{gathered}
$$

Onde

$\lambda_{i}=$ constantes para as quais os polinômios possuem valores inteiros. Os valores de $\lambda$ são tabelados em função do número de níveis do fator e da ordem do polinômio; $x=$ valor ou nível do fator quantitativo;

$\bar{x}=$ média dos valores que podem ser atribuídos ao fator quantitativo $x$;

$d=$ distância entre os níveis do fator $x$;

$a=$ número de níveis do fator $x$.

No caso do fator quantitativo $A$, teor de ligante, as equações polinomiais variam conforme a distribuição granulométrica considerada. Para misturas com distribuição granulométrica correspondente ao centro da faixa B do DNER (1997), os níveis da variável $A$ são 4,$0 ; 4,5 ; 5,0$ e 5,5\%. Nesse caso $\bar{x}=4,75$. Para misturas com distribuição 
granulométrica correspondente ao centro da faixa C do DNER (1997), os níveis da variável $A$ são 5,0; 5,5; 6,0 e 6,5\%. Nesse caso, $\bar{x}=5,75$. Em ambos os casos $\lambda_{l}=2$; $\lambda_{q}=1 ; d=0,5$ e $a=4$. As equações polinomiais simplificadas para o fator quantitativo $A$ são apresentadas na Tabela 6.1 .

Tabela 6.1 - Equações polinomiais para o fator quantitativo $A$

\begin{tabular}{cc}
\hline agregado faixa B & agregado faixa C \\
\hline$P_{l}(A)=4 \times A-19$ & $P_{l}(A)=4 \times A-23$ \\
$P_{q}(A)=\left(\frac{A-4,75}{0,5}\right)^{2}-1,25$ & $P_{q}(A)=\left(\frac{A-5,75}{0,5}\right)^{2}-1,25$ \\
\hline
\end{tabular}

As equações polinomiais correspondentes aos fatores qualitativos $B, C, X 7$ e $X 8$ são definidas conforme as convenções apresentadas na Tabela 6.2.

Tabela 6.2 - Equações polinomiais correspondentes aos fatores qualitativos $B, C, X 7$ e $X 8$

\begin{tabular}{cccl}
\hline fator & $\begin{array}{c}\text { equação } \\
\text { polinomial }\end{array}$ & $\begin{array}{c}\text { variável auxiliar } \\
\text { representativa do } \\
\text { nível do fator }\end{array}$ & $\begin{array}{c}\text { nível ou condição em que o fator é } \\
\text { considerado }\end{array}$ \\
\hline $\begin{array}{c}\text { condição de } \\
\text { envelhecimento } \\
\text { a longo prazo }\end{array}$ & $P(B)=$ & -1 & $\begin{array}{l}\text { sem envelhecimento } \\
\text { a dias em estufa ventilada a } 85^{\circ} \mathrm{C}\end{array}$ \\
\hline $\begin{array}{c}\text { tipo de ligante } \\
\text { asfáltico }\end{array}$ & $P(C)=$ & 0 & 4 meses de exposição ao tempo \\
\hline distribuição & $P(X 7)=$ & -1 & $\begin{array}{l}\text { asfalto convencional } \\
\text { asfalto modificado com polímero } \\
\text { asfalto modificado com borracha }\end{array}$ \\
$\begin{array}{c}\text { granulométrica } \\
\text { do agregado }\end{array}$ & $X 7=$ & -1 & centro da faixa B do DNER (1997) \\
\hline $\begin{array}{c}\text { condição de } \\
\text { envelhecimento } \\
\text { a curto prazo }\end{array}$ & $P(X 8)=$ & 1 & centro da faixa C do DNER (1997) \\
\hline
\end{tabular}

O objetivo de uma análise de regressão é minimizar a diferença entre a observação e a previsão realizada pelo modelo de regressão. Ou seja, deve-se minimizar a soma dos erros.

No caso de um fator quantitativo, torna-se útil encontrar uma curva de resposta para os níveis do fator, de modo que o experimentador disponha de uma equação que relacione a resposta ao fator. Essa equação pode ser utilizada para interpolação, ou seja, para prever a resposta quando o fator possuir níveis entre os níveis utilizados para obtenção da curva. 
Para que variáveis qualitativas possam ter seu comportamento modelado, devem ser utilizados indicadores quantitativos que representem as classes ou níveis em que as variáveis qualitativas são consideradas (NETER et al., 1985). Fatores qualitativos contribuem para a construção de modelos de regressão apenas com termos lineares.

Os modelos de regressão são obtidos a partir da análise de variância dos dados, incorporando apenas os termos correspondentes aos efeitos principais ou de interação que forem considerados significativos pela análise realizada. Deve-se observar entretanto que, por razões de hierarquia, se um termo for incluído em um modelo, todos os termos de ordem inferior também devem ser incluídos (MONTGOMERY, 1997). Ou seja, se o termo quadrático do fator $A$ for incluído ao modelo de regressão por ser considerado significativo, então o termo linear do fator $A$ também deve ser incluído ao modelo, mesmo que não tenha sido considerado significativo pela análise de variância realizada.

Uma vez identificados os efeitos significativos, podem ser construídos modelos estatísticos de comportamento, que relacionem as variáveis independentes ou fatores com as variáveis dependentes ou respostas. A análise de variância fornece as somas dos quadrados $(S Q)$ dos fatores e de suas interações. A soma dos quadrados de um fator está relacionada com a variação ocorrida na resposta em virtude da variação dos níveis daquele fator, sendo obtida pela soma dos quadrados das variações das respostas.

Os coeficientes dos termos do modelo de regressão podem ser calculados dividindo-se a soma dos quadrados $(S Q)$ de cada fator ou interação pela respectiva combinação linear $L$, previamente definida na eq. 2.14 do Capítulo 2 desse trabalho. Assim, os coeficientes dos termos do modelo de regressão são dados por $S Q / L$. Os modelos de comportamento foram estabelecidos com auxílio do programa STATISTICA.

O coeficiente de determinação $\left(R^{2}\right)$ dos modelos pode ser calculado dividindo-se a soma dos quadrados dos termos incorporados ao modelo pela soma dos quadrados total, de acordo com a seguinte expressão

$$
R^{2}=\frac{S Q_{\text {modelo }}}{S Q_{\text {total }}}
$$




\subsection{Resultados do ensaio de resistência à tração por compressão diametral}

O ensaio de resistência à tração por compressão diametral estática foi conduzido para estimativa aproximada da tensão máxima que poderia ser utilizada no ensaio de módulo de resiliência por compressão diametral dinâmica, que corresponde a 30\% da resistência à tração apresentada pela mistura compactada. Além disso foram calculadas também as relações $M R / \sigma_{R}$, para avaliação da capacidade de retorno elástico das misturas. As relações $M R / \sigma_{R}$ serão apresentadas posteriormente neste capítulo, na Tabela 6.10.

Uma vez que esse ensaio teve finalidade auxiliar na presente pesquisa e considerando-se as limitações de tempo e de materiais, apenas um corpo de prova por condição experimental foi submetido ao ensaio de resistência à tração por compressão diametral estática.

Os resultados de resistência à tração $\left(\sigma_{R}\right.$, em $\left.\mathrm{MPa}\right)$ obtidos estão relacionados no Apêndice D e apresentados em forma de matriz fatorial no Apêndice E. Os resultados foram calculados de acordo com o método de ensaio DNER-ME 138/94 (DNER, 1994b), a partir da carga de ruptura $(F$, em N), do diâmetro do corpo de prova $(D$, em $\mathrm{cm})$ e da altura do corpo de prova $(H$, em $\mathrm{cm})$, através da seguinte expressão

$$
\sigma_{R}=\frac{2 F}{100 \pi D H}
$$

Esses resultados foram lançados em gráfico em função do teor de ligante asfáltico empregado na mistura e podem ser observados nas Figuras 6.1 e 6.2, para agregados com distribuições granulométricas correspondentes aos centros das faixas B e C do DNER (1997), respectivamente. Os resultados indicaram o aumento da resistência à tração com o aumento do teor de ligante asfáltico, seguido por uma queda quando foram utilizados os teores de 5,5\%, para a graduação B, e 6,5\%, para a graduação C.

Nas Figuras 6.3 e 6.4 foram lançados os resultados de resistência à tração em função do volume de vazios nas misturas. 


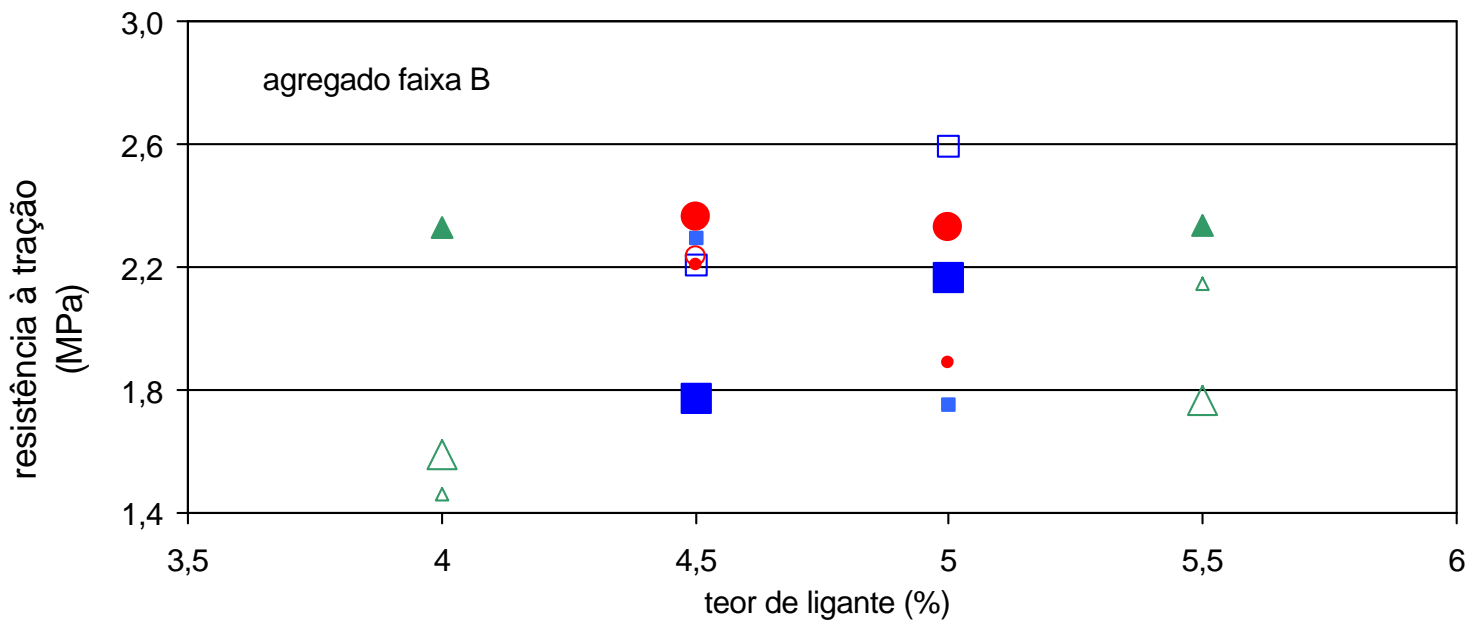

$\square$ asf. com polímero; envelhecimento a longo prazo = não; envelhecimento a curto prazo = não

$\Delta$ asf. convencional; envelhecimento a longo prazo = estufa; envelhecimento a curto prazo = não

$\triangle$ asf. com borracha; envelhecimento a longo prazo = estufa; envelhecimento a curto prazo = não

O asf. com polímero; envelhecimento a longo prazo = exposição ao tempo; envelhecimento a curto prazo = não

口asf. com borracha; envelhecimento a longo prazo = não; envelhecimento a curto prazo $=4 \mathrm{~h}$ em estufa

- asf. convencional; envelhecimento a longo prazo = não; envelhecimento a curto prazo $=4 \mathrm{~h}$ em estufa

$\Delta$ asf. com polímero; envelhecimento a longo prazo = estufa; envelhecimento a curto prazo $=4 \mathrm{~h}$ em estufa

- asf. convencional; envelhecimento a longo prazo = exposição ao tempo; envelhecimento a curto prazo = 4h em estufa

- asf. com borracha; envelhecimento a longo prazo = exposição ao tempo; envelhecimento a curto prazo = 4h em estufa

Figura 6.1 - Valores de resistência à tração em função do teor de ligante asfáltico, para agregado com distribuição granulométrica correspondente ao centro da faixa $\mathrm{B}$

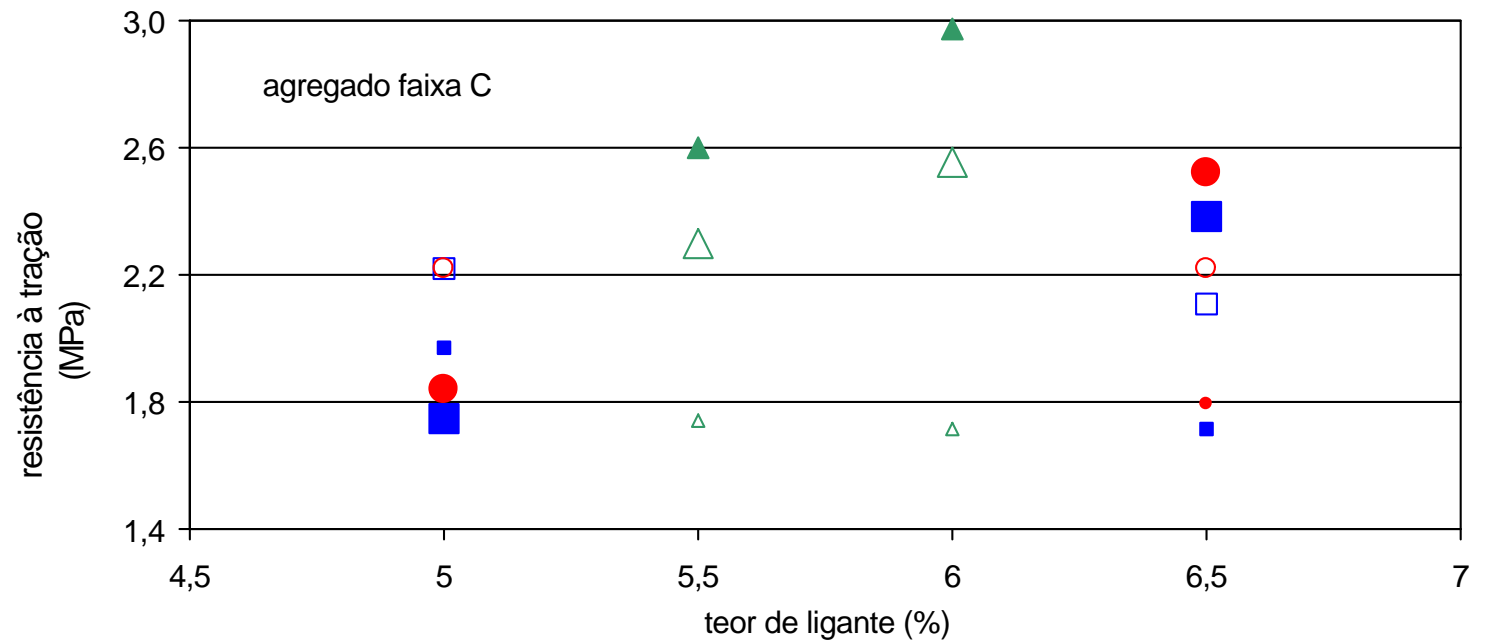

$\square$ asf. com polímero; envelhecimento a longo prazo = não; envelhecimento a curto prazo = não

$\triangle$ asf. convencional; envelhecimento a longo prazo = estufa; envelhecimento a curto prazo = não

$\triangle$ asf. com borracha; envelhecimento a longo prazo = estufa; envelhecimento a curto prazo = não

O asf. com polímero; envelhecimento a longo prazo = exposição ao tempo; envelhecimento a curto prazo = não

- asf. convencional; envelhecimento a longo prazo = não; envelhecimento a curto prazo = 4h em estufa

口 asf. com borracha; envelhecimento a longo prazo = não; envelhecimento a curto prazo = $4 \mathrm{~h}$ em estufa

$\Delta$ asf. com polímero; envelhecimento a longo prazo = estufa; envelhecimento a curto prazo $=4 \mathrm{~h}$ em estufa

- asf. convencional; envelhecimento a longo prazo = exposição ao tempo; envelhecimento a curto prazo = 4h em estufa

- asf. com borracha; envelhecimento a longo prazo = exposição ao tempo; envelhecimento a curto prazo $=4 \mathrm{~h}$ em estufa

Figura 6.2 - Valores de resistência à tração em função do teor de ligante, para agregado com distribuição granulométrica correspondente ao centro da faixa $\mathrm{C}$ 


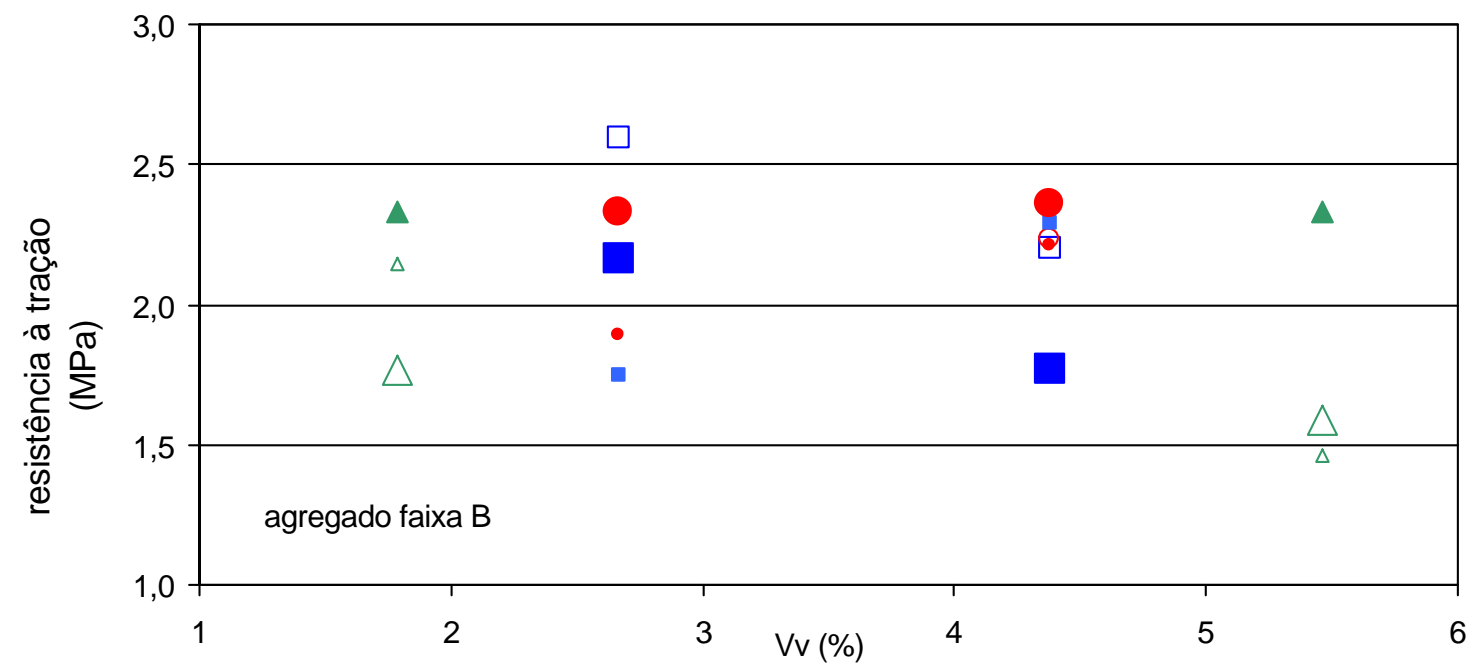

$\square$ asf. com polímero; envelhecimento a longo prazo = não; envelhecimento a curto prazo = não

$\Delta$ asf. convencional; envelhecimento a longo prazo = estufa; envelhecimento a curto prazo = não

$\triangle$ asf. com borracha; envelhecimento a longo prazo = estufa; envelhecimento a curto prazo = não

O asf. com polímero; envelhecimento a longo prazo = exposição ao tempo; envelhecimento a curto prazo = não

口 asf. com borracha; envelhecimento a longo prazo = não; envelhecimento a curto prazo $=4 \mathrm{~h}$ em estufa

- asf. convencional; envelhecimento a longo prazo = não; envelhecimento a curto prazo $=4 \mathrm{~h}$ em estufa

$\Delta$ asf. com polímero; envelhecimento a longo prazo = estufa; envelhecimento a curto prazo $=4 \mathrm{~h}$ em estufa

- asf. convencional; envelhecimento a longo prazo = exposição ao tempo; envelhecimento a curto prazo = 4h em estufa

- asf. com borracha; envelhecimento a longo prazo = exposição ao tempo; envelhecimento a curto prazo = $4 \mathrm{~h}$ em estufa

Figura 6.3 - Valores de resistência à tração em função do volume de vazios, para agregado com distribuição granulométrica correspondente ao centro da faixa $\mathrm{B}$

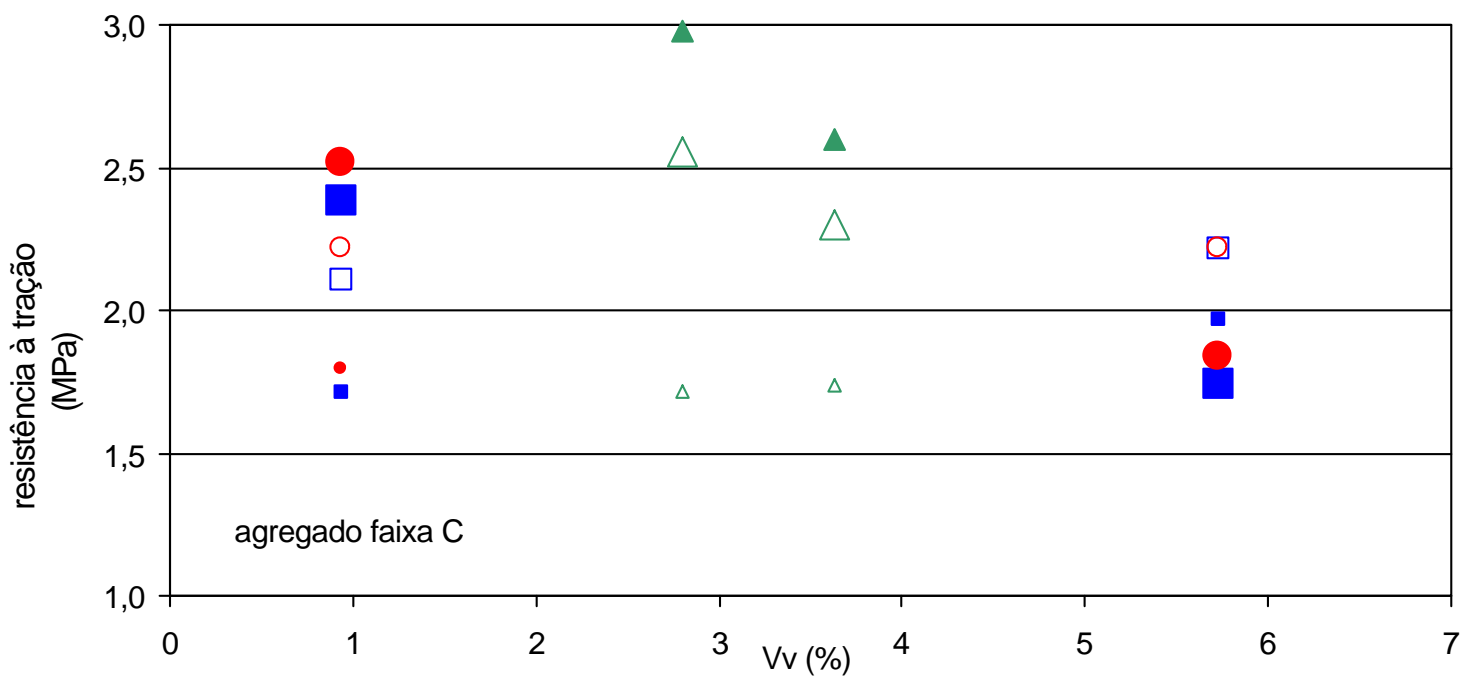

$\square$ asf. com polímero; envelhecimento a longo prazo = não; envelhecimento a curto prazo = não

$\Delta$ asf. convencional; envelhecimento a longo prazo = estufa; envelhecimento a curto prazo = não

$\triangle$ asf. com borracha; envelhecimento a longo prazo = estufa; envelhecimento a curto prazo = não

O asf. com polímero; envelhecimento a longo prazo = exposição ao tempo; envelhecimento a curto prazo = não

- asf. convencional; envelhecimento a longo prazo= não; envelhecimento a curto prazo $=4 \mathrm{~h}$ em estufa

口 asf. com borracha; envelhecimento a ongo prazo = não; envelhecimento a curto prazo $=4 \mathrm{~h}$ em estufa

$\Delta$ asf. com polímero; envelhecimento a longo prazo = estufa; envelhecimento a curto prazo $=4 \mathrm{~h}$ em estufa

- asf. convencional; envelhecimento a longo prazo = exposição ao tempo; envelhecimento a curto prazo = $4 \mathrm{~h}$ em estufa

- asf. com borracha; envelhecimento a longo prazo = exposição ao tempo; envelhecimento a curto prazo $=4 \mathrm{~h}$ em estufa

Figura 6.4 - Valores de resistência à tração em função do volume de vazios, para agregado com distribuição granulométrica correspondente ao centro da faixa $\mathrm{C}$ 
Tanto na análise realizada em função do teor de ligante como na análise realizada em função do volume de vazios, não puderam ser estabelecidos modelos de comportamento para os pontos experimentais, pois a correlação entre as variáveis foi muito baixa.

\subsection{Resultados do ensaio de módulo de resiliência}

O ensaio de módulo de resiliência por compressão diametral dinâmica consiste em aplicar-se repetidamente uma carga de compressão no plano diametral vertical de um corpo de prova cilíndrico, medindo-se a deformação horizontal recuperável resultante. Os resultados do ensaio de módulo de resiliência podem ser encontrados no Apêndice D. A apresentação desses resultados em forma de matrizes fatoriais encontra-se no Apêndice E.

\subsubsection{Análise de variância (ANOVA) realizada com os resultados do ensaio de módulo de resiliência}

As análises de variância dos resultados do ensaio de módulo de resiliência estão apresentadas nas Tabelas F.1 a F.4 do Apêndice F, para a situação em que o fator $A$ é considerado como um fator quantitativo, representando o teor de ligante asfáltico na mistura. Um resumo da análise de variância realizada para essa situação é apresentado na Tabela 6.3.

Nas Tabelas F.5 a F.8 do Apêndice F são apresentadas as análises de variância realizadas considerando-se o fator $A$ como um fator qualitativo, representando o volume de vazios na mistura. Os resultados dessas análises estão resumidos na Tabela 6.4.

Em decorrência de variações inerentes ao método Marshall de compactação, como por exemplo dificuldades em se manter um controle rigoroso da temperatura de moldagem, não foi possível provocar variações uniformes do volume de vazios, o que ocasionou espaçamentos desiguais entre os níveis do fator $A$, nesse caso. 
Para que o experimento pudesse ser analisado considerando-se como uma das variáveis independentes o volume de vazios na mistura, com quatro níveis de variação e espaçamentos desiguais entre os níveis, optou-se por considerar tal variável como sendo uma variável categórica. Dessa forma, seus quatro níveis foram representados pela combinação entre os níveis de duas variáveis auxiliares, al e $a 2$, cada qual com dois níveis de variação.

Tabela 6.3 - Resumo da análise de variância realizada com os resultados do ensaio de módulo de resiliência , considerando-se o fator $A$ (teor de ligante) quantitativo

\begin{tabular}{ccccccc}
\hline & & \multicolumn{5}{c}{ influência significativa? } \\
\cline { 3 - 7 } resposta & confiança & $\begin{array}{c}A \\
\text { teor de } \\
\text { ligante }\end{array}$ & $\begin{array}{c}B \\
\text { condição de } \\
\text { env. a longo } \\
\text { prazo }\end{array}$ & $\begin{array}{c}C \\
\text { tipo de } \\
\text { ligante }\end{array}$ & $\begin{array}{c}X 7 \\
\text { distribuição } \\
\text { granulomé- } \\
\text { trica }\end{array}$ & $\begin{array}{c}X 8 \\
\text { condição de } \\
\text { env. a curto } \\
\text { prazo }\end{array}$ \\
\hline MR total & $99 \%$ & $\operatorname{sim}$ & $\operatorname{sim}$ & não & $\operatorname{sim}$ & não \\
\hline MR total & $95 \%$ & $\operatorname{sim}$ & $\operatorname{sim}$ & $\operatorname{sim}$ & $\operatorname{sim}$ & não \\
\hline MR inst. & $99 \%$ & $\operatorname{sim}$ & $\operatorname{sim}$ & não & $\operatorname{sim}$ & não \\
\hline MR inst. & $95 \%$ & $\operatorname{sim}$ & $\operatorname{sim}$ & $\operatorname{sim}$ & $\operatorname{sim}$ & não \\
\hline
\end{tabular}

Tabela 6.4 - Resumo da análise de variância realizada com os resultados do ensaio de módulo de resiliência , considerando-se o fator $A$ (volume de vazios) qualitativo

\begin{tabular}{ccccccc}
\hline & & \multicolumn{5}{c}{ influência significativa? } \\
\cline { 3 - 7 } resposta & confiança & $\begin{array}{c}A \\
\text { volume } \\
\text { de vazios }\end{array}$ & $\begin{array}{c}B \\
\text { condição de } \\
\text { env. a longo } \\
\text { prazo }\end{array}$ & $\begin{array}{c}\text { tipo de } \\
\text { ligante }\end{array}$ & $\begin{array}{c}X 7 \\
\text { distribuição } \\
\text { granulomé- } \\
\text { trica }\end{array}$ & $\begin{array}{c}X 8 \\
\text { condição de } \\
\text { env. a curto } \\
\text { prazo }\end{array}$ \\
\hline MR total & $99 \%$ & não & $\operatorname{sim}$ & não & sim & não \\
\hline MR total & $95 \%$ & não & $\operatorname{sim}$ & não & sim & não \\
\hline MR inst. & $99 \%$ & não & $\operatorname{sim}$ & não & sim & não \\
\hline MR inst. & $95 \%$ & não & $\operatorname{sim}$ & não & sim & não \\
\hline
\end{tabular}

\subsubsection{Apresentação gráfica e modelagem dos resultados do ensaio de módulo de resiliência}

Nas Figuras 6.5 e 6.7 são apresentados os valores de módulo de resiliência total fornecidos por misturas compostas por agregados com distribuição granulométrica equivalente ao centro da faixa B do DNER (1997) e nas Figuras 6.6 e 6.8, valores de módulo de resiliência total fornecidos por misturas compostas por agregados com distribuição granulométrica equivalente ao centro da faixa C do DNER (1997). 
Além dos pontos experimentais, nessas figuras podem ser encontrados também os modelos estatísticos de comportamento para o módulo de resiliência total em função do teor de ligante asfáltico e da condição de envelhecimento a longo prazo. O modelo estatístico obtido com base no comportamento desses pontos para uma confiança de $99 \%$ é apresentado na eq. 6.6 e tem coeficiente de determinação $\left(\mathrm{R}^{2}\right)$ de 0,60 . Curvas de comportamento geradas por esse modelo foram acrescentadas às Figuras 6.5 e 6.6.

$$
M R_{\text {total }}=13522-117 P_{l}(A)-1904 P_{q}(A)+3769 B-1641 X 7
$$

Diminuindo-se a confiança para $95 \%$, foi obtido o modelo apresentado na eq. 6.7 , com um coeficiente de determinação de 0,63. Curvas de comportamento geradas por esse modelo foram acrescentadas às Figuras 6.7 e 6.8. Pode-se observar que, para essa confiança, além dos fatores teor de ligante, condição de envelhecimento a longo prazo e distribuição granulométrica do agregado, foi também considerado significativo o fator tipo de ligante asfáltico.

$$
M R_{\text {total }}=13522-117 P_{l}(A)-1904 P_{q}(A)+3769 B+1016 C-1641 X 7
$$

Cabe lembrar que os polinômios $P_{l}(A), P_{q}(A), B, C$ e $X 7$, que aparecem nas eq. 6.6 e 6.7, foram definidos anteriormente, conforme descrição apresentada nas Tabelas 6.1 e 6.2.

De acordo com a análise realizada, os maiores valores de módulo de resiliência foram apresentados por misturas envelhecidas ao tempo, os menores valores por misturas que não passaram por nenhum processo de envelhecimento acelerado e valores intermediários foram encontrados para misturas envelhecidas em estufa ventilada por 5 dias a $85^{\circ} \mathrm{C}$. Considerando-se por esse comportamento que os valores de módulo de resiliência tenham aumentado com o aumento da severidade das condições de envelhecimento a longo prazo, conclui-se que a exposição ao tempo causou um envelhecimento mais acentuado às misturas asfálticas analisadas do que o envelhecimento acelerado em estufa. 


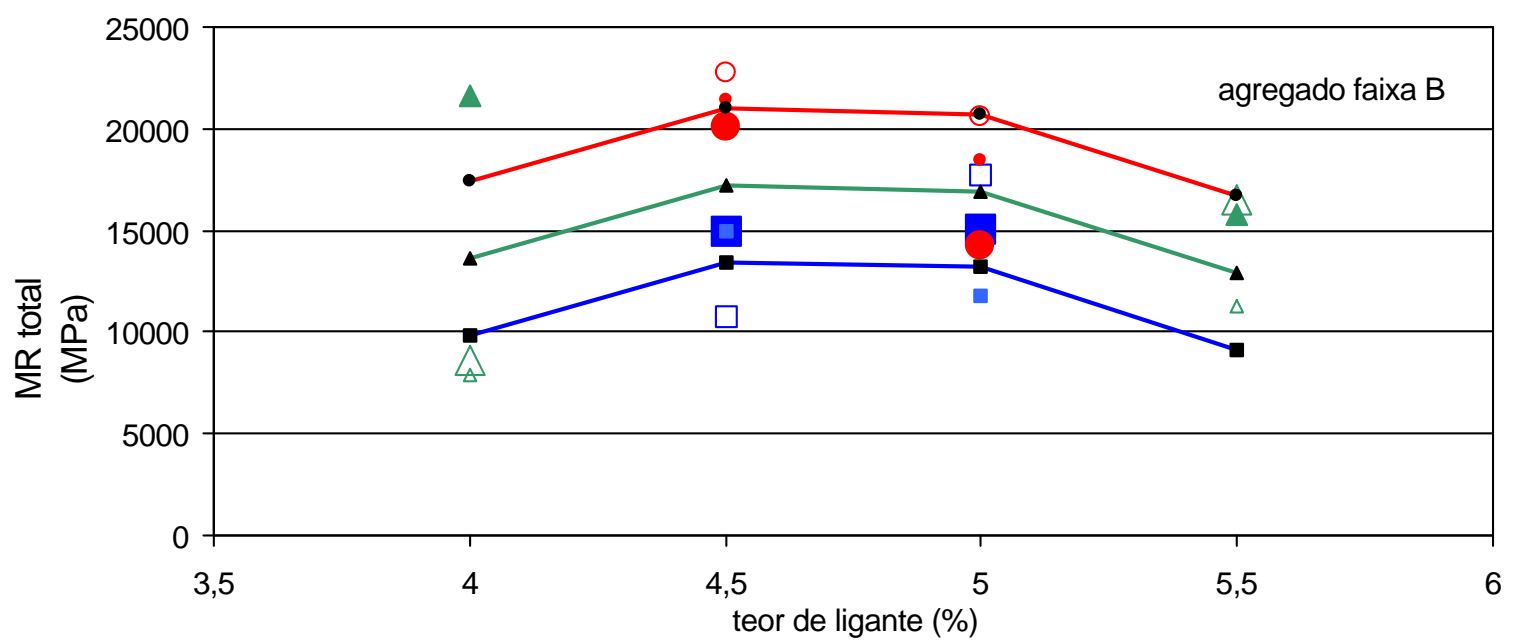

\begin{tabular}{|l}
$\square$ asf. com polímero; envelhecimento a longo prazo = não; envelhecimento a curto prazo = não \\
$\Delta$ asf. convencional; envelhecimento a longo prazo = estufa; envelhecimento a curto prazo = não \\
$\triangle \quad$ asf. com borracha; envelhecimento a longo prazo = estufa; envelhecimento a curto prazo = não \\
asf. com polímero; envelhecimento a longo prazo = exposição ao tempo; envelhecimento a curto prazo = não \\
asf. com borracha; envelhecimento a longo prazo= não; envelhecimento a curto prazo = $4 \mathrm{~h}$ em estufa \\
asf. convencional; envelhecimento a longo prazo = não; envelhecimento a curto prazo = 4h em estufa \\
asf. com polímero; envelhecimento a longo prazo = estufa; envelhecimento a curto prazo = 4h em estufa \\
asf. convencional; envelhecimento a longo prazo = exposição ao tempo; envelhecimento a curto prazo = 4h em estufa \\
asf. com borracha; envelhecimento a longo prazo = exposição ao tempo; envelhecimento a curto prazo = 4h em estufa \\
$\rightarrow-$ modelo para mistura não envelhecida a longo prazo \\
\hline- - modelo para mistura envelhecida a longo prazo em estufa
\end{tabular}

Figura 6.5 - Pontos experimentais e modelos de comportamento referentes ao MR total em função do teor de ligante e da condição de envelhecimento a longo prazo, para a faixa granulométrica B, considerando-se confiança de $99 \%$

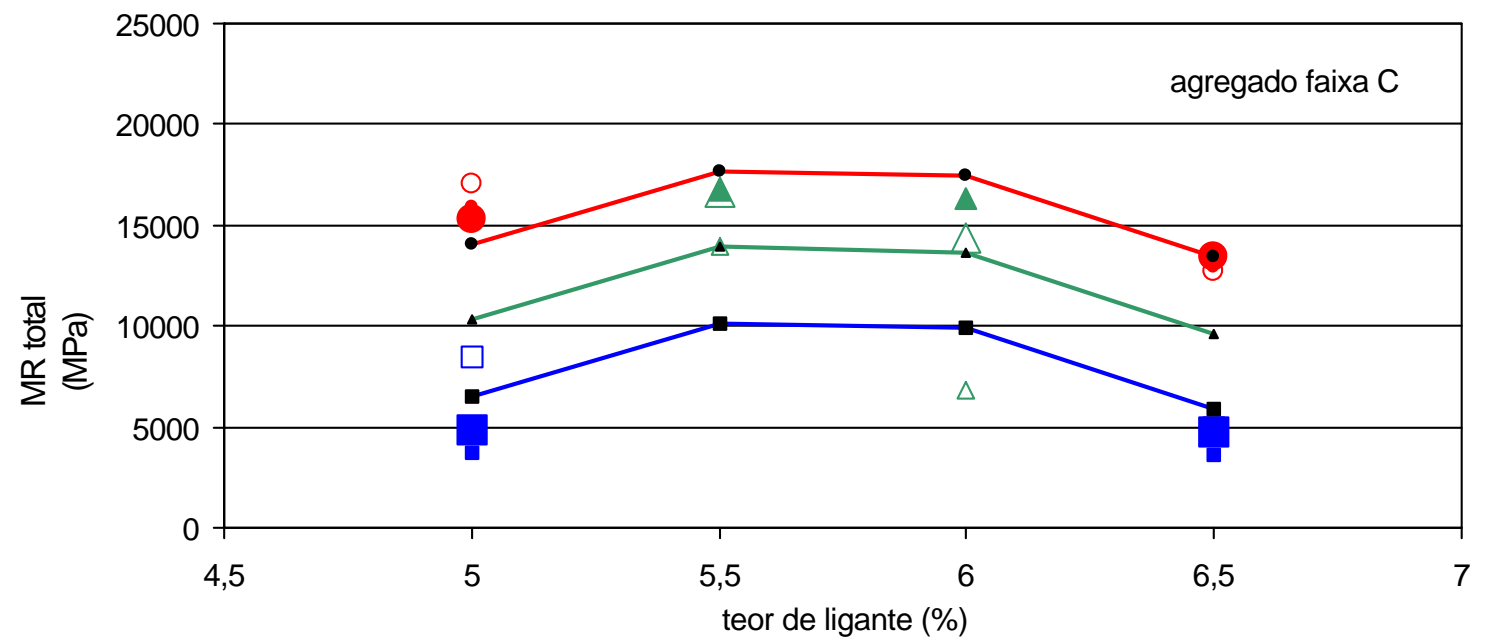

\footnotetext{
$\square$ asf. com polímero; envelhecimento a longo prazo = não; envelhecimento a curto prazo = não

$\triangle$ asf. convencional; envelhecimento a longo prazo = estufa; envelhecimento a curto prazo =não

$\triangle$ asf. com borracha; envelhecimento a longo prazo = estufa; envelhecimento a curto prazo = não

○ asf. com polímero; envelhecimento a longo prazo = exposição ao tempo; envelhecimento a curto prazo = não

- asf. convencional; envelhecimento a longo prazo = não; envelhecimento a curto prazo $=4 \mathrm{~h}$ em estufa

asf. com borracha; envelhecimento a longo prazo = não; envelhecimento a curto prazo $=4 \mathrm{~h}$ em estufa

asf. com polímero; envelhecimento a longo prazo = estufa; envelhecimento a curto prazo $=4 \mathrm{~h}$ em estufa

- $\quad$ asf. convencional; envelhecimento a longo prazo = exposição ao tempo; envelhecimento a curto prazo $=4 \mathrm{~h}$ em estufa

- asf. com borracha; envelhecimento a longo prazo = exposição ao tempo; envelhecimento a curto prazo $=4 \mathrm{~h}$ em estufa

- modelo para mistura não envelhecida a longo prazo

- modelo para mistura envelhecida a longo prazo em estufa

modelo para mistura envelhecida a longo prazo por exposição ao tempo
}

Figura 6.6 - Pontos experimentais e modelos de comportamento referentes ao MR total em função do teor de ligante e da condição de envelhecimento a longo prazo, para a faixa granulométrica C, considerando-se confiança de $99 \%$ 
Quanto ao efeito do fator distribuição granulométrica, a utilização de agregados com distribuição granulométrica correspondente ao centro da faixa B gerou misturas com valores de módulo de resiliência maiores que os valores apresentados por misturas com agregados da faixa $\mathrm{C}$.

De acordo com as dosagens Marshall realizadas, apresentadas no Apêndice B, o teor ótimo para misturas com agregado da faixa B ficou em torno de 5\%, e o teor ótimo para misturas com agregado da faixa $\mathrm{C}$, em torno de 5,5\%. Observando-se os gráficos das Figuras 6.5 a 6.8 nota-se que teores de asfalto intermediários, em torno do teor ótimo, forneceram os maiores valores de módulo de resiliência. Teores extremos, ou seja, o menor e o maior teores adotados no experimento, corresponderam a misturas com os menores valores de módulo de resiliência. Esse comportamento está de acordo com os resultados de Pinto e Preussler (1980), que obtiveram valores decrescentes de MR com o aumento do teor de ligante na mistura, a partir do teor ótimo.

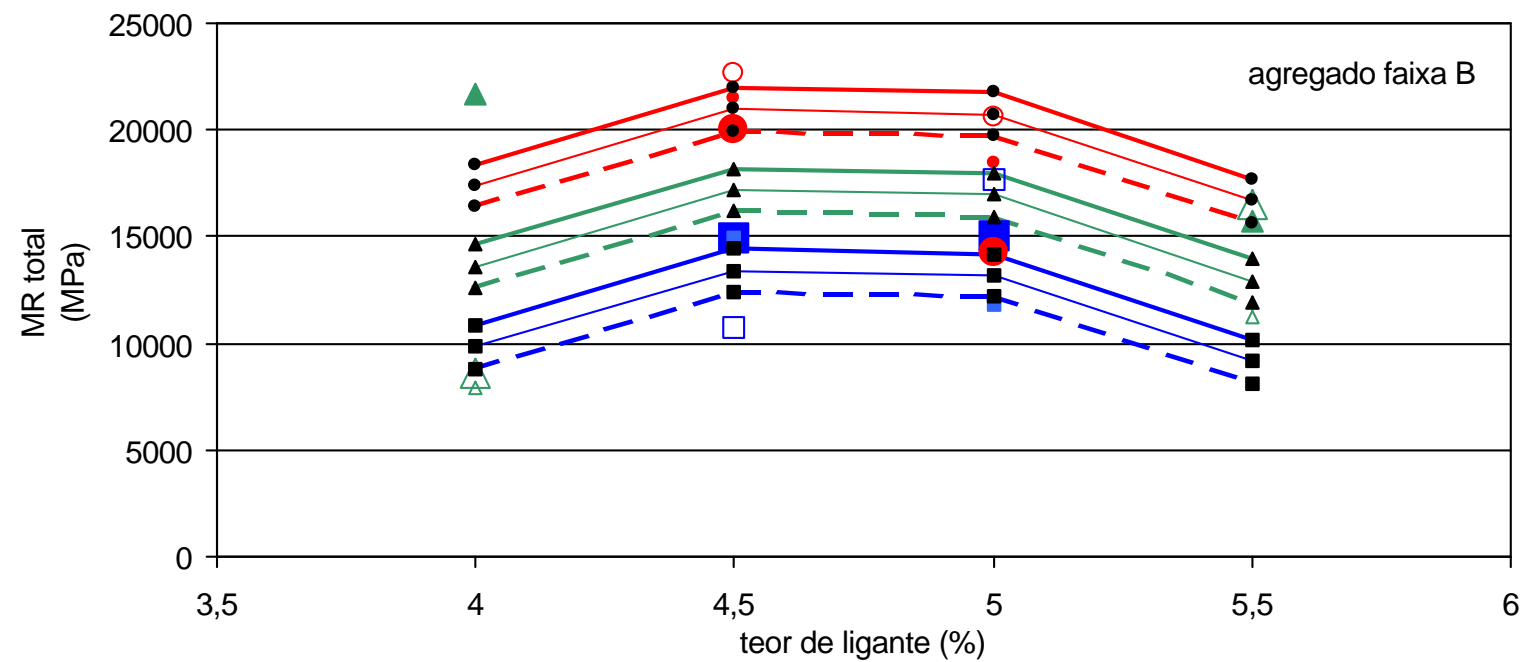

\begin{tabular}{|c|c|}
\hline $\begin{array}{l}- \\
- \\
-\end{array}$ & $\begin{array}{l}\text { asf. com polímero; envelhecimento a longo prazo = não; envelhecimento a curto prazo = não } \\
\text { asf. convencional; envelhecimento a longo prazo = estufa; envelhecimento a curto prazo = não } \\
\text { asf. com borracha; envelhecimento a longo prazo = estufa; envelhecimento a curto prazo = não } \\
\text { asf. com polímero; envelhecimento a longo prazo = exposição ao tempo; envelhecimento a curto prazo = não } \\
\text { asf. com borracha; envelhecimento a longo prazo = não; envelhecimento a curto prazo = 4h em estufa } \\
\text { asf. convencional; envelhecimento a longo prazo = não; envelhecimento a curto prazo = 4h em estufa } \\
\text { asf. com polímero; envelhecimento a longo prazo = estufa; envelhecimento a curto prazo = } 4 \mathrm{~h} \text { em estufa } \\
\text { asf. convencional; envelhecimento a longo prazo = exposição ao tempo; envelhecimento a curto prazo = } 4 \mathrm{~h} \text { em estufa } \\
\text { asf. com borracha; envelhecimento a longo prazo = exposição ao tempo; envelhecimento a curto prazo = 4h em estufa } \\
\text { - modelo para asf. convencional e mistura não envelhecida a longo prazo } \\
\text { - modelo para asf. convencional e mistura envelhecida a longo prazo em estufa } \\
\text { - modelo para asf. convencional e mistura envelhecida a longo prazo por exposição ao tempo } \\
\text { - modelo para asf. com polímero e mistura não envelhecida a longo prazo } \\
\text { - modelo para asf. com polímero e mistura envelhecida a longo prazo em estufa } \\
\text { - modelo para asf. com polímero e mistura envelhecida a longo prazo por exposição ao tempo }\end{array}$ \\
\hline
\end{tabular}

Figura 6.7 - Pontos experimentais e modelos de comportamento referentes ao MR total em função do teor de ligante, do tipo de ligante e da condição de envelhecimento a longo prazo, para a faixa granulométrica B, considerando-se confiança de $95 \%$ 

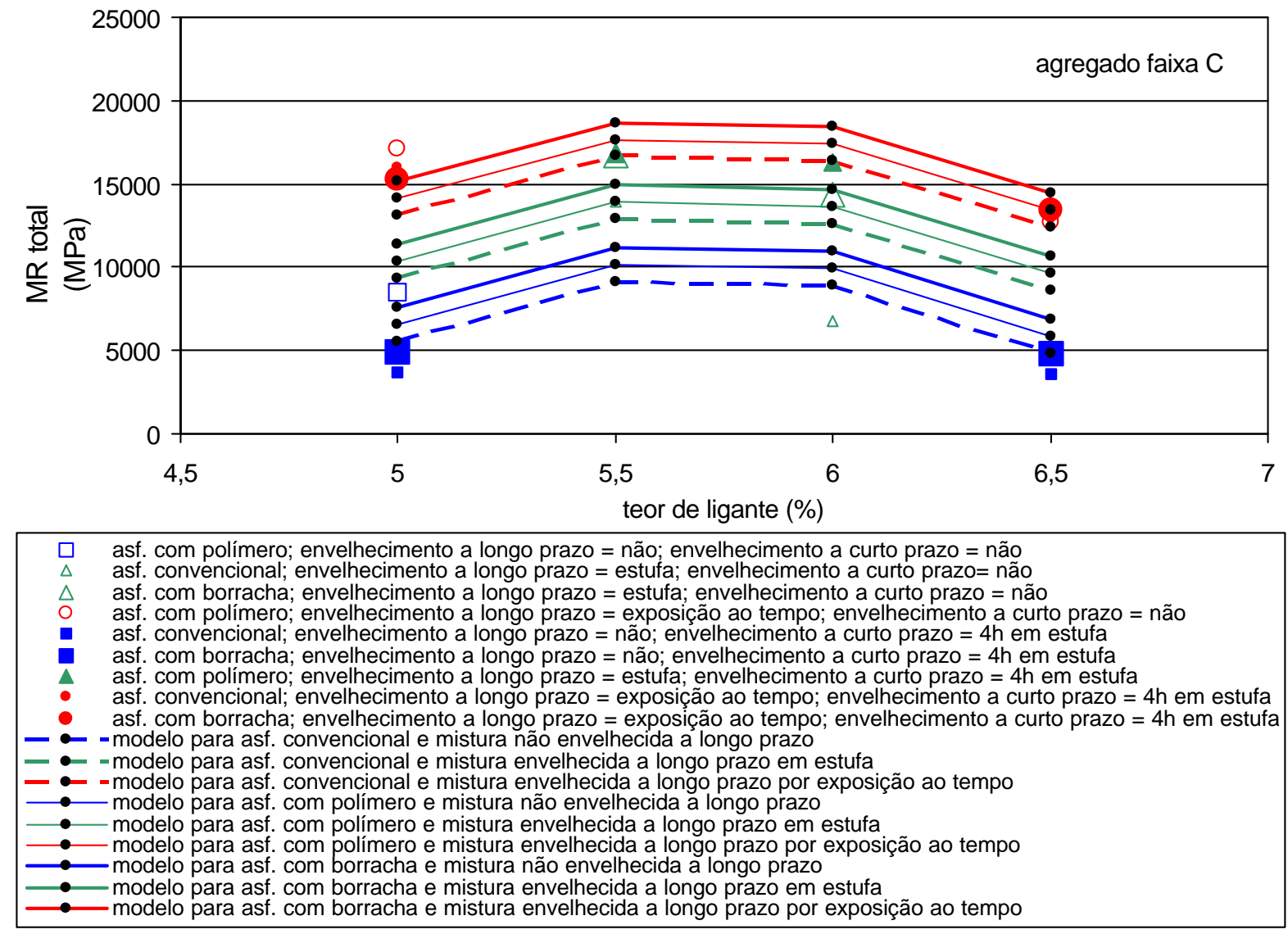

Figura 6.8 - Pontos experimentais e modelos de comportamento referentes ao MR total em função do teor de ligante, do tipo de ligante e da condição de envelhecimento a longo prazo, para a faixa granulométrica C, considerando-se confiança de $95 \%$

Quanto à influência do tipo de asfalto, considerada significativa na análise realizada para uma confiança de 95\%, ligantes asfálticos modificados com borracha forneceram misturas com valores de módulo de resiliência maiores que os apresentados por misturas compostas por ligantes modificados com polímero, que por sua vez foram maiores que os apresentados por misturas com ligante asfáltico convencional, sem a adição de modificadores.

Esse comportamento salientou o aumento da resistência de misturas asfálticas decorrente da adição de modificadores ao asfalto. Nesse caso específico, a adição de $20 \%$ de borracha moída de pneu surtiu um maior efeito no aumento do módulo de resiliência do que a adição de $4,5 \%$ do polímero SBS.

Em virtude do fracionamento do experimento, o efeito que o tipo de asfalto exerce no envelhecimento a longo prazo das misturas, ou seja, o efeito da interação entre os fatores condição de envelhecimento a longo prazo (fator $B$ ) e tipo de ligante asfáltico 
(fator $C$ ), denominada interação $B C$, encontra-se acoplado ao efeito do fator condição de envelhecimento a curto prazo (fator X8), conforme pode ser observado na Tabela 5.11 do Capítulo 5. Como o fator condição de envelhecimento a curto prazo não demonstrou ter influência significativa na variação do módulo de resiliência das misturas, pela análise realizada nesse experimento, isso significa que não houve uma interação significativa entre os fatores tipo de ligante e condição de envelhecimento a longo prazo, ou seja, a adição de modificadores ao asfalto não interferiu significativamente no processo de envelhecimento a longo prazo sofrido pelas misturas, à luz do ensaio de módulo de resiliência.

Os resultados do módulo de resiliência instantâneo são apresentados nas Figuras 6.9 e 6.11, para a distribuição granulométrica correspondente ao centro da faixa B do DNER (1997), e nas Figuras 6.10 e 6.12, para misturas com distribuição granulométrica correspondente ao centro da faixa C do DNER (1997).
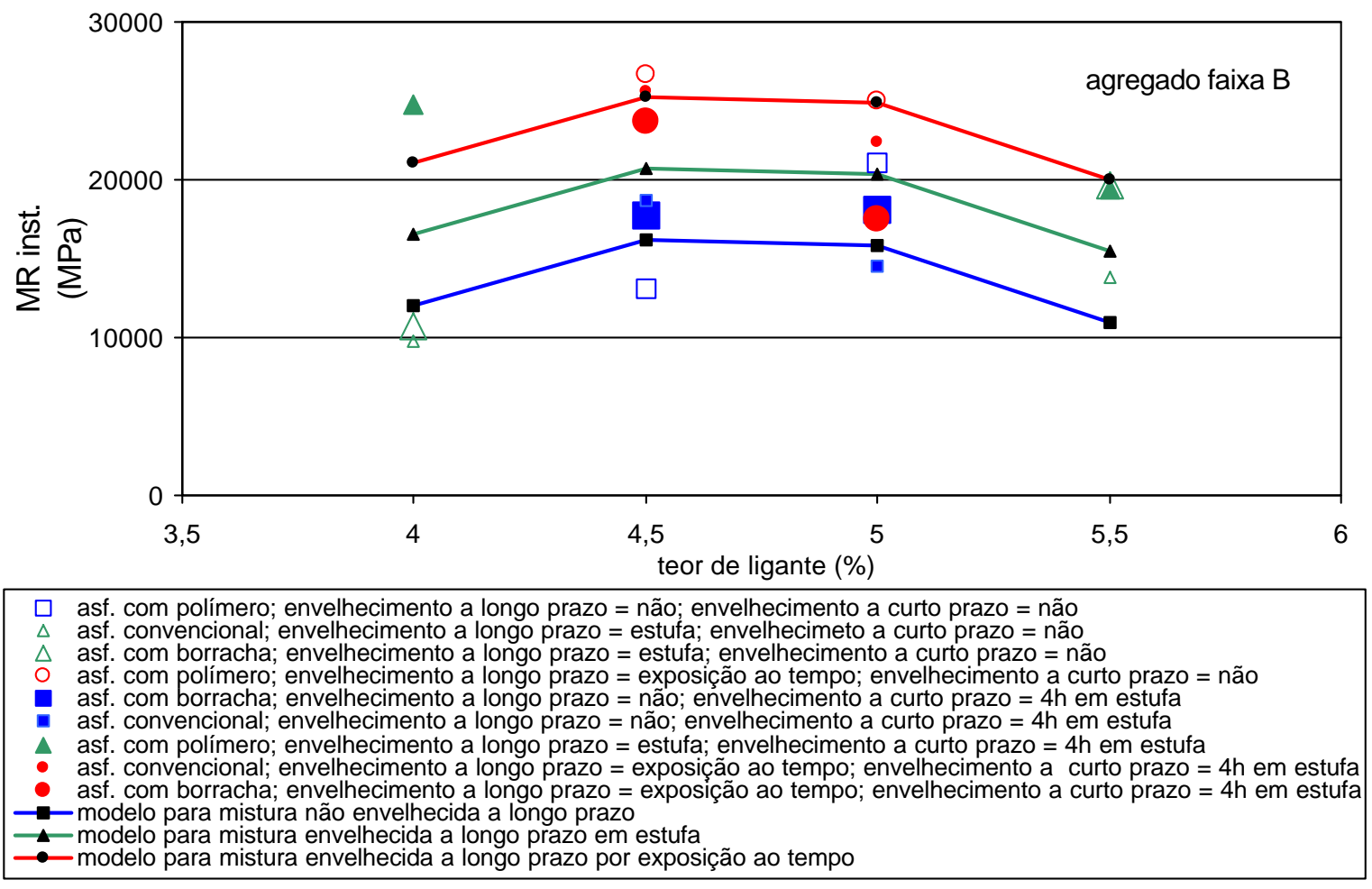

Figura 6.9 - Pontos experimentais e modelos de comportamento referentes ao MR instantâneo em função do teor de ligante e da condição de envelhecimento a longo prazo, para a faixa granulométrica B, considerando-se confiança de $99 \%$ 

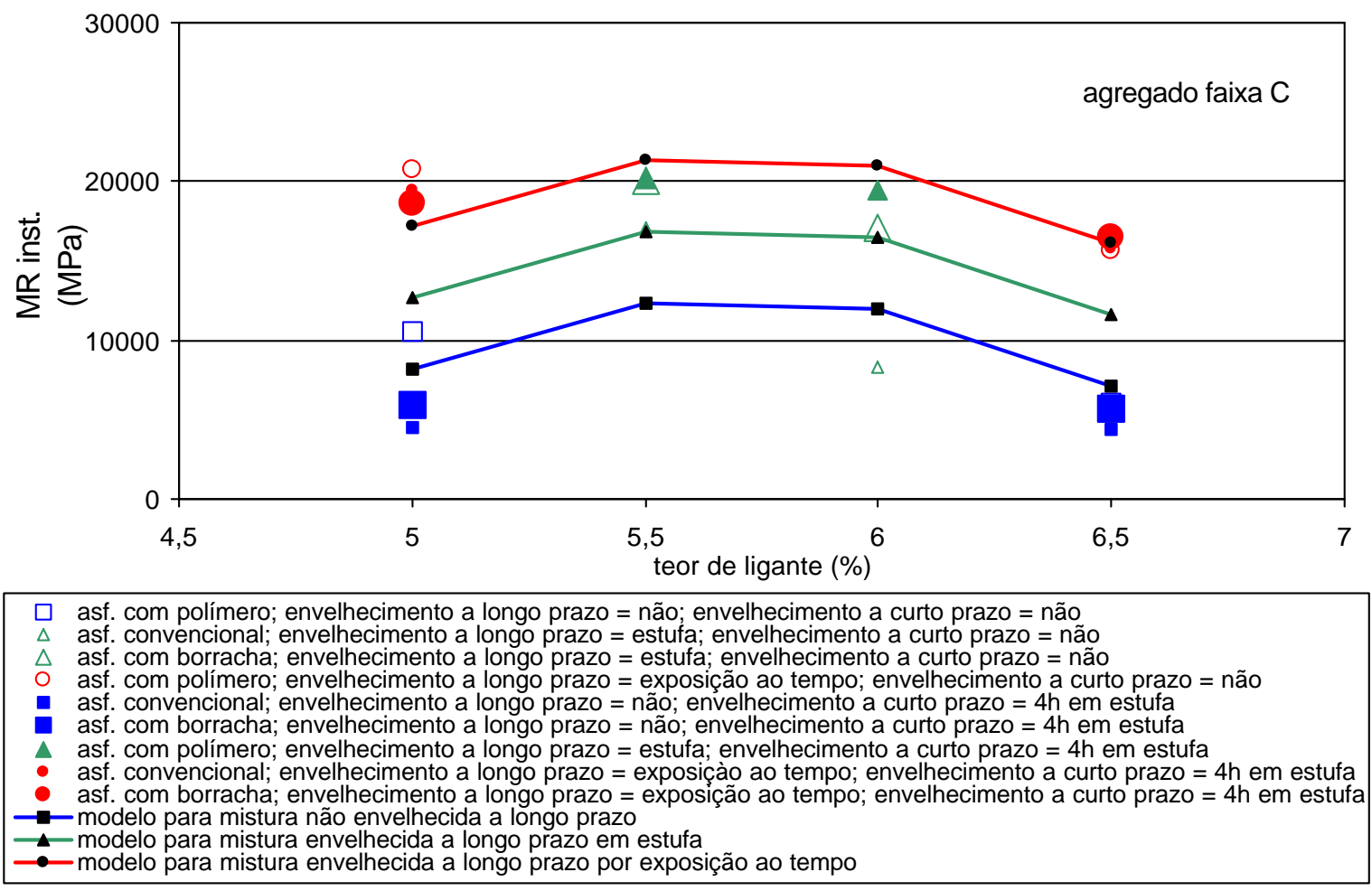

Figura 6.10 - Pontos experimentais e modelos de comportamento referentes ao MR instantâneo em função do teor de ligante e da condição de envelhecimento a longo prazo, para a faixa granulométrica C, considerando-se confiança de $99 \%$
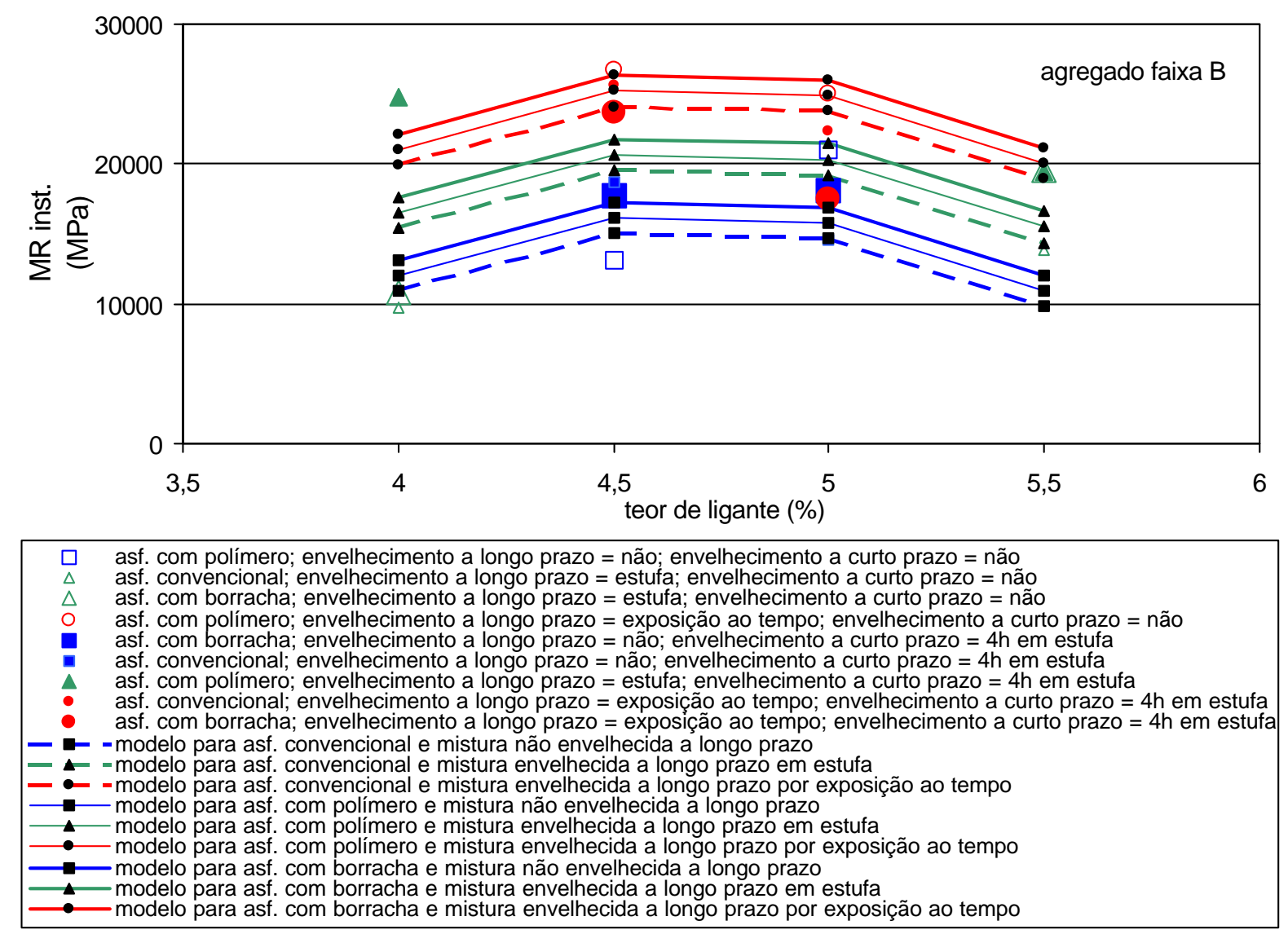

Figura 6.11 - Pontos experimentais e modelos de comportamento referentes ao MR instantâneo em função do teor de ligante, do tipo de ligante e da condição de envelhecimento a longo prazo, para a faixa granulométrica B, considerando-se confiança de $95 \%$ 


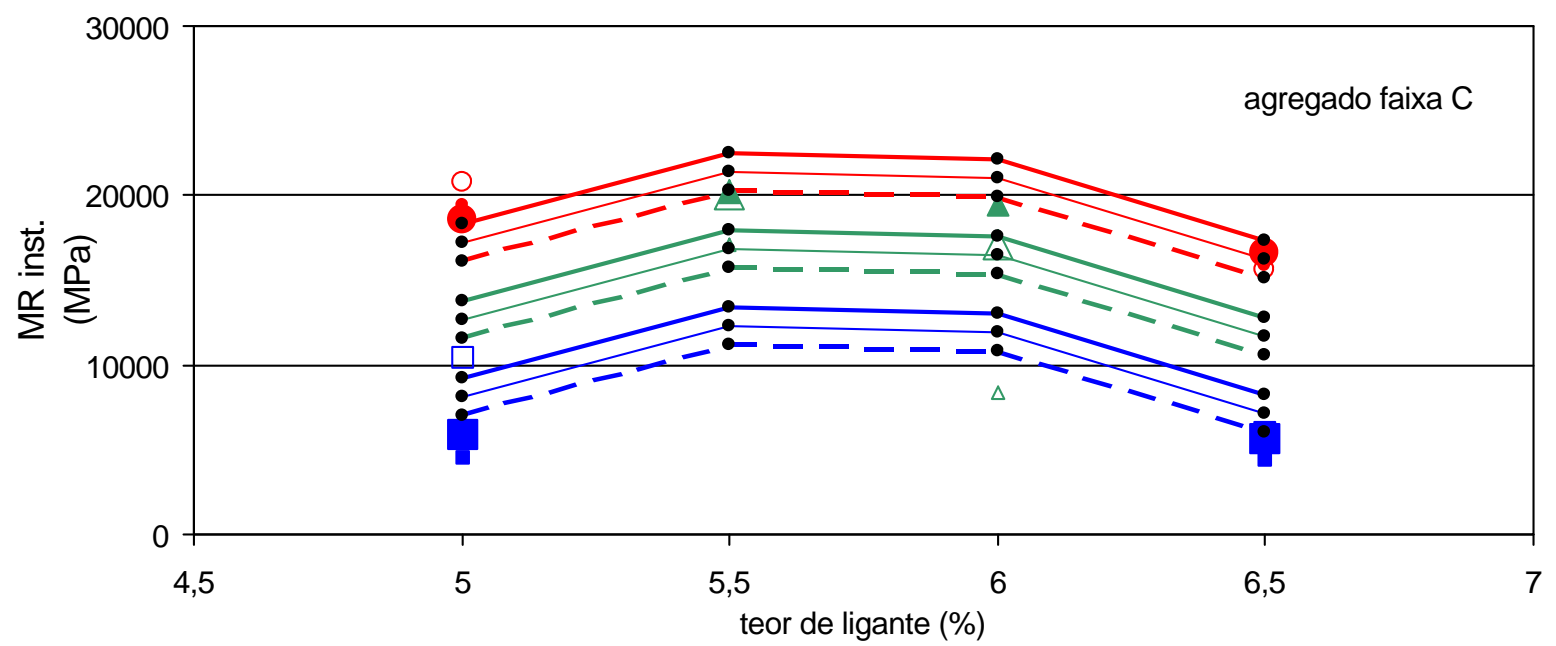

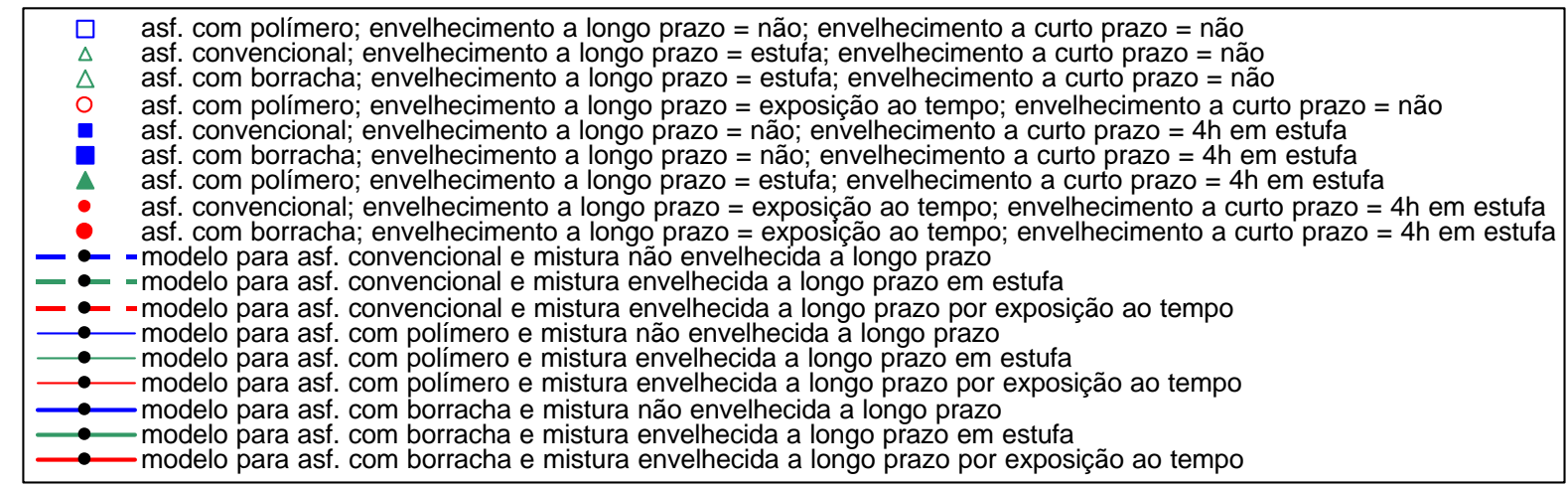

Figura 6.12 - Pontos experimentais e modelos de comportamento referentes ao MR instantâneo em função do teor de ligante, do tipo de ligante e da condição de envelhecimento a longo prazo, para a faixa granulométrica C, considerando-se confiança de $95 \%$

Os gráficos de módulo de resiliência instantâneo são muito semelhantes aos gráficos de módulo de resiliência total, podendo-se dizer que a única diferença é a magnitude dos valores, que é maior para o módulo de resiliência instantâneo. Embora os valores sejam diferentes, a disposição relativa dos pontos é a mesma. Ou seja, praticamente a única diferença entre os gráficos é a escala do eixo Y correspondente aos valores dos módulos. Dessa forma, a análise é a mesma, considerando-se módulo total ou instantâneo.

Um resumo dos modelos de comportamento para os módulos de resiliência total e instantâneo é apresentado na Tabela 6.5.

A análise da variação do módulo de resiliência em função do volume de vazios gerou modelos de comportamento mais pobres, no sentido de apresentarem coeficientes de determinação inferiores aos apresentados pelos modelos gerados pela análise realizada em função do teor de ligante, e também por terem identificado apenas a influência dos 
fatores condição de envelhecimento a longo prazo e distribuição granulométrica, conforme pode ser observado pelo exposto na Tabela 6.6 e nas Figuras 6.13 a 6.16.

As dificuldades encontradas nas análises realizadas em função do volume de vazios provavelmente se devem à maior dispersão de resultados, decorrente da dificuldade de controle dessa variável. Dadas as características do processo de moldagem dos corpos de prova, houve a possibilidade de se realizar um controle maior do teor de ligante do que do volume de vazios. Isso ocorreu devido à dificuldade de manutenção da temperatura de moldagem e também devido às características intrínsecas do processo de ensaio, que provavelmente interferiram no grau de compactação dos corpos de prova, e consequentemente no volume de vazios das misturas. A influência da variação da temperatura de compactação se fez notar principalmente no caso de misturas compostas por asfalto modificado com borracha, pois a trabalhabilidade dessas misturas é especialmente sensível a variações de temperatura, visto que uma pequena queda da temperatura de compactação provoca um significativo aumento da viscosidade do asfalto-borracha.

Tabela 6.5 - Resumo dos modelos de regressão múltipla determinados através da análise do experimento fatorial fracionário assimétrico $1 / 4\left(4 \times 3^{2} \times 2^{2}\right)$, considerando-se o fator $A$ quantitativo, representando o teor de ligante nas misturas

\begin{tabular}{|c|c|c|c|}
\hline $\begin{array}{c}\text { resposta }(Y) \\
(\mathrm{MPa})\end{array}$ & confiança & $\mathrm{R}^{2}$ & modelo \\
\hline MR total & $99 \%$ & 0,60 & $Y=13522-117 P_{l}(A)-1904 P_{q}(A)+3769 B-1641 X 7$ \\
\hline MR total & $95 \%$ & 0,63 & $\begin{array}{l}Y=13522-117 P_{l}(A)-1904 P_{q}(A)+3769 B+1016 C- \\
-1641 X 7\end{array}$ \\
\hline $\begin{array}{c}\text { MR } \\
\text { instantâneo }\end{array}$ & $99 \%$ & 0,62 & $Y=16340-171 P_{l}(A)-2255 P_{q}(A)+4526 B-1918 X 7$ \\
\hline $\begin{array}{c}\text { MR } \\
\text { instantâneo }\end{array}$ & $95 \%$ & 0,65 & $\begin{array}{l}Y=16340-171 P_{l}(A)-2255 P_{q}(A)+4526 B+1107 C- \\
-1918 X 7\end{array}$ \\
\hline
\end{tabular}

Tabela 6.6 - Resumo dos modelos de regressão múltipla determinados através da análise do experimento fatorial fracionário assimétrico $1 / 4\left(4 \times 3^{2} \times 2^{2}\right)$, para níveis de confiança de 99 ou $95 \%$, considerando-se o fator $A$ qualitativo, representando o volume de vazios nas misturas

\begin{tabular}{ccc}
\hline $\begin{array}{c}\text { resposta }(Y) \\
(\mathrm{MPa})\end{array}$ & $\mathrm{R}^{2}$ & modelo \\
\hline MR total & 0,52 & $Y=13488+3722 B-2276 \times 7$ \\
\hline MR instantâneo & 0,53 & $Y=16302+4471 B-2670 \times 7$
\end{tabular}



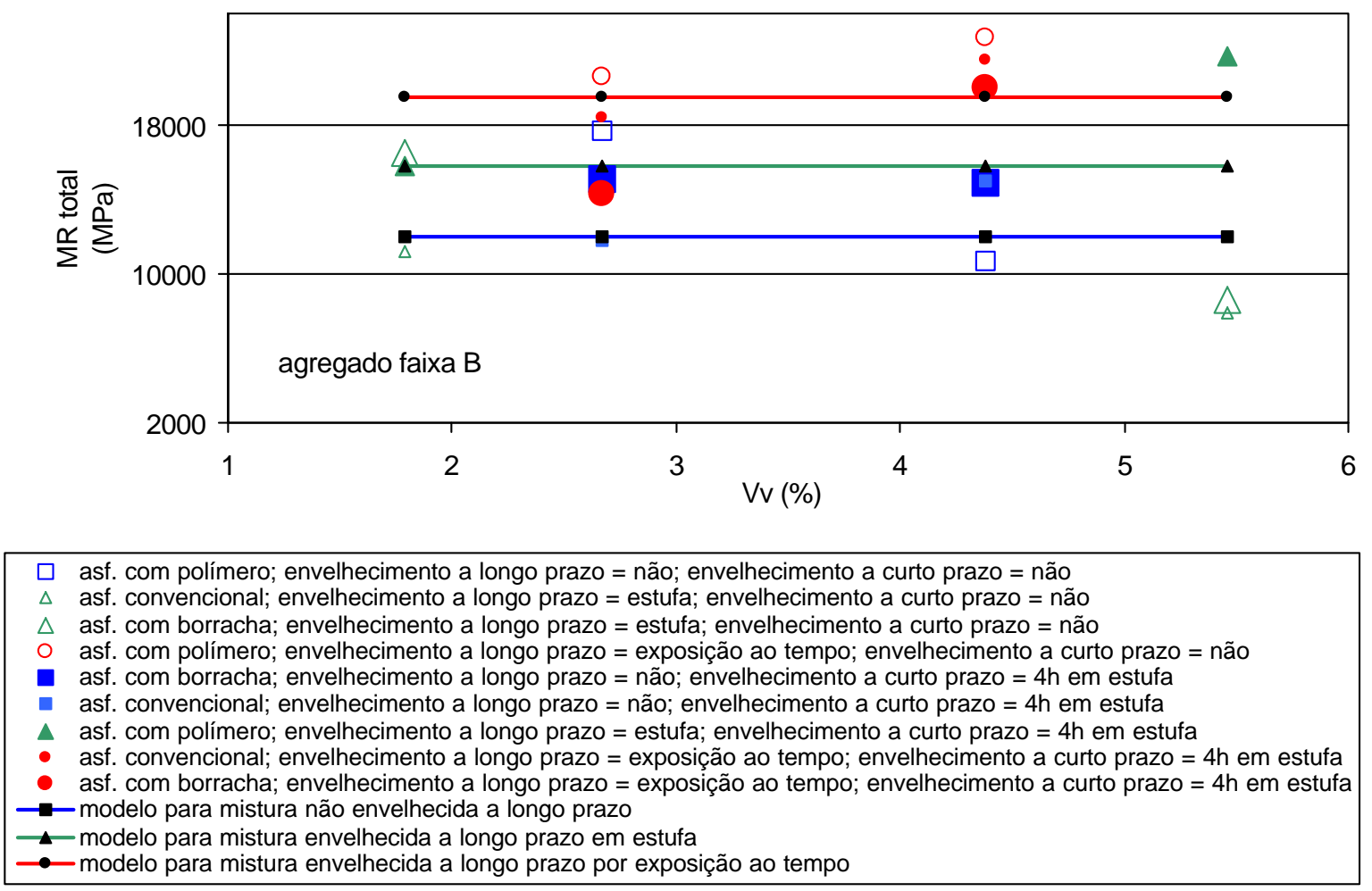

Figura 6.13 - Pontos experimentais e modelos de comportamento referentes ao MR total em função do volume de vazios e da condição de envelhecimento a longo prazo, para a faixa granulométrica B, considerando-se níveis de confiança de $99 \%$ ou $95 \%$

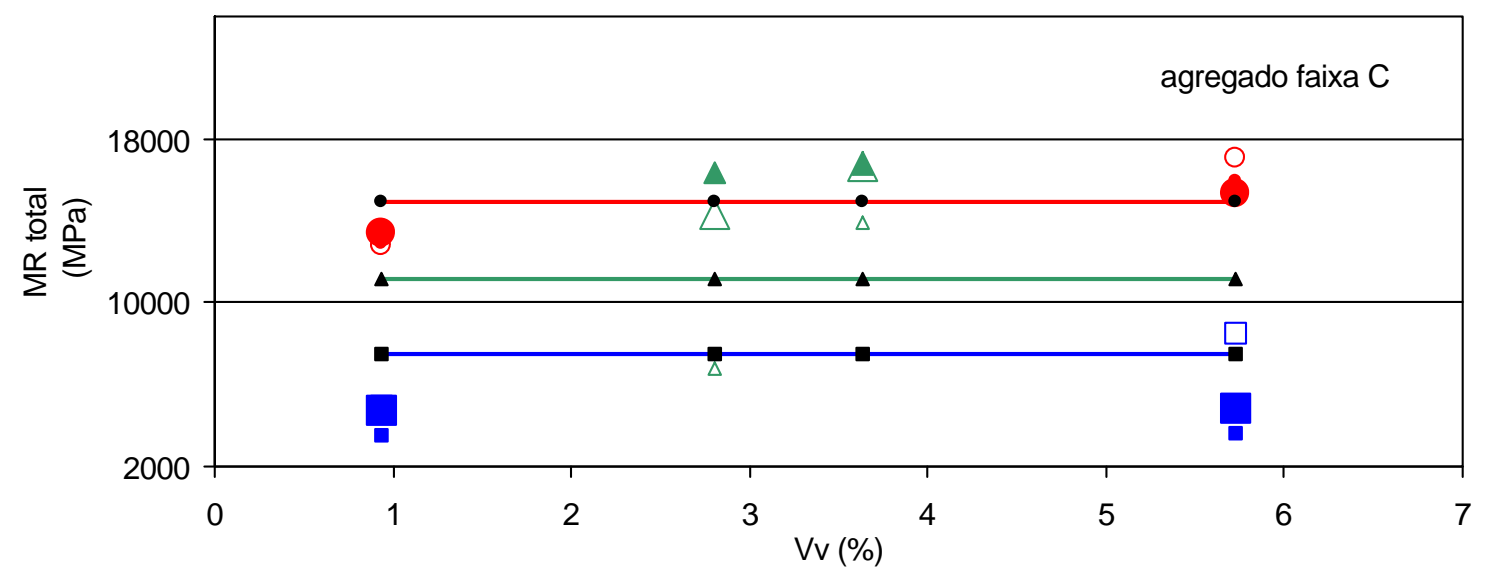

\footnotetext{
$\square$ asf. com polímero; envelhecimento a longo prazo = não; envelhecimento a curto prazo = não

$\Delta$ asf. convencional; envelhecimento a longo prazo $=$ estufa; envelhecimento a curto prazo $=$ não

$\triangle$ asf. com borracha; envelhecimento a longo prazo = estufa; envelhecimento a curto prazo = não

- asf. com polímero; envelhecimento a longo prazo = exposição ao tempo; envelhecimento a curto prazo = não

- asf. convencional; envelhecimento a longo prazo = não; envelhecimento a curto prazo $=4 \mathrm{~h}$ em estufa

asf. com borracha; envelhecimento a longo prazo = não; envelhecimento a curto prazo $=4 \mathrm{~h}$ em estufa

$\Delta$ asf. com polímero; envelhecimento a longo prazo = estufa; envelhecimento a curto prazo $=4 \mathrm{~h}$ em estufa

- asf. convencional; envelhecimento a longo prazo = exposição ao tempo; envelhecimento a curto prazo = 4h em estufa

- asf. com borracha; envelhecimento a longo prazo = exposição ao tempo; envelhecimento a curto prazo = $4 \mathrm{~h}$ em estufa

$\rightarrow$ modelo para mistura não envelhecida a longo prazo

- modelo para mistura envelhecida a longo prazo em estufa

- - modelo para mistura envelhecida a longo prazo por exposição ao tempo
}

Figura 6.14 - Pontos experimentais e modelos de comportamento referentes ao MR total em função do volume de vazios e da condição de envelhecimento a longo prazo, para a faixa granulométrica C, considerando-se níveis de confiança de $99 \%$ ou $95 \%$ 


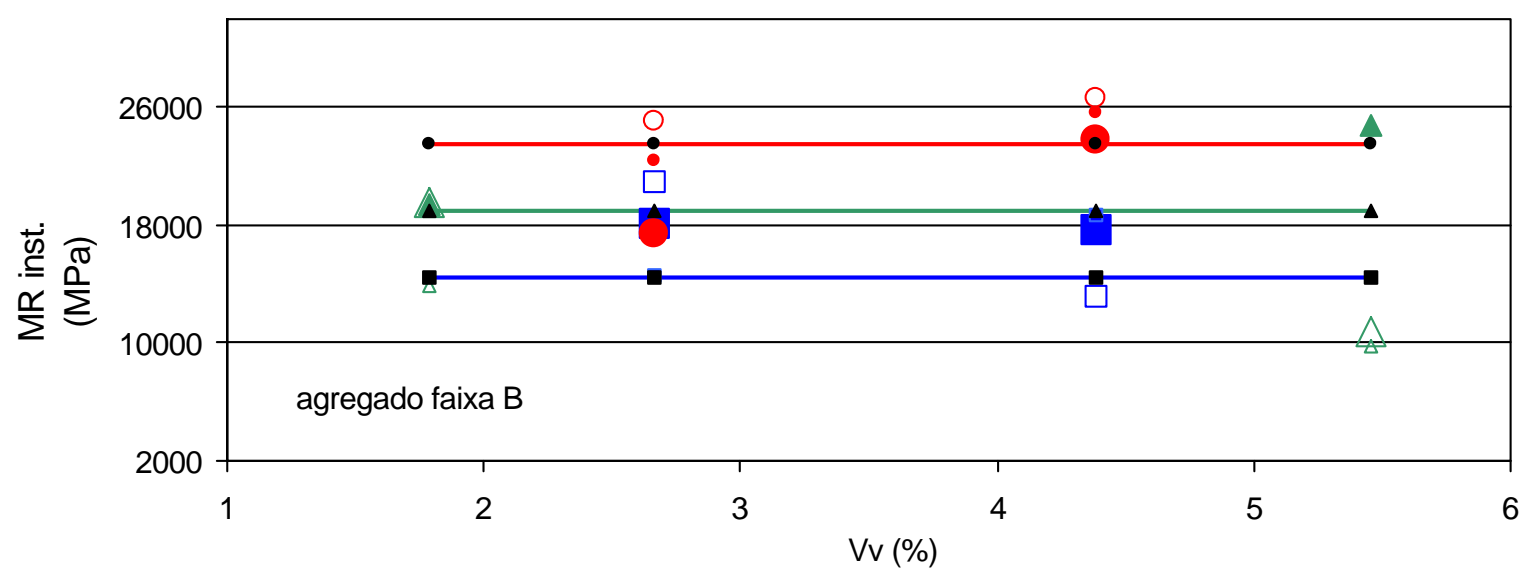

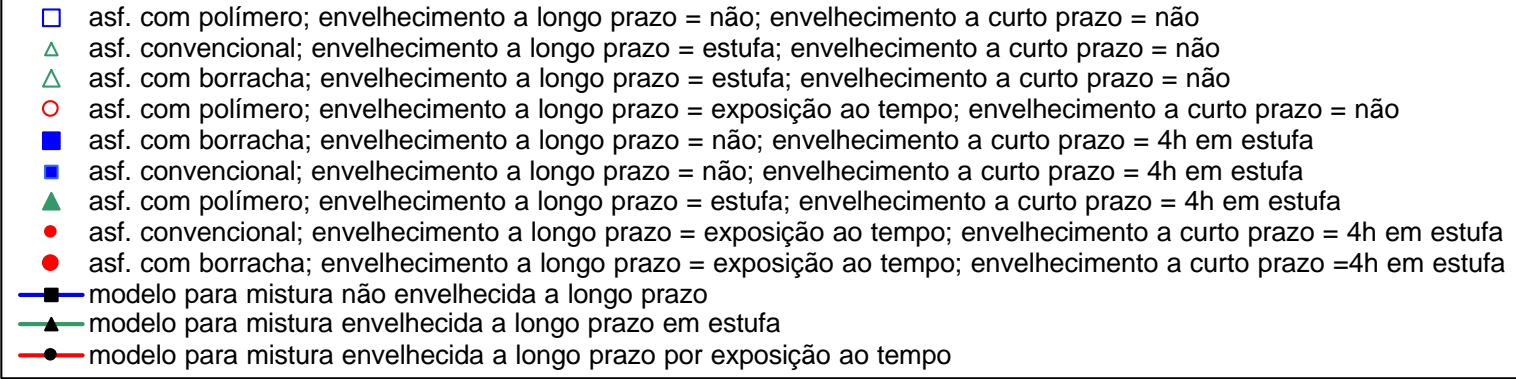

Figura 6.15 - Pontos experimentais e modelos de comportamento referentes ao MR instantâneo em função do volume de vazios e da condição de envelhecimento a longo prazo, para a faixa granulométrica B, considerando-se níveis de confiança de $99 \%$ ou $95 \%$
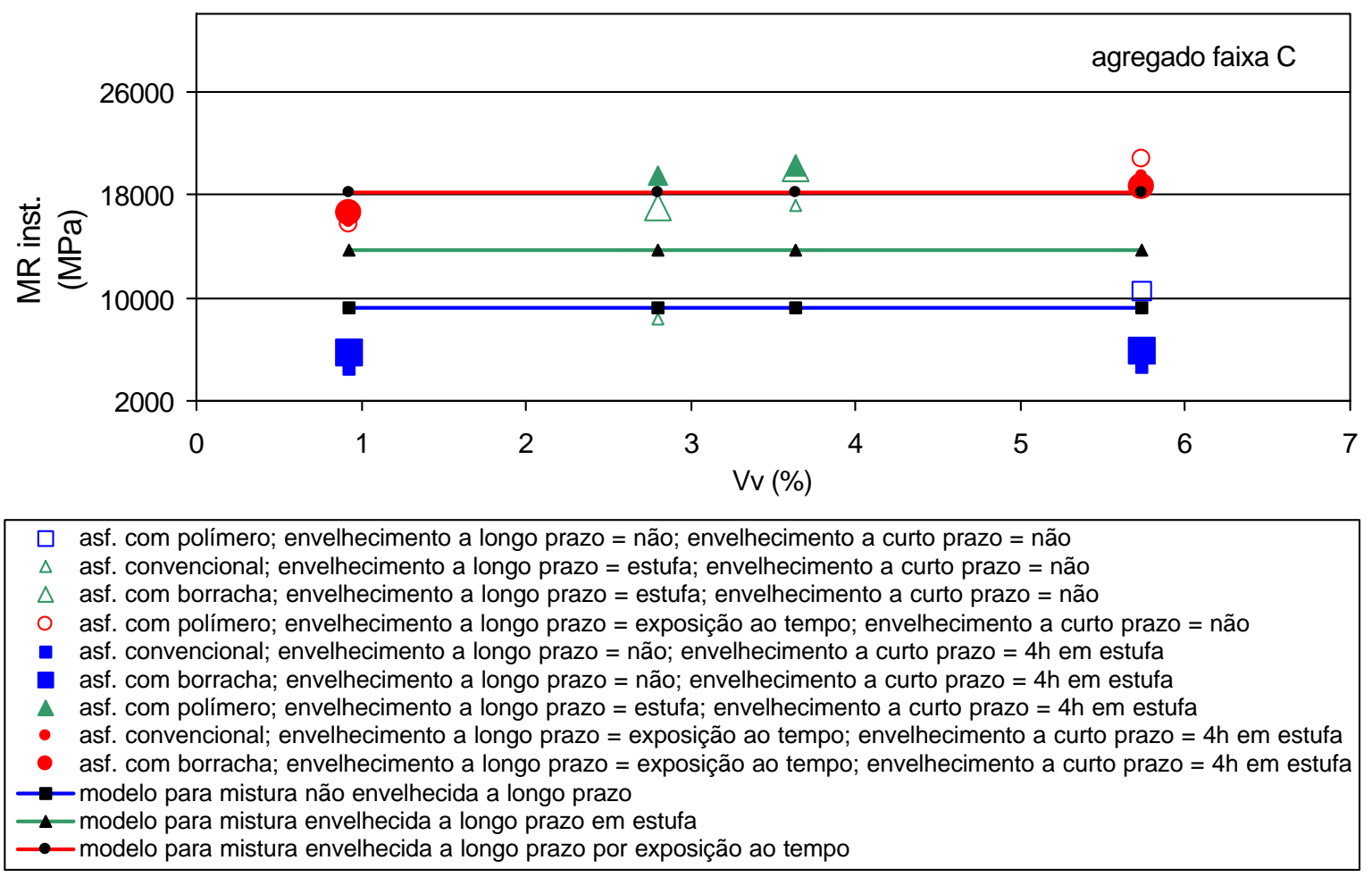

Figura 6.16 - Pontos experimentais e modelos de comportamento referentes ao MR instantâneo em função do volume de vazios e da condição de envelhecimento a longo prazo, para a faixa granulométrica C, considerando-se níveis de confiança de $99 \%$ ou $95 \%$ 
Dessa forma, como os valores de MR não sofreram influência significativa da variação do volume de vazios, optou-se por representar o comportamento dessa variável dependente através de gráficos em colunas, que nesse caso permitem uma visualização mais clara da influência dos fatores considerados significativos, a saber, condição de envelhecimento a longo prazo e distribuição granulométrica do agregado. Nas Figuras 6.17 e 6.18 encontram-se os gráficos indicativos do comportamento do MR total e do MR instantâneo, respectivamente.

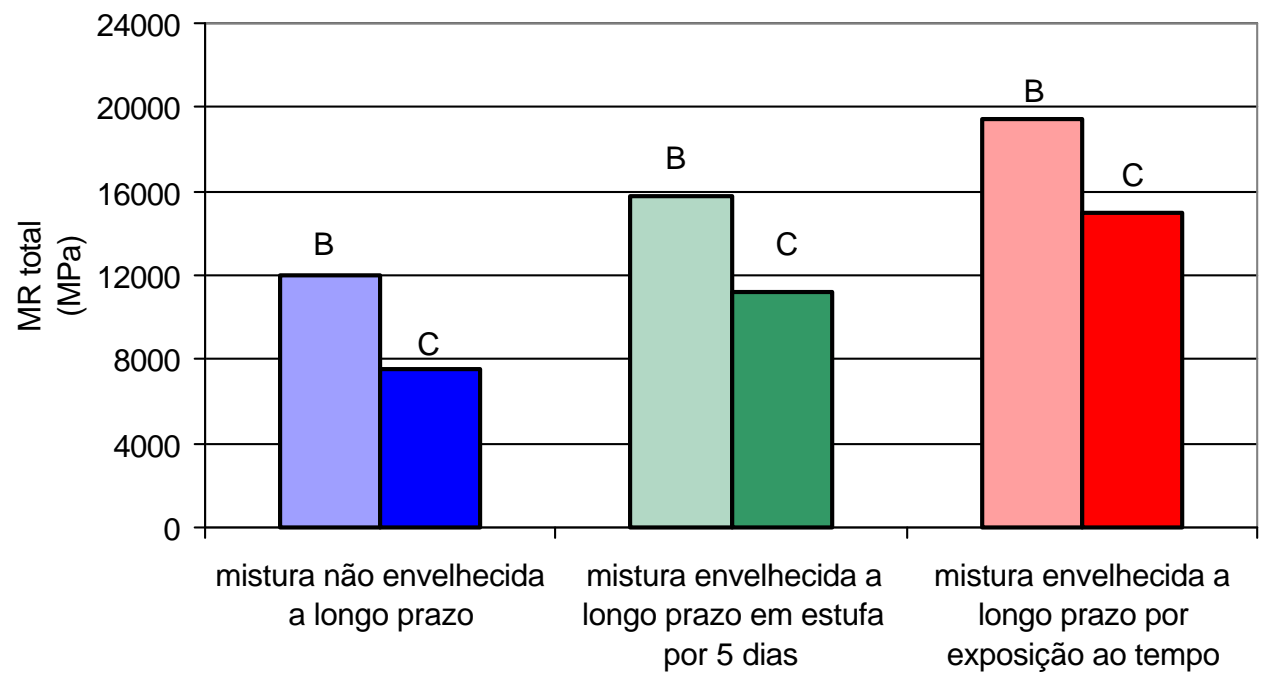

Figura 6.17 - Variação do módulo de resiliência total em função da condição de envelhecimento a longo prazo e da distribuição granulométrica do agregado

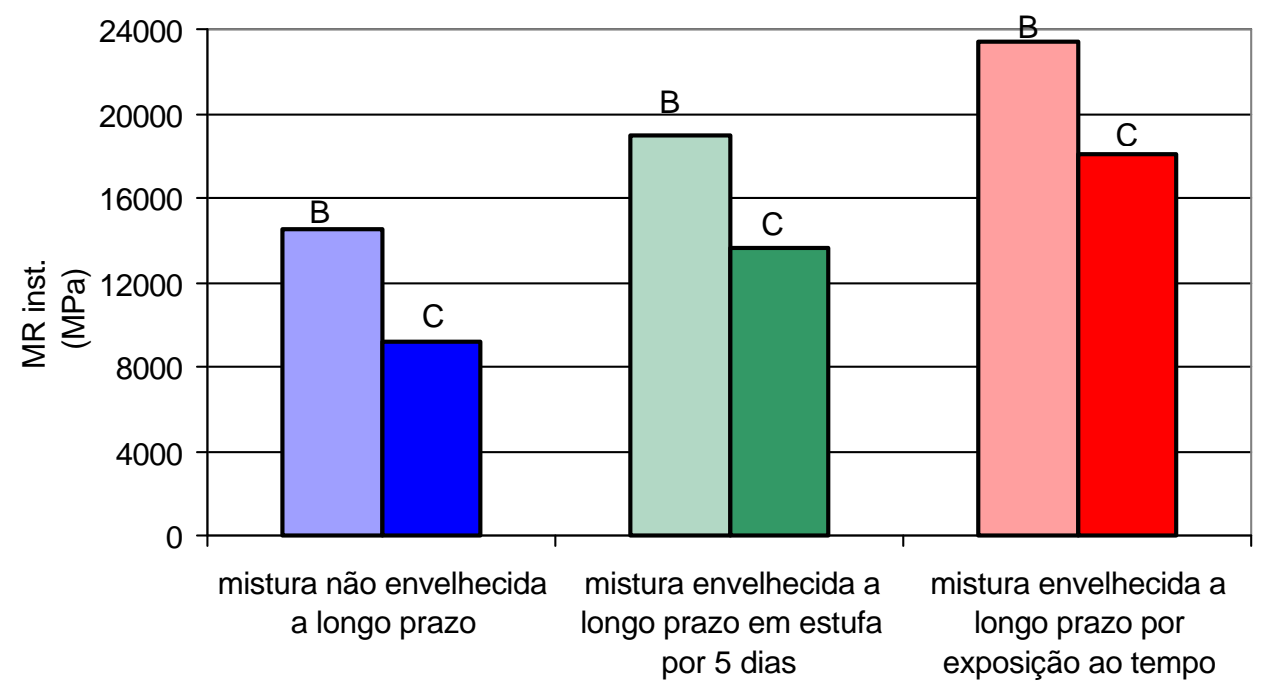

Figura 6.18 - Variação do módulo de resiliência instantâneo em função da condição de envelhecimento a longo prazo e da distribuição granulométrica do agregado 
Em linhas gerais, os principais fatores influentes no comportamento das misturas quanto ao módulo de resiliência foram o teor de ligante, a condição de envelhecimento a longo prazo, o tipo de ligante e a distribuição granulométrica do agregado. O modo como a variação dos três últimos fatores citados interferiu na variação dos valores de módulo de resiliência pode ser resumido pelo exposto nas Tabelas 6.7 a 6.9. A influência do teor de ligante encontra-se ilustrada nos gráficos já apresentados.

Tabela 6.7 - Classificação qualitativa dos valores de MR em função dos níveis do fator $B$

\begin{tabular}{llccc}
\hline & & \multicolumn{3}{c}{ fator $B$} \\
& & \multicolumn{3}{c}{ condição de envelhecimento a longo prazo } \\
\cline { 3 - 5 } resposta & confiança & sem envelhecimento & 5 dias em estufa a & $\begin{array}{c}4 \text { meses de } \\
\text { exposição ao tempo }\end{array}$ \\
\hline MR total & $99 \%$ & menor & intermediário & maior \\
MR total & $95 \%$ & menor & intermediário & maior \\
MR instantâneo & $99 \%$ & menor & intermediário & maior \\
MR instantâneo & $95 \%$ & menor & intermediário & maior \\
\hline
\end{tabular}

Tabela 6.8 - Classificação qualitativa dos valores de MR em função dos níveis do fator $C$

\begin{tabular}{llccc}
\hline & & \multicolumn{3}{c}{$\begin{array}{c}\text { fator } C \\
\text { tipo de ligante }\end{array}$} \\
\cline { 3 - 5 } resposta & confiança & $\begin{array}{c}\text { asfalto } \\
\text { convencional }\end{array}$ & $\begin{array}{c}\text { asfalto modificado } \\
\text { com polímero }\end{array}$ & $\begin{array}{c}\text { asfalto modificado } \\
\text { com borracha }\end{array}$ \\
\hline MR total & $99 \%$ & menor & intermediário & maior \\
MR total & $95 \%$ & menor & intermediário & maior \\
MR instantâneo & $99 \%$ & menor & intermediário & maior \\
MR instantâneo & $95 \%$ & menor & intermediário & maior \\
\hline
\end{tabular}

$\underline{\text { Tabela } 6.9 \text { - Classificação qualitativa dos valores de MR em função dos níveis do fator } X 7}$ fator $X 7$

\begin{tabular}{llcc} 
& & \multicolumn{2}{c}{ distribuição granulométrica } \\
\cline { 3 - 4 } resposta & confiança & centro da faixa B & centro da faixa C \\
\hline MR total & $99 \%$ & maior & menor \\
MR total & $95 \%$ & maior & menor \\
MR instantâneo & $99 \%$ & maior & menor \\
MR instantâneo & $95 \%$ & maior & menor \\
\hline
\end{tabular}

Na Tabela 6.10 são apresentados os valores médios do módulo de resiliência total e do módulo de resiliência instantâneo, bem como os valores das relações $\mathrm{MR}_{\text {total }} / \sigma_{\mathrm{R}} \mathrm{e}$ $\mathrm{MR}_{\mathrm{inst}} / \sigma_{\mathrm{R}}$, para cada uma das condições experimentais testadas em laboratório. Os valores de $\sigma_{\mathrm{R}}$ foram obtidos nas mesmas condições em que foram obtidos os valores de MR. Pode-se observar que, para cerca de metade das condições experimentais, as relações $M R / \sigma_{R}$ são maiores do que as apresentadas na Tabela 4.11 do Capítulo 4 deste trabalho, o que indica a baixa capacidade de recuperação elástica dessas misturas. 
Além disso, comparando-se as relações $M R / \sigma_{R}$ para um mesmo tipo de ligante, pode-se notar que em geral os maiores valores foram obtidos para misturas envelhecidas ao tempo por quatro meses, valores intermediários foram obtidos para misturas envelhecidas em estufa por 5 dias, e os menores valores da relação $M R / \sigma_{R}$ foram apresentados pelas misturas não envelhecidas, indicando a maior capacidade de recuperação elástica das últimas, quando comparadas com misturas envelhecidas.

Tabela 6.10 - Resultados médios de resistência à tração e módulo de resiliência, e relações $\mathrm{MR} / \sigma_{\mathrm{R}}$

\begin{tabular}{|c|c|c|c|c|c|c|c|}
\hline \multirow{2}{*}{$\begin{array}{l}\text { condição } \\
\text { experimental }\end{array}$} & \multicolumn{2}{|c|}{ envelhecimento } & \multirow{2}{*}{$\begin{array}{l}\sigma_{\mathrm{R}} \\
(\mathrm{MPa}) \\
\end{array}$} & \multirow{2}{*}{$\begin{array}{r}\mathrm{MR}_{\text {total }} \\
(\mathrm{MPa})\end{array}$} & \multirow{2}{*}{$\frac{M R_{\text {total }}}{\sigma_{R}}$} & \multirow{2}{*}{$\begin{array}{r}\mathrm{MR}_{\text {inst. }} \\
(\mathrm{MPa})\end{array}$} & \multirow{2}{*}{$\frac{M R_{\text {inst. }}}{\sigma_{R}}$} \\
\hline & longo prazo & curto prazo & & & & & \\
\hline $1-\operatorname{conv} C 0$ & sem env. & 4 horas & 1,970 & 3677 & 1867 & 4561 & 2315 \\
\hline $2-\operatorname{conv}$ B 1 & sem env. & & 2,293 & 14978 & 6533 & 18681 & 8148 \\
\hline $3-\operatorname{conv}$ B 2 & sem env. & 4 horas & 1,754 & 11830 & 6743 & 14536 & 8285 \\
\hline $4-\operatorname{conv} \mathrm{C} 3$ & sem env. & 4 horas & 1,713 & 3570 & 2084 & 4388 & 2561 \\
\hline $5-\operatorname{conv}$ B 0 & 5 dias estufa & $\overline{\mathrm{sem} \epsilon}$ & 1,462 & 7883 & 5391 & 9734 & 6657 \\
\hline $6-\operatorname{conv} C 1$ & 5 dias e & sem & 1,739 & 13916 & 8004 & 17094 & 9832 \\
\hline $7-\operatorname{conv} C 2$ & 5 dias e & sem & 1,713 & 6768 & 3951 & 8336 & 4866 \\
\hline $8-\operatorname{conv}$ B 3 & 5 dias estufa & sem & 2,146 & 11221 & 5228 & 13842 & 6449 \\
\hline $13-\operatorname{conv} \mathrm{C} 0$ & 4 meses & 4 ho & 1,854 & 15945 & 8600 & 19401 & 10464 \\
\hline $14-\operatorname{conv} B 1$ & & $4 \mathrm{~h}$ & 2,210 & 21460 & 9711 & 25591 & 11580 \\
\hline $15-\operatorname{conv}$ B 2 & $4 \mathrm{~ms}$ & $4 \mathrm{~h}$ & 1,890 & 18426 & 9751 & 22340 & 11822 \\
\hline $16-\operatorname{conv} \mathrm{C} 3$ & $4 \mathrm{me}$ & $4 \mathrm{hc}$ & 1,794 & 12890 & 7185 & 15829 & 8824 \\
\hline $17-$ pol C 0 & sem env. & sem env. & $\overline{2,222}$ & 8471 & $\overline{3813}$ & 10495 & 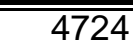 \\
\hline $18-$ pol B 1 & & sem & 2,204 & 10729 & 4868 & 13120 & 5953 \\
\hline $19-$ pol B 2 & & sem & 2,596 & 17712 & 6823 & 21022 & 8098 \\
\hline $20-$ pol C 3 & v. & sem & 2,108 & 4908 & 2328 & 6031 & 2861 \\
\hline $21-$ pol B 0 & 5 dias est & 4 horas & 2,328 & 21666 & 9307 & 24782 & 10645 \\
\hline $22-$ pol C 1 & 5 dias & $4 \mathrm{hc}$ & 2,598 & 16786 & 6460 & 20173 & 7764 \\
\hline $23-$ pol C 2 & $5 \mathrm{dia}$ & 4 ho & 2,976 & 16311 & 5482 & 19426 & 6529 \\
\hline $24-$ pol B 3 & 5 dias estufa & 4 horas & 2,333 & 15767 & 6759 & 19393 & 8313 \\
\hline $29-$ pol C 0 & 4 meses & sem env. & 2,219 & 17077 & 7695 & 20804 & 9374 \\
\hline $30-$ pol B 1 & 4 meses & sem env. & 2,232 & 22702 & 10170 & 26692 & 11958 \\
\hline $31-$ pol B 2 & 4 meses & sem env. & 2,322 & 20584 & 8866 & 25052 & 10791 \\
\hline $32-$ pol C 3 & 4 meses & sem env. & 2,219 & 12752 & 5746 & 15632 & 7044 \\
\hline $499-$ bor $C 0$ & sem env. & 4 4 horas & 1,745 & 44882 & 2798 & 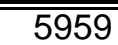 & $\overline{3415}$ \\
\hline $50-$ bor B 1 & sem & 4 horas & 1,773 & 14923 & 8415 & 17697 & 9979 \\
\hline 51 - bor B 2 & sem env. & 4 horas & 2,168 & 15082 & 6957 & 18149 & 8372 \\
\hline $52-$ bor C 3 & sem env. & 4 horas & 2,386 & 4783 & 2004 & 5707 & 2392 \\
\hline $53-$ bor B 0 & 5 dias estufa & sem env. & 1,588 & 8620 & 5429 & 10758 & 6775 \\
\hline $54-$ bor C 1 & 5 dias estufa & sem env. & 2,298 & 16667 & 7251 & 20085 & 8738 \\
\hline $55-$ bor $C 2$ & 5 dias estufa & sem env. & 2,555 & 14325 & 5605 & 17030 & 6664 \\
\hline 56 - bor B 3 & 5 dias estufa & sem env. & 1,768 & 16462 & 9312 & 19586 & 11079 \\
\hline $61-$ bor C 0 & 4 meses & 4 horas & 1,839 & 15306 & 8322 & 18574 & 10099 \\
\hline $62-$ bor B 1 & 4 meses & 4 horas & 2,360 & 20034 & 8490 & 23727 & 10055 \\
\hline 63 - bor B 2 & 4 meses & 4 horas & 2,328 & 14291 & 6138 & 17477 & 7506 \\
\hline $64-$ bor C 3 & 4 meses & 4 horas & 2,520 & 13406 & 5320 & 16539 & 6563 \\
\hline
\end{tabular}




\subsection{Resultados do ensaio de fluência por compressão uniaxial estática}

O ensaio de fluência por compressão uniaxial estática gera uma curva de fluência, que consiste na deformação sofrida pelo corpo de prova em função do tempo de ensaio, a partir da qual podem ser calculados os parâmetros de análise do ensaio. Esses parâmetros são a deformação total do corpo de prova no final do ensaio de fluência; a deformação não recuperável ou deformação viscoplástica, que permanece após o ensaio de recuperação; a deformação recuperável ou deformação elástica, dada pela diferença entre as duas primeiras; a recuperação elástica, relação percentual entre a deformação recuperável e a deformação total; os módulos de fluência após ensaios de fluência e recuperação; e a inclinação da curva de fluência.

O parâmetro módulo de fluência é definido pela relação entre a tensão aplicada e a deformação específica sofrida pelo corpo de prova (VAN DE LOO, 1974), e tem sido muito utilizado como critério para avaliação do potencial de deformação permanente do concreto asfáltico (LITTLE et al., 1993).

O módulo de fluência após ensaio de fluência foi obtido pela relação entre a tensão aplicada e a deformação do corpo de prova após 3600 s de aplicação de carga; o módulo de fluência após ensaio de recuperação foi obtido pela relação entre a tensão aplicada e a deformação remanescente no corpo de prova após o ensaio de recuperação. A inclinação da curva deformação $\times$ tempo, em escala log-log, foi calculada para o trecho entre 1000 s e 3600 s após o início da aplicação de carga.

As respostas do ensaio de creep estático para cada uma das 36 condições experimentais testadas estão relacionadas no Apêndice D e apresentadas em forma de matrizes fatoriais no Apêndice E. Através da análise de variância desses dados determinaram-se os fatores que apresentaram influência significativa em cada uma das respostas ou parâmetros citados. 


\subsubsection{Análise de variância (ANOVA) realizada com os resultados do ensaio de creep estático}

As análises de variância realizadas a partir dos resultados do ensaio de creep estático encontram-se apresentadas nas Tabelas F.9 a F.15 do Apêndice F. Nessas análises, resumidas na Tabela 6.11, o fator $A$ foi considerado um fator quantitativo, representando no caso o teor de ligante asfáltico utilizado na mistura.

Para que o experimento pudesse ser analisado em função da variação do volume de vazios das misturas, também representado pelo fator $A$, este precisou ser considerado como uma variável categórica, uma vez que o espaçamento entre os valores de volume de vazios não é sempre o mesmo. Com esse objetivo, o fator $A$ foi representado por dois fatores qualitativos, $a 1$ e $a 2$. As análises de variância realizadas dessa forma, ou seja, com o fator $A$ representando o volume de vazios das misturas, estão apresentadas nas Tabelas F.16 a F.22 do Apêndice F e resumidas na Tabela 6.12.

Tabela 6.11 - Resumo da análise de variância realizada com os resultados do ensaio de creep estático, considerando-se o fator $A$ (teor de ligante) quantitativo e confiança de $95 \%$ influência significativa?

\begin{tabular}{|c|c|c|c|c|c|c|c|}
\hline resposta & $\begin{array}{c}A \\
\text { teor de } \\
\text { ligante }\end{array}$ & $\begin{array}{c}B \\
\text { condição } \\
\text { de env. a } \\
\text { longo } \\
\text { prazo }\end{array}$ & $\begin{array}{c}C \\
\text { tipo de } \\
\text { ligante }\end{array}$ & $\begin{array}{c}X 7 \\
\text { distribuição } \\
\text { granulomé- } \\
\text { trica }\end{array}$ & $\begin{array}{c}\text { X8 } \\
\text { condição } \\
\text { de env. a } \\
\text { curto } \\
\text { prazo }\end{array}$ & $\begin{array}{c}A C \\
\text { interação } \\
\text { entre os } \\
\text { fatores } A \\
\text { e } C\end{array}$ & $\begin{array}{c}A X 8 \\
\text { interação } \\
\text { entre os } \\
\text { fatores } A \text { e } \\
X 8 \\
\end{array}$ \\
\hline deformação total & sim & não & não & sim & não & não & não \\
\hline $\begin{array}{l}\text { deformação } \\
\text { recuperável }\end{array}$ & $\operatorname{sim}$ & $\operatorname{sim}$ & não & $\operatorname{sim}$ & $\operatorname{sim}$ & não & não \\
\hline $\begin{array}{l}\text { deformação final } \\
\text { (não recuperável) }\end{array}$ & sim & não & $\operatorname{sim}$ & não & não & $\begin{array}{c}\text { sim } \\
\text { (linear) }\end{array}$ & não \\
\hline recuperação & $\begin{array}{c}\text { sim } \\
\text { (linear) }\end{array}$ & $\operatorname{sim}$ & não & não & $\operatorname{sim}$ & não & não \\
\hline $\begin{array}{l}\text { módulo de } \\
\text { fluência }\end{array}$ & $\operatorname{sim}$ & $\operatorname{sim}$ & não & $\operatorname{sim}$ & não & não & não \\
\hline $\begin{array}{l}\text { módulo de } \\
\text { fluência após } \\
\text { recuperação }\end{array}$ & $\operatorname{sim}$ & não & $\operatorname{sim}$ & não & $\operatorname{sim}$ & não & não \\
\hline inclinação & $\begin{array}{c}\text { sim } \\
\text { (linear) }\end{array}$ & $\operatorname{sim}$ & $\operatorname{sim}$ & não & não & não & não \\
\hline
\end{tabular}


Tabela 6.12 - Resumo da análise de variância realizada com os resultados do ensaio creep estático, considerando-se o fator $A$ (volume de vazios) qualitativo e confiança de $95 \%$

\begin{tabular}{|c|c|c|c|c|c|c|c|}
\hline \multirow[b]{2}{*}{ resposta } & \multicolumn{7}{|c|}{ influência significativa? } \\
\hline & $\begin{array}{c}A \\
\text { volume } \\
\text { de } \\
\text { vazios }\end{array}$ & $\begin{array}{c}B \\
\text { condição } \\
\text { de env. a } \\
\text { longo } \\
\text { prazo }\end{array}$ & $\begin{array}{c}C \\
\text { tipo de } \\
\text { ligante }\end{array}$ & $\begin{array}{c}X 7 \\
\text { distribuição } \\
\text { granulomé- } \\
\text { trica }\end{array}$ & $\begin{array}{c}X 8 \\
\text { condição } \\
\text { de env. a } \\
\text { curto } \\
\text { prazo }\end{array}$ & $\begin{array}{c}A C \\
\text { interação } \\
\text { entre os } \\
\text { fatores A } \\
\text { e C }\end{array}$ & $\begin{array}{c}\text { AX8 } \\
\text { interação } \\
\text { entre os } \\
\text { fatores A e } \\
\text { X8 }\end{array}$ \\
\hline deformação total & não & não & não & não & não & não & não \\
\hline $\begin{array}{l}\text { deformação } \\
\text { recuperável }\end{array}$ & não & $\operatorname{sim}$ & não & $\operatorname{sim}$ & sim & não & não \\
\hline $\begin{array}{l}\text { deformação final } \\
\text { (não recuperável) }\end{array}$ & $\operatorname{sim}$ & não & não & não & não & $\operatorname{sim}$ & não \\
\hline recuperação & $\operatorname{sim}$ & $\operatorname{sim}$ & não & não & $\operatorname{sim}$ & não & não \\
\hline $\begin{array}{l}\text { módulo de } \\
\text { fluência }\end{array}$ & não & $\operatorname{sim}$ & não & não & não & não & não \\
\hline $\begin{array}{l}\text { módulo de } \\
\text { fluência após } \\
\text { recuperação }\end{array}$ & não & não & não & não & $\operatorname{sim}$ & não & não \\
\hline inclinação & $\operatorname{sim}$ & não & $\operatorname{sim}$ & não & não & não & não \\
\hline
\end{tabular}

\subsubsection{Apresentação gráfica e modelagem dos resultados do ensaio de creep estático}

A partir da análise de variância realizada foram identificados os fatores cuja variação exerceu influência significativa nos parâmetros de resposta do ensaio de fluência estática. Foram então montados modelos estatísticos de comportamento para cada uma das respostas fornecidas pelo ensaio. Os modelos incluíram apenas os termos correspondentes aos fatores identificados como significativos e encontram-se apresentados nas Tabelas 6.13 e 6.14 .

Os modelos apresentados na Tabela 6.13 foram construídos considerando-se o fator $A$ como um fator quantitativo, representando no caso o teor de ligante asfáltico na mistura. Por outro lado, os modelos apresentados na Tabela 6.14 foram construídos considerando-se o fator $A$ como um fator qualitativo, representando agora o volume de vazios na mistura. 
Tabela 6.13 - Modelos de regressão múltipla determinados através da análise do experimento fatorial fracionário assimétrico $1 / 4\left(4 \times 3^{2} \times 2^{2}\right)$, considerando-se o fator $A$ quantitativo, representando o teor de ligante nas misturas

\begin{tabular}{cc}
\hline resposta $(Y)$ & \multicolumn{1}{c}{ modelo (confiança de 95\%) } \\
\hline $\begin{array}{c}\text { deformação total } \\
(\mathrm{mm} / \mathrm{mm})\end{array}$ & $Y=0,00346+0,00030 P_{l}(A)+0,00046 P_{q}(A)-0,00038 P(X 7)$ \\
$\mathrm{R}^{2}=0,31$ & \\
\hline $\begin{array}{c}\text { deformação recuperável } \\
(\mathrm{mm} / \mathrm{mm})\end{array}$ & $Y=0,0021+0,00004 P_{l}(A)+0,00026 P_{q}(A)+0,00023 P(B)-$ \\
$\mathrm{R}^{2}=0,44$ & $-0,00025 P(X 7)-0,000178 P(X 8)$ \\
\hline $\begin{array}{c}\text { recuperação } \\
(\%)\end{array}$ & $Y=61-3,25 P_{l}(A)+4,24 P(B)-1,92 P(X 8)$ \\
$\mathrm{R}^{2}=0,43$ & \\
\hline módulo de fluência & $Y=121,3-7,6 P_{l}(A)-17,8 P_{q}(A)-11,5 P(B)+10,6 P(X 7)$ \\
$(\mathrm{MPa})$ & \\
$\mathrm{R}^{2}=0,35$ & $Y=0,0947+0,0154 P_{l}(A)+0,0085 P(B)+0,0218 P(C)$ \\
inclinação & \\
$\mathrm{R}^{2}=0,45$ &
\end{tabular}

Tabela 6.14 - Modelos de regressão múltipla determinados através da análise do experimento fatorial fracionário assimétrico $1 / 4\left(4 \times 3^{2} \times 2^{2}\right)$, considerando-se o fator $A$ qualitativo, representando o volume de vazios nas misturas

\begin{tabular}{cl}
\hline resposta $(Y)$ & \multicolumn{1}{c}{ modelo (confiança de 95\%) } \\
\hline $\begin{array}{c}\text { deformação recuperável } \\
(\mathrm{mm} / \mathrm{mm})\end{array}$ & $Y=0,0021+0,000226 P(B)-0,000166 P(X 7)-$ \\
$\mathrm{R}^{2}=0,27$ & $-0,000178 P(X 8)$ \\
\hline $\begin{array}{c}\text { recuperação } \\
(\%)\end{array}$ & $Y=60,8-2,5 a_{1}-1,4 a_{2}+4,2 P(B)-1,9 P(X 8)$ \\
$\mathrm{R}^{2}=0,42$ & \\
módulo de fluência & $Y=122-13,2 P(B)$ \\
$($ MPa) & \\
$\mathrm{R}^{2}=0,23$ & $Y=0,094+0,010 a_{1}+0,0063 a_{2}+0,021 P(C)$ \\
inclinação & \\
$\mathrm{R}^{2}=0,44$ & \\
\hline
\end{tabular}

Os pontos experimentais, que consistem nas respostas do ensaio para cada uma das 36 condições experimentais que constituem o experimento fatorial fracionário em questão, foram apresentados graficamente em função do teor de ligante asfáltico nas Figuras $6.19,6.20,6.23,6.24,6.29,6.30,6.33,6.34,6.37,6.38,6.42,6.43,6.46$ e 6.47. Nas Figuras 6.19, 6.23, 6.29, 6.33, 6.37, 6.42 e 6.46 são apresentados os resultados de deformação total, deformação recuperável, deformação não recuperável, recuperação, módulo de fluência após ensaio de fluência, módulo de fluência após ensaio de recuperação e inclinação, respectivamente, para misturas com distribuição granulométrica do agregado correspondente ao centro da faixa B. Nas Figuras 6.20, $6.24,6.30,6.34,6.38,6.43$ e 6.47 são apresentadas as respectivas respostas para 
misturas com distribuição granulométrica do agregado correspondente ao centro da faixa C. Nessas figuras podem ser observados também modelos estatísticos de comportamento para as variáveis de resposta, apresentados na forma de linhas contínuas ou tracejadas, conforme especificações das legendas.

Nas Figuras 6.21, 6.22, 6.25, 6.26, 6.31, 6.32, 6.35, 6.36, 6.39, 6.40, 6.44, 6.45, 6.48 e 6.49, os resultados do ensaio de creep estático são apresentados em função do volume de vazios. Os resultados de deformação total, deformação recuperável, deformação não recuperável, recuperação, módulo de fluência após ensaio de fluência, módulo de fluência após ensaio de recuperação e inclinação podem ser encontrados nas Figuras $6.21,6.25,6.31,6.35,6.39,6.44$ e 6.48, respectivamente, para misturas com distribuição granulométrica do agregado correspondente ao centro da faixa B. Nas Figuras 6.22, 6.26, 6.32, 6.36, 6.40, 6.45 e 6.49 são apresentadas as respectivas respostas para misturas com distribuição granulométrica do agregado correspondente ao centro da faixa $\mathrm{C}$.

Os resultados de deformação total foram apresentados graficamente nas Figuras 6.19 a 6.22. Nas Figuras 6.19 e 6.20 as deformações totais foram lançadas em função do teor de ligante, para distribuições granulométricas do agregado correspondentes aos centros das faixas B e C do DNER (1997), respectivamente. Em ambas as figuras foram incluídas as curvas dos modelos de comportamento para as faixas B e C, com finalidade de observação da disposição relativa entre elas. 

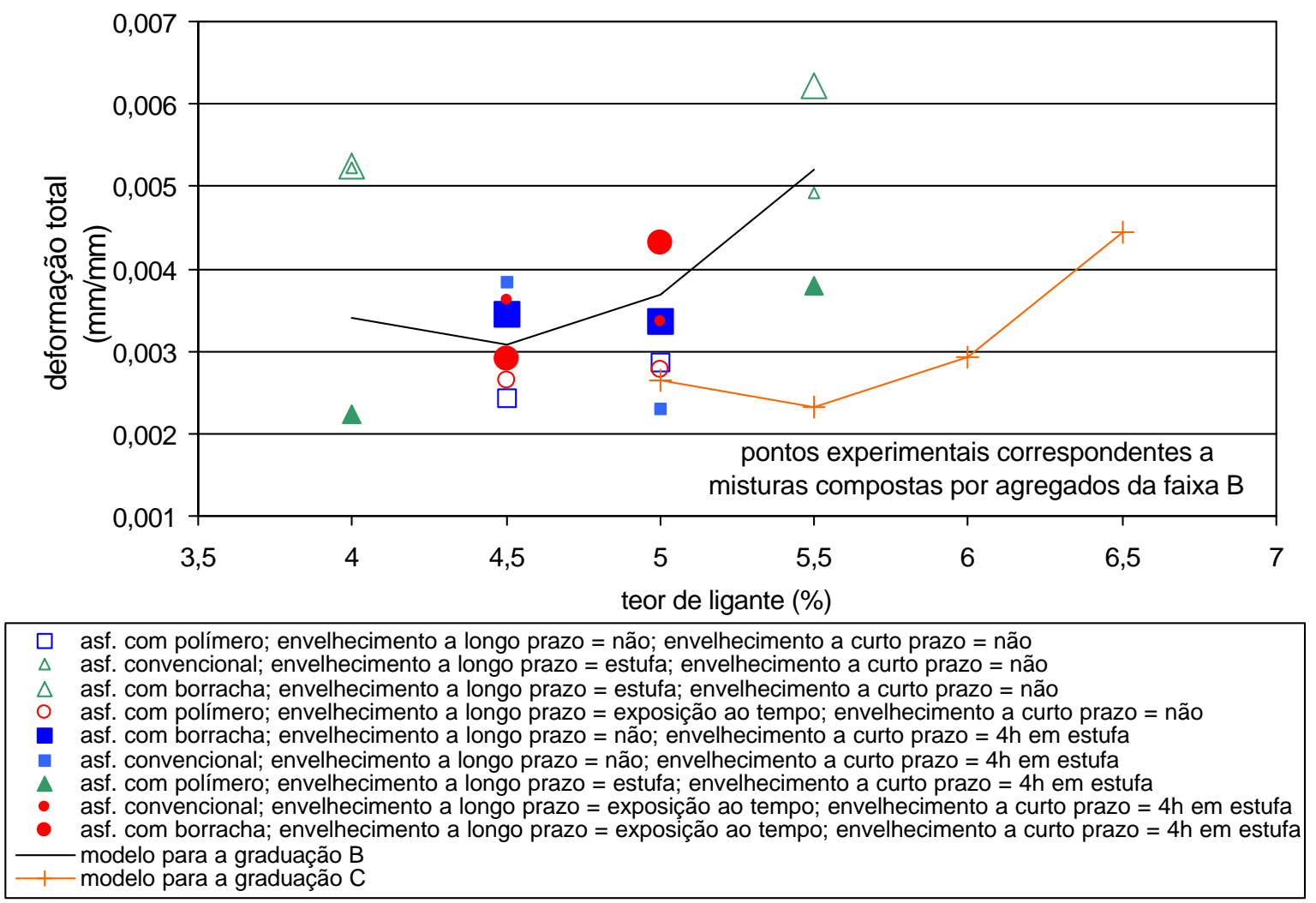

Figura 6.19 - Pontos experimentais e modelos de comportamento referentes à deformação total em função do teor de ligante, para a faixa granulométrica B, considerando-se confiança de $95 \%$

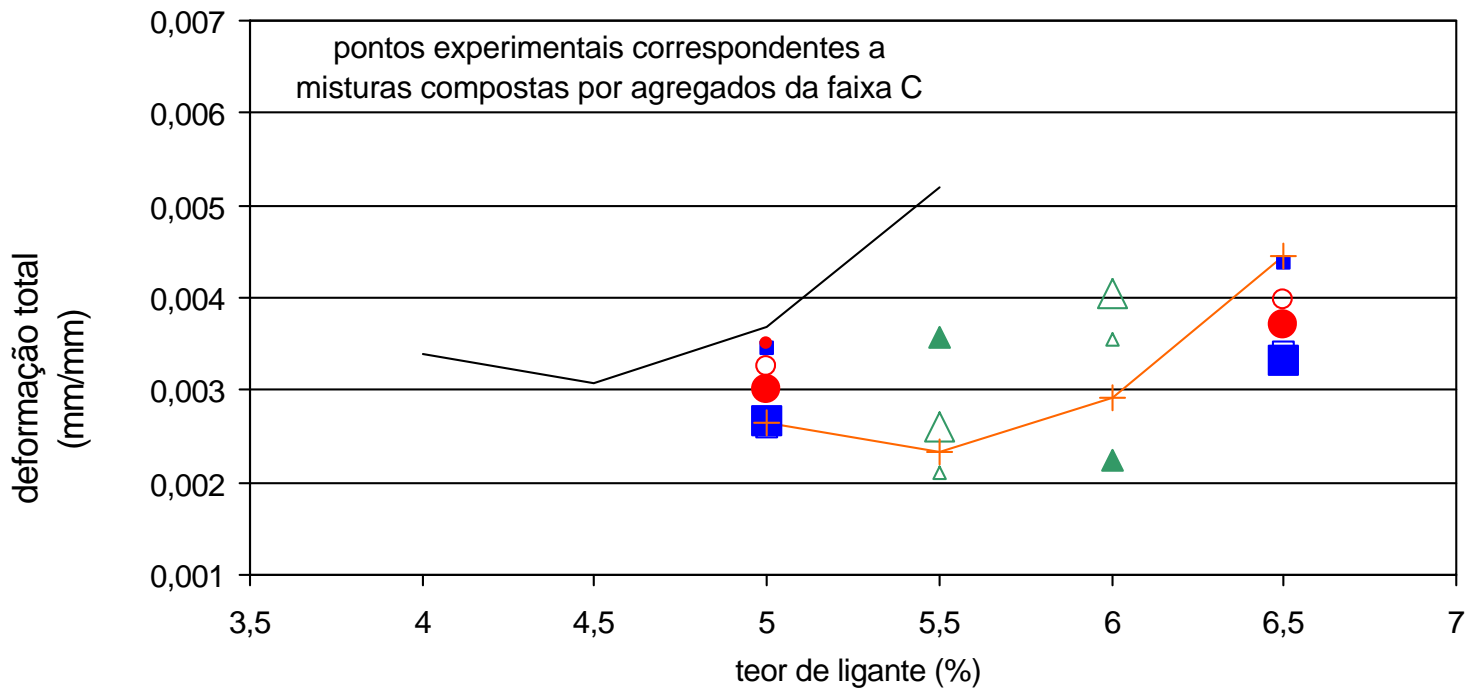

\footnotetext{
$\square$ asf. com polímero; envelhecimento a longo prazo = não; envelhecimento a curto prazo = não asf. convencional; envelhecimento a longo prazo = estufa; envelhecimento a curto prazo = não

asf. com borracha; envelhecimento a longo prazo = estufa; envelhecimento a curto prazo = não

asf. com polímero; envelhecimento a longo prazo = exposição ao tempo; envelhecimento a curto prazo = não

asf. convencional; envelhecimento a longo prazo = não; envelhecimento a curto prazo $=4 \mathrm{~h}$ em estufa

asf com borracha; envelhecimento a longo prazo = não; envelhecimento a curto prazo $=4 \mathrm{~h}$ em estufa

asf. com polímero; envelhecimento a longo prazo = estufa; envelhecimento a curto prazo $=4 \mathrm{~h}$ em estufa

asf. convencional; envelhecimento a longo prazo = exposição ao tempo; envelhecimento a curto prazo = $4 \mathrm{~h}$ em estufa asf. com borracha; envelhecimento a longo prazo = exposição ao tempo; envelhecimento a curto prazo $=4 \mathrm{~h}$ em estufa modelo para a graduação $\mathrm{C}$

modelo para a graduação B
}

Figura 6.20 - Pontos experimentais e modelos de comportamento referentes à deformação total em função do teor de ligante, para a faixa granulométrica C, considerando-se confiança de 95\% 
Nas Figuras 6.21 e 6.22 as deformações totais foram lançadas graficamente em função do volume de vazios na mistura, também para as distribuições granulométricas B e C, respectivamente. Nessas figuras não foram apresentadas curvas de modelo de comportamento, uma vez que não foi possível estabelecer um modelo estatístico de comportamento para a variável dependente deformação total, quando uma das variáveis independentes consideradas foi o volume de vazios. Dessa forma, nessas figuras foram lançados apenas os pontos experimentais.

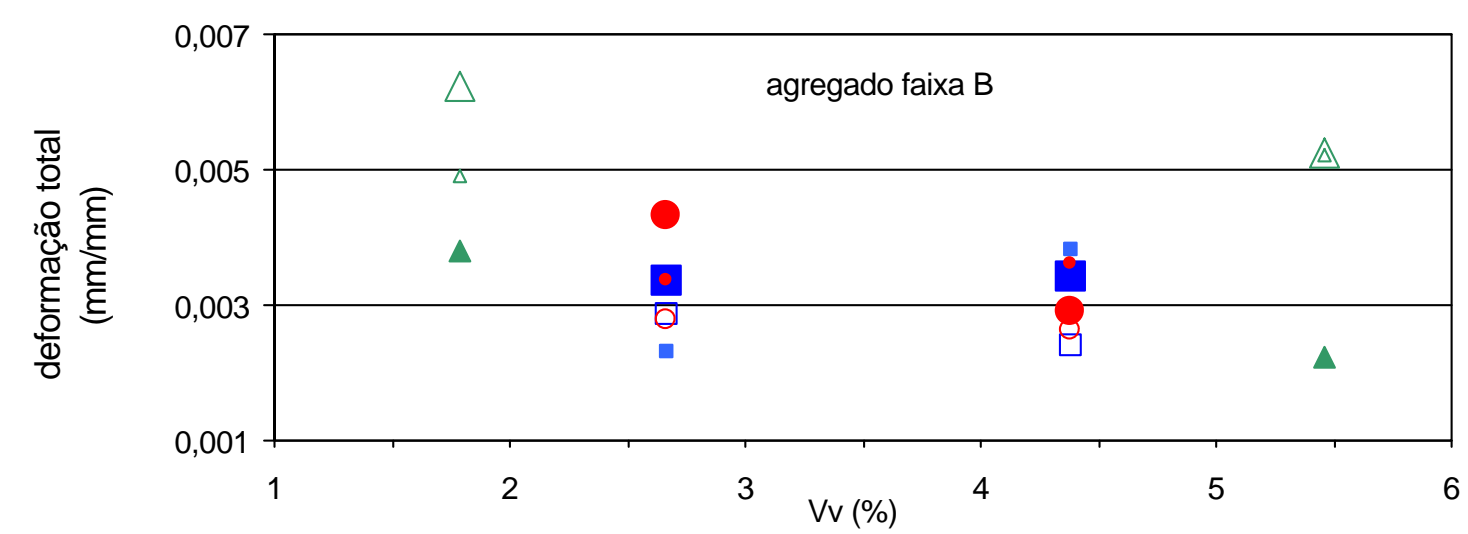

\begin{tabular}{|l}
\hline asf. com polímero; envelhecimento a longo prazo = não; envelhecimento a curto prazo = não \\
$\Delta$ asf. convencional; envelhecimento a longo prazo = estufa; envelhecimento a curto prazo = não \\
$\triangle$ asf. com borracha; envelhecimento a longo prazo = estufa; envelhecimento a curto prazo = não \\
O asf. com polímero; envelhecimento a longo prazo = exposição ao tempo; envelhecimento a curto prazo = não \\
asf. com borracha; envelhecimento a longo prazo = não; envelhecimento a curto prazo = $4 \mathrm{~h}$ em estufa \\
asf. convencional; envelhecimento a longo prazo = não; envelhecimento a curto prazo = $4 \mathrm{~h}$ em estufa \\
asf. com polímero; envelhecimento a longo prazo = estufa; envelhecimento a curto prazo = $4 \mathrm{~h}$ em estufa \\
asf. convencional; envelhecimento a longo prazo = exposição ao tempo; envelhecimento a curto prazo = $4 \mathrm{~h}$ em estufa \\
asf. com borracha; envelhecimento a longo prazo = exposição ao tempo; envelhecimento a curto prazo = $4 \mathrm{~h}$ em estufa
\end{tabular}

Figura 6.21 - Pontos experimentais referentes à deformação total em função do volume de vazios, para a faixa granulométrica $\mathrm{B}$, considerando-se confiança de $95 \%$

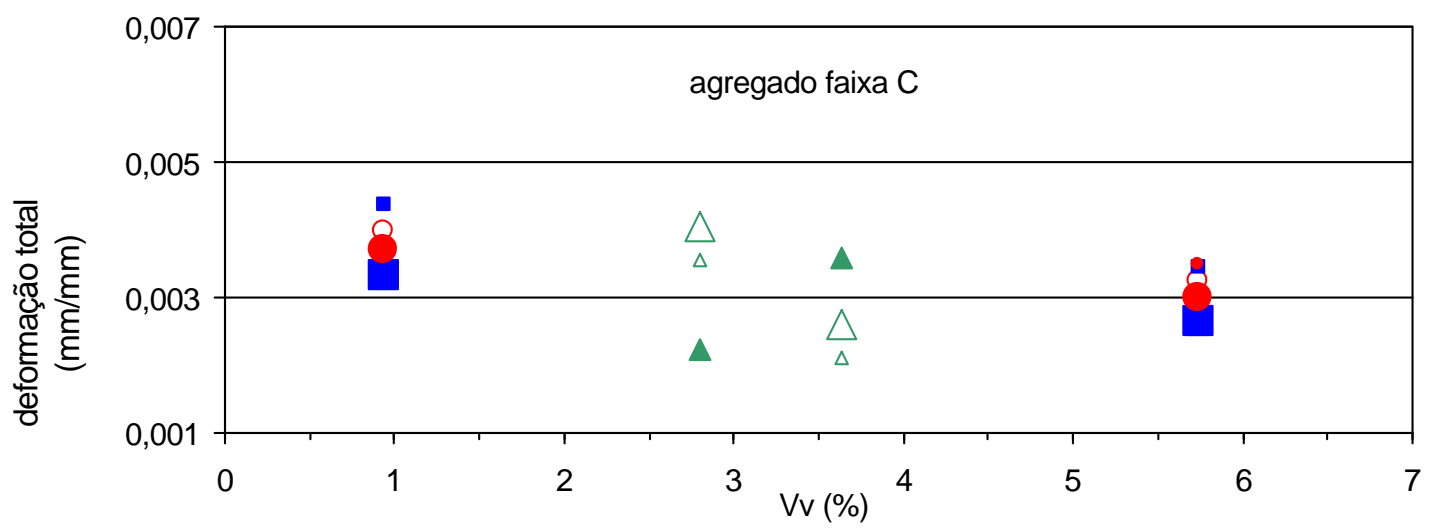

$\square$ asf. com polímero; envelhecimento a longo prazo = não; envelhecimento a curto prazo = não

$\Delta$ asf. convencional; envelhecimento a longo prazo = estufa; envelhecimento a curto prazo = não

$\triangle$ asf. com borracha; envelhecimento a longo prazo = estufa; envelhecimento a curto prazo = não

$\mathrm{O}$ asf. com polímero; envelhecimento a longo prazo = exposição ao tempo; envelhecimento a curto prazo = não

- asf. convencional; envelhecimento a longo prazo = não; envelhecimento a curto prazo $=4 \mathrm{~h}$ em estufa

asf. com borracha; envelhecimento a longo prazo = não; envelhecimento a curto prazo $=4 \mathrm{~h}$ em estufa

$\Delta$ asf. com polímero; envelhecimento a longo prazo = estufa; envelhecimento a curto prazo $=4 \mathrm{~h}$ em estufa

asf. convencional; envelhecimento a longo prazo = exposicão ao tempo; envelhecimento a curto prazo $=4 \mathrm{~h}$ em estufa

asf. com borracha; envelhecimento a longo prazo = exposição ao tempo; envelhecimento a curto prazo = 4h em estufa

Figura 6.22 - Pontos experimentais referentes à deformação total em função do volume de vazios, para a faixa granulométrica $\mathrm{C}$, considerando-se confiança de $95 \%$ 
Observando-se as Figuras 6.19 e 6.20 nota-se que misturas com agregado da faixa B apresentaram uma deformação total maior que a apresentada por misturas com agregado da faixa $\mathrm{C}$, considerando-se teores de ligantes equivalentes, ou seja, comparando-se a deformação total apresentada por misturas com o teor mais seco adotado para a faixa B com a deformação total apresentada por misturas com o teor mais seco adotado para a faixa $\mathrm{C}$, e assim sucessivamente.

Embora teoricamente uma distribuição granulométrica da faixa B devesse gerar misturas com maior resistência à deformação do que misturas compostas por agregados com distribuição granulométrica da faixa $\mathrm{C}$, na prática a moldagem de corpos de prova pelo método Marshall torna-se mais complicada quando tratam-se de misturas com agregado da faixa B. Isso ocorre por dificuldades de homogeneização da mistura, uma vez que as dimensões dos agregados da faixa B são relativamente grandes quando comparadas com as dimensões dos corpos de prova moldados pelo método Marshall. Falhas de compactação podem ser refletidas posteriormente em deformações superiores às esperadas.

A deformação total sofrida pelo corpo de prova mostrou-se dependente também do teor de ligante na mistura. Inicialmente pode-se notar uma diminuição da deformação total, quando o teor de ligante aumentou de um ponto mais seco para um ponto em torno do teor ótimo. A partir de então, aumentos do teor de ligante significaram maiores deformações totais.

A variação da deformação recuperável ou elástica em função da variação do teor de ligante, apresentada nas Figuras 6.23 e 6.24, mostrou-se dependente de todos os fatores considerados no experimento, exceto do fator tipo de ligante asfáltico. Resultados de diversos trabalhos encontrados na literatura têm demonstrado que o ensaio de fluência por compressão uniaxial estática não é capaz de diferenciar as propriedades elásticas de asfaltos modificados. Como o tipo de ligante foi variado justamente pela adição de modificadores ao asfalto convencional, era esperado que tal variação não tivesse influência significativa na deformação recuperável. 


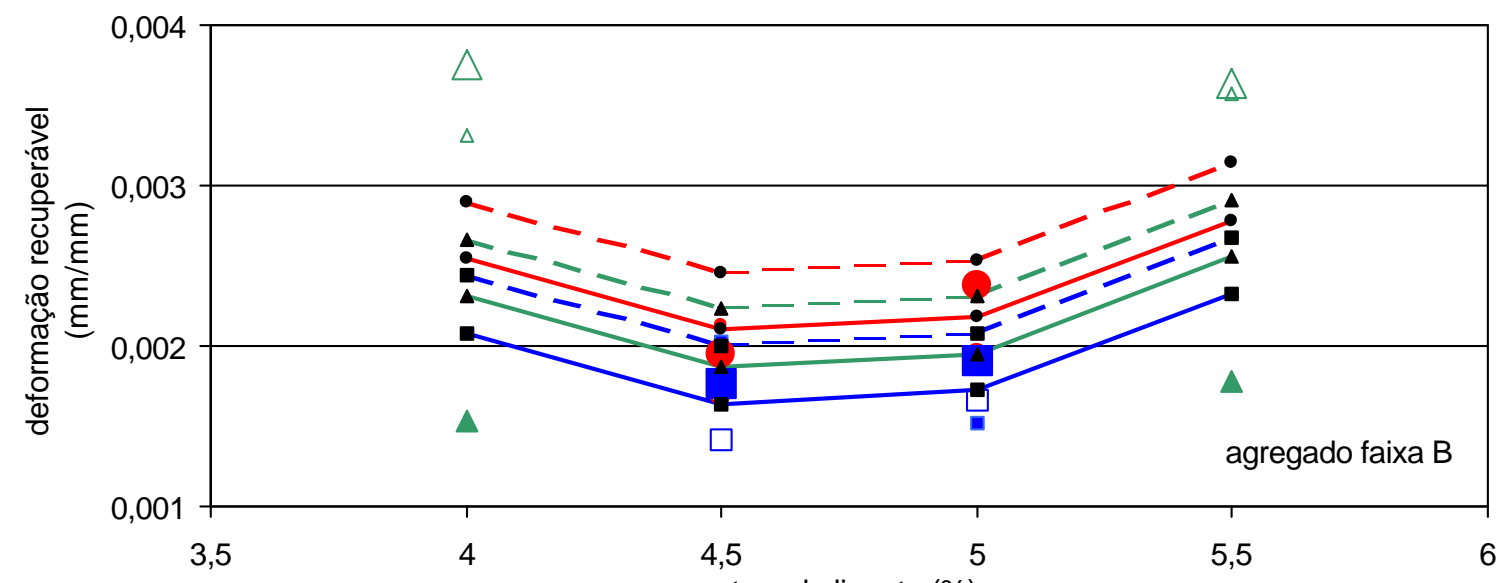

\begin{tabular}{|l} 
teor de ligante (\%) \\
$\begin{array}{l}\text { asf. com polímero; envelhecimento a longo prazo = não; envelhecimento a curto prazo = não } \\
\text { asf. convencional; envelhecimento a longo prazo = estufa; envelhecimento a curto prazo = não }\end{array}$ \\
asf. com borracha; envelhecimento a longo prazo = estufa; envelhecimento a curto prazo = não \\
asf. com polímero; envelhecimento a longo prazo = exposição ao tempo; envelhecimento a curto prazo = não \\
asf. com borracha; envelhecimento a longo prazo = não; envelhecimento a curto prazo = 4h em estufa \\
asf. convencional; envelhecimento a longo prazo = não; envelhecimento a curto prazo $=4 \mathrm{~h}$ em estufa \\
asf. com polímero; envelhecimento a longo prazo = estufa; envelhecimento a curto prazo = 4h em estufa \\
asf. convencional; envelhecimento a longo prazo = exposição ao tempo; envelhecimento a curto prazo = 4h em estufa \\
asf. com borracha; envelhecimento a longo prazo = exposição ao tempo; envelhecimento a curto prazo = 4h em estufa \\
- - modelo para mistura não envelhecida a curto e longo prazos \\
- - modelo para mistuta não envelhecida a curto prazo e envelhecida a longo prazo em estufa \\
- - modelo para mistura não envelhecida a curto prazo e envelhecida a longo prazo por exposição ao tempo
\end{tabular}

Figura 6.23 - Pontos experimentais e modelos de comportamento referentes à deformação recuperável em função do teor de ligante e das condições de envelhecimento a curto e longo prazos, para a faixa granulométrica B, considerando-se confiança de $95 \%$

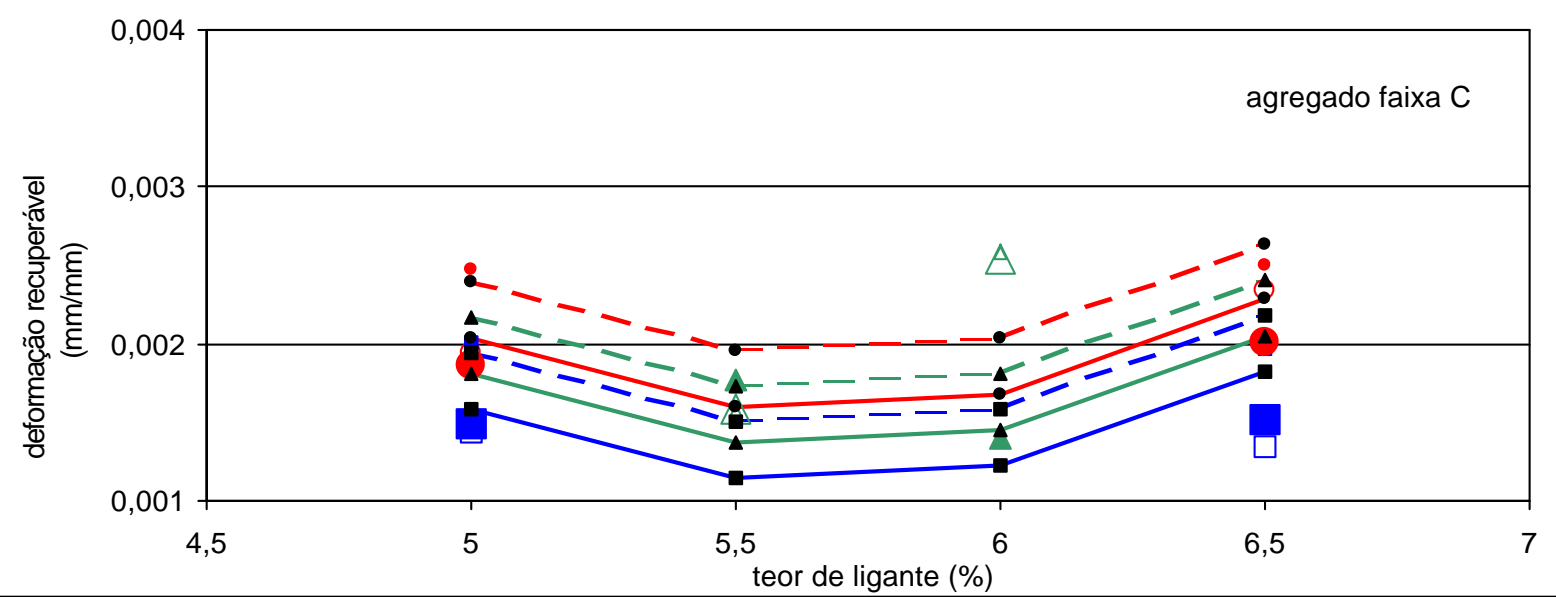

\footnotetext{
$\square \quad$ asf. com polímero; envelhecimento a longo prazo = não; envelhecimento a curto prazo = não

asf. convencional; envelhecimento a longo prazo = estufa; envelhecimento a curto prazo = não

asf. com borracha; envelhecimento a longo prazo = estufa; envelhecimento a curto prazo = não

asf. com polímero; envelhecimento a longo prazo = exposição ao tempo; envelhecimento a curto prazo = não

asf. convencional; envelhecimento a longo prazo = não; envelhecimento a curto prazo $=4 \mathrm{~h}$ em estufa

asf. com borracha; envelhecimento a longo prazo = não; envelhecimento a curto prazo $=4 \mathrm{~h}$ em estufa

asf. com polímero; envelhecimento a longo prazo $=$ estufa; envelhecimento a curto prazo $=4 \mathrm{~h}$ em estufa

asf. convencional; envelhecimento a longo prazo = exposição ao tempo; envelhecimento a curto prazo = 4h em estufa

asf. com borracha; envelhecimento a longo prazo = exposição ao tempo; envelhecimento a curto prazo $=4 \mathrm{~h}$ em estufa

asf. com borracha; envelhecimento a longo prazo = exposição
- modelo para mistura não envelhecida a curto e longo prazos

- - modelo para mistuta não envelhecida a curto prazo e envelhecida a longo prazo em estufa

- $\bullet$ - modelo para mistura não envelhecida a curto prazo e envelhecida a longo prazo por exposição ao tempo

- modelo para mistura envelhecida a curto prazo por 4h em estufa e não envelhecida a longo prazo

modelo para mistuta envelhecida a curto prazo por $4 \mathrm{~h}$ em estufa e envelhecida a longo prazo em estufa

modelo para mistura envelhecida a curto prazo por $4 \mathrm{~h}$ em estufa e envelhecida a longo prazo por exposição ao tempo
}

Figura 6.24 - Pontos experimentais e modelos de comportamento referentes à deformação recuperável em função do teor de ligante e das condições de envelhecimento a curto e longo prazos, para a faixa granulométrica C, considerando-se confiança de $95 \%$ 
Realizando-se a análise da variação da deformação recuperável em função do teor de ligante na mistura, observa-se que a partir do teor ótimo, aumentos do teor de ligante significam aumentos da deformação recuperável. Entretanto, a análise da variação da recuperação em função do teor de ligante, apresentada posteriormente nas Figuras 6.33 e 6.34, irá mostrar uma diminuição da mesma com o aumento do teor de ligante. Isso significa que embora a deformação recuperável possa ter aumentado com o aumento do teor de ligante, a proporção desse aumento foi inferior ao aumento relativo sofrido pela deformação total.

Quando a análise foi realizada em função do volume de vazios, Figuras 6.25 e 6.26, a variação deste, ou seja, o aumento ou a diminuição do volume de vazios da mistura, não foi considerada significativa para explicar a variação da deformação recuperável. Dessa forma, a variação da deformação recuperável em função das condições de envelhecimento a curto e longo prazos foi ilustrada na forma de gráficos em colunas, apresentados nas Figuras 6.27 e 6.28, para misturas com agregados das faixas B e C, respectivamente.

O volume de vazios de um corpo de prova pode ser calculado dividindo-se a diferença entre as densidades teórica e aparente pela densidade teórica. A densidade aparente, por sua vez, é definida como a relação entre a massa ao ar e o volume do corpo de prova, determinado pela diferença entre o peso ao ar e o peso imerso. Dessa forma, os valores de volume de vazios foram conferidos medindo-se o peso imerso e o peso ao ar de todos os corpos de prova. Verificou-se assim uma dispersão considerável nos valores de volume de vazios obtidos. Mais uma vez ressalta-se que essa dispersão provavelmente se deve à dificuldade de controle da temperatura de compactação dos corpos de prova e também às características intrínsecas do método de moldagem, que fazem com que os valores de volume de vazios obtidos não sejam exatamente os esperados. 


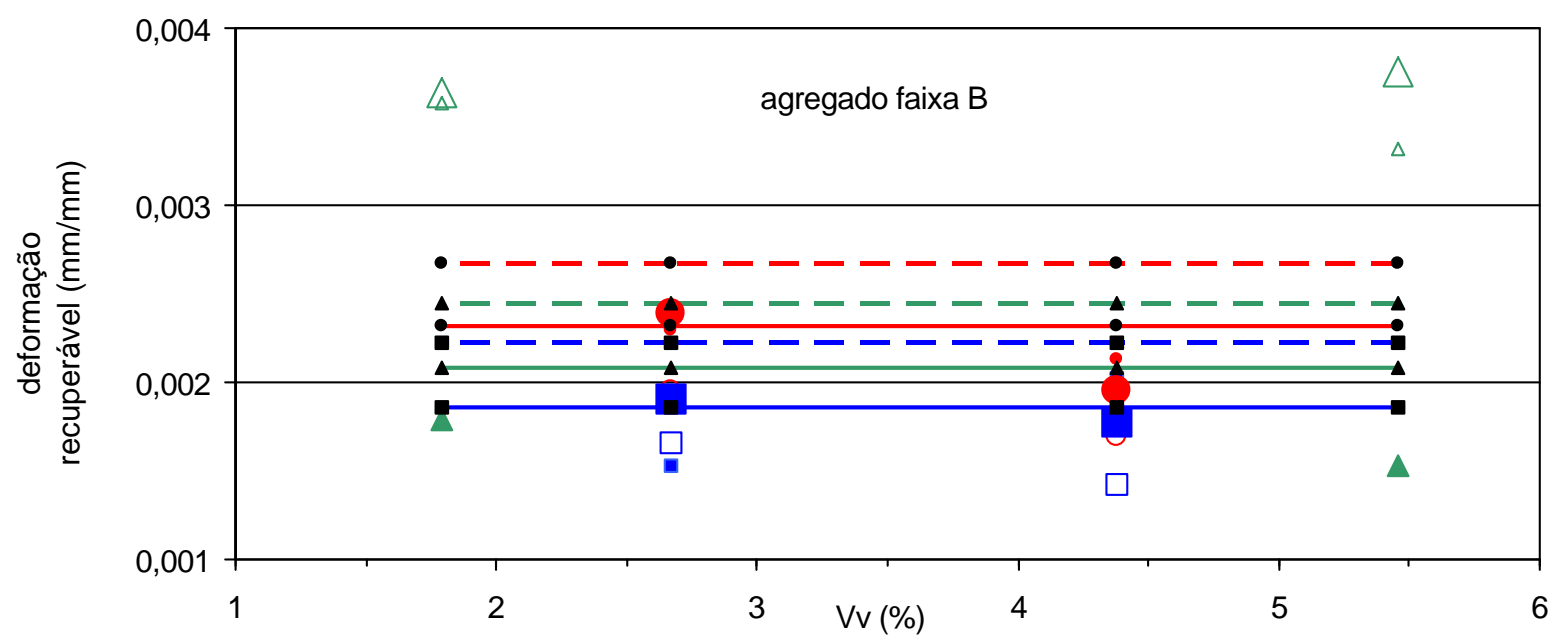

\begin{tabular}{|c|c|}
\hline & 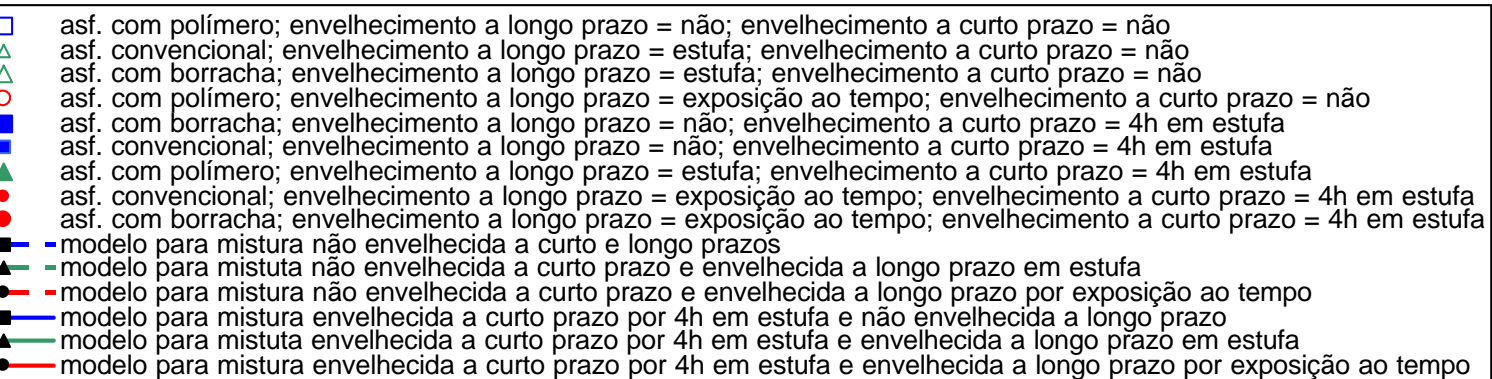 \\
\hline
\end{tabular}

Figura 6.25 - Pontos experimentais e modelos de comportamento referentes à deformação recuperável em função do volume de vazios e das condições de envelhecimento a curto e longo prazos, para a faixa granulométrica $\mathrm{B}$, considerando-se confiança de $95 \%$

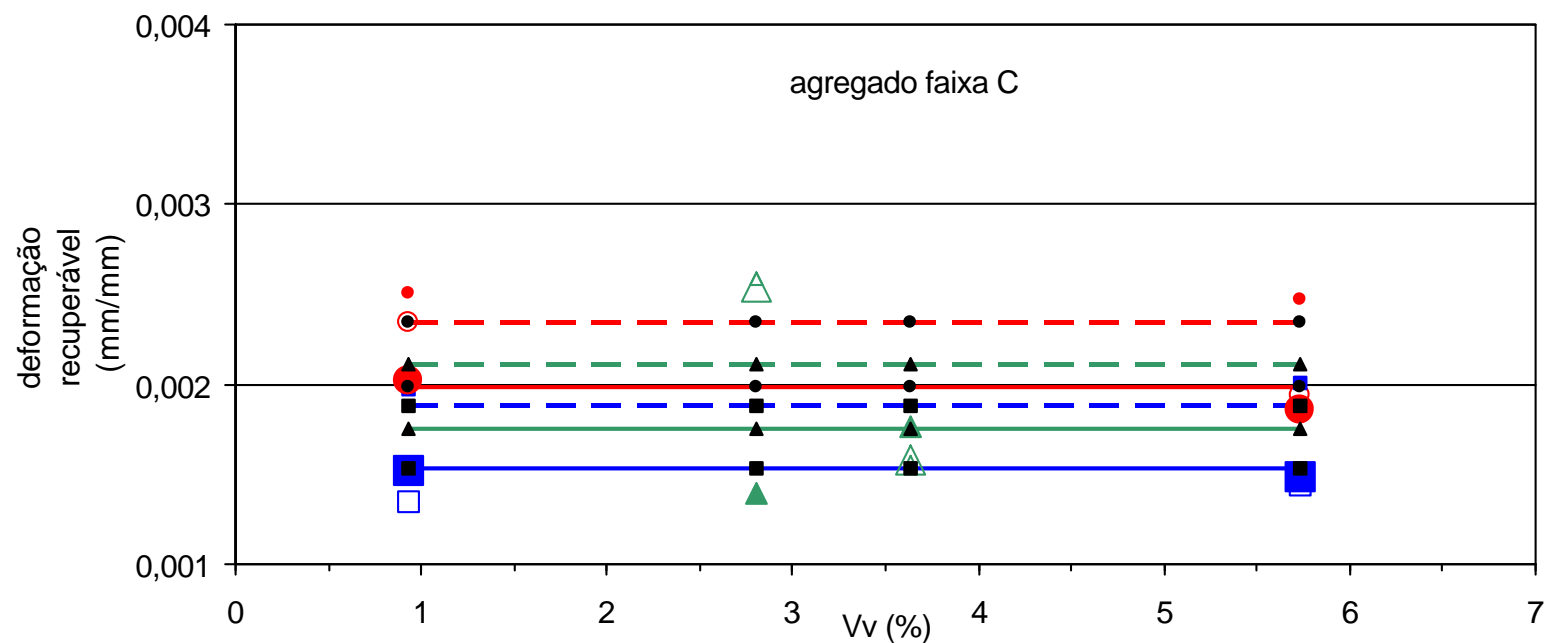

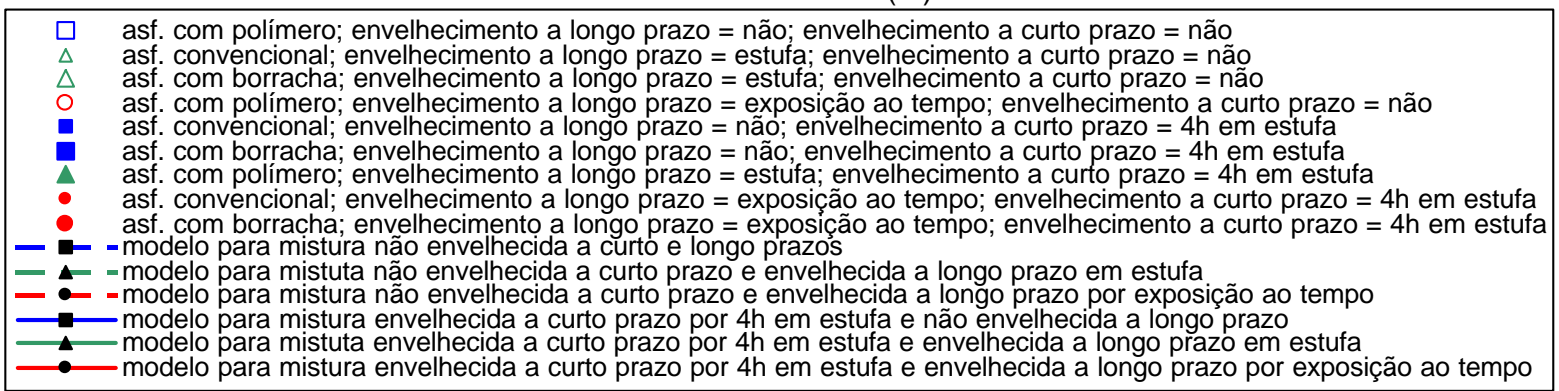

Figura 6.26 - Pontos experimentais e modelos de comportamento referentes à deformação recuperável em função do volume de vazios e das condições de envelhecimento a curto e longo prazos, para a faixa granulométrica $\mathrm{C}$, considerando-se confiança de $95 \%$ 


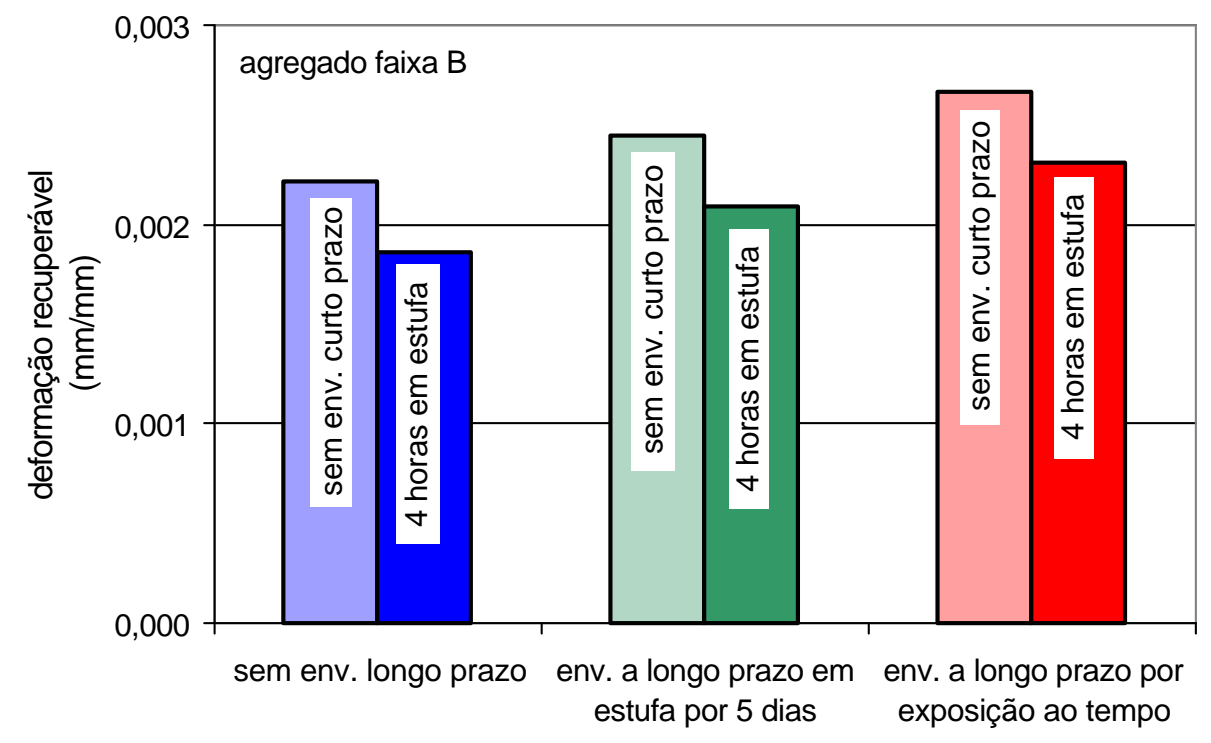

Figura 6.27 - Variação da deformação recuperável em função das condições de envelhecimento a curto e longo prazos, para misturas com agregados da faixa $B$

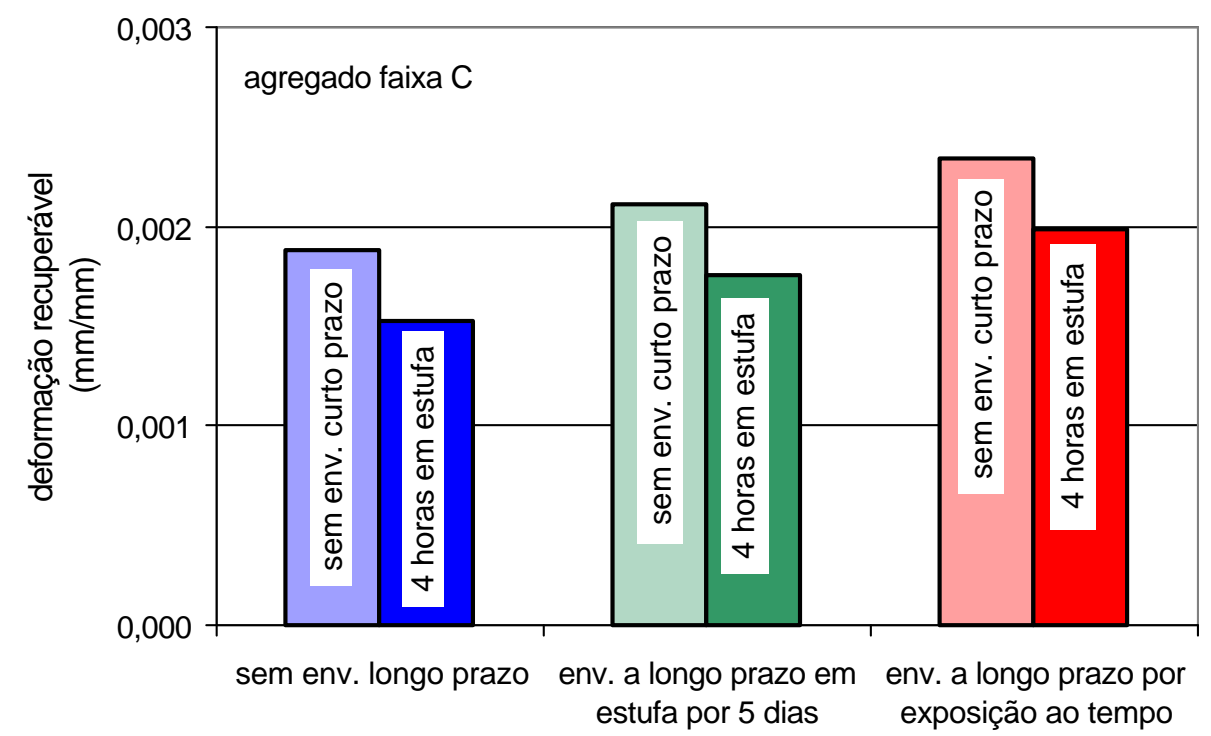

Figura 6.28 - Variação da deformação recuperável em função das condições de envelhecimento a curto e longo prazos, para misturas com agregados da faixa $\mathrm{C}$

A influência das condições de envelhecimento na deformação recuperável ou elástica da mistura foi sempre considerada significativa, tratando-se do envelhecimento a curto ou longo prazos. Misturas envelhecidas a longo prazo apresentaram deformação recuperável superior a apresentada por misturas que não foram submetidas a processos acelerados de envelhecimento.

Por outro lado, misturas envelhecidas a curto prazo apresentaram deformação recuperável inferior à apresentada por misturas que não foram submetidas ao processo 
acelerado de envelhecimento a curto prazo, que no caso consistiu em se manter a mistura solta por 4 horas em estufa ventilada a $135^{\circ} \mathrm{C}$.

A deformação não recuperável tem seus resultados apresentados nas Figuras 6.29 a 6.32. Nas Figuras 6.29 e 6.30 foram apresentados os valores de deformação não recuperável em função do teor de ligante, e nas Figuras 6.31 e 6.32, em função do volume de vazios. Não foram encontrados modelos de comportamento satisfatórios para a resposta deformação não recuperável.

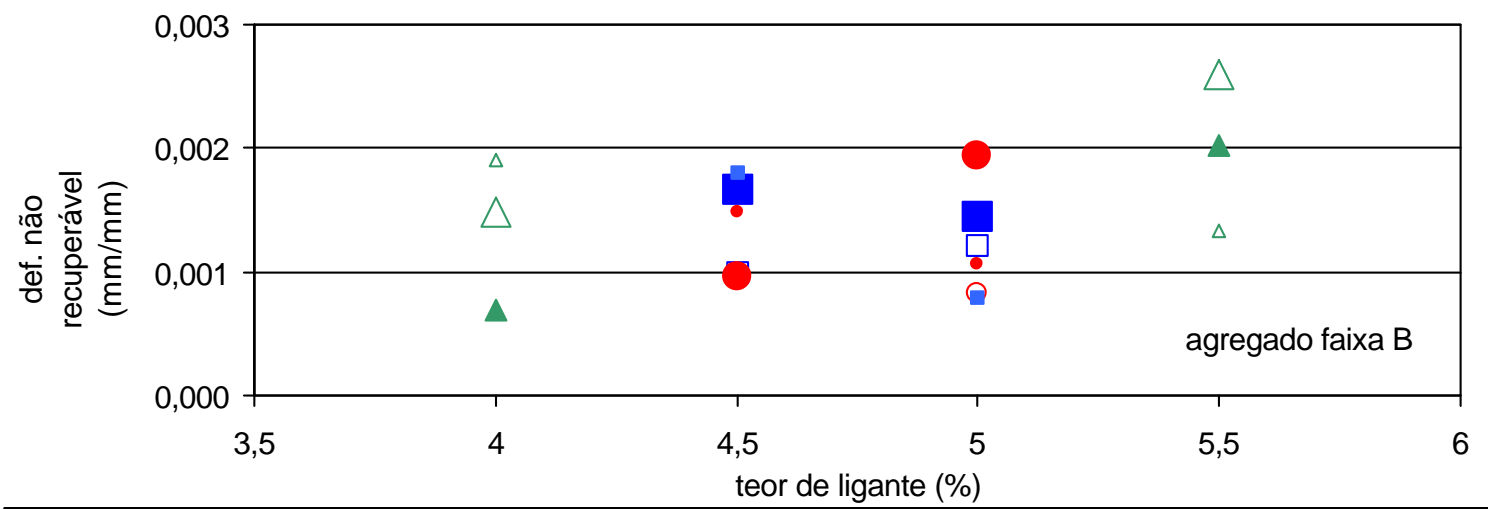

$\square$ asf. com polímero; envelhecimento a longo prazo = não; envelhecimento a curto prazo = não

$\Delta$ asf. convencional; envelhecimento a longo prazo = estufa; envelhecimento a curto prazo = não

$\triangle$ asf. com borracha; envelhecimento a longo prazo = estufa; envelhecimento a curto prazo = não

O asf. com polímero; envelhecimento a longo prazo = exposição ao tempo; envelhecimento a curto prazo = não

- asf. com borracha; envelhecimento a longo prazo = não; envelhecimento a curto prazo $=4 \mathrm{~h}$ em estufa

asf. convencional; envelhecimento a longo prazo = não; envelhecimento a curto prazo = $4 \mathrm{~h}$ em estufa

$\Delta$ asf. com polímero; envelhecimento a longo prazo = estufa; envelhecimento a curto prazo $=4 \mathrm{~h}$ em estufa

- asf. convencional; envelhecimento a longo prazo = exposição ao tempo; envelhecimento a curto prazo = 4h em estufa

- asf. com borracha; envelhecimento a longo prazo = exposição ao tempo; envelhecimento a curto prazo = 4h em estufa

Figura 6.29 - Pontos experimentais referentes à deformação não recuperável em função do teor de ligante, para a faixa granulométrica B, considerando-se confiança de 95\%

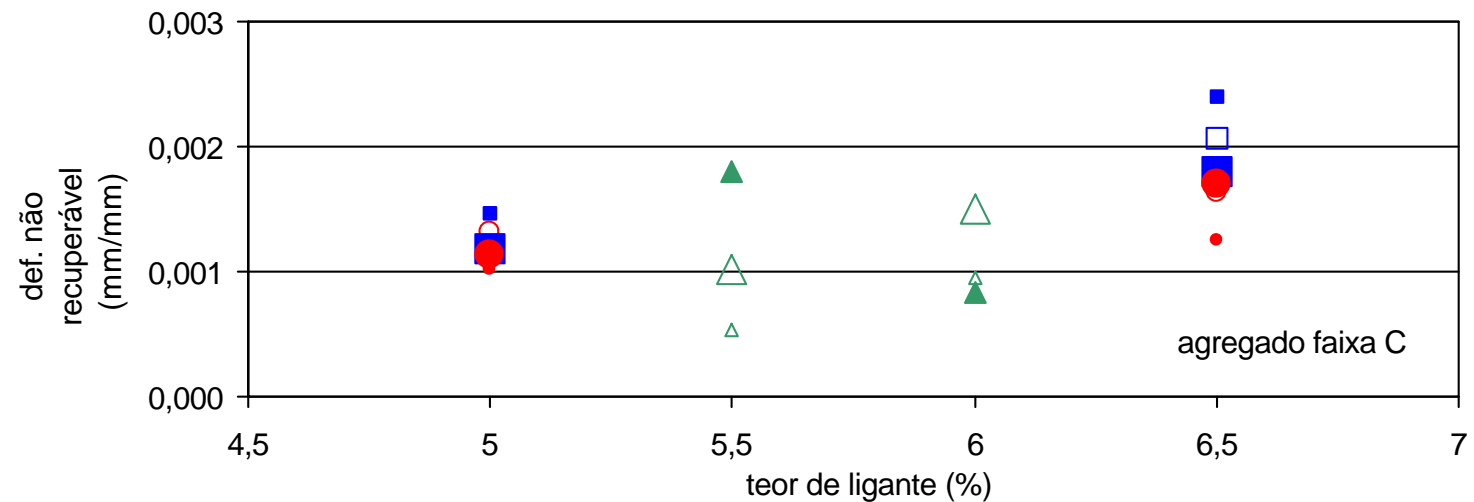

$\square$ asf. com polímero; envelhecimento a longo prazo = não; envelhecimento a curto prazo = não

$\triangle$ asf. convencional; envelhecimento a longo prazo = estufa; envelhecimento a curto prazo = não

$\triangle$ asf. com borracha; envelhecimento a longo prazo = estufa; envelhecimento a curto prazo = não

O asf. com polímero; envelhecimento a longo prazo = exposição ao tempo; envelhecimento a curto prazo = não

- asf. convencional; envelhecimento a longo prazo = não; envelhecimento a curto prazo $=4 \mathrm{~h}$ em estufa

asf. com borracha; envelhecimento a longo prazo = não; envelhecimento a curto prazo $=4 \mathrm{~h}$ em estufa

$\Delta$ asf. com polímero; envelhecimento a longo prazo = estufa; envelhecimento a curto prazo $=4 \mathrm{~h}$ em estufa

- asf. convencional; envelhecimento a longo prazo = exposição ao tempo; envelhecimento a curto prazo = 4h em estufa

- asf. com borracha; envelhecimento a longo prazo = exposição ao tempo; envelhecimento a curto prazo = $4 \mathrm{~h}$ em estufa

Figura 6.30 - Pontos experimentais referentes à deformação não recuperável em função do teor de ligante, para a faixa granulométrica C, considerando-se confiança de 95\% 


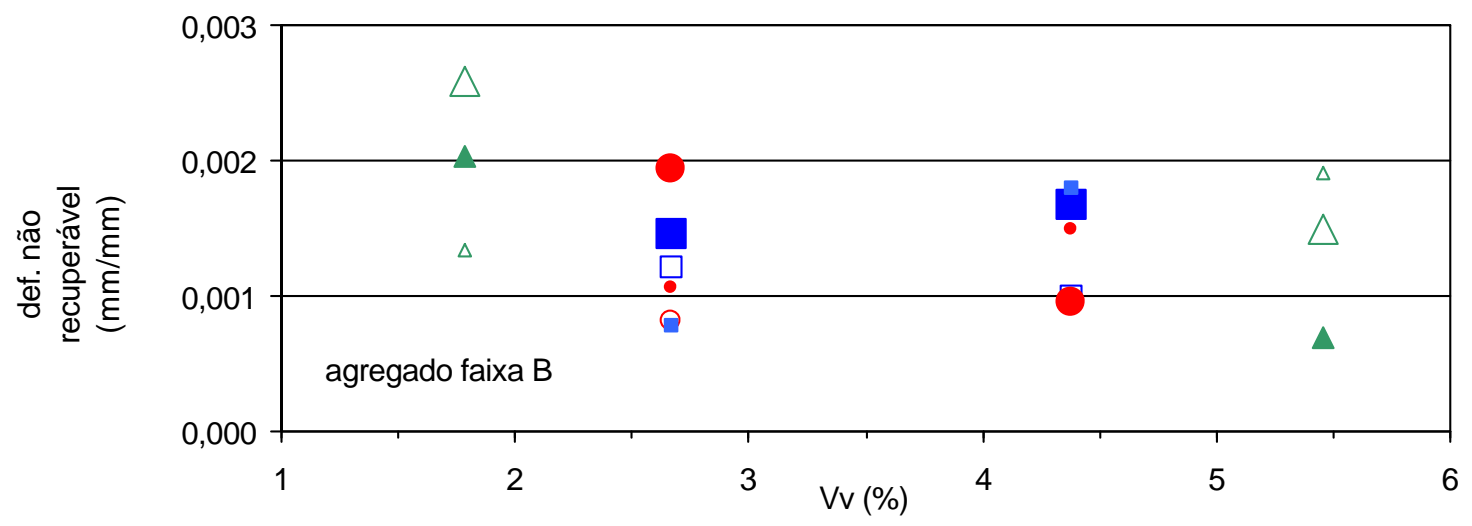

$\square$ asf. com polímero; envelhecimento a longo prazo = não; envelhecimento a curto prazo = não

$\triangle$ asf. convencional; envelhecimento a longo prazo = estufa; envelhecimento a curto prazo = não

$\triangle$ asf. com borracha; envelhecimento a longo prazo = estufa; envelhecimento a curto prazo = não

asf. com polímero; envelhecimento a longo prazo = exposição ao tempo; envelhecimento a curto prazo = não

asf. com borracha; envelhecimento a longo prazo = não; envelhecimento a curto prazo $=4 \mathrm{~h}$ em estufa

asf. convencional; envelhecimento a longo prazo = não; envelhecimento a curto prazo $=4 \mathrm{~h}$ em estufa

$\Delta$ asf. com polímero; envelhecimento a longo prazo = estufa; envelhecimento a curto prazo $=4 \mathrm{~h}$ em estufa

- asf. convencional; envelhecimento a longo prazo = exposicão ao tempo; envelhecimento a curto prazo = $4 \mathrm{~h}$ em estufa

- asf. com borracha; envelhecimento a longo prazo = exposição ao tempo; envelhecimento a curto prazo = 4h em estufa

Figura 6.31 - Pontos experimentais referentes à deformação não recuperável em função do volume de vazios, para a faixa granulométrica B, considerando-se confiança de $95 \%$

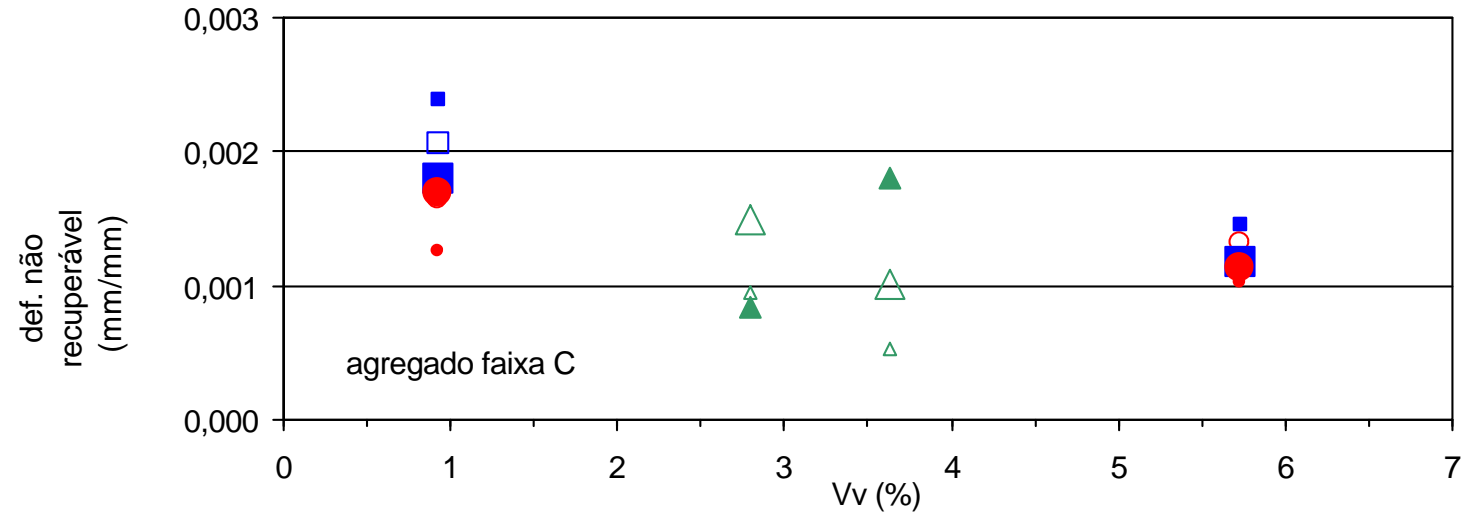

\begin{tabular}{l}
\hline asf. com polímero; envelhecimento a longo prazo = não; envelhecimento a curto prazo = não \\
$\triangle$ asf. convencional; envelhecimento a longo prazo = estufa; envelhecimento a curto prazo = não \\
$\triangle$ asf. com borracha; envelhecimento a longo prazo = estufa; envelhecimento a curto prazo = não \\
O asf. com polímero; envelhecimento a longo prazo = exposição ao tempo; envelhecimento a curto prazo = não \\
asf. convencional; envelhecimento a longo prazo = não; envelhecimento a curto prazo = $4 \mathrm{~h}$ em estufa \\
asf. com borracha; envelhecimento a longo prazo = não; envelhecimento a curto prazo = $4 \mathrm{~h}$ em estufa \\
asf. com polímero; envelhecimento a longo prazo = estufa; envelhecimento a curto prazo = $4 \mathrm{~h}$ em estufa \\
asf. convencional; envelhecimento a longo prazo = exposição ao tempo; envelhecimento a curto prazo = $4 \mathrm{~h}$ em estufa \\
asf. com borracha; envelhecimento a longo prazo = exposição ao tempo; envelhecimento a curto prazo = $4 \mathrm{~h}$ em estufa
\end{tabular}

Figura 6.32 - Pontos experimentais referentes à deformação não recuperável em função do volume de vazios, para a faixa granulométrica $\mathrm{C}$, considerando-se confiança de $95 \%$

A recuperação, ou seja, relação entre a deformação recuperável e a deformação total, pode ser analisada pelo exposto nas Figuras 6.33 a 6.36. Analisando-se os gráficos das Figuras 6.33 e 6.34, nota-se que esta propriedade sofreu influência dos fatores teor de ligante e condições de envelhecimento a curto e longo prazos. Misturas que não foram submetidas ao processo acelerado de envelhecimento a curto prazo apresentaram uma recuperação maior do que misturas envelhecidas a curto prazo, conforme o esperado. 
Entretanto, os maiores valores de recuperação foram apresentados por misturas envelhecidas a longo prazo. Observou-se que o enrijecimento decorrente do envelhecimento aumentou a recuperação elástica apresentada pelas misturas, talvez por transformação de parcela da deformação que antes era viscosa, em elástica retardada. A análise da variação da recuperação em função do volume de vazios, apresentada nas Figuras 6.35 e 6.36, confirmou esse comportamento da variável dependente recuperação.

Quanto à influência do teor de ligante, observou-se que o aumento deste provocou uma redução da recuperação. Em correspondência, o aumento do volume de vazios na mistura foi acompanhado pelo aumento da recuperação da deformação elástica apresentada pela mistura. Como a carga aplicada é estática, talvez esse comportamento se explique por uma maior fluência ou deformação viscoplástica do ligante com o aumento do seu teor.

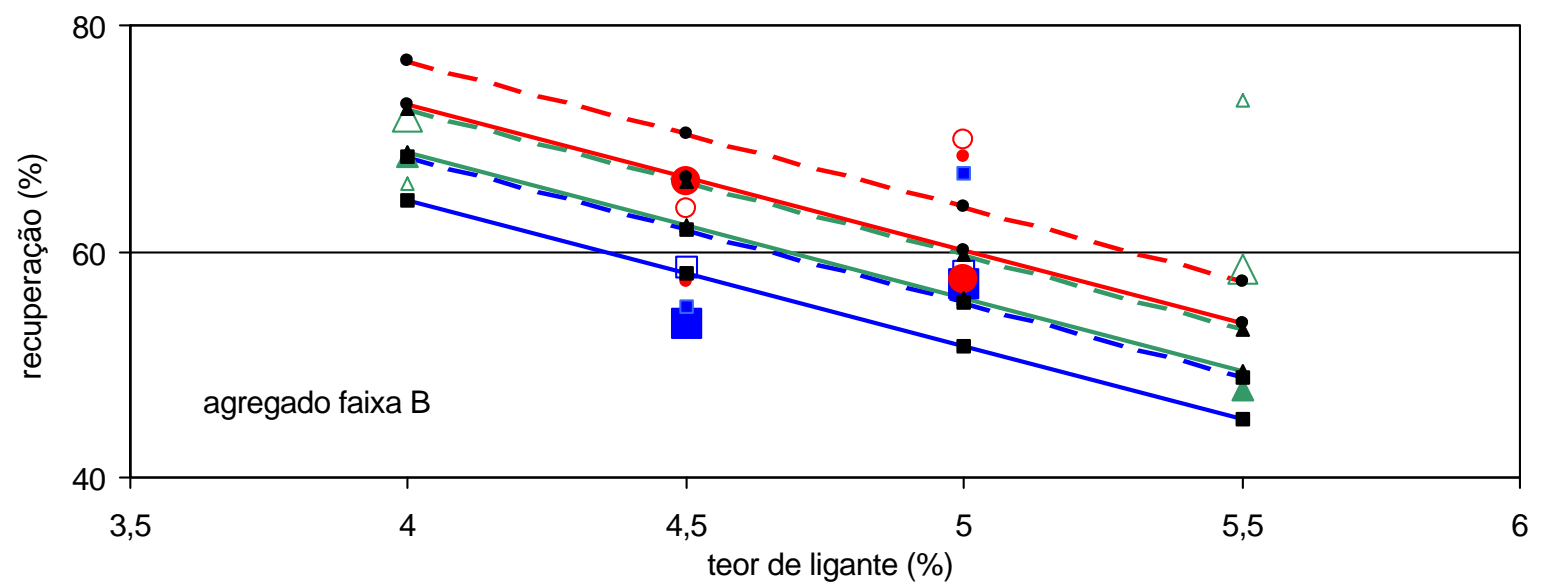

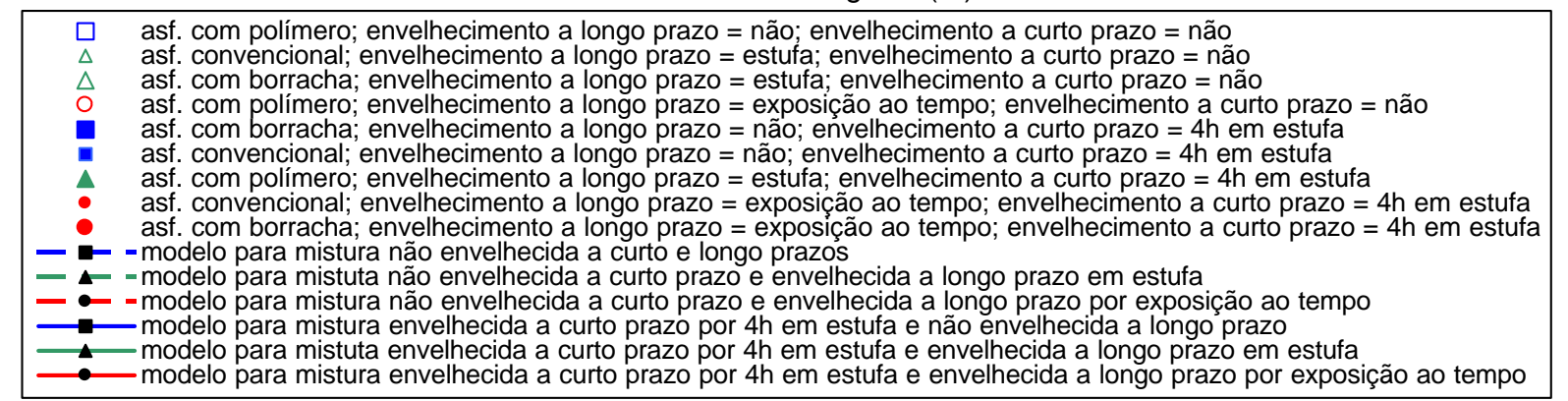

Figura 6.33 - Pontos experimentais e modelos de comportamento referentes à recuperação em função do teor de ligante e das condições de envelhecimento a curto e longo prazos, para a faixa granulométrica B, considerando-se confiança de $95 \%$ 


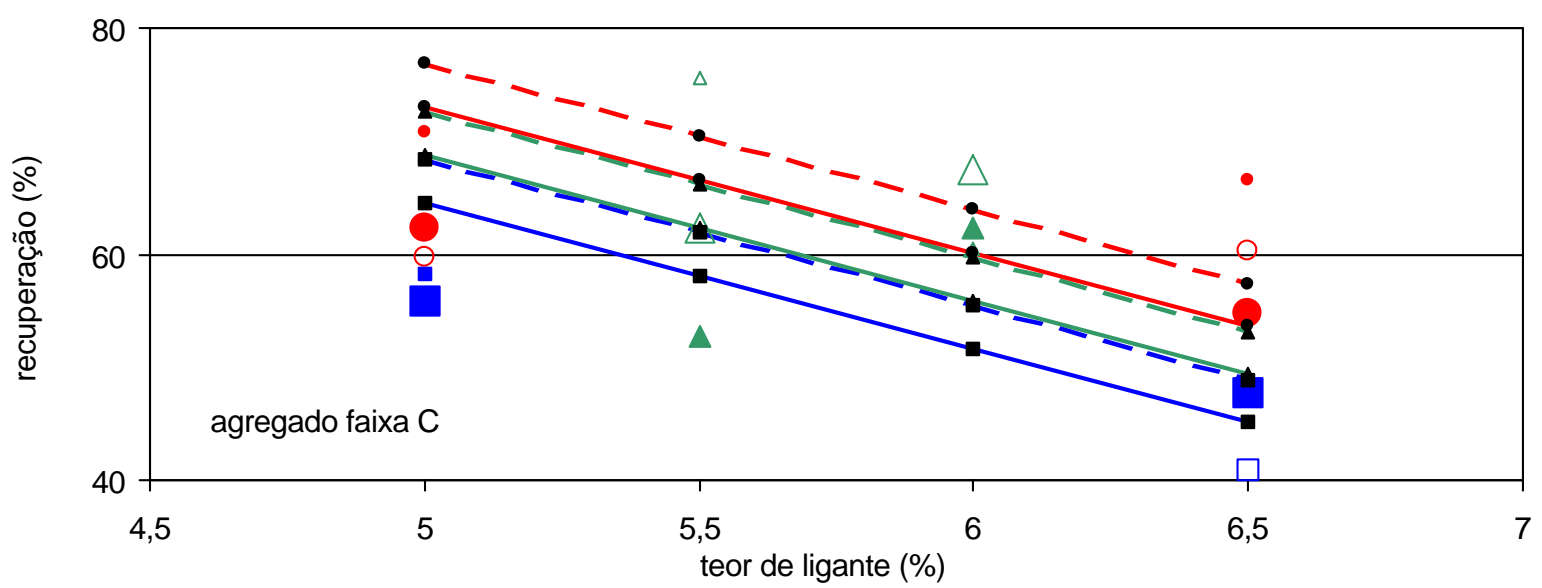

\begin{tabular}{|c|c|}
\hline - & 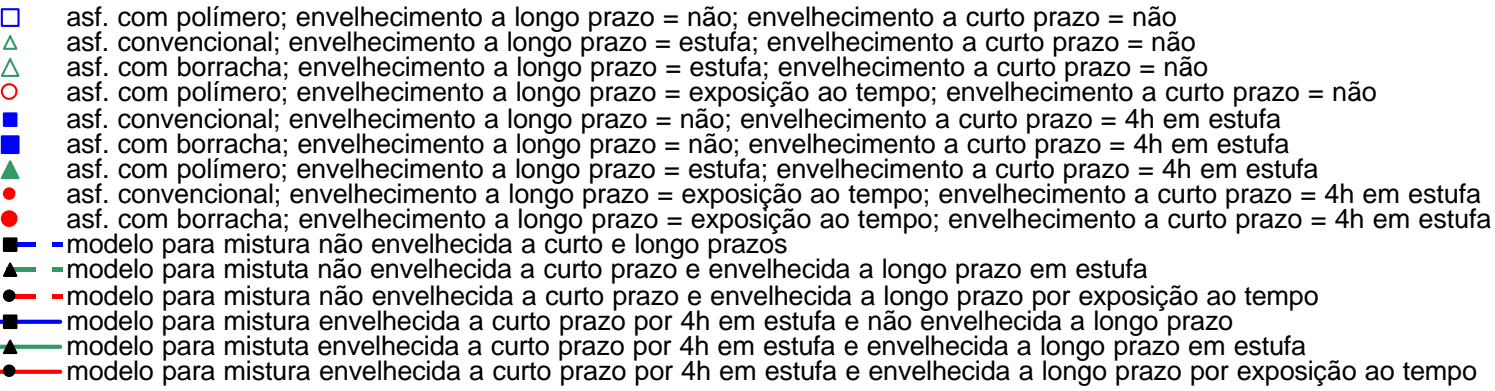 \\
\hline
\end{tabular}

Figura 6.34 - Pontos experimentais e modelos de comportamento referentes à recuperação em função do teor de ligante e das condições de envelhecimento a curto e longo prazos, para a faixa granulométrica C, considerando-se confiança de 95\%
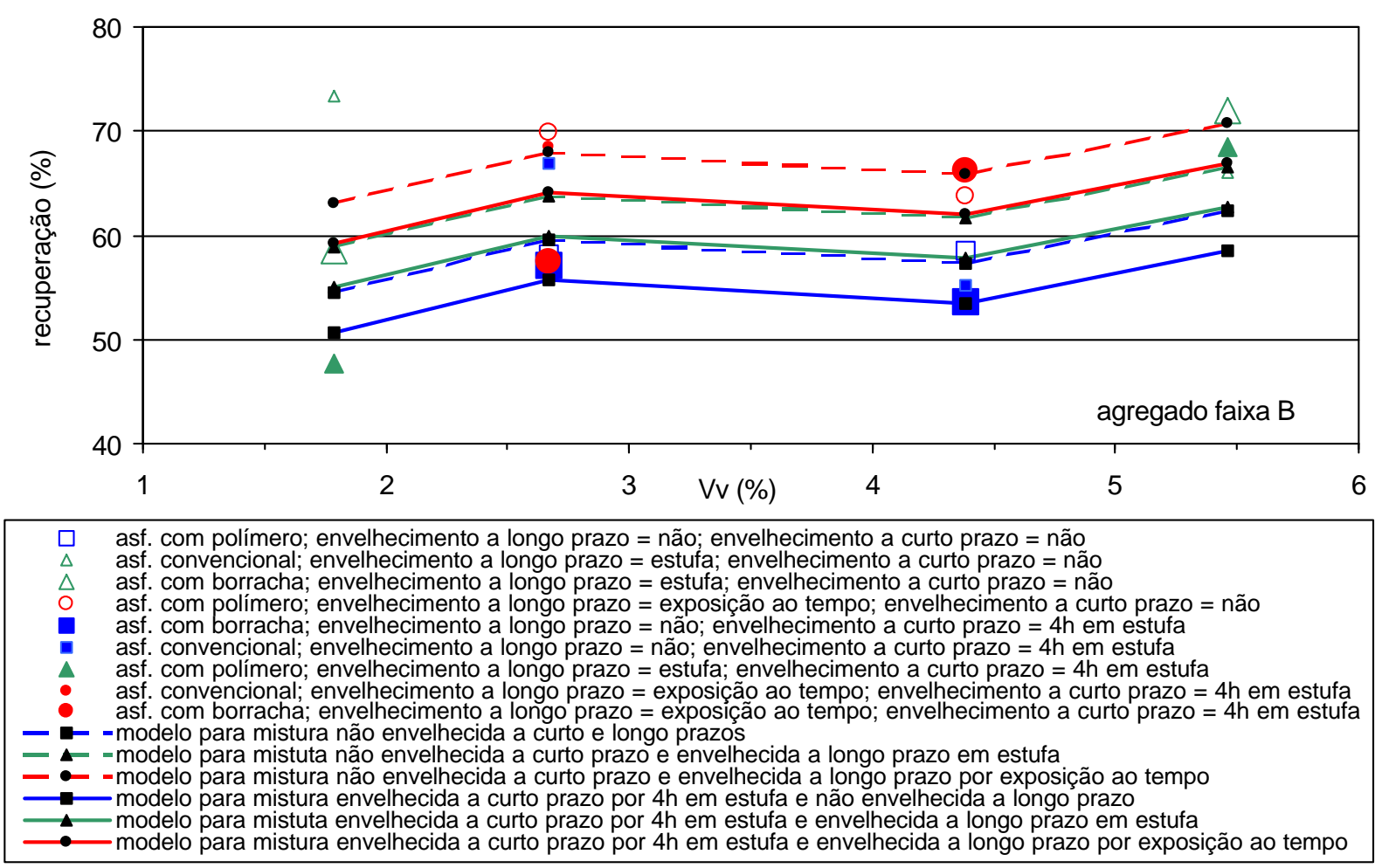

Figura 6.35 - Pontos experimentais e modelos de comportamento referentes à recuperação em função do volume de vazios e das condições de envelhecimento a curto e longo prazos, para a faixa granulométrica B, considerando-se confiança de $95 \%$ 


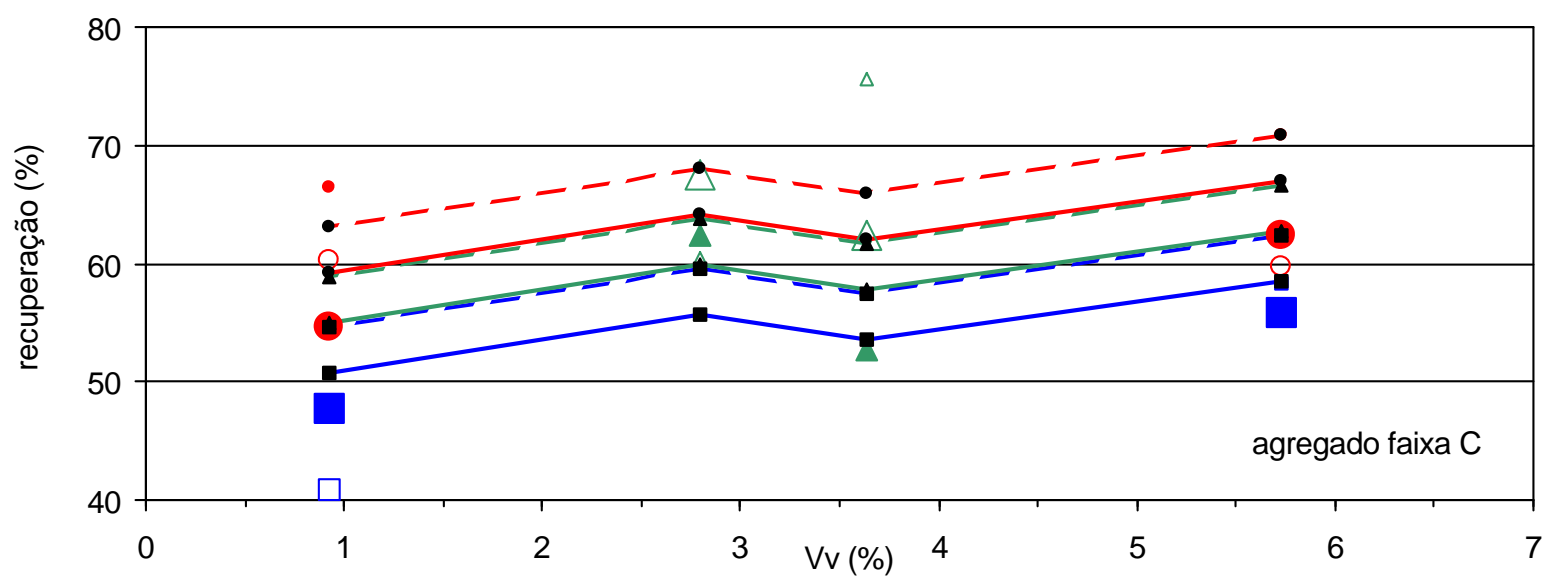

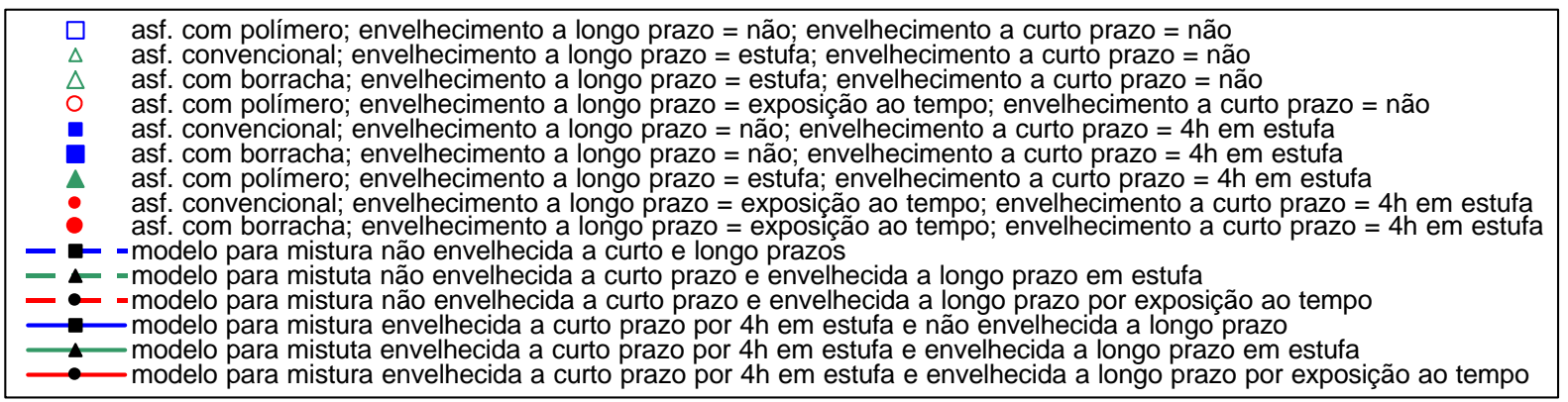

Figura 6.36 - Pontos experimentais e modelos de comportamento referentes à recuperação em função do volume de vazios e das condições de envelhecimento a curto e longo prazos, para a faixa granulométrica $\mathrm{C}$, considerando-se confiança de $95 \%$

O módulo de fluência após ensaio de fluência, apresentado nas Figuras 6.37 e 6.38 em função do teor de ligante, e nas Figuras 6.39 e 6.40 em função do volume de vazios, mostrou-se sempre maior para misturas não envelhecidas a longo prazo. Módulos menores foram encontrados para misturas envelhecidas, sendo que misturas envelhecidas por exposição ao tempo apresentaram módulos menores que os apresentados por misturas envelhecidas em estufa ventilada por 5 dias a $85^{\circ} \mathrm{C}$. Como esse módulo é calculado pela relação entre a tensão aplicada e a deformação total sofrida, módulos menores significam deformações totais maiores, ou seja, misturas envelhecidas ao tempo apresentaram as maiores deformações totais.

A partir da análise realizada em função do volume de vazios nas misturas foi construído um gráfico em colunas, apresentado na Figura 6.41, que permite uma melhor visualização do comportamento do módulo de fluência. 


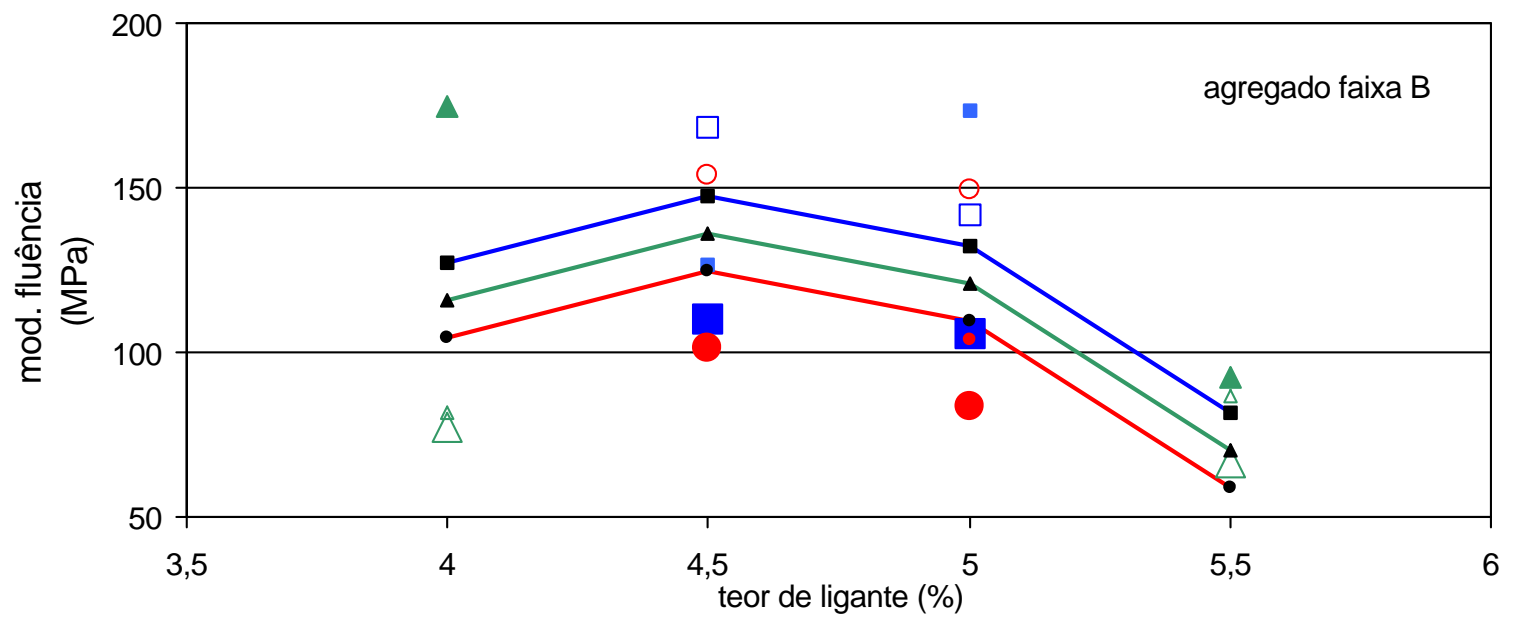

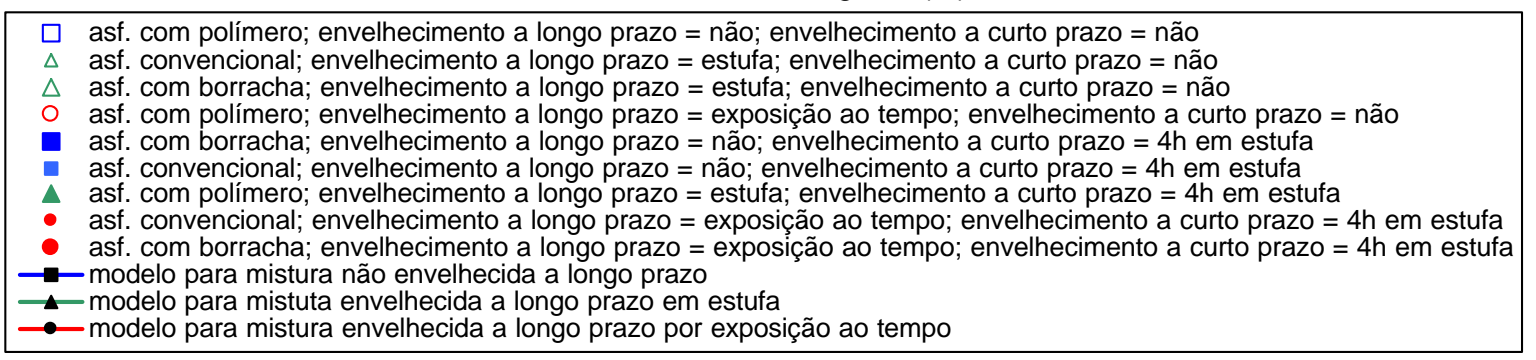

Figura 6.37 - Pontos experimentais e modelos de comportamento referentes ao módulo de fluência em função do teor de ligante e da condição de envelhecimento a longo prazo, para a faixa granulométrica B, considerando-se confiança de $95 \%$
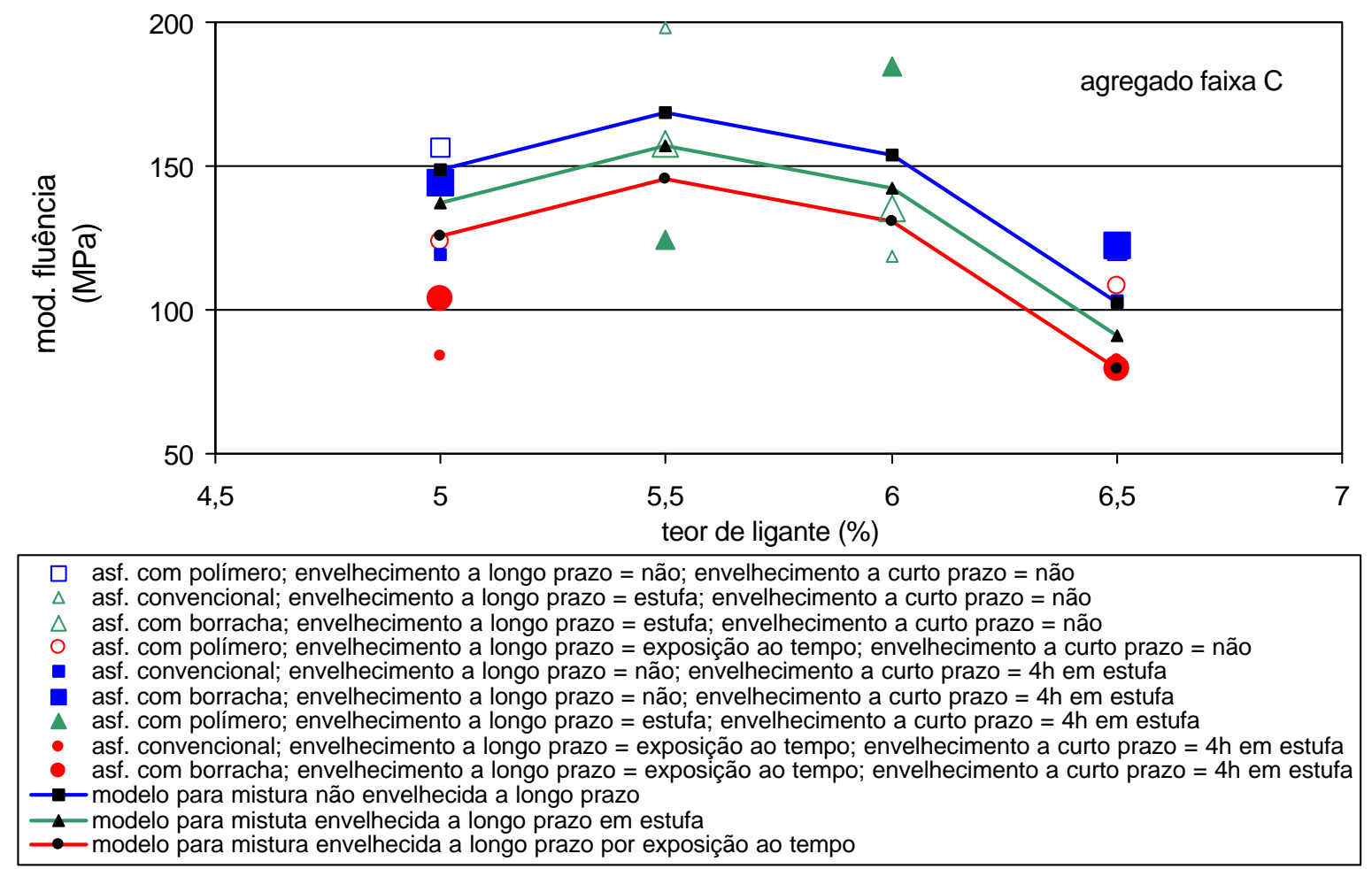

Figura 6.38 - Pontos experimentais e modelos de comportamento referentes ao módulo de fluência em função do teor de ligante e da condição de envelhecimento a longo prazo, para a faixa granulométrica $\mathrm{C}$, considerando-se confiança de $95 \%$ 


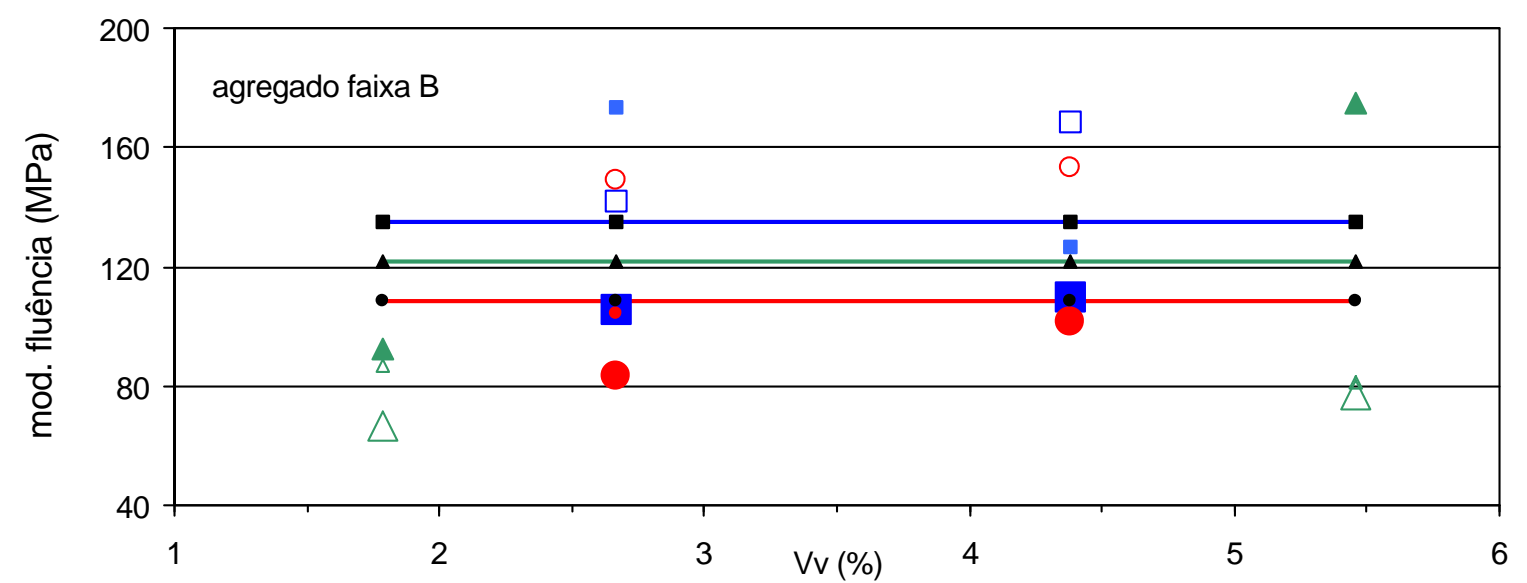

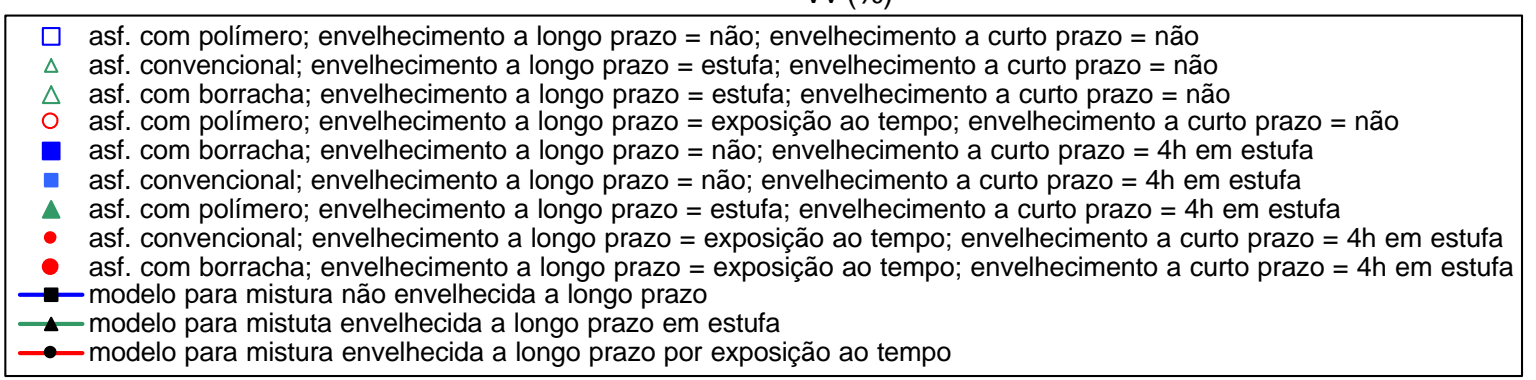

Figura 6.39 - Pontos experimentais e modelos de comportamento referentes ao módulo de fluência em função do volume de vazios e da condição de envelhecimento a longo prazo, para a faixa granulométrica B, considerando-se confiança de $95 \%$
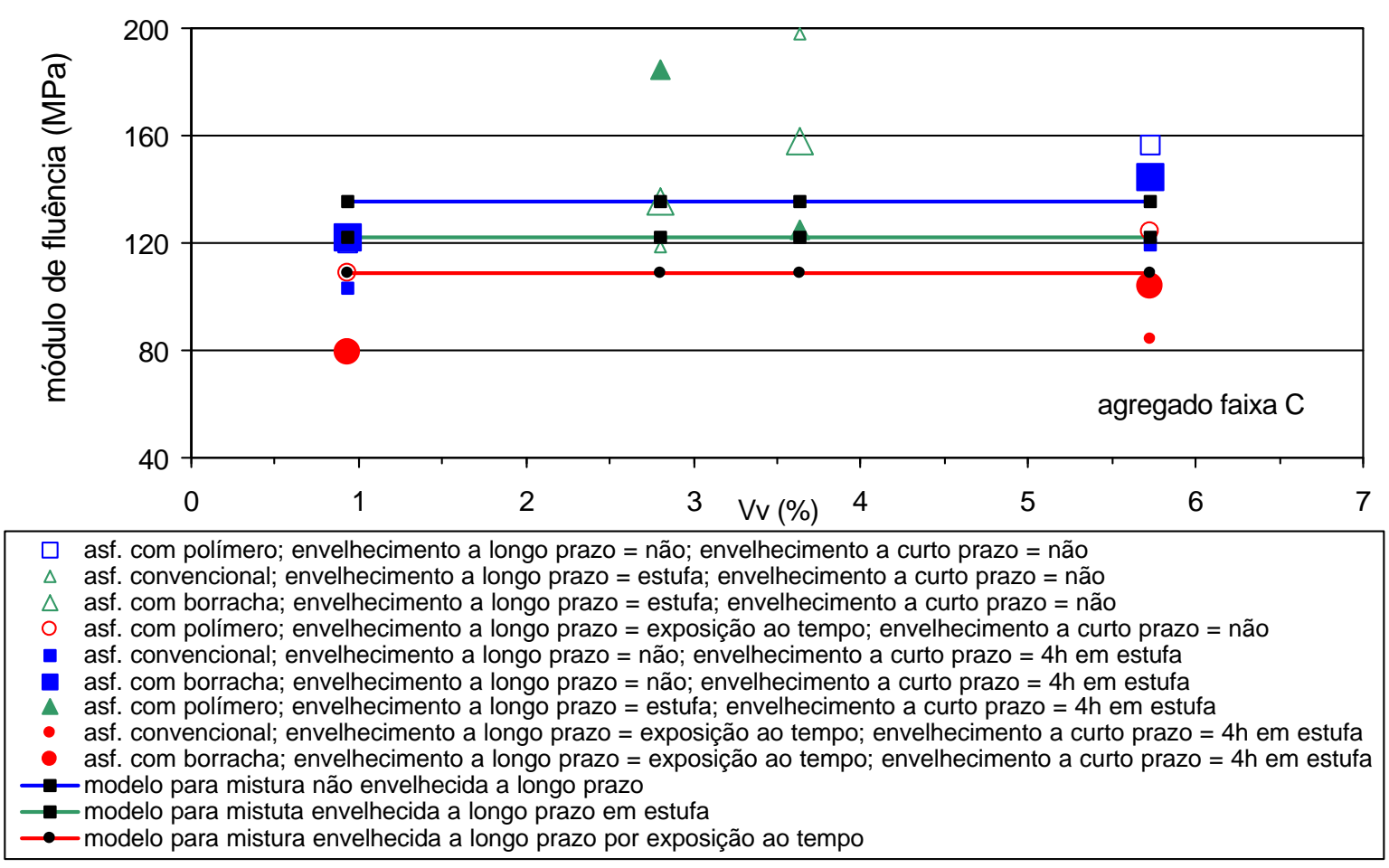

Figura 6.40 - Pontos experimentais e modelos de comportamento referentes ao módulo de fluência em função do volume de vazios e da condição de envelhecimento a longo prazo, para a faixa granulométrica $\mathrm{C}$, considerando-se confiança de $95 \%$ 


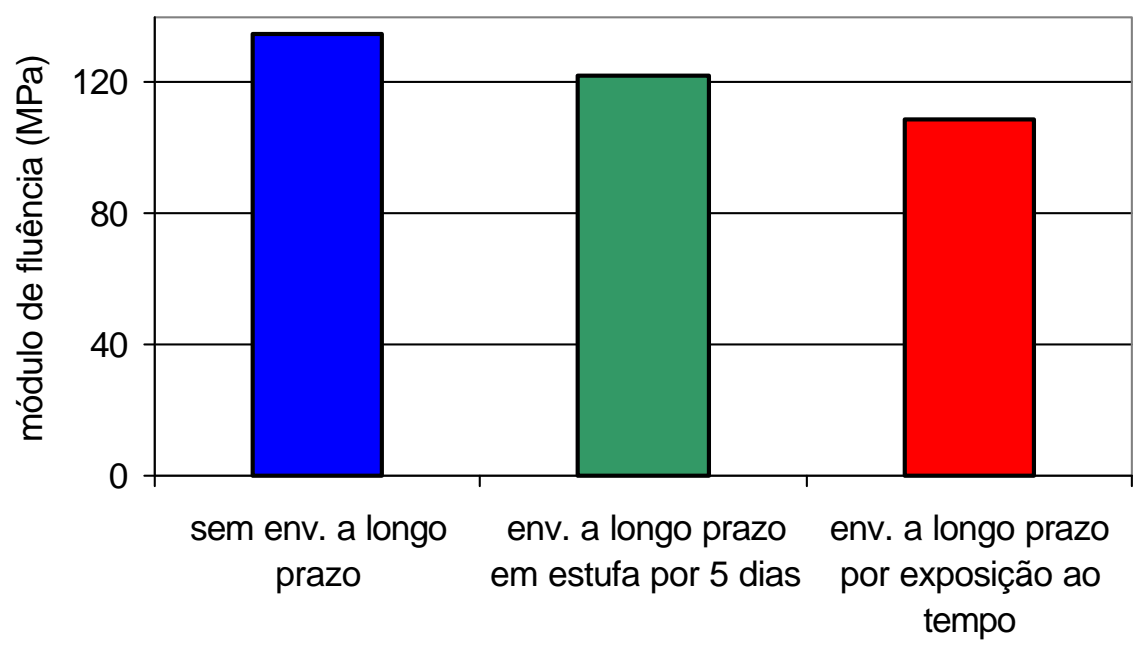

Figura 6.41 - Variação do módulo de fluência do ensaio de creep estático em função da condição de envelhecimento a longo prazo

Utilizando-se a deformação não recuperável, que permanece após o ensaio de recuperação, foi calculado o módulo de fluência após recuperação, cujos resultados podem ser observados nas Figuras 6.42 a 6.45. A variação dessa resposta em função do teor de ligante é apresentada nas Figuras 6.42 e 6.43. Nas Figuras 6.44 e 6.45, os resultados são apresentados em função do volume de vazios. Não puderam ser estabelecidos modelos de comportamento para essa resposta.

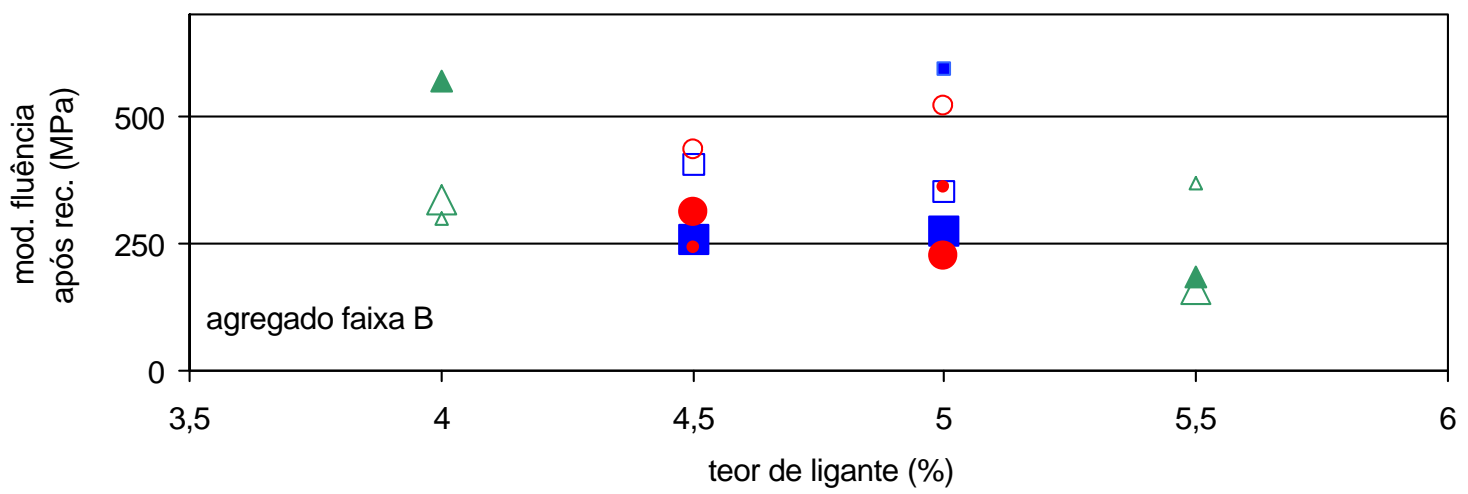

$\square$ asf. com polímero; envelhecimento a longo prazo = não; envelhecimento a curto prazo = não
$\triangle$ asf. convencional; envelhecimento a longo prazo = estufa; envelhecimento a curto prazo = não
$\triangle$ asf. com borracha; envelhecimento a longo prazo = estufa; envelhecimento a curto prazo = não
O asf. com polímero; envelhecimento a longo prazo = exposição ao tempo; envelhecimento a curto prazo = não
asf. com borracha; envelhecimento a longo prazo = não; envelhecimento a curto prazo = $4 \mathrm{~h}$ em estufa
asf. convencional; envelhecimento a longo prazo = não; envelhecimento a curto prazo $=4 \mathrm{~h}$ em estufa
$\Delta$ asf. com polímero; envelhecimento a longo prazo = estufa; envelhecimento a curto prazo = $4 \mathrm{~h}$ em estufa
- asf. convencional; envelhecimento a longo prazo = exposição ao tempo; envelhecimento a curto prazo = $4 \mathrm{~h}$ em estufa
asf. com borracha; envelhecimento a longo prazo = exposição ao tempo; envelhecimento a curto prazo = $4 \mathrm{~h}$ em estufa

Figura 6.42 - Pontos experimentais referentes ao módulo de fluência após recuperação em função do teor de ligante, para a faixa granulométrica B, considerando-se confiança de 95\% 


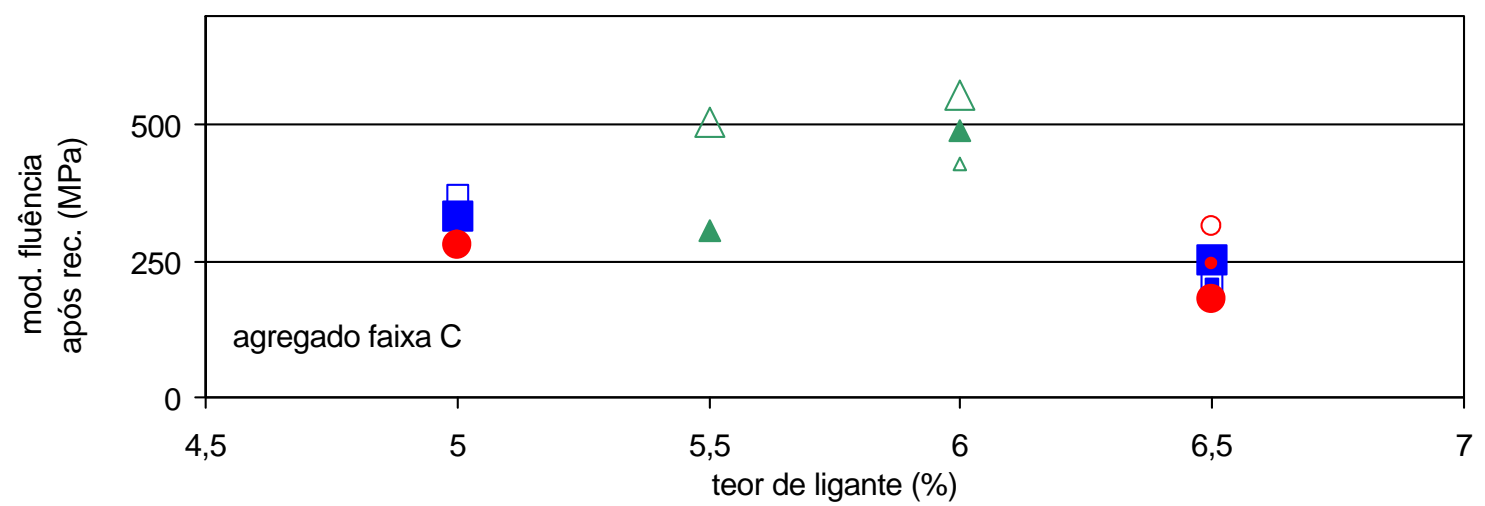

$\square$ asf. com polímero; envelhecimento a longo prazo = não; envelhecimento a curto prazo = não

$\triangle$ asf. convencional; envelhecimento a longo prazo = estufa; envelhecimento a curto prazo $=$ não

$\triangle$ asf. com borracha; envelhecimento a longo prazo = estufa; envelhecimento a curto prazo $=$ não

O asf. com polímero; envelhecimento a longo prazo = exposição ao tempo; envelhecimento a curto prazo = não

- asf. convencional; envelhecimento a longo prazo = não; envelhecimento a curto prazo $=4 \mathrm{~h}$ em estufa

- asf. com borracha; envelhecimento a longo prazo = não; envelhecimento a curto prazo $=4 \mathrm{~h}$ em estufa

$\Delta$ asf. com polímero; envelhecimento a longo prazo = estufa; envelhecimento a curto prazo $=4 \mathrm{~h}$ em estufa

- asf. convencional; envelhecimento a longo prazo = exposição ao tempo; envelhecimento a curto prazo $=4 \mathrm{~h}$ em estufa

- asf. com borracha; envelhecimento a longo prazo = exposição ao tempo; envelhecimento a curto prazo $=4 \mathrm{~h}$ em estufa

Figura 6.43 - Pontos experimentais referentes ao módulo de fluência após recuperação em função do teor de ligante, para a faixa granulométrica C, considerando-se confiança de 95\%

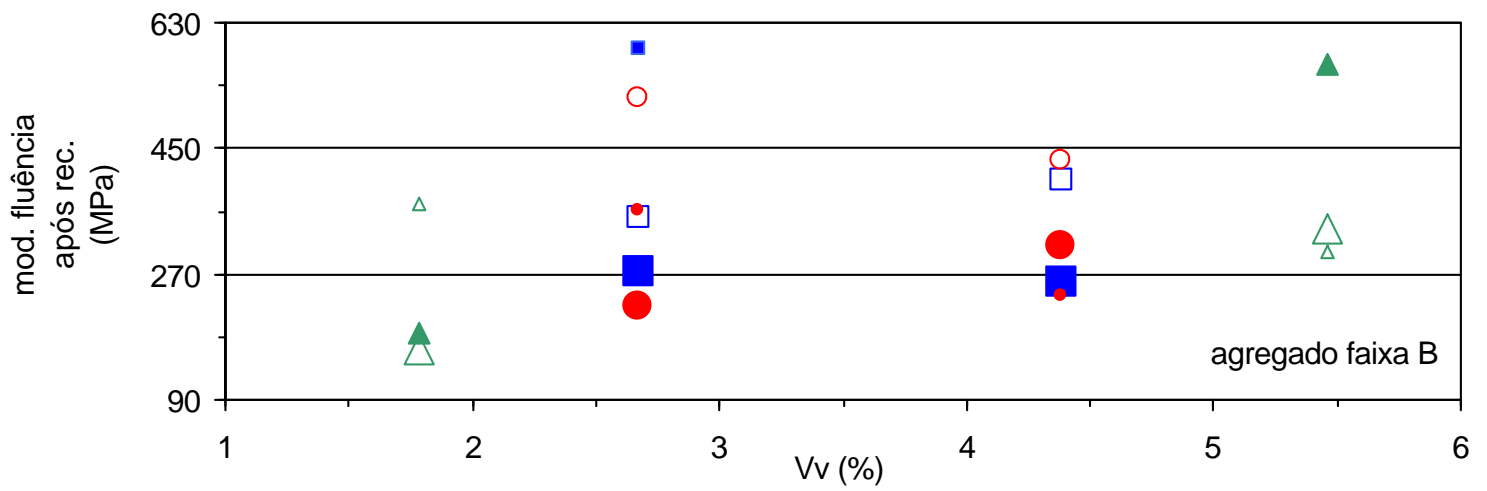

$\square$ asf. com polímero; envelhecimento a longo prazo = não; envelhecimento a curto prazo = não

$\Delta$ asf. convencional; envelhecimento a longo prazo = estufa; envelhecimento a curto prazo = não

$\triangle$ asf. com borracha; envelhecimento a longo prazo = estufa; envelhecimento a curto prazo $=$ não

$\circ$ asf. com polímero; envelhecimento a longo prazo = exposição ao tempo; envelhecimento a curto prazo = não

- asf. com borracha; envelhecimento a longo prazo = não; envelhecimento a curto prazo $=4 \mathrm{~h}$ em estufa

- asf. convencional; envelhecimento a longo prazo = não; envelhecimento a curto prazo $=4 \mathrm{~h}$ em estufa

$\Delta$ asf. com polímero; envelhecimento a longo prazo = estufa; envelhecimento a curto prazo $=4 \mathrm{~h}$ em estufa

- asf. convencional; envelhecimento a longo prazo = exposição ao tempo; envelhecimento a curto prazo $=4 \mathrm{~h}$ em estufa

- asf. com borracha; envelhecimento a longo prazo = exposição ao tempo; envelhecimento a curto prazo $=4 \mathrm{~h}$ em estufa

Figura 6.44 - Pontos experimentais referentes ao módulo de fluência após recuperação em função do volume de vazios, para a faixa granulométrica B, considerando-se confiança de $95 \%$ 


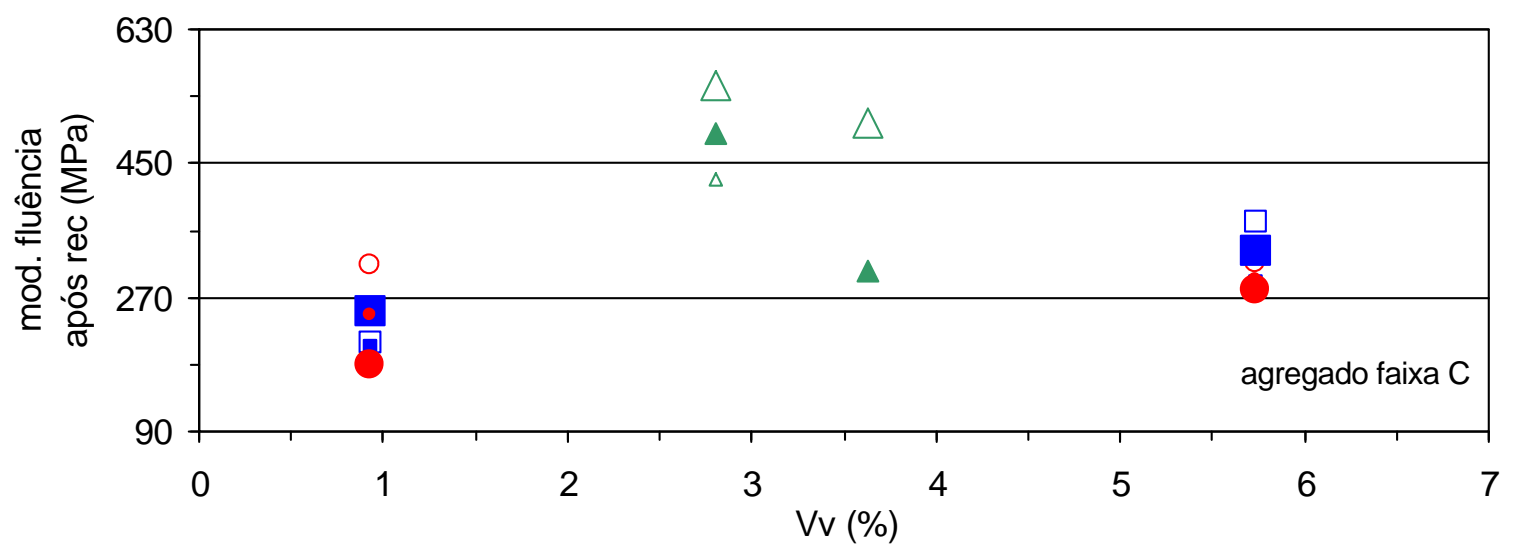

$\square$ asf. com polímero; envelhecimento a longo prazo = não; envelhecimento a curto prazo = não

$\Delta$ asf. convencional; envelhecimento a longo prazo = estufa; envelhecimento a curto prazo = não

$\triangle$ asf. com borracha; envelhecimento a longo prazo = estufa; envelhecimento a curto prazo = não

O asf. com polímero; envelhecimento a longo prazo = exposição ao tempo; envelhecimento a curto prazo = não

- asf. convencional; envelhecimento a longo prazo = não; envelhecimento a curto prazo = $4 \mathrm{~h}$ em estufa

口 asf. com borracha; envelhecimento a longo prazo = não; envelhecimento a curto prazo $=4 \mathrm{~h}$ em estufa

$\Delta$ asf. com polímero; envelhecimento a longo prazo = estufa; envelhecimento a curto prazo $=4 \mathrm{~h}$ em estufa

- asf. convencional; envelhecimento a longo prazo = exposição ao tempo; envelhecimento a curto prazo = 4h em estufa

- asf. com borracha; envelhecimento a longo prazo = exposição ao tempo; envelhecimento a curto prazo $=4 \mathrm{~h}$ em estufa

Figura 6.45 - Pontos experimentais referentes ao módulo de fluência após recuperação em função do volume de vazios, para a faixa granulométrica C, considerando-se confiança de $95 \%$

A inclinação sofreu influência da variação do tipo de ligante, o que foi identificado tanto pela análise realizada em função do teor de ligante (Figuras 6.46 e 6.47), como pela análise realizada em função do volume de vazios (Figuras 6.48 e 6.49). De acordo com as análises realizadas, asfaltos convencionais apresentaram as menores inclinações da curva de fluência, seguidos por asfaltos modificados com polímero. Os maiores valores de inclinação foram apresentados por asfaltos modificados com borracha. Esse comportamento da inclinação da curva de fluência do ensaio de creep estático encontrase ilustrado pela Figura 6.50.

Como maiores inclinações da curva de fluência significam maior suscetibilidade da mistura a deformações permanentes, mais uma vez ressalta-se o fato do ensaio de creep estático não ser adequado para distinguir as propriedades elásticas de asfaltos modificados.

O teor de ligante e o volume de vazios na mistura também mostraram ter influência significativa no comportamento da inclinação da curva de fluência, sendo que os maiores valores de inclinação da curva de fluência foram apresentados por misturas com os teores mais altos de ligante asfáltico, ou seja, com os menores volumes de vazios. 


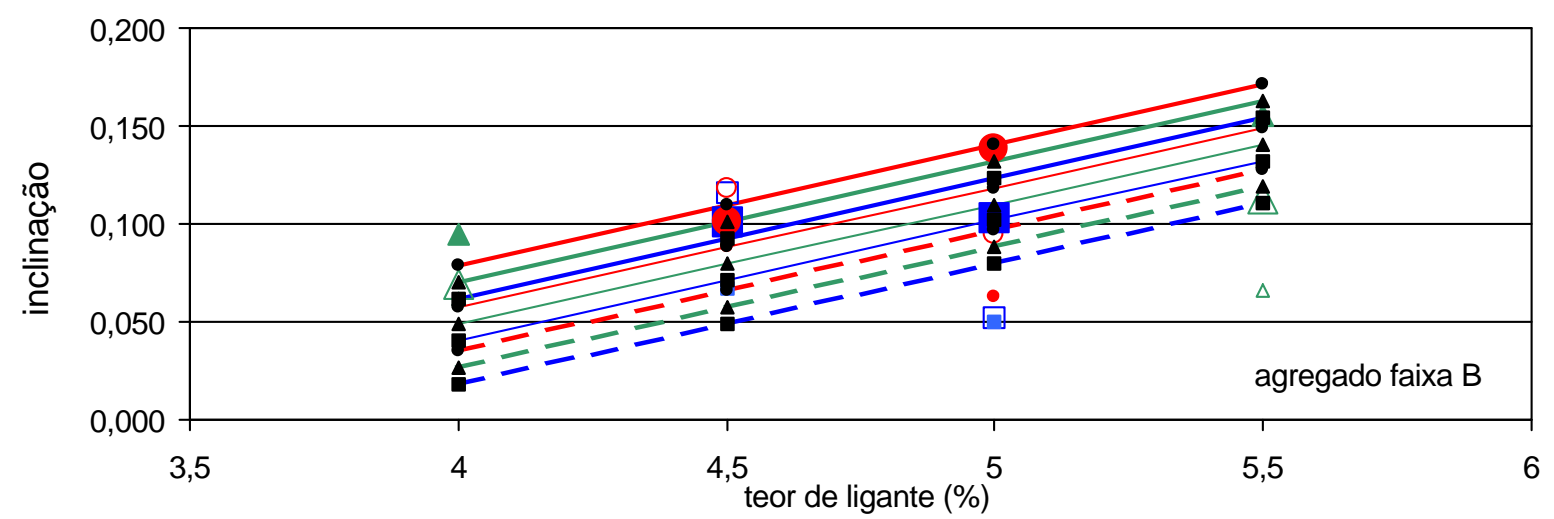

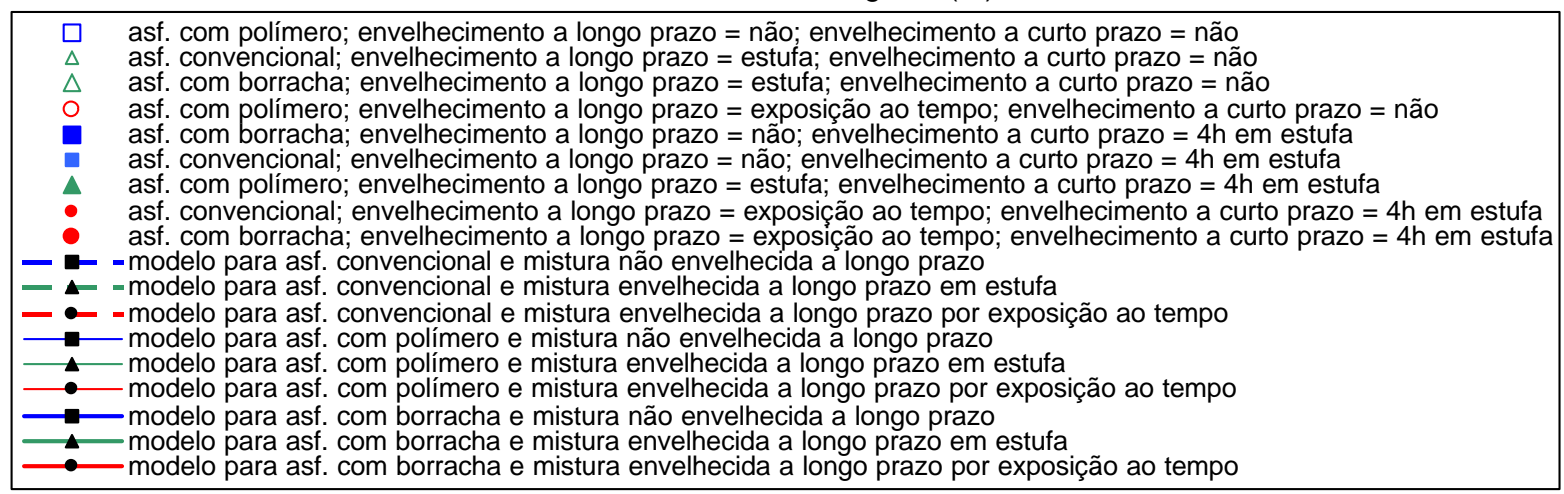

Figura 6.46 - Pontos experimentais e modelos de comportamento referentes à inclinação da curva de fluência em função do teor e do tipo de ligante e da condição de envelhecimento a longo prazo, para a faixa granulométrica B, considerando-se confiança de $95 \%$
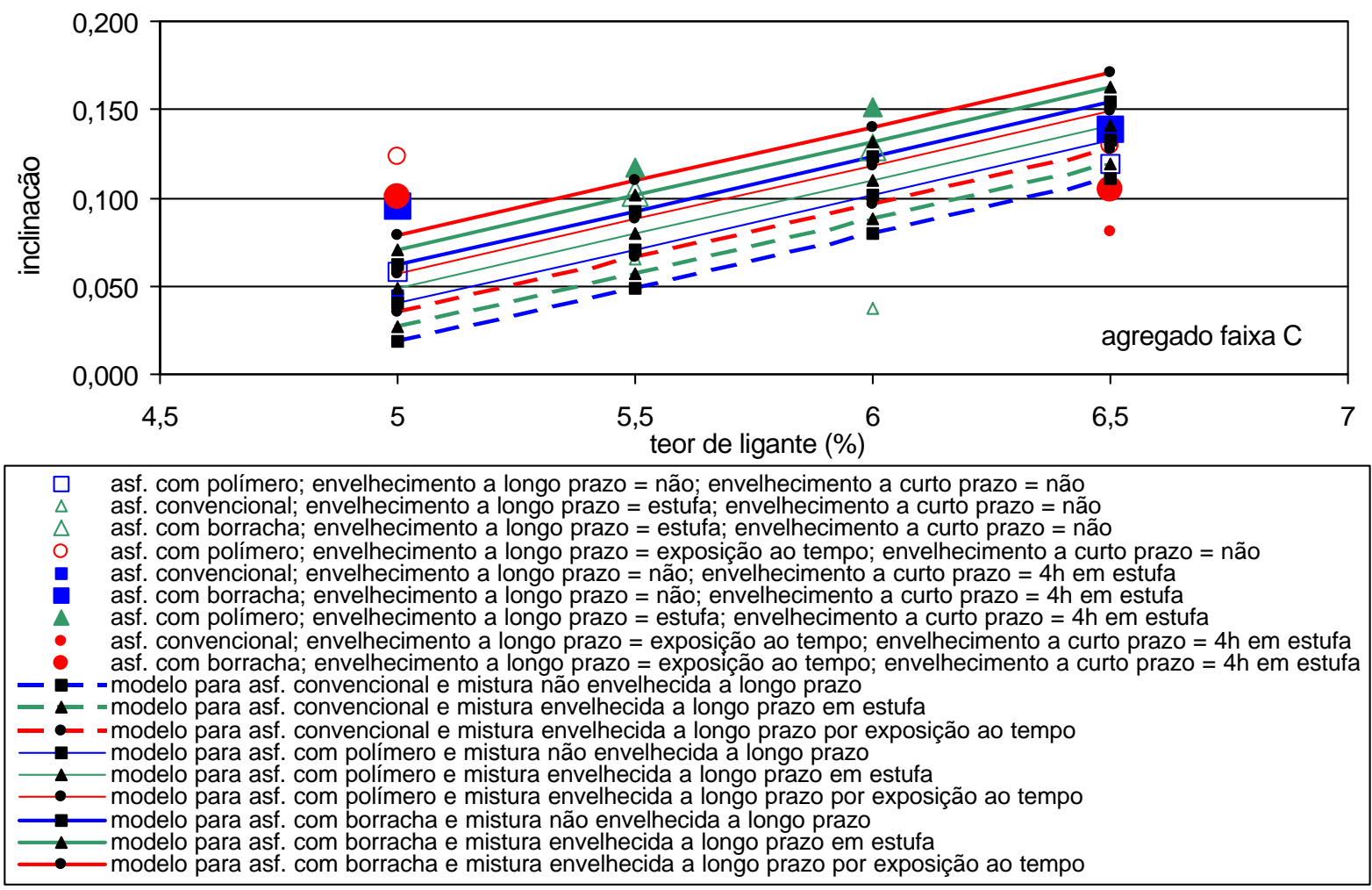

Figura 6.47 - Pontos experimentais e modelos de comportamento referentes à inclinação da curva de fluência em função do teor e do tipo de ligante e da condição de envelhecimento a longo prazo, para a faixa granulométrica C, considerando-se confiança de $95 \%$ 


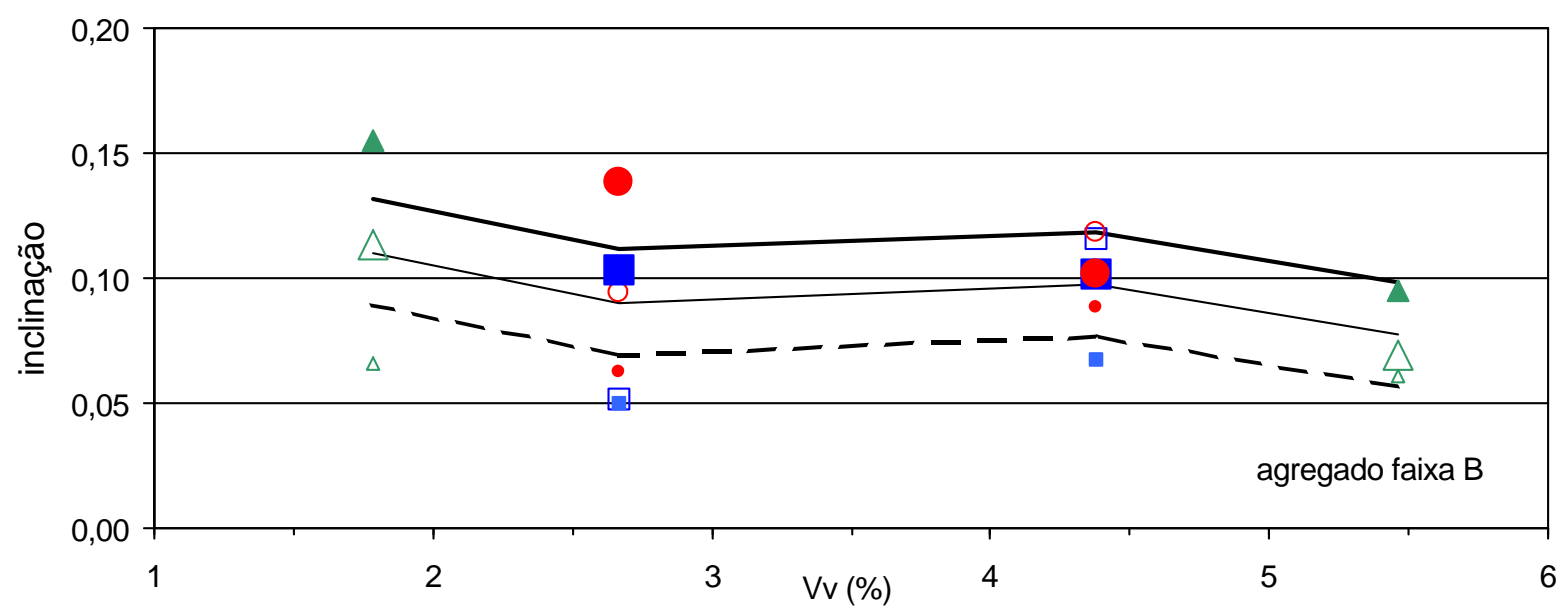

\begin{tabular}{|l}
\hline$\square \quad$ asf. com polímero; envelhecimento a longo prazo = não; envelhecimento a curto prazo = não \\
$\Delta \quad$ asf. convencional; envelhecimento a longo prazo = estufa; envelhecimento a curto prazo = não \\
$\Delta \quad$ asf. com borracha; envelhecimento a longo prazo = estufa; envelhecimento a curto prazo = não \\
asf. com polímero; envelhecimento a longo prazo = exposição ao tempo; envelhecimento a curto prazo = não \\
asf. com borracha; envelhecimento a longo prazo = não; envelhecimento a curto prazo = 4h em estufa \\
asf. convencional; envelhecimento a longo prazo = não; envelhecimento a curto prazo = $4 \mathrm{~h}$ em estufa \\
asf. com polímero; envelhecimento a longo prazo = estufa; envelhecimento a curto prazo = 4h em estufa \\
asf. convencional; envelhecimento a longo prazo = exposição ao tempo; envelhecimento a curto prazo = 4h em estufa \\
asf. com borracha; envelhecimento a longo prazo = exposição ao tempo; envelhecimento a curto prazo = 4h em estufa \\
- modelo para mistura com asfalto convencional \\
- modelo para mistura com asfalto modificado com polímero \\
- modelo para mistura com asfalto modificado com borracha
\end{tabular}

Figura 6.48 - Pontos experimentais e modelos de comportamento referentes à inclinação da curva de fluência em função do volume de vazios e do tipo de ligante, para a faixa granulométrica B, considerando-se confiança de $95 \%$

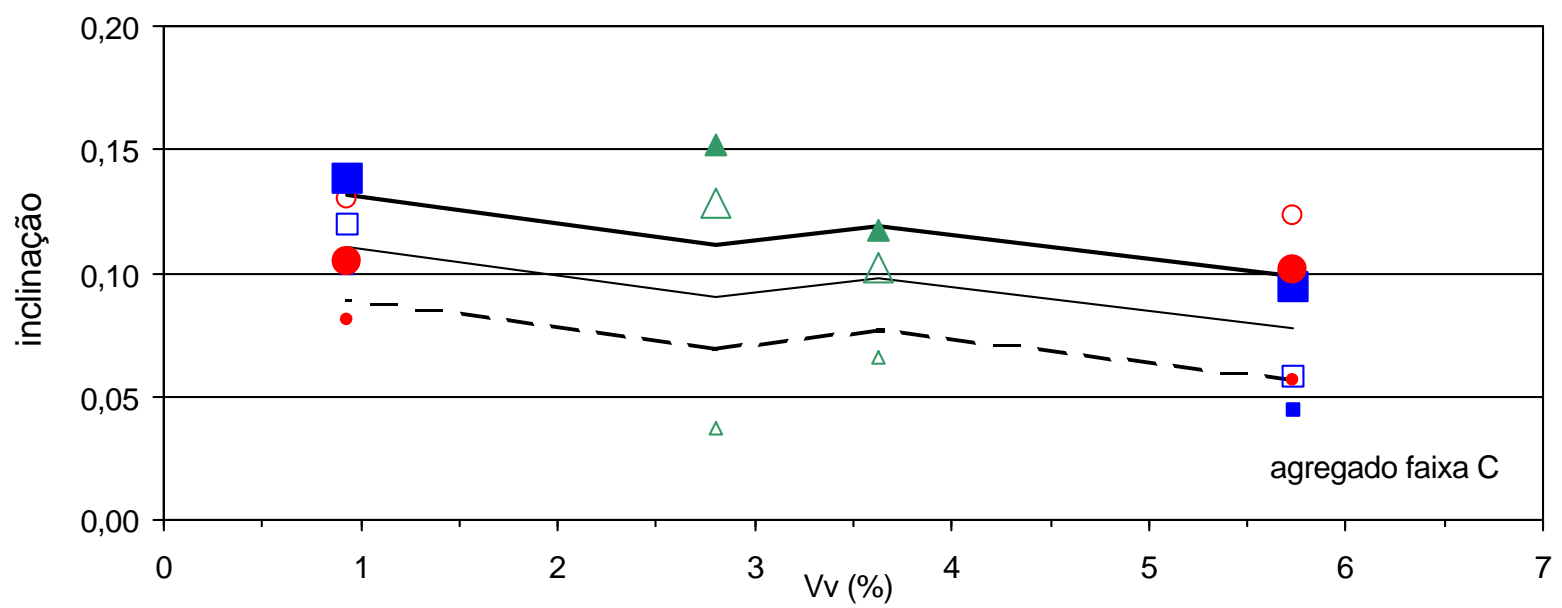

\begin{tabular}{|ll|}
\hline$\square$ & asf. com polímero; envelhecimento a longo prazo = não; envelhecimento a curto prazo = não \\
$\Delta$ & asf. convencional; envelhecimento a longo prazo = estufa; envelhecimento a curto prazo = não \\
$\Delta \quad$ asf. com borracha; envelhecimento a longo prazo = estufa; envelhecimento a curto prazo = não \\
asf. com polímero; envelhecimento a longo prazo = exposição ao tempo; envelhecimento a curto prazo = não \\
asf. convencional; envelhecimento a longo prazo = não; envelhecimento a curto prazo = 4h em estufa \\
asf. com borracha; envelhecimento a longo prazo = não; envelhecimento a curto prazo = $4 \mathrm{~h}$ em estufa \\
asf. com polímero; envelhecimento a longo prazo = estufa; envelhecimento a curto prazo = 4h em estufa \\
asf. convencional; envelhecimento a longo prazo = exposição ao tempo; envelhecimento a curto prazo = $4 \mathrm{~h}$ em estufa \\
asf. com borracha; envelhecimento a longo prazo = exposição ao tempo; envelhecimento a curto prazo = 4h em estufa \\
- modelo para mistura com asfalto convencional \\
- modelo para mistura com asfalto modificado com polímero
\end{tabular}

Figura 6.49 - Pontos experimentais e modelos de comportamento referentes à inclinação da curva de fluência em função do volume de vazios e do tipo de ligante, para a faixa granulométrica $\mathrm{C}$, considerando-se confiança de $95 \%$ 


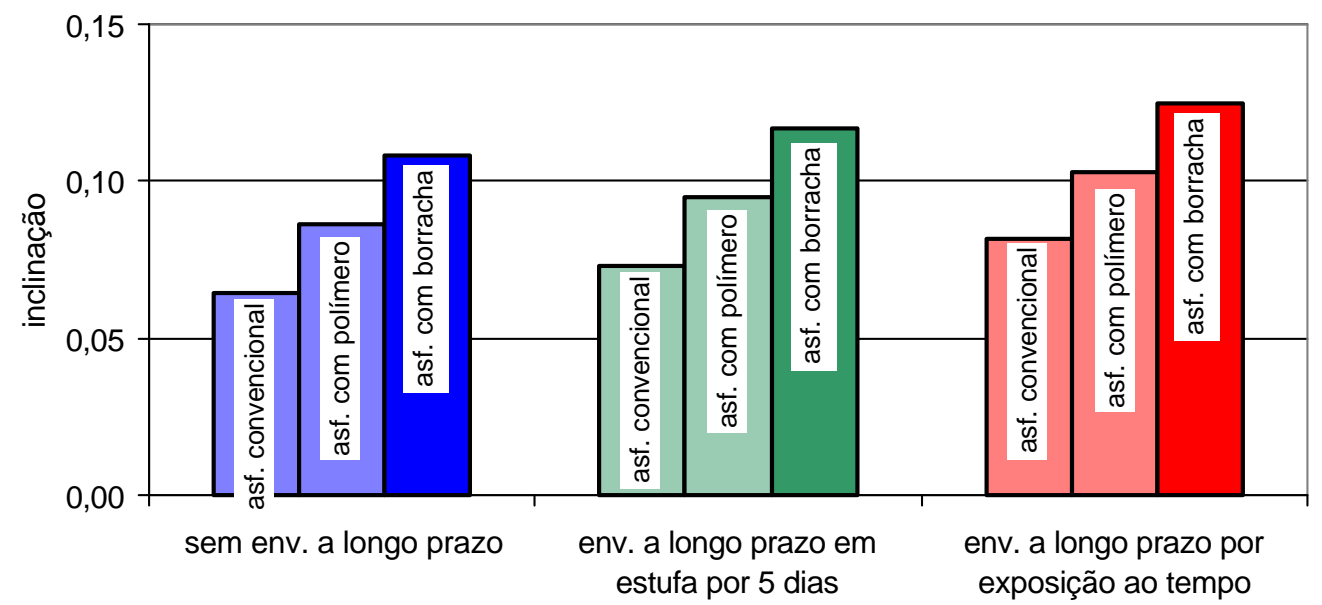

Figura 6.50 - Variação da inclinação da curva de fluência do ensaio de creep estático em função do tipo de ligante e da condição de envelhecimento a longo prazo

A análise realizada em função do teor de ligante identificou como significativo, além dos fatores já citados, o fator condição de envelhecimento a longo prazo, mais uma vez com inversão do comportamento esperado para essa resposta, uma vez que misturas envelhecidas ao tempo apresentaram as maiores inclinações da curva de fluência, seguidas por misturas envelhecidas na estufa. Os menores valores foram apresentados por misturas não envelhecidas a longo prazo.

Numa tentativa de resumir o comportamento apresentado pelas misturas no ensaio de creep estático, avaliações comparativas dos parâmetros do ensaio em função dos níveis dos fatores considerados significativos foram apresentadas nas Tabelas 6.15 a 6.18 .

Tabela 6.15 - Classificação qualitativa das respostas do ensaio de creep estático em função dos níveis do fator $B$

\begin{tabular}{lccc}
\hline & \multicolumn{3}{c}{ fator $B$} \\
\cline { 2 - 4 } & \multicolumn{2}{c}{ condição de envelhecimento a longo prazo } \\
\cline { 2 - 4 } resposta & envelhecimento & 5 dias em estufa a & 4 meses de \\
\hline deformação recuperável & menor & intermediário & maior \\
recuperação & menor & intermediário & maior \\
módulo de fluência & maior & intermediário & menor \\
inclinação & menor & intermediário & maior \\
\hline
\end{tabular}

Tabela 6.16 - Classificação qualitativa das respostas do ensaio de creep estático em função dos níveis do fator $C$

\begin{tabular}{lccc}
\hline & \multicolumn{3}{c}{ fator $C$} \\
& tipo de ligante \\
\cline { 2 - 4 } resposta & asfalto & asfalto modificado & asfalto modificado \\
convencional & com polímero & com borracha \\
\hline inclinação & menor & intermediário & maior \\
\hline
\end{tabular}


Tabela 6.17 - Classificação qualitativa das respostas do ensaio de creep estático em função dos níveis do fator $X 7$

fator $X 7$

distribuição granulométrica

\begin{tabular}{lcc}
\cline { 2 - 3 } resposta & centro da faixa B & centro da faixa C \\
\hline deformação total & maior & menor \\
deformação recuperável & maior & menor \\
módulo de fluência & menor & maior \\
\hline
\end{tabular}

Tabela 6.18 - Classificação qualitativa das respostas do ensaio de creep estático em função dos níveis do fator $X 8$

\begin{tabular}{lcc}
\hline & \multicolumn{2}{c}{ fator $X 8$} \\
& \multicolumn{2}{c}{ condição de envelhecimento a curto prazo } \\
\cline { 2 - 3 } resposta & sem envelhecimento & $4 \mathrm{~h} \mathrm{em} \mathrm{estufa} \mathrm{a} 135^{\circ} \mathrm{C}$ \\
\hline deformação recuperável & maior & menor \\
recuperação & maior & menor \\
\hline
\end{tabular}

Analisando-se os efeitos dos processos acelerados de envelhecimento a longo prazo no comportamento das misturas asfálticas à luz do ensaio de creep estático, dir-se-ia que as misturas envelhecidas a longo prazo apresentam maior capacidade de recuperação da deformação sofrida do que misturas não envelhecidas, além de apresentarem também módulos de fluência após ensaio de fluência menores e inclinações da curva de fluência maiores, o que sugere maior suscetibilidade à deformação total. Supondo-se que os processos de envelhecimento provoquem um enrijecimento das misturas, conclui-se que o ensaio de creep estático não foi capaz de detectar o envelhecimento a longo prazo sofrido pelas misturas, da mesma forma que não é capaz de identificar as propriedades elásticas de misturas compostas por asfaltos modificados.

\subsection{Resultados do ensaio de fluência por compressão uniaxial dinâmica}

Através do ensaio de fluência por compressão uniaxial dinâmica obtiveram-se os valores de deformação total do corpo de prova no final dos 5000 ciclos de aplicação de carga; o módulo de fluência, calculado pela relação entre a tensão aplicada e a deformação total; e a inclinação da curva de fluência, calculada entre 100 e 5000 s de ensaio. Os dados relativos ao ensaio de creep dinâmico estão relacionados no Apêndice D e apresentados em forma de matrizes fatoriais no Apêndice E. 


\subsubsection{Análise de variância (ANOVA) realizada com os resultados do ensaio de creep dinâmico}

As análises de variância dos dados do ensaio de fluência dinâmica, realizadas considerando-se o fator $A$ como um fator quantitativo, representando no caso o teor de ligante asfáltico nas misturas, encontram-se apresentadas nas Tabelas F.23 a F.28 do Apêndice F e estão resumidas nas Tabelas 6.19 e 6.20, para confianças de 99\% e 95\%, respectivamente. Nas Tabelas F.29 a F.31 do Apêndice F encontram-se apresentadas as análises de variância para a situação em que o fator $A$ representa o volume de vazios nas misturas, considerado como um fator qualitativo, pois os níveis dessa variável não são igualmente espaçados. Os resultados dessas análises, realizadas com confiança de $99 \%$ ou $95 \%$, pois os resultados de ambas as análises foram iguais, estão resumidos na Tabela 6.21.

Tabela 6.19 - Resumo da análise de variância realizada com os resultados do ensaio de creep dinâmico, considerando-se o fator $A$ (teor de ligante) quantitativo e confiança de $99 \%$

$$
\text { influência significativa? }
$$

\begin{tabular}{lccccccc}
\cline { 2 - 7 } \multicolumn{1}{c}{ resposta } & $\begin{array}{c}A \\
\text { teor de } \\
\text { ligante }\end{array}$ & $\begin{array}{c}B \\
\text { condição } \\
\text { de env. a } \\
\text { longo } \\
\text { prazo }\end{array}$ & $\begin{array}{c}C \\
\text { tipo de } \\
\text { ligante }\end{array}$ & $\begin{array}{c}X 7 \\
\text { distribuição } \\
\text { granulomé- } \\
\text { trica }\end{array}$ & $\begin{array}{c}X 8 \\
\text { condição } \\
\text { de env. a } \\
\text { curto } \\
\text { prazo }\end{array}$ & $\begin{array}{c}A C \\
\text { interação } \\
\text { entre os } \\
\text { fatores } A \\
\text { e } C\end{array}$ & $\begin{array}{c}A X 8 \\
\text { interação } \\
\text { entre os } \\
\text { fatores } A \text { e } \\
X 8\end{array}$ \\
\hline deformação total & $\begin{array}{c}\text { sim } \\
\text { (linear) }\end{array}$ & $\operatorname{sim}$ & $\operatorname{sim}$ & $\operatorname{sim}$ & $\operatorname{sim}$ & não & não \\
\hline $\begin{array}{l}\text { módulo de } \\
\text { fluência }\end{array}$ & não & $\operatorname{sim}$ & $\operatorname{sim}$ & $\operatorname{sim}$ & não & não & não \\
\hline inclinação & não & não & $\operatorname{sim}$ & $\operatorname{sim}$ & $\operatorname{sim}$ & não & não \\
\hline
\end{tabular}

Tabela 6.20 - Resumo da análise de variância realizada com os resultados do ensaio de creep dinâmico, considerando-se o fator $A$ (teor de ligante) quantitativo e confiança de 95\% influência significativa?

\begin{tabular}{lccccccc}
\cline { 2 - 7 } resposta & $\begin{array}{c}A \\
\text { teor de } \\
\text { ligante }\end{array}$ & $\begin{array}{c}B \\
\text { condição } \\
\text { de env. a } \\
\text { longo } \\
\text { prazo }\end{array}$ & $\begin{array}{c}C \\
\text { tipo de } \\
\text { ligante }\end{array}$ & $\begin{array}{c}X 7 \\
\text { distribuição } \\
\text { granulomé- } \\
\text { trica }\end{array}$ & $\begin{array}{c}\text { condição } \\
\text { de env. a } \\
\text { curto } \\
\text { prazo }\end{array}$ & $\begin{array}{c}A C \\
\text { interação } \\
\text { entre os } \\
\text { fatores } A \\
\text { e } C\end{array}$ & $\begin{array}{c}A X 8 \\
\text { interação } \\
\text { entre os } \\
\text { fatores } A \text { e } \\
X 8\end{array}$ \\
\hline deformação total & $\begin{array}{c}\text { sim } \\
\text { (linear) }\end{array}$ & $\operatorname{sim}$ & $\operatorname{sim}$ & $\operatorname{sim}$ & $\operatorname{sim}$ & não & não \\
\hline $\begin{array}{l}\text { módulo de } \\
\text { fluência }\end{array}$ & não & $\operatorname{sim}$ & $\operatorname{sim}$ & $\operatorname{sim}$ & não & não & não \\
\hline inclinação & sim & não & $\operatorname{sim}$ & $\operatorname{sim}$ & sim & não & não \\
\hline
\end{tabular}


Tabela 6.21 - Resumo da análise de variância realizada com os resultados do ensaio creep dinâmico, considerando-se o fator $A$ (volume de vazios) qualitativo e confiança de $99 \%$ ou $95 \%$ influência significativa?

\begin{tabular}{|c|c|c|c|c|c|c|c|}
\hline resposta & $\begin{array}{c}A \\
\text { volume } \\
\text { de } \\
\text { vazios }\end{array}$ & $\begin{array}{c}B \\
\text { condição } \\
\text { de env. a } \\
\text { longo } \\
\text { prazo }\end{array}$ & $\begin{array}{c}C \\
\text { tipo de } \\
\text { ligante }\end{array}$ & $\begin{array}{c}X 7 \\
\text { distribuição } \\
\text { granulomé- } \\
\text { trica }\end{array}$ & $\begin{array}{c}X 8 \\
\text { condição } \\
\text { de env. a } \\
\text { curto } \\
\text { prazo }\end{array}$ & $\begin{array}{c}A C \\
\text { interação } \\
\text { entre os } \\
\text { fatores } A \\
\text { e } C\end{array}$ & $\begin{array}{c}A X 8 \\
\text { interação } \\
\text { entre os } \\
\text { fatores } A \text { e } \\
X 8\end{array}$ \\
\hline deformação total & $\operatorname{sim}$ & $\operatorname{sim}$ & $\operatorname{sim}$ & $\operatorname{sim}$ & $\operatorname{sim}$ & não & não \\
\hline $\begin{array}{l}\text { módulo de } \\
\text { fluência }\end{array}$ & não & $\operatorname{sim}$ & sim & $\operatorname{sim}$ & não & não & não \\
\hline inclinação & $\operatorname{sim}$ & não & $\operatorname{sim}$ & $\operatorname{sim}$ & $\operatorname{sim}$ & não & não \\
\hline
\end{tabular}

\subsubsection{Apresentação gráfica e modelagem dos resultados do ensaio de creep dinâmico}

A partir da análise de variância dos dados do ensaio de creep dinâmico foram identificados os fatores com influência significativa no comportamento das misturas quanto à deformação total, ao módulo de fluência e à inclinação da curva de fluência. Construíram-se então modelos estatísticos de comportamento para essas respostas. Nos modelos apresentados na Tabela 6.22, o fator $A$ representa o teor de ligante na mistura, sendo no caso um fator quantitativo. Nos modelos apresentados na Tabela 6.23 o fator $A$ representa o volume de vazios na mistura, incluído na análise como um fator qualitativo.

Tabela 6.22 - Modelos de regressão múltipla determinados através da análise do experimento fatorial fracionário assimétrico $1 / 4\left(4 \times 3^{2} \times 2^{2}\right)$, considerando-se o fator $A$ quantitativo, representando o teor de ligante nas misturas

\begin{tabular}{cccc}
\hline resposta $(Y)$ & confiança & $\mathrm{R}^{2}$ & modelo \\
\hline $\begin{array}{c}\text { deformação } \\
\text { total } \\
\text { (mm/mm) }\end{array}$ & $\begin{array}{c}99 \% \\
\mathrm{e}\end{array}$ & 0,52 & $Y=0,0030+0,00031 P_{l}(A)-0,00069 P(B)-$ \\
\hline $\begin{array}{c}\text { módulo de } \\
\text { fluência } \\
(\mathrm{MPa})\end{array}$ & $\begin{array}{c}99 \% \\
\mathrm{e}\end{array}$ & 0,58 & $Y=148+32,7 P(B)+22,5 P(C)-15,2 P(X 7)$ \\
\hline \multirow{2}{*}{$\begin{array}{c}95 \% \\
\text { inclinação }\end{array}$} & $99 \%$ & 0,32 & $Y=0,162-0,024 P(C)+0,0146 P(X 7)+0,0145 P(X 8)$ \\
\cline { 2 - 4 } & $95 \%$ & 0,38 & $Y=0,162+0,013 P_{l}(A)-0,024 P(C)+0,0146 P(X 7)+$ \\
& & & $+0,0145 P(X 8)$ \\
\hline
\end{tabular}


Tabela 6.23 - Modelos de regressão múltipla determinados através da análise do experimento fatorial fracionário assimétrico $1 / 4\left(4 \times 3^{2} \times 2^{2}\right)$, considerando-se o fator $A$ qualitativo, representando o volume de vazios nas misturas

\begin{tabular}{cccc}
\hline resposta $(Y)$ & confiança & $\mathrm{R}^{2}$ & modelo \\
\hline $\begin{array}{c}\text { deformação } \\
\text { total }\end{array}$ & $99 \%$ & 0,60 & $Y=0,0029+0,000069 a_{1}+0,00031 a_{2}-0,00069 P(B)-$ \\
$(\mathrm{mm} / \mathrm{mm})$ & $95 \%$ & & $-0,00057 P(C)+0,00042 P(X 7)-0,00036 P(X 8)$ \\
\hline $\begin{array}{c}\text { módulo de } \\
\text { fluência }\end{array}$ & $99 \%$ & 0,40 & $Y=147+26 P(B)+20 P(C)-14 P(X 7)$ \\
(MPa) & $95 \%$ & & \\
\hline inclinação & $99 \%$ & 0,54 & $Y=0,160+0,0136 a_{1}+0,0159 a_{2}-0,023 P(C)+$ \\
& $\mathrm{e}$ & & $+0,018 P(X 7)+0,014 P(X 8)$ \\
& $95 \%$ & &
\end{tabular}

Nas Figuras 6.51 a 6.54 são apresentados os pontos experimentais e os modelos de comportamento referentes à deformação total do ensaio de creep dinâmico, em função do teor de ligante utilizado na mistura. Nos gráficos das Figuras 6.51 e 6.52 foram lançados os pontos experimentais para as distribuições granulométricas correspondentes aos centros das faixas B e C do DNER (1997), respectivamente, incluindo-se também as curvas de comportamento para a condição de misturas não envelhecidas a curto prazo. Nas Figuras 6.53 e 6.54 podem ser encontrados os mesmos pontos experimentais, mas nesse caso as curvas de comportamento que aparecem nos gráficos referem-se à condição de misturas envelhecidas a curto prazo por 4 horas em estufa ventilada.

Misturas não envelhecidas a curto prazo sofreram deformações totais superiores às sofridas por misturas que foram submetidas ao processo acelerado de envelhecimento a curto prazo.

O mesmo comportamento foi observado em relação aos processos acelerados de envelhecimento a longo prazo, que geraram misturas com menores deformações totais. Nesse caso, misturas envelhecidas por exposição ao tempo foram menos suscetíveis a deformações totais do que misturas envelhecidas em estufa ventilada por 5 dias a $85^{\circ} \mathrm{C}$. As maiores deformações totais foram observadas em misturas não envelhecidas a longo prazo. 

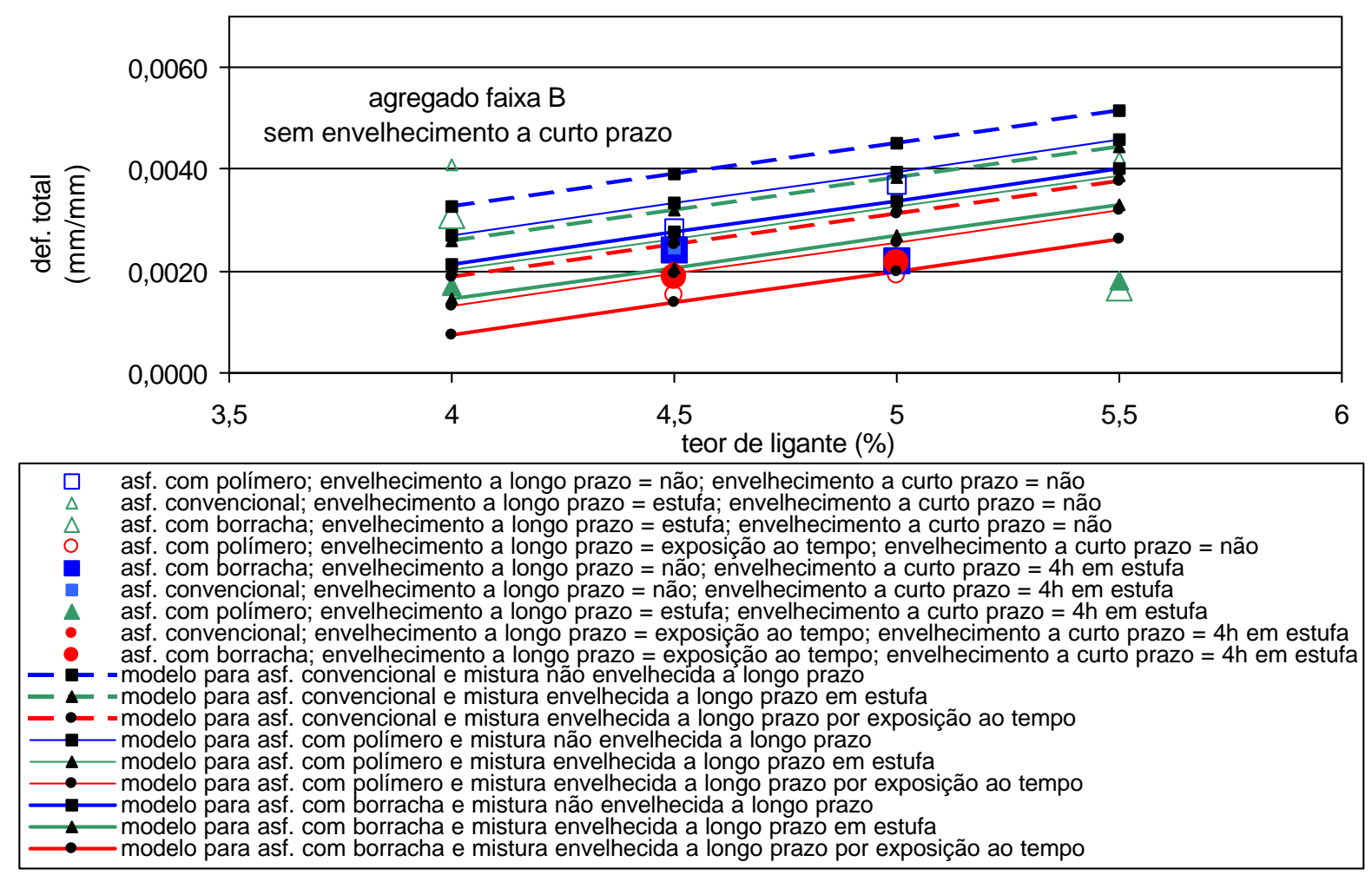

Figura 6.51 - Pontos experimentais e modelos de comportamento referentes à deformação total em função do teor e do tipo de ligante e da condição de envelhecimento a longo prazo, para misturas da faixa B não envelhecidas a curto prazo, considerando-se confiança de $99 \%$ ou $95 \%$
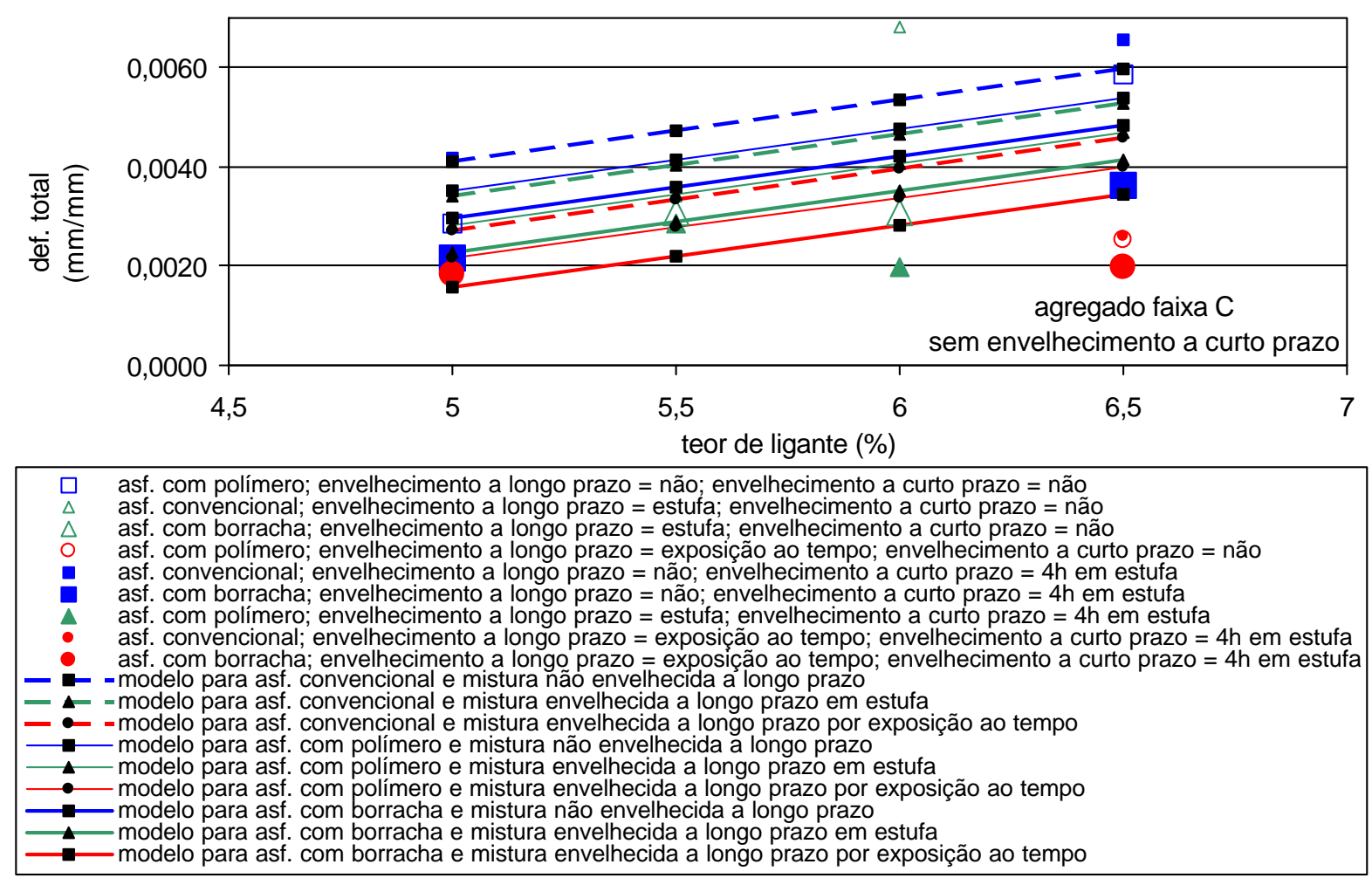

Figura 6.52 - Pontos experimentais e modelos de comportamento referentes à deformação total em função do teor e do tipo de ligante e da condição de envelhecimento a longo prazo, para misturas da faixa C não envelhecidas a curto prazo, considerando-se confiança de $99 \%$ ou $95 \%$ 

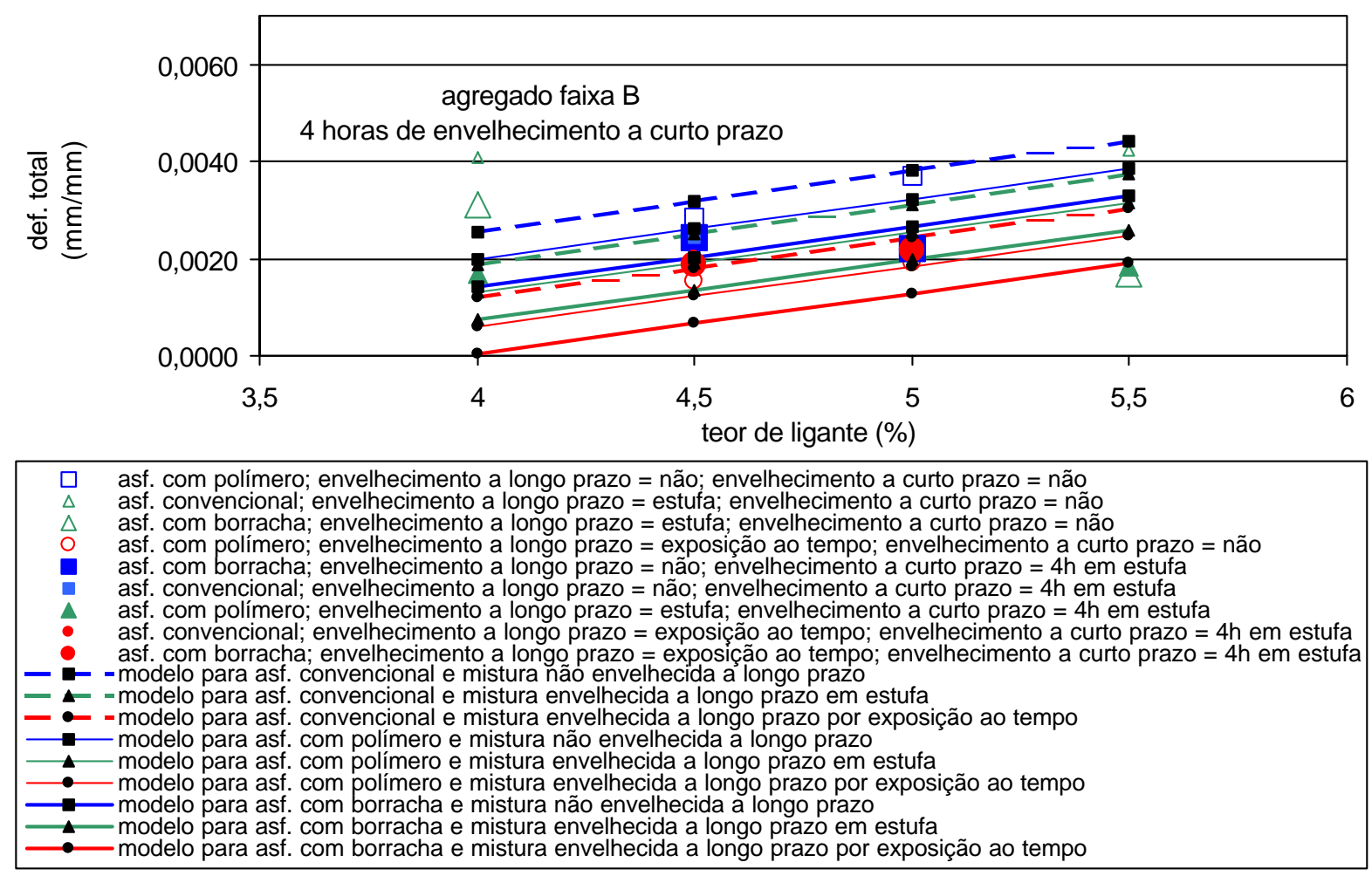

Figura 6.53 - Pontos experimentais e modelos de comportamento referentes à deformação total em função do teor e do tipo de ligante e da condição de envelhecimento a longo prazo, para misturas da faixa B envelhecidas a curto prazo, considerando-se confiança de $99 \%$ ou $95 \%$
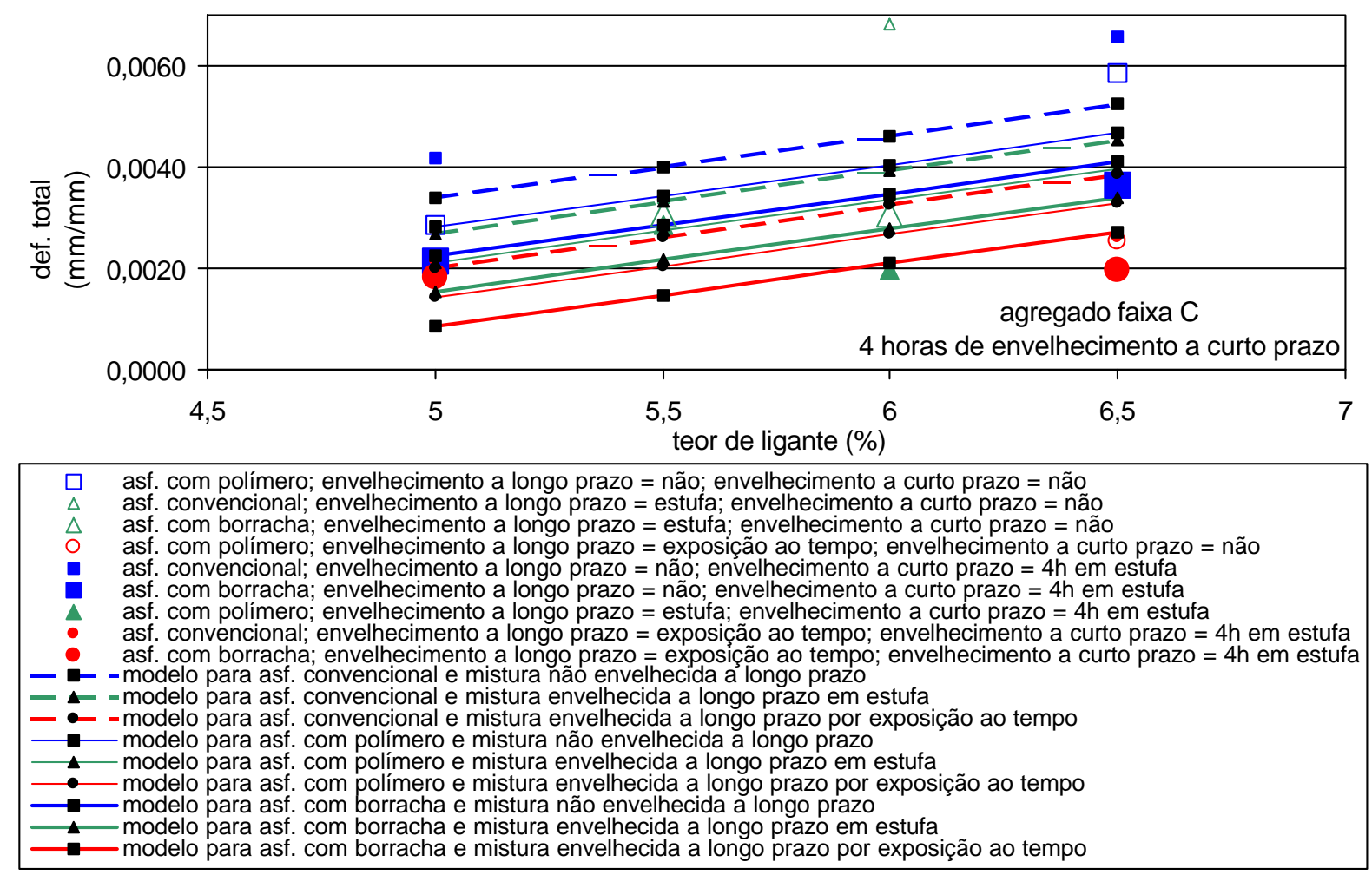

Figura 6.54 - Pontos experimentais e modelos de comportamento referentes à deformação total em função do teor e do tipo de ligante e da condição de envelhecimento a longo prazo, para misturas da faixa C envelhecidas a curto prazo, considerando-se confiança de $99 \%$ ou $95 \%$ 
As deformações totais aumentaram com o aumento do teor de ligante, conforme o esperado. Também conforme o esperado, misturas com distribuição granulométrica do agregado correspondente ao centro da faixa B apresentaram deformações totais inferiores às apresentadas por misturas com distribuição granulométrica correspondente ao centro da faixa $\mathrm{C}$.

Quanto a influência do tipo de ligante, o asfalto modificado com borracha deu origem a misturas com as menores deformações totais, seguido pelo asfalto modificado com polímero e por último, pelo asfalto convencional, com o qual foram obtidas misturas com as maiores deformações totais.

Realizando-se as análises em função do volume de vazios na mistura, foram obtidas respostas equivalentes às obtidas pela análise realizada em função do teor de ligante, conforme pode ser observado pelas Figuras 6.55 a 6.60. Nas Figuras 6.55 e 6.56 foram incluídas curvas de comportamento referentes às misturas compostas por asfalto convencional. Nas Figuras 6.57 e 6.58 as curvas de comportamento referem-se às misturas compostas por asfalto modificado com polímero, e nas Figuras 6.59 e 6.60, às misturas compostas por asfalto modificado com borracha.

Para melhor visualização da variação da deformação total foram construídos gráficos em colunas, apresentados nas Figuras 6.61 a 6.64. Os gráficos das Figuras 6.61 e 6.62 referem-se a misturas compostas por agregados com distribuição granulométrica correspondente ao centro da faixa B do DNER (1997), e os gráficos das Figuras 6.63 e 6.64, a misturas compostas por agregados com distribuição granulométrica correspondente ao centro da faixa C do DNER (1997). Nas Figuras 6.61 e 6.63 pode ser observada a influência da condição de envelhecimento a longo prazo e do tipo de ligante na variação da deformação total, para misturas não envelhecidas a curto prazo. Nas Figuras 6.62 e 6.64 encontra-se ilustrada a variação da deformação total apresentada por misturas envelhecidas a curto prazo por $4 \mathrm{~h}$ em estufa com circulação de ar forçada. 

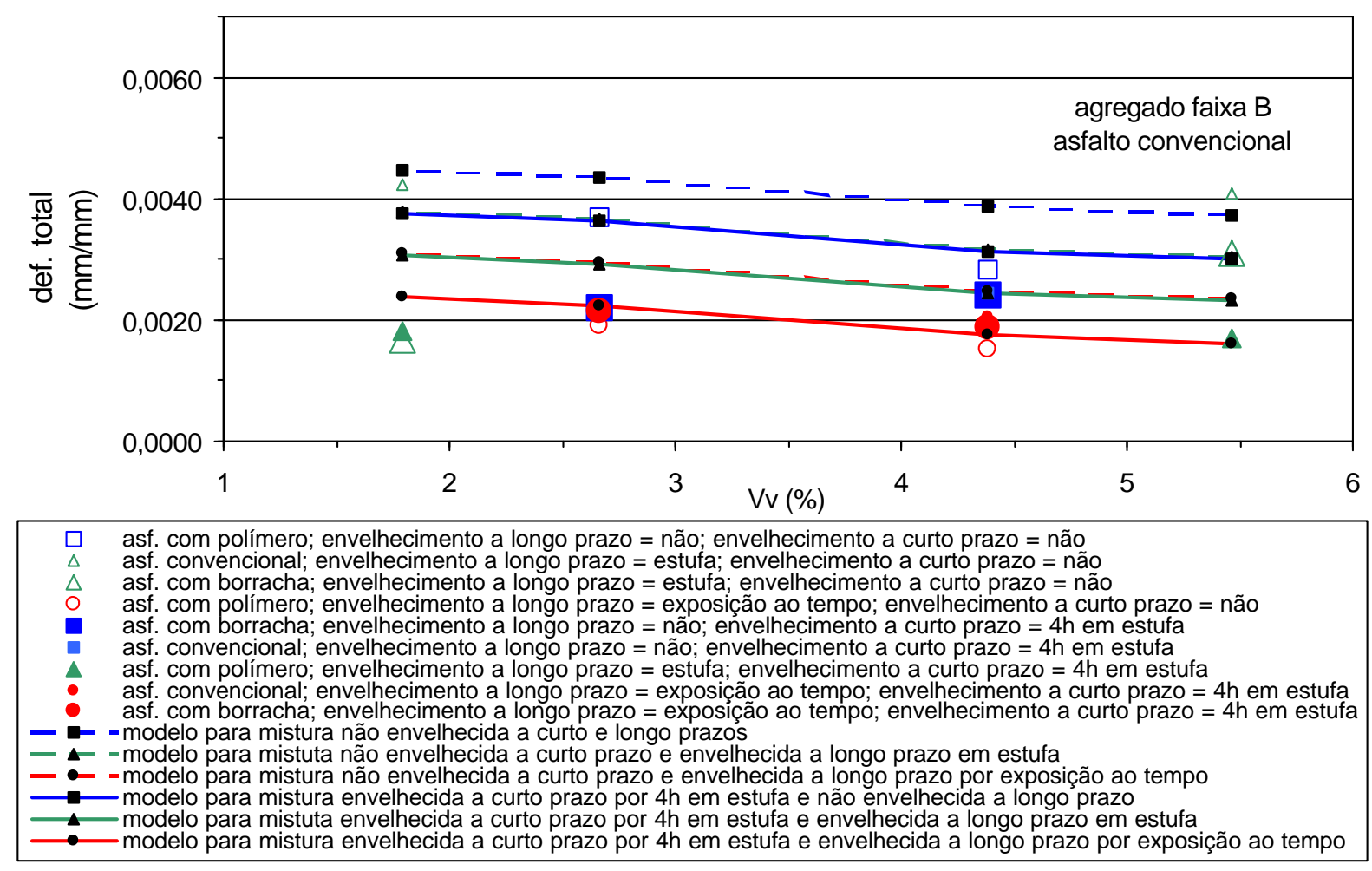

Figura 6.55 - Modelos de comportamento referentes à deformação total em função do volume de vazios, para misturas compostas por asfalto convencional e por agregados da faixa $\mathrm{B}$, considerando-se níveis de confiança de $99 \%$ ou $95 \%$
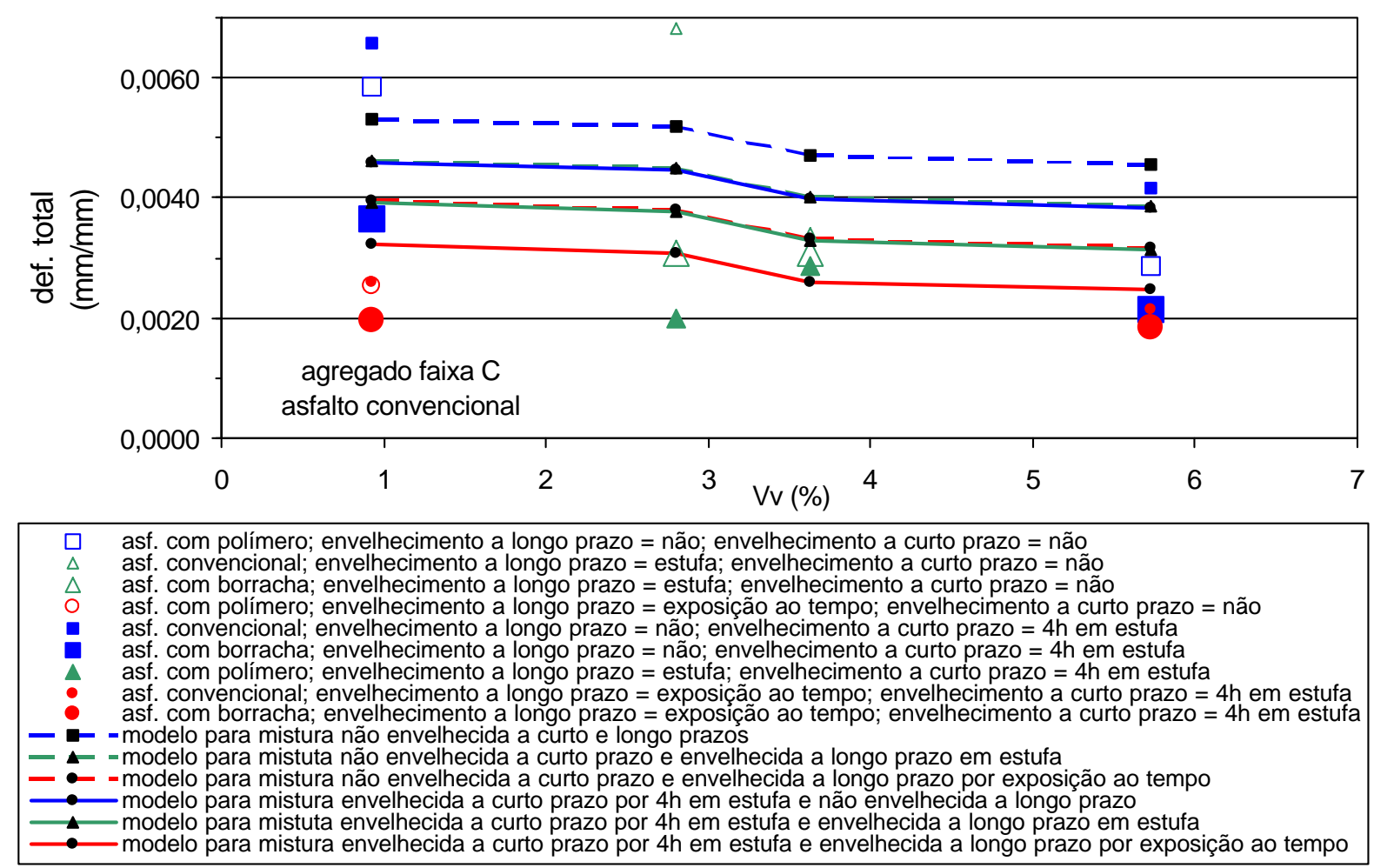

Figura 6.56 - Modelos de comportamento referentes à deformação total em função do volume de vazios, para misturas compostas por asfalto convencional e por agregados da faixa $\mathrm{C}$, considerando-se níveis de confiança de $99 \%$ ou $95 \%$ 


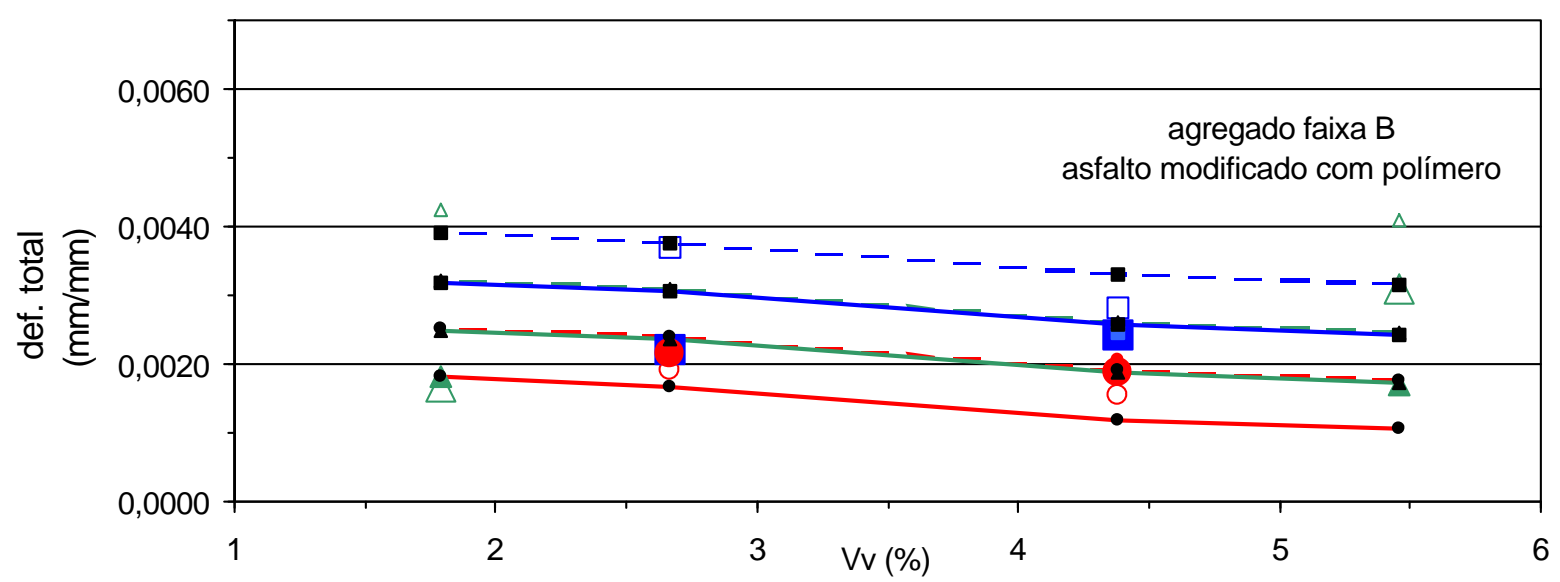

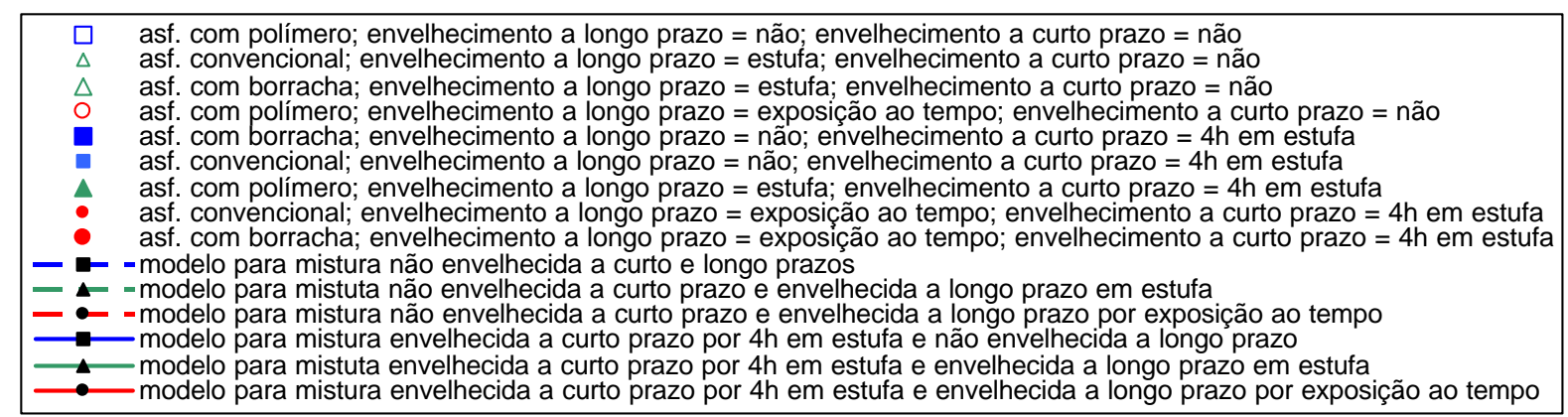

Figura 6.57 - Modelos de comportamento referentes à deformação total em função do volume de vazios, para misturas compostas por asfalto modificado com polímero e por agregados da faixa B, considerando-se níveis de confiança de $99 \%$ ou $95 \%$

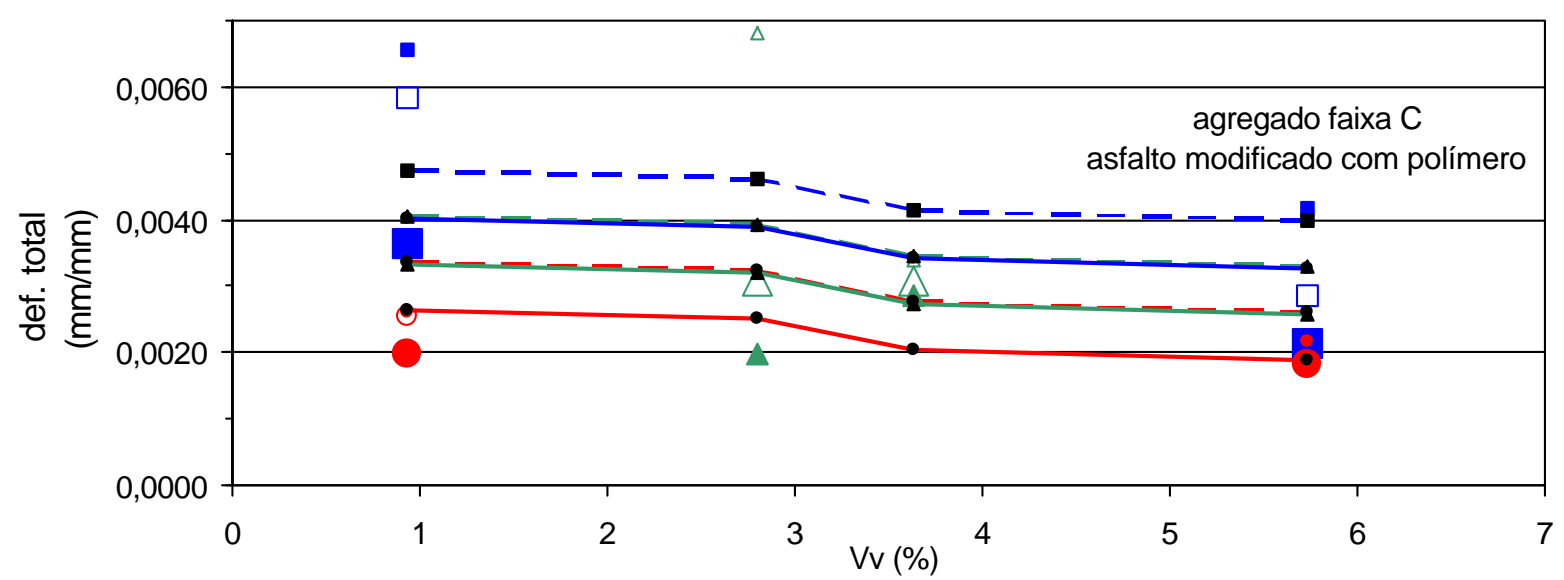

\footnotetext{
$\square \quad$ asf. com polímero; envelhecimento a longo prazo = não; envelhecimento a curto prazo = não asf. convencional; envelhecimento a longo prazo = estufa; envelhecimento a curto prazo = não asf. com borracha; envelhecimento a longo prazo = estufa; envelhecimento a curto prazo = não asf. com polímero; envelhecimento a longo prazo = exposição ao tempo; envelhecimento a curto prazo = não asf. convencional; envelhecimento a longo prazo = não; envelhecimento a curto prazo $=4 \mathrm{~h}$ em estufa asf. com borracha; envelhecimento a longo prazo = não; envelhecimento a curto prazo $=4 \mathrm{~h}$ em estufa asf. com polímero; envelhecimento a longo prazo = estufa; envelhecimento a curto prazo $=4 \mathrm{~h}$ em estufa asf. convencional; envelhecimento a longo prazo = exposicão ao tempo; envelhecimento a curto prazo = $4 \mathrm{~h}$ em estufa asf. convencional; envelhecimento a longo prazo = exposição ao tempo; envelhecimento a curto prazo = $4 \mathrm{~h}$ em estufa asf. com borracha; envelhecimento a longo prazo = exposição

- - modelo para mistura não envelhecida a curto e longo prazos

- - - modelo para mistura não envelhecida a curto prazo e envelhecida a longo prazo por exposição ao tempo - modelo para mistura envelhecida a curto prazo por $4 \mathrm{~h}$ em estufa e não envelhecida a longo prazo modelo para mistuta envelhecida a curto prazo por $4 \mathrm{~h}$ em estufa e envelhecida a longo prazo em estufa modelo para mistura envelhecida a curto prazo por $4 \mathrm{~h}$ em estufa e envelhecida a longo prazo por exposição ao tempo
}

Figura 6.58 - Modelos de comportamento referentes à deformação total em função do volume de vazios, para misturas compostas por asfalto modificado com polímero e por agregados da faixa C, considerando-se níveis de confiança de $99 \%$ ou $95 \%$ 

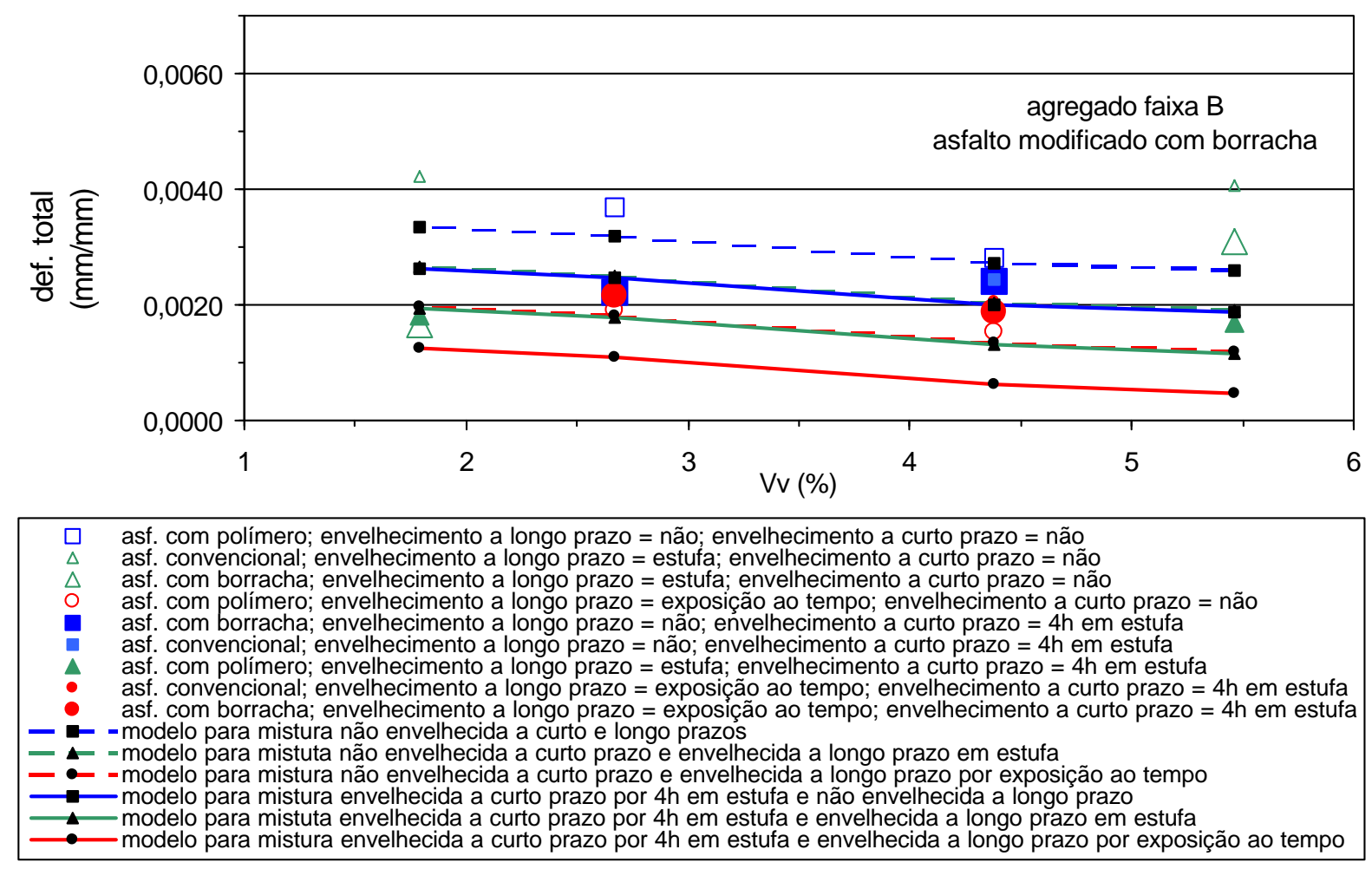

Figura 6.59 - Modelos de comportamento referentes à deformação total em função do volume de vazios, para misturas compostas por asfalto modificado com borracha e por agregados da faixa B, considerando-se níveis de confiança de $99 \%$ ou $95 \%$

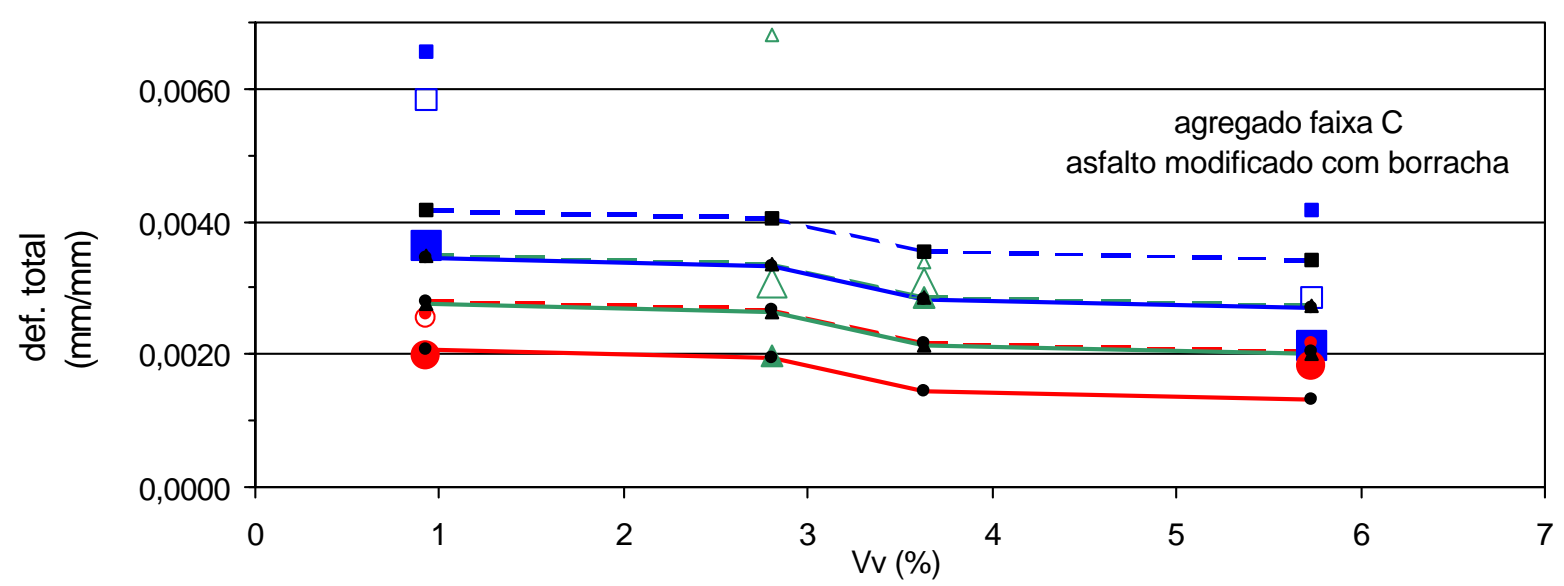

\footnotetext{
$\square \quad$ asf. com polímero; envelhecimento a longo prazo = não; envelhecimento a curto prazo = não

asf. com polimero; envelhecimento a longo prazo = não; envelhecimento a curto prazo = não
asf. convencional; envelhecimento a longo prazo = estufa; envelhecimento a curto prazo = não

asf. com borracha; envelhecimento a longo prazo = estufa; envelhecimento a curto prazo = não

asf. com polímero; envelhecimento a longo prazo = exposição ao tempo; envelhecimento a curto prazo = não

asf. convencional; envelhecimento a longo prazo = não; envelhecimento a curto prazo $=4 \mathrm{~h}$ em estufa

asf. com borracha; envelhecimento a longo prazo = não; envelhecimento a curto prazo $=4 \mathrm{~h}$ em estufa

asf. com polímero; envelhecimento a longo prazo = estufa; envelhecimento a curto prazo $=4 \mathrm{~h}$ em estufa

asf. convencional; envelhecimento a longo prazo = exposicão ao tempo; envelhecimento a curto prazo $=4 \mathrm{~h}$ em estufa

asf com borracha; envelhecimento a longo prazo = exposição ao tempo; envelhecimento a curto prazo = $4 \mathrm{~h}$ em estufa

- - modelo para mistura não envelhecida a curto e longo prazos

- - - - modelo para mistura não envelhecida a curto prazo e envelhecida a longo prazo por exposição ao tempo

- modelo para mistura não envelhecida a curto prazo e envelhecida a longo prazo por exposição ao

modelo para mistuta envelhecida a curto prazo por $4 \mathrm{~h}$ em estufa e envelhecida a longo prazo em estufa

modelo para mistura envelhecida a curto prazo por $4 \mathrm{~h}$ em estufa e envelhecida a longo prazo por exposição ao tempo
}

Figura 6.60 - Modelos de comportamento referentes à deformação total em função do volume de vazios, para misturas compostas por asfalto modificado com borracha e por agregados da faixa C, considerando-se níveis de confiança de $99 \%$ ou $95 \%$ 


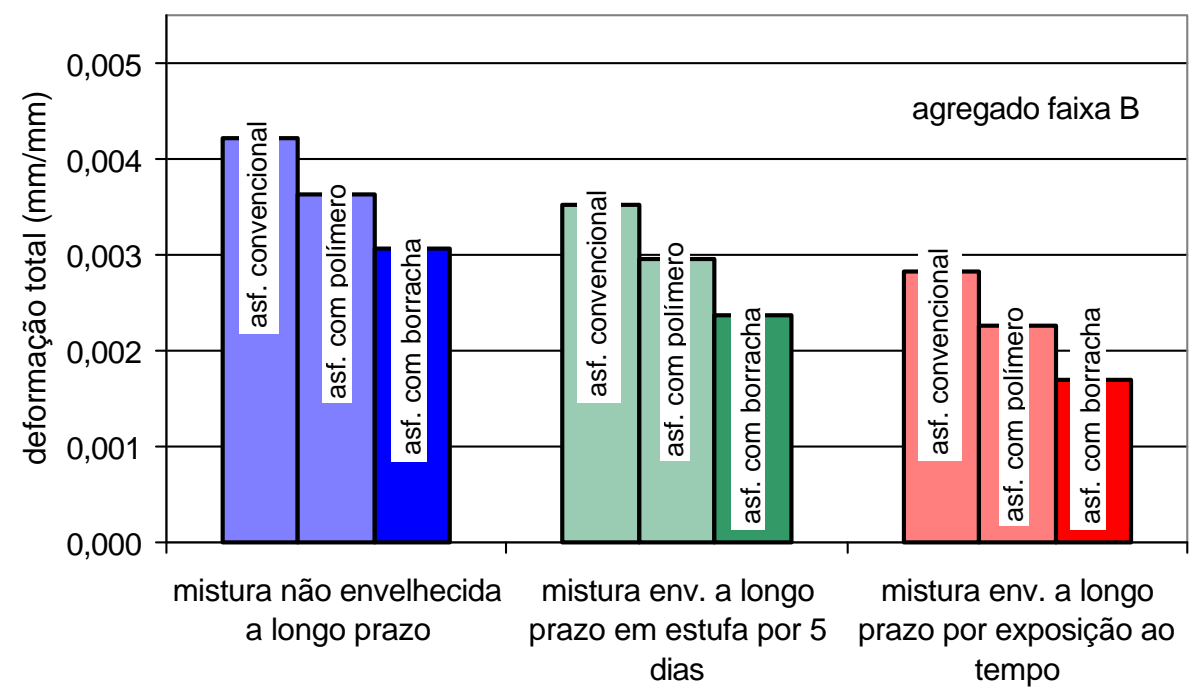

Figura 6.61 - Variação da deformação total do ensaio de creep dinâmico em função do tipo de ligante e da condição de envelhecimento a longo prazo, para agregados da faixa B e misturas não envelhecidas a curto prazo

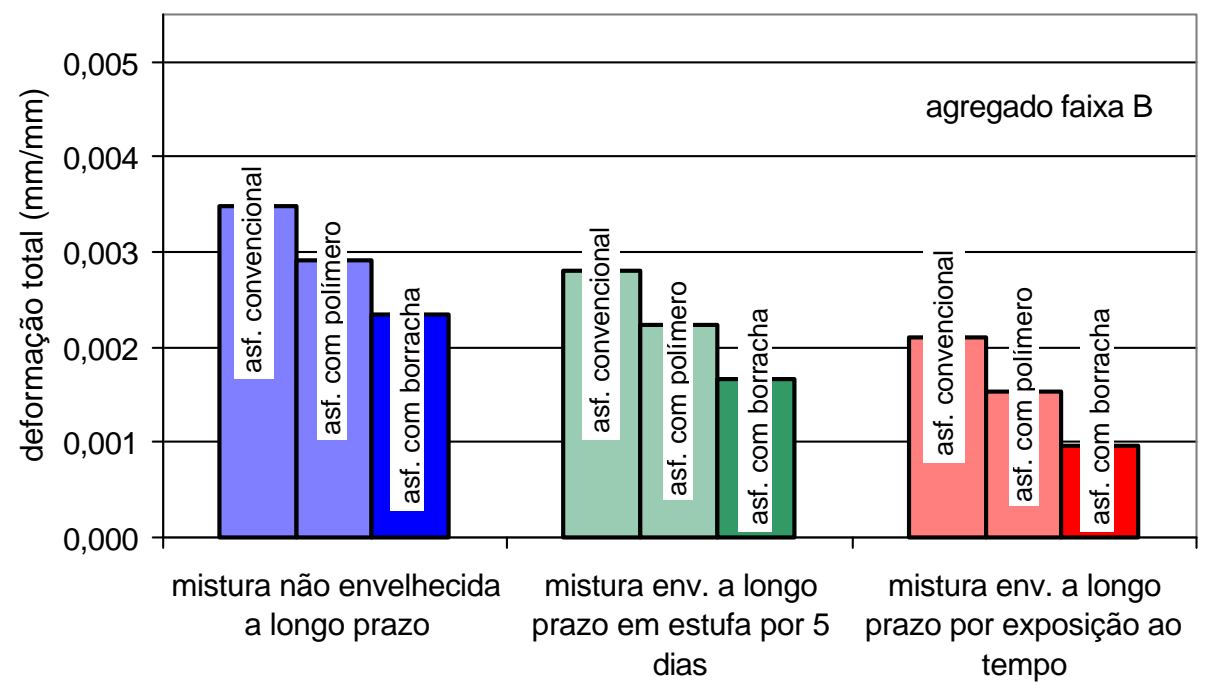

Figura 6.62 - Variação da deformação total do ensaio de creep dinâmico em função do tipo de ligante e da condição de envelhecimento a longo prazo, para agregados da faixa B e misturas envelhecidas a curto prazo por $4 \mathrm{~h}$ em estufa ventilada 


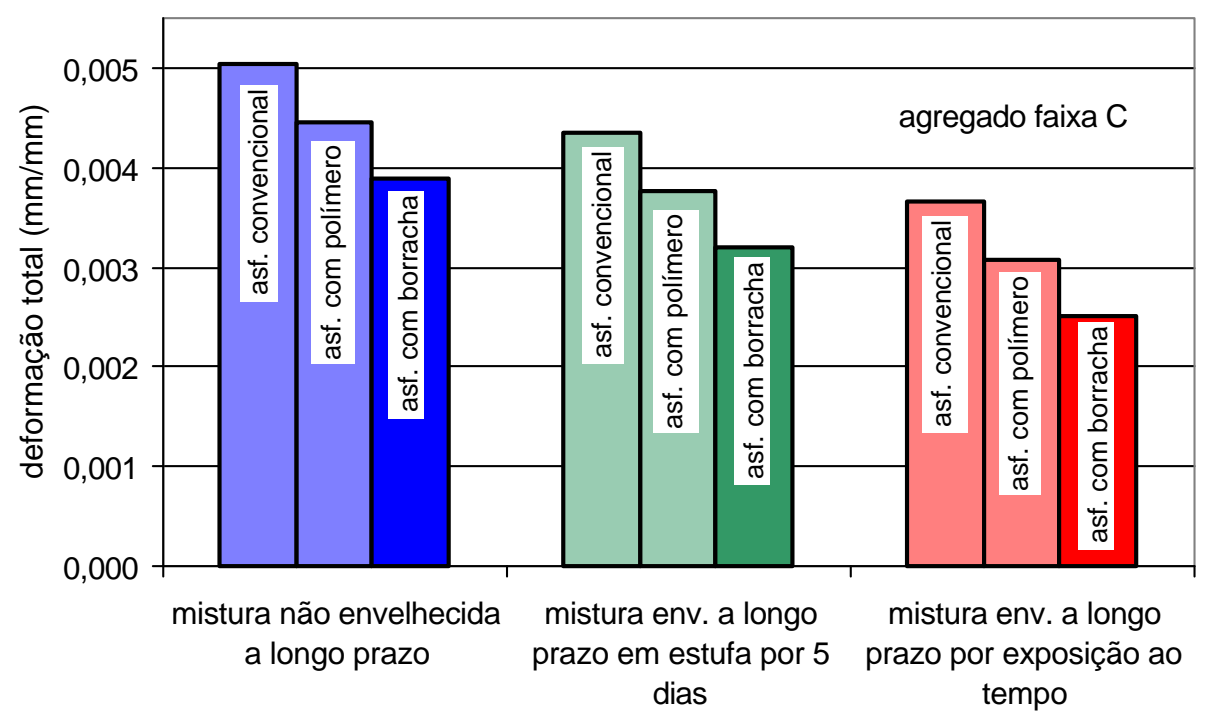

Figura 6.63 - Variação da deformação total do ensaio de creep dinâmico em função do tipo de ligante e da condição de envelhecimento a longo prazo, para agregados da faixa $\mathrm{C}$ e misturas não envelhecidas a curto prazo

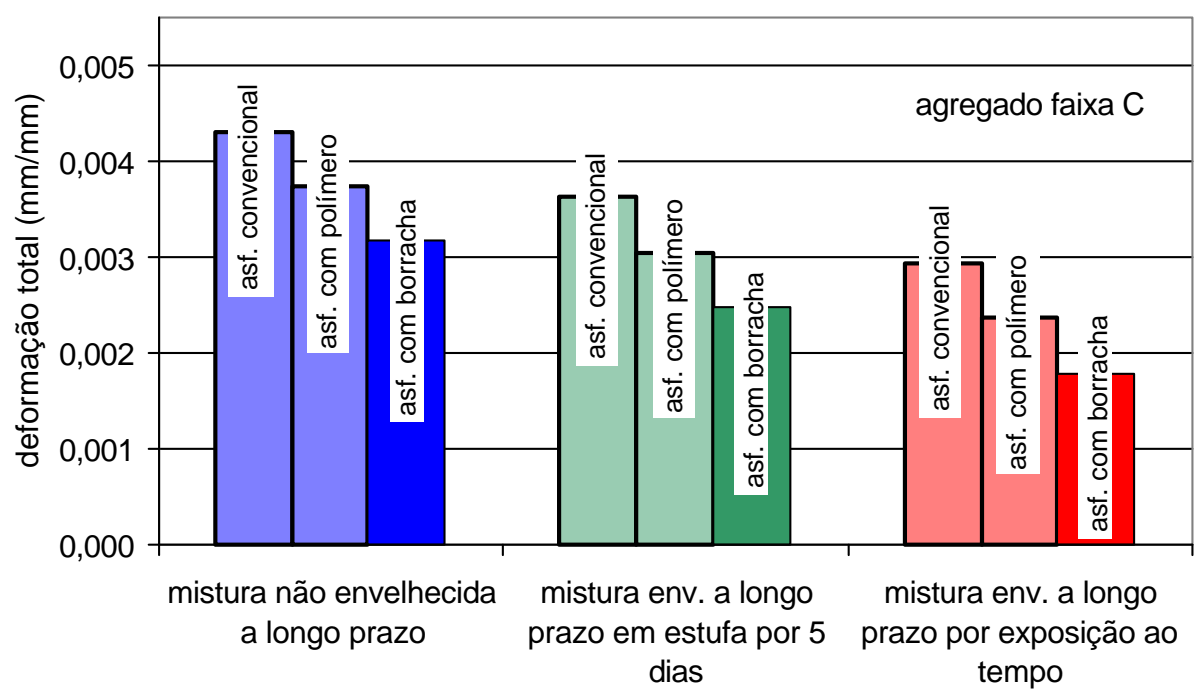

Figura 6.64 - Variação da deformação total do ensaio de creep dinâmico em função do tipo de ligante e da condição de envelhecimento a longo prazo, para agregados da faixa $\mathrm{C}$ e misturas envelhecidas a curto prazo por $4 \mathrm{~h}$ em estufa ventilada

O comportamento do módulo de fluência foi coerente com o comportamento da deformação total, conforme exposto nas Figuras 6.65 a 6.68. Nos gráficos das Figuras 6.65 e 6.66 foram lançados os pontos experimentais em função do teor de ligante, incluindo-se também nesses gráficos curvas de comportamento para o módulo de fluência, que indicaram influência não significativa do teor de ligante. Nas Figuras 6.67 e 6.68 os resultados foram apresentados em função do volume de vazios, cuja variação também não mostrou influenciar de forma significativa a variação do módulo de fluência. 

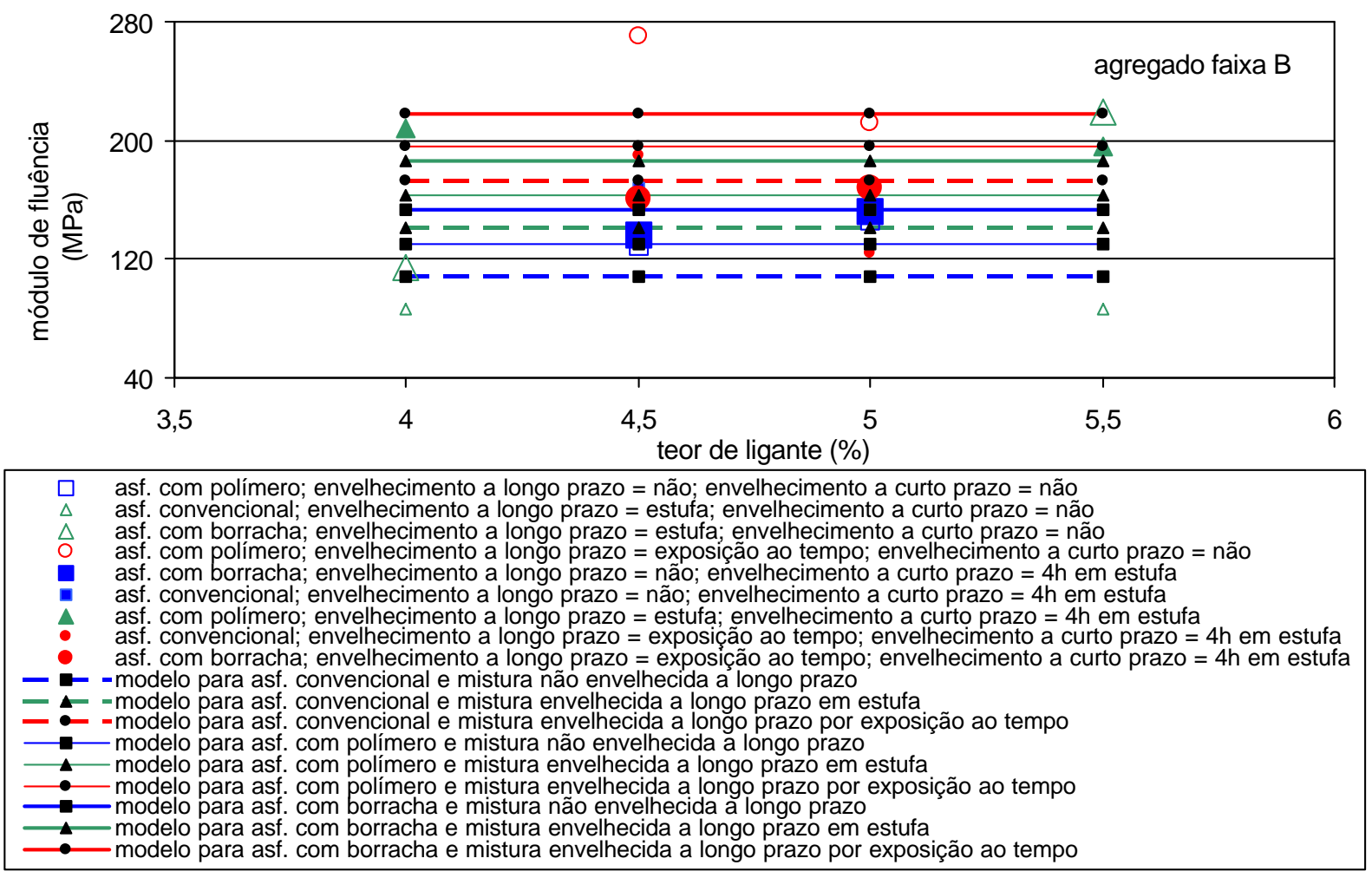

Figura 6.65 - Pontos experimentais e modelos de comportamento referentes ao módulo de fluência em função do teor e tipo de ligante, e da condição de envelhecimento a longo prazo, para a faixa granulométrica B, considerando-se níveis de confiança de $99 \%$ ou $95 \%$
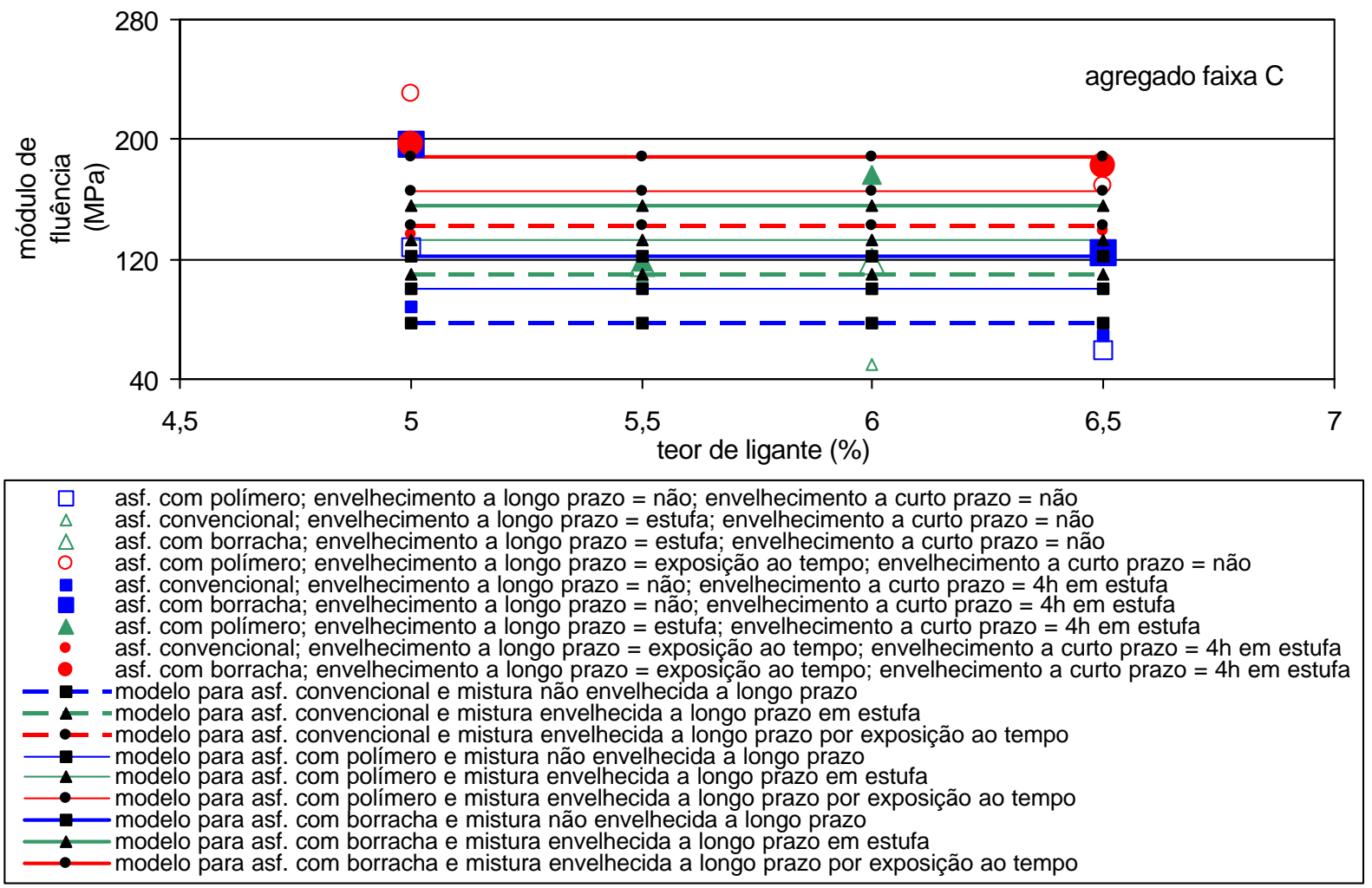

Figura 6.66 - Pontos experimentais e modelos de comportamento referentes ao módulo de fluência em função do teor e tipo de ligante, e da condição de envelhecimento a longo prazo, para a faixa granulométrica C, considerando-se níveis de confiança de $99 \%$ ou $95 \%$ 

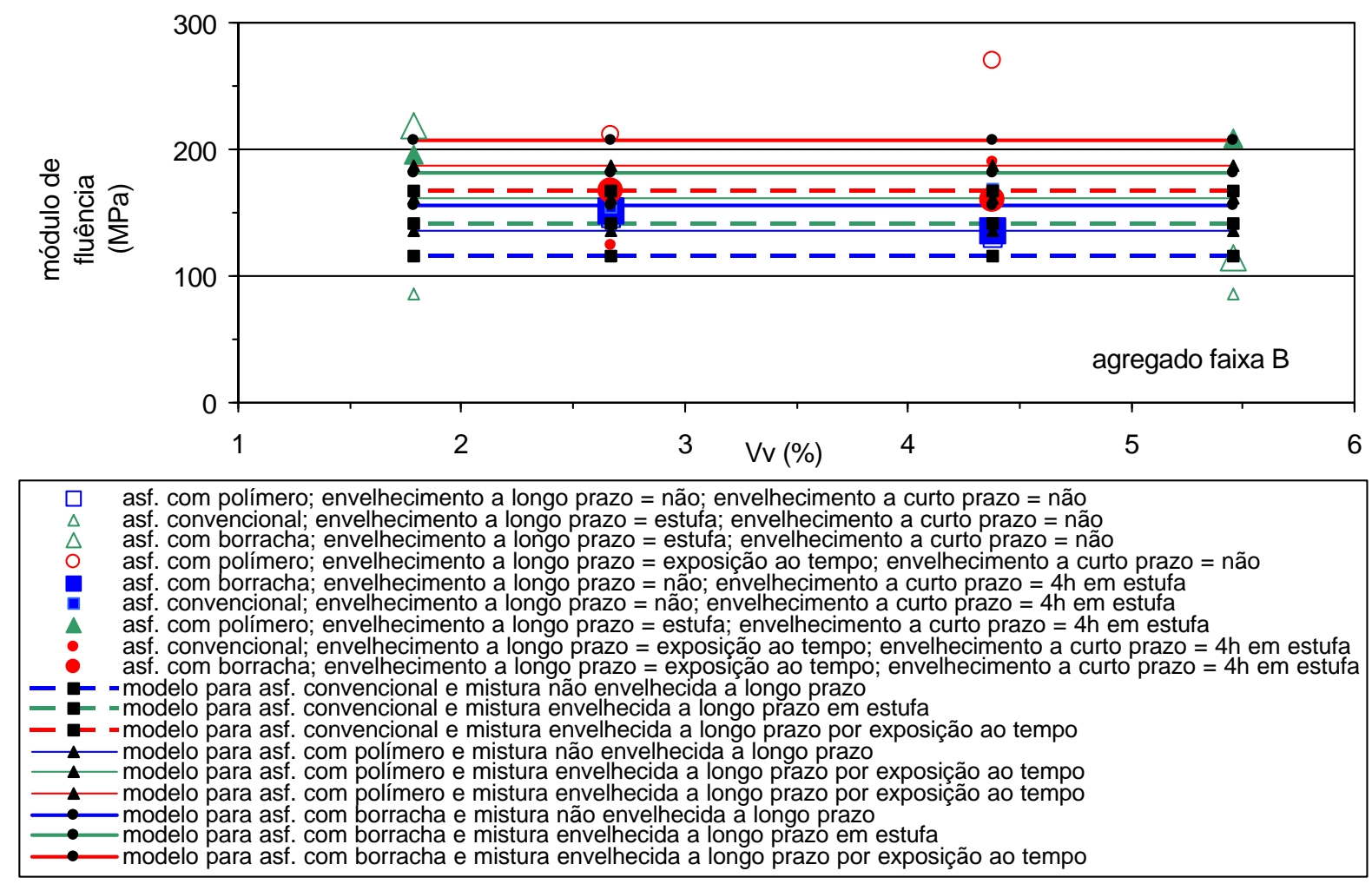

Figura 6.67 - Pontos experimentais e modelos de comportamento referentes ao módulo de fluência em função do volume de vazios, do tipo de ligante e da condição de env. a longo prazo, para a faixa granulométrica B, considerando-se níveis de confiança de $99 \%$ ou $95 \%$
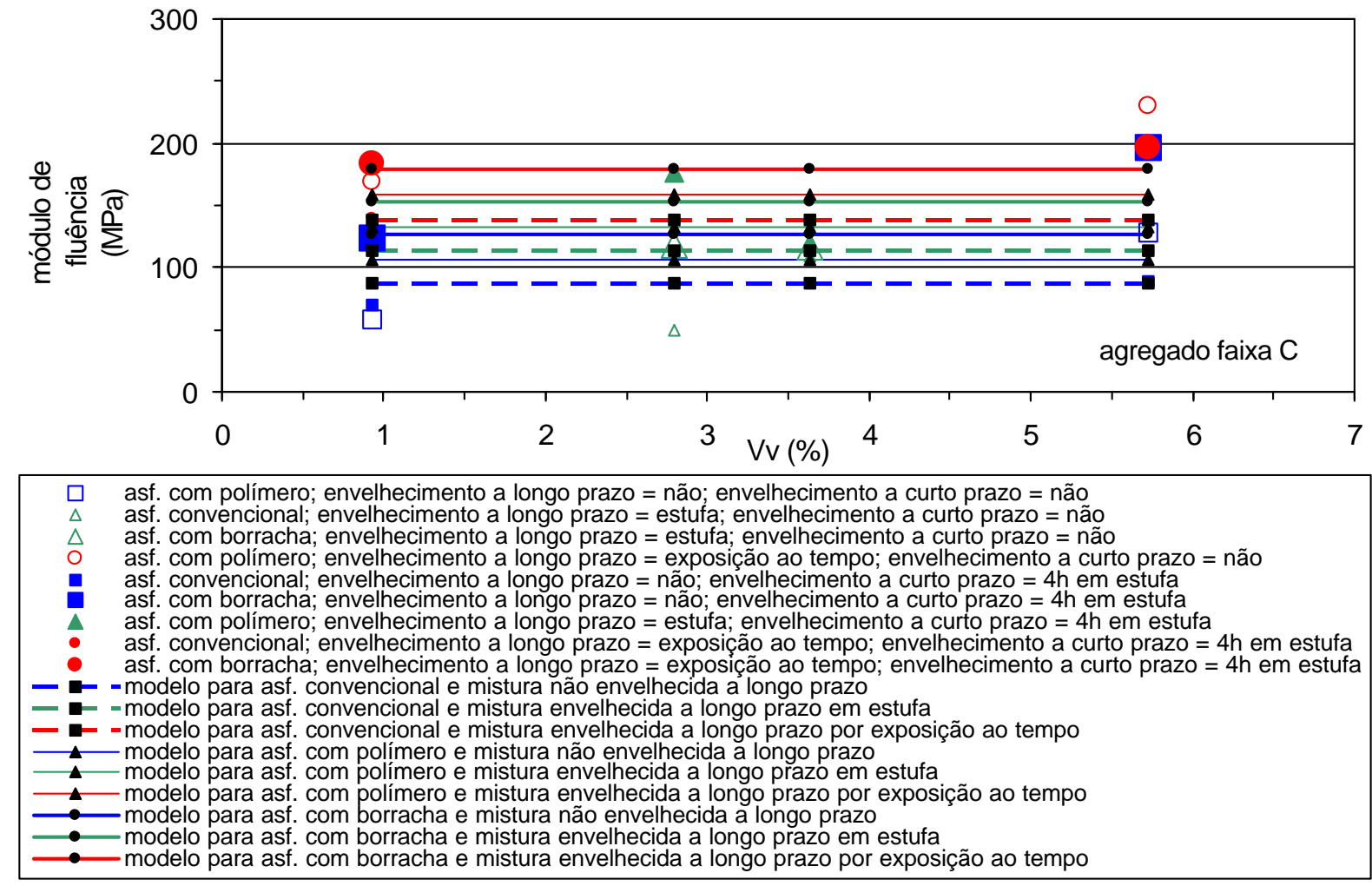

Figura 6.68 - Pontos experimentais e modelos de comportamento referentes ao módulo de fluência em função do volume de vazios, do tipo de ligante e da condição de env. a longo prazo, para a faixa granulométrica C, considerando-se níveis de confiança de $99 \%$ ou $95 \%$ 
A variação do módulo de fluência apresentado pelas misturas em função da condição de envelhecimento a longo prazo e do tipo de ligante encontra-se ilustrada pelas Figuras 6.69 e 6.70, para misturas compostas por agregados com distribuições granulométricas correspondentes aos centros das faixas B e C do DNER (1997), respectivamente.

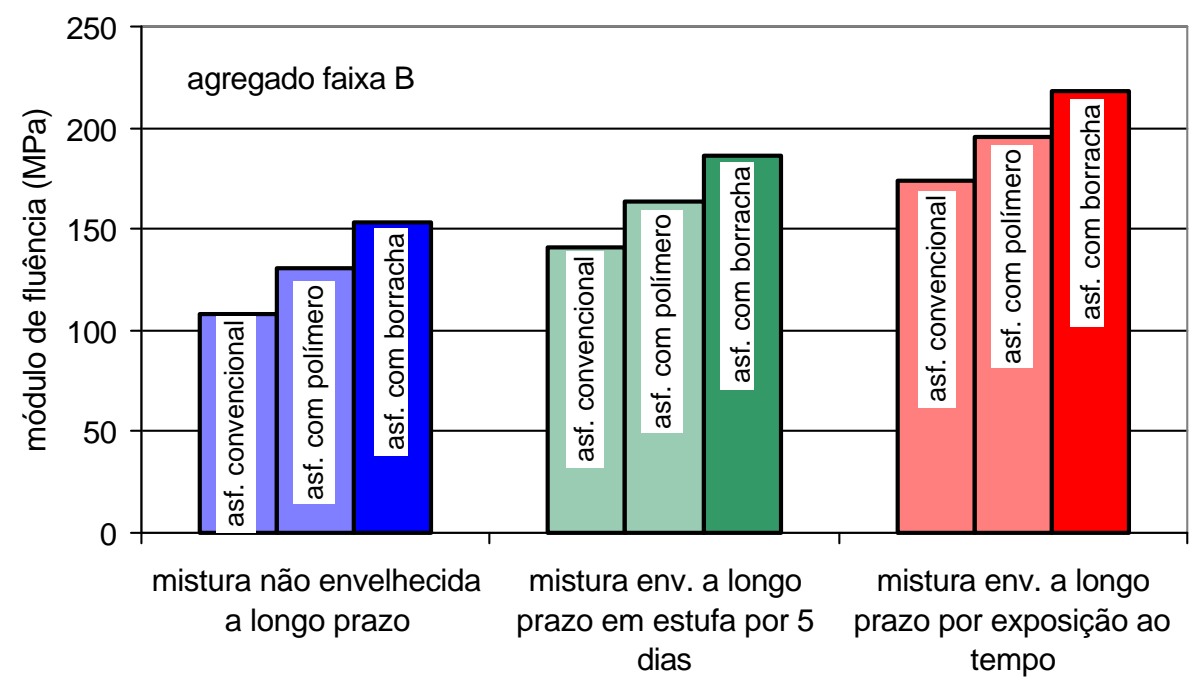

Figura 6.69 - Variação do módulo de fluência do ensaio de creep dinâmico em função do tipo de ligante e da condição de envelhecimento a longo prazo, para agregados da faixa B

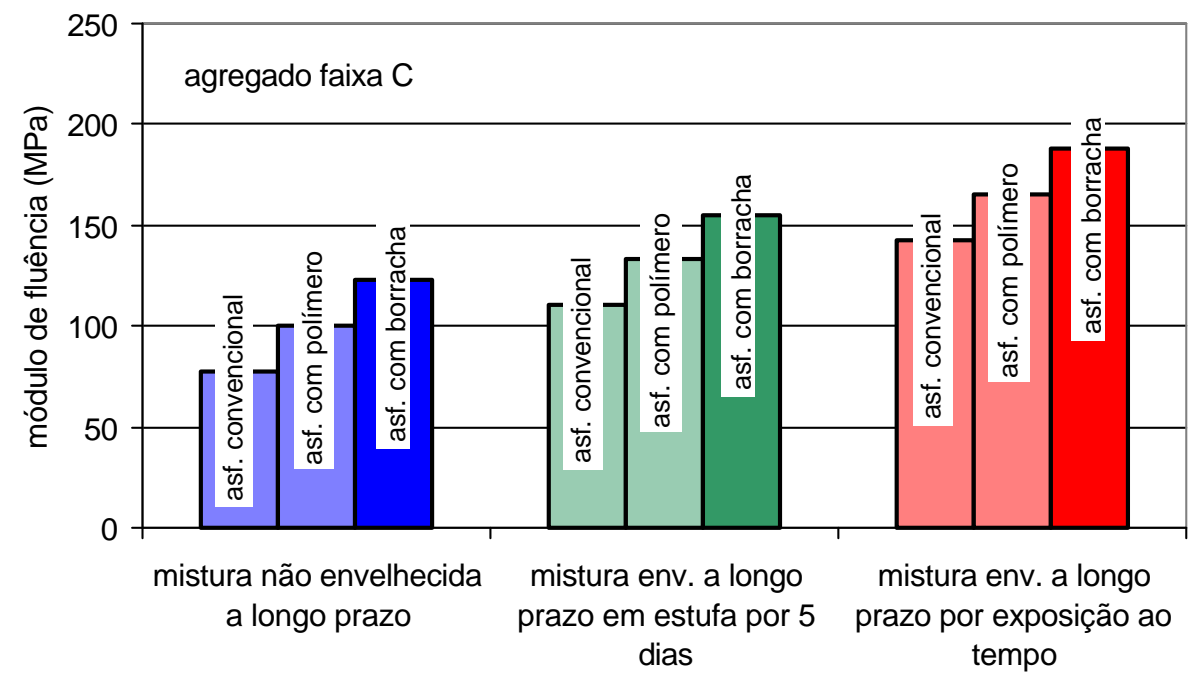

Figura 6.70 - Variação do módulo de fluência do ensaio de creep dinâmico em função do tipo de ligante e da condição de envelhecimento a longo prazo, para agregados da faixa $\mathrm{C}$

O módulo de fluência mostrou-se dependente das condições de envelhecimento a longo prazo, do tipo de ligante e da distribuição granulométrica do agregado. Agregados com distribuição granulométrica correspondente ao centro da faixa B forneceram misturas com módulos de fluência maiores que os apresentados por misturas com agregados da 
faixa C. Isso significa que agregados da faixa $\mathrm{C}$ produziram misturas asfálticas mais suscetíveis a deformações permanentes.

Misturas envelhecidas a longo prazo apresentaram os maiores módulos de fluência, sendo que os módulos apresentados por misturas envelhecidas por exposição ao tempo foram maiores que os apresentados por misturas envelhecidas em estufa ventilada. Os menores módulos e consequentemente a maior suscetibilidade a deformações permanentes foram apresentados por misturas não envelhecidas a longo prazo.

O asfalto convencional foi mais suscetível a deformações permanentes do que os asfaltos modificados, pois apresentou os menores módulos de fluência. Os maiores módulos foram apresentados por misturas compostas por asfalto modificado com borracha. Valores intermediários foram apresentados por misturas compostas por asfalto modificado com polímero.

As variações sofridas pela inclinação da curva de fluência em função das variações dos fatores considerados no experimento podem ser observadas nas Figuras 6.71 a 6.74 , com o fator $A$ representando o teor de ligante. Nas Figuras 6.71 e 6.73 foram apresentados os pontos experimentais correspondentes às distribuições granulométricas das faixas B e C, respectivamente, e curvas de comportamento baseadas em uma análise de variância realizada com confiança de 99\%. Nesse caso não houve variação significativa da inclinação com a variação do teor de ligante. Nas Figuras 6.72 e 6.74 são apresentados os mesmos pontos experimentais, mas curvas de comportamento baseadas em uma análise de variância realizada com confiança de 95\%, agora verificando-se o aumento da inclinação com o aumento do teor de ligante.

Nas Figuras 6.75 e 6.76, as inclinações são apresentadas em função do volume de vazios. Nesse caso, os resultados das análises de variância realizadas com níveis de confiança de $99 \%$ ou $95 \%$ foram iguais e identificaram o teor de ligante como fator influente no comportamento da inclinação da curva de fluência, sendo que esta aumentou com o aumento do teor de ligante utilizado na mistura, indicando maior suscetibilidade a deformações permanentes. 


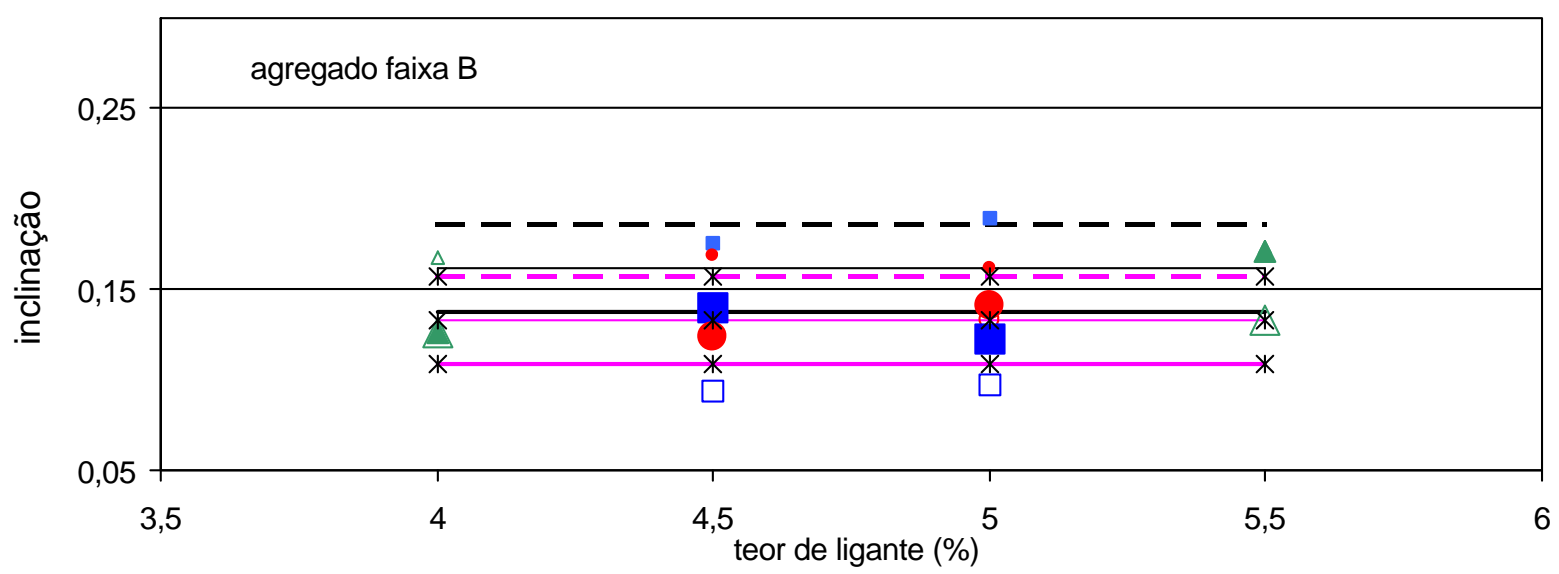

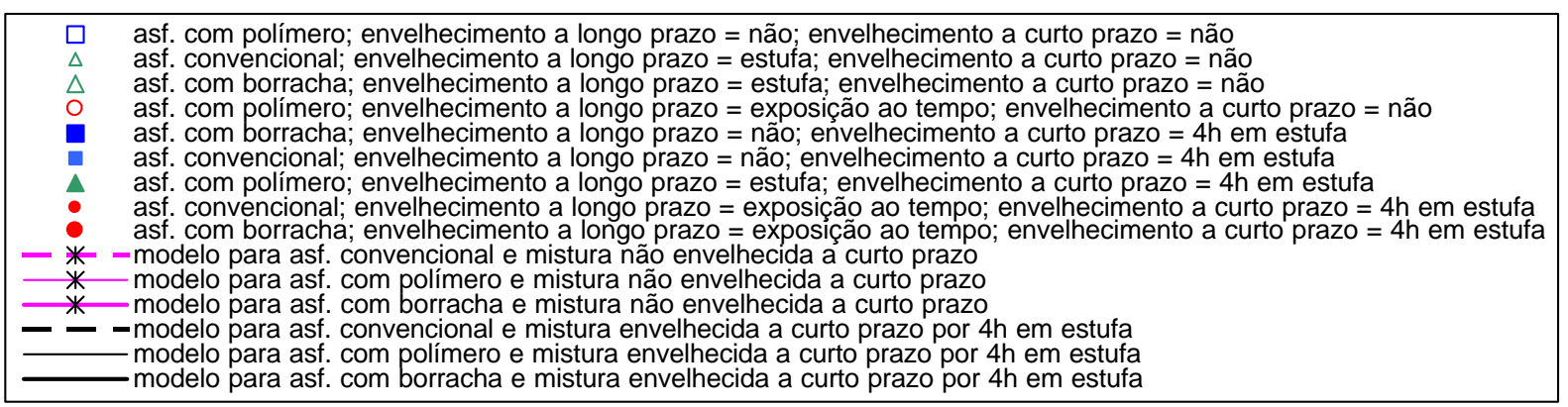

Figura 6.71 - Pontos experimentais e modelos de comportamento referentes à inclinação da curva de fluência em função do tipo de ligante e da condição de envelhecimento a curto prazo, para a faixa granulométrica B, considerando-se confiança de $99 \%$
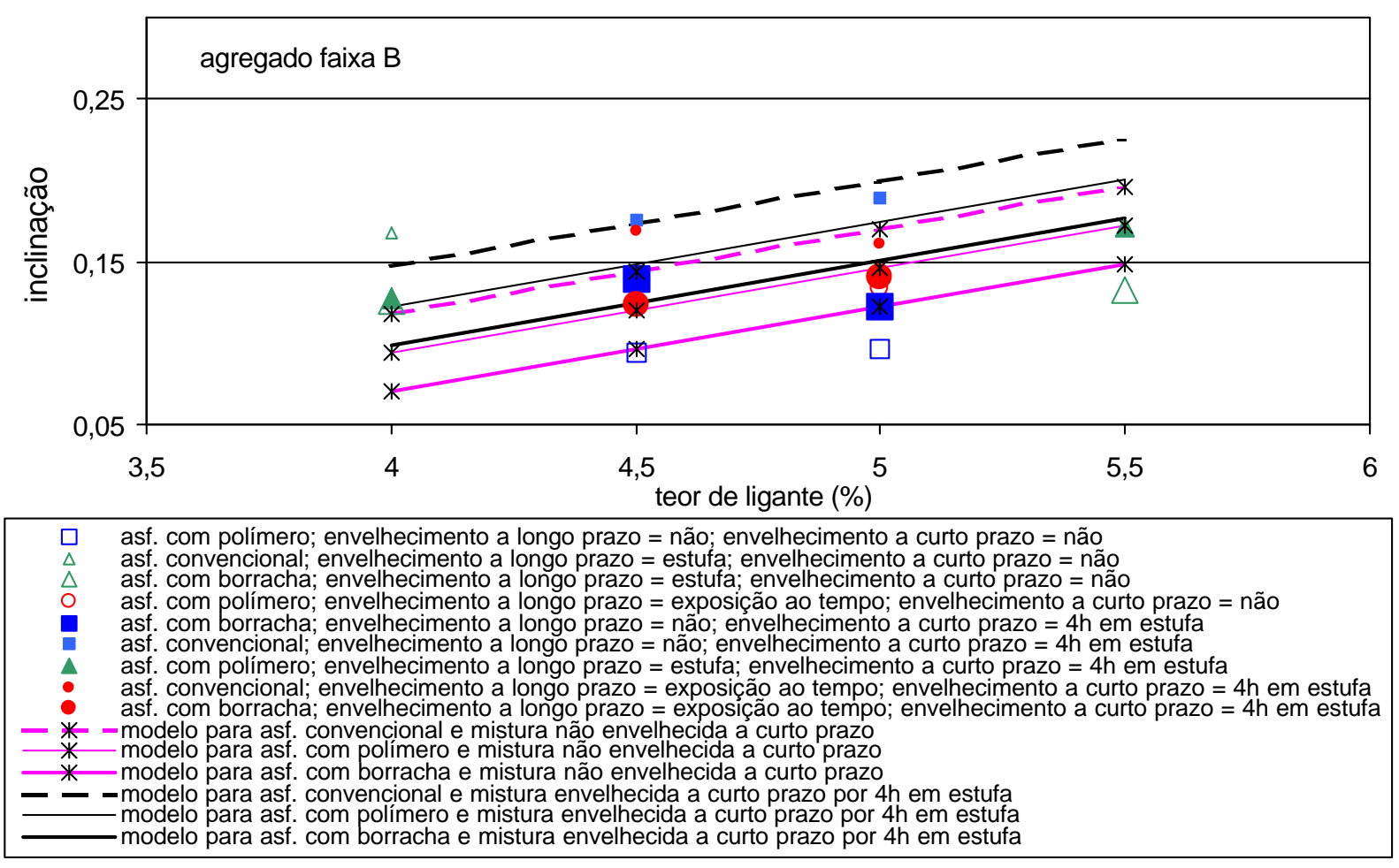

Figura 6.72 - Pontos experimentais e modelos de comportamento referentes à inclinação da curva de fluência em função do teor de ligante, do tipo de ligante e da condição de envelhecimento a curto prazo, para a faixa granulométrica B, considerando-se confiança de $95 \%$ 

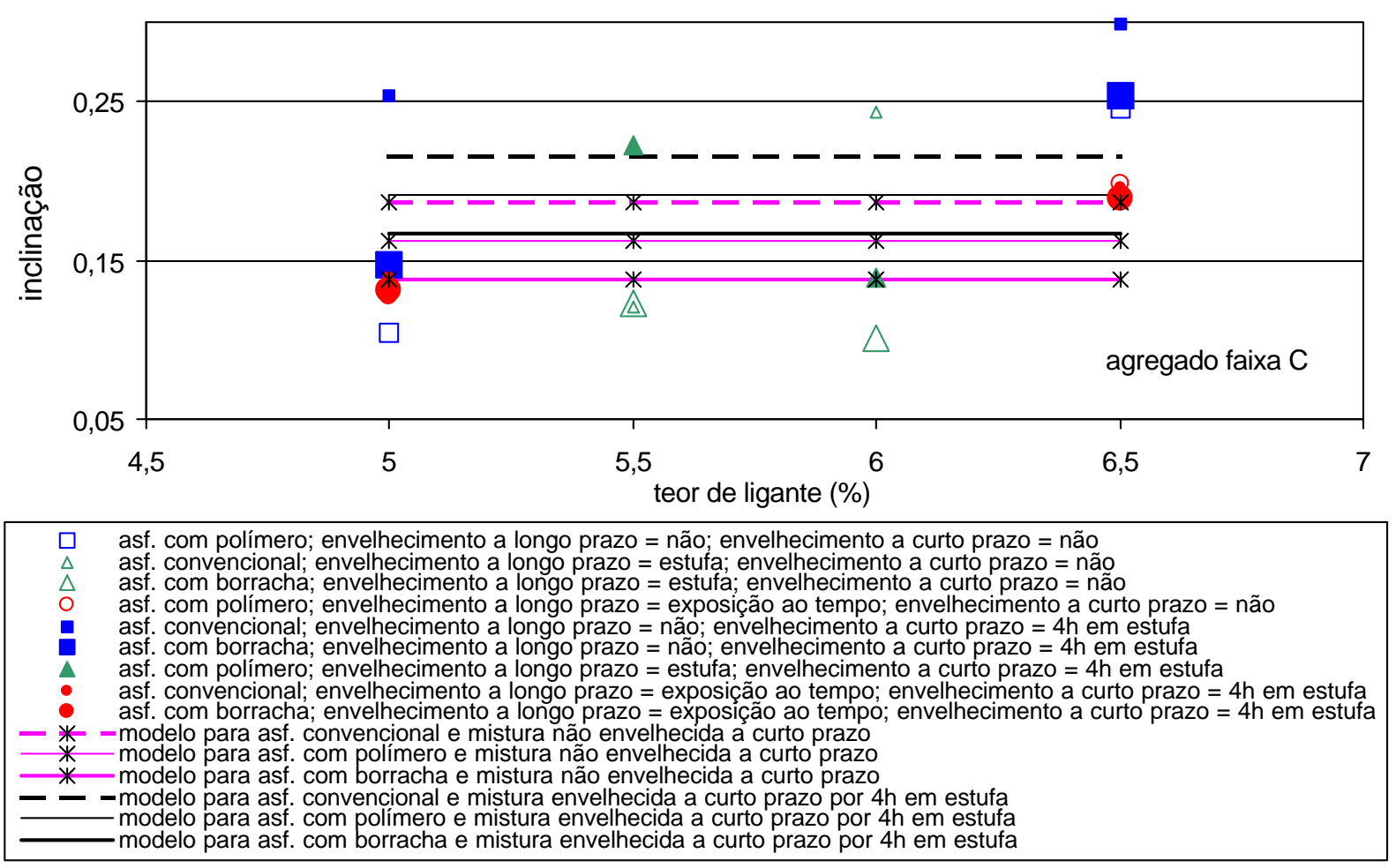

Figura 6.73 - Pontos experimentais e modelos de comportamento referentes à inclinação da curva de fluência em função do tipo de ligante e da condição de envelhecimento a curto prazo, para a faixa granulométrica C, considerando-se confiança de $99 \%$
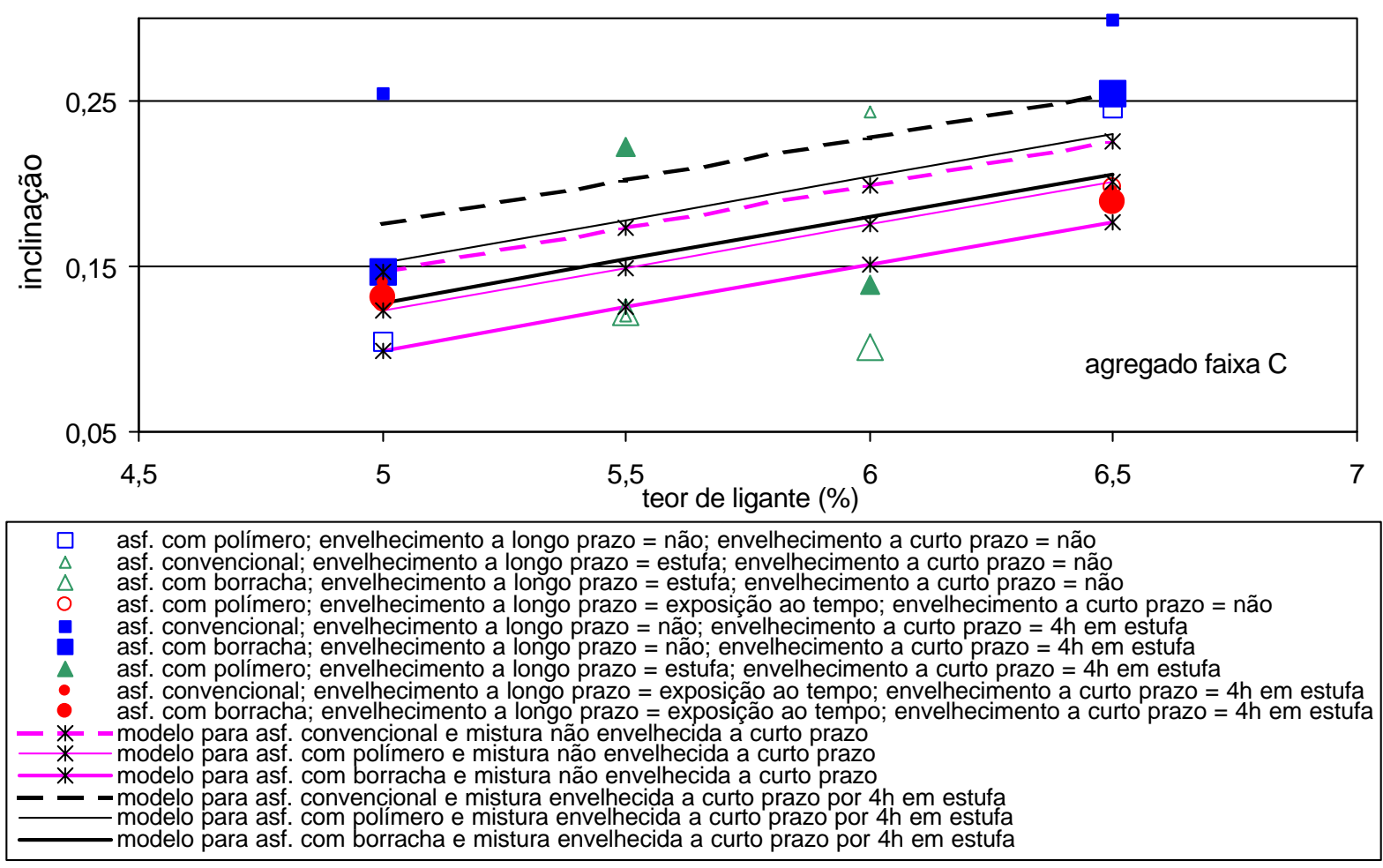

Figura 6.74 - Pontos experimentais e modelos de comportamento referentes à inclinação da curva de fluência em função do teor de ligante, do tipo de ligante e da condição de envelhecimento a curto prazo, para a faixa granulométrica $C$, considerando-se confiança de $95 \%$ 


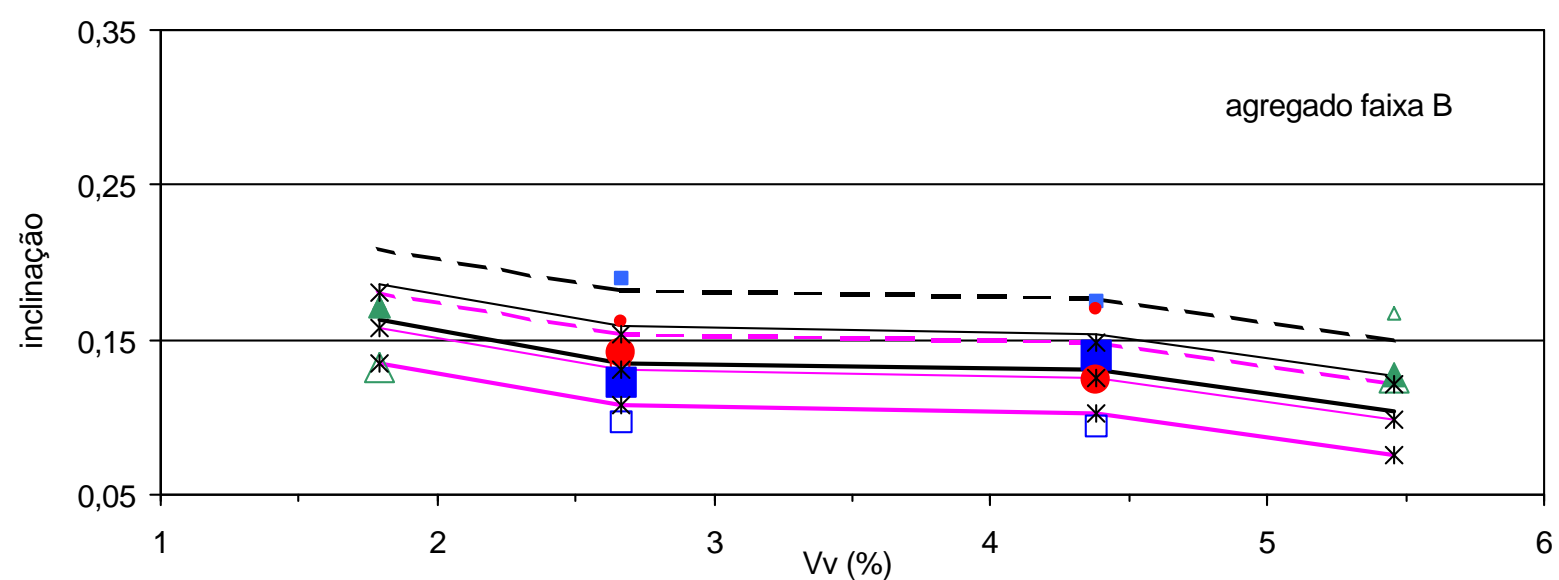

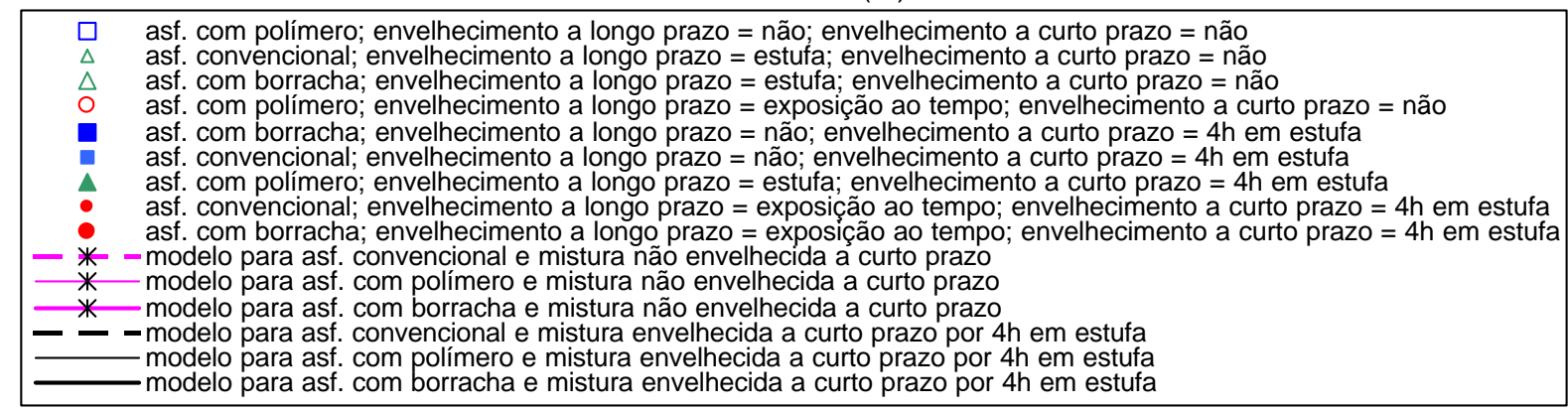

Figura 6.75 - Pontos experimentais e modelos de comportamento referentes à inclinação da curva de fluência em função do volume de vazios, do tipo de ligante e da condição de envelhecimento a curto prazo, para a faixa granulométrica B, considerando-se níveis de confiança de $99 \%$ ou $95 \%$

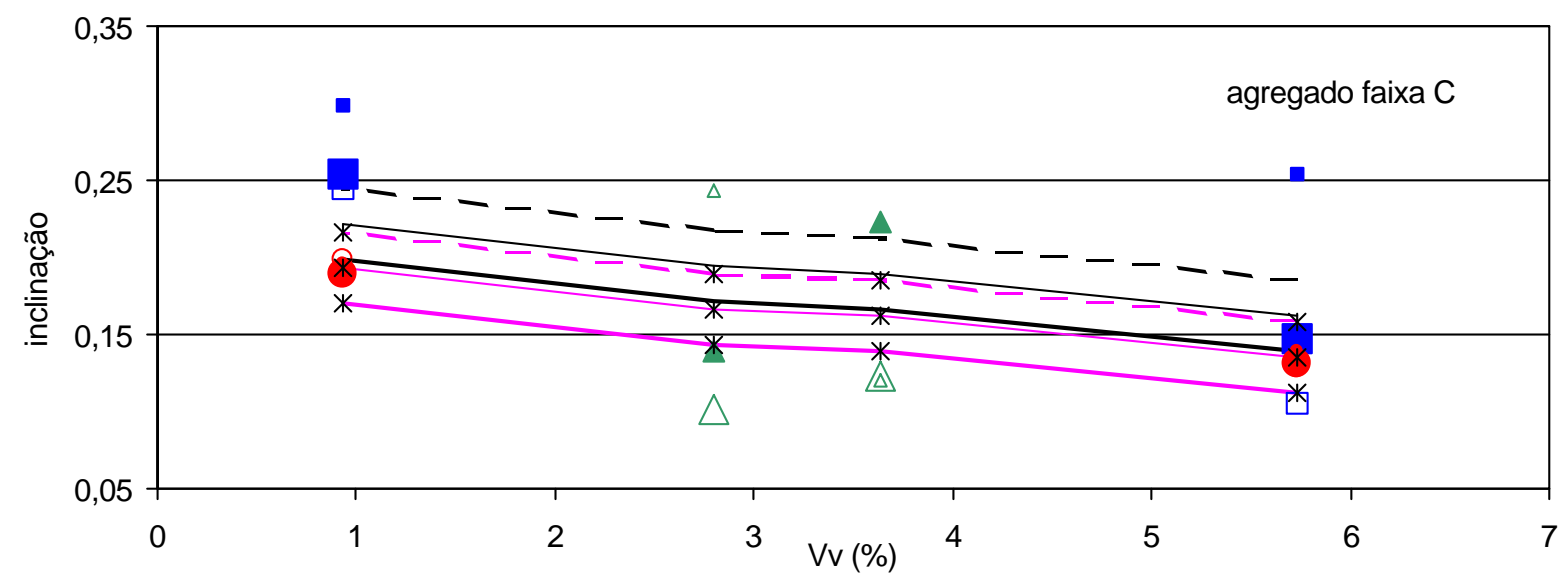

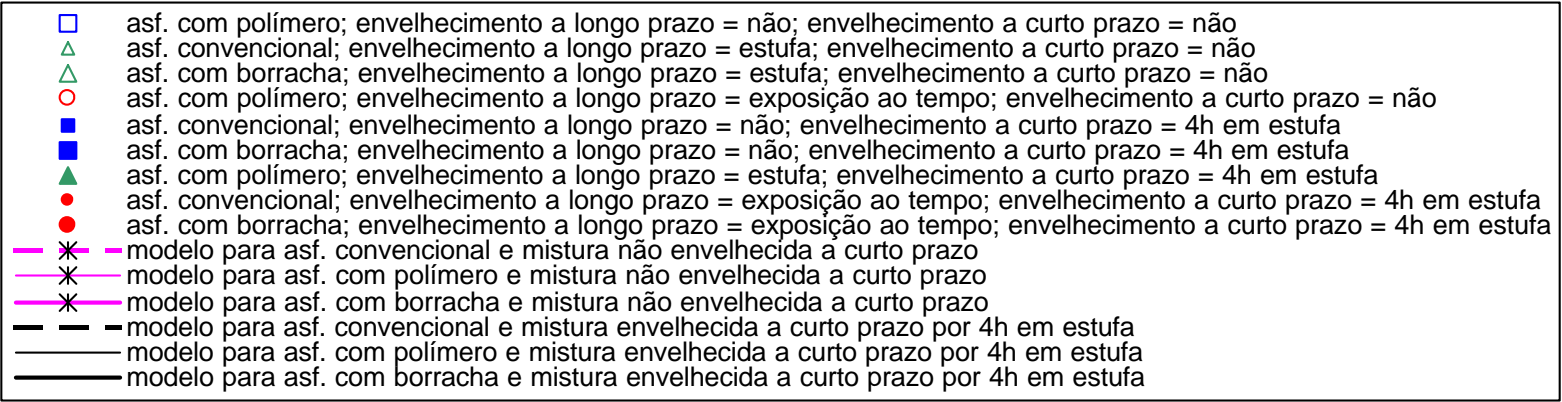

Figura 6.76 - Pontos experimentais e modelos de comportamento referentes à inclinação da curva de fluência em função do volume de vazios, do tipo de ligante e da condição de envelhecimento a curto prazo, para a faixa granulométrica $\mathrm{C}$, considerando-se níveis de confiança de $99 \%$ ou $95 \%$ 
A variação da inclinação da curva de fluência do ensaio de creep dinâmico, em função do tipo de ligante e da distribuição granulométrica do agregado, pode ser visualizada no gráfico da Figura 6.77.

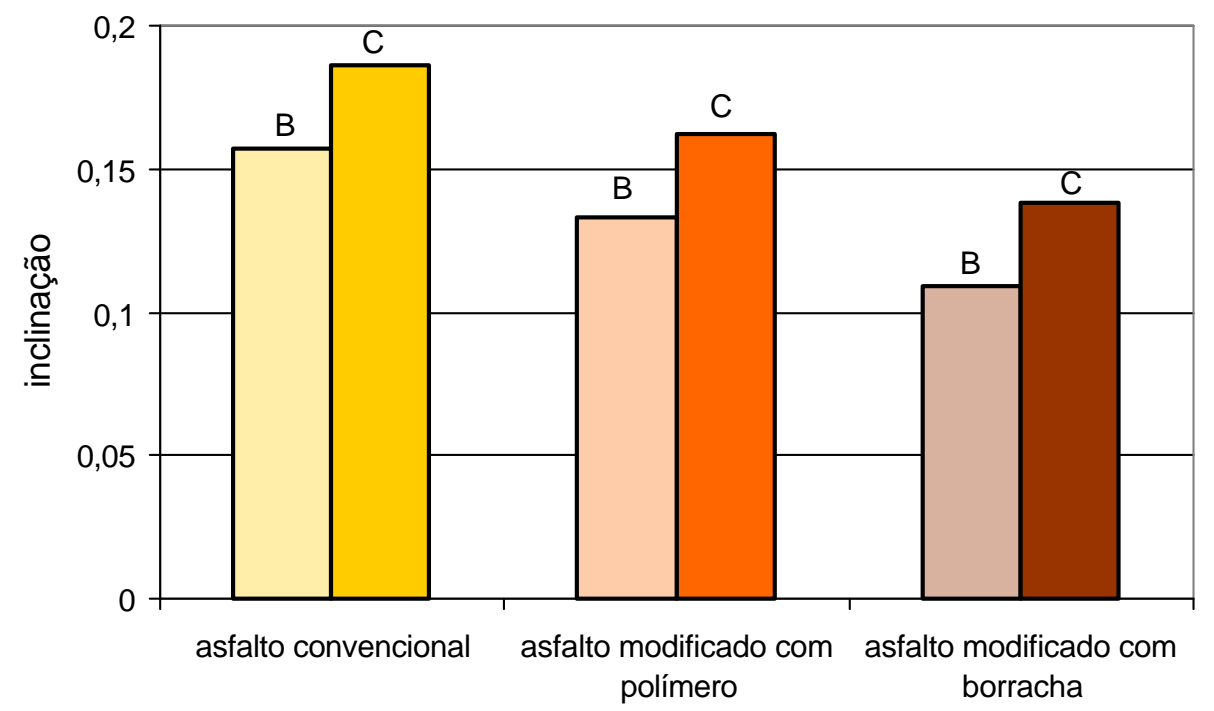

Figura 6.77 - Variação da inclinação da curva de fluência do ensaio de creep dinâmico em função do tipo de ligante e da distribuição granulométrica do agregado

Misturas com distribuição granulométrica correspondente ao centro da faixa B apresentaram inclinações da curva de fluência menores do que as apresentadas por misturas com distribuição granulométrica correspondente ao centro da faixa $\mathrm{C}$, de acordo com o esperado. Entretanto, ao contrário do esperado, misturas não envelhecidas a curto prazo apresentaram inclinações da curva de fluência menores que as apresentadas por misturas que foram submetidas ao processo acelerado de envelhecimento a curto prazo, indicando uma maior suscetibilidade a deformações permanentes das últimas em relação às primeiras.

Quanto à influência do tipo de ligante, também considerada significativa pela análise realizada, misturas compostas pelo asfalto modificado com borracha apresentaram as menores inclinações da curva de fluência, seguidas por misturas compostas pelo asfalto modificado com polímero. As maiores inclinações foram apresentadas por misturas compostas por asfalto convencional, indicando maior suscetibilidade a deformações permanentes dessas últimas. 
Um resumo do modo como a variação dos fatores interferiu na variação dos parâmetros do ensaio de creep dinâmico é apresentado nas Tabelas 6.24 a 6.27.

Tabela 6.24 - Classificação qualitativa das respostas do ensaio de creep dinâmico em função dos níveis do fator $B$

\begin{tabular}{lccc}
\hline & \multicolumn{3}{c}{ fator $B$} \\
& \multicolumn{3}{c}{ condição de envelhecimento a longo prazo } \\
\cline { 2 - 4 } & sem & 5 dias em estufa a & 4 meses de \\
resposta & envelhecimento & $85^{\circ} \mathrm{C}$ & exposição ao tempo \\
\hline deformação total & maior & intermediário & menor \\
módulo de fluência & menor & intermediário & maior \\
\hline
\end{tabular}

Tabela 6.25 - Classificação qualitativa das respostas do ensaio de creep dinâmico em função dos níveis do fator $C$

\begin{tabular}{lccc}
\hline & \multicolumn{3}{c}{$\begin{array}{c}\text { fator } C \\
\text { tipo de ligante }\end{array}$} \\
\cline { 2 - 4 } resposta & asfalto & asfalto modificado & asfalto modificado \\
com polímero & com borracha \\
\hline deformação total & maior & intermediário & menor \\
módulo de fluência & menor & intermediário & maior \\
inclinação & maior & intermediário & menor \\
\hline
\end{tabular}

Tabela 6.26 - Classificação qualitativa das respostas do ensaio de creep dinâmico em função dos níveis do fator $X 7$

\begin{tabular}{lcc}
\hline & \multicolumn{2}{c}{ fator $X 7$} \\
& \multicolumn{2}{c}{ distribuição granulométrica } \\
\cline { 2 - 3 } resposta & centro da faixa B & centro da faixa C \\
\hline deformação total & menor & maior \\
módulo de fluência & maior & menor \\
inclinação & menor & maior \\
\hline
\end{tabular}

Tabela 6.27 - Classificação qualitativa das respostas do ensaio de creep dinâmico em função dos níveis do fator $X 8$

\begin{tabular}{lcc}
\hline & \multicolumn{2}{c}{ fator $X 8$} \\
& \multicolumn{3}{c}{ condição de envelhecimento a curto prazo } \\
\cline { 2 - 3 } resposta & sem envelhecimento & $4 \mathrm{~h}$ em estufa a $135^{\circ} \mathrm{C}$ \\
\hline deformação total & maior & menor \\
inclinação & menor & maior \\
\hline
\end{tabular}

De acordo com a análise dos resultados do ensaio de creep dinâmico, misturas envelhecidas a longo prazo tornaram-se menos suscetíveis a deformações permanentes. Comparando-se os dois métodos empregados para aceleração do envelhecimento a longo prazo, o envelhecimento por exposição ao tempo tornou os corpos de prova menos suscetíveis a deformações permanentes do que o envelhecimento em estufa ventilada. 
Ainda segundo esse ensaio, asfaltos modificados geraram misturas mais resistentes a deformações permanentes do que misturas compostas pelo asfalto convencional. Entre os dois tipos de asfaltos modificados utilizados, misturas com asfalto modificado com borracha apresentaram maior resistência a deformações permanentes do que misturas com asfalto modificado com polímero. 


\section{CONSIDERAÇÕES FINAIS}

Através do desenvolvimento desta pesquisa foi realizada uma investigação sobre a influência de diversos fatores no comportamento mecânico de misturas asfálticas densas compactadas em laboratório. Os fatores selecionados para estudo foram o tipo de ligante asfáltico utilizado nas misturas; a distribuição granulométrica dos agregados; o teor de ligante, que está relacionado com a espessura de película asfáltica recobrindo as partículas de agregado e com o volume de vazios nas misturas; as condições de envelhecimento a curto prazo da mistura solta, não compactada, que correspondem às condições em que ocorre o envelhecimento da mistura durante as fases de mistura em usina, transporte e compactação da mistura no campo; e as condições de envelhecimento a longo prazo da mistura compactada, que correspondem às condições em que ocorre o envelhecimento do revestimento asfáltico ao longo de sua vida útil.

Cada um dos fatores citados foi considerado em vários níveis, para que pudesse ser medido o efeito provocado pela variação de cada fator nas propriedades mecânicas das misturas. Dessa forma foram testados quatro teores de ligante, três condições de envelhecimento a longo prazo, três tipos de ligantes, duas distribuições granulométricas do agregado e duas condições de envelhecimento a curto prazo.

O experimento fatorial completo com cinco fatores, um com quatro níveis de variação, dois com três níveis de variação e dois com dois níveis de variação, envolveria 144 condições experimentais a serem testadas em laboratório. Considerando-se a moldagem de 5 corpos de prova por condição experimental, para o experimento completo seriam necessários 720 corpos de prova. Como para cada condição experimental foram 
realizados um ensaio de resistência à tração, seis de módulo de resiliência (cada corpo de prova foi ensaiado em duas direções), três de creep estático e três de creep dinâmico, para o experimento completo deveriam ser realizados 144 ensaios de resistência à tração, 864 ensaios de módulo de resiliência, 432 ensaios de creep estático e 432 ensaios de creep dinâmico, o que seria inviável em virtude do tempo disponível para a realização da pesquisa.

Dessa forma, utilizou-se a técnica de fracionamento de experimentos, através da qual o experimento completo foi reduzido a um quarto, realizando-se para isso o acoplamento de alguns efeitos. Conforme descrito no Capítulo 5, o experimento reduziu-se a 36 condições experimentais realmente testadas em laboratório.

A partir das variações das propriedades mecânicas das misturas, medidas em laboratório através dos ensaios citados, procurou-se identificar os fatores com influência significativa em cada uma das respostas medidas, através da análise de variância dos resultados. Além disso, procurou-se, também, estabelecer leis de comportamento que refletissem o modo como a variação de cada fator interfere no comportamento das misturas. Para isso, quando foi possível, foram construídos modelos estatísticos de comportamento, que no caso da análise de experimentos fracionados são de grande auxílio para a visualização do comportamento das variáveis.

Além da utilização da técnica de fracionamento, outra medida adotada para tornar viável a execução desse experimento foi a realização de um programa experimental conjunto, envolvendo além desta pesquisa de doutorado, mais três pesquisas de mestrado, também desenvolvidas no Departamento de Transporte da EESC-USP, uma finalizada e duas em andamento, todas relacionadas ao estudo dos fatores influentes no comportamento de misturas asfálticas densas. Como as misturas estudadas foram as mesmas, as quatro pesquisas tiveram em comum uma significativa parte laboratorial, que foi realizada em conjunto. O resultado final dessa cooperação entre pesquisadores foi não somente a agilização da parte experimental dos trabalhos, mas também um enriquecimento da pesquisa como um todo. 


\subsection{Ensaio de módulo de resiliência}

A análise dos resultados desse ensaio mostrou que o envelhecimento das misturas a longo prazo provoca o aumento dos valores de módulo de resiliência. Comparando-se os métodos utilizados nesta pesquisa para aceleração do envelhecimento a longo prazo, verificou-se que o envelhecimento ocasionado pela exposição das misturas compactadas ao tempo pelo período de 4 meses foi mais acentuado do que o envelhecimento ocorrido em estufa ventilada a $85^{\circ} \mathrm{C}$, por 5 dias.

O aumento do módulo de resiliência das misturas em conseqüência do envelhecimento era esperado, pois esse comportamento tem sido observado em diversas pesquisas, podendo-se citar Bell (1989) e Kim et al. (1987), dentre outros. Muitos autores utilizam, inclusive, a razão entre o módulo de resiliência após o envelhecimento e o módulo de resiliência antes do envelhecimento, como indicativo do grau de envelhecimento sofrido pela mistura.

Calculando-se a relação entre o módulo de resiliência e a resistência à tração para cada uma das condições experimentais testadas em laboratório, observou-se que o envelhecimento provocou a queda da capacidade de recuperação elástica das misturas. Os resultados indicaram também que essa queda foi maior no caso do envelhecimento por exposição ao tempo.

A adição de modificadores ao asfalto mostrou ter uma influência positiva na resistência das misturas à fadiga, pois misturas compostas por asfaltos modificados tiveram seus valores de módulo de resiliência aumentados, sem que houvesse redução da capacidade de recuperação elástica. Essa constatação veio ao encontro dos resultados encontrados na literatura consultada, pois parece haver um consenso sobre o aumento do módulo de resiliência de misturas compostas por asfaltos modificados com polímeros, o que se reflete em um aumento da vida de fadiga dessas misturas.

O experimento realizado indicou também que a adição de $20 \%$ de borracha reciclada de pneu ao asfalto foi mais benéfica do que a adição de 4,5\% do polímero SBS, em termos de aumento do módulo de resiliência das misturas. 
Entretanto, a utilização de asfaltos modificados não mostrou interferir nos processos de envelhecimento a longo prazo sofridos pelas misturas. Isso talvez tenha ocorrido por terem sido utilizados os mesmos teores, para os três tipos de ligantes. Particularmente no caso do asfalto-borracha, teores maiores talvez tivessem significado maior resistência ao envelhecimento a longo prazo. Também não foi constatada a influência do envelhecimento a curto prazo no comportamento das misturas, no que se refere ao módulo de resiliência.

Quanto à influência do teor de ligante, os maiores valores de módulo de resiliência foram obtidos para teores em torno do ótimo. No caso de misturas compostas por agregados da faixa B, o teor ótimo obtido através da realização das dosagens Marshall ficou em torno de 5,0 \%, e os maiores valores de módulo de resiliência foram obtidos para misturas com teores de ligante entre $4,5 \%$ e $5,0 \%$. Um aumento do teor para $5,5 \%$ provocou a visível queda dos valores de módulo de resiliência, para misturas da faixa $\mathrm{B}$.

Conforme exposto na Tabela 5.20 do Capítulo 5, um teor de ligante de 5,0\% corresponde à espessura de película em torno de $8 \mu \mathrm{m}$, para misturas compostas por agregados da faixa B. Conclui-se portanto que espessuras de película acima de $8 \mu \mathrm{m}$ provocaram a queda do módulo de resiliência das misturas estudadas.

Para misturas compostas por agregados da faixa $\mathrm{C}$, o teor ótimo obtido pelas dosagens Marshall realizadas ficou em torno de 5,5\%, e os maiores valores de módulo de resiliência foram observados em misturas com teores variando entre 5,5\% e 6,0\%. Aumentando-se o teor de ligante para 6,5\%, observou-se uma visível queda nos valores de módulo de resiliência. No caso dessas misturas, entretanto, o teor de 6,0 \% de ligante corresponde a uma espessura de película em torno $7 \mu \mathrm{m}$, e teores de $6,5 \%$ correspondem a espessuras de película em torno de $8 \mu \mathrm{m}$, conforme apresentado na Tabela 5.21 do Capítulo 5. Conclui-se assim que, para as misturas estudadas da faixa C, valores ideais de espessura de película giraram em torno de $7 \mu \mathrm{m}$, quando a análise foi realizada apenas em função do módulo de resiliência das misturas. Um aumento da espessura de película para $8 \mu \mathrm{m}$ significou a queda do módulo de resiliência dessas misturas. 
Dessa forma, analisando-se o comportamento das misturas com base nos valores de módulo de resiliência obtidos, pode-se indicar que misturas compostas por agregados da faixa $\mathrm{B}$ tenham espessuras de película em torno de $8 \mu \mathrm{m}$, e misturas compostas por agregados da faixa $\mathrm{C}$, espessuras de película em torno de $7 \mu \mathrm{m}$.

Observou-se também que o uso de agregados com distribuição granulométrica mais grossa aumentou o módulo de resiliência das misturas.

\subsection{Ensaio de fluência por compressão uniaxial estática}

Analisando-se os resultados do ensaio de fluência por compressão uniaxial estática verificou-se que não houve influência da variação do tipo de ligante nas respostas obtidas. Isso significa que esse ensaio não foi capaz de distinguir nenhuma mudança no comportamento das misturas quanto à deformação permanente, em decorrência da adição de modificadores ao asfalto. Esse resultado era esperado, pois diversas pesquisas têm constatado que o ensaio de creep estático não é capaz de diferenciar os comportamentos reológicos dos ligantes convencionais e modificados pela adição de polímeros, não detectando assim o aumento da capacidade de recuperação elástica das misturas compostas por asfaltos modificados. Para exemplificar, podem ser citados Valkering et al. (1990), Motta et al. (1996), IBP (1996) e Taira (2001), que verificaram a inadequação do ensaio de creep estático para a avaliação da resistência a deformações permanentes de misturas compostas por asfaltos modificados.

A deformação total sofrida pelas misturas aumentou com o aumento do teor de ligante, assim como a deformação recuperável. Entretanto a recuperação, definida pela razão entre a deformação recuperável e a deformação total, diminuiu, o que significa que o aumento da deformação recuperável com o aumento do teor de ligante foi relativamente menor do que o aumento da deformação total, significando um aumento da deformação não recuperável com o aumento do teor de ligante, em decorrência do aumento da deformação viscosa. 
De acordo com a literatura, em geral o envelhecimento exerce um efeito negativo no desempenho das misturas asfálticas, exceto no que se refere à formação de trilhas de roda, pois o enrijecimento decorrente do envelhecimento melhora a distribuição do carregamento, tornando as misturas mais resistentes a deformações permanentes (FINN, 1990 e BELL et al., 1990).

Entretanto, os resultados do ensaio de creep estático mostraram que as misturas envelhecidas apresentaram os menores valores de módulo de fluência e as maiores inclinações da curva de fluência, indicando que o envelhecimento aumentou a deformação total apresentada pelas misturas e tornou-as mais suscetíveis a deformações. Os resultados do ensaio de creep estático indicaram também que o envelhecimento ao tempo tornou as misturas mais suscetíveis a deformações permanentes do que o envelhecimento em estufa.

Quanto à recuperação elástica, misturas envelhecidas ao tempo apresentaram recuperação superior à apresentada por misturas envelhecidas em estufa ventilada, que por sua vez apresentaram recuperação maior do que misturas não envelhecidas a longo prazo.

O envelhecimento a curto prazo, ao contrário, diminuiu a recuperação elástica das misturas, uma vez que misturas não envelhecidas a curto prazo apresentaram recuperação superior à apresentada por misturas que foram submetidas a 4 horas de envelhecimento em estufa ventilada a $135^{\circ} \mathrm{C}$.

Conclui-se assim que o ensaio de creep estático não foi capaz de identificar a influência do envelhecimento no comportamento das misturas asfálticas quanto a deformação permanente. A explicação talvez esteja no fato desse ensaio permitir o comportamento viscoso das misturas asfálticas.

Pela análise da variação dos parâmetros do ensaio de creep estático inferiu-se que o envelhecimento transforma parte da deformação que antes era viscosa, em deformação elástica retardada, em virtude do enrijecimento do material. Daí a explicação para o aumento da recuperação elástica apresentada pelas misturas envelhecidas. Por outro lado, a deformação total das misturas envelhecidas também aumentou, provavelmente 
pelo fato das misturas terem se tornado mais quebradiças com o envelhecimento, o que fez com que ficassem sujeitas a uma espécie de esmagamento provocado pela aplicação do carregamento estático.

De qualquer forma, como misturas envelhecidas apresentaram módulos de fluência menores e inclinação da curva de fluência maiores, analisando-se o comportamento dessas misturas à luz do ensaio de creep estático dir-se-ia que o envelhecimento tornou as misturas asfálticas mais suscetíveis a deformações permanentes. Entretanto, conforme acima mencionado, sabe-se, pela literatura consultada sobre o assunto, que na verdade o envelhecimento aumenta a resistência das misturas a deformações permanentes.

Conclui-se, assim, que o ensaio de creep estático, por submeter as misturas compactadas a um carregamento estático e dessa forma dar lugar ao comportamento viscoso e a um possível esmagamento das misturas com o tempo de carregamento, não é adequado para a avaliação da suscetibilidade de misturas envelhecidas a deformações permanentes.

\subsection{Ensaio de fluência por compressão uniaxial dinâmica}

Através dos resultados do ensaio de creep dinâmico constatou-se o aumento da resistência a deformações permanentes de misturas envelhecidas, conforme esperado pela literatura consultada.

Dessa forma, misturas envelhecidas a longo prazo apresentaram os menores valores de deformação total e os maiores valores de módulo de fluência. Comparando-se os processos de aceleração de envelhecimento utilizados, constatou-se que misturas envelhecidas ao tempo apresentaram deformações totais menores do que as apresentadas por misturas envelhecidas na estufa ventilada a $85^{\circ} \mathrm{C}$, e módulos de fluência maiores, o que leva a crer que o processo de envelhecimento ao tempo foi mais intenso do que o processo de envelhecimento em estufa. 
O envelhecimento a curto prazo também diminuiu a suscetibilidade das misturas a deformações permanentes, o que foi constatado pelas menores deformações totais apresentadas por essas misturas.

Através do ensaio de creep dinâmico pôde-se notar claramente que a adição de modificadores ao asfalto teve um efeito benéfico ao comportamento das misturas quanto à deformação permanente, diminuindo a deformação total sofrida, aumentando o módulo de fluência das misturas e diminuindo a inclinação da curva de fluência. Ou seja, a adição de modificadores ao asfalto diminuiu a suscetibilidade das misturas a deformações permanentes.

De acordo com a bibliografia consultada, essa melhora no comportamento das misturas ocasionada pela adição de modificadores ao asfalto tem sido constatada não apenas por ensaios realizados em laboratório, mas também pelo monitoramento de trechos experimentais, conforme relatado por Srivastava et al. (1992), Fleckenstein et al. (1992), dentre outros.

Os resultados do ensaio de creep dinâmico indicaram, também, que misturas compostas por asfalto modificado com $20 \%$ de borracha reciclada de pneu apresentaram uma suscetibilidade a deformações permanentes menor do que a apresentada por misturas compostas por asfalto modificado com $4,5 \%$ do polímero SBS.

A influência do teor de ligante e, consequentemente, da espessura de película, se fez notar no comportamento dos parâmetros deformação total e inclinação da curva de fluência, que aumentaram com o aumento do teor de ligante, indicando que quanto maior o teor de ligante na mistura, maior a sua suscetibilidade a deformações permanentes. Em contrapartida, aumentos do volume de vazios até o limite aproximado de 5,5\% corresponderam à diminuição da suscetibilidade a deformações permanentes. $\mathrm{O}$ comportamento de misturas com volumes de vazios superiores a 5,5\% não foi testado nesta pesquisa. O módulo de fluência não sofreu influência significativa do fator teor de ligante, tampouco do fator volume de vazios.

Observou-se também que misturas compostas por agregados da faixa B apresentaram menor suscetibilidade a deformações permanentes do que misturas compostas por 
agregados da faixa C. Concluiu-se, assim, que misturas compostas por agregados de diâmetros maiores oferecem maior resistência a deformações permanentes.

\subsection{Comentários finais}

Através do experimento realizado foi possível identificar o modo como cada um dos fatores selecionados para investigação interfere no comportamento mecânico de misturas asfálticas densas.

A adição de modificadores ao asfalto mostrou interferir de forma positiva nas propriedades das misturas compactadas em laboratório. Comparando-se o comportamento de misturas compostas por asfalto convencional com o comportamento de misturas compostas por asfaltos modificados, verificou-se que a adição de modificadores torna as misturas mais resistentes à fadiga e às deformações permanentes. $\mathrm{O}$ aumento da resistência à fadiga foi identificado pelos maiores valores de módulo de resiliência apresentados por misturas com asfaltos modificados, sem a redução da capacidade de recuperação elástica das mesmas. O aumento da resistência às deformações permanentes foi constatado através do ensaio de creep dinâmico, onde misturas com asfaltos modificados apresentaram deformações totais e inclinações da curva de fluência menores, e módulos de fluência maiores. O ensaio de creep estático não foi capaz de detectar a influência do tipo de ligante no comportamento das misturas.

Os processos de envelhecimento a curto e longo prazos enrijeceram as misturas, o que se refletiu em maiores valores de módulo de resiliência e menor suscetibilidade a deformações permanentes, verificada pela diminuição da deformação total e pelo aumento do módulo de fluência obtido no ensaio de creep dinâmico. O aumento do módulo de resiliência das misturas, nesse caso, não corresponde a um aumento da resistência à fadiga, pois calculando-se as relações $M R / \sigma_{R}$ verificou-se que $o$ envelhecimento provocou a queda da capacidade de recuperação elástica das misturas. Mais uma vez, o ensaio de creep estático não foi capaz de caracterizar adequadamente a interferência do envelhecimento no comportamento das misturas quanto à deformação permanente. 
Comparando-se os métodos de aceleração do envelhecimento a longo prazo utilizados, notou-se que o envelhecimento dos corpos de prova por exposição ao tempo durante quatro meses foi sempre mais acentuado do que o envelhecimento sofrido em estufa ventilada a $85^{\circ} \mathrm{C}$, por cinco dias. Um dos fatores que provavelmente contribuiu para o maior envelhecimento ocorrido por exposição ao tempo foi a ação da radiação ultravioleta.

Os resultados da pesquisa realizada indicaram que misturas compostas por agregados com partículas de diâmetros maiores apresentam módulos de resiliência mais elevados. Entretanto, em geral, misturas com agregados da faixa $B$ apresentaram relações $M R / \sigma_{R}$ maiores do que as apresentadas por misturas com agregados da faixa $\mathrm{C}$, o que significa menor capacidade de recuperação elástica das misturas com agregados da faixa B e, consequentemente, menor resistência à ruptura por fadiga.

Quanto à resistência a deformações permanentes, agregados com distribuição granulométrica correspondente ao centro da faixa B conferiram às misturas menor suscetibilidade a deformações permanentes do que agregados com distribuição granulométrica correspondente ao centro da fixa $\mathrm{C}$, o que foi verificado por menores deformações totais, menores inclinações das curvas de fluência e maiores módulos de fluência apresentados por misturas com agregados da faixa $\mathrm{B}$, no ensaio de creep dinâmico.

O ensaio de creep estático, entretanto, identificou as misturas com agregados da faixa $\mathrm{C}$ como mais resistentes a deformações permanentes do que as misturas com agregados da faixa B. Como segundo a literatura consultada o efeito dinâmico parece estar relacionado com o contato entre as partículas de agregado da mistura (VAN DE LOO, 1974), optou-se por avaliar a influência da distribuição granulométrica na suscetibilidade a deformações permanentes pelo ensaio de creep dinâmico e concluiu-se que misturas com agregado da faixa $\mathrm{B}$ foram menos suscetíveis a deformações permanentes.

Embora o fracionamento realizado no experimento tenha permitido o estudo do comportamento de 144 condições diferentes, não foi possível a avaliação da maioria dos efeitos de interação entre os fatores, em virtude da baixa resolução do experimento. 
Para que as 144 condições experimentais pudessem ser avaliadas através do teste de apenas 36 condições experimentais, houve a necessidade de se acoplar o efeito principal dos fatores com o efeito da interação entre dois fatores. Dessa forma não foi possível avaliar, por exemplo, se a adição de modificadores ao asfalto interfere nos processos de envelhecimento, pois o efeito da interação entre o tipo de ligante e a condição de envelhecimento a longo prazo foi acoplado ao efeito do fator condição de envelhecimento a curto prazo. O efeito da interação entre os fatores tipo de ligante e condição de envelhecimento a curto prazo também não pôde ser avaliado, pois tal efeito foi acoplado ao efeito do fator condição de envelhecimento a longo prazo.

Apesar disso pôde-se constatar que a adição de modificadores ao asfalto não interferiu nos valores de módulo de resiliência apresentados por misturas envelhecidas a longo prazo. Isso porque o fator condição de envelhecimento a curto prazo (X8) não foi considerado significativo nas análises de variância dos módulos de resiliência das misturas. Como o efeito da interação entre os fatores tipo de asfalto e condição de envelhecimento a longo prazo (interação $B C$ ) foi acoplado ao efeito principal do fator condição de envelhecimento a curto prazo $(X 8)$, isso significa que a interação entre esses fatores (interação $B C$ ) também não exerceu efeito significativo nas variações dos módulos de resiliência das misturas.

Além da baixa resolução do experimento realizado, outra dificuldade encontrada foi a variação do fator $A$, teor de ligante, em 4 níveis. Quando se tratam de experimentos assimétricos, com fatores possuindo números de níveis diferentes, a maioria dos programas comerciais de análise estatística permite apenas a consideração de fatores com 2 ou 3 níveis em um mesmo experimento. Como no caso desta pesquisa foram considerados fatores com 2, 3 e 4 níveis, o planejamento e a análise do experimento foram realizados manualmente, seguindo-se o procedimento descrito no Capítulo 2. Quando o fator $A$ foi considerado como um fator qualitativo, representando o volume de vazios na mistura, utilizou-se o artificio de se representar esse fator por dois fatores em dois níveis e, desse modo, foi possível a utilização do programa STATISTICA, através do qual foram estabelecidos os modelos de comportamento apresentados no Capítulo 6, para as situações em que o fator $A$ representa o volume de vazios nas misturas. 
Os resultados desta pesquisa indicaram que os ensaios de módulo de resiliência e creep dinâmico foram capazes de distinguir o comportamento mecânico de misturas asfálticas com características diferentes no que se refere ao tipo de ligante utilizado em sua composição, convencional ou modificado, ao teor de ligante e à distribuição granulométrica do agregado. Esses ensaios também foram capazes de detectar a mudança de comportamento das misturas ao longo do tempo. $\mathrm{O}$ ensaio de creep estático, entretanto, não foi considerado adequado para avaliação do comportamento das misturas quanto à estabilidade e à flexibilidade, com base nos resultados desta pesquisa.

Deve-se observar que as conclusões apresentadas baseiam-se na análise de um experimento fatorial fracionário de resolução III, no qual os efeitos principais dos fatores confundem-se com efeitos de interação entre dois fatores. Embora geralmente exista uma hierarquia em termos de valores absolutos dos efeitos dos fatores e de suas interações, segundo a qual a variação de cada fator individualmente possui efeito maior na variação da resposta do que os efeitos de interação entre dois fatores, que por sua vez são maiores do que os efeitos de interação entre três fatores, as conclusões decorrentes de um experimento fracionado por natureza não podem ser tão exatas quanto seriam caso o experimento fosse completo.

Por último, ressalta-se a importância do controle rigoroso da temperatura de compactação das misturas, principalmente quando são empregados asfaltos modificados, pois nesse caso pequenas quedas de temperatura podem resultar em significativos aumentos de viscosidade, interferindo no grau de compactação das misturas.

\subsection{Sugestões para pesquisas futuras}

Embora a utilização da técnica de fracionamento tenha permitido a avaliação de um grande número de condições experimentais, através da execução de um experimento relativamente pequeno, recomendam-se experimentos com resoluções maiores, que não acoplem os efeitos de interação entre dois fatores com os efeitos principais dos fatores, para que, uma vez detectado que determinado fator possui influência significativa em certa propriedade mecânica das misturas asfálticas em estudo, seja possível também a 
obtenção de informações referentes às circunstâncias em que os efeitos de tal fator se mostram mais acentuados. Essas informações podem ser resgatadas a partir da análise dos efeitos de interação entre os fatores.

Montando-se um experimento fatorial semelhante ao realizado nesta pesquisa, porém sem o acoplamento de efeitos principais com efeitos de interação entre dois fatores, seria possível, por exemplo, verificar se a adição de modificadores ao asfalto exerce influência significativa nos processos de envelhecimento sofridos pela mistura, no que se refere à resistência a deformações permanentes.

Seria interessante, também, a realização de frações do experimento complementares à realizada nesta pesquisa, pois dessa forma, através da junção de frações complementares, seria possível o aumento da resolução do experimento, aumentando-se dessa forma o número de efeitos independentes avaliados. Com isso poderia até mesmo ser montado o experimento completo, o que permitiria não apenas a validação da técnica de fracionamento utilizada, mas também a identificação do grau de fracionamento mais indicado para que os resultados obtidos através da realização do experimento fracionado sejam os mais próximos possíveis dos resultados que seriam obtidos realizando-se o experimento completo.

Recomendam-se experimentos com fatores variando em até 3 níveis, para facilitar o planejamento e a análise dos mesmos através da utilização de módulos de programas comerciais de estatística.

Outra sugestão refere-se à introdução de novas variáveis dependentes. Poderia, por exemplo, ser montado um experimento onde pudesse ser avaliada a interferência dos processos de envelhecimento sofridos pelo ligante em sua adesão ao agregado.

Para avaliação do efeito da oxidação do ligante nas propriedades da mistura compactada, poderia ser montado um experimento onde diferentes tipos de ligantes fossem propositadamente oxidados. Comparando-se as propriedades mecânicas de misturas compostas por ligantes oxidados com o comportamento de misturas compostas pelos mesmos ligantes, porém não oxidados, poderia ser avaliado o grau da influência que a oxidação dos ligantes exerce no comportamento das misturas compactadas. Seria 
interessante que a avaliação dessas misturas fosse feita através de ensaios de módulo de resiliência, para estimativa da sensibilidade dos valores de módulo de resiliênca das misturas a oxidações eventualmente sofridas pelo ligante, durante os processos de mistura e compactação. 


\section{REFERÊNCIAS BIBLIOGRÁFICAS}

ABNT (1993). Dosagem de misturas betuminosas pelo método Marshall. NBR 12891. Associação Brasileira de Normas Técnicas. Rio de Janeiro.

AASHTO (2001). Standard Practice for Mixture Conditioning of Hot Mix Asphalt (HMA). Edição publicada sob a designação PP2-00. American Association of State Highway and Transportation Officials. 3p.

AASHTO (1994). Standard test method for determining the resilient modulus of bituminous mixtures by indirect tension. Edição publicada sob a designação TP31-94. American Association of State Highway and Transportation Officials. Washington, 31p.

AASHTO (1993). AASHTO guide for design of pavement structures. American Association of State Highway and Transportation Officials. Washington.

ABSON, G.; BURTON, C. (1960). The use of chlorinated solvents in the Abson recovery method. Proceedings. Association of Asphalt Paving Technologists. n.29, p.246-252.

ABWAHAB, Y.; SOSNOVSKE, D.; BELL, C.A.; RYUS, P. (1993). Evaluation of asphalt-aggregate mixture aging by dynamic mechanical analysis. Transportation Research Record. n.1386, p. 22-30. Washington, D.C.

ACHCAR, J.A. (1995). Planejamento de experimentos em engenharia e indústria. ICMSC-USP, São Carlos.

ADDELMAN, S. (1962a). Orthogonal main effect plans for asymmetric factorial experiments. Technometrics, v.4, n.1, p.21-46.

ADDELMAN, S. (1962b). Symmetrical and asymmetrical fractional factorial plans. Technometrics, v.4, n.1, p.47-58.

AEDO, J.L.C.; ROMANEL, C.; MOTTA, L.G. (1996). Um programa de computador para análise tridimensional não-linear de pavimentos flexíveis pelo método dos elementos finitos. In: ANAIS DA $30^{\circ}$ REUNIÃO ANUAL DE PAVIMENTAÇÃO, 1996. Anais. Salvador. v.3, p. 986-1009. 
AL-ABDUL WAHHAB, H.I.; FATANI, M.N.; NOURELDIN, A.S.; BUBSHAIT, A.; ALDUBABE, I.A. (1995). National study of asphalt pavement rutting in Saudi Arabia. Transportation Research Record. n.1473, p.35-42.

AMARAL, S.C. (2000). Estudos de misturas asfálticas densas com agregados do estado do Pará, utilizando asfalto convencional (CAP-40) e asfalto modificado com polímero SBS (BETUFLEX B 65/60). 147p. São Carlos. Dissertação (Mestrado) Escola de Engenharia de São Carlos, Universidade de São Paulo.

ANANI, B.A.; BALGHUNAIM, F.A.; AL-HAZZAA, A.S. (1990). Laboratory and field study of pavement rutting in Saudi Arabia. Transportation Research Record. n.1259, p.79-90.

ASTM (1982). Standard method of indirect tension test for resilient modulus of bituminous mixtures. Edição publicada sob a designação D 4123-82. American Society for testing and Materials. Philadelphia, EUA. 5p.

ASTM (1993). Standard test method for recovery of asphalt from solution using the rotavapor apparatus. Edição publicada sob a designação D 5404-93. American Society for testing and Materials. Philadelphia, EUA. 3p.

ASTM (1995a). Standard test method for recovery of asphalt from solution by Abson method. Edição publicada sob a designação D 1856-95a. American Society for testing and Materials. Philadelphia, EUA. 4p.

ASTM (1995b). Standard test methods for quantitative extraction of bitumen from bituminous paving mixtures. Edição publicada sob a designação D 2172-95. American Society for testing and Materials. Philadelphia, EUA. 11p.

BAHIA, H.U.; ZHAI, H. e RANGEL, A. (1998). Evaluation of stability, nature of modifier, and short-term aging of modified binders using new tests LAST, PAT, and modified RTFO. Transportation Research Record. n.1638, p.64-71.

BALADI, G. (1989). Fatigue life and permanent deformation characteristics of asphalt concrete mixes. Transportation Research Record. n.1227, p.75-87.

BELL, C.A. (1990). Relationship between laboratory aging tests and field performance of asphalt-concrete mixtures. Serviceability and Durability of Construction Materials. v.2, p.745-754.

BELL, C.A. (1989). Summary report on: Aging of asphalt-aggregates systems. Publicação SR-OSU-A-003A-89-2 do Strategic Highway Research Program. National Research Council. Washington, D.C. 121p.

BELL, C.A.; ABWAHAB, Y.; CRISTI, M.E. (1990). Laboratory aging of asphaltaggregate mixtures. Serviceability and Durability of Construction Materials. v.1, p.254262. 
BELL, C.A.; ABWAHAB, Y.; CRISTI, M.E. (1991). Investigation of laboratory aging procedures for asphalt-aggregate mixtures. Transportation Research Record. n.1323, p.32-46. Washington, D.C.

BERNUCCI, L.B.; CAMPOS, O.S.; DOMINGUES, F.A.A.; MOMM, L. (1996). Estudos para a formulação de CBUQ considerando a deformação permanente para as rodovias da rede DERSA. In: ANAIS DA 30 REUNIÃO ANUAL DE PAVIMENTAÇÃO, 1996. Anais. Salvador. v.1, p.19-34.

BERTOLLO, S.A.M. (2002). Avaliação laboratorial de misturas asfálticas densas modificadas com borracha reciclada de pneus. 198p. São Carlos. Tese (Doutorado) Escola de Engenharia de São Carlos, Universidade de São Paulo.

BEZERRA NETO, R.S.. (2004). Análise comparativa de pavimentos dimensionados através dos métodos empírico do DNER e mecanístico e proposta de um catálogo simplificado de pavimentos para a região de campo grande (MS). 169p. Dissertação (Mestrado) - Escola de Engenharia de São Carlos, Universidade de São Paulo, São Carlos. 2004.

BISSADA, A. F. (1983). Compatibility of asphalt paving mixtures and relation to permanent deformation. Transportation Research Record. n.911, p1-10.

BOX, G.E.P.; CONNOR, L.R.; COUSINS, W.R.; DAVIES, O.L.; HIMSWORTH, F.R.; SILLITTO, G.P. (1971). The design and analysis of industrial experiments. London e New York, Longman Group Limited.

BOX, G.E.P.; HUNTER, W.G.; HUNTER, J.S. (1978). Statistics for experimenters. An introduction to design, data analysis, and model building. John Wiley \& Sons. New York.

BROOME, D.C. (1949). The testing of bituminous mixtures. 2 ed. Edward Arnold \& CO. London, England.

BROWN, E.R.; CROSS, S.A. (1989). A study of in place rutting of asphalt pavements. Association of Asphalt Paving Technologists. v.58, p.1-39.

BURR, B.L.; DAVISON, R.R.; GLOVER, C.J.; BULLIN, J.A. (1990). Solvent removal from asphalt. Transportation Research Record. n.1269, p.1-8.

BURR, B.L.; DAVISON, R.R.; JEMISON, H.B.; GLOVER, C.J.; BULLIN, J.A. (1991). Asphalt hardening in extraction solvents. Transportation Research Record. n.1323, p.7076.

BURR, B.L.; GLOVER, C.J.; DAVISON, R.R.; BULLIN, J.A. (1993). New apparatus and procedure for the extraction and recovery of asphalt binder from pavement mixtures. Transportation Research Record. n.1391, p.20-29.

BUTTON, J.W. (1996). Permeability of asphalt surface seals and their effect on aging of underlying asphalt concrete. Transportation Research Record. n.1535, p.124-130. Washington, D.C. 
CARPINETTI, L.C.R. (2000). Planejamento e análise de experimentos. EESC-USP. São Carlos.

CASTELL, M.A.; PINTADO, P. (1999). Sensitivity analysis for estimation of pavement fatigue life. Journal of Transportation Engineering. v.125, n.2, p.114-122.

CERATTI, J.A.; RUWER, P.M.; OLIVEIRA, J.A. (1996). Estudo do comportamento mecânico de concreto asfáltico com ligante modificado com polímero. $13^{\circ}$ Encontro de Asfalto-IBP, p.290-303.

CHAPUIS, R.P.; LÉGARÉ, P.-P. (1992). A simple method for determining the surface area of fine aggregates and fillers in bituminous mixtures. Effects of aggregates and mineral fillers on asphalt mixture performance, ASTM STP 1147, R.C. Meininger, ed., American Society for Testing and Materials. p. 177-186. Philadelphia, 1992.

CHEHOVITS, J.; MANNING, M. (1984). Materials and methods for sealing cracks in asphalt concrete pavements. Transportation Research Record. n. 990, p. 21-30.

CHENG, C.S. (1989). Some orthogonal main-effect plans for asymmetrical factorials. Technometrics, v.31, n.4, p.475-77.

COELHO, V. (1996). Contribuição ao estudo das deformações permanentes, nas condições do Brasil, em camadas de concreto asfáltico de pavimentação. São Carlos. 281p. Tese (Doutorado) - Escola de Engenharia de São Carlos, Universidade de São Paulo.

COELHO, V.; SÓRIA, M.H.A. (1995). Influência da granulometria e da temperatura nas deformações permanentes das trilhas-de-rodas. In: ANAIS DA $29^{\circ}$ REUNIÃO ANUAL DE PAVIMENTAÇÃO, 1995. Anais. Cuiabá. v.2, p.403-431.

COELHO, V.; SÓRIA, M.H.A. (1994). Influência da temperatura dos corpos de prova nos resultados do ensaio Marshall. In: ANAIS DA $28^{\circ}$ REUNIÃO ANUAL DE PAVIMENTAÇÃO, 1994. Anais. Belo Horizonte. v.1, p.317-348.

COETZEE, N.F.; MONISMITH, C.L. (1979). Analytical study of minimization of reflection cracking in asphalt concrete overlays by use of a rubber-asphalt interlayer. Transportation Research Record. n.700, p.100-108.

COLLINS-GARCIA, H.; TIA, M.; ROQUE, R.; CHOUBANE, B. (2000). Alternative solvent for reducing health and environmental hazards extracting asphalt. Transportation Research Record. n.1712, p.79-85.

COPLANTZ, J.S.; YAPP, M.T.; FINN, F.N. (1993). Review of relationships between modified asphalt properties and pavement performance. Publicação SHRP-A-631 do Strategic Highway Research Program. National Research Council. Washington, D.C. $243 p$.

CORTÉ, J.F.; BROSSEAUD, Y.; SIMONCELLI, J.P.; CAROFF, G. (1993). Investigation of rutting of asphalt surface layers: influence of binder and axle loading configuration. Transportation Research Record. n.1436, p.28-37. 
DNER (1994a). Especificação de serviço DNER-ES 133/94. Misturas betuminosas determinação do módulo de resiliência. Departamento Nacional de Estradas de Rodagem. Rio de Janeiro.

DNER (1994b). Especificação de serviço DNER-ES 138/94. Misturas betuminosas determinação da resistência à tração por compressão diametral. Departamento Nacional de Estradas de Rodagem. Rio de Janeiro.

DNER (1994c). Método de ensaio DNER-ME 78/94. Agregado graúdo - adesividade a ligante betuminoso. Departamento Nacional de Estradas de Rodagem. Rio de Janeiro.

DNER (1994d). Método de ensaio DNER-ME 79/94. Agregado - adesividade a ligante betuminoso. Departamento Nacional de Estradas de Rodagem. Rio de Janeiro.

DNER (1994e). Método de ensaio DNER-ME 84/95. Agregado miúdo - determinação da densidade real. Departamento Nacional de Estradas de Rodagem. Rio de Janeiro.

DNER (1994f). Procedimento DNER-PRO 269/94. Projeto de restauração de pavimentos flexíveis. Departamento Nacional de Estradas de Rodagem. Rio de Janeiro.

DNER (1997). Especificação de serviço DNER-ES 313/97. Pavimentação - Concreto betuminoso - Norma Rodoviária. Departamento Nacional de Estradas de Rodagem. Rio de Janeiro.

DNER (1998). Método de ensaio DNER-ME 35/98. Agregados - determinação da abrasão "Los Angeles". Departamento Nacional de Estradas de Rodagem. Rio de Janeiro.

DNER (1999). Especificação de serviço DNER-ES 385/99. Pavimentação - Concreto asfáltico com asfalto polímero - Norma Rodoviária. Departamento Nacional de Estradas de Rodagem. Rio de Janeiro.

ECKMANN, B. (1989). Exxon research in pavement design - Moebius Software: A case study reduction of creep through polymer modification. Proceedings. AAPT Association of asphalt Paving Technologists. v.58, p.337-361.

ESCH, D.C. (1982). Construction and benefits of rubber-modified asphalt pavements. Transportation Research Record. n.860, p. 05-13.

FAXINA, A.L. (2002). Estudo em laboratório do desempenho de concreto asfáltico usinado a quente empregando ligante tipo asfalto-borracha. 274p. Dissertação (Mestrado) - Escola de Engenharia de São Carlos, Universidade de São Paulo, São Carlos. 2002.

FINN, F.N. (1990). Material properties related to pavement performance. Serviceability and Durability of Construction Materials. v.2, p.735-744. 
FLECKENSTEIN, L.J.; MAHBOUB, K.; ALLEN, D.L. (1992). Performance of polymer modified asphalt mixes in Kentucky. Polymer Modified Asphalt Binders, American Society for Testing and Materials, ASTM STP 1108, p.173-185.

FORETTI, A.C. (1999). Estudo de misturas preparadas com asfalto convencional e asfalto modificado com polímeros. 81p. São Carlos. Dissertação (Mestrado) - Escola de Engenharia de São Carlos, Universidade de São Paulo.

FREITAS, F.J.S. (1996). Asfalto modificado com EVA. In: ANAIS DA $30^{\circ}$ REUNIÃO ANUAL DE PAVIMENTAÇÃO, 1996. Anais. Salvador. v.1, p.61-74.

GARCIA-DIAZ, A.; PHILLIPS, D.T. (1995). Principles of experimental design and analysis. Chapman \& Hall. London.

GARRICK, N.W. (1995). Nonlinear differential equation for modeling asphalt aging. Journal of Materials in Civil Engineering. v.7, n.4, p.265-268.

GOODRICH, J. (1991). Asphaltic binder rheology, asphalt concrete rheology and asphalt concrete mix properties. Proceedings AATP. Association of Asphalt Paving Technologists, v.60, p.80-120.

GOWDA, G.V.; HALL, K.D.; ELLIOTT, R.P. (1996). Arkansas experience with crumb rubber modified mixes using Marshall and Strategic Highway Research Program Level I Design Methods. Transportation Research Record. n.1530, p.25-33.

GROVE, D.M.; DAVIS, T.P. (1991). Taguchi's idle column method. Technometrics, v.33, n.3, p.349-53.

HEITZMAN, M. (1992). Design and construction of asphalt paving materials with crumb rubber modifier. Transportation Research Record. n.1339, p.01-08.

HENSLEY, M.J.; LEAHY, R.B. (1989). Asphalt concrete mixtures as related to pavement rutting: case studies. Transportation Research Record. n.1217, p.87-96.

HILLS, J.F. (1973). The creep of asphalt mixes. Journal of the Institute of Petroleum, v.59, n.570, p.247-262.

HINKELMANN, K.; KEMPTHORNE, O. (1994). Design and analysis of experiments. Introduction to experimental design. v.1. John Wiley \& Sons, Inc.

HOPMAN, P.C.; VALKERING, C.P.; VAN DER HEIDE, J.P.J. (1992). Mixes and five procedures: Search for a performance-related mix design procedure. Proceeding. AATP - Association of Asphalt Paving Technologists. v.61, p.188-216.

HSU, T.W.; TSENG, K.H. (1996). Effect of rest periods on fatigue response of asphalt concrete mixtures. Journal of Transportation engineering. v.122, n.4, p.316-322.

HUFF, B.J.; VALLERGA, B.A. (1981). Characteristics and performance of asphaltrubber material containing a blend of reclaim and crumb rubber. Transportation Research Record. n. 821, p29-37. 
IBP - Instituto Brasileiro de Petróleo. (1996). Asfalto modificado com polímeros. Informativo O Asfalto, ano 7, n.1, p.1-6.

ISACSSON, U.; LU, X. (1995). Testing and appraisal of polymer modified road bitumens - state of the art. Materials and Structures, v.28, p.139-159.

JIMENEZ, R.A.; MEIER Jr, W.R. (1985). Laboratory evaluation of asphalt-rubber SAL. Transportation Research Record. n.1034, p 86-96.

JIMENEZ, R.A. (1982). Laboratory measurements of asphalt-rubber concrete mixtures. Transportation Research Record. n.843, p 04-11.

KANDHAL, P.S.; CHAKRABORTY, S. (1996). Effect of asphalt film thickness on shortand long-term aging of asphalt paving mixtures. Transportation Research Record. n. 1535 , p. 83-90. Washington, D.C.

KANDHAL, P.S.; FOO, K.Y.; MALLICK, R.B. (1998). Critical review of voids in mineral aggregate requirements in Superpave. Transportation Research Record. n.1609, p.21-27. Washington, D.C.

KEMP, G.R.; SHERMAN, G.B. (1984). Significant studies on asphalt durability: California experience. Transportation Research Record. n. 999, p. 36-41.

KENIS, W.J.; SHARMA, M.G. (1976). Rut depth prediction and test procedures for permanent deformation in asphalt pavements. Transportation Research Record. n.616, p.28-30.

KHEDR, S.A. (1986). Deformation mechanism in asphaltic concrete. Journal of Transportation Engineering. v.112, n.1, p.29-45.

KIM, O.K.; BELL, C.A.; WILSON, J.E.; BOYLE, G. (1987). Development of laboratory oxidative aging procedures for asphalt cements and asphalt mixtures. Transportation Research Record. n.1115, p.101-112. Washington, D.C.

KHOSLA, N.P. (1991). Effect of the use of modifiers on performance of asphaltic pavements. Transportation Research Record. n.1317, p.10-22.

KRUTZ, N.C.; STROUP-GARDINER, M. (1990). Relationship between permanent deformation of asphalt concrete and moisture sensitivity. Transportation Research Record. n.1259, p.169-177.

KRUTZ, N.C.; STROUP-GARDINER, M. (1992). Permanent deformation characteristics of recycled tire rubber-modified and unmodified asphalt concrete mixtures. Transportation Research Record. n.1339, p.38-44.

LAI, J.S.; ANDERSON, D. (1973). Irrecoverable and recoverable nonlinear viscoelastic properties of asphalt concrete. Transportation Research Record. n.468, p.73-88. 
LAI, J.S.; HUFFERD, W.L. (1976). Predicting permanent deformation of asphalt concrete from creep tests. Transportation Research Record. n.616, p.41-43.

LEITE, L.F.M. (1999). Estudos de preparo e caracterização de asfaltos modificados por polímero. 266p. Tese (Doutorado) - Universidade Federal do Rio de Janeiro, Rio de Janeiro.

LIANG, R.Y.; LEE, S. (1996). Short-term and long-term aging behavior of rubber modified asphalt paving mixture. Transportation Research Record. n.1530, p.11-17.

LING, M.; CURTIS, C.W.; HANSON, D.I.; HOLL, J.N. (1997). Quantitative analysis of polymers and crumb rubber in hot-mix asphalts. Transportation Research Record. n.1586, p.57-67.

LITTLE, D.N.; BUTTON, J.W.; YOUSSEF, H. (1993). Development of criteria to evaluate uniaxial creep data and asphalt concrete permanent deformation potential. Transportation Research Record. n.1417, p.49-57.

MADAPATTI, R.R.; LEE, K.W.; MANNING, F.J.; FRANCO, C.A. (1996). Feasibility of crumb rubber use for pavement asphalt construction. Transportation Research Record. n.1530, p.64-71.

MAHBOUB, K. (1990). Asphalt concrete creep as related to rutting. Journal of Materials in Civil Engineering, v.2, n.3, p.147-163.

MARGOLIN, B.H. (1967). Systematic methods for analyzing $2^{\mathrm{n}} 3^{\mathrm{m}}$ factorial experiments with applications. Technometrics. v.9, n.2. p.245-59.

MARGOLIN, B.H. (1968). Orthogonal main-effect $2^{\mathrm{n}} 3^{\mathrm{m}}$ designs and two-factor interaction aliasing. Technometrics, v.10, n.3, p.559-73.

MASON, R.L.; GUNST, R.F.; HESS, J.L. (1989). Statistical design and analysis of experiments with applications to engineering and science. John Wiley \& Sons.

MAUPIN, G.W. (1972). Results of indirect tensile tests related to asphalt fatigue. Highway Research Record, n.404, p.1-7.

MEDINA, J. (1988). Notas históricas acerca de mecânica dos pavimentos. In: ANAIS DA $23^{\circ}$ REUNIÃO ANUAL DE PAVIMENTAÇÃO, 1988. Anais. Florianópolis. p.329345.

MERIGHI, J.V. (1999). Estudo da deformação permanente de misturas asfálticas em ensaios de laboratório. 255p. Tese (Doutorado) - Escola Politécnica, Universidade de São Paulo, São Paulo.

MOMM, L.; DOMINGUES, F.A.A. (1996). Comportamento das misturas asfálticas à deflexão: módulo, um dilema não resolvido. In: ANAIS DA $30^{\circ}$ REUNIÃO ANUAL DE PAVIMENTAÇÃO, 1996. Anais. Salvador. p.674-774. 
MONTGOMERY, D.C. (1997). Design and analysis of experiments. 4 ed., John Wiley $\&$ Sons, Inc. New York.

MOHAMED, E.H.H.; YUE, Z. (1994). Criteria for evaluation of rutting potential based on repetitive uniaxial compression test. Transportation Research Record. n.1454, p.7481.

MORILHA JR, A.; TRICHÊS, G. (2003). Análise comparativa de envelhecimento em laboratório de nove ligantes asfálticos. In: ANAIS DA $34^{\circ}$ REUNIÃO ANUAL DE PAVIMENTAÇÃO, 2003. Anais. Campinas. p.110-128.

MORRIS, G.R.; McDONALD, C.H. (1976). Asphalt-rubber stress-absorbing membranes: field performance and state of the art. Transportation Research Record. n. 595, p52-58.

MOTTA, L.M.G.; MEDINA, J. (1991). Um método de dimensionamento de pavimentos flexíveis desenvolvido no Brasil. In: ANAIS DA $25^{\circ}$ REUNIÃO ANUAL DE PAVIMENTAÇÃO, 1991. Anais.

MOTTA, L.M.G.; MEDINA, J.; SCALCO, R. (1993). O projeto estrutural de pavimentos flexíveis e a dosagem de misturas asfálticas. In: ANAIS DA $27^{\circ}$ REUNIÃO ANUAL DE PAVIMENTAÇÃO, 1993. Anais. Teresina. p. 524-545.

MOTTA, L.M.G.; PINTO, S. (1994). O uso de ensaios estáticos na definição de parâmetros de comportamento das misturas asfálticas. $12^{\circ}$ Encontro de Asfalto-IBP, p.152-178.

MOTTA, L.M.G.; SÁ, M.F.P.; OLIVEIRA, P.M.F.; SOUSA, A.M. (1996). O ensaio de creep estático e dinâmico na avaliação das misturas asfálticas. In: ANAIS DA $30^{\circ}$ REUNIÃO ANUAL DE PAVIMENTAÇÃO, 1996. Anais. Salvador. p.115-135.

MOUILLET, V.; LAMONTAGNE, J.; DURRIEU, F.; KISTER, J.; MARTIN, D. (2003). Development of a new methodology for characterization of polymer modified bitumens aging by infrared microspectrometry imaging. Proceedings of the $6^{\text {th }}$ International RILEM Symposium. Performance Testing and Evaluation of Bituminous Materials PTEBM'03. RILEM Publications S.A.R.L.

NAMBOODIRI, N.K.; CARTER, L.F; BLALOCK JR, H.M. (1975). Applied multivariate analysis and experimental designs. McGraw-Hill Book Company.

NETER, J; WASSERMAN, W.; KUTNER, M.H. (1985). Applied linear statistical models. Regression, analysis of variance, and experimental designs. $2^{\text {nd }}$ ed. Irwin.

NOURELDIN, M.S.; MANKE, P.G. (1978). Study of transverse cracking in flexible highway pavements in Oklahoma. Transportation Research Record. n.695, p.28-32.

ODA, S. (2000). Análise da viabilidade técnica da utilização do ligante asfaltoborracha em obras de pavimentação. São Carlos. Tese (Doutorado) - Escola de Engenharia de São Carlos, Universidade de São Paulo. 
OLIVEIRA, P.M.F.; MOTTA, L.M.G. (1996). Estudo comparativo de misturas preparadas com asfalto-polímero. $13^{\circ}$ Encontro de Asfalto-IBP, p.46-59.

OTENG-SEIFAH, S.; MANKE, P.G. (1976). Study of rutting in flexible highway pavements in Oklahoma. Transportation Research Record. n.602, p.97-99.

PERL, M.; UZAN, J.; SIDES, A. (1983). Visco-elasto-plastic constitutive law for a bituminous mixture under repeated loading. Transportation Research Record. n.911. p.20-27.

PETERSEN, J.C. (1990). Effects of physicochemical factors on asphalt aging. Serviceability and Durability of Construction Materials. v.1, p.244-253.

PETERSEN, J.C.; BRANTHAVER, J.F.; ROBERTSON, R.E.; HARNSBERGER, P.M.; DUVALL, J.J.; ENSLEY, E.K. (1993). Effects of physicochemical factors on asphalt oxidation kinetics. Transportation Research Record. n.1391, p.1-10. Washington, D.C.

PEUTZ, M.G.F.; VAN KEMPEN, H.P.M.; JONES, A. (1968). Layered systems under normal surface loads. Highway Research Record. n.228, p.34.

PINTO, S. (1991). Estudo do comportamento à fadiga de misturas betuminosas e aplicação na avaliação estrututal de pavimentos. Rio de Janeiro. Tese (Doutorado). COPPE - UFRJ.

PINTO, S.; PREUSSLER, E.S. (1980). Módulos resilientes de concretos asfálticos. Instituto de Pesquisas Rodoviárias do Departamento Nacional de Estradas de Rodagem. Rio de Janeiro.

PIRATELLI FILHO, A. (1997). Método para avaliação do desempenho de máquinas de medir a três coordenadas através de planejamento de experimentos. São Carlos. Tese (Doutorado) - Escola de Engenharia de São Carlos, Universidade de São Paulo.

PLACKETT, R.L. (1946). Some generalizations in the multifactorial design. Biometrika, n.33, p.328-32.

PLACKETT, R.L.; BURMAN, J.P. (1946). The design of optimum multifactorial experiments. Biometrika, n.33, p.305-25.

PONNIAH, J.; KENNEPOHL, G. (1996). Polymer-modified asphalt pavements in Ontario: performance and cost-effectiveness. Transportation Research Record. n.1545, p.151-160.

PREUSSLER, E. S.; PINTO, S. (1982). Proposição de método para projeto de reforço de pavimentos flexíveis, considerando a resiliência. In: ANAIS DA $17^{\circ}$ REUNIÃO ANUAL DE PAVIMENTAÇÃO, 1982. Anais. Brasília. p.205-222.

RAAD, L.; SABOUNDJIAN, S. (2001). Field aging effects on the fatigue of asphalt concrete and asphalt-rubber concrete. Transportation Research Record. n.3097, p.01-33. 
RAMOS, C.R.; LÁO, V.L.E.S.T.; MARTINHO, F.G.; MACEDO, M.M.D. (1996). Asfalto modificado com polímero. Uma opção para melhoria dos asfaltos nacionais. $13^{\circ}$ Encontro de Asfalto-IBP, p.60-81.

ROBERTS, F.L.; KANDHAL, P.S.; BROWN, E.R.; LEE, D.Y.; KENNEDY, T.W. (1991). Hot mix asphalt materials, mixture design, and construction. 1 ed. Napa Education Foundation. Lanham, Maryland.

ROBERTS, F.L.; LYTTON, R. (1987). FAA mixture design procedure for asphalt-rubber concrete. Transportation Research Record. n.1115, p.216-225.

SÁ, M.F.P.; MOTTA, L.M.G. (1996). Utilização de ensaios de creep estático e dinâmico para caracterização de misturas asfálticas. $13^{\circ}$ Encontro de Asfalto-IBP, p.91-115.

SALTER, R.J.; MAT, J. (1990). Some effects of rubber additives on asphalt mixes. Transportation Research Record. n.1269, p.79-86.

SCHMIDT, R.J. (1972). A practical method for measuring the resilient modulus of asphalt-treated mixes. Highway Research Record. n.404, p.22-32.

SHULER, T.S.; PAVLOVICH, R.D.; EPPS, J.A. (1985). Field performance of rubbermodified asphalt paving materials. Transportation Research Record. n.1034, p.96-102.

SILVEIRA, M.A. (1999). Efeitos da adição de polímero em areia-asfalto a frio. 103p. São Carlos. Dissertação (Mestrado) - Escola de Engenharia de São Carlos, Universidade de São Paulo.

SOSNOVSKE, D.A.; AbWAHAB, Y.; BELL, C.A. (1993). Role of asphalt and aggregate in the aging of bituminous mixtures. Transportation Research Record. n.1386, p.10-21. Washington, D.C.

SOUSA, J.B.; CRAUS, J.; MONISMITH, C.L. (1991). Summary report on permanent deformation in asphalt concrete. Publicação SHRP-A/IR-91-104 do Strategic Highway Research Program. National Research Council. Washington, D.C. 120p.

SOUSA, J.B.; PAIS, J.C.; PRATES, M.; BARROS, R; LANGLOIS, P.; LECLERC, A.M. (1998). Effect of aggregate gradation on fatigue life of asphalt concrete mixes. Transportation Research Record. n.1630. p.62-68.

SOUZA, F.V.; SOARES, J.B. (2002). Previsão do comportamento mecânico de misturas asfálticas a partir dos resultados do ensaio de creep estático. In: ANAIS DA XVI CONGRESSO DE PESQUISA E ENSINO EM TRANSPORTES, 2002. Anais. v.1, p.2941.

SRIVASTAVA, A.; HOPMAN, P.C.; MOLENAAR, A.A.A. (1992). SBS-polymer modified asphal binder and its applications on overlay design. Polymer Modified Asphalt Binders, American Society for Testing and Materials, ASTM STP 1108, p.309329.

STEPHENS, J.E. (1982). Field evaluation of rubber-modified bituminous concrete. Transportation Research Record. n.843, p.11-21. 
TAIRA, C. (2001). Avaliação do desempenho em laboratório de misturas asfálticas densas utilizando asfalto convencional (CAP-20) e asfalto modificado com polímero SBS (BETUFLEX B 65/60). 153p. São Carlos. Dissertação (Mestrado) - Escola de Engenharia de São Carlos, Universidade de São Paulo.

TAKALLOU, H.B.; HICKS, R.G. (1988). Development of improved mix and construction guidelines for rubber-modified asphalt pavements. Transportation Research Record. n.1171, p.113-120.

TANGELLA, S.C.S.R.; CRAUS, J.; DEACON, J.A.; MONISMITH, C.L. (1990). Summary report on fatigue response of asphalt mixtures. Publicação TM-UCB-A003A-89-3, Project A-003-A do Strategic Highway Research Program. Institute of Transportation Studies. University of California. Berkeley, California.

TAYEBALI, A.A.; GOODRICH, J.L.; SOUSA, J.B.; MONISMITH, C.L. (1991). Relationships between modified asphalt binders rheology and binder-aggregate mixture permanent deformation response. Proceedings. AAPT - Association of Asphalt Paving Technologists. v.60, p.121-159.

TAYEBALI, A.A.; GOODRICH, J.L.; SOUSA, J.B.; MONISMITH, C.L. (1992). Influence of rheological properties of modified asphalt binders on the load deformation characteristics of the binder-aggregate. Polymer Modified Asphalt Binders, American Society for Testing and Materials, ASTM STP 1108, p. 77-96.

TONIAL, I.A. (2001). Influência do envelhecimento do revestimento asfáltico na vida de fadiga de pavimentos. 151p. Rio de Janeiro. Dissertação (Mestrado) - Universidade Federal do Rio de Janeiro.

ULMGREN, N. (1996). Functional testing of asphalt mixes for permanent deformation by dynamic creep test - Modification of method and round robin test. EAPA/Eurobitume Congress, Strasbourg 7-10 of May 1996.

VALKERING, C.P.; LANCON, D.J.L.; HILSTER, E.; STOKER, D.A. (1990). Rutting resistance of asphalt mixes containing non-conventional and polymer-modified binders. Symposium - Improved Rut Resistance. Proceedings. AATP - Association of Asphalt Paving Technologists. v.59, p.590-609.

VAN DE LOO, P.J. (1974). Creep testing, a simple tool to judge asphalt mix stability. Association of Asphalt Paving Technologists (AAPT), Proceedings, v.43, p.253-284.

VAN DE LOO, P.J. (1976). Pratical approach to the prediction of rutting in asphalt pavements: The Shell Method. Transportation Research Record 616, p. 15-21.

VAN DE LOO, P.J. (1978). The creep test: a key tool in asphalt mix design and in prediction of pavement rutting. Association of Asphalt Paving Technologists (AAPT), Proceedings, v.47, p.522-557. 
VAN der POEL, C. (1954). A general system describing the visco-elastic properties of bitumens and its relation to routine test data. Journal of Applied Chemistry. v.4, p.221236.

VERHASSELT, A.F.; CROQUET, F.S. (1993). Comparing field and laboratory aging of bitumens on a kinetic basis. Transportation Research Record. n.1391. p.30-38.

VON QUINTUS, H.; SCHEROCMAN, J.; HUGHES, C.; KENNEDY, T. (1991). NCHRP Report 338: Asphalt-aggregate mix analysis system, AAMAS. TRB, National Research Council, Washington, D.C.

WANG, J.C.; WU, C.F.J. (1991). An approach to the construction of asymmetrical orthogonal arrays. Journal of the American Statistical Association, v.86, n.414, p.450-56.

YODER, E.J.; WITCZAK, M.W. (1975). Principles of pavement design. 2.ed., John Wiley \& Sons, Inc. New York.

ZAMAN, A.A.; FRICKE, A.L.; BEATTY, C.L. (1995). Rheological properties of rubber-modified asphalt. Journal Transportation Engineering, ASCE. v.121, n.6, p.461-467.

ZANZOTTO, L.; KENNEPOHL, G.J. (1996). Development of rubber and asphalt binders by depolymerization and devulcanization of scrap tires in asphalt. Transportation Research Record. n.1530, p.51-58. 


\section{APÊNDICE A - Tabelas relativas à montagem do experimento fatorial}

No capítulo 5, os arranjos do experimento fatorial completo $2^{6}$ e do experimento fatorial fracionário $2^{8-2}$ foram parcialmente apresentados nas Tabelas 5.8 e 5.10 , respectivamente, para não prejudicar a visualização do conjunto. Aqui essas tabelas são apresentadas de forma completa.

$\mathrm{O}$ arranjo do experimento fatorial completo $2^{6}$ encontra-se apresentado na Tabela A.1, na qual foram apresentadas as colunas referentes aos efeitos principais dos fatores e as colunas referentes aos efeitos de interação entre dois fatores. Na Tabela A.2 pode ser encontrado o arranjo do experimento fatorial fracionário $2^{8-2}$, onde foram apresentadas apenas as interações entre os fatores $A C$ e $A X 8$, pois os demais efeitos de interação estão acoplados aos efeitos principais dos fatores, confundindo-se com esses.

Em ambas as tabelas as condições experimentais replicadas são destacadas por asteriscos. Por facilidade de representação utilizou-se a notação 12 para indicar o efeito da interação entre os fatores $X 1$ e $X 2,13$ para indicar o efeito da interação entre os fatores $X 1$ e $X 3$, e assim sucessivamente. 
Tabela A.1 - Arranjo do experimento fatorial completo $2^{6}$

\begin{tabular}{|c|c|c|c|c|c|c|c|c|c|c|c|c|c|c|c|c|c|c|}
\hline \multirow{3}{*}{$\begin{array}{l}\text { cond. } \\
\text { exp. }\end{array}$} & \multicolumn{6}{|c|}{ fatores } & \multirow{2}{*}{\multicolumn{12}{|c|}{ interaçōes entre os fatores }} \\
\hline & \multirow{2}{*}{\multicolumn{2}{|c|}{$\frac{(4 \text { niveis) }}{x^{1}}$}} & \multirow{2}{*}{\multicolumn{2}{|c|}{$\frac{(3 \text { níveis) }}{x^{3}}$}} & \multicolumn{2}{|c|}{$\begin{array}{c}\text { C } \\
\text { (3 níveis) }\end{array}$} & & \multirow[b]{2}{*}{34} & & & & & & & & & & \\
\hline & & & & & $\frac{15}{x 5}$ & $\frac{1116}{x 6}$ & 12 & & 56 & 13 & 14 & 134 & 23 & $\begin{array}{l}\text { aca } \\
24\end{array}$ & 234 & 123 & 124 & 1234 \\
\hline 1 & 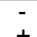 & 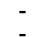 & $\therefore$ & $\therefore$ & _. & 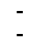 & + & + & + & + & + & 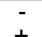 & + & + & $\therefore$ & - & - & + \\
\hline $\begin{array}{l}2 \\
3\end{array}$ & $\begin{array}{lll}+ \\
-\end{array}$ & $i$ & 5 & - & - & - & 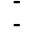 & + & $\begin{array}{l}+ \\
+\end{array}$ & + & + & $\begin{array}{l}+ \\
-\end{array}$ & $\begin{array}{l}+ \\
-\end{array}$ & $\begin{array}{l}+ \\
\text { - }\end{array}$ & t & + & + & - \\
\hline 4 & + & + & 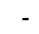 & - & - & - & + & + & + & - & - & + & - & - & + & - & - & + \\
\hline * 5 & & & + & - & - & - & + & - & + & - & + & + & - & + & + & + & - & - \\
\hline${ }_{*}^{*} 6$ & + & - & + & - & - & - & - & - & + & + & - & $\bar{s}$ & 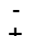 & + & \pm & - & + & + \\
\hline$\div \quad 7$ & + & + & + & - & 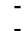 & - & $t$ & - & + & 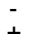 & + & + & + & - & - & - & + & + \\
\hline * 8 & + & + & + & + & - & - & + & - & $\begin{array}{l}+ \\
+\end{array}$ & $\begin{array}{l}\mathrm{T} \\
+\end{array}$ & - & + & $\begin{array}{l}+ \\
+\end{array}$ & - & + & $\stackrel{+}{+}$ & + & - \\
\hline * 10 & + & - & - & + & - & - & - & - & + & - & + & - & + & - & + & + & - & + \\
\hline * 11 & 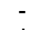 & + & - & + & 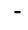 & - & 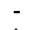 & - & + & + & - & + & - & + & 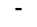 & + & - & + \\
\hline $\begin{array}{c}122 \\
13\end{array}$ & \pm & \pm & $\overline{+}$ & + & - & - & + & $\bar{t}$ & + & - & \pm & $\overline{-}$ & - & \pm & - & $\overline{+}$ & + & $\bar{t}$ \\
\hline 14 & + & - & + & $\begin{array}{l}+ \\
+\end{array}$ & - & - & - & + & + & + & + & + & - & - & - & $\stackrel{+}{-}$ & $\stackrel{+}{-}$ & \pm \\
\hline 15 & 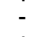 & + & + & + & - & - & - & + & + & - & - & - & + & + & + & - & - & - \\
\hline 16 & + & + & + & + & - & - & + & + & + & + & + & + & + & + & + & + & + & + \\
\hline 17 & 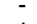 & 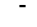 & 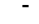 & 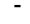 & + & - & + & + & - & + & + & - & + & + & - & & - & + \\
\hline 18 & + & - & - & - & + & - & - & + & - & - & - & + & + & + & - & + & + & - \\
\hline 19 & 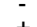 & + & - & - & + & - & - & + & - & + & + & - & - & - & + & + & + & - \\
\hline $\begin{array}{l}20 \\
* 21\end{array}$ & + & \pm & + & - & $\begin{array}{l}+ \\
+\end{array}$ & 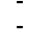 & + & $\stackrel{+}{-}$ & - & - & + & $\begin{array}{l}+ \\
+\end{array}$ & 5 & + & $\begin{array}{l}+ \\
+\end{array}$ & + & - & \pm \\
\hline * 22 & + & - & + & - & + & - & - & - & - & + & - & - & - & + & + & - & + & + \\
\hline $\begin{array}{c}* 23 \\
\end{array}$ & r & + & + & - & + & - & - & - & - & - & + & + & + & - & - & - & + & + \\
\hline * 24 & + & + & + & - & + & - & + & - & - & + & - & - & + & - & - & + & & - \\
\hline * 25 & & & & + & + & - & + & - & - & + & - & + & + & - & + & - & + & - \\
\hline * 26 & + & - & - & + & + & - & - & - & - & - & + & - & + & - & + & + & - & + \\
\hline $\begin{array}{l}* \\
*\end{array}$ & & + & - & + & + & - & & - & - & + & - & + & & + & & + & - & + \\
\hline * 28 & + & + & - & + & + & - & + & - & - & - & + & - & - & + & - & - & + & - \\
\hline 29 & 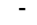 & - & + & + & + & - & + & + & - & - & - & - & - & - & - & + & + & + \\
\hline 30 & + & - & + & + & + & - & & + & - & + & + & + & - & - & - & & - & - \\
\hline 31 & - & + & + & + & + & - & - & + & - & - & - & - & + & + & + & - & - & - \\
\hline 32 & + & + & + & + & + & - & + & + & - & + & + & + & + & + & + & + & + & + \\
\hline 33 & $\bar{t}$ & - & 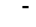 & 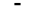 & 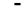 & + & + & + & - & + & + & & + & + & - & - & - & + \\
\hline 34 & + & + & - & - & - & + & 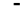 & + & - & - & - & + & + & + & - & + & + & - \\
\hline 35 & + & + & - & 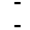 & - & + & 5 & + & - & + & + & $\overline{-}$ & - & - & + & + & + & - \\
\hline $\begin{array}{r}36 \\
\times 37\end{array}$ & & & + & - & 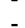 & + & + & + & - & 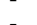 & 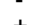 & + & - & - & + & 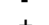 & - & + \\
\hline $\begin{array}{r}* \\
* 38\end{array}$ & + & - & & - & - & $\begin{array}{l}+ \\
+\end{array}$ & \pm & - & $=$ & + & $\stackrel{+}{+}$ & + & - & + & + & $\stackrel{+}{-}$ & - & - \\
\hline * 39 & - & + & & - & - & + & - & - & - & - & + & + & + & - & - & - & + & $\begin{array}{l}+ \\
+\end{array}$ \\
\hline * 40 & + & + & + & - & - & + & + & - & - & + & - & - & + & - & - & + & - & - \\
\hline * 41 & & & & + & - & + & + & - & - & + & - & + & + & - & + & - & + & - \\
\hline * 42 & + & - & - & + & - & + & - & - & - & - & + & - & + & - & + & + & - & + \\
\hline *433 & 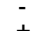 & + & - & + & - & + & - & - & - & + & - & + & - & + & - & + & - & + \\
\hline $\begin{array}{l}44 \\
45\end{array}$ & + & + & + & + & - & + & + & t & - & - & + & - & - & + & - & - & & - \\
\hline $\begin{array}{l}45 \\
46\end{array}$ & + & 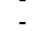 & + & $\begin{array}{l}+ \\
+\end{array}$ & - & $\begin{array}{l}+ \\
+\end{array}$ & \pm & $\begin{array}{l}+ \\
+\end{array}$ & $=$ & + & + & + & $=$ & - & - & $\stackrel{+}{-}$ & $\stackrel{+}{-}$ & $\stackrel{+}{-}$ \\
\hline 47 & 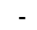 & + & + & + & - & + & - & + & - & - & - & - & + & + & + & - & - & - \\
\hline 48 & + & + & + & + & - & + & + & + & - & + & + & + & + & + & + & + & + & + \\
\hline 49 & - & - & - & - & + & + & + & + & + & + & + & - & + & + & - & - & - & + \\
\hline 50 & + & - & - & - & + & + & & + & + & - & - & + & + & + & - & + & + & - \\
\hline 51 & - & + & - & - & + & + & - & + & + & + & + & - & - & - & + & + & + & - \\
\hline 52 & + & + & - & - & + & + & + & + & + & - & - & + & - & - & + & - & - & + \\
\hline * 53 & & & + & & + & + & + & & + & - & + & + & - & + & + & + & - & - \\
\hline * 54 & + & - & + & - & + & + & & - & + & + & - & - & - & + & + & - & + & + \\
\hline * 55 & & + & + & - & + & + & - & & + & - & + & + & + & - & - & - & + & + \\
\hline * 56 & + & + & + & - & + & + & + & - & + & + & - & - & + & - & - & + & - & - \\
\hline * 57 & & & & + & + & + & $T$ & & $T$ & + & - & + & + & - & & & & - \\
\hline * 58 & + & - & - & + & + & + & - & - & + & - & + & - & + & - & + & + & - & + \\
\hline * 59 & 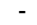 & + & - & + & + & + & - & - & + & + & - & + & - & + & - & + & - & + \\
\hline * 60 & + & + & - & + & + & + & + & - & + & - & + & - & - & + & - & - & + & - \\
\hline 61 & - & & + & + & + & + & + & + & + & - & - & - & - & - & - & + & + & + \\
\hline 62 & + & - & + & + & + & + & & + & + & + & + & + & - & - & - & - & - & - \\
\hline 63 & + & + & + & + & + & + & $\overline{+}$ & + & + & - & - & - & + & + & + & $\bar{z}$ & - & - \\
\hline
\end{tabular}


Tabela A.1 (Continuação) - Arranjo do experimento fatorial completo $2^{6}$

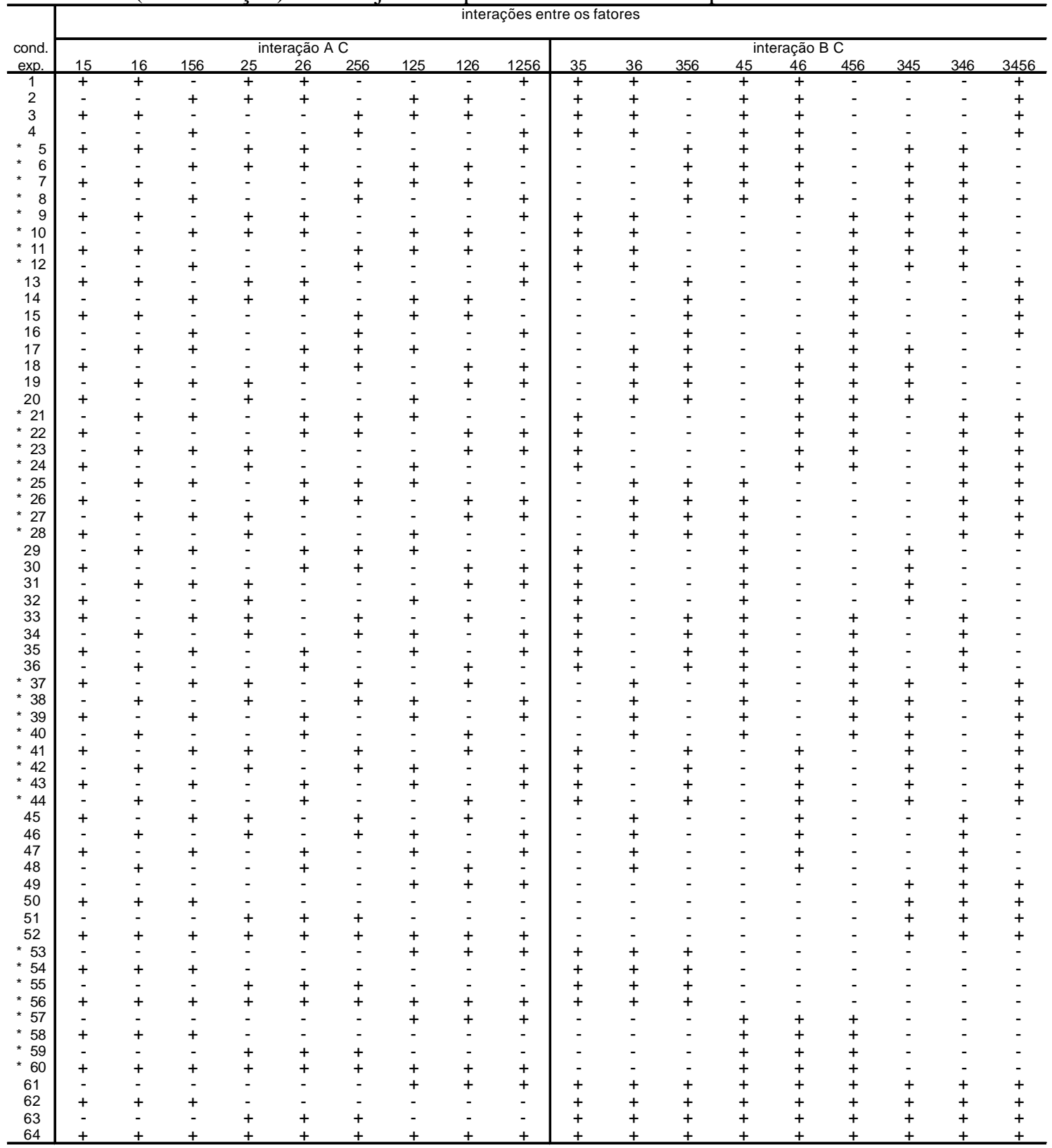


Tabela A.2 - Arranjo do experimento fatorial fracionário $2^{8-2}$

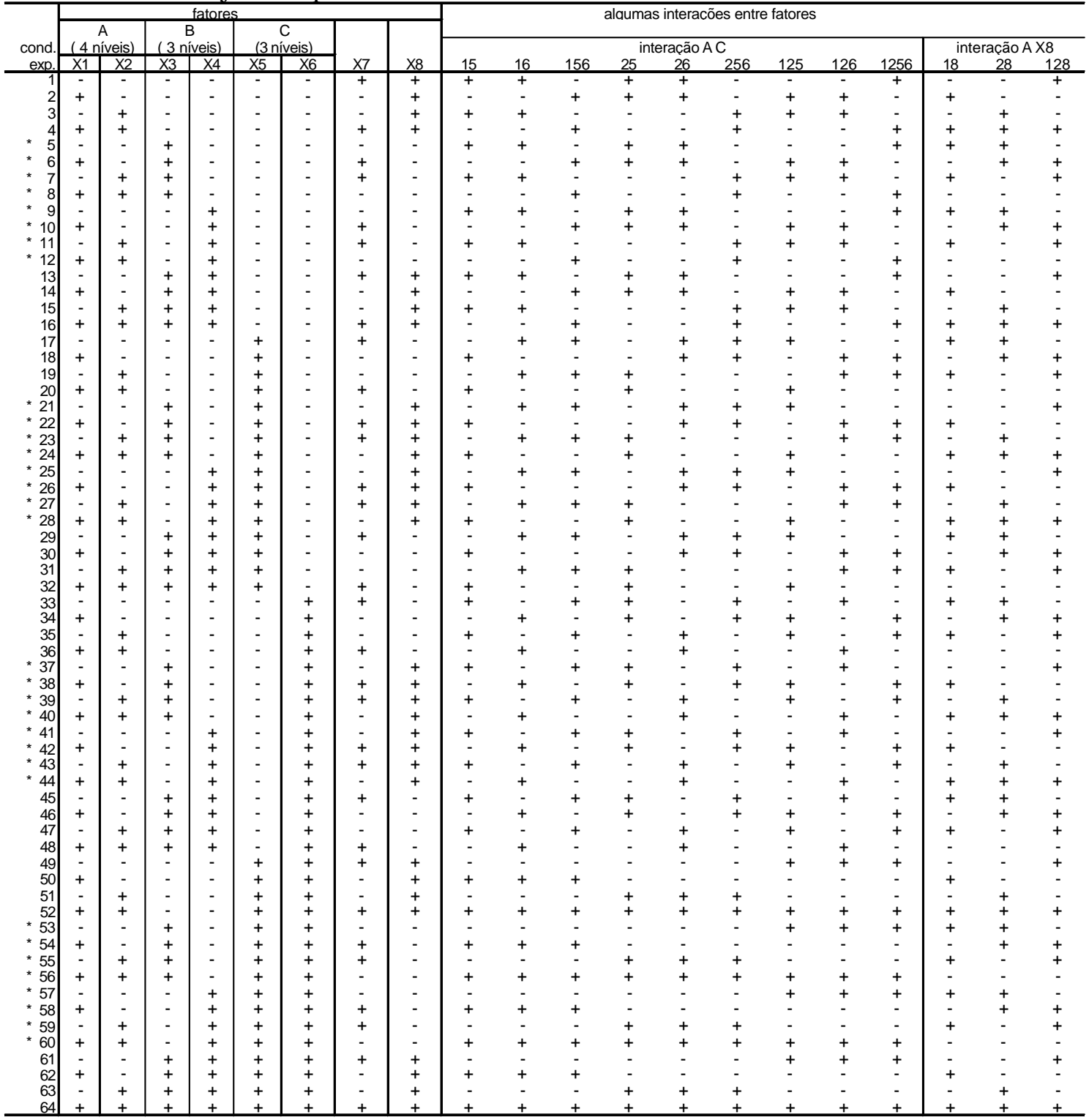




\section{APÊNDICE B - Resultados das dosagens Marshall iniciais}

São apresentadas as planilhas das dosagens Marshall iniciais, realizadas para definição dos teores de ligante utilizados na pesquisa. Apresentam-se também resumos dos resultados obtidos para cada dosagem, bem como os respectivos gráficos de densidade aparente, estabilidade, fluência, volume de vazios e a relação betume vazios (RBV). 
Tabela B.1 - Dados referentes à dosagem Marshall realizada para a mistura composta por asfalto convencional e agregado da faixa B

\begin{tabular}{|c|c|c|c|c|c|c|c|c|c|c|c|c|c|c|c|c|c|c|}
\hline \multicolumn{19}{|c|}{ Planilha de Cálculo do Ensaio Marshall } \\
\hline \multicolumn{19}{|c|}{ asfalto convencional - graduação B } \\
\hline $\mathrm{cp}$ & $\begin{array}{l}\text { lig. } \\
\text { (\%) }\end{array}$ & agreg. & $\begin{array}{l}\text { peso } \\
\text { ao ar } \\
\text { (a) }\end{array}$ & $\begin{array}{l}\text { peso. ar } \\
\text { parafin. } \\
\text { (a) }\end{array}$ & $\begin{array}{l}\text { peso im. } \\
\text { c/ par. } \\
\text { (a) }\end{array}$ & $\begin{array}{l}\text { peso } \\
\text { paraf. } \\
\text { (a) }\end{array}$ & $\begin{array}{c}\text { volume } \\
\text { parf. } \\
\left(\mathrm{cm}^{3}\right)\end{array}$ & $\begin{array}{c}\text { volume } \\
\text { total } \\
\left(\mathrm{cm}^{3}\right)\end{array}$ & $\begin{array}{c}\text { vol. } \\
\mathrm{cp}\end{array}$ & \begin{tabular}{|c|} 
dens. \\
aparente \\
$\left(\mathrm{g} / \mathrm{cm}^{3}\right)$
\end{tabular} & deform & $\begin{array}{l}\text { corr. } \\
\text { da } \\
\text { altura }\end{array}$ & estabil. & $\begin{array}{l}\text { dens. } \\
\text { teórica } \\
\left(\mathrm{a} / \mathrm{cm}^{3}\right)\end{array}$ & fluên. & $\mathrm{Vb}$ & Vv & RBV \\
\hline 1 & 4,0 & 96,0 & 1219,37 & 1273,26 & 726,50 & 53,89 & 58,58 & 546,760 & 488,2 & 2,498 & 31,60 & 1,07 & 15092 & 2,679 & 2,54 & 9,76 & 6,75 & 59,10 \\
\hline 2 & 4,0 & 96,0 & 1223,75 & 1269,11 & 728,40 & 45,36 & 49,30 & 540,710 & 491,4 & 2,490 & 31 & 1,06 & & 2,679 & 2,54 & 9,73 & 7,03 & 58,05 \\
\hline 3 & 4,0 & 96,0 & 1216,05 & 1275,28 & 722,70 & 59,23 & 64,38 & & 488,2 & 2,491 & 32,20 & 1,02 & 14660 & 2,679 & 2,79 & 9,73 & 7,01 & 58,13 \\
\hline 4 & 4,5 & 95,5 & 1225,22 & 127 & 733,60 & 51,81 & 56,32 & 543,430 & 487,1 & 2,515 & 39,60 & 1,07 & & 2,656 & 3,05 & 11,05 & $\overline{5,31}$ & 67,55 \\
\hline 5 & 4,5 & 95,5 & 1227,84 & 1270,63 & 736,30 & 42,79 & 46,51 & 330 & 487,8 & 2,517 & 35,40 & 1,05 & 16591 & 2,656 & 3,30 & 11,06 & 5,24 & 67,84 \\
\hline 6 & 4,5 & 95,5 & 1227,90 & 1270,61 & 735,30 & 42,71 & 46,42 & ,310 & 488,9 & 2,512 & 37,50 & 1,07 & 17910 & 2,656 & 3,30 & 11,04 & 5,45 & 66,96 \\
\hline 7 & 5,0 & 95,0 & 1226,80 & 1264,07 & 738,50 & 37,27 & 40,51 & 525,570 & 485,1 & 2,529 & 40,50 & 1,04 & 18800 & 2,634 & 3,56 & 12,35 & 3,99 & 75,58 \\
\hline 8 & 5,0 & 95,0 & 1224,41 & 1250,98 & 739,00 & 26,57 & 28,88 & & 483,1 & 2,534 & 41,80 & 1,14 & 21270 & 2,634 & 3,81 & 12,38 & 3,79 & 76,56 \\
\hline 9 & 5,0 & 95,0 & 1229,49 & & & 24 & & & 484,4 & 38 & 41,60 & 1,10 & & 2,634 & 3,56 & 12,39 & 3,64 & 77,30 \\
\hline$\overline{10}$ & 5,5 & 94,5 & 122111 & & & 24,4 & 26,57 & & 483,4 & 2,526 & & 1,13 & & 2,613 & 3,81 & 13,57 & 3,31 & 80,38 \\
\hline 11 & 5,5 & 94,5 & 1236,25 & 1260,04 & 744,30 & 23,79 & 25,86 & 740 & 489,9 & 2,524 & 38,50 & 1,10 & 18903 & 2,613 & 4,06 & 13,55 & 3,41 & 79,90 \\
\hline 12 & 5,5 & 94,5 & 1234,27 & 1260,14 & 742,60 & 25,87 & 28,12 & 517,540 & 489,4 & 2,522 & 37,00 & 1,10 & 18167 & 2,613 & 4,06 & 13,55 & 3,47 & 79,59 \\
\hline 13 & 6,0 & 94,0 & 1235,91 & 1261,83 & 740,70 & 25,92 & 28,17 & 521,130 & 493,0 & 2,507 & 28,40 & 1,11 & 14071 & 2,591 & 4,57 & 14,69 & 3,25 & 81,88 \\
\hline 14 & 6,0 & 94,0 & 1230,05 & 1258,31 & 737,20 & 28,26 & 30,72 & 521,110 & 490,4 & 2,508 & 27,40 & 1,10 & & 2,591 & 4,32 & 14,70 & 3,21 & 82,09 \\
\hline 15 & 6,0 & 94,0 & 1228,38 & 1256,68 & 736,10 & 28,30 & 30,76 & 520,580 & 489,8 & 2,508 & 28,50 & 1,10 & 13993 & 2,591 & 4,57 & 14,69 & 3,23 & 82,00 \\
\hline
\end{tabular}

obs: constante do anel $=45,5$; densidade da parafina $=0,92 \mathrm{~g} / \mathrm{cm}^{3}$ 
Tabela B.2 - Dados referentes à dosagem Marshall realizada para a mistura composta por asfalto modificado por 4,5\% do polímero S.B.S. e agregado da faixa $B$

Planilha de Cálculo do Ensaio Marshall

asfalto modificado com 4,5\% do polímero S.B.S. - graduacão B

\begin{tabular}{|c|c|c|c|c|c|c|c|c|c|c|c|c|c|c|c|c|c|c|}
\hline $\mathrm{cp}$ & lig. & agreg. & $\begin{array}{l}\text { peso } \\
\text { ao ar } \\
\text { (g) }\end{array}$ & $\begin{array}{l}\text { peso. ar } \\
\text { parafin. } \\
\text { (g) }\end{array}$ & $\begin{array}{c}\text { peso im } \\
\text { c/ par. } \\
\text { (g) }\end{array}$ & $\begin{array}{c}\text { peso } \\
\text { paraf. } \\
\text { (g) }\end{array}$ & $\begin{array}{l}\text { volume } \\
\text { parf. } \\
\left(\mathrm{cm}^{3}\right)\end{array}$ & $\begin{array}{c}\text { volume } \\
\text { total } \\
\left(\mathrm{cm}^{3}\right)\end{array}$ & $\begin{array}{c}\text { vol. } \\
\mathrm{cp} \\
\left(\mathrm{cm}^{3}\right)\end{array}$ & $\begin{array}{c}\text { dens. } \\
\text { aparente } \\
\left(\mathrm{g} / \mathrm{cm}^{3}\right)\end{array}$ & $\begin{array}{c}\text { deform } \\
\text { do } \\
\text { anel }\end{array}$ & $\begin{array}{c}\text { corr. } \\
\text { da } \\
\text { altura }\end{array}$ & estabil. & $\begin{array}{c}\text { dens. } \\
\text { teórica } \\
\left(\mathrm{g} / \mathrm{cm}^{3}\right)\end{array}$ & fluên. & $\mathrm{Vb}$ & Vv & RBV \\
\hline 1 & 4,0 & 96,0 & 1226,62 & 1248,02 & 731,70 & 21,40 & 23,26 & 516,320 & 493,1 & 2,488 & 32,70 & 1,14 & 16639 & 2,679 & 3,30 & 9,72 & 7,13 & 57,70 \\
\hline 2 & 4,0 & 0 & 36,36 & 2,51 & 0,30 & 16,15 & & & 494,7 & 499 & ,10 & 1,14 & 158 & 679 & ,05 & 9,76 & 69 & 59,34 \\
\hline 3 & 4,0 & 96,0 & 1234,63 & 1256,83 & 737,10 & 22,20 & 24,13 & 19,730 & 495,6 & 2,491 & 31,50 & 1,14 & 16029 & 2,679 & & 9,73 & 7,00 & 58,17 \\
\hline 4 & 4,5 & 95,5 & 1218,98 & 1251,07 & 731,60 & 32,09 & 34,88 & 9,470 & 484,6 & 2,515 & 35,50 & 1,14 & 18064 & 2,656 & 3,56 & 11,05 & $\overline{5,30}$ & 67,59 \\
\hline 5 & 4,5 & 95,5 & 1224,32 & & 734,20 & 27,14 & 29,50 & & 487,8 & & & 1,14 & 18420 & 2,656 & 3,56 & 11,03 & & 66,71 \\
\hline 6 & 4,5 & 95,5 & 123 & & 743,90 & 23,07 & & & 489,6 & &, 70 & 1,14 & 18166 & 2,656 & 3,56 & 11,09 & 5,00 & 68,92 \\
\hline 7 & 5,0 & 95,0 & 1238,24 & 1266,41 & 747,10 & 28,17 & 30,62 & & 488,7 & 2,534 & 39,80 & 1,14 & 20252 & 2,634 & 3,81 & 12,37 & 3,82 & 76,43 \\
\hline 8 & 5,0 & 95,0 & 1227,06 & 1257,59 & 740,20 & 30,53 & 33,18 & 517,390 & 484,2 & 2,534 & 42,20 & 1,14 & 21473 & 2,634 & 3,81 & 12,37 & 3,80 & 76,50 \\
\hline 9 & 5,0 & 95,0 & 1232,47 & 1262,58 & 744,50 & 30,11 & 32,73 & 080 & 485,4 & 2,539 & 39,00 & 1,14 & 19845 & 2,634 & 3,81 & 12,40 & 3,60 & 77,48 \\
\hline 10 & 5,5 & 94,5 & 1236,66 & 1265,81 & 743,30 & 29,15 & 31,68 & 522,510 & 490,8 & 2,520 & 45,90 & 1,14 & 23356 & 2,613 & 4,32 & 13,53 & 3,56 & 79,15 \\
\hline 11 & 5,5 & 94,5 & 1232,44 & 1267,21 & 741,40 & 34,77 & 37,79 & & 488,0 & & 32,20 & 1,14 & 16385 & 2,613 & 4,06 & 13,56 & 3,34 & 80,24 \\
\hline 12 & 5,5 & 94,5 & & & 743,30 & 25,76 & 28,00 & & 490,6 & & & 1,14 & 16334 & 2,613 & 4,06 & 13,53 & 3,56 & 79,16 \\
\hline$\overline{13}$ & 6,0 & $\overline{94,0}$ & 1226,97 & 5,00 & 735,80 & 38,03 & & & 487,9 & 2,515 & & 1,14 & 15520 & 2,591 & 4,06 & $\overline{14,74}$ & 2,95 & 83,33 \\
\hline 14 & 6,0 & 94 & 1228,07 & 8,53 & 736,00 & 30,46 & 33,11 & & 489,4 & 2,509 & & 1,14 & 18166 & 2,591 & 4,57 & 14,70 & 3,17 & 82,26 \\
\hline 15 & 6,0 & 94,0 & 1232,83 & 1264,84 & 738,10 & 32,01 & 34,79 & 526,740 & 491,9 & 2,506 & 31,20 & 1,09 & 15180 & 2,591 & 4,32 & 14,68 & 3,29 & 81,67 \\
\hline
\end{tabular}

obs: constante do anel $=45,5$; densidade da parafina $=0,92 \mathrm{~g} / \mathrm{cm}^{3}$ 
Tabela B.3 - Dados referentes à dosagem Marshall realizada para a mistura composta por asfalto modificado por 20\% de borracha e agregado da faixa B

Planilha de Cálculo do Ensaio Marshall

\begin{tabular}{|c|c|c|c|c|c|c|c|c|c|c|c|c|c|c|c|c|c|c|}
\hline \multicolumn{19}{|c|}{ asfalto modificado com $20 \%$ de borracha - graduação B } \\
\hline $\mathrm{cp}$ & (\%) & (\%) & $\begin{array}{l}\text { peso } \\
\text { ao ar } \\
(\mathrm{g})\end{array}$ & $\begin{array}{c}\text { peso. ar } \\
\text { parafin. } \\
\text { (g) }\end{array}$ & $\begin{array}{c}\text { peso im } \\
\text { c/ par. } \\
\text { (g) }\end{array}$ & $\begin{array}{c}\text { peso } \\
\text { paraf. } \\
(\mathrm{g})\end{array}$ & $\begin{array}{c}\text { volume } \\
\text { parf. } \\
\left(\mathrm{cm}^{3}\right)\end{array}$ & $\begin{array}{c}\text { volume } \\
\text { total } \\
\left(\mathrm{cm}^{3}\right)\end{array}$ & $\begin{array}{c}\text { vol. } \\
\mathrm{cp} \\
\left(\mathrm{cm}^{3}\right)\end{array}$ & $\begin{array}{c}\text { dens. } \\
\text { aparente } \\
\left(\mathrm{g} / \mathrm{cm}^{3}\right)\end{array}$ & $\begin{array}{c}\text { deform } \\
\text { do } \\
\text { anel }\end{array}$ & $\begin{array}{c}\text { corr. } \\
\text { da } \\
\text { altura }\end{array}$ & estabil. & $\begin{array}{l}\text { dens. } \\
\text { teórica } \\
\left(\mathrm{g} / \mathrm{cm}^{3}\right)\end{array}$ & $(\mathrm{mm})$ & (\%) & $(\%)$ & RBV \\
\hline 1 & 4,0 & 96,0 & 1226,49 & 1230,74 & 734,00 & 4,25 & 4,62 & 496,740 & 492,1 & 2,492 & 28,40 & 1,09 & 13817 & 2,678 & 3.05 & 9,75 & 6,94 & 58,43 \\
\hline 2 & 4,0 & 96,0 & 1231,41 & 1240,26 & 738,00 & 8,85 & 9,62 & 502,260 & 492,6 & 2,500 & 27,70 & 1,09 & 13477 & 2,678 & 3,05 & 9,78 & 6,66 & 59,48 \\
\hline 3 & 4,0 & 96,0 & 1222,87 & 1231,60 & 726,50 & 8,73 & 9,49 & 505,100 & 495,6 & 2,467 & 27,20 & 1,04 & 12626 & 2,678 & 3,05 & 9,66 & 7,87 & 55,11 \\
\hline 4 & $\overline{4,5}$ & 95,5 & 1226,97 & 1242,78 & 740,00 & $\overline{15,81}$ & 17,18 & 502,780 & 485,6 & 2,527 & 28,60 & 1,09 & 13915 & 2,656 & 3,56 & 11,13 & 4,86 & 69,62 \\
\hline 5 & 4,5 & 95,5 & 1222,75 & 1242,52 & 737,00 & 19,77 & 21,49 & 505,520 & 484,0 & 2,526 & 29,20 & 1,09 & 14207 & 2,656 & 3,81 & 11,12 & 4,88 & 69,52 \\
\hline 6 & 4,5 & 95,5 & 1221,71 & 1226,20 & 732,00 & 4,49 & 4,88 & 494,200 & 489,3 & 2,497 & 28,80 & 1,09 & 14012 & 2,656 & 3,56 & 10,99 & 5,98 & 64,75 \\
\hline 7 & 5,0 & 95,0 & 1221,64 & 1231,70 & 737,50 & 10,06 & 10,93 & 494,200 & 483,3 & 2,528 & 30,10 & 1,14 & 15316 & 2,634 & 4,32 & 12,37 & 4,02 & 75,49 \\
\hline 8 & 5,0 & 95,0 & 1228,71 & 1256,24 & 742,00 & 27,53 & 29,92 & 514,240 & 484,3 & 2,537 & 30,80 & 1,09 & 14985 & 2,634 & 3,81 & 12,41 & 3,67 & 77,18 \\
\hline 9 & 5,0 & 95,0 & 1233,49 & 1248,78 & 746,00 & 15,29 & 16,62 & 502,780 & 486,2 & 2,537 & 29,20 & 1,09 & 14207 & 2,634 & 3,81 & 12,41 & 3,66 & 77,22 \\
\hline 10 & 5,5 & 94,5 & 1234,63 & 1257,74 & 743,00 & 23,11 & 25,12 & 514,740 & 489,6 & 2,522 & 27,00 & 1,09 & 13136 & 2,612 & $\overline{3,81}$ & 13,57 & 3,46 & 79,69 \\
\hline 11 & 5,5 & 94,5 & 1236,92 & 1254,40 & 746,00 & 17,48 & 19,00 & 508,400 & 489,4 & 2,527 & 25,50 & 1,09 & 12406 & 2,612 & 4,06 & 13,60 & 3,24 & 80,78 \\
\hline 12 & 5,5 & 94,5 & 1232,10 & 1249,18 & 742,00 & 17,08 & 18,57 & 507,180 & 488,6 & 2,522 & 29,40 & 1,09 & 14304 & 2,612 & 4,32 & 13,57 & 3,46 & 79,69 \\
\hline 13 & 6,0 & 94,0 & 1238,49 & $\overline{1250,64}$ & 745,00 & $\overline{12,15}$ & 13,21 & 505,640 & 492,4 & 2,515 & 26,70 & 1,09 & 12990 & 2,591 & 4,57 & 14,77 & 2,92 & 83,50 \\
\hline 14 & 6,0 & 94,0 & 1228,20 & 1234,60 & 733,50 & 6,40 & 6,96 & 501,100 & 494,1 & 2,486 & 25,40 & 1,09 & 12358 & 2,591 & 4,32 & 14,59 & 4,06 & 78,24 \\
\hline 15 & 6,0 & 94,0 & 1229,50 & 1251,77 & 739,00 & 22,27 & 24,21 & 512,770 & 488,6 & 2,517 & 22,50 & 1,09 & 10947 & 2,591 & 4,57 & 14,77 & 2,86 & 83,79 \\
\hline
\end{tabular}

obs: constante do anel $=45,5$; densidade da parafina $=0,92 \mathrm{~g} / \mathrm{cm}^{3}$ 
Tabela B.4 - Dados referentes à dosagem Marshall realizada para a mistura composta por asfalto convencional e agregado da faixa C

\begin{tabular}{|c|c|c|c|c|c|c|c|c|c|c|c|c|c|c|c|c|c|c|}
\hline \multicolumn{19}{|c|}{ Planilha de Cálculo do Ensaio Marshall } \\
\hline \multicolumn{19}{|c|}{ asfalto convencional - graduação C } \\
\hline $\mathrm{cp}$ & & & $\begin{array}{l}\text { peso } \\
\text { ao ar }\end{array}$ & $\begin{array}{l}\text { peso. ar } \\
\text { parafin. }\end{array}$ & $\begin{array}{l}\text { peso im. } \\
\text { c/ par. }\end{array}$ & $\begin{array}{l}\text { peso } \\
\text { paraf. }\end{array}$ & $\begin{array}{c}\text { volume } \\
\text { parf. }\end{array}$ & $\begin{array}{c}\text { volume } \\
\text { total }\end{array}$ & $\begin{array}{c}\text { vol. } \\
\mathrm{cp}\end{array}$ & $\begin{array}{c}\text { dens. } \\
\text { aparente }\end{array}$ & $\begin{array}{c}\text { deform } \\
\text { do }\end{array}$ & $\begin{array}{c}\text { corr. } \\
\text { da }\end{array}$ & estabil. & $\begin{array}{l}\text { dens. } \\
\text { teórica }\end{array}$ & fluên. & $\mathrm{Vb}$ & Vv & RBV \\
\hline & $(\%)$ & (\%) & (g) & (g) & (g) & (g) & $\left(\mathrm{cm}^{3}\right)$ & $\left(\mathrm{cm}^{3}\right)$ & $\left(\mathrm{cm}^{3}\right)$ & $\left(\mathrm{g} / \mathrm{cm}^{3}\right)$ & anel & altura & $(\mathrm{N})$ & $\left(\mathrm{g} / \mathrm{cm}^{3}\right)$ & $(\mathrm{mm})$ & $(\%)$ & $(\%)$ & (\%) \\
\hline 1 & 4,5 & 95,5 & 1228,93 & 1257,57 & 733,20 & 28,64 & 31,13 & 524,37 & 493,2 & 2,492 & 36,50 & 1,06 & 17269 & 2,656 & 3,05 & 10,95 & 6,20 & 63,84 \\
\hline 2 & 4,5 & 95,5 & 1227,26 & 1262,18 & 732,20 & 34,92 & 37,96 & 529,98 & 492,0 & 2,494 & 33,00 & 1,05 & 15466 & 2,656 & 3,05 & 10,96 & 6,10 & 64,26 \\
\hline 3 & 4,5 & 95,5 & 1224,93 & 1254,08 & 729,30 & 29,15 & 31,68 & 524,78 & 493,1 & 2,484 & 34,40 & 1,07 & 16429 & 2,656 & 3,05 & 10,92 & 6,48 & 62,75 \\
\hline 4 & $\overline{5,0}$ & 95,0 & 1235,30 & 1260,14 & 739,90 & 24,84 & 27,00 & 520,24 & 493,2 & 2,504 & 37,80 & 1,05 & 17716 & 2,634 & 3,30 & 12,23 & 4,93 & 71,27 \\
\hline 5 & 5,0 & 95,0 & 1245,83 & 1267,68 & 741,80 & 21,85 & 23,75 & 525,88 & 502,1 & 2,481 & 39,20 & 1,05 & 18372 & 2,634 & 3,30 & 12,11 & 5,82 & 67,56 \\
\hline 6 & 5,0 & 95,0 & 1234,32 & 1265,30 & 738,80 & 30,98 & 33,67 & 526,50 & 492,8 & 2,505 & 38,20 & 1,05 & 17903 & 2,634 & 3,05 & 12,23 & 4,92 & 71,29 \\
\hline 7 & 5,5 & 94,5 & 1236,85 & 1273,33 & 741,00 & 36,48 & 39,65 & 532,33 & 492,7 & 2,510 & 41,20 & 1,05 & 19309 & 2,613 & 3,56 & 13,48 & 3,91 & 77,51 \\
\hline 8 & 5,5 & 94,5 & 1237,52 & 1269,03 & 741,70 & 31,51 & 34,25 & 527,33 & 493,1 & 2,510 & 45,00 & 1,05 & 21090 & 2,613 & 3,56 & 13,48 & 3,94 & 77,39 \\
\hline 9 & 5,5 & 94,5 & 1237,00 & 1270,60 & 740,40 & 33,60 & 36,52 & 530,20 & 493,7 & 2,506 & 42,80 & 1,05 & 20059 & 2,613 & 3,81 & 13,46 & 4,10 & 76,67 \\
\hline 10 & 6,0 & 94,0 & 1242,31 & 1273,91 & 743,00 & 31,60 & 34,35 & 530,91 & 496,6 & 2,502 & 31,50 & 1,06 & 14904 & 2,591 & 3,81 & 14,66 & 3,46 & 80,92 \\
\hline 11 & 6,0 & 94,0 & 1234,44 & 1272,21 & 737,00 & 37,77 & 41,05 & 535,21 & 494,2 & 2,498 & 31,70 & 1,05 & 14857 & 2,591 & 3,81 & 14,64 & 3,60 & 80,25 \\
\hline 12 & 6,0 & 94,0 & 1244,97 & 1282,97 & 743,20 & 38,00 & 41,30 & 539,77 & 498,5 & 2,498 & 32,70 & 1,06 & 15472 & 2,591 & 4,06 & 14,63 & 3,62 & 80,17 \\
\hline 13 & 6,5 & 93,5 & 1243,48 & 1273,09 & 741,60 & 29,61 & 32,18 & 531,49 & 499,3 & 2,490 & 28,00 & 1,07 & 13373 & 2,570 & 4,06 & 15,81 & 3,11 & 83,54 \\
\hline 14 & 6,5 & 93,5 & 1237,29 & 1278,51 & 737,60 & 41,22 & 44,80 & 540,91 & 496,1 & 2,494 & 26,60 & 1,05 & 12467 & 2,570 & 4,32 & 15,83 & 2,97 & 84,18 \\
\hline 15 & 6,5 & 93,5 & 1248,70 & 1285,13 & 744,50 & 36,43 & 39,60 & 540,63 & 501,0 & 2,492 & 29,30 & 1,05 & 13732 & 2,570 & 4,32 & 15,82 & 3,04 & 83,87 \\
\hline
\end{tabular}

obs: constante do anel $=45,5$; densidade da parafina $=0,92 \mathrm{~g} / \mathrm{cm}^{3}$ 
Tabela B.5 - Dados referentes à dosagem Marshall realizada para a mistura composta por asfalto modificado por 4,5\% do polímero S.B.S. e agregado da faixa $\mathrm{C}$

Planilha de Cálculo do Ensaio Marshall

asfalto modificado com $4,5 \%$ do polímero S.B.S. - graduação C

\begin{tabular}{|c|c|c|c|c|c|c|c|c|c|c|c|c|c|c|c|c|c|c|}
\hline $\mathrm{cp}$ & lig. & agreg & $\begin{array}{l}\text { peso } \\
\text { ao ar } \\
\text { (g) }\end{array}$ & $\begin{array}{l}\text { peso. ar } \\
\text { parafin. } \\
\text { (g) }\end{array}$ & $\begin{array}{c}\text { peso im. } \\
\text { c/ par. } \\
\text { (g) }\end{array}$ & $\begin{array}{c}\text { peso } \\
\text { paraf. } \\
\text { (g) }\end{array}$ & $\begin{array}{l}\text { volume } \\
\text { parf. } \\
\left(\mathrm{cm}^{3}\right)\end{array}$ & $\begin{array}{c}\text { volume } \\
\text { total } \\
\left(\mathrm{cm}^{3}\right)\end{array}$ & $\begin{array}{c}\text { vol. } \\
\mathrm{cp} \\
\left(\mathrm{cm}^{3}\right)\end{array}$ & $\begin{array}{c}\text { dens. } \\
\text { aparente } \\
\left(\mathrm{g} / \mathrm{cm}^{3}\right)\end{array}$ & $\begin{array}{c}\text { deform } \\
\text { do } \\
\text { anel }\end{array}$ & $\begin{array}{l}\text { corr. } \\
\text { da } \\
\text { altura }\end{array}$ & estabil. & $\begin{array}{c}\text { dens. } \\
\text { teórica } \\
\left(\mathrm{g} / \mathrm{cm}^{3}\right)\end{array}$ & fluên. & (\%) & (\%) & RBV \\
\hline 1 & 4,5 & 95,5 & 1223,03 & 1235,88 & 730,90 & 12,85 & 13,97 & 504,98 & 491,0 & 2,491 & 31,90 & 1,09 & 15520 & 2,656 & 3,30 & 10,95 & 6,23 & 63,73 \\
\hline 2 & 4,5 & 95,5 & 1247,41 & 54,78 & 745,95 & 7,37 & 01 & 508,83 & 500,8 & 2,491 & 32,20 & 1,04 & 14948 & 2,656 & 3,56 & 10,95 & 6,23 & 63,72 \\
\hline 3 & 4,5 & 95,5 & 1238,74 & 1250,02 & 738,90 & 11,28 & 12,26 & 511,12 & 498,9 & 2,483 & 30,70 & 1,04 & 14251 & 2,656 & 3,81 & 10,91 & 6,52 & 62,61 \\
\hline 4 & 5,0 & $\overline{95,0}$ & 1240,72 & 1260,30 & 742,10 & 19,58 & 21,28 & 518,20 & 496,9 & 2,497 & 32,20 & 1,04 & 14948 & 2,634 & 3,81 & 12,19 & 5,22 & 70,03 \\
\hline 5 & 5,0 & 95,0 & 1237,23 & 1256,09 & 740,30 & 18,86 & 20,50 & & 495,3 & 2,498 & 37,80 & 1,09 & 18391 & 2,634 & 3,56 & 12,20 & 5,17 & 70,21 \\
\hline 6 & 5,0 & 95,0 & 1234,77 & & 738,70 & 24,30 & 26,41 & 520,37 & 494,0 & 2,500 & 39,30 & 1,09 & 19121 & 2,634 & 3,81 & 12,21 & 5,11 & 70,50 \\
\hline 7 & 5,5 & 94,5 & 1237,49 & 1264,23 & 743,90 & 26,74 & 29,07 & 520,33 & 491,3 & 2,519 & 45,00 & 1,09 & 21894 & 2,613 & 4,06 & 13,53 & 3,59 & 79,05 \\
\hline 8 & 5,5 & 94,5 & 1234,39 & 1257,01 & 739,90 & 22,62 & 24,59 & 517,11 & 492,5 & 2,506 & 44,70 & 1,09 & 21748 & 2,613 & 3,81 & 13,46 & 4,07 & 76,77 \\
\hline 9 & 5,5 & 94,5 & 1241,16 & 1262,47 & 744,00 & 21,31 & 23,16 & 518,47 & 495,3 & 2,506 & 43,00 & 1,09 & 20921 & 2,613 & 4,06 & 13,46 & 4,09 & 76,70 \\
\hline 10 & 6,0 & 94,0 & 1237,76 & 1256,41 & 741,20 & 18,65 & 20,27 & 515,21 & 494,9 & 2,501 & 41,60 & 1,09 & 20240 & 2,591 & 3,81 & 14,65 & 3,49 & 80,74 \\
\hline 11 & 6,0 & 94,0 & 1242,82 & 1269,60 & 744,80 & 26,78 & 29,11 & 524,80 & 495,7 & 2,507 & 41,40 & 1,04 & 19218 & 2,591 & 4,57 & 14,69 & 3,25 & 81,90 \\
\hline 12 & 6,0 & 94,0 & 1240,97 & & 744,00 & 22,10 & 24,02 & 519,07 & 495,0 & 2,507 & 41,60 & 1,09 & 20240 & 2,591 & 4,32 & 14,69 & 3,27 & 81,81 \\
\hline$\overline{13}$ & 6,5 & 93,5 & 1235,91 & & 738,10 & 29,23 & 31,77 & 527,04 & $\overline{495,3}$ & 2,495 & $\overline{31, \varepsilon}$ & 1,09 & 15472 & 2,570 & 5,08 & $\overline{15,84}$ & 2,92 & 84,44 \\
\hline 14 & 6,5 & 93,5 & 1226,70 & 1255,68 & 732,90 & 28,98 & 31,50 & 522,78 & 491,3 & 2,497 & 32 & 1,09 & 15763 & 2,570 & 5,08 & 15,85 & 2,86 & 84,71 \\
\hline 15 & 6,5 & 93,5 & 1236,72 & 1264,12 & 740,40 & 27,40 & 29,78 & 523,72 & 493,9 & 2,504 & 36,00 & 1,09 & 17515 & 2,570 & 5,08 & $15,8 s$ & 2,59 & 85,97 \\
\hline
\end{tabular}

obs: constante do anel $=45,5$; densidade da parafina $=0,92 \mathrm{~g} / \mathrm{cm}^{3}$ 
Tabela B.6 - Dados referentes à dosagem Marshall realizada para a mistura composta por asfalto modificado por 20\% de borracha e agregado da faixa $\mathrm{C}$

Planilha de Cálculo do Ensaio Marshall

asfalto modificado com $20 \%$ de borracha - graduacão C

\begin{tabular}{|c|c|c|c|c|c|c|c|c|c|c|c|c|c|c|c|c|c|c|}
\hline $\mathrm{cp}$ & (\%) & agreg & $\begin{array}{l}\text { peso } \\
\text { ao ar } \\
\text { (g) }\end{array}$ & $\begin{array}{l}\text { peso. ar } \\
\text { parafin. } \\
\text { (g) }\end{array}$ & $\begin{array}{c}\text { peso im. } \\
\text { c/ par. } \\
\text { (g) }\end{array}$ & $\begin{array}{c}\text { peso } \\
\text { paraf. } \\
\text { (g) }\end{array}$ & $\begin{array}{l}\text { volume } \\
\text { parf. } \\
\left(\mathrm{cm}^{3}\right)\end{array}$ & $\begin{array}{c}\text { volume } \\
\text { total } \\
\left(\mathrm{cm}^{3}\right)\end{array}$ & $\begin{array}{c}\text { vol. } \\
\mathrm{cp} \\
\left(\mathrm{cm}^{3}\right)\end{array}$ & $\begin{array}{l}\text { dens. } \\
\text { aparente } \\
\left(\mathrm{g} / \mathrm{cm}^{3}\right)\end{array}$ & $\begin{array}{c}\text { deform } \\
\text { do } \\
\text { anel }\end{array}$ & $\begin{array}{c}\text { corr. } \\
\text { da } \\
\text { altura }\end{array}$ & estabil. & $\begin{array}{c}\text { dens. } \\
\text { teórica } \\
\left(\mathrm{g} / \mathrm{cm}^{3}\right)\end{array}$ & $(\mathrm{mm})$ & (\%) & (\%) & $(\%)$ \\
\hline 1 & 4,5 & 95,5 & 1231,02 & 1237,34 & 732,50 & 6,32 & 6,87 & 504,84 & 498,0 & 2,472 & 22,80 & $\begin{array}{ll}1,04 \\
\end{array}$ & 10584 & 2,656 & 3,05 & 10,88 & 6,91 & 61,16 \\
\hline 2 & 4,5 & 95,5 & 20,1 & & 724,00 & 8,89 & 9 & & 495,4 & 463 & 25,60 & 1,09 & 124 & 656 & 3,05 & 10,84 & 7,25 & 59,92 \\
\hline 3 & 4,5 & 95,5 & 1229,82 & 68 & 733,00 & 6,86 & 7,46 & 503,68 & 496,2 & 2,478 & 23,50 & 1,04 & 10909 & 2,656 & 3,56 & 0,91 & 6,68 & 62,04 \\
\hline 4 & $\overline{5,0}$ & $\overline{95,0}$ & 1229,06 & 1240,34 & 736,50 & 1,28 & 12,26 & 503,84 & 491,6 & & & 1,09 & 14401 & 634 & 3,56 & 12,23 & 5,07 & $\overline{70,72}$ \\
\hline 5 & 5,0 & 95,0 & 1223,20 & 1234,96 & 732,50 & 11,76 & 12,78 & & 489,7 & 2,498 & 30,30 & 1,09 & 14742 & 2,634 & 3,30 & 12,22 & 5,15 & 70,35 \\
\hline 6 & 5,0 & 95,0 & 1225,38 & 1242,13 & 732,00 & 16,75 & 18,21 & 510,13 & 491,9 & 2,491 & 28,10 & 1,09 & 13671 & 2,634 & 3,56 & 12,19 & 5,42 & 69,23 \\
\hline 7 & 5,5 & 94,5 & 1234,47 & 1249,20 & 741,00 & 14,73 & 16,01 & & 492,2 & 2,508 & 31,10 & 1,09 & 15131 & 2,612 & 3,81 & 13,50 & 3,98 & 77,25 \\
\hline 8 & 5,5 & 94,5 &, 25 & & & & 16,17 & & 491,0 & & & 1,09 & & 2,612 & 3,81 & 13,49 & 4,06 & 76,85 \\
\hline 9 & 5,5 & 94,5 & 1238,10 & & 742,50 & 15,20 & 16,52 & & 494,3 & 2,505 & 32,00 & 1,09 & 15569 & 2,612 & 4,06 & 13,48 & 4,10 & 76,68 \\
\hline 10 & $\overline{6,0}$ & $\overline{94,0}$ & 1238,01 & 1248,25 & 740,50 & 10,24 & 11,13 & 507,75 & 496,6 & 2,493 & 25,60 & 1,04 & 11884 & 2,591 & 4,32 & 14,64 & 3,77 & $\overline{79,50}$ \\
\hline 11 & 6,0 & 94,0 & 1243,59 & 1255,06 & 743,50 & 11,47 & 12,47 & 511,56 & 499,1 & 2,492 & 26,30 & 1,04 & 12209 & 2,591 & 4,32 & 14,63 & 3,82 & 79,30 \\
\hline 12 & 6,0 & 94,0 & 1240,65 & 1252,10 & 741,00 & 11,45 & 12,45 & & 498,7 & 2,488 & 24,10 & 1,04 & 11187 & 2,591 & 4,32 & 14,61 & 3,96 & 78,66 \\
\hline 13 & 6,5 & $\overline{93,5}$ & 1239,59 & 1252,70 & 738,00 & $\overline{13,11}$ & 14,25 & & 500,5 & 2,477 & 19,70 & 1,04 & 9145 & 2,570 & 4,57 & 15,75 & 3,61 & 81,37 \\
\hline 14 & 6,5 & 93,5 & 1238,23 & & 737,50 & & 14,51 & & 499,6 & 2,479 & 19,20 & 1,04 & 3 & 2,570 & 4,57 & 15,76 & 3,54 & 81,65 \\
\hline 15 & 6,5 & 93,5 & 1244,13 & 1255,45 & 738,50 & 11,32 & 12,30 & & 504,6 & 2,465 & 19 & 1,04 & 9052 & 2,570 & 4,57 & 15,68 & 4,06 & 79,44 \\
\hline
\end{tabular}

obs: constante do anel $=45,5$; densidade da parafina $=0,92 \mathrm{~g} / \mathrm{cm}^{3}$ 
Tabela B7 - Resumo da dosagem Marshall para a graduação B; asfalto convencional

\begin{tabular}{ccccccc}
\hline teor & $\begin{array}{c}\text { Dap } \\
(\%)\end{array}$ & $\begin{array}{c}\mathrm{E} \\
\left(\mathrm{g} / \mathrm{cm}^{3}\right)\end{array}$ & $\begin{array}{c}\mathrm{F} \\
(\mathrm{N})\end{array}$ & $\begin{array}{c}\mathrm{Vv} \\
(\mathrm{mm})\end{array}$ & $\begin{array}{c}\text { RBV } \\
(\%)\end{array}$ & $\begin{array}{c}\text { VAM } \\
(\%)\end{array}$ \\
\hline 4,0 & 2,493 & 14901 & 2,6 & 6,93 & 58 & 16,67 \\
4,5 & 2,515 & 17805 & 3,2 & 5,33 & 67 & 16,38 \\
5,0 & 2,534 & 20165 & 3,6 & 3,81 & 76 & 16,18 \\
5,5 & 2,524 & 18863 & 4,0 & 3,40 & 80 & 16,95 \\
6,0 & 2,508 & 13839 & 4,5 & 3,23 & 82 & 17,92 \\
\hline
\end{tabular}
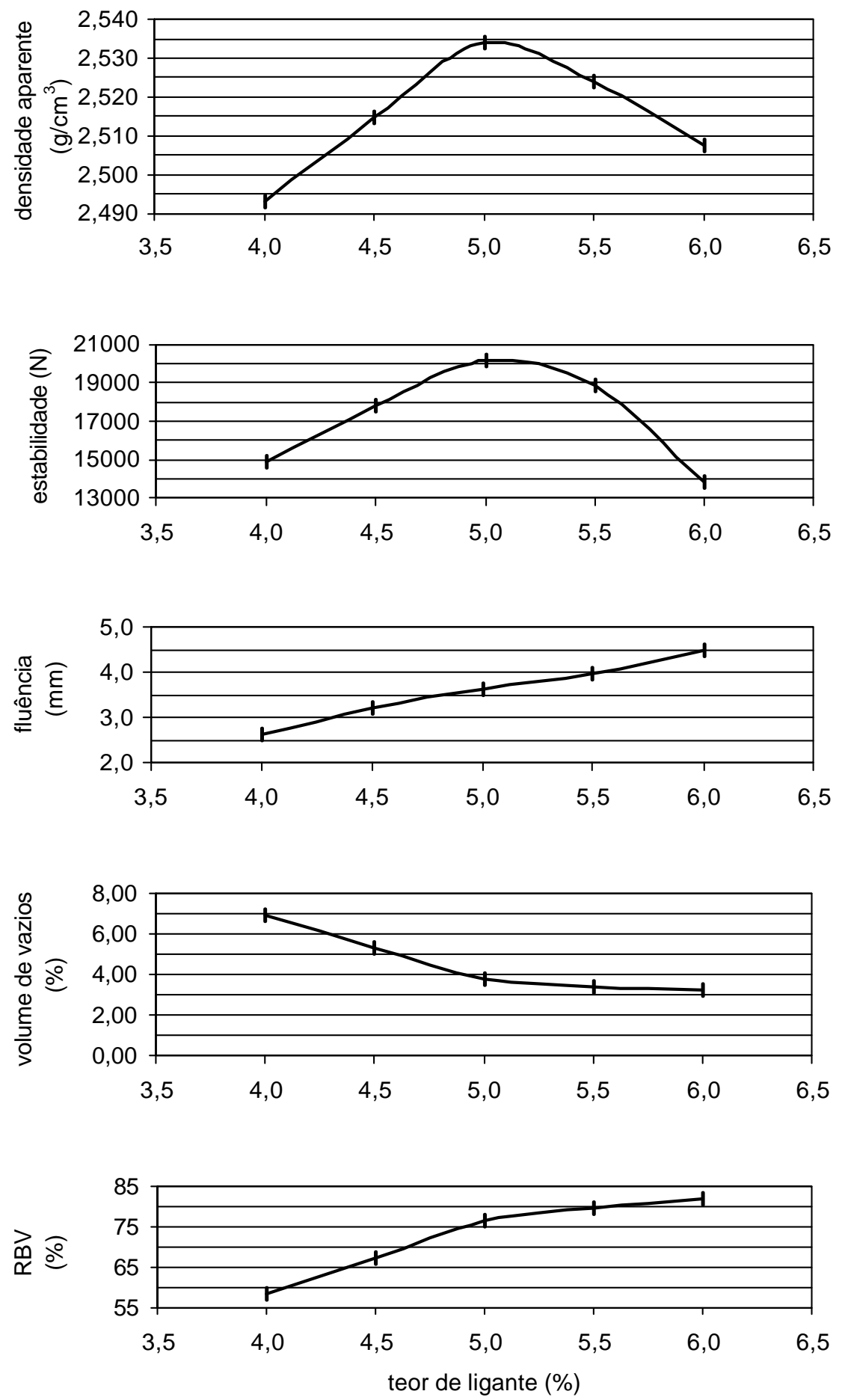


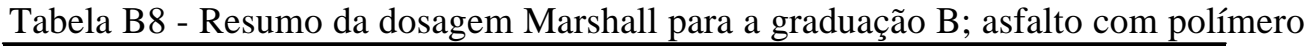

\begin{tabular}{ccccccc}
\hline $\begin{array}{c}\text { teor } \\
(\%)\end{array}$ & $\begin{array}{c}\text { Dap } \\
\left(\mathrm{g} / \mathrm{cm}^{3}\right)\end{array}$ & $\begin{array}{c}\mathrm{E} \\
(\mathrm{N})\end{array}$ & $\begin{array}{c}\mathrm{F} \\
(\mathrm{mm})\end{array}$ & $\begin{array}{c}\text { Vv } \\
(\%)\end{array}$ & $\begin{array}{c}\text { RBV } \\
(\%)\end{array}$ & $\begin{array}{c}\text { VAM } \\
(\%)\end{array}$ \\
\hline 4,0 & 2,493 & 16164 & 3,2 & 6,94 & 58 & 16,68 \\
4,5 & 2,516 & 18217 & 3,6 & 5,27 & 68 & 16,33 \\
5,0 & 2,536 & 20523 & 3,8 & 3,74 & 77 & 16,12 \\
5,5 & 2,522 & 18692 & 4,1 & 3,49 & 80 & 17,03 \\
6,0 & 2,510 & 16288 & 4,3 & 3,14 & 82 & 17,85 \\
\hline
\end{tabular}
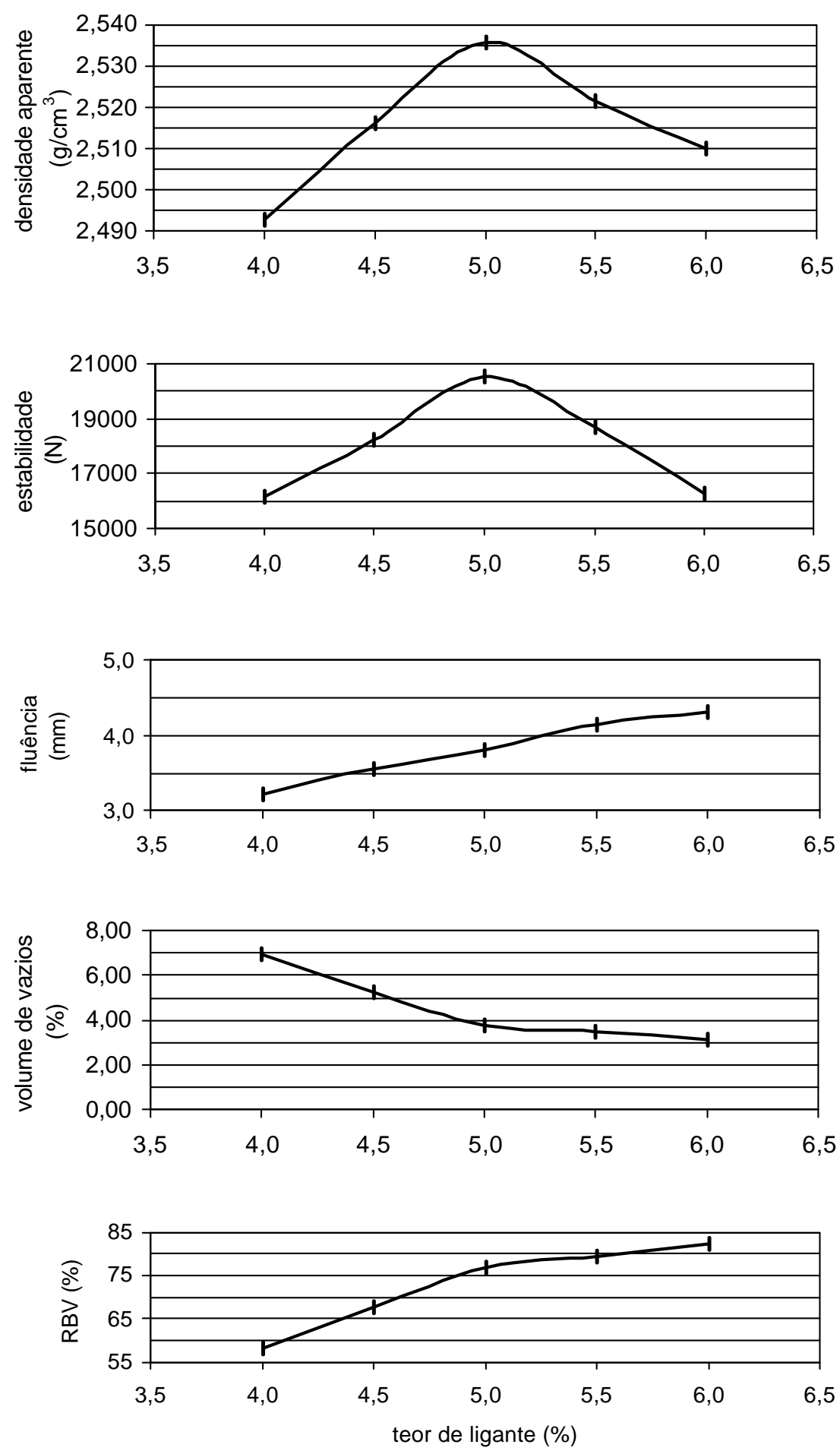
Tabela B9 - Resumo da dosagem Marshall para a graduação B; asfalto com borracha

\begin{tabular}{ccccccc}
\hline teor & $\begin{array}{c}\text { Dap } \\
(\%)\end{array}$ & $\begin{array}{c}\mathrm{E} \\
\left(\mathrm{g} / \mathrm{cm}^{3}\right)\end{array}$ & $\begin{array}{c}\mathrm{F} \\
(\mathrm{N})\end{array}$ & $\begin{array}{c}\text { Vv } \\
(\mathrm{mm})\end{array}$ & $\begin{array}{c}\text { RBV } \\
(\%)\end{array}$ & $\begin{array}{c}\text { VAM } \\
(\%)\end{array}$ \\
\hline 4,0 & 2,486 & 13307 & 3,1 & 7,16 & 58 & 16,89 \\
4,5 & 2,517 & 14044 & 3,6 & 5,24 & 68 & 16,32 \\
5,0 & 2,534 & 14836 & 4,0 & 3,78 & 77 & 16,18 \\
5,5 & 2,524 & 13282 & 4,1 & 3,38 & 80 & 16,97 \\
6,0 & 2,506 & 12098 & 4,5 & 3,28 & 82 & 17,99 \\
\hline
\end{tabular}
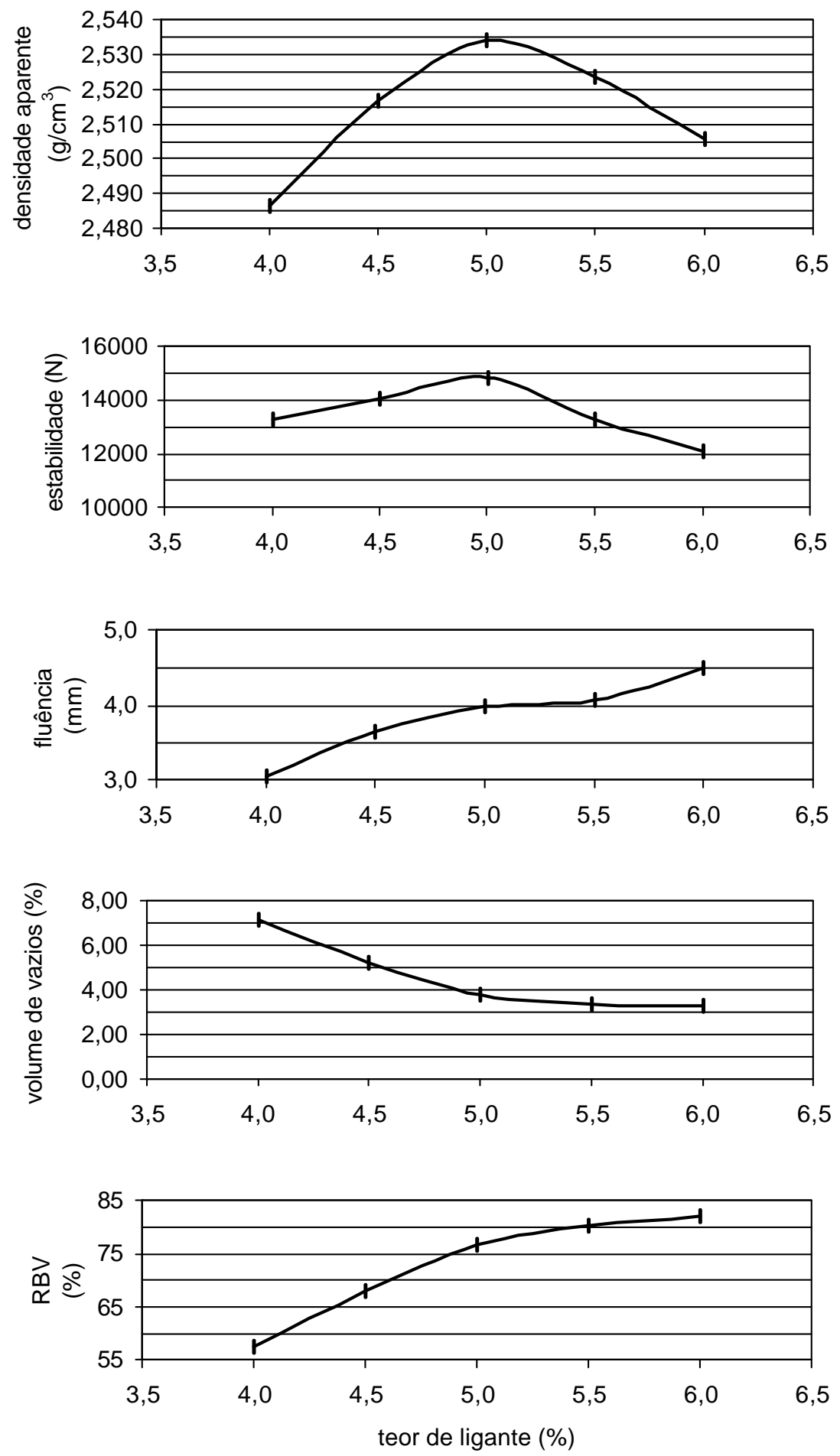
Tabela B10 - Resumo da dosagem Marshall para a graduação C; asfalto convencional

\begin{tabular}{ccccccc}
\hline teor & Dap & $\mathrm{E}$ & $\mathrm{F}$ & $\mathrm{Vv}$ & $\mathrm{RBV}$ & $\mathrm{VAM}$ \\
$(\%)$ & $\left(\mathrm{g} / \mathrm{cm}^{3}\right)$ & $(\mathrm{N})$ & $(\mathrm{mm})$ & $(\%)$ & $(\%)$ & $(\%)$ \\
\hline 4,5 & 2,490 & 16388 & 3,1 & 6,26 & 63,6 & 17,20 \\
5,0 & 2,497 & 17997 & 3,2 & 5,22 & 70,0 & 17,41 \\
5,5 & 2,509 & 20153 & 3,6 & 3,98 & 77,2 & 17,46 \\
6,0 & 2,499 & 15077 & 3,9 & 3,56 & 80,4 & 18,20 \\
6,5 & 2,492 & 13191 & 4,2 & 3,04 & 83,9 & 18,86 \\
\hline
\end{tabular}
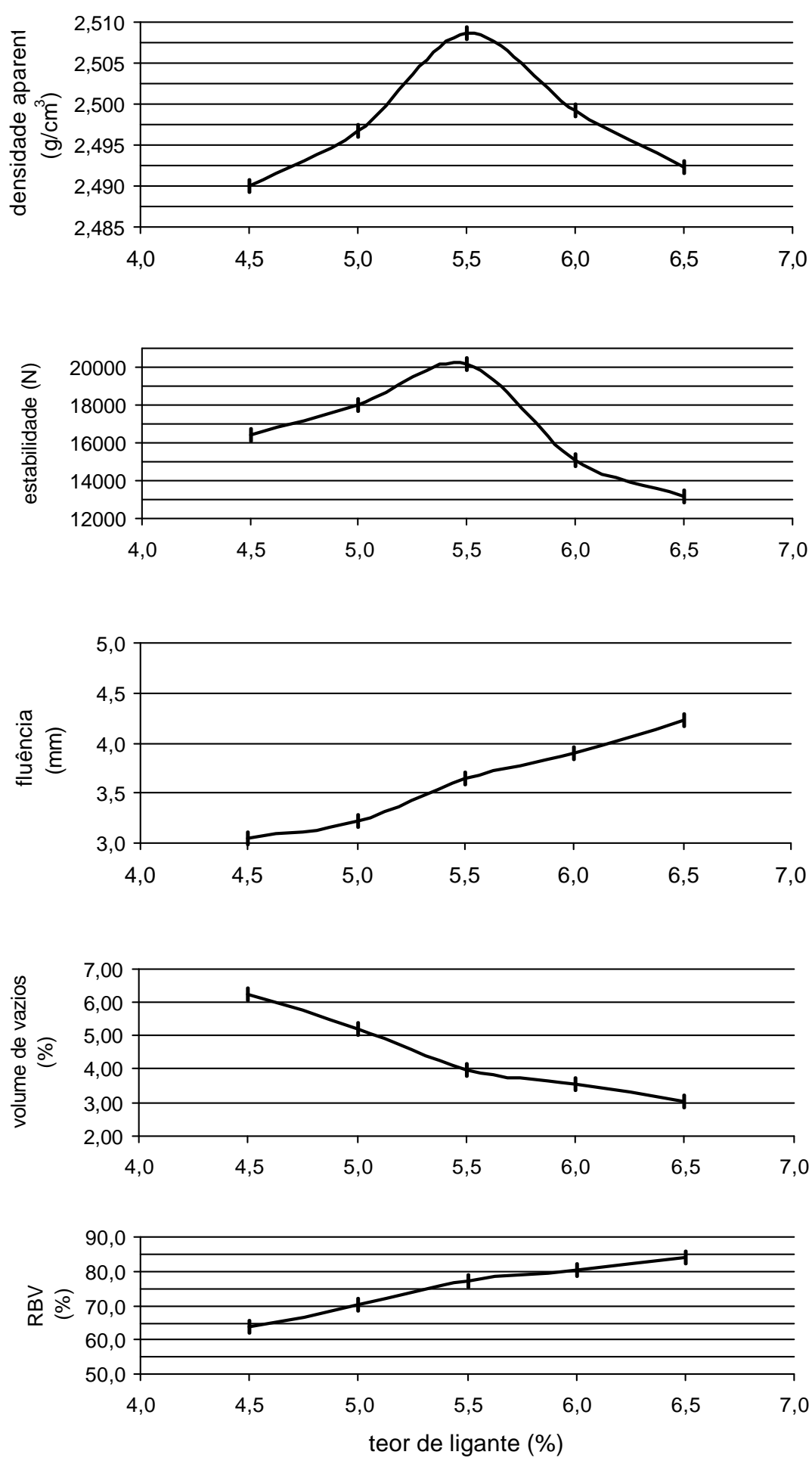
Tabela B11 - Resumo da dosagem Marshall para a graduação C; asfalto com polímero

\begin{tabular}{ccccccc}
\hline $\begin{array}{c}\text { teor } \\
(\%)\end{array}$ & $\begin{array}{c}\text { Dap } \\
\left(\mathrm{g} / \mathrm{cm}^{3}\right)\end{array}$ & $\begin{array}{c}\mathrm{E} \\
(\mathrm{N})\end{array}$ & $\begin{array}{c}\mathrm{F} \\
(\mathrm{mm})\end{array}$ & $\begin{array}{c}\text { Vv } \\
(\%)\end{array}$ & $\begin{array}{c}\text { RBV } \\
(\%)\end{array}$ & $\begin{array}{c}\text { VAM } \\
(\%)\end{array}$ \\
\hline 4,5 & 2,488 & 14906 & 3,6 & 6,33 & 63,4 & 17,26 \\
5,0 & 2,498 & 17486 & 3,7 & 5,17 & 70,2 & 17,36 \\
5,5 & 2,510 & 21521 & 4,0 & 3,92 & 77,5 & 17,40 \\
6,0 & 2,505 & 19899 & 4,2 & 3,34 & 81,5 & 18,01 \\
6,5 & 2,499 & 16250 & 5,1 & 2,79 & 85,0 & 18,65 \\
\hline
\end{tabular}
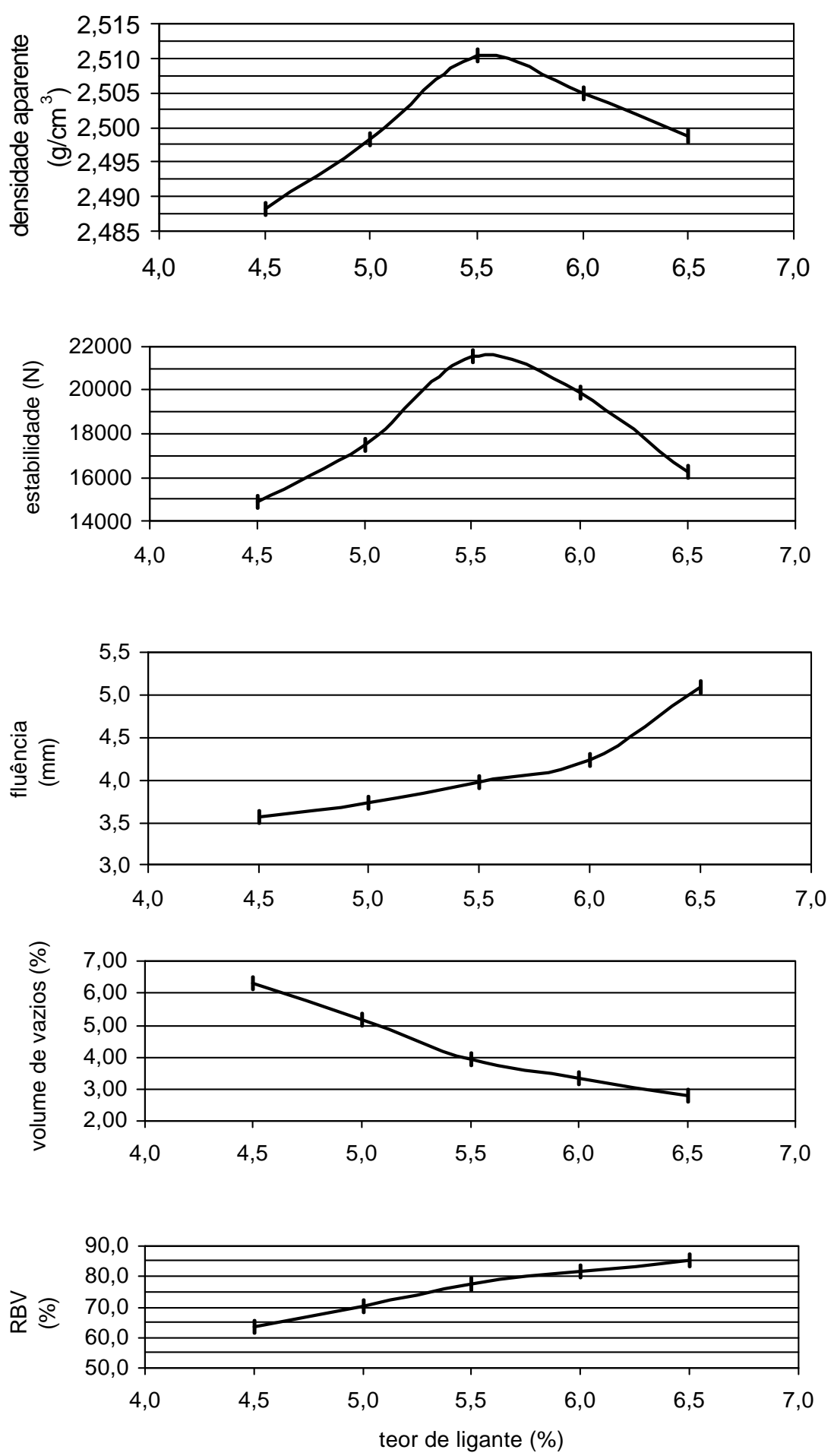
Tabela B12 - Resumo da dosagem Marshall para a graduação C; asfalto com borracha

\begin{tabular}{ccccccc}
\hline $\begin{array}{c}\text { teor } \\
(\%)\end{array}$ & $\begin{array}{c}\text { Dap } \\
\left(\mathrm{g} / \mathrm{cm}^{3}\right)\end{array}$ & $\begin{array}{c}\mathrm{E} \\
(\mathrm{N})\end{array}$ & $\begin{array}{c}\mathrm{F} \\
(\mathrm{mm})\end{array}$ & $\begin{array}{c}\mathrm{Vv} \\
(\%)\end{array}$ & $\begin{array}{c}\text { RBV } \\
(\%)\end{array}$ & $\begin{array}{c}\text { VAM } \\
(\%)\end{array}$ \\
\hline 4,5 & 2,471 & 11316 & 3,2 & 6,95 & 61,0 & 17,83 \\
5,0 & 2,496 & 14271 & 3,5 & 5,21 & 70,1 & 17,42 \\
5,5 & 2,506 & 15228 & 3,9 & 4,05 & 76,9 & 17,53 \\
6,0 & 2,491 & 11760 & 4,3 & 3,85 & 79,2 & 18,47 \\
6,5 & 2,474 & 9037 & 4,6 & 3,74 & 80,8 & 19,47 \\
\hline
\end{tabular}
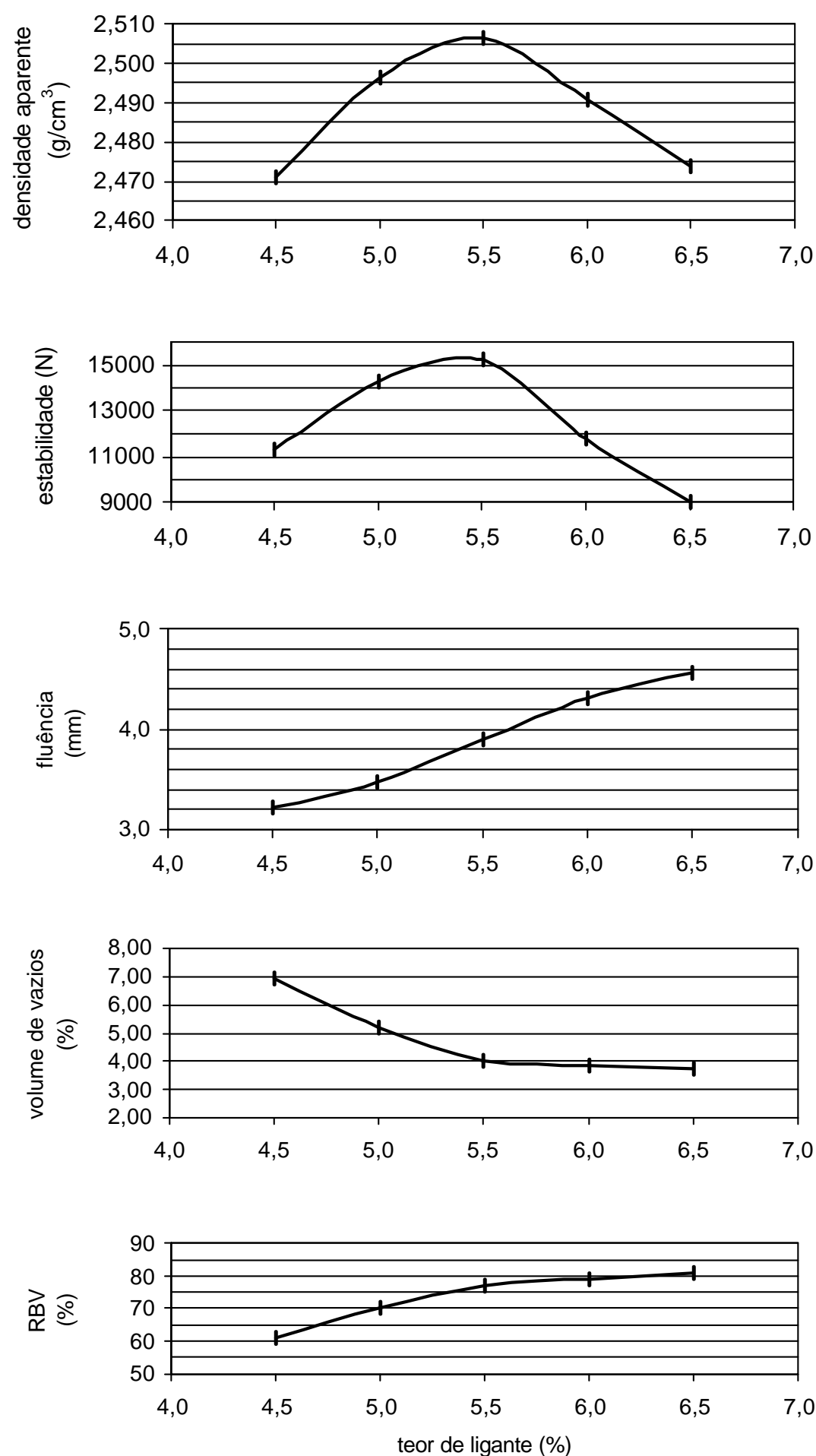


\section{APÊNDICE C - Definição dos teores de ligante em função das espessuras de película}

São apresentados os cálculos das superfícies específicas dos agregados, para as curvas granulométricas correspondentes aos centros das faixas B e C do DNER (1997), segundo método sugerido por Chapuis e Légaré (1992); os cálculos das espessuras de película de ligante e a definição dos teores de ligante em função das espessuras de película desejadas. 
Determinação da Superfície Específica

(segundo método sugerido por Chapuis e Légaré, 1992)

Agregado de natureza basáltica (basalto/diabásio)

Faixas granulométricas adotadas:

centro da faixa B do DNER ES 313/97 (DNER, 1997)

densidade real do agregado $\quad \gamma_{\text {agregado }}=\quad 2,872 \quad(\mathrm{~g} / \mathrm{cm} 3)$

centro da faixa C do DNER ES 313/97 (DNER, 1997)

densidade real do agregado $\quad \gamma_{\text {agregado }}=\quad 2,872 \quad(\mathrm{~g} / \mathrm{cm} 3)$

Fórmula para cálculo da supefície específica

Considerando-se os grãos esféricos

Para cada grão:

$\mathrm{A}=4 \pi \mathrm{r}^{2}$

$\mathrm{V}=4 / 3 \pi \mathrm{r}^{3}$

$S^{\prime}=\frac{4 \pi r^{2}}{\frac{4}{3} \pi r^{3} \gamma}=\frac{3}{r \gamma}=\frac{6}{D \gamma}$

sendo $\gamma=2,65 \mathrm{~g} / \mathrm{cm} 3=2,6510^{3} \mathrm{Kg} / \mathrm{m}^{3}$

$S^{\prime}=\frac{1}{D} \frac{6}{2,65} \frac{m^{2}}{K g} \quad \begin{aligned} & \text { (sendo } \mathrm{D} \text { em } \mathrm{mm} \text { ) } \\ & \text { para agregado }=\text { quartzo }\end{aligned}$

para agregados de outro tipo:

$S^{\prime}=\frac{6}{D \gamma} \frac{m^{2}}{K g} \quad$ (sendo D em $\mathrm{mm}$ e $\gamma \mathrm{em} \mathrm{g} / \mathrm{cm}^{3}$ )

$S=\frac{\sum\left(S^{\prime} \times \% \text { de agregado por fração }\right)}{100}$ 
Centro da faixa B do DNER (1997)

\begin{tabular}{|c|c|c|c|c|c|}
\hline & $\begin{array}{c}\% \\
\text { da fração }\end{array}$ & $\gamma\left(\mathrm{g} / \mathrm{cm}^{3}\right)$ & $\begin{array}{l}\mathrm{D}_{\text {médio }} \\
(\mathrm{mm})\end{array}$ & $\begin{array}{c}\text { fator } \\
S^{\prime}\end{array}$ & $\begin{array}{c}\text { fator } \mathrm{S}^{\prime} \\
* \% \mathrm{fr}\end{array}$ \\
\hline $\mathrm{a}=\%$ pass pela \# $25,4 \mathrm{~mm}$ e ret na \# $19,1 \mathrm{~mm}$ & 10 & 2,872 & 22,250 & 0,094 & 0,939 \\
\hline $\mathrm{b}=\%$ pass pela \# $19,1 \mathrm{~mm}$ e ret na \# $12,7 \mathrm{~mm}$ & 16 & 2,872 & 15,900 & 0,131 & 2,102 \\
\hline $\mathrm{c}=\%$ pass pela $\# 12,7 \mathrm{~mm}$ e ret na $\# 9,5 \mathrm{~mm}$ & 11 & 2,872 & 11,100 & 0,188 & 2,070 \\
\hline $\mathrm{d}=\%$ pass pela \# 9,5 mm e ret na \# 4,8 mm & 19 & 2,872 & 7,150 & 0,292 & 5,552 \\
\hline $\mathrm{e}=\%$ pass pela $\# 4,8 \mathrm{~mm}$ e ret na \# $2,0 \mathrm{~mm}$ & 11 & 2,872 & 3,400 & 0,614 & 6,759 \\
\hline $\mathrm{f}=\%$ pass pela \# 2,0 $\mathrm{mm}$ e ret na \# $0,42 \mathrm{~mm}$ & 12 & 2,872 & 1,210 & 1,727 & 20,719 \\
\hline $\mathrm{g}=\%$ pass pela $\# 0,42 \mathrm{~mm}$ e ret na $\# 0,180 \mathrm{~mm}$ & 7 & 2,872 & 0,300 & 6,964 & 48,747 \\
\hline $\mathrm{h}=\%$ pass pela \# $0,180 \mathrm{~mm}$ e ret na \# $0,074 \mathrm{~mm}$ & 9 & 2,872 & 0,127 & 16,450 & 148,049 \\
\hline $\mathrm{i}=\%$ pass pela \# $0,074 \mathrm{~mm}$ e ret na \# 0,066 & 2,19 & 2,872 & 0,070 & 29,845 & 65,390 \\
\hline $\mathrm{j}=\%$ pass pela \# $0,066 \mathrm{~mm}$ e ret na \# 0,048 & 0,68 & 2,872 & 0,060 & 34,819 & 23,781 \\
\hline $\mathrm{k}=\%$ pass pela $\# 0,048 \mathrm{~mm}$ e ret na \# 0,035 & 0,55 & 2,872 & 0,040 & 52,228 & 28,752 \\
\hline $1=\%$ pass pela $\# 0,035 \mathrm{~mm}$ e ret na $\# 0,025$ & 0,44 & 2,872 & 0,030 & 69,638 & 30,397 \\
\hline $\mathrm{m}=\%$ pass pela $\# 0,025 \mathrm{~mm}$ e ret na $\# 0,018$ & 0,27 & 2,872 & 0,020 & 104,457 & 27,786 \\
\hline $\mathrm{n}=\%$ pass pela \# $0,018 \mathrm{~mm}$ e ret na \# 0,013 & 0,27 & 2,872 & 0,015 & 139,276 & 36,978 \\
\hline $\mathrm{o}=\%$ pass pela \# $0,013 \mathrm{~mm}$ e ret na \# 0,0094 & 0,23 & 2,872 & 0,010 & 208,914 & 47,632 \\
\hline $\mathrm{p}=\%$ pass pela \# $0,0094 \mathrm{~mm}$ e ret na \# 0,0067 & 0,15 & 2,872 & 0,008 & 261,142 & 39,563 \\
\hline $\mathrm{q}=\%$ pass pela \# $0,0067 \mathrm{~mm}$ e ret na \# 0,0048 & 0,08 & 2,872 & 0,006 & 348,189 & 26,462 \\
\hline $\mathrm{r}=\%$ pass pela \# $0,0048 \mathrm{~mm}$ e ret na \# 0,0033 & 0,08 & 2,872 & 0,004 & 522,284 & 39,694 \\
\hline $\mathrm{t}=\%$ pass pela \# 0,0033 & 0,08 & 2,872 & 0,003 & 633,072 & 50,646 \\
\hline & & & \multicolumn{2}{|c|}{$\mathrm{S} * 100=$} & 652,017 \\
\hline
\end{tabular}

Centro da faixa C do DNER (1997)

\begin{tabular}{|c|c|c|c|c|c|}
\hline & $\begin{array}{c}\% \\
\text { da fração }\end{array}$ & $\gamma\left(\mathrm{g} / \mathrm{cm}^{3}\right)$ & $\begin{array}{l}\mathrm{D}_{\text {médio }} \\
(\mathrm{mm})\end{array}$ & $\begin{array}{c}\text { fator } \\
S^{\prime}\end{array}$ & $\begin{array}{l}\text { fator } \mathrm{S}^{\prime} \\
* \% \mathrm{fr}\end{array}$ \\
\hline$a=\%$ ret na $\# 12,7 \mathrm{~mm}$ & 7 & 2,872 & 15,900 & 0,131 & 0,920 \\
\hline $\mathrm{b}=\%$ pass pela $\# 12,7 \mathrm{~mm}$ e ret na $\# 9,5 \mathrm{~mm}$ & 6 & 2,872 & 11,100 & 0,188 & 1,129 \\
\hline $\mathrm{c}=\%$ pass pela $\# 9,5 \mathrm{~mm}$ e ret na $\# 4,8 \mathrm{~mm}$ & 20 & 2,872 & 7,150 & 0,292 & 5,844 \\
\hline $\mathrm{d}=\%$ pass pela \# $4,8 \mathrm{~mm}$ e ret na \# $2,0 \mathrm{~mm}$ & 14 & 2,872 & 3,400 & 0,614 & 8,602 \\
\hline $\mathrm{e}=\%$ pass pela \# $2,0 \mathrm{~mm}$ e ret na \# $0,42 \mathrm{~mm}$ & 26 & 2,872 & 1,210 & 1,727 & 44,891 \\
\hline $\mathrm{f}=\%$ pass pela \# $0,42 \mathrm{~mm}$ e ret na $\# 0,180 \mathrm{~mm}$ & 8 & 2,872 & 0,300 & 6,964 & 55,710 \\
\hline $\mathrm{g}=\%$ pass pela \# $0,180 \mathrm{~mm}$ e ret na \# $0,074 \mathrm{~mm}$ & 12 & 2,872 & 0,127 & 16,450 & 197,399 \\
\hline $\mathrm{i}=\%$ pass pela \# $0,074 \mathrm{~mm}$ e ret na \# 0,066 & 3,07 & 2,872 & 0,070 & 29,845 & 91,546 \\
\hline $\mathrm{j}=\%$ pass pela \# $0,066 \mathrm{~mm}$ e ret na \# 0,048 & 0,96 & 2,872 & 0,060 & 34,819 & 33,294 \\
\hline $\mathrm{k}=\%$ pass pela \# $0,048 \mathrm{~mm}$ e ret na \# 0,035 & 0,77 & 2,872 & 0,040 & 52,228 & 40,252 \\
\hline $1=\%$ pass pela \# $0,035 \mathrm{~mm}$ e ret na \# 0,025 & 0,61 & 2,872 & 0,030 & 69,638 & 42,556 \\
\hline $\mathrm{m}=\%$ pass pela \# $0,025 \mathrm{~mm}$ e ret na \# 0,018 & 0,37 & 2,872 & 0,020 & 104,457 & 38,900 \\
\hline $\mathrm{n}=\%$ pass pela \# $0,018 \mathrm{~mm}$ e ret na \# 0,013 & 0,37 & 2,872 & 0,015 & 139,276 & 51,769 \\
\hline $\mathrm{o}=\%$ pass pela \# $0,013 \mathrm{~mm}$ e ret na \# 0,0094 & 0,32 & 2,872 & 0,010 & 208,914 & 66,685 \\
\hline $\mathrm{p}=\%$ pass pela $\# 0,0094 \mathrm{~mm}$ e ret na $\# 0,0067$ & 0,21 & 2,872 & 0,008 & 261,142 & 55,388 \\
\hline $\mathrm{q}=\%$ pass pela \# $0,0067 \mathrm{~mm}$ e ret na \# 0,0048 & 0,11 & 2,872 & 0,006 & 348,189 & 37,047 \\
\hline $\mathrm{r}=\%$ pass pela $\# 0,0048 \mathrm{~mm}$ e ret na \# 0,0033 & 0,11 & 2,872 & 0,004 & 522,284 & 55,571 \\
\hline $\mathrm{t}=\%$ pass pela $\# 0,0033$ & 0,11 & 2,872 & 0,003 & 633,072 & 67,359 \\
\hline
\end{tabular}

$\mathrm{S}=\quad 8,949 \mathrm{~m}^{2} / \mathrm{kg}$ 
Cálculo das espessuras de película para o asfalto convencional (CAP 20), asfalto modificado com polímero e asfalto modificado com borracha

\section{GRADUAC̣ÃO B}

teor de asfalto $=$ $4,5 \%$

superfície específica do agregado $=$ $6,520 \mathrm{~m}^{2} / \mathrm{Kg}$ de agregado $d_{b}=\quad 1024 \mathrm{Kg} / \mathrm{m}^{3}$ (asfalto convencional)

Considerando $1 \mathrm{Kg}$ de massa asfáltica: massa de agregado $=\quad 0,955 \mathrm{Kg}$ massa de asfalto $=\quad 0,045 \mathrm{Kg}$ massa de asfalto $/ \mathrm{Kg}$ de agr. $=0,045 \mathrm{Kg} / 0,955 \mathrm{Kg}=\quad 0,04712 \mathrm{Kg}$ de asf $/ \mathrm{Kg}$ de agr espessura $=\mathrm{e}=\frac{\text { (massa de asfalto } / \mathrm{Kg} \text { de agregado) }}{\text { (superice }}$ de película (superfície específica do agregado * peso específico do asfalto)

$$
e=\frac{0,04712 \frac{K g(\text { asfalto })}{K g(\text { agregado })}}{6,520 \frac{m^{2}}{K g(\text { agregado })} \times 1024 \frac{K g(\text { asfalto })}{m^{3}}} \Rightarrow \quad \begin{array}{llr} 
& \\
& e= & 7,06 \mathrm{E}-06 \mathrm{~m} \\
& & 7,06 \mu \mathrm{m}
\end{array}
$$

Tabela C1 - Espessura de película em função do teor de ligante adotado (faixa B)

\begin{tabular}{c|c|c|l|c|c|c}
\hline $\begin{array}{c}\text { teor de } \\
\text { asfalto } \\
(\%)\end{array}$ & $\begin{array}{c}\text { massa de } \\
\text { asfalto } \\
(\mathrm{Kg})\end{array}$ & $\begin{array}{c}\text { massa de } \\
\text { agregado } \\
(\mathrm{Kg})\end{array}$ & $\begin{array}{c}\text { massa de asf/ } \\
\text { Kg de agregado }\end{array}$ & $\mathrm{S}$ & $\mathrm{d}_{\mathrm{b}}$ & $\mathrm{e}$ \\
\hline 4,0 & 0,040 & 0,960 & 0,04167 & 6,520 & 1024 & 6,24 \\
4,5 & 0,045 & 0,955 & 0,04712 & 6,520 & 1024 & 7,06 \\
5,0 & 0,050 & 0,950 & 0,05263 & 6,520 & 1024 & 7,88 \\
5,5 & 0,055 & 0,945 & 0,05820 & 6,520 & 1024 & 8,72 \\
6,0 & 0,060 & 0,940 & 0,06383 & 6,520 & 1024 & 9,56 \\
\hline
\end{tabular}

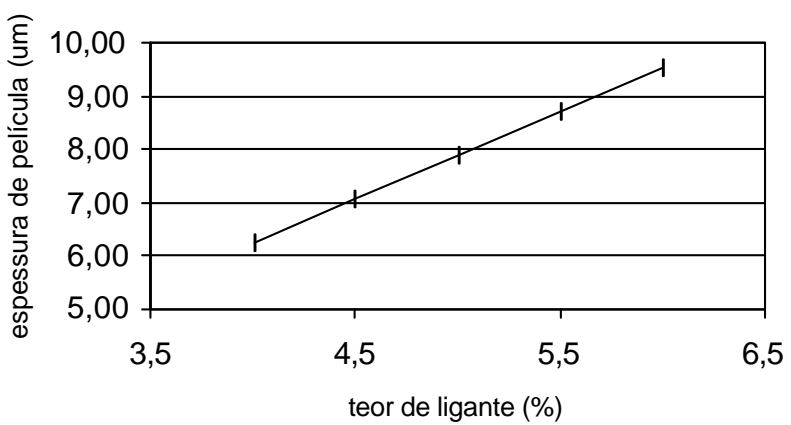

Figura C1 - Espessura de película em função do teor de ligante (faixa B) 
Cálculo das espessuras de película para o asfalto convencional (CAP 20), asfalto modificado com polímero e asfalto modificado com borracha

\section{GRADUAC̣ÃO C}

teor de asfalto $=$ $4,5 \%$

superfície específica do agregado $=$ $\mathrm{d}_{\mathrm{b}}=\quad 1024 \mathrm{Kg} / \mathrm{m}^{3}$ (asfalto convencional)

$8,949 \mathrm{~m}^{2} / \mathrm{Kg}$ de agregado

Considerando $1 \mathrm{Kg}$ de massa asfáltica:

massa de agregado $=\quad 0,955 \mathrm{Kg}$

massa de asfalto $=\quad 0,045 \mathrm{Kg}$

massa de asfalto $/ \mathrm{Kg}$ de agr. $=0,045 \mathrm{Kg} / 0,955 \mathrm{Kg}=\quad 0,04712 \mathrm{Kg}$ de asf $/ \mathrm{Kg}$ de agr

espessura $=\mathrm{e}=\quad$ (massa de asfalto $/ \mathrm{Kg}$ de agregado)

de película $\quad$ (superfície específica do agregado * peso específico do asfalto)

$$
e=\frac{0,04712 \frac{K g(\text { asfalto })}{K g(\text { agregado })}}{8,949 \frac{m^{2}}{K g(\text { agregado })} \times 1024 \frac{K g(\text { asfalto })}{m^{3}}} \Rightarrow \quad \begin{array}{llr}
\mathrm{e}= & 5,14 \mathrm{E}-06 \mathrm{~m} \\
& & 5,14 \mu \mathrm{m}
\end{array}
$$

Tabela C2 - Espessura de película em função do teor de ligante adotado (faixa C)

\begin{tabular}{c|c|c|l|c|c|c}
\hline $\begin{array}{c}\text { teor de } \\
\text { asfalto } \\
(\%)\end{array}$ & $\begin{array}{c}\text { massa de } \\
\text { asfalto } \\
(\mathrm{Kg})\end{array}$ & $\begin{array}{c}\text { massa de } \\
\text { agregado } \\
(\mathrm{Kg})\end{array}$ & $\begin{array}{c}\text { massa de asf/ } \\
\text { Kg de agregado }\end{array}$ & $\begin{array}{c}\mathrm{S} \\
\left(\mathrm{m}^{2} / \mathrm{Kg}\right)\end{array}$ & $\begin{array}{c}\mathrm{d}_{\mathrm{b}} \\
\left(\mathrm{Kg} / \mathrm{m}^{3}\right)\end{array}$ & $(\mu \mathrm{m})$ \\
\hline 4,0 & 0,040 & 0,960 & 0,04167 & 8,949 & 1024 & 4,55 \\
4,5 & 0,045 & 0,955 & 0,04712 & 8,949 & 1024 & 5,14 \\
5,0 & 0,050 & 0,950 & 0,05263 & 8,949 & 1024 & 5,74 \\
5,5 & 0,055 & 0,945 & 0,05820 & 8,949 & 1024 & 6,35 \\
6,0 & 0,060 & 0,940 & 0,06383 & 8,949 & 1024 & 6,97 \\
6,5 & 0,065 & 0,935 & 0,06952 & 8,949 & 1024 & 7,59 \\
7,0 & 0,070 & 0,930 & 0,07527 & 8,949 & 1024 & 8,21 \\
\hline
\end{tabular}

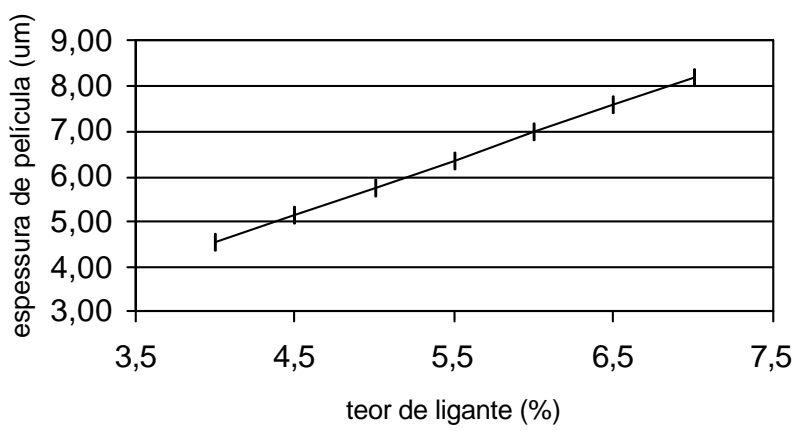

Figura C2 - Espessura de película em função do teor de ligante (faixa C) 
Escolha dos teores de ligante em funçao da espessura de película

FAIXA B DO DNER (1997)

ESPESSURA DE PELÍCULA $=\quad 6 \mu \mathrm{m}$

Determinação do teor de ligante $\left(\gamma_{\mathrm{CAP} 20}=\gamma_{\text {asf mod polímero }}=\gamma_{\text {asf mod borracha }}\right)$

$\gamma_{\text {agregado }}=\quad 2,872 \mathrm{~g} / \mathrm{cm}^{3}=\quad 2872 \mathrm{Kg} / \mathrm{m}^{3}$

$\gamma_{\text {ligante }}=\quad 1,024 \mathrm{~g} / \mathrm{cm}^{3}=\quad 1024 \mathrm{Kg} / \mathrm{m}^{3}$

superfície específica do agregado $=\quad 6,520 \mathrm{~m}^{2} / \mathrm{Kg}$

$\begin{array}{ccc}\text { peso } & \text { de ligante } \\ \text { por } & K g & \text { agreg }\end{array}=\begin{gathered}\text { sup erfície específica } \\ \text { do agregado }\end{gathered}\left(\frac{m^{2}}{K g \quad \text { agreg }}\right) \times \begin{aligned} & \begin{array}{c}\text { espessura } \\ \text { película }\end{array} \\ & (m) \times \gamma_{\text {ligante }}\end{aligned}\left(\frac{K g}{m^{3}}\right)$

peso de ligante por Kg de agreg $=\quad 6,520 \frac{\mathrm{m}^{2}}{\mathrm{Kg}(\text { agregado })} \times 6 \times 10^{-6} \mathrm{~m} \times 1,024 \times 10^{3} \times \frac{\mathrm{Kg}}{\mathrm{m}^{3}}$

peso de ligante por $\mathrm{Kg}$ de agregado $=\quad 0,0401 \mathrm{Kg}$ de asfalto $/ \mathrm{Kg}$ de agregado

teor de ligante por peso total da mistura $=\frac{0,0401 \times 100}{(1+0,0401)}=\quad 3,85 \%$ de

ligante na mistura

Tabela C3 - Teor de ligante em função da espessura de película (faixa B)

\begin{tabular}{c|c|c|l|l}
\hline $\begin{array}{c}\text { espessura } \\
\text { de película } \\
(\mu \mathrm{m})\end{array}$ & $\mathrm{S}$ & $\mathrm{d}_{\mathrm{b}}$ & $\begin{array}{l}\text { peso de ligante/ } \\
\text { Kg de agregado }\end{array}$ & $\begin{array}{c}\text { teor de ligante por } \\
\text { peso total da mistura } \\
(\%)\end{array}$ \\
\hline 6 & 6,520 & 1024 & 0,0401 & 3,85 \\
7 & 6,520 & 1024 & 0,0467 & 4,46 \\
8 & 6,520 & 1024 & 0,0534 & 5,07 \\
9 & 6,520 & 1024 & 0,0601 & 5,67 \\
10 & 6,520 & 1024 & 0,0668 & 6,26 \\
\hline
\end{tabular}


Escolha dos teores de ligante em funçao da espessura de película

FAIXA C DO DNER (1997)

ESPESSURA DE PELÍCULA $=\quad 6 \mu \mathrm{m}$

Determinação do teor de ligante $\quad\left(\gamma_{\mathrm{CAP} 20}=\gamma_{\text {asf mod polímero }}=\gamma_{\text {asf mod borracha }}\right)$

$\gamma_{\text {agregado }}=\quad 2,872 \mathrm{~g} / \mathrm{cm}^{3}=\quad 2872 \mathrm{Kg} / \mathrm{m}^{3}$

$\gamma_{\text {ligante }}=\quad 1,024 \mathrm{~g} / \mathrm{cm}^{3}=1024 \mathrm{Kg} / \mathrm{m}^{3}$

superfície específica do agregado $=\quad 8,949 \mathrm{~m}^{2} / \mathrm{Kg}$

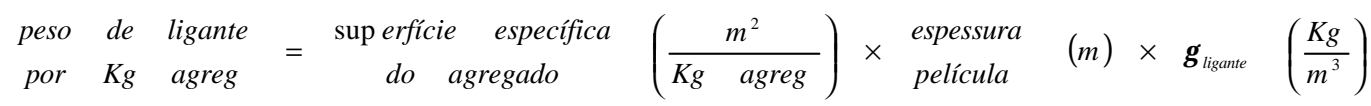

peso de ligante por $\mathrm{Kg}$ de agreg $=8,949 \frac{\mathrm{m}^{2}}{\mathrm{Kg}(\text { agregado })} \times 6 \times 10^{-6} \mathrm{~m} \times 1,024 \times 10^{3} \times \frac{\mathrm{Kg}}{\mathrm{m}^{3}}$

peso de ligante por $\mathrm{Kg}$ de agregado $=\quad 0,0550 \mathrm{Kg}$ de asfalto $/ \mathrm{Kg}$ de agregado

teor de ligante por peso total da mistura $=\frac{0,0550 \times 100}{(1+0,0550)}=\quad 5,21 \%$ de

ligante na mistura

Tabela C4 - Teor de ligante em função da espessura de película (faixa C)

\begin{tabular}{c|c|c|c|c}
\hline $\begin{array}{c}\text { espessura } \\
\text { de película } \\
(\mu \mathrm{m})\end{array}$ & $\mathrm{S}$ & $\mathrm{d}_{\mathrm{b}}$ & $\begin{array}{l}\text { peso de ligante/ } \\
\text { Kg de agregado }\end{array}$ & $\begin{array}{c}\text { teor de ligante por } \\
\text { peso total da mistura } \\
(\%)\end{array}$ \\
\hline 6 & 8,949 & 1024 & 0,0550 & 5,21 \\
7 & 8,949 & 1024 & 0,0641 & 6,03 \\
8 & 8,949 & 1024 & 0,0733 & 6,83 \\
9 & 8,949 & 1024 & 0,0825 & 7,62 \\
10 & 8,949 & 1024 & 0,0916 & 8,39 \\
\hline
\end{tabular}




\section{APÊNDICE D - Apresentação dos dados}

São apresentados os dados do experimento, obtidos através da realização dos ensaios de tração por compressão diametral, módulo de resiliência por compressão diametral dinâmica e fluência por compressão uniaxial estática e dinâmica. Nas Tabelas D.2 a D.26 as condições experimentais nas quais os experimentos foram conduzidos são resumidas através de abreviações, expressões e símbolos descritos com maiores detalhes na Tabela D.1.

Tabela D.1 - Abreviações, símbolos e expressões utilizadas nas tabelas de apresentação dos dados obtidos dos ensaios realizados

\begin{tabular}{|c|c|c|}
\hline tipo de ligante & $\begin{array}{l}\text { conv } \\
\text { pol } \\
\text { bor }\end{array}$ & $\begin{array}{l}\text { asfalto convencional } \\
\text { asfalto modificado com polímero } \\
\text { asfalto modificado com borracha }\end{array}$ \\
\hline agregado com distribuição & $\mathrm{CO}$ & faixa $\mathrm{C}$; teor de ligante $=5,0 \%$ \\
\hline granulométrica & C 1 & faixa $C$; teor de ligante $=5,5 \%$ \\
\hline correspondente ao centro da & $\mathrm{C} 2$ & faixa $C$; teor de ligante $=6,0 \%$ \\
\hline faixa $\mathrm{C}$ do DNER & C 3 & faixa $\mathrm{C}$; teor de ligante $=6,5 \%$ \\
\hline agregado com distribuição & B 0 & faixa $B$; teor de ligante $=4,0 \%$ \\
\hline granulométrica & B 1 & faixa $B$; teor de ligante $=4,5 \%$ \\
\hline correspondente ao centro da & B 2 & faixa $\mathrm{B}$; teor de ligante $=5,0 \%$ \\
\hline faixa B do DNER & B 3 & faixa $\mathrm{B}$; teor de ligante $=5,5 \%$ \\
\hline \multirow{3}{*}{$\begin{array}{l}\text { condição de envelhecimento } \\
\text { da mistura a longo prazo }\end{array}$} & sem env. & mistura sem envelhecimento a longo prazo \\
\hline & 5 dias estufa & $\begin{array}{c}\text { mistura envelhecida em estufa ventilada por } 5 \\
\text { dias, a } 85^{\circ} \mathrm{C}\end{array}$ \\
\hline & 4 meses & $\begin{array}{c}\text { misturas envelhecida por exposição ao tempo } \\
\text { durante } 4 \text { meses }\end{array}$ \\
\hline \multirow{2}{*}{$\begin{array}{l}\text { condição de envelhecimento } \\
\text { a curto prazo }\end{array}$} & sem env. & mistura sem envelhecimento a curto prazo \\
\hline & 4 horas & $\begin{array}{l}\text { mistura envelhecida em estufa ventilada por } \\
\qquad 4 \text { horas, a } 135^{\circ} \mathrm{C}\end{array}$ \\
\hline
\end{tabular}


Tabela D.2 - Valores de resistência à tração por compressão diametral (MPa), para o experimento realizado com apenas uma observação por condição experimental

\begin{tabular}{|c|c|c|c|}
\hline \multirow{2}{*}{$\begin{array}{c}\text { condição } \\
\text { experimental }\end{array}$} & \multicolumn{2}{|c|}{ envelhecimento } & \multirow[b]{2}{*}{$\sigma_{\mathrm{R}}(\mathrm{MPa})$} \\
\hline & longo prazo & curto prazo & \\
\hline $1-\operatorname{conv} \mathrm{C} 0$ & sem env. & 4 horas & 1,970 \\
\hline $2-\operatorname{conv} \mathrm{B} 1$ & sem env. & 4 horas & 2,293 \\
\hline $3-\operatorname{conv}$ B 2 & sem env. & 4 horas & 1,754 \\
\hline $4-\operatorname{conv} C 3$ & sem env. & 4 horas & 1,713 \\
\hline $5-$ conv B 0 & 5 dias estufa & sem env. & 1,462 \\
\hline $6-$ conv $\mathrm{C} 1$ & 5 dias estufa & sem env. & 1,739 \\
\hline $7-\operatorname{conv} \mathrm{C} 2$ & 5 dias estufa & sem env. & 1,713 \\
\hline $8-\operatorname{conv} \mathrm{B} 3$ & 5 dias estufa & sem env. & 2,146 \\
\hline $13-\operatorname{conv} \mathrm{C} 0$ & 4 meses & 4 horas & 1,854 \\
\hline $14-$ conv B 1 & 4 meses & 4 horas & 2,210 \\
\hline $15-\operatorname{conv}$ B 2 & 4 meses & 4 horas & 1,890 \\
\hline $16-\operatorname{conv} C 3$ & 4 meses & 4 horas & 1,794 \\
\hline $17-$ pol C 0 & sem env. & sem env. & 2,222 \\
\hline $18-$ pol B 1 & sem env. & sem env. & 2,204 \\
\hline $19-$ pol B 2 & sem env. & sem env. & 2,596 \\
\hline $20-$ pol C 3 & sem env. & sem env. & 2,108 \\
\hline $21-$ pol B 0 & 5 dias estufa & 4 horas & 2,328 \\
\hline $22-$ pol C 1 & 5 dias estufa & 4 horas & 2,598 \\
\hline $23-$ pol C 2 & 5 dias estufa & 4 horas & 2,976 \\
\hline $24-$ pol B 3 & 5 dias estufa & 4 horas & 2,333 \\
\hline $29-$ pol C 0 & 4 meses & sem env. & 2,219 \\
\hline $30-$ pol B 1 & 4 meses & sem env. & 2,232 \\
\hline $31-$ pol B 2 & 4 meses & sem env. & 2,322 \\
\hline $32-$ pol C 3 & 4 meses & sem env. & 2,219 \\
\hline 49 - bor $C 0$ & sem env. & 4 horas & 1,745 \\
\hline $50-$ bor B 1 & sem env. & 4 horas & 1,773 \\
\hline 51 - bor B 2 & sem env. & 4 horas & 2,168 \\
\hline 52 - bor C 3 & sem env. & 4 horas & 2,386 \\
\hline 53 - bor B 0 & 5 dias estufa & sem env. & 1,588 \\
\hline 54 - bor C 1 & 5 dias estufa & sem env. & 2,298 \\
\hline $55-$ bor $C 2$ & 5 dias estufa & sem env. & 2,555 \\
\hline 56 - bor B 3 & 5 dias estufa & sem env. & 1,768 \\
\hline $61-$ bor C 0 & 4 meses & 4 horas & 1,839 \\
\hline $62-$ bor B 1 & 4 meses & 4 horas & 2,360 \\
\hline $63-$ bor B 2 & 4 meses & 4 horas & 2,328 \\
\hline 64 - bor C 3 & 4 meses & 4 horas & 2,520 \\
\hline
\end{tabular}


Tabela D.3 - Valores de módulo de resiliência total (MPa), para o experimento realizado com três observações por condição experimental

\begin{tabular}{|c|c|c|c|c|c|c|}
\hline \multirow[t]{2}{*}{$\begin{array}{c}\text { condição } \\
\text { experimental }\end{array}$} & \multicolumn{2}{|c|}{ envelhecimento } & \multicolumn{3}{|c|}{$\begin{array}{r}\text { MR total (MPa) } \\
\text { éplicas ou observações }\end{array}$} & \multirow[b]{2}{*}{$\bar{Y}$} \\
\hline & longo prazo & curto prazo & Y1 & $\mathrm{Y} 2$ & Y3 & \\
\hline $1-\operatorname{conv} \mathrm{C} 0$ & sem env. & 4 horas & 4057 & 3298 & 5565 & 4307 \\
\hline $2-\operatorname{conv}$ B 1 & sem env. & 4 horas & 18233 & 14912 & 15044 & 16063 \\
\hline $3-\operatorname{conv}$ B 2 & sem env. & 4 horas & 14839 & 10852 & 12808 & 12833 \\
\hline $4-\operatorname{conv} \mathrm{C} 3$ & sem env. & 4 horas & 2084 & 3669 & 3472 & 3075 \\
\hline $5-$ conv B 0 & 5 dias estufa & sem env. & 7373 & 10575 & 8394 & 8781 \\
\hline $6-\operatorname{conv} C 1$ & 5 dias estufa & sem env. & 16771 & 11061 & 9267 & 12367 \\
\hline $7-\operatorname{conv} C 2$ & 5 dias estufa & sem env. & 4254 & 4627 & 8909 & 5930 \\
\hline 8 - conv B 3 & 5 dias estufa & sem env. & 9181 & 11825 & 10617 & 10541 \\
\hline $13-\operatorname{conv} \mathrm{C} 0$ & 4 meses & 4 horas & 15966 & 15923 & 18226 & 16705 \\
\hline $14-$ conv B 1 & 4 meses & 4 horas & 22238 & 20682 & 27400 & 23440 \\
\hline $15-\operatorname{conv}$ B 2 & 4 meses & 4 horas & 18100 & 18752 & 15348 & 17400 \\
\hline $16-\operatorname{conv} \mathrm{C} 3$ & 4 meses & 4 horas & 15856 & 13225 & 12554 & 13879 \\
\hline $17-$ pol C 0 & sem env. & sem env. & 8375 & 8568 & 7592 & 8178 \\
\hline $18-$ pol B 1 & sem env. & sem env. & 10926 & 10532 & 9522 & 10327 \\
\hline $19-$ pol B 2 & sem env. & sem env. & 20029 & 18181 & 17243 & 18484 \\
\hline $20-$ pol C 3 & sem env. & sem env. & 4975 & 4840 & 5130 & 4982 \\
\hline $21-$ pol B 0 & 5 dias estufa & 4 horas & 21897 & 22288 & 21436 & 21874 \\
\hline 22 - pol C 1 & 5 dias estufa & 4 horas & 18022 & 12987 & 15551 & 15520 \\
\hline $23-$ pol C 2 & 5 dias estufa & 4 horas & 17331 & 15292 & 20176 & 17600 \\
\hline $24-$ pol B 3 & 5 dias estufa & 4 horas & 13683 & 16247 & 15286 & 15072 \\
\hline $29-$ pol C 0 & 4 meses & sem env. & 17263 & 17779 & 16890 & 17311 \\
\hline $30-$ pol B 1 & 4 meses & sem env. & 23128 & 22276 & 26906 & 24103 \\
\hline $31-p o l$ B 2 & 4 meses & sem env. & 21402 & 16627 & 19766 & 19265 \\
\hline $32-$ pol C 3 & 4 meses & sem env. & 15297 & 21170 & 10207 & 15558 \\
\hline 49 - bor C 0 & sem env. & 4 horas & 4681 & 5084 & 4218 & 4661 \\
\hline 50 - bor B 1 & sem env. & 4 horas & 19725 & 14631 & 15216 & 16524 \\
\hline 51 - bor B 2 & sem env. & 4 horas & 14586 & 15578 & 11563 & 13909 \\
\hline 52 - bor C 3 & sem env. & 4 horas & 3889 & 4446 & 5119 & 4485 \\
\hline 53 - bor B 0 & 5 dias estufa & sem env. & 16655 & 8800 & 8441 & 11298 \\
\hline 54 - bor C 1 & 5 dias estufa & sem env. & 18114 & 15220 & 19311 & 16667 \\
\hline 55 - bor C 2 & 5 dias estufa & sem env. & 16965 & 18262 & 10387 & 14325 \\
\hline 56 - bor B 3 & 5 dias estufa & sem env. & 16509 & 11920 & 16415 & 14948 \\
\hline $61-$ bor C 0 & 4 meses & 4 horas & 19732 & 17399 & 13213 & 16781 \\
\hline 62 - bor B 1 & 4 meses & 4 horas & 27621 & 12446 & 27436 & 22501 \\
\hline 63 - bor B 2 & 4 meses & 4 horas & 15091 & 13340 & 13491 & 13974 \\
\hline $64-$ bor C 3 & 4 meses & 4 horas & 20984 & 14586 & 12227 & 15932 \\
\hline
\end{tabular}


Tabela D.4 - Valores de módulo de resiliência instantâneo (MPa), para o experimento realizado com três observações por condição experimental

\begin{tabular}{|c|c|c|c|c|c|c|}
\hline \multirow[t]{2}{*}{$\begin{array}{c}\text { condição } \\
\text { experimental }\end{array}$} & \multicolumn{2}{|c|}{ envelhecimento } & \multicolumn{3}{|c|}{$\begin{array}{l}\text { MR instantâneo (MPa) } \\
\text { réplicas ou observações }\end{array}$} & \multirow{2}{*}{$\bar{Y}$} \\
\hline & longo prazo & curto prazo & $\mathrm{Y} 1$ & Y2 & Y3 & \\
\hline $1-$ conv $\mathrm{C} 0$ & sem env. & 4 horas & 5048 & 4075 & 6885 & 5336 \\
\hline $2-\operatorname{conv}$ B 1 & sem env. & 4 horas & 22084 & 18543 & 18819 & 19815 \\
\hline $3-\operatorname{conv}$ B 2 & sem env. & 4 horas & 18418 & 13409 & 15663 & 15830 \\
\hline $4-\operatorname{conv} \mathrm{C} 3$ & sem env. & 4 horas & 2498 & 4520 & 4256 & 3758 \\
\hline $5-$ conv B 0 & 5 dias estufa & sem env. & 9059 & 13124 & 10410 & 10864 \\
\hline $6-\operatorname{conv} \mathrm{C} 1$ & 5 dias estufa & sem env. & 20487 & 13701 & 11466 & 15218 \\
\hline $7-\operatorname{conv} \mathrm{C} 2$ & 5 dias estufa & sem env. & 5138 & 5578 & 11093 & 7270 \\
\hline $8-\operatorname{conv}$ B 3 & 5 dias estufa & sem env. & 11179 & 14548 & 13136 & 12954 \\
\hline $13-\operatorname{conv} \mathrm{C} 0$ & 4 meses & 4 horas & 19184 & 19619 & 22305 & 20369 \\
\hline $14-\operatorname{conv} B 1$ & 4 meses & 4 horas & 26285 & 24896 & 32614 & 27932 \\
\hline $15-\operatorname{conv} B 2$ & 4 meses & 4 horas & 22125 & 22554 & 18832 & 21170 \\
\hline $16-\operatorname{conv} C 3$ & 4 meses & 4 horas & 19484 & 16211 & 15447 & 17047 \\
\hline $17-$ pol C 0 & sem env. & sem env. & 10375 & 10614 & 9427 & 10139 \\
\hline $18-$ pol B 1 & sem env. & sem env. & 13352 & 12888 & 11768 & 12669 \\
\hline $19-$ pol B 2 & sem env. & sem env. & 23895 & 21579 & 20465 & 21979 \\
\hline $20-$ pol C 3 & sem env. & sem env. & 6166 & 5897 & 6342 & 6135 \\
\hline $21-$ pol B 0 & 5 dias estufa & 4 horas & 25229 & 25146 & 24336 & 24903 \\
\hline $22-$ pol C 1 & 5 dias estufa & 4 horas & 21256 & 16197 & 19090 & 18848 \\
\hline $23-$ pol C 2 & 5 dias estufa & 4 horas & 20376 & 18477 & 22901 & 20585 \\
\hline $24-$ pol B 3 & 5 dias estufa & 4 horas & 17170 & 20128 & 18657 & 18652 \\
\hline $29-$ pol C 0 & 4 meses & sem env. & 20894 & 21593 & 20714 & 21067 \\
\hline $30-$ pol B 1 & 4 meses & sem env. & 27734 & 25651 & 31558 & 28314 \\
\hline $31-$ pol B 2 & 4 meses & sem env. & 25915 & 20414 & 24189 & 23506 \\
\hline $32-$ pol C 3 & 4 meses & sem env. & 18596 & 24942 & 12668 & 18735 \\
\hline 49 - bor C 0 & sem env. & 4 horas & 5612 & 6306 & 4699 & 5539 \\
\hline $50-$ bor B 1 & sem env. & 4 horas & 22834 & 17027 & 18367 & 19410 \\
\hline $51-$ bor B 2 & sem env. & 4 horas & 17296 & 19002 & 14192 & 16830 \\
\hline 52 - bor C 3 & sem env. & 4 horas & 4830 & 5519 & 5895 & 5414 \\
\hline 53 - bor B 0 & 5 dias estufa & sem env. & 19564 & 10993 & 10524 & 13694 \\
\hline $54-$ bor C 1 & 5 dias estufa & sem env. & 21619 & 18551 & 22547 & 20085 \\
\hline 55 - bor C 2 & 5 dias estufa & sem env. & 19128 & 21155 & 12905 & 17030 \\
\hline $56-$ bor B 3 & 5 dias estufa & sem env. & 19813 & 15009 & 19359 & 18060 \\
\hline $61-$ bor $\mathrm{C} 0$ & 4 meses & 4 horas & 23002 & 21029 & 16120 & 20050 \\
\hline $62-$ bor B 1 & 4 meses & 4 horas & 32405 & 15049 & 32308 & 26587 \\
\hline $63-$ bor B 2 & 4 meses & 4 horas & 18490 & 14202 & 16464 & 16385 \\
\hline $64-$ bor C 3 & 4 meses & 4 horas & 25579 & 17969 & 15110 & 19553 \\
\hline
\end{tabular}


Tabela D.5 - Valores de módulo de resiliência total (MPa), para o experimento reduzido a duas observações por condição experimental

\begin{tabular}{|c|c|c|c|c|c|}
\hline \multirow{3}{*}{$\begin{array}{c}\text { condição } \\
\text { experimental }\end{array}$} & \multirow{2}{*}{\multicolumn{2}{|c|}{ envelhecimento }} & \multicolumn{3}{|c|}{$\mathrm{MR}$ total $(\mathrm{MPa})$} \\
\hline & & & réplicas ou obs & vações & \\
\hline & longo prazo & curto prazo & $\mathrm{Y} 1$ & Y2 & $Y$ \\
\hline $1-\operatorname{conv} C 0$ & sem env. & 4 horas & 4057 & 3298 & 3677 \\
\hline $2-\operatorname{conv}$ B 1 & sem env. & 4 horas & 14912 & 15044 & 14978 \\
\hline $3-\operatorname{conv}$ B 2 & sem env. & 4 horas & 10852 & 12808 & 11830 \\
\hline $4-\operatorname{conv} C 3$ & sem env. & 4 horas & 3669 & 3472 & 3570 \\
\hline $5-\operatorname{conv}$ B 0 & 5 dias estufa & sem env. & 7373 & 8394 & 7883 \\
\hline $6-\operatorname{conv} C 1$ & 5 dias estufa & sem env. & 16771 & 11061 & 13916 \\
\hline $7-\operatorname{conv} C 2$ & 5 dias estufa & sem env. & 4627 & 8909 & 6768 \\
\hline $8-\operatorname{conv} B 3$ & 5 dias estufa & sem env. & 11825 & 10617 & 11221 \\
\hline $13-\operatorname{conv} \mathrm{C} 0$ & 4 meses & 4 horas & 15966 & 15923 & 15945 \\
\hline $14-\operatorname{conv}$ B 1 & 4 meses & 4 horas & 22238 & 20682 & 21460 \\
\hline $15-\operatorname{conv} B 2$ & 4 meses & 4 horas & 18100 & 18752 & 18426 \\
\hline $16-\operatorname{conv} C 3$ & 4 meses & 4 horas & 13225 & 12554 & 12890 \\
\hline $17-$ pol C 0 & sem env. & sem env. & 8375 & 8568 & 8471 \\
\hline 18-pol B 1 & sem env. & sem env. & 10926 & 10532 & 10729 \\
\hline $19-$ pol B 2 & sem env. & sem env. & 18181 & 17243 & 17712 \\
\hline $20-$ pol C 3 & sem env. & sem env. & 4975 & 4840 & 4908 \\
\hline $21-$ pol B 0 & 5 dias estufa & 4 horas & 21897 & 21436 & 21666 \\
\hline $22-$ pol C 1 & 5 dias estufa & 4 horas & 18022 & 15551 & 16786 \\
\hline $23-$ pol C 2 & 5 dias estufa & 4 horas & 17331 & 15292 & 16311 \\
\hline $24-$ pol B 3 & 5 dias estufa & 4 horas & 16247 & 15286 & 15767 \\
\hline $29-$ pol C 0 & 4 meses & sem env. & 17263 & 16890 & 17077 \\
\hline $30-$ pol B 1 & 4 meses & sem env. & 23128 & 22276 & 22702 \\
\hline $31-p o l$ B 2 & 4 meses & sem env. & 21402 & 19766 & 20584 \\
\hline $32-$ pol C 3 & 4 meses & sem env. & 15297 & 10207 & 12752 \\
\hline $49-$ bor C 0 & sem env. & 4 horas & 4681 & 5084 & 4882 \\
\hline $50-$ bor B 1 & sem env. & 4 horas & 14631 & 15216 & 14923 \\
\hline 51 - bor B 2 & sem env. & 4 horas & 14586 & 15578 & 15082 \\
\hline $52-$ bor C 3 & sem env. & 4 horas & 4446 & 5119 & 4783 \\
\hline 53 - bor B 0 & 5 dias estufa & sem env. & 8800 & 8441 & 8620 \\
\hline $54-$ bor C 1 & 5 dias estufa & sem env. & 18114 & 15220 & 16667 \\
\hline $55-$ bor C 2 & 5 dias estufa & sem env. & 18262 & 10387 & 14325 \\
\hline 56 - bor B 3 & 5 dias estufa & sem env. & 16509 & 16415 & 16462 \\
\hline $61-$ bor C 0 & 4 meses & 4 horas & 17399 & 13213 & 15306 \\
\hline $62-$ bor B 1 & 4 meses & 4 horas & 27621 & 12446 & 20034 \\
\hline $63-$ bor B 2 & 4 meses & 4 horas & 15091 & 13491 & 14291 \\
\hline $64-$ bor C 3 & 4 meses & 4 horas & 14586 & 12227 & 13406 \\
\hline
\end{tabular}


Tabela D.6 - Valores de módulo de resiliência instantâneo (MPa), para o experimento reduzido a duas observações por condição experimental

\begin{tabular}{|c|c|c|c|c|c|}
\hline \multirow[t]{2}{*}{$\begin{array}{c}\text { condição } \\
\text { experimental }\end{array}$} & \multicolumn{2}{|c|}{ envelhecimento } & \multicolumn{2}{|c|}{$\begin{array}{l}\text { MR instantâneo (MPa) } \\
\text { réplicas ou observações }\end{array}$} & \multirow{2}{*}{$\bar{Y}$} \\
\hline & longo prazo & curto prazo & Y1 & Y2 & \\
\hline $1-\operatorname{conv} \mathrm{C} 0$ & sem env. & 4 horas & 5048 & 4075 & 4561 \\
\hline $2-\operatorname{conv}$ B 1 & sem env. & 4 horas & 18543 & 18819 & 18681 \\
\hline $3-\operatorname{conv} \mathrm{B} 2$ & sem env. & 4 horas & 13409 & 15663 & 14536 \\
\hline $4-\operatorname{conv} \mathrm{C} 3$ & sem env. & 4 horas & 4520 & 4256 & 4388 \\
\hline $5-\operatorname{conv} \mathrm{B} 0$ & 5 dias estufa & sem env. & 9059 & 10410 & 9734 \\
\hline $6-\operatorname{conv} \mathrm{C} 1$ & 5 dias estufa & sem env. & 20487 & 13701 & 17094 \\
\hline $7-\operatorname{conv} \mathrm{C} 2$ & 5 dias estufa & sem env. & 5578 & 11093 & 8336 \\
\hline $8-\operatorname{conv}$ B 3 & 5 dias estufa & sem env. & 14548 & 13136 & 13842 \\
\hline $13-\operatorname{conv} \mathrm{C} 0$ & 4 meses & 4 horas & 19184 & 19619 & 19401 \\
\hline $14-\operatorname{conv}$ B 1 & 4 meses & 4 horas & 26285 & 24896 & 25591 \\
\hline $15-\operatorname{conv}$ B 2 & 4 meses & 4 horas & 22125 & 22554 & 22340 \\
\hline $16-\operatorname{conv} C 3$ & 4 meses & 4 horas & 16211 & 15447 & 15829 \\
\hline $17-$ pol C 0 & sem env. & sem env. & 10375 & 10614 & 10495 \\
\hline $18-$ pol B 1 & sem env. & sem env. & 13352 & 12888 & 13120 \\
\hline $19-$ pol B 2 & sem env. & sem env. & 21579 & 20465 & 21022 \\
\hline $20-$ pol C 3 & sem env. & sem env. & 6166 & 5897 & 6031 \\
\hline $21-$ pol B 0 & 5 dias estufa & 4 horas & 25229 & 24336 & 24782 \\
\hline $22-$ pol C 1 & 5 dias estufa & 4 horas & 21256 & 19090 & 20173 \\
\hline $23-$ pol C 2 & 5 dias estufa & 4 horas & 20376 & 18477 & 19426 \\
\hline $24-$ pol B 3 & 5 dias estufa & 4 horas & 20128 & 18657 & 19393 \\
\hline $29-$ pol C 0 & 4 meses & sem env. & 20894 & 20714 & 20804 \\
\hline $30-$ pol B 1 & 4 meses & sem env. & 27734 & 25651 & 26692 \\
\hline $31-$ pol B 2 & 4 meses & sem env. & 25915 & 24189 & 25052 \\
\hline $32-$ pol C 3 & 4 meses & sem env. & 18596 & 12668 & 15632 \\
\hline $49-$ bor $\mathrm{C} 0$ & sem env. & 4 horas & 5612 & 6306 & 5959 \\
\hline $50-\operatorname{bor} B 1$ & sem env. & 4 horas & 17027 & 18367 & 17697 \\
\hline $51-$ bor B 2 & sem env. & 4 horas & 17296 & 19002 & 18149 \\
\hline 52 - bor C 3 & sem env. & 4 horas & 5519 & 5895 & 5707 \\
\hline $53-$ bor B 0 & 5 dias estufa & sem env. & 10993 & 10524 & 10758 \\
\hline $54-$ bor C 1 & 5 dias estufa & sem env. & 21619 & 18551 & 20085 \\
\hline $55-$ bor C 2 & 5 dias estufa & sem env. & 21155 & 12905 & 17030 \\
\hline $56-$ bor B 3 & 5 dias estufa & sem env. & 19813 & 19359 & 19586 \\
\hline $61-$ bor C 0 & 4 meses & 4 horas & 21029 & 16120 & 18574 \\
\hline 62 - bor B 1 & 4 meses & 4 horas & 32405 & 15049 & 23727 \\
\hline $63-$ bor B 2 & 4 meses & 4 horas & 18490 & 16464 & 17477 \\
\hline $64-$ bor $C 3$ & 4 meses & 4 horas & 17969 & 15110 & 16539 \\
\hline
\end{tabular}


Tabela D.7 - Valores de deformação total $(\mathrm{mm} / \mathrm{mm})$ obtidos do ensaio de creep estático, para o experimento realizado com três observações por condição experimental

\begin{tabular}{|c|c|c|c|c|c|c|}
\hline \multirow[t]{2}{*}{$\begin{array}{l}\text { condição } \\
\text { experimental }\end{array}$} & \multicolumn{2}{|c|}{ envelhecimento } & \multicolumn{3}{|c|}{$\begin{array}{l}\text { deformação total }(\mathrm{mm} / \mathrm{mm}) \\
\text { réplicas ou observações }\end{array}$} & \multirow[b]{2}{*}{$Y$} \\
\hline & longo prazo & curto prazo & Y1 & Y2 & Y3 & \\
\hline $1-\operatorname{conv} C 0$ & sem env. & 4 horas & 0,00356 & 0,00217 & 0,00336 & 0,00303 \\
\hline $2-\operatorname{conv}$ B 1 & sem env. & 4 horas & 0,00394 & 0,00252 & 0,00515 & 0,00387 \\
\hline $3-\operatorname{conv}$ B 2 & sem env. & 4 horas & 0,00367 & 0,00213 & 0,00250 & 0,00276 \\
\hline $4-\operatorname{conv} C 3$ & sem env. & 4 horas & 0,00476 & 0,00399 & 0,00522 & 0,00466 \\
\hline $5-\operatorname{conv}$ B 0 & 5 dias estufa & sem env. & 0,00531 & 0,00808 & 0,00515 & 0,00618 \\
\hline $6-\operatorname{conv} C 1$ & 5 dias estufa & sem env. & 0,00169 & 0,00252 & 0,00158 & 0,00193 \\
\hline $7-\operatorname{conv} C 2$ & 5 dias estufa & sem env. & 0,00374 & 0,00348 & 0,00360 & 0,00361 \\
\hline $8-\operatorname{conv}$ B 3 & 5 dias estufa & sem env. & 0,00482 & 0,00541 & 0,00501 & 0,00508 \\
\hline $13-\operatorname{conv} \mathrm{C} 0$ & 4 meses & 4 horas & 0,00331 & 0,00368 & 0,00303 & 0,00334 \\
\hline $14-\operatorname{conv}$ B 1 & 4 meses & 4 horas & 0,00335 & 0,00366 & 0,00359 & 0,00353 \\
\hline $15-\operatorname{conv}$ B 2 & 4 meses & 4 horas & 0,00347 & 0,00334 & 0,00338 & 0,00340 \\
\hline $16-\operatorname{conv} C 3$ & 4 meses & 4 horas & 0,00367 & 0,00386 & 0,00428 & 0,00394 \\
\hline $17-$ pol C 0 & sem env. & sem env. & 0,00252 & 0,00194 & 0,00269 & 0,00238 \\
\hline $18-$ pol B 1 & sem env. & sem env. & 0,00245 & 0,00240 & 0,00310 & 0,00265 \\
\hline 19-pol B 2 & sem env. & sem env. & 0,00343 & 0,00276 & 0,00299 & 0,00306 \\
\hline $20-$ pol C 3 & sem env. & sem env. & 0,00427 & 0,00354 & 0,00329 & 0,00370 \\
\hline $21-$ pol B 0 & 5 dias estufa & 4 horas & 0,00202 & 0,00244 & 0,00291 & 0,00246 \\
\hline $22-$ pol C 1 & 5 dias estufa & 4 horas & 0,00431 & 0,00469 & 0,00284 & 0,00394 \\
\hline $23-$ pol C 2 & 5 dias estufa & 4 horas & 0,00223 & 0,00225 & 0,00496 & 0,00314 \\
\hline $24-$ pol B 3 & 5 dias estufa & 4 horas & 0,00359 & 0,00289 & 0,00402 & 0,00350 \\
\hline $29-$ pol C 0 & 4 meses & sem env. & 0,00340 & 0,00312 & 0,00284 & 0,00312 \\
\hline $30-$ pol B 1 & 4 meses & sem env. & 0,00264 & 0,00286 & 0,00265 & 0,00272 \\
\hline $31-$ pol B 2 & 4 meses & sem env. & 0,00279 & 0,00268 & 0,00275 & 0,00274 \\
\hline $32-$ pol C 3 & 4 meses & sem env. & 0,00404 & 0,00393 & 0,00411 & 0,00402 \\
\hline $49-$ bor $\mathrm{C} 0$ & sem env. & 4 horas & 0,00273 & 0,00246 & 0,00262 & 0,00260 \\
\hline $50-$ bor B 1 & sem env. & 4 horas & 0,00225 & 0,00269 & 0,00421 & 0,00305 \\
\hline $51-$ bor B 2 & sem env. & 4 horas & 0,00262 & 0,00306 & 0,00369 & 0,00312 \\
\hline $52-$ bor C 3 & sem env. & 4 horas & 0,00338 & 0,00328 & 0,00460 & 0,00375 \\
\hline $53-$ bor B 0 & 5 dias estufa & sem env. & 0,00515 & 0,00533 & 0,00649 & 0,00566 \\
\hline $54-$ bor C 1 & 5 dias estufa & sem env. & 0,00243 & 0,00277 & 0,00259 & 0,00260 \\
\hline $55-$ bor $C 2$ & 5 dias estufa & sem env. & 0,00202 & 0,00607 & 0,00545 & 0,00451 \\
\hline $56-$ bor B 3 & 5 dias estufa & sem env. & 0,00621 & 0,00664 & 0,00623 & 0,00636 \\
\hline 61 - bor C 0 & 4 meses & 4 horas & 0,00295 & 0,00306 & 0,00347 & 0,00316 \\
\hline $62-$ bor B 1 & 4 meses & 4 horas & 0,00283 & 0,00299 & 0,00272 & 0,00285 \\
\hline 63 - bor B 2 & 4 meses & 4 horas & 0,00330 & 0,00418 & 0,00447 & 0,00398 \\
\hline $64-$ bor C 3 & 4 meses & 4 horas & 0,00367 & 0,00376 & 0,00267 & 0,00337 \\
\hline
\end{tabular}


Tabela D.8 - Valores de deformação recuperável $(\mathrm{mm} / \mathrm{mm})$ obtidos do ensaio de creep estático, para o experimento realizado com três observações por condição experimental

\begin{tabular}{|c|c|c|c|c|c|c|}
\hline \multirow{3}{*}{$\begin{array}{l}\text { condição } \\
\text { experimental }\end{array}$} & \multirow{2}{*}{\multicolumn{2}{|c|}{ envelhecimento }} & \multirow{2}{*}{\multicolumn{4}{|c|}{ deformação recuperável $(\mathrm{mm} / \mathrm{mm})$}} \\
\hline & & & & & & \\
\hline & longo prazo & curto prazo & $\mathrm{Y} 1$ & Y2 & Y3 & $Y$ \\
\hline $1-\operatorname{conv} C 0$ & sem env. & 4 horas & 0,00211 & 0,00174 & 0,00190 & 0,00192 \\
\hline $2-\operatorname{conv}$ B 1 & sem env. & 4 horas & 0,00228 & 0,00155 & 0,00251 & 0,00211 \\
\hline $3-$ conv B 2 & sem env. & 4 horas & 0,00244 & 0,00143 & 0,00162 & 0,00183 \\
\hline $4-\operatorname{conv}$ C 3 & sem env. & 4 horas & 0,00223 & 0,00172 & 0,00196 & 0,00197 \\
\hline $5-\operatorname{conv}$ B 0 & 5 dias estufa & sem env. & 0,00336 & 0,00437 & 0,00328 & 0,00367 \\
\hline $6-\operatorname{conv} C 1$ & 5 dias estufa & sem env. & 0,00129 & 0,00185 & 0,00074 & 0,00129 \\
\hline $7-\operatorname{conv} C 2$ & 5 dias estufa & sem env. & 0,00279 & 0,00258 & 0,00260 & 0,00265 \\
\hline $8-\operatorname{conv}$ B 3 & 5 dias estufa & sem env. & 0,00351 & 0,00368 & 0,00364 & 0,00361 \\
\hline $13-\operatorname{conv} \mathrm{C} 0$ & 4 meses & 4 horas & 0,00246 & 0,00248 & 0,00254 & 0,00249 \\
\hline $14-\operatorname{conv}$ B 1 & 4 meses & 4 horas & 0,00206 & 0,00208 & 0,00219 & 0,00211 \\
\hline $15-\operatorname{conv}$ B 2 & 4 meses & 4 horas & 0,00226 & 0,00226 & 0,00234 & 0,00228 \\
\hline $16-\operatorname{conv} C 3$ & 4 meses & 4 horas & 0,00243 & 0,00258 & 0,00302 & 0,00268 \\
\hline $17-$ pol C 0 & sem env. & sem env. & 0,00153 & 0,00150 & 0,00135 & 0,00146 \\
\hline $18-$ pol B 1 & sem env. & sem env. & 0,00142 & 0,00142 & 0,00143 & 0,00142 \\
\hline $19-$ pol B 2 & sem env. & sem env. & 0,00221 & 0,00159 & 0,00173 & 0,00184 \\
\hline $20-$ pol C 3 & sem env. & sem env. & 0,00179 & 0,00140 & 0,00130 & 0,00150 \\
\hline $21-$ pol B 0 & 5 dias estufa & 4 horas & 0,00124 & 0,00183 & 0,00182 & 0,00163 \\
\hline $22-$ pol C 1 & 5 dias estufa & 4 horas & 0,00197 & 0,00260 & 0,00158 & 0,00205 \\
\hline $23-$ pol C 2 & 5 dias estufa & 4 horas & 0,00133 & 0,00147 & 223 & 0,00167 \\
\hline $24-$ pol B 3 & 5 dias estufa & 4 horas & 0,00162 & 0,00141 & 0,00195 & 0,00166 \\
\hline $29-$ pol C 0 & 4 meses & sem env. & 0,00200 & 0,00189 & 0,00184 & 0,00191 \\
\hline $30-$ pol B 1 & 4 meses & sem env. & 0,00171 & 0,00170 & 0,00168 & 0,00169 \\
\hline $31-$ pol B 2 & 4 meses & sem env. & 0,00193 & 0,00205 & 0,00198 & 0,00198 \\
\hline $32-$ pol C 3 & 4 meses & sem env. & 0,00252 & 0,00217 & 0,00292 & 0,00253 \\
\hline $49-$ bor C 0 & sem env. & 4 horas & 0,00149 & 0,00139 & 0,00149 & 0,00145 \\
\hline $50-$ bor B 1 & sem env. & 4 horas & 0,00136 & 0,00148 & 0,00207 & 0,00163 \\
\hline $51-$ bor B 2 & sem env. & 4 horas & 0,00168 & 0,00171 & 0,00211 & 0,00183 \\
\hline $52-$ bor C 3 & sem env. & 4 horas & 0,00153 & 0,00152 & 0,00167 & 0,00157 \\
\hline 53 - bor B 0 & 5 dias estufa & sem env. & 0,00336 & 0,00414 & 0,00356 & 0,00369 \\
\hline $54-$ bor C 1 & 5 dias estufa & sem env. & 0,00166 & 0,00150 & 0,00190 & 0,00169 \\
\hline $55-$ bor $C 2$ & 5 dias estufa & sem env. & 0,00157 & 0,00352 & 0,00365 & 0,00291 \\
\hline $56-$ bor B 3 & 5 dias estufa & sem env. & 0,00370 & 0,00370 & 0,00357 & 0,00366 \\
\hline $61-$ bor C 0 & 4 meses & 4 horas & 0,00189 & 0,00183 & 0,00207 & 0,00193 \\
\hline $62-$ bor B 1 & 4 meses & 4 horas & 0,00193 & 0,00197 & 0,00199 & 0,00196 \\
\hline $63-$ bor B 2 & 4 meses & 4 horas & 0,00207 & 0,00216 & 0,00261 & 0,00228 \\
\hline $64-$ bor C 3 & 4 meses & 4 horas & 0,00194 & 0,00209 & 0,00202 & 0,00202 \\
\hline
\end{tabular}


Tabela D.9 - Valores de deformação não recuperável $(\mathrm{mm} / \mathrm{mm})$ obtidos do ensaio de creep estático, para o experimento realizado com três observações por condição experimental

\begin{tabular}{|c|c|c|c|c|c|c|}
\hline \multirow{3}{*}{$\begin{array}{c}\text { condição } \\
\text { experimental }\end{array}$} & \multicolumn{6}{|c|}{ deformação não recuperável $(\mathrm{mm} / \mathrm{mm})$} \\
\hline & \multicolumn{2}{|c|}{ envelhecimento } & \multicolumn{3}{|c|}{ réplicas ou observações } & \multirow[b]{2}{*}{$Y$} \\
\hline & longo prazo & curto prazo & $\mathrm{Y} 1$ & Y2 & Y3 & \\
\hline $1-\operatorname{conv} C 0$ & sem env. & 4 horas & 0,00146 & 0,00043 & 0,00147 & 0,00112 \\
\hline $2-\operatorname{conv}$ B 1 & sem env. & 4 horas & 0,00166 & 0,00097 & 0,00264 & 0,00176 \\
\hline $3-\operatorname{conv}$ B 2 & sem env. & 4 horas & 0,00123 & 0,00070 & 0,00087 & 0,00093 \\
\hline $4-\operatorname{conv} C 3$ & sem env. & 4 horas & 0,00253 & 0,00227 & 0,00327 & 0,00269 \\
\hline $5-$ conv B 0 & 5 dias estufa & sem env. & 0,00195 & 0,00371 & 0,00187 & 0,00251 \\
\hline $6-\operatorname{conv} C 1$ & 5 dias estufa & sem env. & 0,00039 & 0,00068 & 0,00085 & 0,00064 \\
\hline $7-\operatorname{conv} C 2$ & 5 dias estufa & sem env. & 0,00095 & 0,00091 & 0,00101 & 0,00095 \\
\hline $8-\operatorname{conv}$ B 3 & 5 dias estufa & sem env. & 0,00131 & 0,00173 & 0,00137 & 0,00147 \\
\hline $13-\operatorname{conv} \mathrm{C} 0$ & 4 meses & 4 horas & 0,00085 & 0,00120 & 0,00049 & 0,00085 \\
\hline $14-\operatorname{conv} B 1$ & 4 meses & 4 horas & 0,00130 & 0,00158 & 0,00140 & 0,00143 \\
\hline $15-\operatorname{conv}$ B 2 & 4 meses & 4 horas & 0,00122 & 0,00108 & 0,00104 & 0,00111 \\
\hline $16-\operatorname{conv} C 3$ & 4 meses & 4 horas & 0,00124 & 0,00128 & 0,00126 & 0,00126 \\
\hline $17-$ pol C 0 & sem env. & sem env. & 0,00099 & 0,00044 & 0,00134 & 0,00092 \\
\hline $18-$ pol B 1 & sem env. & sem env. & 0,00102 & 0,00098 & 0,00167 & 0,00122 \\
\hline $19-$ pol B 2 & sem env. & sem env. & 0,00122 & 0,00117 & 0,00126 & 0,00122 \\
\hline $20-$ pol C 3 & sem env. & sem env. & 0,00248 & 0,00214 & 0,00199 & 0,00220 \\
\hline $21-$ pol B 0 & 5 dias estufa & 4 horas & 0,00077 & 0,00061 & 0,00110 & 0,00083 \\
\hline $22-$ pol C 1 & 5 dias estufa & 4 horas & 0,00234 & 0,00209 & 0,00126 & 0,00190 \\
\hline $23-$ pol C 2 & 5 dias estufa & 4 horas & 0,00091 & 0,00078 & 0,00273 & 0,00147 \\
\hline $24-$ pol B 3 & 5 dias estufa & 4 horas & 0,00198 & 0,00149 & 0,00208 & 0,00185 \\
\hline $29-$ pol C 0 & 4 meses & sem env. & 0,00141 & 0,00123 & 0,00100 & 0,00121 \\
\hline $30-$ pol B 1 & 4 meses & sem env. & 0,00093 & 0,00116 & 0,00097 & 0,00102 \\
\hline $31-$ pol B 2 & 4 meses & sem env. & 0,00086 & 0,00063 & 0,00078 & 0,00076 \\
\hline $32-$ pol C 3 & 4 meses & sem env. & 0,00153 & 0,00176 & 0,00119 & 0,00149 \\
\hline $49-$ bor C 0 & sem env. & 4 horas & 0,00125 & 0,00107 & 0,00113 & 0,00115 \\
\hline 50 - bor B 1 & sem env. & 4 horas & 0,00089 & 0,00121 & 0,00214 & 0,00141 \\
\hline $51-$ bor B 2 & sem env. & 4 horas & 0,00094 & 0,00134 & 0,00158 & 0,00128 \\
\hline $52-$ bor C 3 & sem env. & 4 horas & 0,00185 & 0,00176 & 0,00293 & 0,00218 \\
\hline $53-$ bor B 0 & 5 dias estufa & sem env. & 0,00179 & 0,00119 & 0,00293 & 0,00197 \\
\hline $54-$ bor $C 1$ & 5 dias estufa & sem env. & 0,00077 & 0,00126 & 0,00070 & 0,00091 \\
\hline $55-$ bor $C 2$ & 5 dias estufa & sem env. & 0,00045 & 0,00256 & 0,00181 & 0,00160 \\
\hline $56-$ bor B 3 & 5 dias estufa & sem env. & 0,00252 & 0,00294 & 0,00266 & 0,00270 \\
\hline $61-$ bor $C 0$ & 4 meses & 4 horas & 0,00106 & 0,00122 & 0,00140 & 0,00122 \\
\hline $62-$ bor B 1 & 4 meses & 4 horas & 0,00090 & 0,00102 & 0,00072 & 0,00088 \\
\hline $63-$ bor B 2 & 4 meses & 4 horas & 0,00123 & 0,00202 & 0,00186 & 0,00170 \\
\hline $64-$ bor $C 3$ & 4 meses & 4 horas & 0,00173 & 0,00167 & 0,00066 & 0,00135 \\
\hline
\end{tabular}


Tabela D.10 - Valores de recuperação (\%) obtidos do ensaio de creep estático, para o experimento realizado com três observações por condição experimental

\begin{tabular}{|c|c|c|c|c|c|c|}
\hline \multirow[t]{2}{*}{$\begin{array}{l}\text { condição } \\
\text { experimental }\end{array}$} & \multicolumn{2}{|c|}{ envelhecimento } & \multicolumn{4}{|c|}{$\begin{array}{l}\text { recuperação (\%) } \\
\text { réplicas ou observações }\end{array}$} \\
\hline & longo prazo & curto prazo & Y1 & Y2 & Y3 & $Y$ \\
\hline $1-\operatorname{conv} C 0$ & sem env. & 4 horas & 59,48 & 80,24 & 57,10 & 65,61 \\
\hline $2-\operatorname{conv}$ B 1 & sem env. & 4 horas & 56,91 & 61,65 & 48,70 & 55,75 \\
\hline $3-$ conv B 2 & sem env. & 4 horas & 63,90 & 69,25 & 64,50 & 65,88 \\
\hline $4-\operatorname{conv}$ C 3 & sem env. & 4 horas & 49,05 & 45,32 & 37,45 & 43,94 \\
\hline $5-\operatorname{conv}$ B 0 & 5 dias estufa & sem env. & 67,82 & 54,07 & 64,30 & 62,06 \\
\hline $6-\operatorname{conv} C 1$ & 5 dias estufa & sem env. & 76,59 & 74,48 & 46,47 & 65,85 \\
\hline $7-\operatorname{conv} C 2$ & 5 dias estufa & sem env. & 74,87 & 74,32 & 69,15 & 72,78 \\
\hline $8-\operatorname{conv}$ B 3 & 5 dias estufa & sem env. & 72,01 & 66,63 & 74,73 & 71,12 \\
\hline $13-\operatorname{conv} C 0$ & 4 meses & 4 horas & 74,31 & 67,26 & 83,25 & 74,94 \\
\hline $14-\operatorname{conv}$ B 1 & 4 meses & 4 horas & 61,84 & 53,83 & 60,92 & 58,86 \\
\hline $15-\operatorname{conv}$ B 2 & 4 meses & 4 horas & 62,43 & 67,28 & 69,60 & 66,44 \\
\hline $16-\operatorname{conv} C 3$ & 4 meses & 4 horas & 65,87 & 67,17 & 72,68 & 68,57 \\
\hline $17-$ pol C 0 & sem env. & sem env. & 60,86 & 77,56 & 51,35 & 63,26 \\
\hline $18-$ pol B 1 & sem env. & sem env. & 58,31 & 58,85 & 50,86 & 56,00 \\
\hline $19-$ pol B 2 & sem env. & sem env. & 64,44 & 58,04 & 58,37 & 60,28 \\
\hline $20-$ pol C 3 & sem env. & sem env. & 41,80 & 42,20 & 39,57 & 41,19 \\
\hline $21-$ pol B 0 & 5 dias estufa & 4 horas & 61,73 & 75,04 & 61,78 & 66,18 \\
\hline $22-$ pol C 1 & 5 dias estufa & 4 horas & 46,65 & 55,47 & 58,85 & 53,66 \\
\hline $23-$ pol C 2 & 5 dias estufa & 4 horas & 59,38 & 65,33 & 44,43 & 56,38 \\
\hline $24-$ pol B 3 & 5 dias estufa & 4 horas & 44,85 & 48,50 & 50,64 & 47,99 \\
\hline $29-$ pol C 0 & 4 meses & sem env. & 58,62 & 60,73 & 64,74 & 61,36 \\
\hline $30-$ pol B 1 & 4 meses & sem env. & 64,90 & 59,64 & 62,58 & 62,37 \\
\hline $31-$ pol B 2 & 4 meses & sem env. & 69,23 & 76,73 & 70,53 & 72,16 \\
\hline $32-$ pol C 3 & 4 meses & sem env. & 65,46 & 55,24 & 72,25 & 64,31 \\
\hline $49-$ bor C 0 & sem env. & 4 horas & 54,41 & 57,06 & 57,43 & 56,30 \\
\hline $50-$ bor B 1 & sem env. & 4 horas & 60,27 & 56,27 & 51,05 & 55,86 \\
\hline 51 - bor B 2 & sem env. & 4 horas & 66,06 & 53,88 & 60,28 & 60,07 \\
\hline $52-$ bor C 3 & sem env. & 4 horas & 45,63 & 49,82 & 36,81 & 44,08 \\
\hline 53 - bor B 0 & 5 dias estufa & sem env. & 66,29 & 77,66 & 54,53 & 66,16 \\
\hline $54-$ bor C 1 & 5 dias estufa & sem env. & 70,30 & 54,49 & 62,49 & 62,42 \\
\hline $55-$ bor $C 2$ & 5 dias estufa & sem env. & 76,52 & 58,53 & 63,95 & 66,33 \\
\hline 56 - bor B 3 & 5 dias estufa & sem env. & 59,04 & 57,55 & 57,84 & 58,14 \\
\hline $61-$ bor C 0 & 4 meses & 4 horas & 64,42 & 60,25 & 61,82 & 62,16 \\
\hline $62-$ bor B 1 & 4 meses & 4 horas & 66,46 & 66,05 & 75,51 & 69,34 \\
\hline $63-$ bor B 2 & 4 meses & 4 horas & 61,94 & 56,19 & 58,74 & 58,96 \\
\hline $64-$ bor C 3 & 4 meses & 4 horas & 52,54 & 56,81 & 75,20 & 61,52 \\
\hline
\end{tabular}


Tabela D.11 - Valores de módulo de fluência (MPa) obtidos do ensaio de creep estático, para o experimento realizado com três observações por condição experimental

\begin{tabular}{|c|c|c|c|c|c|c|}
\hline \multirow[t]{2}{*}{$\begin{array}{l}\text { condição } \\
\text { experimental }\end{array}$} & \multicolumn{2}{|c|}{ envelhecimento } & \multicolumn{3}{|c|}{$\begin{array}{l}\text { módulo de fluência (MPa) } \\
\text { réplicas ou observações }\end{array}$} & \multirow[b]{2}{*}{$Y$} \\
\hline & longo prazo & curto prazo & Y1 & Y2 & Y3 & \\
\hline $1-\operatorname{conv} C 0$ & sem env. & 4 horas & 120,49 & 177,83 & 117,70 & 138,67 \\
\hline $2-\operatorname{conv}$ B 1 & sem env. & 4 horas & 78,14 & 178,60 & 74,93 & 110,56 \\
\hline $3-\operatorname{conv}$ B 2 & sem env. & 4 horas & 84,91 & 185,44 & 162,00 & 144,12 \\
\hline $4-\operatorname{conv} \mathrm{C} 3$ & sem env. & 4 horas & 97,01 & 109,23 & 74,78 & 93,68 \\
\hline $5-$ conv B 0 & 5 dias estufa & sem env. & 85,98 & 49,42 & 77,00 & 70,80 \\
\hline $6-\operatorname{conv} C 1$ & 5 dias estufa & sem env. & 235,38 & 160,72 & 251,55 & 215,89 \\
\hline $7-\operatorname{conv} C 2$ & 5 dias estufa & sem env. & 104,78 & 115,32 & 122,39 & 114,16 \\
\hline $8-\operatorname{conv}$ B 3 & 5 dias estufa & sem env. & 90,42 & 75,43 & 82,81 & 82,89 \\
\hline $13-\operatorname{conv} C 0$ & 4 meses & 4 horas & 88,16 & 80,06 & 135,09 & 101,10 \\
\hline $14-\operatorname{conv}$ B 1 & 4 meses & 4 horas & 86,19 & 91,62 & 113,26 & 97,02 \\
\hline $15-\operatorname{conv}$ B 2 & 4 meses & 4 horas & 90,90 & 87,48 & 120,44 & 99,61 \\
\hline $16-\operatorname{conv} C 3$ & 4 meses & 4 horas & 88,64 & 76,16 & 107,28 & 90,69 \\
\hline $17-$ pol C 0 & sem env. & sem env. & 160,17 & 213,01 & 152,71 & 175,30 \\
\hline $18-$ pol B 1 & sem env. & sem env. & 167,89 & 169,15 & 143,17 & 160,07 \\
\hline $19-$ pol B 2 & sem env. & sem env. & 117,45 & 146,44 & 137,60 & 133,83 \\
\hline $20-$ pol C 3 & sem env. & sem env. & 90,69 & 120,57 & 120,06 & 110,44 \\
\hline $21-$ pol B 0 & 5 dias estufa & 4 horas & 192,28 & 157,62 & 104,49 & 151,46 \\
\hline $22-$ pol C 1 & 5 dias estufa & 4 horas & 100,63 & 82,37 & 148,69 & 110,57 \\
\hline $23-$ pol C 2 & 5 dias estufa & 4 horas & 195,79 & 172,98 & 60,58 & 143,12 \\
\hline $24-$ pol B 3 & 5 dias estufa & 4 horas & 110,75 & 134,02 & 73,57 & 106,11 \\
\hline $29-$ pol C 0 & 4 meses & sem env. & 118,86 & 129,03 & 142,22 & 130,04 \\
\hline $30-$ pol B 1 & 4 meses & sem env. & 152,74 & 142,16 & 154,32 & 149,74 \\
\hline $31-$ pol B 2 & 4 meses & sem env. & 143,89 & 154,51 & 154,73 & 151,04 \\
\hline $32-$ pol C 3 & 4 meses & sem env. & 109,13 & 107,77 & 102,34 & 106,41 \\
\hline $49-$ bor C 0 & sem env. & 4 horas & 141,69 & 159,45 & 146,80 & 149,31 \\
\hline $50-$ bor B 1 & sem env. & 4 horas & 171,61 & 150,79 & 69,22 & 130,54 \\
\hline $51-$ bor B 2 & sem env. & 4 horas & 154,50 & 130,46 & 81,34 & 122,10 \\
\hline 52 - bor C 3 & sem env. & 4 horas & 115,10 & 129,77 & 92,85 & 112,57 \\
\hline 53 - bor B 0 & 5 dias estufa & sem env. & 78,19 & 75,69 & 61,57 & 71,82 \\
\hline $54-$ bor $C 1$ & 5 dias estufa & sem env. & 171,00 & 144,99 & 176,22 & 164,07 \\
\hline $55-$ bor $C 2$ & 5 dias estufa & sem env. & 204,39 & 66,64 & 103,74 & 124,92 \\
\hline 56 - bor B 3 & 5 dias estufa & sem env. & 66,29 & 70,99 & 66,25 & 67,84 \\
\hline $61-$ bor C 0 & 4 meses & 4 horas & 105,74 & 101,89 & 126,09 & 111,24 \\
\hline $62-$ bor B 1 & 4 meses & 4 horas & 104,93 & 97,65 & 166,45 & 123,01 \\
\hline 63 - bor B 2 & 4 meses & 4 horas & 90,02 & 74,37 & 92,24 & 85,54 \\
\hline $64-$ bor C 3 & 4 meses & 4 horas & 80,41 & 78,00 & 153,19 & 103,87 \\
\hline
\end{tabular}


Tabela D.12 - Valores de módulo de fluência após recuperação (MPa) obtidos do ensaio de creep estático, para o experimento realizado com três observações por condição experimental

\begin{tabular}{|c|c|c|c|c|c|c|}
\hline \multirow{2}{*}{$\begin{array}{c}\text { condição } \\
\text { experimental }\end{array}$} & \multicolumn{2}{|c|}{ envelhecimento } & \multicolumn{4}{|c|}{$\begin{array}{l}\text { módulo de fluência após recuperação (MPa) } \\
\text { réplicas ou observações }\end{array}$} \\
\hline & longo prazo & curto prazo & $\mathrm{Y} 1$ & Y2 & Y3 & $Y$ \\
\hline $1-\operatorname{conv} C 0$ & sem env. & 4 horas & 299,69 & 907,29 & 285,43 & 497,47 \\
\hline $2-\operatorname{conv}$ B 1 & sem env. & 4 horas & 178,80 & 467,10 & 146,05 & 263,98 \\
\hline $3-\operatorname{conv}$ B 2 & sem env. & 4 horas & 237,10 & 739,47 & 451,09 & 475,89 \\
\hline $4-\operatorname{conv}$ C 3 & sem env. & 4 horas & 201,34 & 210,56 & 119,56 & 177,15 \\
\hline $5-\operatorname{conv}$ B 0 & 5 dias estufa & sem env. & 364,15 & 107,59 & 237,59 & 236,44 \\
\hline $6-\operatorname{conv} C 1$ & 5 dias estufa & sem env. & 1005,46 & 747,74 & 469,94 & 741,05 \\
\hline $7-\operatorname{conv} C 2$ & 5 dias estufa & sem env. & 471,43 & 462,68 & 393,62 & 442,58 \\
\hline $8-\operatorname{conv}$ B 3 & 5 dias estufa & sem env. & 316,65 & 237,60 & 423,11 & 325,79 \\
\hline $13-\operatorname{conv} \mathrm{C} 0$ & 4 meses & 4 horas & 343,12 & 244,52 & 1202,81 & 596,82 \\
\hline $14-\operatorname{conv}$ B 1 & 4 meses & 4 horas & 258,35 & 191,04 & 289,83 & 246,40 \\
\hline $15-\operatorname{conv}$ B 2 & 4 meses & 4 horas & 239,68 & 309,81 & 412,50 & 320,66 \\
\hline $16-\operatorname{conv} C 3$ & 4 meses & 4 horas & 257,32 & 235,34 & 445,70 & 312,79 \\
\hline $17-$ pol C 0 & sem env. & sem env. & 414,17 & 948,15 & 329,39 & 563,90 \\
\hline 18-pol B 1 & sem env. & sem env. & 402,89 & 410,15 & 353,94 & 388,99 \\
\hline $19-$ pol B 2 & sem env. & sem env. & 330,31 & 369,22 & 338,01 & 345,85 \\
\hline $20-$ pol C 3 & sem env. & sem env. & 156,94 & 223,36 & 198,39 & 192,90 \\
\hline $21-$ pol B 0 & 5 dias estufa & 4 horas & 507,76 & 631,52 & 270,26 & 469,85 \\
\hline $22-$ pol C 1 & 5 dias estufa & 4 horas & 192,92 & 184,96 & 415,93 & 264,60 \\
\hline $23-$ pol C 2 & 5 dias estufa & 4 horas & 482,73 & 499,61 & 108,32 & 363,55 \\
\hline $24-$ pol B 3 & 5 dias estufa & 4 horas & 200,08 & 259,99 & 168,03 & 209,37 \\
\hline $29-$ pol C 0 & 4 meses & sem env. & 299,98 & 335,73 & 405,29 & 347,00 \\
\hline $30-$ pol B 1 & 4 meses & sem env. & 441,33 & 354,77 & 425,90 & 407,33 \\
\hline $31-$ pol B 2 & 4 meses & sem env. & 522,39 & 687,36 & 520,98 & 576,91 \\
\hline $32-$ pol C 3 & 4 meses & sem env. & 386,09 & 240,57 & 408,08 & 344,91 \\
\hline $49-$ bor C 0 & sem env. & 4 horas & 311,37 & 386,50 & 353,12 & 350,33 \\
\hline $50-$ bor B 1 & sem env. & 4 horas & 432,55 & 359,01 & 159,61 & 317,05 \\
\hline $51-$ bor B 2 & sem env. & 4 horas & 510,27 & 294,08 & 257,28 & 353,88 \\
\hline $52-$ bor C 3 & sem env. & 4 horas & 214,45 & 291,29 & 148,08 & 217,94 \\
\hline 53 - bor B 0 & 5 dias estufa & sem env. & 328,83 & 338,78 & 137,98 & 268,53 \\
\hline $54-$ bor C 1 & 5 dias estufa & sem env. & 685,47 & 321,28 & 902,25 & 636,33 \\
\hline $55-$ bor $C 2$ & 5 dias estufa & sem env. & 943,66 & 167,65 & 270,57 & 460,63 \\
\hline 56 - bor B 3 & 5 dias estufa & sem env. & 160,76 & 176,72 & 160,22 & 165,90 \\
\hline $61-$ bor C 0 & 4 meses & 4 horas & 300,26 & 258,08 & 365,21 & 307,85 \\
\hline $62-$ bor B 1 & 4 meses & 4 horas & 333,10 & 291,10 & 797,37 & 473,85 \\
\hline 63 - bor B 2 & 4 meses & 4 horas & 235,94 & 221,32 & 226,78 & 228,01 \\
\hline $64-$ bor C 3 & 4 meses & 4 horas & 168,72 & 192,57 & 634,49 & 331,93 \\
\hline
\end{tabular}


Tabela D.13 - Valores de inclinação da curva de fluência obtidos do ensaio de creep estático, para o experimento realizado com três observações por condição experimental

\begin{tabular}{|c|c|c|c|c|c|c|}
\hline \multirow[t]{2}{*}{$\begin{array}{l}\text { condição } \\
\text { experimental }\end{array}$} & \multicolumn{2}{|c|}{ envelhecimento } & \multicolumn{4}{|c|}{$\begin{array}{r}\text { inclinação } \\
\text { réplicas ou observações }\end{array}$} \\
\hline & longo prazo & curto prazo & Y1 & Y2 & Y3 & $Y$ \\
\hline $1-\operatorname{conv} C 0$ & sem env. & 4 horas & 0,03636 & 0,02790 & 0,05271 & 0,03899 \\
\hline $2-\operatorname{conv}$ B 1 & sem env. & 4 horas & 0,09148 & 0,07269 & 0,06148 & 0,07522 \\
\hline $3-$ conv B 2 & sem env. & 4 horas & 0,05088 & 0,04447 & 0,05624 & 0,05053 \\
\hline $4-\operatorname{conv} \mathrm{C} 3$ & sem env. & 4 horas & 0,03758 & 0,16661 & 0,08223 & 0,09547 \\
\hline $5-$ conv B 0 & 5 dias estufa & sem env. & 0,07227 & 0,10387 & 0,05013 & 0,07542 \\
\hline $6-\operatorname{conv} C 1$ & 5 dias estufa & sem env. & 0,02420 & 0,10724 & 0,04677 & 0,05940 \\
\hline $7-\operatorname{conv} C 2$ & 5 dias estufa & sem env. & 0,02862 & 0,04107 & 0,03296 & 0,03422 \\
\hline $8-\operatorname{conv}$ B 3 & 5 dias estufa & sem env. & 0,06017 & 0,06673 & 0,07139 & 0,06610 \\
\hline $13-\operatorname{conv} \mathrm{C} 0$ & 4 meses & 4 horas & 0,04719 & 0,06586 & 0,05336 & 0,05547 \\
\hline $14-\operatorname{conv}$ B 1 & 4 meses & 4 horas & 0,08877 & 0,09684 & 0,07971 & 0,08844 \\
\hline $15-$ conv B 2 & 4 meses & 4 horas & 0,11800 & 0,06990 & 0,05519 & 0,08103 \\
\hline $16-\operatorname{conv} C 3$ & 4 meses & 4 horas & 0,10741 & 0,05418 & 0,04945 & 0,07035 \\
\hline $17-$ pol C 0 & sem env. & sem env. & 0,05065 & 0,04011 & 0,06645 & 0,05240 \\
\hline 18 - pol B 1 & sem env. & sem env. & 0,12745 & 0,10421 & 0,11412 & 0,11526 \\
\hline $19-$ pol B 2 & sem env. & sem env. & 0,09371 & 0,04735 & 0,05642 & 0,06583 \\
\hline $20-$ pol C 3 & sem env. & sem env. & 0,15236 & 0,12083 & 0,11819 & 0,13046 \\
\hline $21-$ pol B 0 & 5 dias estufa & 4 horas & 0,12191 & 0,06794 & 0,17132 & 0,12039 \\
\hline $22-$ pol C 1 & 5 dias estufa & 4 horas & 0,12183 & 0,18157 & 1290 & 0,13877 \\
\hline $23-$ pol C 2 & 5 dias estufa & 4 horas & 15986 & 319 & 0,18560 & 0,16288 \\
\hline $24-p o l$ B 3 & 5 dias estufa & 4 horas & 0,15640 & 0,15214 & 0,15389 & 0,15414 \\
\hline $29-$ pol C 0 & neses & sem env. & 0,14067 & 0,10534 & 0,10974 & 0,11858 \\
\hline $30-$ pol B 1 & 4 meses & sem env. & 0,14112 & 0,10321 & 0,09577 & 0,11337 \\
\hline $31-$ pol B 2 & 4 meses & sem env. & 0,07852 & 0,06382 & 0,11034 & 0,08423 \\
\hline $32-$ pol C 3 & 4 meses & sem env. & 0,11788 & 0,14167 & 0,08390 & 0,11448 \\
\hline $49-$ bor C 0 & sem env. & 4 horas & 0,09942 & 0,11634 & 0,09040 & 0,10206 \\
\hline $50-$ bor B 1 & sem env. & 4 horas & 0,10122 & 0,10136 & 0,11277 & 0,10512 \\
\hline 51 - bor B 2 & sem env. & 4 horas & 0,08431 & 0,10854 & 0,09882 & 0,09722 \\
\hline 52 - bor C 3 & sem env. & 4 horas & 0,15593 & 0,12137 & 0,13916 & 0,13882 \\
\hline 53 - bor B 0 & 5 dias estufa & sem env. & 0,08161 & 0,05612 & 0,10635 & 0,08136 \\
\hline $54-$ bor $C 1$ & 5 dias estufa & sem env. & 0,09961 & 0,10496 & 0,11586 & 0,10681 \\
\hline $55-$ bor $C 2$ & 5 dias estufa & sem env. & 0,07949 & 0,11029 & 0,14567 & 0,11182 \\
\hline 56 - bor B 3 & 5 dias estufa & sem env. & 0,11543 & 0,10619 & 0,11110 & 0,11091 \\
\hline $61-$ bor C 0 & 4 meses & 4 horas & 0,11549 & 0,08644 & 0,09097 & 0,09763 \\
\hline $62-$ bor B 1 & 4 meses & 4 horas & 0,12232 & 0,08033 & 0,09015 & 0,09760 \\
\hline $63-$ bor B 2 & 4 meses & 4 horas & 0,09654 & 0,17826 & 0,09811 & 0,12430 \\
\hline $64-$ bor C 3 & 4 meses & 4 horas & 0,09777 & 0,11191 & 0,09036 & 0,10002 \\
\hline
\end{tabular}


Tabela D.14 - Valores de deformação total $(\mathrm{mm} / \mathrm{mm})$ obtidos do ensaio de creep estático, para o experimento reduzido a duas observações por condição experimental

\begin{tabular}{|c|c|c|c|c|c|}
\hline \multirow{3}{*}{$\begin{array}{c}\text { condição } \\
\text { experimental }\end{array}$} & \multirow{2}{*}{\multicolumn{2}{|c|}{ envelhecimento }} & \multicolumn{3}{|c|}{ leformação total $(\mathrm{mm} / \mathrm{mm})$} \\
\hline & & & réplicas ou & ervações & \\
\hline & longo prazo & curto prazo & $\mathrm{Y} 1$ & Y2 & $Y$ \\
\hline $1-\operatorname{conv} C 0$ & sem env. & 4 horas & 0,00356 & 0,00336 & 0,00346 \\
\hline $2-\operatorname{conv}$ B 1 & sem env. & 4 horas & 0,00252 & 0,00515 & 0,00383 \\
\hline $3-\operatorname{conv}$ B 2 & sem env. & 4 horas & 0,00213 & 0,00250 & 0,00231 \\
\hline $4-\operatorname{conv}$ C 3 & sem env. & 4 horas & 0,00476 & 0,00399 & 0,00437 \\
\hline $5-\operatorname{conv}$ B 0 & 5 dias estufa & sem env. & 0,00531 & 0,00515 & 0,00523 \\
\hline $6-\operatorname{conv} C 1$ & 5 dias estufa & sem env. & 0,00169 & 0,00252 & 0,00211 \\
\hline $7-\operatorname{conv} C 2$ & 5 dias estufa & sem env. & 0,00348 & 0,00360 & 0,00354 \\
\hline $8-\operatorname{conv}$ B 3 & 5 dias estufa & sem env. & 0,00482 & 0,00501 & 0,00491 \\
\hline $13-\operatorname{conv} \mathrm{C} 0$ & 4 meses & 4 horas & 0,00331 & 0,00368 & 0,00350 \\
\hline $14-\operatorname{conv}$ B 1 & 4 meses & 4 horas & 0,00366 & 0,00359 & 0,00362 \\
\hline $15-\operatorname{conv}$ B 2 & 4 meses & 4 horas & 0,00334 & 0,00338 & 0,00336 \\
\hline $16-\operatorname{conv} C 3$ & 4 meses & 4 horas & 0,00367 & 0,00386 & 0,00376 \\
\hline $17-$ pol C 0 & sem env. & sem env. & 0,00252 & 0,00269 & 0,00261 \\
\hline $18-$ pol B 1 & sem env. & sem env. & 0,00245 & 0,00240 & 0,00242 \\
\hline $19-$ pol B 2 & sem env. & sem env. & 0,00276 & 0,00299 & 0,00287 \\
\hline $20-$ pol C 3 & sem env. & sem env. & 0,00354 & 0,00329 & 0,00341 \\
\hline $21-$ pol B 0 & 5 dias estufa & 4 horas & 0,00202 & 0,00244 & 0,00223 \\
\hline $22-$ pol C 1 & 5 dias estufa & 4 horas & 0,00431 & 0,00284 & 0,00357 \\
\hline $23-$ pol C 2 & 5 dias estufa & 4 horas & 0,00223 & 0,00225 & 0,00224 \\
\hline $24-$ pol B 3 & 5 dias estufa & 4 horas & 0,00359 & 0,00402 & 0,00380 \\
\hline $29-$ pol C 0 & 4 meses & sem env. & 0,00340 & 0,00312 & 0,00326 \\
\hline $30-$ pol B 1 & 4 meses & sem env. & 0,00264 & 0,00265 & 0,00264 \\
\hline 31 - pol B 2 & 4 meses & sem env. & 0,00279 & 0,00275 & 0,00277 \\
\hline $32-$ pol C 3 & 4 meses & sem env. & 0,00404 & 0,00393 & 0,00398 \\
\hline $49-$ bor C 0 & sem env. & 4 horas & 0,00273 & 0,00262 & 0,00267 \\
\hline $50-$ bor B 1 & sem env. & 4 horas & 0,00269 & 0,00421 & 0,00345 \\
\hline $51-$ bor B 2 & sem env. & 4 horas & 0,00306 & 0,00369 & 0,00337 \\
\hline $52-$ bor C 3 & sem env. & 4 horas & 0,00338 & 0,00328 & 0,00333 \\
\hline $53-$ bor B 0 & 5 dias estufa & sem env. & 0,00515 & 0,00533 & 0,00524 \\
\hline $54-$ bor C 1 & 5 dias estufa & sem env. & 0,00243 & 0,00277 & 0,00260 \\
\hline $55-$ bor $C 2$ & 5 dias estufa & sem env. & 0,00202 & 0,00607 & 0,00404 \\
\hline 56 - bor B 3 & 5 dias estufa & sem env. & 0,00621 & 0,00623 & 0,00622 \\
\hline $61-$ bor C 0 & 4 meses & 4 horas & 0,00295 & 0,00306 & 0,00301 \\
\hline $62-$ bor B 1 & 4 meses & 4 horas & 0,00283 & 0,00299 & 0,00291 \\
\hline $63-$ bor B 2 & 4 meses & 4 horas & 0,00418 & 0,00447 & 0,00432 \\
\hline $64-$ bor C 3 & 4 meses & 4 horas & 0,00367 & 0,00376 & 0,00371 \\
\hline
\end{tabular}


Tabela D.15 - Valores de deformação recuperável $(\mathrm{mm} / \mathrm{mm})$ obtidos do ensaio de creep estático, para o experimento reduzido a duas observações por condição experimental

\begin{tabular}{|c|c|c|c|c|c|}
\hline \multirow{3}{*}{$\begin{array}{c}\text { condição } \\
\text { experimental }\end{array}$} & \multicolumn{5}{|c|}{ deformação recuperável $(\mathrm{mm} / \mathrm{mm})$} \\
\hline & \multicolumn{2}{|c|}{ envelhecimento } & \multicolumn{2}{|c|}{ réplicas ou observações } & \\
\hline & longo prazo & curto prazo & Y1 & Y2 & $Y$ \\
\hline $1-\operatorname{conv} \mathrm{C} 0$ & sem env. & 4 horas & 0,00211 & 0,00190 & 0,00200 \\
\hline $2-\operatorname{conv}$ B 1 & sem env. & 4 horas & 0,00155 & 0,00251 & 0,00203 \\
\hline $3-\operatorname{conv}$ B 2 & sem env. & 4 horas & 0,00143 & 0,00162 & 0,00153 \\
\hline $4-\operatorname{conv} C 3$ & sem env. & 4 horas & 0,00223 & 0,00172 & 0,00197 \\
\hline $5-\operatorname{conv}$ B 0 & 5 dias estufa & sem env. & 0,00336 & 0,00328 & 0,00332 \\
\hline $6-\operatorname{conv} C 1$ & 5 dias estufa & sem env. & 0,00129 & 0,00185 & 0,00157 \\
\hline $7-\operatorname{conv} C 2$ & 5 dias estufa & sem env. & 0,00258 & 0,00260 & 0,00259 \\
\hline $8-\operatorname{conv}$ B 3 & 5 dias estufa & sem env. & 0,00351 & 0,00364 & 0,00358 \\
\hline $13-\operatorname{conv} \mathrm{C} 0$ & 4 meses & 4 horas & 0,00246 & 0,00248 & 0,00247 \\
\hline $14-\operatorname{conv}$ B 1 & 4 meses & 4 horas & 0,00208 & 0,00219 & 0,00213 \\
\hline $15-\operatorname{conv}$ B 2 & 4 meses & 4 horas & 0,00226 & 0,00234 & 0,00230 \\
\hline $16-\operatorname{conv}$ C 3 & 4 meses & 4 horas & 0,00243 & 0,00258 & 0,00250 \\
\hline $17-$ pol C 0 & sem env. & sem env. & 0,00153 & 0,00135 & 0,00144 \\
\hline $18-$ pol B 1 & sem env. & sem env. & 0,00142 & 0,00142 & 0,00142 \\
\hline $19-$ pol B 2 & sem env. & sem env. & 0,00159 & 0,00173 & 0,00166 \\
\hline $20-$ pol C 3 & sem env. & sem env. & 0,00140 & 0,00130 & 0,00135 \\
\hline $21-$ pol B 0 & 5 dias estufa & 4 horas & 0,00124 & 0,00183 & 0,00154 \\
\hline $22-$ pol C 1 & 5 dias estufa & 4 horas & 0,00197 & 0,00158 & 0,00177 \\
\hline $23-$ pol C 2 & 5 dias estufa & 4 horas & 0,00133 & 0,00147 & 0,00140 \\
\hline $24-$ pol B 3 & 5 dias estufa & 4 horas & 0,00162 & 0,00195 & 0,00178 \\
\hline $29-$ pol C 0 & 4 meses & sem env. & 0,00200 & 0,00189 & 0,00194 \\
\hline $30-$ pol B 1 & 4 meses & sem env. & 0,00171 & 0,00168 & 0,00169 \\
\hline $31-$ pol B 2 & 4 meses & sem env. & 0,00193 & 0,00198 & 0,00195 \\
\hline $32-$ pol C 3 & 4 meses & sem env. & 0,00252 & 0,00217 & 0,00234 \\
\hline $49-$ bor $C 0$ & sem env. & 4 horas & 0,00149 & 0,00149 & 0,00149 \\
\hline $50-$ bor B 1 & sem env. & 4 horas & 0,00148 & 0,00207 & 0,00177 \\
\hline $51-$ bor B 2 & sem env. & 4 horas & 0,00171 & 0,00211 & 0,00191 \\
\hline $52-$ bor C 3 & sem env. & 4 horas & 0,00153 & 0,00152 & 0,00152 \\
\hline $53-$ bor B 0 & 5 dias estufa & sem env. & 0,00336 & 0,00414 & 0,00375 \\
\hline $54-$ bor C 1 & 5 dias estufa & sem env. & 0,00166 & 0,00150 & 0,00158 \\
\hline $55-$ bor $C 2$ & 5 dias estufa & sem env. & 0,00157 & 0,00352 & 0,00254 \\
\hline 56 - bor B 3 & 5 dias estufa & sem env. & 0,00370 & 0,00357 & 0,00364 \\
\hline $61-$ bor C 0 & 4 meses & 4 horas & 0,00189 & 0,00183 & 0,00186 \\
\hline 62 - bor B 1 & 4 meses & 4 horas & 0,00193 & 0,00197 & 0,00195 \\
\hline $63-$ bor B 2 & 4 meses & 4 horas & 0,00216 & 0,00261 & 0,00238 \\
\hline $64-$ bor C 3 & 4 meses & 4 horas & 0,00194 & 0,00209 & 0,00202 \\
\hline
\end{tabular}


Tabela D.16 - Valores de deformação não recuperável $(\mathrm{mm} / \mathrm{mm})$ obtidos do ensaio de creep estático, para o experimento reduzido a duas observações por condição experimental

\begin{tabular}{|c|c|c|c|c|c|}
\hline \multirow{3}{*}{$\begin{array}{l}\text { condição } \\
\text { experimental }\end{array}$} & \multirow{2}{*}{\multicolumn{2}{|c|}{ envelhecimento }} & \multicolumn{3}{|c|}{ deformação não recuperável $(\mathrm{mm} / \mathrm{mm})$} \\
\hline & & & réplicas ou o & servações & \\
\hline & longo prazo & curto prazo & $\mathrm{Y}_{1}$ & Y2 & $Y$ \\
\hline $1-\operatorname{conv} C 0$ & sem env. & 4 horas & 0,00146 & 0,00147 & 0,00146 \\
\hline $2-\operatorname{conv}$ B 1 & sem env. & 4 horas & 0,00097 & 0,00264 & 0,00181 \\
\hline $3-\operatorname{conv}$ B 2 & sem env. & 4 horas & 0,00070 & 0,00087 & 0,00079 \\
\hline $4-\operatorname{conv} \mathrm{C} 3$ & sem env. & 4 horas & 0,00253 & 0,00227 & 0,00240 \\
\hline $5-\operatorname{conv}$ B 0 & 5 dias estufa & sem env. & 0,00195 & 0,00187 & 0,00191 \\
\hline $6-\operatorname{conv} C 1$ & 5 dias estufa & sem env. & 0,00039 & 0,00068 & 0,00053 \\
\hline $7-\operatorname{conv} C 2$ & 5 dias estufa & sem env. & 0,00091 & 0,00101 & 0,00096 \\
\hline $8-\operatorname{conv} B 3$ & 5 dias estufa & sem env. & 0,00131 & 0,00137 & 0,00134 \\
\hline $13-\operatorname{conv} \mathrm{C} 0$ & 4 meses & 4 horas & 0,00085 & 0,00120 & 0,00103 \\
\hline $14-\operatorname{conv}$ B 1 & 4 meses & 4 horas & 0,00158 & 0,00140 & 0,00149 \\
\hline $15-\operatorname{conv} B 2$ & 4 meses & 4 horas & 0,00108 & 0,00104 & 0,00106 \\
\hline $16-\operatorname{conv} \mathrm{C} 3$ & 4 meses & 4 horas & 0,00124 & 0,00128 & 0,00126 \\
\hline 17- pol C 0 & sem env. & sem env. & 0,00099 & 0,00134 & 0,00116 \\
\hline $18-$ pol B 1 & sem env. & sem env. & 0,00102 & 0,00098 & 0,00100 \\
\hline $19-$ pol B 2 & sem env. & sem env. & 0,00117 & 0,00126 & 0,00121 \\
\hline $20-$ pol C 3 & sem env. & sem env. & 0,00214 & 0,00199 & 0,00206 \\
\hline $21-$ pol B 0 & 5 dias estufa & 4 horas & 0,00077 & 0,00061 & 0,00069 \\
\hline $22-$ pol C 1 & 5 dias estufa & 4 horas & 0,00234 & 0,00126 & 0,00180 \\
\hline $23-$ pol C 2 & 5 dias estufa & 4 horas & 0,00091 & 0,00078 & 0,00084 \\
\hline $24-$ pol B 3 & 5 dias estufa & 4 horas & 0,00198 & 0,00208 & 0,00203 \\
\hline $29-$ pol C 0 & 4 meses & sem env. & 0,00141 & 0,00123 & 0,00132 \\
\hline $30-$ pol B 1 & 4 meses & sem env. & 0,00093 & 0,00097 & 0,00095 \\
\hline $31-$ pol B 2 & 4 meses & sem env. & 0,00086 & 0,00078 & 0,00082 \\
\hline $32-$ pol C 3 & 4 meses & sem env. & 0,00153 & 0,00176 & 0,00164 \\
\hline $49-$ bor C 0 & sem env. & 4 horas & 0,00125 & 0,00113 & 0,00119 \\
\hline $50-$ bor B 1 & sem env. & 4 horas & 0,00121 & 0,00214 & 0,00168 \\
\hline $51-$ bor B 2 & sem env. & 4 horas & 0,00134 & 0,00158 & 0,00146 \\
\hline $52-$ bor C 3 & sem env. & 4 horas & 0,00185 & 0,00176 & 0,00181 \\
\hline 53 - bor B 0 & 5 dias estufa & sem env. & 0,00179 & 0,00119 & 0,00149 \\
\hline $54-$ bor C 1 & 5 dias estufa & sem env. & 0,00077 & 0,00126 & 0,00101 \\
\hline $55-$ bor $C 2$ & 5 dias estufa & sem env. & 0,00045 & 0,00256 & 0,00150 \\
\hline $56-$ bor B 3 & 5 dias estufa & sem env. & 0,00252 & 0,00266 & 0,00259 \\
\hline $61-$ bor C 0 & 4 meses & 4 horas & 0,00106 & 0,00122 & 0,00114 \\
\hline $62-$ bor B 1 & 4 meses & 4 horas & 0,00090 & 0,00102 & 0,00096 \\
\hline $63-$ bor B 2 & 4 meses & 4 horas & 0,00202 & 0,00186 & 0,00194 \\
\hline $64-$ bor C 3 & 4 meses & 4 horas & 0,00173 & 0,00167 & 0,00170 \\
\hline
\end{tabular}


Tabela D.17 - Valores de recuperação (\%) obtidos do ensaio de creep estático, para o experimento reduzido a duas observações por condição experimental

\begin{tabular}{|c|c|c|c|c|c|}
\hline \multirow{3}{*}{$\begin{array}{l}\text { condição } \\
\text { experimental }\end{array}$} & \multirow{2}{*}{\multicolumn{2}{|c|}{ envelhecimento }} & \multicolumn{3}{|c|}{ recuperação (\%) } \\
\hline & & & réplicas ou ob & vações & \\
\hline & longo prazo & curto prazo & $\mathrm{Y} 1$ & Y2 & $Y$ \\
\hline $1-\operatorname{conv} C 0$ & sem env. & 4 horas & 59,48 & 57,10 & 58,29 \\
\hline $2-\operatorname{conv}$ B 1 & sem env. & 4 horas & 61,65 & 48,70 & 55,18 \\
\hline $3-\operatorname{conv}$ B 2 & sem env. & 4 horas & 69,25 & 64,50 & 66,87 \\
\hline $4-\operatorname{conv} C 3$ & sem env. & 4 horas & 49,05 & 45,32 & 47,18 \\
\hline $5-$ conv B 0 & 5 dias estufa & sem env. & 67,82 & 64,30 & 66,06 \\
\hline $6-\operatorname{conv} C 1$ & 5 dias estufa & sem env. & 76,59 & 74,48 & 75,53 \\
\hline $7-\operatorname{conv} C 2$ & 5 dias estufa & sem env. & 74,32 & 46,47 & 60,40 \\
\hline $8-\operatorname{conv}$ B 3 & 5 dias estufa & sem env. & 72,01 & 74,73 & 73,37 \\
\hline $13-\operatorname{conv} \mathrm{C} 0$ & 4 meses & 4 horas & 74,31 & 67,26 & 70,79 \\
\hline $14-\operatorname{conv}$ B 1 & 4 meses & 4 horas & 53,83 & 60,92 & 57,38 \\
\hline $15-\operatorname{conv}$ B 2 & 4 meses & 4 horas & 67,28 & 69,60 & 68,44 \\
\hline $16-\operatorname{conv} C 3$ & 4 meses & 4 horas & 65,87 & 67,17 & 66,52 \\
\hline $17-$ pol C 0 & sem env. & sem env. & 60,86 & 51,35 & 56,10 \\
\hline $18-$ pol B 1 & sem env. & sem env. & 58,31 & 58,85 & 58,58 \\
\hline 19 - pol B 2 & sem env. & sem env. & 58,04 & 58,37 & 58,20 \\
\hline $20-$ pol C 3 & sem env. & sem env. & 42,20 & 39,57 & 40,88 \\
\hline $21-$ pol B 0 & 5 dias estufa & 4 horas & 61,73 & 75,04 & 68,39 \\
\hline $22-$ pol C 1 & 5 dias estufa & 4 horas & 46,65 & 58,85 & 52,75 \\
\hline $23-$ pol C 2 & 5 dias estufa & 4 horas & 59,38 & 65,33 & 62,36 \\
\hline $24-$ pol B 3 & 5 dias estufa & 4 horas & 44,85 & 50,64 & 47,74 \\
\hline $29-$ pol C 0 & 4 meses & sem env. & 58,62 & 60,73 & 59,67 \\
\hline $30-$ pol B 1 & 4 meses & sem env. & 64,90 & 62,58 & 63,74 \\
\hline $31-$ pol B 2 & 4 meses & sem env. & 69,23 & 70,53 & 69,88 \\
\hline $32-$ pol C 3 & 4 meses & sem env. & 65,46 & 55,24 & 60,35 \\
\hline $49-$ bor C 0 & sem env. & 4 horas & 54,41 & 57,43 & 55,92 \\
\hline $50-$ bor B 1 & sem env. & 4 horas & 56,27 & 51,05 & 53,66 \\
\hline 51 - bor B 2 & sem env. & 4 horas & 53,88 & 60,28 & 57,08 \\
\hline 52 - bor C 3 & sem env. & 4 horas & 45,63 & 49,82 & 47,72 \\
\hline 53 - bor B 0 & 5 dias estufa & sem env. & 66,29 & 77,66 & 71,98 \\
\hline $54-$ bor C 1 & 5 dias estufa & sem env. & 70,30 & 54,49 & 62,39 \\
\hline $55-$ bor $C 2$ & 5 dias estufa & sem env. & 76,52 & 58,53 & 67,52 \\
\hline 56 - bor B 3 & 5 dias estufa & sem env. & 59,04 & 57,84 & 58,44 \\
\hline 61 - bor C 0 & 4 meses & 4 horas & 64,42 & 60,25 & 62,33 \\
\hline 62 - bor B 1 & 4 meses & 4 horas & 66,46 & 66,05 & 66,25 \\
\hline $63-$ bor B 2 & 4 meses & 4 horas & 56,19 & 58,74 & 57,46 \\
\hline $64-$ bor C 3 & 4 meses & 4 horas & 52,54 & 56,81 & 54,68 \\
\hline
\end{tabular}


Tabela D.18 - Valores de módulo de fluência (MPa) obtidos do ensaio de creep estático, para o experimento reduzido a duas observações por condição experimental

\begin{tabular}{|c|c|c|c|c|c|}
\hline \multirow{3}{*}{$\begin{array}{l}\text { condição } \\
\text { experimental }\end{array}$} & \multirow{2}{*}{\multicolumn{2}{|c|}{ envelhecimento }} & \multirow{2}{*}{\multicolumn{2}{|c|}{$\begin{array}{l}\text { módulo de fluência (MPa) } \\
\text { réplicas ou observações }\end{array}$}} & \multirow[b]{3}{*}{$Y$} \\
\hline & & & & & \\
\hline & longo prazo & curto prazo & $\mathrm{Y} 1$ & Y2 & \\
\hline $1-\operatorname{conv} C 0$ & sem env. & 4 horas & 120,49 & 117,70 & 119,10 \\
\hline $2-\operatorname{conv}$ B 1 & sem env. & 4 horas & 178,60 & 74,93 & 126,77 \\
\hline $3-\operatorname{conv}$ B 2 & sem env. & 4 horas & 185,44 & 162,00 & 173,72 \\
\hline $4-\operatorname{conv} C 3$ & sem env. & 4 horas & 97,01 & 109,23 & 103,12 \\
\hline $5-\operatorname{conv}$ B 0 & 5 dias estufa & sem env. & 85,98 & 77,00 & 81,49 \\
\hline $6-\operatorname{conv} C 1$ & 5 dias estufa & sem env. & 235,38 & 160,72 & 198,05 \\
\hline $7-\operatorname{conv} C 2$ & 5 dias estufa & sem env. & 115,32 & 122,39 & 118,85 \\
\hline $8-\operatorname{conv}$ B 3 & 5 dias estufa & sem env. & 90,42 & 82,81 & 86,62 \\
\hline $13-\operatorname{conv} \mathrm{C} 0$ & 4 meses & 4 horas & 88,16 & 80,06 & 84,11 \\
\hline $14-\operatorname{conv}$ B 1 & 4 meses & 4 horas & 91,62 & 113,26 & 102,44 \\
\hline $15-\operatorname{conv}$ B 2 & 4 meses & 4 horas & 87,48 & 120,44 & 103,96 \\
\hline $16-\operatorname{conv} C 3$ & 4 meses & 4 horas & 88,64 & 76,16 & 82,40 \\
\hline 17- pol C 0 & sem env. & sem env. & 160,17 & 152,71 & 156,44 \\
\hline $18-$ pol B 1 & sem env. & sem env. & 167,89 & 169,15 & 168,52 \\
\hline $19-$ pol B 2 & sem env. & sem env. & 146,44 & 137,60 & 142,02 \\
\hline $20-$ pol C 3 & sem env. & sem env. & 120,57 & 120,06 & 120,32 \\
\hline $21-$ pol B 0 & 5 dias estufa & 4 horas & 192,28 & 157,62 & 174,95 \\
\hline $22-$ pol C 1 & 5 dias estufa & 4 horas & 100,63 & 148,69 & 124,66 \\
\hline $23-$ pol C 2 & 5 dias estufa & 4 horas & 195,79 & 172,98 & 184,38 \\
\hline $24-$ pol B 3 & 5 dias estufa & 4 horas & 110,75 & 73,57 & 92,16 \\
\hline $29-$ pol C 0 & 4 meses & sem env. & 118,86 & 129,03 & 123,95 \\
\hline $30-$ pol B 1 & 4 meses & sem env. & 152,74 & 154,32 & 153,53 \\
\hline $31-$ pol B 2 & 4 meses & sem env. & 143,89 & 154,73 & 149,31 \\
\hline $32-$ pol C 3 & 4 meses & sem env. & 109,13 & 107,77 & 108,45 \\
\hline $49-$ bor C 0 & sem env. & 4 horas & 141,69 & 146,80 & 144,24 \\
\hline 50 - bor B 1 & sem env. & 4 horas & 150,79 & 69,22 & 110,01 \\
\hline $51-$ bor B 2 & sem env. & 4 horas & 130,46 & 81,34 & 105,90 \\
\hline $52-$ bor C 3 & sem env. & 4 horas & 115,10 & 129,77 & 122,43 \\
\hline $53-$ bor B 0 & 5 dias estufa & sem env. & 78,19 & 75,69 & 76,94 \\
\hline $54-$ bor $C 1$ & 5 dias estufa & sem env. & 171,00 & 144,99 & 157,99 \\
\hline $55-$ bor $C 2$ & 5 dias estufa & sem env. & 204,39 & 66,64 & 135,52 \\
\hline 56 - bor B 3 & 5 dias estufa & sem env. & 66,29 & 66,25 & 66,27 \\
\hline $61-$ bor $\mathrm{C} 0$ & 4 meses & 4 horas & 105,74 & 101,89 & 103,82 \\
\hline $62-$ bor B 1 & 4 meses & 4 horas & 104,93 & 97,65 & 101,29 \\
\hline $63-$ bor B 2 & 4 meses & 4 horas & 74,37 & 92,24 & 83,31 \\
\hline $64-$ bor C 3 & 4 meses & 4 horas & 80,41 & 78,00 & 79,21 \\
\hline
\end{tabular}


Tabela D.19 - Valores de módulo de fluência após recuperação (MPa) obtidos do ensaio de creep estático, para o experimento reduzido a duas observações por condição experimental

\begin{tabular}{|c|c|c|c|c|c|}
\hline \multirow{3}{*}{$\begin{array}{l}\text { condição } \\
\text { experimental }\end{array}$} & \multirow{2}{*}{\multicolumn{2}{|c|}{ envelhecimento }} & \multicolumn{3}{|c|}{ módulo de fluência após recuperação (MPa) } \\
\hline & & & réplicas ou & ervações & \\
\hline & longo prazo & curto prazo & $\mathrm{Y} 1$ & Y2 & $Y$ \\
\hline $1-\operatorname{conv} C 0$ & sem env. & 4 horas & 299,69 & 285,43 & 292,56 \\
\hline $2-\operatorname{conv}$ B 1 & sem env. & 4 horas & 467,10 & 146,05 & 306,57 \\
\hline $3-\operatorname{conv}$ B 2 & sem env. & 4 horas & 739,47 & 451,09 & 595,28 \\
\hline $4-\operatorname{conv} \mathrm{C} 3$ & sem env. & 4 horas & 201,34 & 210,56 & 205,95 \\
\hline $5-\operatorname{conv}$ B 0 & 5 dias estufa & sem env. & 364,15 & 237,59 & 300,87 \\
\hline $6-\operatorname{conv} C 1$ & 5 dias estufa & sem env. & 1005,46 & 747,74 & 876,60 \\
\hline $7-\operatorname{conv} C 2$ & 5 dias estufa & sem env. & 462,68 & 393,62 & 428,15 \\
\hline $8-\operatorname{conv}$ B 3 & 5 dias estufa & sem env. & 316,65 & 423,11 & 369,88 \\
\hline $13-\operatorname{conv} \mathrm{C} 0$ & 4 meses & 4 horas & 343,12 & 244,52 & 293,82 \\
\hline $14-\operatorname{conv}$ B 1 & 4 meses & 4 horas & 191,04 & 289,83 & 240,43 \\
\hline $15-\operatorname{conv}$ B 2 & 4 meses & 4 horas & 309,81 & 412,50 & 361,15 \\
\hline $16-\operatorname{conv} C 3$ & 4 meses & 4 horas & 257,32 & 235,34 & 246,33 \\
\hline $17-$ pol C 0 & sem env. & sem env. & 414,17 & 329,39 & 371,78 \\
\hline $18-$ pol B 1 & sem env. & sem env. & 402,89 & 410,15 & 406,52 \\
\hline $19-$ pol B 2 & sem env. & sem env. & 369,22 & 338,01 & 353,62 \\
\hline $20-$ pol C 3 & sem env. & sem env. & 223,36 & 198,39 & 210,88 \\
\hline $21-$ pol B 0 & 5 dias estufa & 4 horas & 507,76 & 631,52 & 569,64 \\
\hline $22-$ pol C 1 & 5 dias estufa & 4 horas & 192,92 & 415,93 & 304,42 \\
\hline $23-$ pol C 2 & 5 dias estufa & 4 horas & 482,73 & 499,61 & 491,17 \\
\hline $24-$ pol B 3 & 5 dias estufa & 4 horas & 200,08 & 168,03 & 184,06 \\
\hline $29-$ pol C 0 & 4 meses & sem env. & 299,98 & 335,73 & 317,86 \\
\hline $30-$ pol B 1 & 4 meses & sem env. & 441,33 & 425,90 & 433,61 \\
\hline $31-$ pol B 2 & 4 meses & sem env. & 522,39 & 520,98 & 521,68 \\
\hline $32-$ pol C 3 & 4 meses & sem env. & 386,09 & 240,57 & 313,33 \\
\hline $49-$ bor C 0 & sem env. & 4 horas & 311,37 & 353,12 & 332,25 \\
\hline $50-$ bor B 1 & sem env. & 4 horas & 359,01 & 159,61 & 259,31 \\
\hline $51-$ bor B 2 & sem env. & 4 horas & 294,08 & 257,28 & 275,68 \\
\hline $52-$ bor C 3 & sem env. & 4 horas & 214,45 & 291,29 & 252,87 \\
\hline 53 - bor B 0 & 5 dias estufa & sem env. & 328,83 & 338,78 & 333,81 \\
\hline $54-$ bor C 1 & 5 dias estufa & sem env. & 685,47 & 321,28 & 503,37 \\
\hline $55-$ bor C 2 & 5 dias estufa & sem env. & 943,66 & 167,65 & 555,65 \\
\hline 56 - bor B 3 & 5 dias estufa & sem env. & 160,76 & 160,22 & 160,49 \\
\hline $61-$ bor C 0 & 4 meses & 4 horas & 300,26 & 258,08 & 279,17 \\
\hline 62 - bor B 1 & 4 meses & 4 horas & 333,10 & 291,10 & 312,10 \\
\hline 63 - bor B 2 & 4 meses & 4 horas & 221,32 & 226,78 & 224,05 \\
\hline $64-$ bor C 3 & 4 meses & 4 horas & 168,72 & 192,57 & 180,65 \\
\hline
\end{tabular}


Tabela D.20 - Valores de inclinação da curva de fluência obtidos do ensaio de creep estático, para o experimento reduzido a duas observações por condição experimental

\begin{tabular}{|c|c|c|c|c|c|}
\hline \multirow{3}{*}{$\begin{array}{c}\text { condição } \\
\text { experimental }\end{array}$} & \multirow{2}{*}{\multicolumn{2}{|c|}{ envelhecimento }} & \multicolumn{3}{|c|}{ inclinação } \\
\hline & & & réplicas ou ob & servações & \\
\hline & longo prazo & curto prazo & $\mathrm{Y} 1$ & Y2 & $Y$ \\
\hline $1-\operatorname{conv} C 0$ & sem env. & 4 horas & 0,03636 & 0,05271 & 0,04453 \\
\hline $2-\operatorname{conv}$ B 1 & sem env. & 4 horas & 0,07269 & 0,06148 & 0,06708 \\
\hline $3-\operatorname{conv}$ B 2 & sem env. & 4 horas & 0,04447 & 0,05624 & 0,05036 \\
\hline $4-\operatorname{conv}$ C 3 & sem env. & 4 horas & 0,03758 & 0,16661 & 0,10209 \\
\hline $5-$ conv B 0 & 5 dias estufa & sem env. & 0,07227 & 0,05013 & 0,06120 \\
\hline $6-\operatorname{conv} C 1$ & 5 dias estufa & sem env. & 0,02420 & 0,10724 & 0,06572 \\
\hline $7-\operatorname{conv} C 2$ & 5 dias estufa & sem env. & 0,04107 & 0,03296 & 0,03702 \\
\hline $8-\operatorname{conv}$ B 3 & 5 dias estufa & sem env. & 0,06017 & 0,07139 & 0,06578 \\
\hline $13-\operatorname{conv} C 0$ & 4 meses & 4 horas & 0,04719 & 0,06586 & 0,05652 \\
\hline $14-\operatorname{conv}$ B 1 & 4 meses & 4 horas & 0,09684 & 0,07971 & 0,08828 \\
\hline $15-\operatorname{conv}$ B 2 & 4 meses & 4 horas & 0,06990 & 0,05519 & 0,06255 \\
\hline $16-\operatorname{conv} C 3$ & 4 meses & 4 horas & 0,10741 & 0,05418 & 0,08080 \\
\hline $17-$ pol C 0 & sem env. & sem env. & 0,05065 & 0,06645 & 0,05855 \\
\hline $18-$ pol B 1 & sem env. & sem env. & 0,12745 & 0,10421 & 0,11583 \\
\hline $19-$ pol B 2 & sem env. & sem env. & 0,04735 & 0,05642 & 0,05189 \\
\hline $20-$ pol C 3 & sem env. & sem env. & 0,12083 & 0,11819 & 0,11951 \\
\hline $21-$ pol B 0 & 5 dias estufa & 4 horas & 0,12191 & 0,06794 & 0,09492 \\
\hline $22-$ pol C 1 & 5 dias estufa & 4 horas & 0,12183 & 0,11290 & 0,11736 \\
\hline $23-$ pol C 2 & 5 dias estufa & 4 horas & 0,15986 & 0,14319 & 0,15152 \\
\hline $24-$ pol B 3 & 5 dias estufa & 4 horas & 0,15640 & 5389 & 0,15514 \\
\hline $29-$ pol C 0 & 4 meses & sem env. & 0,14067 & 0,10534 & 0,12300 \\
\hline $30-$ pol B 1 & $4 \mathrm{me}$ & sem env. & 0,14112 & 0,09577 & 0,11844 \\
\hline $31-\mathrm{pol} \mathrm{B} 2$ & 4 meses & sem env. & 0,07852 & 0,11034 & 0,09443 \\
\hline $32-$ pol C 3 & 4 meses & sem env. & 0,11788 & 0,14167 & 0,12978 \\
\hline $49-$ bor C 0 & sem env. & 4 horas & 0,09942 & 0,09040 & 0,09491 \\
\hline $50-$ bor B 1 & sem env. & 4 horas & 0,10122 & 0,10136 & 0,10129 \\
\hline $51-$ bor B 2 & sem env. & 4 horas & 0,10854 & 0,09882 & 0,10368 \\
\hline $52-$ bor C 3 & sem env. & 4 horas & 0,15593 & 0,12137 & 0,13865 \\
\hline $53-$ bor B 0 & 5 dias estufa & sem env. & 0,08161 & 0,05612 & 0,06886 \\
\hline $54-$ bor C 1 & 5 dias estufa & sem env. & 0,09961 & 0,10496 & 0,10229 \\
\hline $55-$ bor C 2 & 5 dias estufa & sem env. & 0,11029 & 0,14567 & 0,12798 \\
\hline 56 - bor B 3 & 5 dias estufa & sem env. & 0,11543 & 0,11110 & 0,11326 \\
\hline $61-$ bor $\mathrm{C} 0$ & 4 meses & 4 horas & 0,11549 & 0,08644 & 0,10096 \\
\hline $62-$ bor B 1 & 4 meses & 4 horas & 0,12232 & 0,08033 & 0,10132 \\
\hline $63-$ bor B 2 & 4 meses & 4 horas & 0,17826 & 0,09811 & 0,13818 \\
\hline $64-$ bor C 3 & 4 meses & 4 horas & 0,09777 & 0,11191 & 0,10484 \\
\hline
\end{tabular}


Tabela D.21 - Valores de deformação total $(\mathrm{mm} / \mathrm{mm})$ obtidos do ensaio de creep dinâmico, para o experimento realizado com três observações por condição experimental

\begin{tabular}{|c|c|c|c|c|c|c|}
\hline \multirow[t]{2}{*}{$\begin{array}{l}\text { condição } \\
\text { experimental }\end{array}$} & \multicolumn{2}{|c|}{ envelhecimento } & \multicolumn{3}{|c|}{$\begin{array}{r}\text { deformação total }(\mathrm{mm} / \mathrm{mm}) \\
\text { réplicas ou observações }\end{array}$} & \multirow[b]{2}{*}{$\bar{Y}$} \\
\hline & longo prazo & curto prazo & Y1 & $\mathrm{Y} 2$ & $\mathrm{Y} 3$ & \\
\hline $1-\operatorname{conv} C 0$ & sem env. & 4 horas & 0,00379 & 0,00718 & 0,00455 & 0,00517 \\
\hline $2-\operatorname{conv}$ B 1 & sem env. & 4 horas & 0,00240 & 0,00250 & 0,00331 & 0,00273 \\
\hline $3-\operatorname{conv}$ B 2 & sem env. & 4 horas & 0,00251 & 0,00198 & 0,00380 & 0,00276 \\
\hline $4-\operatorname{conv} C 3$ & sem env. & 4 horas & 0,00858 & 0,00613 & 0,00702 & 0,00724 \\
\hline $5-$ conv B 0 & 5 dias estufa & sem env. & 0,00408 & 0,00564 & 0,00408 & 0,00460 \\
\hline $6-\operatorname{conv} C 1$ & 5 dias estufa & sem env. & 0,00344 & 0,00336 & 0,00363 & 0,00348 \\
\hline $7-\operatorname{conv} C 2$ & 5 dias estufa & sem env. & 0,00753 & 0,00611 & 0,00466 & 0,00610 \\
\hline $8-\operatorname{conv}$ B 3 & 5 dias estufa & sem env. & 0,00372 & 0,00475 & 0,00202 & 0,00349 \\
\hline $13-\operatorname{conv} \mathrm{C} 0$ & 4 meses & 4 horas & 0,00260 & 0,00206 & 0,00225 & 0,00230 \\
\hline $14-\operatorname{conv}$ B 1 & 4 meses & 4 horas & 0,00199 & 0,00212 & 0,00223 & 0,00211 \\
\hline $15-\operatorname{conv}$ B 2 & 4 meses & 4 horas & 0,00261 & 0,00221 & 0,00204 & 0,00229 \\
\hline $16-\operatorname{conv} C 3$ & 4 meses & 4 horas & 0,00289 & 0,00231 & 0,00285 & 0,00268 \\
\hline $17-$ pol C 0 & sem env. & sem env. & 0,00301 & 0,00342 & 0,00273 & 0,00305 \\
\hline $18-$ pol B 1 & sem env. & sem env. & 0,00276 & 0,00290 & 0,00325 & 0,00297 \\
\hline $19-$ pol B 2 & sem env. & sem env. & 0,00348 & 0,00393 & 0,00294 & 0,00345 \\
\hline $20-$ pol C 3 & sem env. & sem env. & 0,00602 & 0,00375 & 0,00568 & 0,00515 \\
\hline $21-$ pol B 0 & 5 dias estufa & 4 horas & 0,00170 & 0,00169 & 0,00186 & 0,00175 \\
\hline $22-$ pol C 1 & 5 dias estufa & 4 horas & 0,00268 & 0,00306 & 0,00216 & 0,00263 \\
\hline $23-$ pol C 2 & 5 dias estufa & 4 horas & 0,00150 & 0,00158 & 0,00246 & 0,00185 \\
\hline $24-$ pol B 3 & 5 dias estufa & 4 horas & 0,00211 & 0,00188 & 0,00177 & 0,00192 \\
\hline $29-$ pol C 0 & 4 meses & sem env. & 0,00137 & 0,00184 & 0,00176 & 0,00166 \\
\hline $30-$ pol B 1 & 4 meses & sem env. & 0,00143 & 0,00164 & 0,00120 & 0,00142 \\
\hline $31-\mathrm{pol}$ B 2 & 4 meses & sem env. & 0,00155 & 0,00189 & 0,00194 & 0,00179 \\
\hline $32-$ pol C 3 & 4 meses & sem env. & 0,00252 & 0,00256 & 0,00191 & 0,00233 \\
\hline $49-$ bor $C 0$ & sem env. & 4 horas & 0,00175 & 0,00284 & 0,00146 & 0,00202 \\
\hline $50-$ bor B 1 & sem env. & 4 horas & 0,00228 & 0,00255 & 0,00305 & 0,00263 \\
\hline $51-$ bor B 2 & sem env. & 4 horas & 0,00246 & 0,00170 & 0,00196 & 0,00204 \\
\hline $52-$ bor C 3 & sem env. & 4 horas & 0,00337 & 0,00393 & 0,00155 & 0,00295 \\
\hline 53 - bor B 0 & 5 dias estufa & sem env. & 0,00309 & 0,00312 & 0,00343 & 0,00321 \\
\hline $54-$ bor $C 1$ & 5 dias estufa & sem env. & 0,00306 & 0,00309 & 0,00113 & 0,00242 \\
\hline $55-$ bor $C 2$ & 5 dias estufa & sem env. & 0,00264 & 0,00308 & 0,00309 & 0,00294 \\
\hline 56 - bor B 3 & 5 dias estufa & sem env. & 0,00200 & 0,00165 & 0,00170 & 0,00178 \\
\hline $61-$ bor C 0 & 4 meses & 4 horas & 0,00204 & 0,00163 & 0,00193 & 0,00187 \\
\hline $62-$ bor B 1 & 4 meses & 4 horas & 0,00237 & 0,00185 & 0,00193 & 0,00205 \\
\hline $63-$ bor B 2 & 4 meses & 4 horas & 0,00199 & 0,00238 & 0,00233 & 0,00223 \\
\hline $64-$ bor C 3 & 4 meses & 4 horas & 0,00194 & 0,00201 & 0,00271 & 0,00222 \\
\hline
\end{tabular}


Tabela D.22 - Valores de módulo de fluência (MPa) obtidos do ensaio de creep dinâmico, para o experimento realizado com três observações por condição experimental

\begin{tabular}{|c|c|c|c|c|c|c|}
\hline \multirow[t]{2}{*}{$\begin{array}{l}\text { condição } \\
\text { experimental }\end{array}$} & \multicolumn{2}{|c|}{ envelhecimento } & \multicolumn{3}{|c|}{$\begin{array}{l}\text { módulo de fluência (MPa) } \\
\text { réplicas ou observações }\end{array}$} & \multirow[b]{2}{*}{$Y$} \\
\hline & longo prazo & curto prazo & Y1 & Y2 & Y3 & \\
\hline $1-\operatorname{conv} C 0$ & sem env. & 4 horas & 97,09 & 50,73 & 79,15 & 75,66 \\
\hline $2-\operatorname{conv}$ B 1 & sem env. & 4 horas & 186,31 & 149,93 & 103,85 & 146,70 \\
\hline $3-\operatorname{conv}$ B 2 & sem env. & 4 horas & 135,00 & 172,72 & 80,56 & 129,42 \\
\hline $4-\operatorname{conv} \mathrm{C} 3$ & sem env. & 4 horas & 43,60 & 80,18 & 58,74 & 60,84 \\
\hline $5-\operatorname{conv}$ B 0 & 5 dias estufa & sem env. & 86,50 & 63,13 & 86,21 & 78,61 \\
\hline $6-\operatorname{conv} C 1$ & 5 dias estufa & sem env. & 106,53 & 111,64 & 102,73 & 106,97 \\
\hline $7-\operatorname{conv} C 2$ & 5 dias estufa & sem env. & 44,353 & 55,829 & 75,92 & 58,70 \\
\hline $8-\operatorname{conv}$ B 3 & 5 dias estufa & sem env. & 94,25 & 78,50 & 177,48 & 116,74 \\
\hline $13-\operatorname{conv}$ C 0 & 4 meses & 4 horas & 157,13 & 142,46 & 131,26 & 143,62 \\
\hline $14-\operatorname{conv}$ B 1 & 4 meses & 4 horas & 206,96 & 172,18 & 135,86 & 171,67 \\
\hline $15-\operatorname{conv}$ B 2 & 4 meses & 4 horas & 112,901 & 135,207 & 196,825 & 148,31 \\
\hline $16-\operatorname{conv} C 3$ & 4 meses & 4 horas & 142,21 & 136,37 & 108,46 & 129,01 \\
\hline 17 - pol C 0 & sem env. & sem env. & 128,94 & 111,46 & 127,43 & 122,61 \\
\hline $18-$ pol B 1 & sem env. & sem env. & 133,08 & 125,89 & 112,01 & 123,66 \\
\hline $19-$ pol B 2 & sem env. & sem env. & 155,10 & 137,75 & 127,24 & 140,03 \\
\hline $20-$ pol C 3 & sem env. & sem env. & 57,10 & 92,42 & 60,32 & 69,95 \\
\hline $21-$ pol B 0 & 5 dias estufa & 4 horas & 208,20 & 208,50 & 162,63 & 193,11 \\
\hline $22-$ pol C 1 & 5 dias estufa & 4 horas & 126,323 & 111,064 & 189,449 & 142,28 \\
\hline $23-$ pol C 2 & 5 dias estufa & 4 horas & 213,44 & 221,60 & 138,38 & 191,14 \\
\hline $24-p o l$ B 3 & 5 dias estufa & 4 horas & 148,00 & 178,64 & 213,20 & 179,95 \\
\hline $29-$ pol C 0 & 4 meses & sem env. & 299,36 & 225,49 & 235,65 & 253,50 \\
\hline $30-$ pol B 1 & 4 meses & sem env. & 292,91 & 247,75 & 340,13 & 293,60 \\
\hline $31-$ pol B 2 & 4 meses & sem env. & 259,79 & 210,91 & 212,02 & 227,57 \\
\hline $32-$ pol C 3 & 4 meses & sem env. & 167,63 & 170,01 & 213,49 & 183,71 \\
\hline $49-$ bor C 0 & sem env. & 4 horas & 215,31 & 131,30 & 263,26 & 203,29 \\
\hline $50-$ bor B 1 & sem env. & 4 horas & 133,18 & 139,16 & 108,21 & 126,85 \\
\hline $51-$ bor B 2 & sem env. & 4 horas & 143,53 & 194,57 & 160,03 & 166,04 \\
\hline $52-$ bor C 3 & sem env. & 4 horas & 152,36 & 95,28 & 243,83 & 163,83 \\
\hline 53 - bor B 0 & 5 dias estufa & sem env. & 114,30 & 113,40 & 105,49 & 111,06 \\
\hline $54-$ bor $C 1$ & 5 dias estufa & sem env. & 118,45 & 115,41 & 333,98 & 189,28 \\
\hline $55-$ bor C 2 & 5 dias estufa & sem env. & 134,85 & 114,79 & 121,89 & 123,84 \\
\hline $56-$ bor B 3 & 5 dias estufa & sem env. & 174,43 & 211,25 & 227,28 & 204,32 \\
\hline $61-$ bor C 0 & 4 meses & 4 horas & 198,72 & 193,85 & 157,08 & 183,22 \\
\hline 62 - bor B 1 & 4 meses & 4 horas & 171,78 & 165,80 & 154,88 & 164,15 \\
\hline 63 - bor B 2 & 4 meses & 4 horas & 155,91 & 127,31 & 179,21 & 154,14 \\
\hline $64-$ bor C 3 & 4 meses & 4 horas & 209,53 & 156,25 & 114,74 & 160,18 \\
\hline
\end{tabular}


Tabela D.23 - Valores de inclinação da curva de fluência obtidos do ensaio de creep dinâmico, para o experimento realizado com três observações por condição experimental

\begin{tabular}{|c|c|c|c|c|c|c|}
\hline \multirow[t]{2}{*}{$\begin{array}{l}\text { condição } \\
\text { experimental }\end{array}$} & \multicolumn{2}{|c|}{ envelhecimento } & \multicolumn{4}{|c|}{$\begin{array}{r}\text { inclinação } \\
\text { réplicas ou observações }\end{array}$} \\
\hline & longo prazo & curto prazo & Y1 & Y2 & Y3 & $Y$ \\
\hline $1-\operatorname{conv} C 0$ & sem env. & 4 horas & 0,27079 & 0,19818 & 0,23701 & 0,23533 \\
\hline $2-\operatorname{conv}$ B 1 & sem env. & 4 horas & 0,16517 & 0,18592 & 0,21775 & 0,18961 \\
\hline $3-\operatorname{conv}$ B 2 & sem env. & 4 horas & 0,17497 & 0,20427 & 0,28926 & 0,22283 \\
\hline $4-\operatorname{conv} C 3$ & sem env. & 4 horas & 0,45884 & 0,26488 & 0,33337 & 0,35236 \\
\hline $5-$ conv B 0 & 5 dias estufa & sem env. & 0,17330 & 0,25668 & 0,16169 & 0,19722 \\
\hline $6-\operatorname{conv} C 1$ & 5 dias estufa & sem env. & 0,10783 & 0,13267 & 0,15852 & 0,13301 \\
\hline $7-\operatorname{conv} C 2$ & 5 dias estufa & sem env. & 0,25642 & 0,22966 & 0,15316 & 0,21308 \\
\hline $8-\operatorname{conv}$ B 3 & 5 dias estufa & sem env. & 0,15963 & 0,18751 & 0,19691 & 0,18135 \\
\hline $13-\operatorname{conv} \mathrm{C} 0$ & 4 meses & 4 horas & 0,22925 & 0,12827 & 0,15080 & 0,16944 \\
\hline $14-\operatorname{conv}$ B 1 & 4 meses & 4 horas & 0,18241 & 0,15573 & 0,19210 & 0,17675 \\
\hline $15-$ conv B 2 & 4 meses & 4 horas & 0,15892 & 0,18303 & 0,16356 & 0,16850 \\
\hline $16-\operatorname{conv} C 3$ & 4 meses & 4 horas & 0,19486 & 0,19726 & 0,21713 & 0,20309 \\
\hline $17-$ pol C 0 & sem env. & sem env. & 0,10768 & 0,14321 & 0,10201 & 0,11763 \\
\hline $18-$ pol B 1 & sem env. & sem env. & 0,07837 & 0,10982 & 0,10816 & 0,09879 \\
\hline $19-$ pol B 2 & sem env. & sem env. & 0,07785 & 0,11602 & 0,16190 & 0,11859 \\
\hline $20-$ pol C 3 & sem env. & sem env. & 0,21785 & 0,16045 & 0,27259 & 0,21696 \\
\hline $21-$ pol B 0 & 5 dias estufa & 4 horas & 0,11955 & 0,13330 & 0,15873 & 0,13719 \\
\hline $22-$ pol C 1 & 5 dias estufa & 4 horas & 0,22159 & 0,16472 & 0,22307 & 0,20313 \\
\hline $23-$ pol C 2 & 5 dias estufa & 4 horas & 0,10826 & 0,09129 & 0,16965 & 0,12307 \\
\hline $24-$ pol B 3 & 5 dias estufa & 4 horas & 0,15810 & 0,17322 & 0,16950 & 0,16694 \\
\hline $29-$ pol C 0 & 4 meses & sem env. & 0,13370 & 0,12571 & 0,13006 & 0,12982 \\
\hline $30-$ pol B 1 & 4 meses & sem env. & 0,13757 & 0,14126 & 0,13474 & 0,13785 \\
\hline $31-$ pol B 2 & 4 meses & sem env. & 0,14926 & 0,12889 & 0,13777 & 0,13864 \\
\hline $32-$ pol C 3 & 4 meses & sem env. & 0,23006 & 0,16635 & 0,12943 & 0,17528 \\
\hline $49-$ bor C 0 & sem env. & 4 horas & 0,07138 & 0,21777 & 0,07658 & 0,12191 \\
\hline $50-$ bor B 1 & sem env. & 4 horas & 0,14877 & 0,11149 & 0,13097 & 0,13041 \\
\hline $51-$ bor B 2 & sem env. & 4 horas & 0,10479 & 0,09912 & 0,13965 & 0,11452 \\
\hline $52-$ bor C 3 & sem env. & 4 horas & 0,23116 & 0,27678 & 0,10650 & 0,20481 \\
\hline $53-$ bor B 0 & 5 dias estufa & sem env. & 0,09800 & 0,15296 & 0,08611 & 0,11236 \\
\hline $54-$ bor C 1 & 5 dias estufa & sem env. & 0,10503 & 0,14016 & 0,02621 & 0,09047 \\
\hline $55-$ bor $C 2$ & 5 dias estufa & sem env. & 0,10579 & 0,13552 & 0,06669 & 0,10267 \\
\hline 56 - bor B 3 & 5 dias estufa & sem env. & 0,13024 & 0,12443 & 0,14060 & 0,13175 \\
\hline $61-$ bor $C 0$ & 4 meses & 4 horas & 0,14080 & 0,12183 & 0,23999 & 0,16754 \\
\hline $62-$ bor B 1 & 4 meses & 4 horas & 0,16156 & 0,13417 & 0,11310 & 0,13628 \\
\hline $63-$ bor B 2 & 4 meses & 4 horas & 0,12902 & 0,21215 & 0,15264 & 0,16460 \\
\hline $64-$ bor C 3 & 4 meses & 4 horas & 0,18252 & 0,19489 & 0,21897 & 0,19880 \\
\hline
\end{tabular}


Tabela D.24 - Valores de deformação total $(\mathrm{mm} / \mathrm{mm})$ obtidos do ensaio de creep dinâmico, para o experimento reduzido a duas observações por condição experimental

\begin{tabular}{|c|c|c|c|c|c|}
\hline \multirow{3}{*}{$\begin{array}{c}\text { condição } \\
\text { experimental }\end{array}$} & \multirow{2}{*}{\multicolumn{2}{|c|}{ envelhecimento }} & \multirow{2}{*}{\multicolumn{3}{|c|}{ eformação total $(\mathrm{mm} / \mathrm{mm})$}} \\
\hline & & & & servações & \\
\hline & longo prazo & curto prazo & Y1 & Y2 & $Y$ \\
\hline $1-\operatorname{conv} C 0$ & sem env. & 4 horas & 0,00379 & 0,00455 & 0,00417 \\
\hline $2-\operatorname{conv}$ B 1 & sem env. & 4 horas & 0,00240 & 0,00250 & 0,00245 \\
\hline $3-\operatorname{conv}$ B 2 & sem env. & 4 horas & 0,00251 & 0,00198 & 0,00225 \\
\hline $4-\operatorname{conv} C 3$ & sem env. & 4 horas & 0,00613 & 0,00702 & 0,00657 \\
\hline $5-$ conv B 0 & 5 dias estufa & sem env. & 0,00408 & 0,00408 & 0,00408 \\
\hline $6-\operatorname{conv} C 1$ & 5 dias estufa & sem env. & 0,00344 & 0,00336 & 0,00340 \\
\hline $7-\operatorname{conv} C 2$ & 5 dias estufa & sem env. & 0,00753 & 0,00611 & 0,00682 \\
\hline $8-\operatorname{conv}$ B 3 & 5 dias estufa & sem env. & 0,00372 & 0,00475 & 0,00423 \\
\hline $13-\operatorname{conv} \mathrm{C} 0$ & 4 meses & 4 horas & 0,00206 & 0,00225 & 0,00215 \\
\hline $14-\operatorname{conv}$ B 1 & 4 meses & 4 horas & 0,00199 & 0,00212 & 0,00205 \\
\hline $15-\operatorname{conv}$ B 2 & 4 meses & 4 horas & 0,00221 & 0,00204 & 0,00213 \\
\hline $16-\operatorname{conv} C 3$ & 4 meses & 4 horas & 0,00289 & 0,00231 & 0,00260 \\
\hline 17 - pol C 0 & sem env. & sem env. & 0,00301 & 0,00273 & 0,00287 \\
\hline 18 - pol B 1 & sem env. & sem env. & 0,00276 & 0,00290 & 0,00283 \\
\hline $19-$ pol B 2 & sem env. & sem env. & 0,00348 & 0,00393 & 0,00370 \\
\hline $20-$ pol C 3 & sem env. & sem env. & 0,00602 & 0,00568 & 0,00585 \\
\hline 21 - pol B 0 & 5 dias estufa & 4 horas & 0,00170 & 0,00169 & 0,00170 \\
\hline $22-$ pol C 1 & 5 dias estufa & 4 horas & 0,00268 & 0,00306 & 0,00287 \\
\hline $23-$ pol C 2 & 5 dias estufa & 4 horas & 0,00150 & 0,00246 & 0,00198 \\
\hline $24-$ pol B 3 & 5 dias estufa & 4 horas & 0,00188 & 0,00177 & 0,00182 \\
\hline $29-$ pol C 0 & 4 meses & sem env. & 0,00184 & 0,00176 & 0,00180 \\
\hline $30-$ pol B 1 & 4 meses & sem env. & 0,00143 & 0,00164 & 0,00153 \\
\hline $31-$ pol B 2 & 4 meses & sem env. & 0,00189 & 0,00194 & 0,00191 \\
\hline $32-$ pol C 3 & 4 meses & sem env. & 0,00252 & 0,00256 & 0,00254 \\
\hline $49-$ bor C 0 & sem env. & 4 horas & 0,00284 & 0,00146 & 0,00215 \\
\hline $50-$ bor B 1 & sem env. & 4 horas & 0,00228 & 0,00255 & 0,00242 \\
\hline 51 - bor B 2 & sem env. & 4 horas & 0,00246 & 0,00196 & 0,00221 \\
\hline $52-$ bor C 3 & sem env. & 4 horas & 0,00337 & 0,00393 & 0,00365 \\
\hline 53 - bor B 0 & 5 dias estufa & sem env. & 0,00309 & 0,00312 & 0,00311 \\
\hline $54-$ bor $C 1$ & 5 dias estufa & sem env. & 0,00306 & 0,00309 & 0,00307 \\
\hline $55-$ bor $C 2$ & 5 dias estufa & sem env. & 0,00308 & 0,00309 & 0,00309 \\
\hline 56 - bor B 3 & 5 dias estufa & sem env. & 0,00165 & 0,00170 & 0,00167 \\
\hline 61 - bor C 0 & 4 meses & 4 horas & 0,00204 & 0,00163 & 0,00183 \\
\hline $62-$ bor B 1 & 4 meses & 4 horas & 0,00185 & 0,00193 & 0,00189 \\
\hline $63-$ bor B 2 & 4 meses & 4 horas & 0,00199 & 0,00233 & 0,00216 \\
\hline $64-$ bor C 3 & 4 meses & 4 horas & 0,00194 & 0,00201 & $0,0019 \varepsilon$ \\
\hline
\end{tabular}


Tabela D.25 - Valores de módulo de fluência (MPa) obtidos do ensaio de creep dinâmico, para o experimento reduzido a duas observações por condição experimental

\begin{tabular}{|c|c|c|c|c|c|}
\hline \multirow{3}{*}{$\begin{array}{l}\text { condição } \\
\text { experimental }\end{array}$} & \multirow{2}{*}{\multicolumn{2}{|c|}{ envelhecimento }} & \multirow{2}{*}{\multicolumn{2}{|c|}{$\begin{array}{l}\text { módulo de fluência (MPa) } \\
\text { réplicas ou observações }\end{array}$}} & \multirow[b]{3}{*}{$Y$} \\
\hline & & & & & \\
\hline & longo prazo & curto prazo & $\mathrm{Y} 1$ & $\mathrm{Y} 2$ & \\
\hline $1-\operatorname{conv} C 0$ & sem env. & 4 horas & 97,09 & 79,15 & 88,12 \\
\hline 2 - conv B 1 & sem env. & 4 horas & 186,31 & 149,93 & 168,12 \\
\hline $3-$ conv B 2 & sem env. & 4 horas & 135,00 & 172,72 & 153,86 \\
\hline $4-\operatorname{conv} C 3$ & sem env. & 4 horas & 80,18 & 58,74 & 69,46 \\
\hline $5-$ conv B 0 & 5 dias estufa & sem env. & 86,50 & 86,21 & 86,35 \\
\hline $6-\operatorname{conv} C 1$ & 5 dias estufa & sem env. & 106,53 & 111,64 & 109,09 \\
\hline $7-\operatorname{conv} C 2$ & 5 dias estufa & sem env. & 44,353 & 55,829 & 50,09 \\
\hline $8-\operatorname{conv} B 3$ & 5 dias estufa & sem env. & 94,25 & 78,50 & 86,37 \\
\hline $13-\operatorname{conv}$ C 0 & 4 meses & 4 horas & 142,46 & 131,26 & 136,86 \\
\hline $14-\operatorname{conv}$ B 1 & 4 meses & 4 horas & 206,96 & 172,18 & 189,57 \\
\hline $15-\operatorname{conv}$ B 2 & 4 meses & 4 horas & 112,901 & 135,207 & 124,05 \\
\hline $16-\operatorname{conv} C \mathrm{C}$ & 4 meses & 4 horas & 142,21 & 136,37 & 139,29 \\
\hline 17 - pol C 0 & sem env. & sem env. & 128,94 & 127,43 & 128,19 \\
\hline 18 - pol B 1 & sem env. & sem env. & 133,08 & 125,89 & 129,49 \\
\hline $19-$ pol B 2 & sem env. & sem env. & 155,10 & 137,75 & 146,42 \\
\hline $20-$ pol C 3 & sem env. & sem env. & 57,10 & 60,32 & 58,71 \\
\hline $21-$ pol B 0 & 5 dias estufa & 4 horas & 208,20 & 208,50 & 208,35 \\
\hline $22-$ pol C 1 & 5 dias estufa & 4 horas & 126,32 & 111,06 & 118,69 \\
\hline $23-$ pol C 2 & 5 dias estufa & 4 horas & 213,44 & 138,38 & 175,91 \\
\hline $24-p o l$ B 3 & 5 dias estufa & 4 horas & 178,64 & 213,20 & 195,92 \\
\hline $29-$ pol C 0 & 4 meses & sem env. & 225,49 & 235,65 & 230,57 \\
\hline $30-$ pol B 1 & 4 meses & sem env. & 292,91 & 247,75 & 270,33 \\
\hline $31-$ pol B 2 & 4 meses & sem env. & 210,91 & 212,02 & 211,47 \\
\hline $32-$ pol C 3 & 4 meses & sem env. & 167,63 & 170,01 & 168,82 \\
\hline 49 - bor C 0 & sem env. & 4 horas & 131,30 & 263,26 & 197,28 \\
\hline $50-$ bor B 1 & sem env. & 4 horas & 133,18 & 139,16 & 136,17 \\
\hline 51 - bor B 2 & sem env. & 4 horas & 143,53 & 160,03 & 151,78 \\
\hline $52-$ bor C 3 & sem env. & 4 horas & 152,36 & 95,28 & 123,82 \\
\hline 53 - bor B 0 & 5 dias estufa & sem env. & 114,30 & 113,40 & 113,85 \\
\hline $54-$ bor $C 1$ & 5 dias estufa & sem env. & 118,45 & 115,41 & 116,93 \\
\hline $55-$ bor $C 2$ & 5 dias estufa & sem env. & 114,79 & 121,89 & 118,34 \\
\hline $56-$ bor B 3 & 5 dias estufa & sem env. & 211,25 & 227,28 & 219,27 \\
\hline $61-$ bor C 0 & 4 meses & 4 horas & 198,72 & 193,85 & 196,28 \\
\hline $62-$ bor B 1 & 4 meses & 4 horas & 165,80 & 154,88 & 160,34 \\
\hline $63-$ bor B 2 & 4 meses & 4 horas & 155,91 & 179,21 & 167,56 \\
\hline 64 - bor C 3 & 4 meses & 4 horas & 209,53 & 156,25 & 182,89 \\
\hline
\end{tabular}


Tabela D.26 - Valores de inclinação da curva de fluência obtidos do ensaio de creep dinâmico, para o experimento reduzido a duas observações por condição experimental

\begin{tabular}{|c|c|c|c|c|c|}
\hline \multirow{3}{*}{$\begin{array}{c}\text { condição } \\
\text { experimental }\end{array}$} & \multirow{2}{*}{\multicolumn{2}{|c|}{ envelhecimento }} & \multicolumn{3}{|c|}{ inclinação } \\
\hline & & & réplicas ou ob & servações & \\
\hline & longo prazo & curto prazo & Y1 & $\mathrm{Y} 2$ & $Y$ \\
\hline $1-\operatorname{conv} C 0$ & sem env. & 4 horas & 0,27079 & 0,23701 & 0,25390 \\
\hline $2-\operatorname{conv}$ B 1 & sem env. & 4 horas & 0,16517 & 0,18592 & 0,17555 \\
\hline $3-\operatorname{conv}$ B 2 & sem env. & 4 horas & 0,17497 & 0,20427 & 0,18962 \\
\hline $4-\operatorname{conv}$ C 3 & sem env. & 4 horas & 0,26488 & 0,33337 & 0,29913 \\
\hline $5-$ conv B 0 & 5 dias estufa & sem env. & 0,17330 & 0,16169 & 0,16749 \\
\hline $6-\operatorname{conv} C 1$ & 5 dias estufa & sem env. & 0,10783 & 0,13267 & 0,12025 \\
\hline $7-\operatorname{conv} C 2$ & 5 dias estufa & sem env. & 0,25642 & 0,22966 & 0,24304 \\
\hline $8-\operatorname{conv}$ B 3 & 5 dias estufa & sem env. & 0,15963 & 0,18751 & 0,17357 \\
\hline $13-\operatorname{conv} C 0$ & 4 meses & 4 horas & 0,12827 & 0,15080 & 0,13954 \\
\hline $14-\operatorname{conv}$ B 1 & 4 meses & 4 horas & 0,18241 & 0,15573 & 0,16907 \\
\hline $15-\operatorname{conv}$ B 2 & 4 meses & 4 horas & 0,15892 & 0,16356 & 0,16124 \\
\hline $16-\operatorname{conv} C 3$ & 4 meses & 4 horas & 0,19486 & 0,19726 & 0,19606 \\
\hline $17-$ pol C 0 & sem env. & sem env. & 0,10768 & 0,10201 & 0,10484 \\
\hline 18-pol B 1 & sem env. & sem env. & 0,07837 & 0,10982 & 0,09410 \\
\hline $19-$ pol B 2 & sem env. & sem env. & 0,07785 & 0,11602 & 0,09694 \\
\hline $20-$ pol C 3 & sem env. & sem env. & 0,21785 & 0,27259 & 0,24522 \\
\hline $21-$ pol B 0 & 5 dias estufa & 4 horas & 0,11955 & 0,13330 & 0,12642 \\
\hline $22-$ pol C 1 & 5 dias estufa & 4 horas & 0,22159 & 0,22307 & 0,22233 \\
\hline $23-$ pol C 2 & 5 dias estufa & 4 horas & 0,10826 & 0,16965 & 0,13896 \\
\hline $24-$ pol B 3 & 5 dias estufa & 4 horas & 0,17322 & 0,16950 & 0,17136 \\
\hline $29-$ pol C 0 & 4 meses & sem env. & 0,12571 & 0,13006 & 0,12788 \\
\hline $30-$ pol B 1 & $4 \mathrm{me}$ & sem env. & 0,13757 & 0,14126 & 0,13941 \\
\hline $31-$ pol B 2 & 4 meses & sem env. & 0,12889 & 0,13777 & 0,13333 \\
\hline $32-$ pol C 3 & 4 meses & sem env. & 0,23006 & 0,16635 & 0,19820 \\
\hline $49-$ bor C 0 & sem env. & 4 horas & 0,21777 & 0,07658 & 0,14718 \\
\hline 50 - bor B 1 & sem env. & 4 horas & 0,14877 & 0,13097 & 0,13987 \\
\hline $51-$ bor B 2 & sem env. & 4 horas & 0,10479 & 0,13965 & 0,12222 \\
\hline $52-$ bor C 3 & sem env. & 4 horas & 0,23116 & 0,27678 & 0,25397 \\
\hline $53-$ bor B 0 & 5 dias estufa & sem env. & 0,09800 & 0,15296 & 0,12548 \\
\hline $54-$ bor C 1 & 5 dias estufa & sem env. & 0,10503 & 0,14016 & 0,12259 \\
\hline $55-$ bor C 2 & 5 dias estufa & sem env. & 0,13552 & 0,06669 & 0,10111 \\
\hline $56-$ bor B 3 & 5 dias estufa & sem env. & 0,12443 & 0,14060 & 0,13251 \\
\hline $61-$ bor C 0 & 4 meses & 4 horas & 0,14080 & 0,12183 & 0,13132 \\
\hline $62-$ bor B 1 & 4 meses & 4 horas & 0,13417 & 0,11310 & 0,12364 \\
\hline $63-$ bor B 2 & 4 meses & 4 horas & 0,12902 & 0,15264 & 0,14083 \\
\hline $64-$ bor C 3 & 4 meses & 4 horas & 0,18252 & 0,19489 & 0,18871 \\
\hline
\end{tabular}




\section{APÊNDICE E - Apresentação dos dados em forma de matrizes fatoriais}

Os dados apresentados no Apêndice D são reapresentados em outro formato, destacando-se as respostas obtidas em função do fracionamento realizado.

Os teores de ligante utilizados para cada faixa granulométrica adotada seguem as convenções da Tabela E.1.

Tabela E.1 - Identificação dos teores de ligante de acordo com a faixa granulométrica considerada

teores de ligante para as respectivas faixas granulométricas

\begin{tabular}{ccc} 
& \multicolumn{2}{c}{ granulométricas } \\
\hline $\begin{array}{c}\text { níveis da variável } A \\
\text { (teor de ligante) }\end{array}$ & centro da faixa B & centro da faixa C \\
\hline 0 & $4,0 \%$ & $5,0 \%$ \\
\hline 1 & $4,5 \%$ & $5,5 \%$ \\
\hline 2 & $5,0 \%$ & $6,0 \%$ \\
\hline 3 & $5,5 \%$ & $6,5 \%$ \\
\hline
\end{tabular}




\begin{tabular}{|c|c|c|c|c|c|c|c|c|c|c|c|c|c|}
\hline & \multicolumn{12}{|c|}{ Resistência à tração $(\mathrm{MPa})$} \\
\hline & & \multicolumn{4}{|c|}{$\begin{array}{l}\text { sem envelhecimento a longo } \\
\text { prazo }\end{array}$} & \multicolumn{4}{|c|}{$\begin{array}{l}\text { envelhecimento a longo } \\
\text { prazo acelerado em estufa }\end{array}$} & \multicolumn{4}{|c|}{$\begin{array}{l}\text { envelhecimento a longo } \\
\text { prazo por exposição ao } \\
\text { tempo }\end{array}$} \\
\hline & & \multicolumn{2}{|c|}{$\begin{array}{l}\text { sem env. a } \\
\text { curto prazo }\end{array}$} & \multicolumn{2}{|c|}{$\begin{array}{l}4 \text { h de env. a } \\
\text { curto prazo }\end{array}$} & \multicolumn{2}{|c|}{$\begin{array}{l}\text { sem env. a } \\
\text { curto prazo }\end{array}$} & \multicolumn{2}{|c|}{$\begin{array}{l}4 \text { h de env. a } \\
\text { curto prazo }\end{array}$} & \multicolumn{2}{|c|}{$\begin{array}{l}\text { sem env. a } \\
\text { curto prazo }\end{array}$} & \multicolumn{2}{|c|}{$\begin{array}{l}4 \text { h de env. a } \\
\text { curto prazo }\end{array}$} \\
\hline & & $\mathrm{B}$ & $\mathrm{C}$ & $\mathrm{B}$ & $\mathrm{C}$ & $\mathrm{B}$ & $\mathrm{C}$ & B & $\mathrm{C}$ & $\mathrm{B}$ & $\mathrm{C}$ & B & $\mathrm{C}$ \\
\hline \multirow{3}{*}{$\begin{array}{l}0 \\
\stackrel{0}{0}\end{array}$} & 璐 & & & & 1,970 & 1,462 & & & & & & & 1,854 \\
\hline & 状 & & 2,222 & & & & & 2,328 & & & 2,219 & & \\
\hline & 蚝 & & & & 1,745 & 1,588 & & & & & & & 1,839 \\
\hline \multirow{3}{*}{$\overline{\vec{o}}$} & 状 & & & 2,293 & & & 1,739 & & & & & 2,210 & \\
\hline & 㟧 & 2,204 & & & & & & & 2,598 & 2,232 & & & \\
\hline & 崩苛 & & & 1,773 & & & 2,298 & & & & & 2,360 & \\
\hline \multirow{3}{*}{ 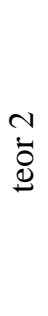 } & 嫣 & & & 1,754 & & & 1,713 & & & & & 1,890 & \\
\hline & पे & 2,596 & & & & & & & 2,976 & 2,322 & & & \\
\hline & 蟋 & & & 2,168 & & & 2,555 & & & & & 2,328 & \\
\hline \multirow{3}{*}{ 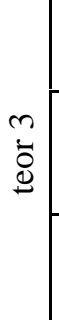 } & 樆 & & & & 1,713 & 2,146 & & & & & & & 1,794 \\
\hline & 崩 & & 2,108 & & & & & 2,333 & & & 2,219 & & \\
\hline & 感 & & & & 2,386 & 1,768 & & & & & & & 2,520 \\
\hline
\end{tabular}




\begin{tabular}{|c|c|c|c|c|c|c|c|c|c|c|c|c|c|}
\hline & \multicolumn{12}{|c|}{ Módulo de Resiliência Total $\left(10^{3} \mathrm{MPa}\right)$} \\
\hline & & \multicolumn{4}{|c|}{$\begin{array}{l}\text { sem envelhecimento a longo } \\
\text { prazo }\end{array}$} & \multicolumn{4}{|c|}{$\begin{array}{l}\text { envelhecimento a longo } \\
\text { prazo acelerado em estufa }\end{array}$} & \multicolumn{4}{|c|}{$\begin{array}{c}\text { envelhecimento a longo } \\
\text { prazo por exposição ao } \\
\text { tempo }\end{array}$} \\
\hline & & \multicolumn{2}{|c|}{$\begin{array}{l}\text { sem env. a } \\
\text { curto prazo }\end{array}$} & \multicolumn{2}{|c|}{$\begin{array}{l}4 \text { h de env. a } \\
\text { curto prazo }\end{array}$} & \multicolumn{2}{|c|}{$\begin{array}{l}\text { sem env. a } \\
\text { curto prazo }\end{array}$} & \multicolumn{2}{|c|}{$\begin{array}{l}4 \text { h de env. a } \\
\text { curto prazo }\end{array}$} & \multicolumn{2}{|c|}{$\begin{array}{l}\text { sem env. a } \\
\text { curto prazo }\end{array}$} & \multicolumn{2}{|c|}{$\begin{array}{l}4 \text { h de env. a } \\
\text { curto prazo }\end{array}$} \\
\hline & & $\mathrm{B}$ & $\mathrm{C}$ & $\mathrm{B}$ & $\mathrm{C}$ & $\mathrm{B}$ & $\mathrm{C}$ & $\mathrm{B}$ & $\mathrm{C}$ & $\mathrm{B}$ & $\mathrm{C}$ & $\mathrm{B}$ & $\mathrm{C}$ \\
\hline \multirow{3}{*}{$\begin{array}{l}0 \\
\dot{0} \\
\mathscr{D}\end{array}$} & $\begin{array}{ll}\dot{\vec{s}} & \grave{\delta} \\
\dot{\sigma}\end{array}$ & & & & 3,7 & 7,9 & & & & & & & 15,9 \\
\hline & $\begin{array}{ll}4 \\
\dot{g} \\
\ddot{g}\end{array}$ & & 8,5 & & & & & 21,7 & & & 17,0 & & \\
\hline & $\begin{array}{l}\dot{\vec{v}} \\
\vec{\sigma} \\
0\end{array}$ & & & & 4,9 & 8,6 & & & & & & & 15,3 \\
\hline \multirow{3}{*}{ ت্ট } & $\ddot{\vec{a}} \overrightarrow{0}$ & & & 15,0 & & & 13,9 & & & & & 21,5 & \\
\hline & $\begin{array}{ll}4 \\
\dot{g} \\
\dot{g}\end{array}$ & 10,7 & & & & & & & 16,8 & 22,7 & & & \\
\hline & $\begin{array}{l}4 \\
\text { ज }\end{array}$ & & & 14,9 & & & 16,7 & & & & & 20,0 & \\
\hline \multirow{3}{*}{ 它 } & $\begin{array}{ll}\dot{\vec{z}} & \dot{0} \\
\overrightarrow{0}\end{array}$ & & & 11,8 & & & 6,7 & & & & & 18,4 & \\
\hline & 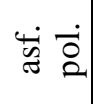 & 17,7 & & & & & & & 16,3 & 20,6 & & & \\
\hline & 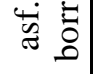 & & & 15,0 & & & 14,3 & & & & & 14,3 & \\
\hline \multirow{3}{*}{ m } & $\begin{array}{ll}\overrightarrow{0} \\
\dot{\sigma}\end{array}$ & & & & 3,6 & 11,2 & & & & & & & 12,9 \\
\hline & 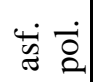 & & 4,9 & & & & & 15,8 & & & 12,7 & & \\
\hline & 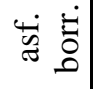 & & & & 4,8 & 16,5 & & & & & & & 13,4 \\
\hline
\end{tabular}




\begin{tabular}{|c|c|c|c|c|c|c|c|c|c|c|c|c|c|}
\hline & \multicolumn{12}{|c|}{ Módulo de Resiliência Instantâneo $\left(10^{3} \mathrm{MPa}\right)$} \\
\hline & & \multicolumn{4}{|c|}{$\begin{array}{l}\text { sem envelhecimento a longo } \\
\text { prazo }\end{array}$} & \multicolumn{4}{|c|}{$\begin{array}{l}\text { envelhecimento a longo } \\
\text { prazo acelerado em estufa }\end{array}$} & \multicolumn{4}{|c|}{$\begin{array}{c}\text { envelhecimento a longo } \\
\text { prazo por exposição ao } \\
\text { tempo }\end{array}$} \\
\hline & & \multicolumn{2}{|c|}{$\begin{array}{l}\text { sem env. a } \\
\text { curto prazo }\end{array}$} & \multicolumn{2}{|c|}{$\begin{array}{l}4 \text { h de env. a } \\
\text { curto prazo }\end{array}$} & \multicolumn{2}{|c|}{$\begin{array}{l}\text { sem env. a } \\
\text { curto prazo }\end{array}$} & \multicolumn{2}{|c|}{$\begin{array}{l}4 \mathrm{~h} \text { de env. a } \\
\text { curto prazo }\end{array}$} & \multicolumn{2}{|c|}{$\begin{array}{l}\text { sem env. a } \\
\text { curto prazo }\end{array}$} & \multicolumn{2}{|c|}{$\begin{array}{l}4 \text { h de env. a } \\
\text { curto prazo }\end{array}$} \\
\hline & & $\mathrm{B}$ & $\mathrm{C}$ & $\mathrm{B}$ & $\mathrm{C}$ & $\mathrm{B}$ & $\mathrm{C}$ & $\mathrm{B}$ & $\mathrm{C}$ & $\mathrm{B}$ & $\mathrm{C}$ & $\mathrm{B}$ & $\mathrm{C}$ \\
\hline \multirow{3}{*}{$\begin{array}{l}0 \\
\dot{0} \\
\mathscr{D}\end{array}$} & 䄈 & & & & 4,6 & 9,7 & & & & & & & 19,4 \\
\hline & $\begin{array}{ll}4 \\
\dot{g} \\
\ddot{g}\end{array}$ & & 10,5 & & & & & 24,8 & & & 20,8 & & \\
\hline & \begin{tabular}{ll}
4 & $\vdots$ \\
\multirow{2}{*}{} & 0 \\
0
\end{tabular} & & & & 6,0 & 10,8 & & & & & & & 18,6 \\
\hline \multirow{3}{*}{ ت্ট } & $\ddot{\vec{a}} \overrightarrow{0}$ & & & 18,7 & & & 17,1 & & & & & 25,6 & \\
\hline & $\begin{array}{ll}4 \\
\dot{g} \\
\dot{g}\end{array}$ & 13,1 & & & & & & & 20,2 & 26,7 & & & \\
\hline & $\begin{array}{l}4 \\
\text { ज }\end{array}$ & & & 17,7 & & & 20,0 & & & & & 23,7 & \\
\hline \multirow{3}{*}{ 它 } & $\begin{array}{ll}\dot{\vec{z}} & \dot{0} \\
\overrightarrow{0}\end{array}$ & & & 14,5 & & & 8,3 & & & & & 22,3 & \\
\hline & 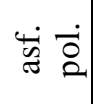 & 21,0 & & & & & & & 19,4 & 25,1 & & & \\
\hline & 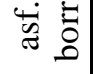 & & & 18,1 & & & 17,0 & & & & & 17,5 & \\
\hline \multirow{3}{*}{ m } & $\begin{array}{ll}\overrightarrow{0} \\
\dot{\sigma}\end{array}$ & & & & 4,4 & 13,8 & & & & & & & 15,8 \\
\hline & 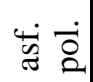 & & 6,0 & & & & & 19,4 & & & 15,6 & & \\
\hline & 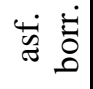 & & & & 5,7 & 19,6 & & & & & & & 16,5 \\
\hline
\end{tabular}




\begin{tabular}{|c|c|c|c|c|c|c|c|c|c|c|c|c|c|}
\hline & \multirow{2}{*}{\multicolumn{12}{|c|}{$\begin{array}{l}\text { Ensaio de Creep Estático } \\
\text { Deformação Total (\%) }\end{array}$}} \\
\hline & & & & & & & & & & & & & \\
\hline & & \multicolumn{4}{|c|}{$\begin{array}{l}\text { sem envelhecimento a longo } \\
\text { prazo }\end{array}$} & \multicolumn{4}{|c|}{$\begin{array}{l}\text { envelhecimento a longo } \\
\text { prazo acelerado em estufa }\end{array}$} & \multicolumn{4}{|c|}{$\begin{array}{l}\text { envelhecimento a longo } \\
\text { prazo por exposição ao } \\
\text { tempo }\end{array}$} \\
\hline & & \multicolumn{2}{|c|}{$\begin{array}{l}\text { sem env. a } \\
\text { curto prazo }\end{array}$} & \multicolumn{2}{|c|}{$\begin{array}{l}4 \text { h de env. a } \\
\text { curto prazo }\end{array}$} & \multicolumn{2}{|c|}{$\begin{array}{l}\text { sem env. a } \\
\text { curto prazo }\end{array}$} & \multicolumn{2}{|c|}{$\begin{array}{l}4 \mathrm{~h} \text { de env. a } \\
\text { curto prazo }\end{array}$} & \multicolumn{2}{|c|}{$\begin{array}{l}\text { sem env. a } \\
\text { curto prazo }\end{array}$} & \multicolumn{2}{|c|}{$\begin{array}{l}4 \mathrm{~h} \text { de env. a } \\
\text { curto prazo }\end{array}$} \\
\hline & & $\mathrm{B}$ & $\mathrm{C}$ & $\mathrm{B}$ & $\mathrm{C}$ & $\mathrm{B}$ & $\mathrm{C}$ & $\mathrm{B}$ & $\mathrm{C}$ & $\mathrm{B}$ & $\mathrm{C}$ & $\mathrm{B}$ & $\mathrm{C}$ \\
\hline \multirow{3}{*}{$\stackrel{0}{\ddot{0}}$} & $\dot{\vec{\sigma}} \vec{\delta}$ & & & & 0,35 & 0,52 & & & & & & & 0,35 \\
\hline & घं & & 0,26 & & & & & 0,22 & & & 0,33 & & \\
\hline & 峁 & & & & 0,27 & 0,52 & & & & & & & 0,30 \\
\hline \multirow{3}{*}{ ت্ّ } & $\dot{\vec{a}} \overrightarrow{0}$ & & & 0,38 & & & 0,21 & & & & & 0,36 & \\
\hline & पें & 0,24 & & & & & & & 0,36 & 0,26 & & & \\
\hline & $\dot{\vec{g}}$ & & & 0,35 & & & 0,26 & & & & & 0,29 & \\
\hline \multirow{3}{*}{$\begin{array}{l}\sim \\
\ddot{D}\end{array}$} & $\dot{\vec{z}} \overrightarrow{0}$ & & & 0,23 & & & 0,35 & & & & & 0,34 & \\
\hline & पें & 0,29 & & & & & & & 0,22 & 0,28 & & & \\
\hline & 崩 & & & 0,34 & & & 0,40 & & & & & 0,43 & \\
\hline \multirow{3}{*}{ m } & 蚝 & & & & 0,44 & 0,49 & & & & & & & 0,38 \\
\hline & यें & & 0,34 & & & & & 0,38 & & & 0,40 & & \\
\hline & 感 & & & & 0,33 & 0,62 & & & & & & & 0,37 \\
\hline
\end{tabular}




\begin{tabular}{|c|c|c|c|c|c|c|c|c|c|c|c|c|c|}
\hline & \multicolumn{12}{|c|}{$\begin{array}{c}\text { Ensaio de Creep Estático } \\
\text { Deformação Recuperável (\%) }\end{array}$} \\
\hline & & \multicolumn{4}{|c|}{$\begin{array}{l}\text { sem envelhecimento a longo } \\
\text { prazo }\end{array}$} & \multicolumn{4}{|c|}{$\begin{array}{l}\text { envelhecimento a longo } \\
\text { prazo acelerado em estufa }\end{array}$} & \multicolumn{4}{|c|}{$\begin{array}{l}\text { envelhecimento a longo } \\
\text { prazo por exposição ao } \\
\text { tempo }\end{array}$} \\
\hline & & \multicolumn{2}{|c|}{$\begin{array}{l}\text { sem env. a } \\
\text { curto prazo }\end{array}$} & \multicolumn{2}{|c|}{$\begin{array}{l}4 \mathrm{~h} \text { de env. a } \\
\text { curto prazo }\end{array}$} & \multicolumn{2}{|c|}{$\begin{array}{l}\text { sem env. a } \\
\text { curto prazo }\end{array}$} & \multicolumn{2}{|c|}{$\begin{array}{l}4 \mathrm{~h} \text { de env. a } \\
\text { curto prazo }\end{array}$} & \multicolumn{2}{|c|}{$\begin{array}{l}\text { sem env. a } \\
\text { curto prazo }\end{array}$} & \multicolumn{2}{|c|}{$\begin{array}{l}4 \text { h de env. a } \\
\text { curto prazo }\end{array}$} \\
\hline & & $\mathrm{B}$ & $\mathrm{C}$ & $\mathrm{B}$ & $\mathrm{C}$ & $\mathrm{B}$ & $\mathrm{C}$ & $\mathrm{B}$ & $\mathrm{C}$ & $\mathrm{B}$ & $\mathrm{C}$ & $\mathrm{B}$ & $\mathrm{C}$ \\
\hline \multirow{3}{*}{$\begin{array}{l}0 \\
\ddot{0} \\
\mathscr{Q}\end{array}$} & $\dot{\vec{s}} \overrightarrow{0}$ & & & & 0,20 & 0,33 & & & & & & & 0,25 \\
\hline & 焉 & & 0,14 & & & & & 0,15 & & & 0,19 & & \\
\hline & 嫣 & & & & 0,15 & 0,38 & & & & & & & 0,19 \\
\hline \multirow{3}{*}{$\overline{\overrightarrow{0}}$} & 峁 & & & 0,20 & & & 0,16 & & & & & 0,21 & \\
\hline & पें & 0,14 & & & & & & & 0,18 & 0,17 & & & \\
\hline & 峁 & & & 0,18 & & & 0,16 & & & & & 0,19 & \\
\hline \multirow{3}{*}{ 离 } & 崩 & & & 0,15 & & & 0,26 & & & & & 0,23 & \\
\hline & 崩 & 0,17 & & & & & & & 0,14 & 0,20 & & & \\
\hline & 崩 & & & 0,19 & & & 0,25 & & & & & 0,24 & \\
\hline \multirow{3}{*}{ ?ִ } & 崩 & & & & 0,20 & 0,36 & & & & & & & 0,25 \\
\hline & प्ष & & 0,13 & & & & & 0,18 & & & 0,23 & & \\
\hline & 崩 & & & & 0,15 & 0,36 & & & & & & & 0,20 \\
\hline
\end{tabular}




\begin{tabular}{|c|c|c|c|c|c|c|c|c|c|c|c|c|c|}
\hline & \multicolumn{12}{|c|}{$\begin{array}{c}\text { Ensaio de Creep Estático } \\
\text { Deformação não Recuperável (\%) }\end{array}$} \\
\hline & & \multicolumn{4}{|c|}{$\begin{array}{l}\text { sem envelhecimento a longo } \\
\text { prazo }\end{array}$} & \multicolumn{4}{|c|}{$\begin{array}{l}\text { envelhecimento a longo } \\
\text { prazo acelerado em estufa }\end{array}$} & \multicolumn{4}{|c|}{$\begin{array}{l}\text { envelhecimento a longo } \\
\text { prazo por exposição ao } \\
\text { tempo }\end{array}$} \\
\hline & & \multicolumn{2}{|c|}{$\begin{array}{l}\text { sem env. a } \\
\text { curto prazo }\end{array}$} & \multicolumn{2}{|c|}{$\begin{array}{l}4 \text { h de env. a } \\
\text { curto prazo }\end{array}$} & \multicolumn{2}{|c|}{$\begin{array}{l}\text { sem env. a } \\
\text { curto prazo }\end{array}$} & \multicolumn{2}{|c|}{$\begin{array}{l}4 \mathrm{~h} \text { de env. a } \\
\text { curto prazo }\end{array}$} & \multicolumn{2}{|c|}{$\begin{array}{l}\text { sem env. a } \\
\text { curto prazo }\end{array}$} & \multicolumn{2}{|c|}{$\begin{array}{l}4 \mathrm{~h} \text { de env. a } \\
\text { curto prazo }\end{array}$} \\
\hline & & $\mathrm{B}$ & $\mathrm{C}$ & $\mathrm{B}$ & $\mathrm{C}$ & $\mathrm{B}$ & $\mathrm{C}$ & $\mathrm{B}$ & $\mathrm{C}$ & $\mathrm{B}$ & $\mathrm{C}$ & $\mathrm{B}$ & $\mathrm{C}$ \\
\hline \multirow{3}{*}{$\stackrel{0}{\square}$} & $\dot{\vec{g}} \overrightarrow{0}$ & & & & 0,15 & 0,19 & & & & & & & 0,10 \\
\hline & 逭 & & 0,12 & & & & & 0,07 & & & 0,13 & & \\
\hline & 蚝 & & & & 0,12 & 0,15 & & & & & & & 0,11 \\
\hline \multirow{3}{*}{ ఫ̈ } & $\dot{\vec{g}} \overrightarrow{0}$ & & & 0,18 & & & 0,05 & & & & & 0,15 & \\
\hline & $\dot{\vec{c}}$ & 0,10 & & & & & & & 0,18 & 0,10 & & & \\
\hline & 峁 & & & 0,17 & & & 0,10 & & & & & 0,10 & \\
\hline \multirow{3}{*}{$\stackrel{2}{\overrightarrow{0}}$} & $\dot{\vec{g}} \vec{\delta}$ & & & 0,08 & & & 0,10 & & & & & 0,11 & \\
\hline & $\begin{array}{l}4 \\
\vec{\sigma}\end{array}$ & 0,12 & & & & & & & 0,08 & 0,08 & & & \\
\hline & 峁 & & & 0,15 & & & 0,15 & & & & & 0,19 & \\
\hline \multirow{3}{*}{$\stackrel{m}{\overrightarrow{0}}$} & $\dot{\vec{g}} \overrightarrow{0}$ & & & & 0,24 & 0,13 & & & & & & & 0,13 \\
\hline & 崩 & & 0,21 & & & & & 0,20 & & & 0,16 & & \\
\hline & 崩 & & & & 0,18 & 0,26 & & & & & & & 0,17 \\
\hline
\end{tabular}




\begin{tabular}{|c|c|c|c|c|c|c|c|c|c|c|c|c|c|}
\hline & \multicolumn{12}{|c|}{$\begin{array}{c}\text { Ensaio de Creep Estático } \\
\text { Recuperação (\%) }\end{array}$} \\
\hline & & \multicolumn{4}{|c|}{$\begin{array}{c}\text { sem envelhecimento a longo } \\
\text { prazo }\end{array}$} & \multicolumn{4}{|c|}{$\begin{array}{l}\text { envelhecimento a longo } \\
\text { prazo acelerado em estufa }\end{array}$} & \multicolumn{4}{|c|}{$\begin{array}{l}\text { envelhecimento a longo } \\
\text { prazo por exposição ao } \\
\text { tempo }\end{array}$} \\
\hline & & \multicolumn{2}{|c|}{$\begin{array}{l}\text { sem env. a } \\
\text { curto prazo }\end{array}$} & \multicolumn{2}{|c|}{$\begin{array}{l}4 \mathrm{~h} \text { de env. a } \\
\text { curto prazo }\end{array}$} & \multicolumn{2}{|c|}{$\begin{array}{l}\text { sem env. a } \\
\text { curto prazo }\end{array}$} & \multicolumn{2}{|c|}{$\begin{array}{l}4 \text { h de env. a } \\
\text { curto prazo }\end{array}$} & \multicolumn{2}{|c|}{$\begin{array}{l}\text { sem env. a } \\
\text { curto prazo }\end{array}$} & \multicolumn{2}{|c|}{$\begin{array}{l}4 \mathrm{~h} \text { de env. a } \\
\text { curto prazo }\end{array}$} \\
\hline & & $\mathrm{B}$ & $\mathrm{C}$ & $\mathrm{B}$ & $\mathrm{C}$ & $\mathrm{B}$ & $\mathrm{C}$ & $\mathrm{B}$ & $\mathrm{C}$ & $\mathrm{B}$ & $\mathrm{C}$ & $\mathrm{B}$ & $\mathrm{C}$ \\
\hline \multirow{3}{*}{$\begin{array}{l}0 \\
\stackrel{0}{0} \\
\stackrel{\Xi}{ \pm}\end{array}$} & 状 & & & & 58,29 & 66,06 & & & & & & & 70,79 \\
\hline & 崩 & & 56,10 & & & & & 68,39 & & & 59,67 & & \\
\hline & 峁 & & & & 55,92 & 71,98 & & & & & & & 62,33 \\
\hline \multirow{3}{*}{$\overline{\overrightarrow{0}}$} & 蚝 & & & 55,18 & & & 75,53 & & & & & 57,38 & \\
\hline & पें & 58,58 & & & & & & & 52,75 & 63,74 & & & \\
\hline & 峁 & & & 53,66 & & & 62,39 & & & & & 66,25 & \\
\hline \multirow{3}{*}{$\begin{array}{c}\sim \\
\ddot{0} \\
\Phi\end{array}$} & 迥 & & & 66,87 & & & 60,40 & & & & & 68,44 & \\
\hline & प्यें & 58,20 & & & & & & & 62,36 & 69,88 & & & \\
\hline & 峁 & & & 57,08 & & & 67,52 & & & & & 57,46 & \\
\hline \multirow{3}{*}{ 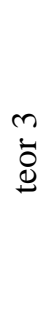 } & 崩 & & & & 47,18 & 73,37 & & & & & & & 66,52 \\
\hline & प्ष & & 40,88 & & & & & 47,74 & & & 60,35 & & \\
\hline & 状 & & & & 47,72 & 58,44 & & & & & & & 54,68 \\
\hline
\end{tabular}




\begin{tabular}{|c|c|c|c|c|c|c|c|c|c|c|c|c|c|}
\hline & \multicolumn{12}{|c|}{$\begin{array}{l}\text { Ensaio de Creep Estático } \\
\text { Módulo de Fluência (MPa) }\end{array}$} \\
\hline & & \multicolumn{4}{|c|}{$\begin{array}{l}\text { sem envelhecimento a longo } \\
\text { prazo }\end{array}$} & \multicolumn{4}{|c|}{$\begin{array}{l}\text { envelhecimento a longo } \\
\text { prazo acelerado em estufa }\end{array}$} & \multicolumn{4}{|c|}{$\begin{array}{l}\text { envelhecimento a longo } \\
\text { prazo por exposição ao } \\
\text { tempo }\end{array}$} \\
\hline & & \multicolumn{2}{|c|}{$\begin{array}{l}\text { sem env. a } \\
\text { curto prazo }\end{array}$} & \multicolumn{2}{|c|}{$\begin{array}{l}4 \mathrm{~h} \text { de env. a } \\
\text { curto prazo }\end{array}$} & \multicolumn{2}{|c|}{$\begin{array}{l}\text { sem env. a } \\
\text { curto prazo }\end{array}$} & \multicolumn{2}{|c|}{$\begin{array}{l}4 \text { h de env. a } \\
\text { curto prazo }\end{array}$} & \multicolumn{2}{|c|}{$\begin{array}{l}\text { sem env. a } \\
\text { curto prazo }\end{array}$} & \multicolumn{2}{|c|}{$\begin{array}{l}4 \mathrm{~h} \text { de env. a } \\
\text { curto prazo }\end{array}$} \\
\hline & & $\mathrm{B}$ & $\mathrm{C}$ & $\mathrm{B}$ & $\mathrm{C}$ & $\mathrm{B}$ & $\mathrm{C}$ & $\mathrm{B}$ & $\mathrm{C}$ & $\mathrm{B}$ & $\mathrm{C}$ & $\mathrm{B}$ & $\mathrm{C}$ \\
\hline \multirow{3}{*}{$\begin{array}{l}0 \\
\dot{0} \\
0\end{array}$} & $\dot{\vec{\sigma}} \vec{\delta}$ & & & & 119,1 & 81,5 & & & & & & & 84,1 \\
\hline & घं & & 156,4 & & & & & 175,0 & & & 123,9 & & \\
\hline & 荘 & & & & 144,2 & 76,9 & & & & & & & 103,8 \\
\hline \multirow{3}{*}{ ت্ّ } & $\dot{\vec{g}} \overrightarrow{\mathrm{g}}$ & & & 126,8 & & & 198,1 & & & & & 102,4 & \\
\hline & पें & 168,5 & & & & & & & 124,7 & 153,5 & & & \\
\hline & 崩 & & & 110,0 & & & 158,0 & & & & & 101,3 & \\
\hline \multirow{3}{*}{$\begin{array}{l}\sim \\
\ddot{D}\end{array}$} & 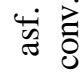 & & & 173,7 & & & 118,9 & & & & & 104,0 & \\
\hline & 感 & 142,0 & & & & & & & 184,4 & 149,3 & & & \\
\hline & 岮 & & & 105,9 & & & 135,5 & & & & & 83,3 & \\
\hline \multirow{3}{*}{ m } & 蚝 & & & & 103,1 & 86,6 & & & & & & & 82,4 \\
\hline & प্் & & 120,3 & & & & & 92,2 & & & 108,5 & & \\
\hline & 荘 & & & & 122,4 & 66,27 & & & & & & & 79,2 \\
\hline
\end{tabular}




\begin{tabular}{|c|c|c|c|c|c|c|c|c|c|c|c|c|c|}
\hline & \multicolumn{12}{|c|}{$\begin{array}{c}\text { Ensaio de Creep Estático } \\
\text { Módulo de Fluência após Recuperação (MPa) }\end{array}$} \\
\hline & & \multicolumn{4}{|c|}{$\begin{array}{c}\text { sem envelhecimento a longo } \\
\text { prazo }\end{array}$} & \multicolumn{4}{|c|}{$\begin{array}{l}\text { envelhecimento a longo } \\
\text { prazo acelerado em estufa }\end{array}$} & \multicolumn{4}{|c|}{$\begin{array}{l}\text { envelhecimento a longo } \\
\text { prazo por exposição ao } \\
\text { tempo }\end{array}$} \\
\hline & & \multicolumn{2}{|c|}{$\begin{array}{l}\text { sem env. a } \\
\text { curto prazo }\end{array}$} & \multicolumn{2}{|c|}{$\begin{array}{l}4 \mathrm{~h} \text { de env. a } \\
\text { curto prazo }\end{array}$} & \multicolumn{2}{|c|}{$\begin{array}{l}\text { sem env. a } \\
\text { curto prazo }\end{array}$} & \multicolumn{2}{|c|}{$\begin{array}{l}4 \text { h de env. a } \\
\text { curto prazo }\end{array}$} & \multicolumn{2}{|c|}{$\begin{array}{l}\text { sem env. a } \\
\text { curto prazo }\end{array}$} & \multicolumn{2}{|c|}{$\begin{array}{l}4 \mathrm{~h} \text { de env. a } \\
\text { curto prazo }\end{array}$} \\
\hline & & $\mathrm{B}$ & $\mathrm{C}$ & $\mathrm{B}$ & $\mathrm{C}$ & $\mathrm{B}$ & $\mathrm{C}$ & $\mathrm{B}$ & $\mathrm{C}$ & $\mathrm{B}$ & $\mathrm{C}$ & $\mathrm{B}$ & $\mathrm{C}$ \\
\hline \multirow{3}{*}{$\begin{array}{l}0 \\
\ddot{0} \\
\stackrel{\leftrightarrow}{U}\end{array}$} & 峁 & & & & 292,6 & 300,9 & & & & & & & 293,8 \\
\hline & प्山ें & & 371,8 & & & & & 569,6 & & & 317,9 & & \\
\hline & 峁 & & & & 332,3 & 333,8 & & & & & & & 279,2 \\
\hline \multirow{3}{*}{$\overline{\ddot{D}}$} & $\dot{\vec{a}} \overrightarrow{0}$ & & & 306,6 & & & 876,6 & & & & & 240,4 & \\
\hline & प्षे & 406,5 & & & & & & & 304,4 & 433,6 & & & \\
\hline & 崩 & & & 259,3 & & & 503,4 & & & & & 312,1 & \\
\hline \multirow{3}{*}{$\begin{array}{c}\sim \\
\ddot{0} \\
\Phi\end{array}$} & 峁 & & & 595,3 & & & 428,2 & & & & & 361,2 & \\
\hline & प्रें & 353,6 & & & & & & & 491,2 & 521,7 & & & \\
\hline & 崩 & & & 275,7 & & & 555,7 & & & & & 224,1 & \\
\hline \multirow{3}{*}{$\stackrel{m}{\overrightarrow{0}}$} & 峁 & & & & 206,0 & 369,9 & & & & & & & 246,3 \\
\hline & 语 & & 210,9 & & & & & 184,1 & & & $\begin{array}{c}313,3 \\
3\end{array}$ & & \\
\hline & 感 & & & & 252,9 & 160,5 & & & & & & & 180,7 \\
\hline
\end{tabular}




\begin{tabular}{|c|c|c|c|c|c|c|c|c|c|c|c|c|c|}
\hline & \multicolumn{12}{|c|}{$\begin{array}{c}\text { Ensaio de Creep Estático } \\
\text { Inclinação da curva de fluência }\end{array}$} \\
\hline & & \multicolumn{4}{|c|}{$\begin{array}{l}\text { sem envelhecimento a longo } \\
\text { prazo }\end{array}$} & \multicolumn{4}{|c|}{$\begin{array}{l}\text { envelhecimento a longo } \\
\text { prazo acelerado em estufa }\end{array}$} & \multicolumn{4}{|c|}{$\begin{array}{l}\text { envelhecimento a longo } \\
\text { prazo por exposição ao } \\
\text { tempo }\end{array}$} \\
\hline & & \multicolumn{2}{|c|}{$\begin{array}{l}\text { sem env. a } \\
\text { curto prazo }\end{array}$} & \multicolumn{2}{|c|}{$\begin{array}{l}4 \mathrm{~h} \text { de env. a } \\
\text { curto prazo }\end{array}$} & \multicolumn{2}{|c|}{$\begin{array}{l}\text { sem env. a } \\
\text { curto prazo }\end{array}$} & \multicolumn{2}{|c|}{$\begin{array}{l}4 \mathrm{~h} \text { de env. a } \\
\text { curto prazo }\end{array}$} & \multicolumn{2}{|c|}{$\begin{array}{l}\text { sem env. a } \\
\text { curto prazo }\end{array}$} & \multicolumn{2}{|c|}{$\begin{array}{l}4 \mathrm{~h} \text { de env. a } \\
\text { curto prazo }\end{array}$} \\
\hline & & $\mathrm{B}$ & $\mathrm{C}$ & $\mathrm{B}$ & $\mathrm{C}$ & $\mathrm{B}$ & $\mathrm{C}$ & $\mathrm{B}$ & $\mathrm{C}$ & $\mathrm{B}$ & $\mathrm{C}$ & $\mathrm{B}$ & $\mathrm{C}$ \\
\hline \multirow{3}{*}{$\stackrel{0}{0}$} & 拧 & & & & 0,044 & 0,061 & & & & & & & 0,056 \\
\hline & ज्ञ & & 0,059 & & & & & 0,095 & & & 0,123 & & \\
\hline & 崩 & & & & 0,095 & 0,069 & & & & & & & 0,101 \\
\hline \multirow{3}{*}{$\overline{\vec{D}}$} & 峁 & & & 0,067 & & & 0,066 & & & & & 0,088 & \\
\hline & 哆 & 0,116 & & & & & & & 0,117 & 0,118 & & & \\
\hline & 㱐 & & & 0,101 & & & 0,102 & & & & & 0,101 & \\
\hline \multirow{3}{*}{ 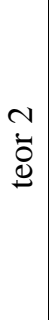 } & 桴 & & & 0,050 & & & 0,037 & & & & & 0,062 & \\
\hline & 哆 & 0,052 & & & & & & & 0,151 & 0,095 & & & \\
\hline & 缡 & & & 0,104 & & & 0,128 & & & & & 0,138 & \\
\hline \multirow{3}{*}{ m } & 范 & & & & 0,102 & 0,066 & & & & & & & 0,081 \\
\hline & 桴 & & 0,120 & & & & & 0,155 & & & 0,130 & & \\
\hline & 崩 & & & & 0,139 & 0,113 & & & & & & & 0,105 \\
\hline
\end{tabular}




\begin{tabular}{|c|c|c|c|c|c|c|c|c|c|c|c|c|c|}
\hline & \multirow{2}{*}{\multicolumn{12}{|c|}{$\begin{array}{c}\text { Ensaio de Creep Dinâmico } \\
\text { Deformação Total (\%) }\end{array}$}} \\
\hline & & & & & & & & & & & & & \\
\hline & & \multicolumn{4}{|c|}{$\begin{array}{l}\text { sem envelhecimento a longo } \\
\text { prazo }\end{array}$} & \multicolumn{4}{|c|}{$\begin{array}{l}\text { envelhecimento a longo } \\
\text { prazo acelerado em estufa }\end{array}$} & \multicolumn{4}{|c|}{$\begin{array}{l}\text { envelhecimento a longo } \\
\text { prazo por exposição ao } \\
\text { tempo }\end{array}$} \\
\hline & & \multicolumn{2}{|c|}{$\begin{array}{l}\text { sem env. a } \\
\text { curto prazo }\end{array}$} & \multicolumn{2}{|c|}{$\begin{array}{l}4 \text { h de env. a } \\
\text { curto prazo }\end{array}$} & \multicolumn{2}{|c|}{$\begin{array}{l}\text { sem env. a } \\
\text { curto prazo }\end{array}$} & \multicolumn{2}{|c|}{$\begin{array}{l}4 \text { h de env. a } \\
\text { curto prazo }\end{array}$} & \multicolumn{2}{|c|}{$\begin{array}{l}\text { sem env. a } \\
\text { curto prazo }\end{array}$} & \multicolumn{2}{|c|}{$\begin{array}{l}4 \mathrm{~h} \text { de env. a } \\
\text { curto prazo }\end{array}$} \\
\hline & & $\mathrm{B}$ & $\mathrm{C}$ & $\mathrm{B}$ & $\mathrm{C}$ & $\mathrm{B}$ & $\mathrm{C}$ & $\mathrm{B}$ & $\mathrm{C}$ & $\mathrm{B}$ & $\mathrm{C}$ & $\mathrm{B}$ & $\mathrm{C}$ \\
\hline \multirow{3}{*}{$\stackrel{0}{0}$} & $\dot{\vec{g}} \overrightarrow{0}$ & & & & 0,42 & 0,41 & & & & & & & 0,22 \\
\hline & 逭 & & 0,29 & & & & & 0,17 & & & 0,18 & & \\
\hline & 崩 & & & & 0,22 & 0,31 & & & & & & & 0,18 \\
\hline \multirow{3}{*}{ ت्ञ } & $\dot{\vec{\sigma}} \vec{\delta}$ & & & 0,24 & & & 0,34 & & & & & 0,21 & \\
\hline & पे & 0,28 & & & & & & & 0,29 & 0,15 & & & \\
\hline & 崩 & & & 0,24 & & & 0,31 & & & & & 0,19 & \\
\hline \multirow{3}{*}{$\stackrel{2}{\overrightarrow{0}}$} & $\dot{\vec{g}} \vec{\delta}$ & & & 0,22 & & & 0,68 & & & & & 0,21 & \\
\hline & 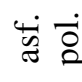 & 0,37 & & & & & & & 0,20 & 0,19 & & & \\
\hline & 峁 & & & 0,22 & & & 0,31 & & & & & 0,22 & \\
\hline \multirow{3}{*}{$\stackrel{m}{\overrightarrow{0}}$} & $\dot{\vec{g}} \overrightarrow{0}$ & & & & 0,66 & 0,42 & & & & & & & 0,26 \\
\hline & 崩 & & 0,59 & & & & & 0,18 & & & 0,25 & & \\
\hline & 崩 & & & & 0,36 & 0,17 & & & & & & & 0,20 \\
\hline
\end{tabular}




\begin{tabular}{|c|c|c|c|c|c|c|c|c|c|c|c|c|c|}
\hline & \multicolumn{12}{|c|}{$\begin{array}{l}\text { Ensaio de Creep Dinâmico } \\
\text { Módulo de Fluência (MPa) }\end{array}$} \\
\hline & & \multicolumn{4}{|c|}{$\begin{array}{c}\text { sem envelhecimento a longo } \\
\text { prazo }\end{array}$} & \multicolumn{4}{|c|}{$\begin{array}{l}\text { envelhecimento a longo } \\
\text { prazo acelerado em estufa }\end{array}$} & \multicolumn{4}{|c|}{$\begin{array}{l}\text { envelhecimento a longo } \\
\text { prazo por exposição ao } \\
\text { tempo }\end{array}$} \\
\hline & & \multicolumn{2}{|c|}{$\begin{array}{l}\text { sem env. a } \\
\text { curto prazo }\end{array}$} & \multicolumn{2}{|c|}{$\begin{array}{l}4 \text { h de env. a } \\
\text { curto prazo }\end{array}$} & \multicolumn{2}{|c|}{$\begin{array}{l}\text { sem env. a } \\
\text { curto prazo }\end{array}$} & \multicolumn{2}{|c|}{$\begin{array}{l}4 \text { h de env. a } \\
\text { curto prazo }\end{array}$} & \multicolumn{2}{|c|}{$\begin{array}{l}\text { sem env. a } \\
\text { curto prazo }\end{array}$} & \multicolumn{2}{|c|}{$\begin{array}{l}4 \mathrm{~h} \text { de env. a } \\
\text { curto prazo }\end{array}$} \\
\hline & & $\mathrm{B}$ & $\mathrm{C}$ & $\mathrm{B}$ & $\mathrm{C}$ & $\mathrm{B}$ & $\mathrm{C}$ & $\mathrm{B}$ & $\mathrm{C}$ & $\mathrm{B}$ & $\mathrm{C}$ & $\mathrm{B}$ & $\mathrm{C}$ \\
\hline \multirow{3}{*}{$\begin{array}{l}0 \\
\dot{0} \\
\stackrel{\Delta}{U}\end{array}$} & 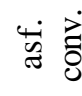 & & & & 88,12 & 86,3 & & & & & & & 136,9 \\
\hline & 焉 & & 128,2 & & & & & 208,4 & & & 230,6 & & \\
\hline & 嫣 & & & & 197,3 & 113,9 & & & & & & & 196,3 \\
\hline \multirow{3}{*}{$\overline{\overrightarrow{0}}$} & 峁 & & & 168,1 & & & 109,1 & & & & & 189,6 & \\
\hline & पें & 129,5 & & & & & & & 118,7 & 270,3 & & & \\
\hline & 范 & & & 136,2 & & & 116,9 & & & & & 160,3 & \\
\hline \multirow{3}{*}{$\begin{array}{c}\sim \\
\ddot{0} \\
\Phi\end{array}$} & 迥 & & & 153,9 & & & 50,1 & & & & & 124,1 & \\
\hline & प्यें & 146,4 & & & & & & & 175,9 & 211,5 & & & \\
\hline & 峁 & & & 151,8 & & & 118,3 & & & & & 167,6 & \\
\hline \multirow{3}{*}{ 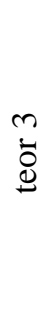 } & 崩 & & & & 69,5 & 86,4 & & & & & & & 139,3 \\
\hline & प्ष & & 58,7 & & & & & 195,9 & & & 168,8 & & \\
\hline & 崩 & & & & 123,8 & 219,3 & & & & & & & 182,9 \\
\hline
\end{tabular}




\begin{tabular}{|c|c|c|c|c|c|c|c|c|c|c|c|c|c|}
\hline & \multicolumn{12}{|c|}{$\begin{array}{c}\text { Ensaio de Creep Dinâmico } \\
\text { Inclinação da Curva de Fluência }\end{array}$} \\
\hline & & \multicolumn{4}{|c|}{$\begin{array}{c}\text { sem envelhecimento a longo } \\
\text { prazo }\end{array}$} & \multicolumn{4}{|c|}{$\begin{array}{l}\text { envelhecimento a longo } \\
\text { prazo acelerado em estufa }\end{array}$} & \multicolumn{4}{|c|}{$\begin{array}{l}\text { envelhecimento a longo } \\
\text { prazo por exposição ao } \\
\text { tempo }\end{array}$} \\
\hline & & \multicolumn{2}{|c|}{$\begin{array}{l}\text { sem env. a } \\
\text { curto prazo }\end{array}$} & \multicolumn{2}{|c|}{$\begin{array}{l}4 \mathrm{~h} \text { de env. a } \\
\text { curto prazo }\end{array}$} & \multicolumn{2}{|c|}{$\begin{array}{l}\text { sem env. a } \\
\text { curto prazo }\end{array}$} & \multicolumn{2}{|c|}{$\begin{array}{l}4 \text { h de env. a } \\
\text { curto prazo }\end{array}$} & \multicolumn{2}{|c|}{$\begin{array}{l}\text { sem env. a } \\
\text { curto prazo }\end{array}$} & \multicolumn{2}{|c|}{$\begin{array}{l}4 \mathrm{~h} \text { de env. a } \\
\text { curto prazo }\end{array}$} \\
\hline & & $\mathrm{B}$ & $\mathrm{C}$ & $\mathrm{B}$ & $\mathrm{C}$ & $\mathrm{B}$ & $\mathrm{C}$ & $\mathrm{B}$ & $\mathrm{C}$ & $\mathrm{B}$ & $\mathrm{C}$ & $\mathrm{B}$ & $\mathrm{C}$ \\
\hline \multirow{3}{*}{$\begin{array}{l}0 \\
\ddot{0} \\
\stackrel{\leftrightarrow}{U}\end{array}$} & 峁 & & & & 0,254 & 0,167 & & & & & & & 0,139 \\
\hline & प्山ें & & 0,105 & & & & & 0,126 & & & 0,128 & & \\
\hline & 峁 & & & & 0,147 & 0,125 & & & & & & & 0,131 \\
\hline \multirow{3}{*}{$\overline{\ddot{D}}$} & $\dot{\vec{a}} \overrightarrow{0}$ & & & 0,176 & & & 0,120 & & & & & 0,169 & \\
\hline & प्षे & 0,094 & & & & & & & 0,222 & 0,139 & & & \\
\hline & 崩 & & & 0,140 & & & 0,122 & & & & & 0,124 & \\
\hline \multirow{3}{*}{$\begin{array}{c}\sim \\
\ddot{0} \\
\Phi\end{array}$} & 峁 & & & 0,190 & & & 0,243 & & & & & 0,161 & \\
\hline & प्रें & 0,097 & & & & & & & 0,139 & 0,133 & & & \\
\hline & 崩 & & & 0,122 & & & 0,101 & & & & & 0,141 & \\
\hline \multirow{3}{*}{$\stackrel{m}{\overrightarrow{0}}$} & 峁 & & & & 0,299 & 0,174 & & & & & & & 0,196 \\
\hline & प्ष & & 0,245 & & & & & 0,171 & & & 0,198 & & \\
\hline & 感 & & & & 0,254 & 0,133 & & & & & & & 0,189 \\
\hline
\end{tabular}




\section{APÊNDICE F - Tabelas de análise de variância}

Tabelas da análise de variância (ANOVA) realizada com os resultados do ensaio de MR

Tabela F.1 - Tabela da análise de variância do MR total (MPa), realizada com nível de significância de 0,01, ou seja, confiança de $99 \%$, considerando-se o fator $A$ quantitativo, representando o teor de ligante

\begin{tabular}{|c|c|c|c|c|c|c|c|}
\hline $\begin{array}{l}\text { fonte de } \\
\text { variação }\end{array}$ & $\begin{array}{l}\text { graus de } \\
\text { liberdade } \\
(\mathrm{GL})\end{array}$ & & $\begin{array}{c}\text { soma de quadrados } \\
\qquad S Q=r L^{2} / 2^{n}\end{array}$ & $\begin{array}{c}\text { quadrado } \\
\text { médio } \\
\mathrm{QM}=\mathrm{SQ} / \mathrm{GL}\end{array}$ & $F_{0}=\frac{Q M t r a t}{Q M e r r o}$ & $F_{0,01}$ & $\begin{array}{c}\text { significativo } \\
?\end{array}$ \\
\hline$\overline{\mathrm{Al}}$ & 1 & & $\mathrm{SQ} A \mathrm{Al}=4,37 \mathrm{E}+05$ & $4,37 E+05$ & 0,04 & 7,08 & não \\
\hline $\mathrm{Aq}$ & 1 & & $S Q A q=2,32 E+08$ & $2,32 E+08$ & 18,79 & 7,08 & $\operatorname{sim}$ \\
\hline$B$ & 1 & & $S Q B=9,09 E+08$ & $9,09 E+08$ & 73,64 & 7,08 & $\operatorname{sim}$ \\
\hline C & 1 & & $S Q C=6,60 E+07$ & $6,60 \mathrm{E}+07$ & 5,35 & 7,08 & não \\
\hline $\mathrm{X} 7$ & 1 & & $\mathrm{SQ} \times 7=1,72 \mathrm{E}+08$ & $1,72 \mathrm{E}+08$ & 13,93 & 7,08 & $\operatorname{sim}$ \\
\hline $\mathrm{X} 8$ & 1 & & $\mathrm{SQ} \times 8=1,76 \mathrm{E}+06$ & $1,76 \mathrm{E}+06$ & 0,14 & 7,08 & não \\
\hline AIC & 1 & & $\mathrm{SQ} A I C=1,29 \mathrm{E}+07$ & $1,29 E+07$ & 1,05 & 7,08 & não \\
\hline $\mathrm{AqC}$ & 1 & & $S Q A q C=1,00 E+06$ & $1,00 \mathrm{E}+06$ & 0,08 & 7,08 & não \\
\hline AIX8 & 1 & & $\mathrm{SQ}$ AIX8 $=8,93 \mathrm{E}+06$ & $8,93 E+06$ & 0,72 & 7,08 & não \\
\hline $\mathrm{Ag} \times 8$ & 1 & & $\mathrm{SQ} A q \times 8=2,64 \mathrm{E}+07$ & $2,64 \mathrm{E}+07$ & 2,14 & 7,08 & não \\
\hline$\overline{\text { erro }}$ & $\begin{array}{c}\mathrm{N}-\mathrm{m} \\
71-10=\end{array}$ & 61 & SQerro $=7,53 \mathrm{E}+08$ & $1,23 \mathrm{E}+07$ & & & \\
\hline $\begin{array}{l}\text { variação } \\
\text { total }\end{array}$ & $\begin{array}{c}N-1 \\
(2 * 36-1)=\end{array}$ & 71 & SQtotal $=2,18 \mathrm{E}+09$ & $3,08 \mathrm{E}+07$ & & & \\
\hline
\end{tabular}

Tabela F.2 - Tabela da análise de variância do MR total (MPa), realizada com nível de significância de 0,05, ou seja, confiança de 95\%, considerando-se o fator $A$ quantitativo, representando o teor de ligante

\begin{tabular}{|c|c|c|c|c|c|c|c|}
\hline $\begin{array}{l}\text { fonte de } \\
\text { variação }\end{array}$ & $\begin{array}{l}\text { graus de } \\
\text { liberdade } \\
\text { (GL) }\end{array}$ & & $\begin{array}{c}\text { soma de quadrados } \\
\qquad S Q=r L^{2} / 2^{n}\end{array}$ & $\begin{array}{c}\text { quadrado } \\
\text { médio } \\
\mathrm{QM}=\mathrm{SQ} / \mathrm{GL}\end{array}$ & $F_{0}=\frac{Q M \text { trat }}{\text { QMerro }}$ & $F_{0,05}$ & $\begin{array}{c}\text { significativo } \\
?\end{array}$ \\
\hline$\overline{\mathrm{Al}}$ & 1 & & $\mathrm{SQAl}=4,37 \mathrm{E}+05$ & $4,37 E+05$ & 0,04 & 4,00 & não \\
\hline $\mathrm{Aq}$ & 1 & & $S Q A q=2,32 E+08$ & $2,32 E+08$ & 18,79 & 4,00 & $\operatorname{sim}$ \\
\hline B & 1 & & $S Q B=9,09 E+08$ & $9,09 \mathrm{E}+08$ & 73,64 & 4,00 & $\operatorname{sim}$ \\
\hline C & 1 & & $S Q C=6,60 E+07$ & $6,60 \mathrm{E}+07$ & 5,35 & 4,00 & $\operatorname{sim}$ \\
\hline X7 & 1 & & $\mathrm{SQ} \times 7=1,72 \mathrm{E}+08$ & $1,72 E+08$ & 13,93 & 4,00 & $\operatorname{sim}$ \\
\hline X8 & 1 & & $\mathrm{SQ} \times 8=1,76 \mathrm{E}+06$ & $1,76 \mathrm{E}+06$ & 0,14 & 4,00 & não \\
\hline AIC & 1 & & $\mathrm{SQ} A I C=1,29 E+07$ & $1,29 E+07$ & 1,05 & 4,00 & não \\
\hline $\mathrm{AqC}$ & 1 & & $S Q A q C=1,00 E+06$ & $1,00 \mathrm{E}+06$ & 0,08 & 4,00 & não \\
\hline AIX8 & 1 & & $\mathrm{SQ}$ AIX8 $=8,93 \mathrm{E}+06$ & $8,93 E+06$ & 0,72 & 4,00 & não \\
\hline $\mathrm{Aq} \times 8$ & 1 & & $\mathrm{SQ} A q \times 8=2,64 \mathrm{E}+07$ & $2,64 \mathrm{E}+07$ & 2,14 & 4,00 & não \\
\hline erro & $\begin{array}{c}\mathrm{N}-\mathrm{m} \\
71-10=\end{array}$ & 61 & SQerro $=7,53 \mathrm{E}+08$ & $1,23 \mathrm{E}+07$ & & & \\
\hline $\begin{array}{l}\text { variação } \\
\text { total }\end{array}$ & $\begin{array}{c}N-1 \\
(2 * 36-1)=\end{array}$ & 71 & SQtotal $=2,18 \mathrm{E}+09$ & $3,08 \mathrm{E}+07$ & & & \\
\hline
\end{tabular}


Tabela F.3 - Tabela da análise de variância do MR instantâneo (MPa), realizada com nível de significância de 0,01 , ou seja, confiança de $99 \%$, considerando-se o fator $A$ quantitativo, representando o teor de ligante

\begin{tabular}{|c|c|c|c|c|c|c|c|}
\hline $\begin{array}{l}\text { fonte de } \\
\text { variação }\end{array}$ & $\begin{array}{l}\text { graus de } \\
\text { liberdade } \\
\text { (GL) }\end{array}$ & & $\begin{array}{l}\text { soma de quadrados } \\
\qquad S Q=r L^{2} / 2^{n}\end{array}$ & $\begin{array}{c}\text { quadrado } \\
\text { médio } \\
\mathrm{QM}=\mathrm{SQ} / \mathrm{GL}\end{array}$ & $F_{0}=\frac{Q M t r a t}{Q M e r r o}$ & $F_{0,01}$ & $\begin{array}{c}\text { significativo } \\
?\end{array}$ \\
\hline$\overline{\mathrm{Al}}$ & 1 & & $\overline{\mathrm{SQ} A \mathrm{Al}}=9,34 \mathrm{E}+05$ & $9,34 \mathrm{E}+05$ & 0,06 & 7,08 & não \\
\hline $\mathrm{Aq}$ & 1 & & $S Q A q=3,25 E+08$ & $3,25 E+08$ & 20,17 & 7,08 & $\operatorname{sim}$ \\
\hline$B$ & 1 & & $S Q B=1,31 E+09$ & $1,31 \mathrm{E}+09$ & 81,36 & 7,08 & $\operatorname{sim}$ \\
\hline C & 1 & & $S Q C=7,84 E+07$ & $7,84 \mathrm{E}+07$ & 4,86 & 7,08 & não \\
\hline $\mathrm{X} 7$ & 1 & & $S Q \times 7=2,35 E+08$ & $2,35 E+08$ & 14,59 & 7,08 & $\operatorname{sim}$ \\
\hline $\mathrm{X} 8$ & 1 & & $S Q \times 8=2,37 E+06$ & $2,37 E+06$ & 0,15 & 7,08 & não \\
\hline AIC & 1 & & $\mathrm{SQ} A I C=1,48 E+07$ & $1,48 \mathrm{E}+07$ & 0,92 & 7,08 & não \\
\hline $\mathrm{AqC}$ & 1 & & $S Q A q C=6,15 E+05$ & $6,15 E+05$ & 0,04 & 7,08 & não \\
\hline AIX8 & 1 & & $\mathrm{SQ}$ AIX8 $=1,09 \mathrm{E}+07$ & $1,09 E+07$ & 0,68 & 7,08 & não \\
\hline $\mathrm{Aq} \times 8$ & 1 & & $\mathrm{SQ} A q \times 8=4,12 \mathrm{E}+07$ & $4,12 E+07$ & 2,56 & 7,08 & não \\
\hline erro & $\begin{array}{c}\mathrm{N}-\mathrm{m} \\
71-10=\end{array}$ & 61 & SQerro $=9,83 E+08$ & $1,61 \mathrm{E}+07$ & & & \\
\hline $\begin{array}{l}\text { variação } \\
\text { total }\end{array}$ & $\begin{array}{c}N-1 \\
(2 * 36-1)=\end{array}$ & 71 & SQtotal $=3,00 \mathrm{E}+09$ & $4,23 \mathrm{E}+07$ & & & \\
\hline
\end{tabular}

Tabela F.4 - Tabela da análise de variância do MR instantâneo (MPa), realizada com nível de significância de 0,05 , ou seja, confiança de $95 \%$, considerando-se o fator $A$ quantitativo, representando o teor de ligante

\begin{tabular}{|c|c|c|c|c|c|c|c|}
\hline $\begin{array}{l}\text { fonte de } \\
\text { variação }\end{array}$ & $\begin{array}{l}\text { graus de } \\
\text { liberdade } \\
(\mathrm{GL})\end{array}$ & & $\begin{array}{c}\text { soma de quadrados } \\
\qquad S Q=r L^{2} / 2^{n}\end{array}$ & $\begin{array}{c}\text { quadrado } \\
\text { médio } \\
\mathrm{QM}=\mathrm{SQ} / \mathrm{GL}\end{array}$ & $F_{0}=\frac{Q M \text { trat }}{\text { QMerro }}$ & $F_{0,05}$ & $\begin{array}{c}\text { significativo } \\
?\end{array}$ \\
\hline$\overline{\mathrm{Al}}$ & 1 & & $\mathrm{SQ} A \mathrm{Al}=9,34 \mathrm{E}+05$ & $9,34 \mathrm{E}+05$ & 0,06 & 4,00 & não \\
\hline $\mathrm{Aq}$ & 1 & & $S Q A q=3,25 E+08$ & $3,25 E+08$ & 20,17 & 4,00 & $\operatorname{sim}$ \\
\hline$B$ & 1 & & $S Q B=1,31 E+09$ & $1,31 E+09$ & 81,36 & 4,00 & $\operatorname{sim}$ \\
\hline C & 1 & & $S Q C=7,84 E+07$ & $7,84 \mathrm{E}+07$ & 4,86 & 4,00 & $\operatorname{sim}$ \\
\hline X7 & 1 & & $\mathrm{SQ} \times 7=2,35 \mathrm{E}+08$ & $2,35 E+08$ & 14,59 & 4,00 & $\operatorname{sim}$ \\
\hline X8 & 1 & & $S Q \times 8=2,37 E+06$ & $2,37 E+06$ & 0,15 & 4,00 & não \\
\hline AIC & 1 & & $S Q A I C=1,48 E+07$ & $1,48 \mathrm{E}+07$ & 0,92 & 4,00 & não \\
\hline $\mathrm{AqC}$ & 1 & & $S Q A q C=6,15 E+05$ & $6,15 \mathrm{E}+05$ & 0,04 & 4,00 & não \\
\hline AIX8 & 1 & & $\mathrm{SQ}$ AIX $8=1,09 E+07$ & $1,09 E+07$ & 0,68 & 4,00 & não \\
\hline $\mathrm{Ag} \times 8$ & 1 & & $\mathrm{SQ} A q X 8=4,12 \mathrm{E}+07$ & $4,12 \mathrm{E}+07$ & 2,56 & 4,00 & não \\
\hline erro & $\begin{array}{c}\mathrm{N}-\mathrm{m} \\
71-10=\end{array}$ & 61 & SQerro $=9,83 \mathrm{E}+08$ & $1,61 \mathrm{E}+07$ & & & \\
\hline $\begin{array}{l}\text { variação } \\
\text { total }\end{array}$ & $\begin{array}{c}N-1 \\
(2 * 36-1)=\end{array}$ & 71 & SQtotal $=3,00 E+09$ & $4,23 \mathrm{E}+07$ & & & \\
\hline
\end{tabular}

Tabela F.5 - Tabela da análise de variância do MR total (MPa), realizada com nível de significância de 0,01 , ou seja, confiança de $99 \%$, considerando-se o fator $A$ qualitativo, representando o volume de vazios

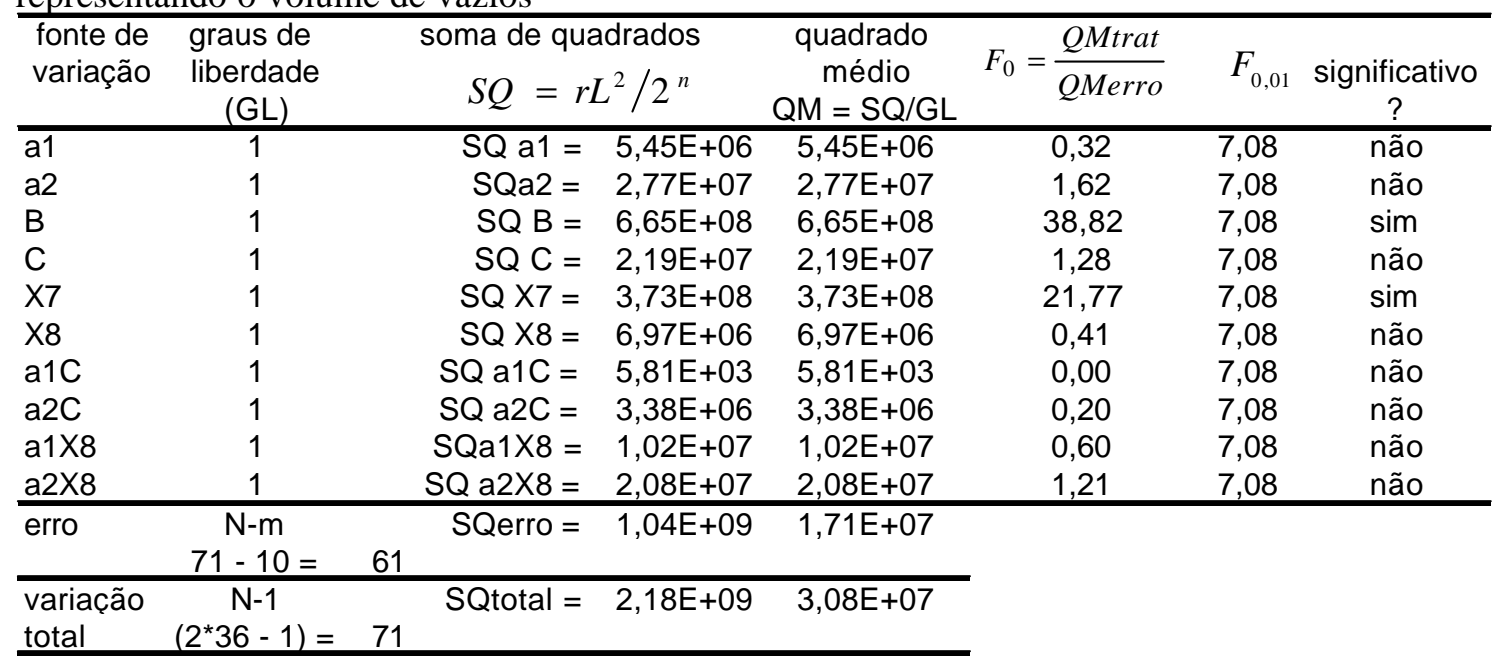


Tabela F.6 - Tabela da análise de variância do MR total (MPa), realizada com nível de significância de 0,05 , ou seja, confiança de $95 \%$, considerando-se o fator $A$ qualitativo, representando o volume de vazios

\begin{tabular}{|c|c|c|c|c|c|c|c|}
\hline \multirow{2}{*}{$\begin{array}{l}\text { fonte de } \\
\text { variação }\end{array}$} & \multirow{2}{*}{$\begin{array}{l}\text { graus de } \\
\text { liberdade } \\
\text { (GL) }\end{array}$} & & \multirow{2}{*}{$\begin{array}{l}\text { soma de quadrados } \\
\qquad S Q=r L^{2} / 2^{n}\end{array}$} & \multirow{2}{*}{$\begin{array}{c}\text { quadrado } \\
\text { médio } \\
\mathrm{QM}=\mathrm{SQ} / \mathrm{GL}\end{array}$} & \multirow{2}{*}{$F_{0}=\frac{Q M \text { trat }}{\text { QMerro }}$} & \multirow[b]{2}{*}{$F_{0,05}$} & \multirow[b]{2}{*}{$\begin{array}{c}\text { significativo } \\
?\end{array}$} \\
\hline & & & & & & & \\
\hline $\mathrm{a} 1$ & 1 & & $5,45 \mathrm{E}+06$ & $5,45 \mathrm{E}+06$ & 0,32 & 4,00 & não \\
\hline a2 & 1 & & $2,77 E+07$ & $2,77 E+07$ & 1,62 & 4,00 & não \\
\hline B & 1 & & $6,65 E+08$ & $6,65 \mathrm{E}+08$ & 38,82 & 4,00 & $\operatorname{sim}$ \\
\hline C & 1 & & $2,19 \mathrm{E}+07$ & $2,19 \mathrm{E}+07$ & 1,28 & 4,00 & não \\
\hline X7 & 1 & & $3,73 E+08$ & $3,73 E+08$ & 21,77 & 4,00 & $\operatorname{sim}$ \\
\hline $\mathrm{X} 8$ & 1 & & $6,97 \mathrm{E}+06$ & $6,97 E+06$ & 0,41 & 4,00 & não \\
\hline a1C & 1 & & $\mathrm{SQ}$ a1C $=$ & $5,81 E+03$ & 0,00 & 4,00 & não \\
\hline $\mathrm{a} 2 \mathrm{C}$ & 1 & & $\mathrm{SQ}$ a2C $=$ & $3,38 E+06$ & 0,20 & 4,00 & não \\
\hline a1X8 & 1 & & SQa1X8 = & $1,02 E+07$ & 0,60 & 4,00 & não \\
\hline $\mathrm{a} 2 \times 8$ & 1 & & $\mathrm{SQ}$ a $2 \times 8=$ & $2,08 \mathrm{E}+07$ & 1,21 & 4,00 & não \\
\hline erro & $\begin{array}{c}\mathrm{N}-\mathrm{m} \\
71-10=\end{array}$ & 61 & $1,04 \mathrm{E}+09$ & $1,71 \mathrm{E}+07$ & & & \\
\hline $\begin{array}{l}\text { variação } \\
\text { total }\end{array}$ & $\begin{array}{c}N-1 \\
(2 * 36-1)=\end{array}$ & 71 & $2,18 \mathrm{E}+09$ & $3,08 \mathrm{E}+07$ & & & \\
\hline
\end{tabular}

Tabela F.7 - Tabela da análise de variância do MR instantâneo (MPa), realizada com nível de significância de 0,01 , ou seja, confiança de $99 \%$, considerando-se o fator $A$ qualitativo, representando o volume de vazios

\begin{tabular}{|c|c|c|c|c|c|c|c|}
\hline \multirow{2}{*}{$\begin{array}{l}\text { fonte de } \\
\text { variação }\end{array}$} & \multirow{2}{*}{$\begin{array}{l}\text { graus de } \\
\text { liberdade } \\
(G L)\end{array}$} & \multicolumn{2}{|r|}{ soma de quadrados } & \multirow{2}{*}{$\begin{array}{c}\text { quadrado } \\
\text { médio } \\
\mathrm{QM}=\mathrm{SQ} / \mathrm{GL}\end{array}$} & \multirow{2}{*}{$F_{0}=\frac{Q M \text { trat }}{\text { QMerro }}$} & \multirow[b]{2}{*}{$F_{0,01}$} & \multirow[b]{2}{*}{$\begin{array}{c}\text { significativo } \\
?\end{array}$} \\
\hline & & & $S Q=r L^{2} / 2^{n}$ & & & & \\
\hline$\overline{\mathrm{a} 1}$ & 1 & & $8,20 \mathrm{E}+06$ & $8,20 \mathrm{E}+06$ & 0,36 & 7,08 & não \\
\hline a2 & 1 & & $3,53 E+07$ & $3,53 \mathrm{E}+07$ & 1,53 & 7,08 & não \\
\hline B & 1 & & $9,60 \mathrm{E}+08$ & $9,60 \mathrm{E}+08$ & 41,60 & 7,08 & $\operatorname{sim}$ \\
\hline C & 1 & & $2,40 \mathrm{E}+07$ & $2,40 \mathrm{E}+07$ & 1,04 & 7,08 & não \\
\hline $\mathrm{X} 7$ & 1 & & $5,13 E+08$ & $5,13 E+08$ & 22,25 & 7,08 & $\operatorname{sim}$ \\
\hline X8 & 1 & & $8,45 E+06$ & $8,45 E+06$ & 0,37 & 7,08 & não \\
\hline a1C & 1 & & $\mathrm{SQ}$ a1C $=$ & $1,05 E+05$ & 0,00 & 7,08 & não \\
\hline a2C & 1 & & $\mathrm{SQ}$ a2C $=$ & $3,25 E+06$ & 0,14 & 7,08 & não \\
\hline a1X8 & 1 & & SQa1X8 = & $1,51 \mathrm{E}+07$ & 0,66 & 7,08 & não \\
\hline a2X8 & 1 & & $\mathrm{SQ}$ a $2 \times 8=$ & $2,26 \mathrm{E}+07$ & 0,98 & 7,08 & não \\
\hline$\overline{\text { erro }}$ & $\begin{array}{c}N-m \\
71-10=\end{array}$ & 61 & $1,41 \mathrm{E}+09$ & $2,31 \mathrm{E}+07$ & & & \\
\hline $\begin{array}{l}\text { variação } \\
\text { total }\end{array}$ & $\begin{array}{c}N-1 \\
(2 * 36-1)=\end{array}$ & 71 & $3,00 E+09$ & $4,23 E+07$ & & & \\
\hline
\end{tabular}

Tabela F.8 - Tabela da análise de variância do MR instantâneo (MPa), realizada com nível de significância de 0,05 , ou seja, confiança de $95 \%$, considerando-se o fator $A$ qualitativo, representando o volume de vazios

\begin{tabular}{|c|c|c|c|c|c|c|c|}
\hline \multirow{2}{*}{$\begin{array}{l}\text { fonte de } \\
\text { variação }\end{array}$} & \multirow{2}{*}{$\begin{array}{c}\text { graus de } \\
\text { liberdade } \\
(G L)\end{array}$} & \multicolumn{2}{|r|}{ soma de quadrados } & \multirow{2}{*}{$\begin{array}{c}\text { quadrado } \\
\text { médio } \\
\mathrm{QM}=\mathrm{SQ} / \mathrm{GL}\end{array}$} & \multirow{2}{*}{$F_{0}=\frac{Q M \text { trat }}{\text { QMerro }}$} & \multirow[b]{2}{*}{$F_{0,05}$} & \multirow[b]{2}{*}{$\begin{array}{c}\text { significativo } \\
?\end{array}$} \\
\hline & & & $S Q=r L^{2} / 2^{n}$ & & & & \\
\hline a1 & $\frac{1}{1}$ & & $8,20 \mathrm{E}+06$ & $8,20 \mathrm{E}+06$ & 0,36 & 4,00 & não \\
\hline a2 & 1 & & $3,53 \mathrm{E}+07$ & $3,53 \mathrm{E}+07$ & 1,53 & 4,00 & não \\
\hline$B$ & 1 & & $9,60 \mathrm{E}+08$ & $9,60 \mathrm{E}+08$ & 41,60 & 4,00 & $\operatorname{sim}$ \\
\hline C & 1 & & $2,40 E+07$ & $2,40 \mathrm{E}+07$ & 1,04 & 4,00 & não \\
\hline X7 & 1 & & $5,13 E+08$ & $5,13 E+08$ & 22,25 & 4,00 & $\operatorname{sim}$ \\
\hline $\mathrm{X} 8$ & 1 & & $8,45 E+06$ & $8,45 E+06$ & 0,37 & 4,00 & não \\
\hline a1C & 1 & & $\mathrm{SQ}$ a1C = & $1,05 E+05$ & 0,00 & 4,00 & não \\
\hline a2C & 1 & & $\mathrm{SQ}$ a2C $=$ & $3,25 E+06$ & 0,14 & 4,00 & não \\
\hline a1X8 & 1 & & $\mathrm{SQa} 1 \times 8=$ & $1,51 \mathrm{E}+07$ & 0,66 & 4,00 & não \\
\hline$a 2 \times 8$ & 1 & & $\mathrm{SQ}$ a $2 \times 8=$ & $2,26 \mathrm{E}+07$ & 0,98 & 4,00 & não \\
\hline erro & $\begin{array}{c}\mathrm{N}-\mathrm{m} \\
71-10=\end{array}$ & 61 & SQerro $=1,41 \mathrm{E}+09$ & $2,31 \mathrm{E}+07$ & & & \\
\hline $\begin{array}{l}\text { variação } \\
\text { total }\end{array}$ & $\begin{array}{c}N-1 \\
(2 * 36-1)=\end{array}$ & 71 & SQtotal $=3,00 \mathrm{E}+09$ & $4,23 \mathrm{E}+07$ & & & \\
\hline
\end{tabular}


Tabelas da análise de variância (ANOVA) realizada com os resultados do ensaio de creep estático

Tabela F.9 - Tabela da análise de variância da deformação total $(\mathrm{mm} / \mathrm{mm})$, realizada com nível de significância de 0,05 , ou seja, confiança de $95 \%$, considerando-se o fator $A$ quantitativo, representando o teor de ligante

\begin{tabular}{|c|c|c|c|c|c|c|c|}
\hline \multirow{2}{*}{$\begin{array}{l}\text { fonte de } \\
\text { variação }\end{array}$} & \multirow{2}{*}{$\begin{array}{l}\text { graus de } \\
\text { liberdade } \\
\text { (GL) }\end{array}$} & \multicolumn{2}{|r|}{ soma de quadrados } & \multirow{2}{*}{$\begin{array}{c}\text { quadrado } \\
\text { médio } \\
\mathrm{QM}=\mathrm{SQ} / \mathrm{GL}\end{array}$} & \multirow{2}{*}{$F_{0}=\frac{Q M \text { trat }}{\text { QMerro }}$} & \multirow[b]{2}{*}{$F_{0,05}$} & \multirow[b]{2}{*}{$\begin{array}{c}\text { significativo } \\
?\end{array}$} \\
\hline & & & $S Q=r L^{2} / 2^{n}$ & & & & \\
\hline$\overline{\mathrm{Al}}$ & 1 & & $2,81 E-06$ & $2,81 \mathrm{E}-06$ & $\overline{3,63}$ & 4,00 & não \\
\hline $\mathrm{Aq}$ & 1 & & $S Q A q=1,40 E-05$ & $1,40 \mathrm{E}-05$ & 18,10 & 4,00 & $\operatorname{sim}$ \\
\hline B & 1 & & $S Q B=1,05 E-06$ & 1,05E-06 & 1,35 & 4,00 & não \\
\hline C & 1 & & $S Q C=6,34 E-07$ & 6,34E-07 & 0,82 & 4,00 & não \\
\hline $\mathrm{X} 7$ & 1 & & $S Q X 7=7,00 E-06$ & 7,00E-06 & 9,05 & 4,00 & $\operatorname{sim}$ \\
\hline X8 & 1 & & $\mathrm{SQ} \times 8=5,14 \mathrm{E}-07$ & $5,14 \mathrm{E}-07$ & 0,66 & 4,00 & não \\
\hline AIC & 1 & & $\mathrm{SQ} A I C=9,63 \mathrm{E}-07$ & 9,63E-07 & 1,24 & 4,00 & não \\
\hline $\mathrm{AqC}$ & 1 & & $\mathrm{SQ} A q C=4,34 \mathrm{E}-07$ & 4,34E-07 & 0,56 & 4,00 & não \\
\hline AIX8 & 1 & & $\mathrm{SQ}$ AIX $8=1,55 \mathrm{E}-08$ & $1,55 \mathrm{E}-08$ & 0,02 & 4,00 & não \\
\hline $\mathrm{Ag} \times 8$ & 1 & & $\mathrm{SQ} \mathrm{AqX8}=1,00 \mathrm{E}-06$ & $1,00 \mathrm{E}-06$ & 1,29 & 4,00 & não \\
\hline erro & $\begin{array}{c}\mathrm{N}-\mathrm{m} \\
71-10=\end{array}$ & 61 & SQerro $=4,72 \mathrm{E}-05$ & 7,74E-07 & & & \\
\hline $\begin{array}{l}\text { variação } \\
\text { total }\end{array}$ & $\begin{array}{c}N-1 \\
(2 * 36-1)=\end{array}$ & 71 & SQtotal $=7,56 \mathrm{E}-05$ & 1,06E-06 & & & \\
\hline
\end{tabular}

Tabela F.10 - Tabela da análise de variância da deformação recuperável $(\mathrm{mm} / \mathrm{mm})$, realizada com nível de significância de 0,05 , ou seja, confiança de $95 \%$, considerando-se o fator $A$ quantitativo, representando o teor de ligante

\begin{tabular}{|c|c|c|c|c|c|c|c|}
\hline \multirow{2}{*}{$\begin{array}{l}\text { fonte de } \\
\text { variação }\end{array}$} & \multirow{2}{*}{$\begin{array}{l}\text { graus de } \\
\text { liberdade } \\
(\mathrm{GL})\end{array}$} & \multicolumn{2}{|r|}{ soma de quadrados } & \multirow{2}{*}{$\begin{array}{c}\text { quadrado } \\
\text { médio } \\
\mathrm{QM}=\mathrm{SQ} / \mathrm{GL}\end{array}$} & \multirow{2}{*}{$F_{0}=\frac{Q M \text { trat }}{\text { QMerro }}$} & \multirow{2}{*}{$F_{0,05}$} & \multirow[b]{2}{*}{$\begin{array}{c}\text { significativo } \\
?\end{array}$} \\
\hline & & & $S Q=r L^{2} / 2^{n}$ & & & & \\
\hline$\overline{\mathrm{Al}}$ & 1 & & $\mathrm{SQAI}=5,28 \mathrm{E}-08$ & $5,28 \mathrm{E}-08$ & 0,19 & 4,00 & não \\
\hline $\mathrm{Aq}$ & 1 & & $S Q A q=4,30 E-06$ & 4,30E-06 & 15,24 & 4,00 & $\operatorname{sim}$ \\
\hline B & 1 & & $S Q B=3,51 E-06$ & 3,51E-06 & 12,43 & 4,00 & $\operatorname{sim}$ \\
\hline $\mathrm{C}$ & 1 & & $S Q C=7,63 E-08$ & 7,63E-08 & 0,27 & 4,00 & não \\
\hline $\mathrm{X} 7$ & 1 & & $S Q \times 7=4,10 E-06$ & 4,10E-06 & 14,53 & 4,00 & $\operatorname{sim}$ \\
\hline $\mathrm{X} 8$ & 1 & & $S Q \times 8=2,30 E-06$ & 2,30E-06 & 8,15 & 4,00 & $\operatorname{sim}$ \\
\hline AIC & 1 & & $\mathrm{SQ} A I C=3,85 \mathrm{E}-08$ & 3,85E-08 & 0,14 & 4,00 & não \\
\hline $\mathrm{AqC}$ & 1 & & $\mathrm{SQ} A q C=6,96 \mathrm{E}-08$ & 6,96E-08 & 0,25 & 4,00 & não \\
\hline AIX8 & 1 & & $\mathrm{SQ}$ AIX8 $=4,00 \mathrm{E}-07$ & 4,00E-07 & 1,42 & 4,00 & não \\
\hline $\mathrm{Ag} \times 8$ & 1 & & $\mathrm{SQ} A q \times 8=5,00 \mathrm{E}-07$ & 5,00E-07 & 1,77 & 4,00 & não \\
\hline erro & $\begin{array}{c}\mathrm{N}-\mathrm{m} \\
71-10=\end{array}$ & 61 & SQerro $=1,72 \mathrm{E}-05$ & $2,82 \mathrm{E}-07$ & & & \\
\hline $\begin{array}{l}\text { variação } \\
\text { total }\end{array}$ & $\begin{array}{c}N-1 \\
(2 * 36-1)=\end{array}$ & 71 & SQtotal $=3,26 \mathrm{E}-05$ & 4,59E-07 & & & \\
\hline
\end{tabular}


Tabela F.11 - Tabela da análise de variância da deformação não recuperável $(\mathrm{mm} / \mathrm{mm})$, realizada com nível de significância de 0,05 , ou seja, confiança de $95 \%$, considerando-se o fator A quantitativo, representando o teor de ligante

\begin{tabular}{|c|c|c|c|c|c|c|c|}
\hline \multirow{2}{*}{$\begin{array}{l}\text { fonte de } \\
\text { variação }\end{array}$} & \multirow{2}{*}{$\begin{array}{c}\text { graus de } \\
\text { liberdade } \\
(\mathrm{GL})\end{array}$} & \multicolumn{2}{|r|}{ soma de quadrados } & \multirow{2}{*}{$\begin{array}{c}\text { quadrado } \\
\text { médio } \\
\mathrm{QM}=\mathrm{SQ} / \mathrm{GL}\end{array}$} & \multirow{2}{*}{$F_{0}=\frac{Q M \text { trat }}{\text { QMerro }}$} & \multirow[b]{2}{*}{$F_{0,05}$} & \multirow[b]{2}{*}{$\begin{array}{c}\text { significativo } \\
?\end{array}$} \\
\hline & & & $S Q=r L^{2} / 2^{n}$ & & & & \\
\hline$\overline{\mathrm{Al}}$ & $\frac{1}{1}$ & & $\mathrm{SQ} A \mathrm{I}=1,75 \mathrm{E}-06$ & $1,75 \mathrm{E}-06$ & 7,85 & 4,00 & $\operatorname{sim}$ \\
\hline $\mathrm{Aq}$ & 1 & & $S Q A q=2,67 E-06$ & 2,67E-06 & 11,98 & 4,00 & $\operatorname{sim}$ \\
\hline$B$ & 1 & & $S Q B=7,28 E-07$ & 7,28E-07 & 3,27 & 4,00 & não \\
\hline C & 1 & & $S Q C=1,15 E-06$ & $1,15 E-06$ & 5,16 & 4,00 & $\operatorname{sim}$ \\
\hline X7 & 1 & & $S Q \times 7=6,40 E-09$ & $6,40 \mathrm{E}-09$ & 0,03 & 4,00 & não \\
\hline $\mathrm{x} 8$ & 1 & & $S Q \times 8=1,70 E-07$ & $1,70 \mathrm{E}-07$ & 0,76 & 4,00 & não \\
\hline AIC & 1 & & $\mathrm{SQ} A I C=1,40 \mathrm{E}-06$ & 1,40E-06 & 6,28 & 4,00 & $\operatorname{sim}$ \\
\hline $\mathrm{AqC}$ & 1 & & $\mathrm{SQ} A q C=1,58 \mathrm{E}-07$ & $1,58 \mathrm{E}-07$ & 0,71 & 4,00 & não \\
\hline AIX8 & 1 & & $\mathrm{SQ}$ AIX $8=4,58 \mathrm{E}-08$ & 4,58E-08 & 0,21 & 4,00 & não \\
\hline $\mathrm{Ag} \times 8$ & 1 & & $\mathrm{SQ} A q \times 8=9,00 \mathrm{E}-08$ & $9,00 \mathrm{E}-08$ & 0,40 & 4,00 & não \\
\hline erro & $\begin{array}{c}\mathrm{N}-\mathrm{m} \\
71-10=\end{array}$ & 61 & SQerro $=1,36 \mathrm{E}-05$ & $2,23 \mathrm{E}-07$ & & & \\
\hline $\begin{array}{l}\text { variação } \\
\text { total }\end{array}$ & $\begin{array}{c}N-1 \\
(2 * 36-1)=\end{array}$ & 71 & SQtotal $=2,18 \mathrm{E}-05$ & $3,06 \mathrm{E}-07$ & & & \\
\hline
\end{tabular}

Tabela F.12 - Tabela da análise de variância da recuperação (\%), realizada com nível de significância de 0,05 , ou seja, confiança de $95 \%$, considerando-se o fator $A$ quantitativo, representando o teor de ligante

\begin{tabular}{|c|c|c|c|c|c|c|c|}
\hline $\begin{array}{l}\text { fonte de } \\
\text { variação }\end{array}$ & $\begin{array}{l}\text { graus de } \\
\text { liberdade } \\
\text { (GL) }\end{array}$ & & $\begin{array}{l}\text { soma de quadrados } \\
\qquad S Q=r L^{2} / 2^{n}\end{array}$ & $\begin{array}{c}\text { quadrado } \\
\text { médio } \\
\mathrm{QM}=\mathrm{SQ} / \mathrm{GL}\end{array}$ & $F_{0}=\frac{\text { QMtrat }}{\text { QMerro }}$ & $F_{0,05}$ & $\begin{array}{c}\text { significativo } \\
?\end{array}$ \\
\hline$\overline{\mathrm{Al}}$ & 1 & & $\mathrm{SQAl}=5,80 \mathrm{E}+02$ & $5,80 \mathrm{E}+02$ & 10,44 & 4,00 & $\operatorname{sim}$ \\
\hline $\mathrm{Aq}$ & 1 & & $S Q A q=1,46 E+02$ & $1,46 \mathrm{E}+02$ & 2,62 & 4,00 & não \\
\hline$B$ & 1 & & $S Q B=8,64 E+02$ & $8,64 \mathrm{E}+02$ & 15,54 & 4,00 & $\operatorname{sim}$ \\
\hline C & 1 & & $S Q C=2,13 E+02$ & $2,13 E+02$ & 3,83 & 4,00 & não \\
\hline $\mathrm{X} 7$ & 1 & & $\mathrm{SQ} \times 7=1,08 \mathrm{E}+02$ & $1,08 \mathrm{E}+02$ & 1,94 & 4,00 & não \\
\hline $\mathrm{X} 8$ & 1 & & $S Q \times 8=2,63 E+02$ & $2,63 E+02$ & 4,73 & 4,00 & $\operatorname{sim}$ \\
\hline AIC & 1 & & $\mathrm{SQ} A I C=8,60 \mathrm{E}+01$ & $8,60 \mathrm{E}+01$ & 1,55 & 4,00 & não \\
\hline $\mathrm{AqC}$ & 1 & & $S Q A q C=1,35 E+01$ & $1,35 \mathrm{E}+01$ & 0,24 & 4,00 & não \\
\hline AIX8 & 1 & & SQ AIX8 = 1,37E+01 & $1,37 E+01$ & 0,25 & 4,00 & não \\
\hline $\mathrm{Ag} \times 8$ & 1 & & $\mathrm{SQ} A q \times 8=6,88 \mathrm{E}+00$ & $6,88 \mathrm{E}+00$ & 0,12 & 4,00 & não \\
\hline erro & $\begin{array}{c}\mathrm{N}-\mathrm{m} \\
71-10=\end{array}$ & 61 & SQerro $=3,39 \mathrm{E}+03$ & $5,56 \mathrm{E}+01$ & & & \\
\hline $\begin{array}{l}\text { variação } \\
\text { total }\end{array}$ & $\begin{array}{c}\mathrm{N}-1 \\
(2 * 36-1)=\end{array}$ & 71 & SQtotal $=5,68 \mathrm{E}+03$ & $8,01 \mathrm{E}+01$ & & & \\
\hline
\end{tabular}

Tabela F.13 - Tabela da análise de variância do módulo de fluência (MPa), realizada com nível de significância de 0,05 , ou seja, confiança de $95 \%$, considerando-se o fator $A$ quantitativo,

\begin{tabular}{|c|c|c|c|c|c|c|c|}
\hline $\begin{array}{l}\text { fonte de } \\
\text { variação }\end{array}$ & $\begin{array}{l}\text { graus de } \\
\text { liberdade } \\
(G L)\end{array}$ & & $\begin{array}{c}\text { soma de quadrados } \\
S Q=r L^{2} / 2^{n}\end{array}$ & $\begin{array}{c}\text { quadrado } \\
\text { médio } \\
\mathrm{QM}=\mathrm{SQ} / \mathrm{GL}\end{array}$ & $F_{0}=\frac{Q M \text { trat }}{\text { QMerro }}$ & $F_{0,05}$ & $\begin{array}{c}\text { significativo } \\
?\end{array}$ \\
\hline$\overline{\mathrm{Al}}$ & 1 & & $\mathrm{SQ} A \mathrm{Al}=1,84 \mathrm{E}+03$ & $1,84 \mathrm{E}+03$ & 1,83 & 4,00 & não \\
\hline $\mathrm{Aq}$ & 1 & & $S Q A q=2,03 E+04$ & $2,03 E+04$ & 20,23 & 4,00 & $\operatorname{sim}$ \\
\hline$B$ & 1 & & $S Q B=8,50 E+03$ & $8,50 E+03$ & 8,47 & 4,00 & $\operatorname{sim}$ \\
\hline $\mathrm{C}$ & 1 & & $S Q C=1,26 E+03$ & $1,26 \mathrm{E}+03$ & 1,25 & 4,00 & não \\
\hline $\mathrm{X} 7$ & 1 & & $\mathrm{SQ} \times 7=7,19 \mathrm{E}+03$ & $7,19 \mathrm{E}+03$ & 7,16 & 4,00 & $\operatorname{sim}$ \\
\hline X8 & 1 & & $S Q \times 8=2,42 E+03$ & $2,42 E+03$ & 2,41 & 4,00 & não \\
\hline AIC & 1 & & $\mathrm{SQ} A I C=4,55 \mathrm{E}+02$ & $4,55 \mathrm{E}+02$ & 0,45 & 4,00 & não \\
\hline $\mathrm{AqC}$ & 1 & & $S Q A q C=1,69 E+03$ & $1,69 E+03$ & 1,68 & 4,00 & não \\
\hline AIX8 & 1 & & $\mathrm{SQ} A I X 8=1,38 \mathrm{E}+03$ & $1,38 E+03$ & 1,37 & 4,00 & não \\
\hline $\mathrm{Ag} \times 8$ & 1 & & $\mathrm{SQ} A q \times 8=1,38 \mathrm{E}+03$ & $1,38 \mathrm{E}+03$ & 1,37 & 4,00 & não \\
\hline erro & $\begin{array}{c}\mathrm{N}-\mathrm{m} \\
71-10=\end{array}$ & 61 & SQerro $=6,13 \mathrm{E}+04$ & $1,00 \mathrm{E}+03$ & & & \\
\hline $\begin{array}{l}\text { variação } \\
\text { total }\end{array}$ & $\begin{array}{c}N-1 \\
(2 * 36-1)=\end{array}$ & 71 & SQtotal $=1,08 \mathrm{E}+05$ & $1,52 \mathrm{E}+03$ & & & \\
\hline
\end{tabular}


Tabela F.14 - Tabela da análise de variância do módulo de fluência após recuperação (MPa), realizada com nível de significância de 0,05 , ou seja, confiança de $95 \%$, considerando-se o fator A quantitativo, representando o teor de ligante

\begin{tabular}{|c|c|c|c|c|c|c|c|}
\hline $\begin{array}{l}\text { fonte de } \\
\text { variação }\end{array}$ & $\begin{array}{l}\text { graus de } \\
\text { liberdade } \\
\text { (GL) }\end{array}$ & & $\begin{array}{c}\text { soma de quadrados } \\
S Q=r L^{2} / 2^{n}\end{array}$ & $\begin{array}{c}\text { quadrado } \\
\text { médio } \\
\mathrm{QM}=\mathrm{SQ} / \mathrm{GL}\end{array}$ & $F_{0}=\frac{\text { QMtrat }}{\text { QMerro }}$ & $F_{0,05}$ & $\begin{array}{c}\text { significativo } \\
?\end{array}$ \\
\hline$\overline{\mathrm{Al}}$ & 1 & & $\overline{S Q A I}=4,23 E+04$ & $4,23 \mathrm{E}+04$ & 2,01 & 4,00 & não \\
\hline $\mathrm{Aq}$ & 1 & & $S Q A q=3,35 E+05$ & $3,35 \mathrm{E}+05$ & 15,96 & 4,00 & $\operatorname{sim}$ \\
\hline B & 1 & & $S Q B=6,84 E+02$ & $6,84 \mathrm{E}+02$ & 0,03 & 4,00 & não \\
\hline C & 1 & & $S Q C=1,01 E+05$ & $1,01 \mathrm{E}+05$ & 4,80 & 4,00 & $\operatorname{sim}$ \\
\hline $\mathrm{X} 7$ & 1 & & $\mathrm{SQ} \times 7=2,66 \mathrm{E}+03$ & $2,66 \mathrm{E}+03$ & 0,13 & 4,00 & não \\
\hline X8 & 1 & & $\mathrm{SQ} \times 8=1,55 \mathrm{E}+05$ & $1,55 \mathrm{E}+05$ & 7,36 & 4,00 & $\operatorname{sim}$ \\
\hline $\mathrm{AIC}$ & 1 & & $S Q A I C=3,49 E+04$ & $3,49 \mathrm{E}+04$ & 1,66 & 4,00 & não \\
\hline $\mathrm{AqC}$ & 1 & & $S Q A q C=2,08 E+04$ & $2,08 \mathrm{E}+04$ & 0,99 & 4,00 & não \\
\hline AIX8 & 1 & & SQ AIX8 $=7,93 E+04$ & $7,93 \mathrm{E}+04$ & 3,78 & 4,00 & não \\
\hline $\mathrm{Aq} \times 8$ & 1 & & $\mathrm{SQ} A q \times 8=1,68 \mathrm{E}+04$ & $1,68 \mathrm{E}+04$ & 0,80 & 4,00 & não \\
\hline$\overline{\text { erro }}$ & $\begin{array}{c}\mathrm{N}-\mathrm{m} \\
71-10=\end{array}$ & 61 & SQerro $=1,28 \mathrm{E}+06$ & $2,10 \mathrm{E}+04$ & & & \\
\hline $\begin{array}{l}\text { variação } \\
\text { total }\end{array}$ & $\begin{array}{c}\mathrm{N}-1 \\
(2 * 36-1)=\end{array}$ & 71 & SQtotal $=2,07 \mathrm{E}+06$ & $2,91 \mathrm{E}+04$ & & & \\
\hline
\end{tabular}

Tabela F.15 - Tabela da análise de variância da inclinação da curva de fluência, realizada com nível de significância de 0,05 , ou seja, confiança de $95 \%$, considerando-se o fator $A$ quantitativo, representando o teor de ligante

\begin{tabular}{|c|c|c|c|c|c|c|c|}
\hline \multirow{2}{*}{$\begin{array}{l}\text { fonte de } \\
\text { variação }\end{array}$} & \multirow{2}{*}{$\begin{array}{l}\text { graus de } \\
\text { liberdade } \\
\text { (GL) }\end{array}$} & \multicolumn{2}{|r|}{ soma de quadrados } & \multirow{2}{*}{$\begin{array}{c}\text { quadrado } \\
\text { médio } \\
\mathrm{QM}=\mathrm{SQ} / \mathrm{GL}\end{array}$} & \multirow{2}{*}{$F_{0}=\frac{Q M \text { trat }}{\text { QMerro }}$} & \multirow{2}{*}{$F_{0,05}$} & \multirow[b]{2}{*}{$\begin{array}{c}\text { significativo } \\
?\end{array}$} \\
\hline & & & $S Q=r L^{2} / 2^{n}$ & & & & \\
\hline$\overline{\mathrm{Al}}$ & 1 & & $\mathrm{SQ} \mathrm{Al}=7,57 \mathrm{E}-03$ & 7,57E-03 & 9,38 & 4,00 & $\operatorname{sim}$ \\
\hline $\mathrm{Aq}$ & 1 & & $S Q A q=8,52 E-05$ & 8,52E-05 & 0,11 & 4,00 & não \\
\hline$B$ & 1 & & $S Q B=4,58 E-03$ & $4,58 \mathrm{E}-03$ & 5,67 & 4,00 & $\operatorname{sim}$ \\
\hline C & 1 & & $S Q C=3,04 E-02$ & 3,04E-02 & 37,60 & 4,00 & $\operatorname{sim}$ \\
\hline $\mathrm{X} 7$ & 1 & & $S Q \times 7=4,49 E-04$ & 4,49E-04 & 0,56 & 4,00 & não \\
\hline X8 & 1 & & $S Q \times 8=1,91 E-05$ & 1,91E-05 & 0,02 & 4,00 & não \\
\hline AIC & 1 & & $\mathrm{SQ} A I C=2,58 \mathrm{E}-04$ & 2,58E-04 & 0,32 & 4,00 & não \\
\hline $\mathrm{AqC}$ & 1 & & $\mathrm{SQ} A q C=1,71 \mathrm{E}-03$ & 1,71E-03 & 2,12 & 4,00 & não \\
\hline AIX8 & 1 & & $\mathrm{SQ}$ AIX8 $=2,03 \mathrm{E}-05$ & 2,03E-05 & 0,03 & 4,00 & não \\
\hline $\mathrm{Ag} \times 8$ & 1 & & $\mathrm{SQ} A q \times 8=1,55 \mathrm{E}-05$ & $1,55 \mathrm{E}-05$ & 0,02 & 4,00 & não \\
\hline erro & $\begin{array}{c}\mathrm{N}-\mathrm{m} \\
71-10=\end{array}$ & 61 & SQerro $=4,93 \mathrm{E}-02$ & $8,07 E-04$ & & & \\
\hline $\begin{array}{l}\text { variação } \\
\text { total }\end{array}$ & $\begin{array}{c}N-1 \\
(2 * 36-1)= \\
\end{array}$ & 71 & SQtotal $=9,43 \mathrm{E}-02$ & 1,33E-03 & & & \\
\hline
\end{tabular}

Tabela F.16 - Tabela da análise de variância da deformação total $(\mathrm{mm} / \mathrm{mm})$, realizada com nível de significância de 0,05 , ou seja, confiança de $95 \%$, considerando-se o fator $A$ qualitativo, representando o volume de vazios

\begin{tabular}{|c|c|c|c|c|c|c|c|}
\hline $\begin{array}{l}\text { fonte de } \\
\text { variação }\end{array}$ & $\begin{array}{l}\text { graus de } \\
\text { liberdade } \\
\text { (GL) }\end{array}$ & & $\begin{array}{l}\text { soma de quadrados } \\
\qquad S Q=r L^{2} / 2^{n}\end{array}$ & $\begin{array}{c}\text { quadrado } \\
\text { médio } \\
\mathrm{QM}=\mathrm{SQ} / \mathrm{GL}\end{array}$ & $F_{0}=\frac{Q M \text { trat }}{\text { QMerro }}$ & $F_{0,05}$ & $\begin{array}{c}\text { significativo } \\
?\end{array}$ \\
\hline$\overline{\mathrm{a} 1}$ & 1 & & $8,31 \mathrm{E}-07$ & $8,31 \mathrm{E}-07$ & 0,83 & 4,00 & não \\
\hline a2 & 1 & & $3,92 E-06$ & 3,92E-06 & 3,92 & 4,00 & não \\
\hline B & 1 & & $6,28 E-07$ & $6,28 \mathrm{E}-07$ & 0,63 & 4,00 & não \\
\hline C & 1 & & $6,27 E-08$ & $6,27 E-08$ & 0,06 & 4,00 & não \\
\hline $\mathrm{X} 7$ & 1 & & $2,24 \mathrm{E}-06$ & 2,24E-06 & 2,24 & 4,00 & não \\
\hline X8 & 1 & & $1,34 \mathrm{E}-06$ & $1,34 \mathrm{E}-06$ & 1,34 & 4,00 & não \\
\hline a1C & 1 & & $\mathrm{SQ}$ a $1 \mathrm{C}=$ & $2,28 E-07$ & 0,23 & 4,00 & não \\
\hline a2C & 1 & & $\mathrm{SQ}$ a2C $=$ & 1,77E-06 & 1,77 & 4,00 & não \\
\hline a1X8 & 1 & & $S Q$ a $1 \times 8=$ & 2,49E-06 & 2,48 & 4,00 & não \\
\hline$a 2 \times 8$ & 1 & & $\mathrm{SQ}$ a2X8 = & $9,91 \mathrm{E}-07$ & 0,99 & 4,00 & não \\
\hline erro & $\begin{array}{c}\mathrm{N}-\mathrm{m} \\
71-10=\end{array}$ & 61 & SQerro = & $1,00 \mathrm{E}-06$ & & & \\
\hline $\begin{array}{l}\text { variação } \\
\text { total }\end{array}$ & $\begin{array}{c}N-1 \\
(2 * 36-1)=\end{array}$ & 71 & SQtotal $=7,56 \mathrm{E}-05$ & & & & \\
\hline
\end{tabular}


Tabela F.17 - Tabela da análise de variância da deformação recuperável $(\mathrm{mm} / \mathrm{mm})$, realizada com nível de significância de 0,05 , ou seja, confiança de $95 \%$, considerando-se o fator $A$ qualitativo, representando o volume de vazios

\begin{tabular}{|c|c|c|c|c|c|c|c|}
\hline $\begin{array}{l}\text { fonte de } \\
\text { variação }\end{array}$ & $\begin{array}{l}\text { graus de } \\
\text { liberdade } \\
(G L)\end{array}$ & & $\begin{array}{l}\text { soma de quadrados } \\
\qquad S Q=r L^{2} / 2^{n}\end{array}$ & $\begin{array}{c}\text { quadrado } \\
\text { médio } \\
\mathrm{QM}=\mathrm{SQ} / \mathrm{GL}\end{array}$ & $F_{0}=\frac{\text { QMtrat }}{\text { QMerro }}$ & $F_{0,05}$ & $\begin{array}{c}\text { significativo } \\
?\end{array}$ \\
\hline$\overline{\mathrm{a} 1}$ & 1 & & $1,70 \mathrm{E}-07$ & $1,70 \mathrm{E}-07$ & 0,43 & 4,00 & não \\
\hline a2 & 1 & & $7,03 E-07$ & 7,03E-07 & 1,79 & 4,00 & não \\
\hline $\mathrm{B}$ & 1 & & $2,46 \mathrm{E}-06$ & $2,46 \mathrm{E}-06$ & 6,29 & 4,00 & $\operatorname{sim}$ \\
\hline $\mathrm{C}$ & 1 & & $2,05 E-07$ & $2,05 E-07$ & 0,52 & 4,00 & não \\
\hline X7 & 1 & & 1,98E-06 & 1,98E-06 & 5,04 & 4,00 & $\operatorname{sim}$ \\
\hline $\mathrm{X} 8$ & 1 & & $2,26 \mathrm{E}-06$ & $2,26 \mathrm{E}-06$ & 5,77 & 4,00 & $\operatorname{sim}$ \\
\hline a1c & 1 & & $\mathrm{SQ}$ a $1 \mathrm{C}=$ & $8,97 \mathrm{E}-08$ & 0,23 & 4,00 & não \\
\hline $\mathrm{a} 2 \mathrm{C}$ & 1 & & $\mathrm{SQ}$ a2C $=$ & 3,77E-08 & 0,10 & 4,00 & não \\
\hline a1X8 & 1 & & $S Q$ a $1 \times 8=$ & $4,31 \mathrm{E}-07$ & 1,10 & 4,00 & não \\
\hline$a 2 \times 8$ & 1 & & $\mathrm{SQ}$ a $2 \times 8=$ & $5,04 \mathrm{E}-07$ & 1,29 & 4,00 & não \\
\hline erro & $\begin{array}{c}\mathrm{N}-\mathrm{m} \\
71-10=\end{array}$ & 61 & SQerro = & $3,92 \mathrm{E}-07$ & & & \\
\hline $\begin{array}{l}\text { variação } \\
\text { total }\end{array}$ & $\begin{array}{c}N-1 \\
(2 * 36-1)=\end{array}$ & 71 & SQtotal $=3,26 \mathrm{E}-05$ & & & & \\
\hline
\end{tabular}

Tabela F.18 - Tabela da análise de variância da deformação não recuperável $(\mathrm{mm} / \mathrm{mm})$, realizada com nível de significância de 0,05 , ou seja, confiança de $95 \%$, considerando-se o fator A qualitativo, representando o volume de vazios

\begin{tabular}{|c|c|c|c|c|c|c|c|}
\hline $\begin{array}{l}\text { fonte de } \\
\text { variação }\end{array}$ & $\begin{array}{l}\text { graus de } \\
\text { liberdade } \\
(\mathrm{GL})\end{array}$ & & $\begin{array}{c}\text { soma de quadrados } \\
\qquad S Q=r L^{2} / 2^{n}\end{array}$ & $\begin{array}{c}\text { quadrado } \\
\text { médio } \\
\mathrm{QM}=\mathrm{SQ} / \mathrm{GL}\end{array}$ & $F_{0}=\frac{Q M \text { trat }}{\text { QMerro }}$ & $F_{0,05}$ & $\begin{array}{c}\text { significativo } \\
?\end{array}$ \\
\hline$\overline{\mathrm{a} 1}$ & 1 & & 1,75E-06 & $1,75 E-06$ & 7,15 & 4,00 & $\operatorname{sim}$ \\
\hline a2 & 1 & & $1,32 \mathrm{E}-06$ & $1,32 E-06$ & 5,41 & 4,00 & $\operatorname{sim}$ \\
\hline B & 1 & & $6,11 \mathrm{E}-07$ & $6,11 \mathrm{E}-07$ & 2,50 & 4,00 & não \\
\hline C & 1 & & $4,92 \mathrm{E}-07$ & $4,92 \mathrm{E}-07$ & 2,01 & 4,00 & não \\
\hline X7 & 1 & & 8,78E-09 & 8,78E-09 & 0,04 & 4,00 & não \\
\hline X8 & 1 & & $1,18 \mathrm{E}-07$ & $1,18 \mathrm{E}-07$ & 0,48 & 4,00 & não \\
\hline a1C & 1 & & $\mathrm{SQ}$ a1C = & 2,95E-08 & 0,12 & 4,00 & não \\
\hline a2C & 1 & & $\mathrm{SQ}$ a $2 \mathrm{C}=$ & $1,30 \mathrm{E}-06$ & 5,31 & 4,00 & $\operatorname{sim}$ \\
\hline a1X8 & 1 & & $\mathrm{SQ}$ a $1 \times 8=$ & $8,58 \mathrm{E}-07$ & 3,51 & 4,00 & não \\
\hline$a 2 \times 8$ & 1 & & $\mathrm{SQ}$ a $2 \times 8=$ & $8,55 \mathrm{E}-08$ & 0,35 & 4,00 & não \\
\hline erro & $\begin{array}{c}N-m \\
71-10=\end{array}$ & 61 & SQerro = & $2,45 \mathrm{E}-07$ & & & \\
\hline $\begin{array}{l}\text { variação } \\
\text { total }\end{array}$ & $\begin{array}{c}N-1 \\
(2 * 36-1)=\end{array}$ & 71 & SQtotal $=$ & & & & \\
\hline
\end{tabular}

Tabela F.19 - Tabela da análise de variância da recuperação (\%), realizada com nível de significância de 0,05 , ou seja, confiança de $95 \%$, considerando-se o fator $A$ qualitativo, representando o volume de vazios

\begin{tabular}{|c|c|c|c|c|c|c|c|}
\hline $\begin{array}{c}\text { fonte de } \\
\text { variação }\end{array}$ & $\begin{array}{l}\text { graus de } \\
\text { liberdade } \\
\text { (GL) }\end{array}$ & & $\begin{array}{l}\text { soma de quadrados } \\
\qquad S Q=r L^{2} / 2^{n}\end{array}$ & $\begin{array}{c}\text { quadrado } \\
\text { médio } \\
\mathrm{QM}=\mathrm{SQ} / \mathrm{GL}\end{array}$ & $F_{0}=\frac{\text { QMtrat }}{\text { QMerro }}$ & $F_{0,05}$ & $\begin{array}{c}\text { significativo } \\
?\end{array}$ \\
\hline a1 & 1 & & $4,40 \mathrm{E}+02$ & $4,40 \mathrm{E}+02$ & 8,19 & 4,00 & $\operatorname{sim}$ \\
\hline a2 & 1 & & $1,40 E+02$ & $1,40 \mathrm{E}+02$ & 2,61 & 4,00 & não \\
\hline B & 1 & & $8,64 \mathrm{E}+02$ & $8,64 \mathrm{E}+02$ & 16,07 & 4,00 & $\operatorname{sim}$ \\
\hline $\mathrm{C}$ & 1 & & $2,13 E+02$ & $2,13 E+02$ & 3,96 & 4,00 & não \\
\hline $\mathrm{X} 7$ & 1 & & $\mathrm{SQ} \times 7=1,82 \mathrm{E}+02$ & $1,82 \mathrm{E}+02$ & 3,39 & 4,00 & não \\
\hline $\mathrm{X} 8$ & 1 & & $\mathrm{SQ} \times 8=2,63 \mathrm{E}+02$ & $2,63 \mathrm{E}+02$ & 4,89 & 4,00 & $\operatorname{sim}$ \\
\hline a1C & 1 & & $\mathrm{SQ}$ a $1 \mathrm{C}=$ & $1,51 \mathrm{E}+01$ & 0,28 & 4,00 & não \\
\hline a2C & 1 & & $\mathrm{SQ}$ a2C $=$ & $7,10 \mathrm{E}+01$ & 1,32 & 4,00 & não \\
\hline a1X8 & 1 & & $\mathrm{SQ}$ a $1 \mathrm{X} 8=1,51 \mathrm{E}+02$ & $1,51 \mathrm{E}+02$ & 2,80 & 4,00 & não \\
\hline $\mathrm{a} 2 \times 8$ & 1 & & $\mathrm{SQ}$ a $2 \times 8=$ & $1,81 E+00$ & 0,03 & 4,00 & não \\
\hline erro & $\begin{array}{c}\mathrm{N}-\mathrm{m} \\
71-10=\end{array}$ & 61 & SQerro $=3,28 \mathrm{E}+03$ & $5,38 \mathrm{E}+01$ & & & \\
\hline $\begin{array}{l}\text { variação } \\
\text { total }\end{array}$ & $\begin{array}{c}\mathrm{N}-1 \\
(2 * 36-1)=\end{array}$ & 71 & SQtotal $=5,68 \mathrm{E}+03$ & & & & \\
\hline
\end{tabular}


Tabela F.20 - Tabela da análise de variância do módulo de fluência (MPa), realizada com nível de significância de 0,05 , ou seja, confiança de $95 \%$, considerando-se o fator $A$ qualitativo, representando o volume de vazios

\begin{tabular}{|c|c|c|c|c|c|c|c|}
\hline $\begin{array}{l}\text { fonte de } \\
\text { variação }\end{array}$ & $\begin{array}{l}\text { graus de } \\
\text { liberdade } \\
(G L)\end{array}$ & & $\begin{array}{l}\text { soma de quadrados } \\
\qquad S Q=r L^{2} / 2^{n}\end{array}$ & $\begin{array}{c}\text { quadrado } \\
\text { médio } \\
\mathrm{QM}=\mathrm{SQ} / \mathrm{GL}\end{array}$ & $F_{0}=\frac{\text { QMtrat }}{\text { QMerro }}$ & $F_{0,05}$ & $\begin{array}{c}\text { significativo } \\
?\end{array}$ \\
\hline a1 & 1 & & $8,58 \mathrm{E}+02$ & $8,58 \mathrm{E}+02$ & 0,63 & 4,00 & não \\
\hline a2 & 1 & & $3,94 \mathrm{E}+03$ & $3,94 \mathrm{E}+03$ & 2,89 & 4,00 & não \\
\hline$B$ & 1 & & $8,36 \mathrm{E}+03$ & $8,36 \mathrm{E}+03$ & 6,13 & 4,00 & $\operatorname{sim}$ \\
\hline $\mathrm{C}$ & 1 & & $7,32 \mathrm{E}+02$ & $7,32 \mathrm{E}+02$ & 0,54 & 4,00 & não \\
\hline X7 & 1 & & $1,57 E+03$ & $1,57 \mathrm{E}+03$ & 1,15 & 4,00 & não \\
\hline X8 & 1 & & $2,42 E+03$ & $2,42 E+03$ & 1,77 & 4,00 & não \\
\hline a1C & 1 & & $S Q$ a $1 \mathrm{C}=$ & $7,85 \mathrm{E}+01$ & 0,06 & 4,00 & não \\
\hline a2C & 1 & & $\mathrm{SQ}$ a2C $=$ & $2,84 \mathrm{E}+02$ & 0,21 & 4,00 & não \\
\hline a1X8 & 1 & & $\mathrm{SQ}$ a1X8 = & $4,75 E+03$ & 3,48 & 4,00 & não \\
\hline $\mathrm{a} 2 \times 8$ & 1 & & $\mathrm{SQ}$ a $2 \times 8=$ & $1,38 \mathrm{E}+03$ & 1,01 & 4,00 & não \\
\hline erro & $\begin{array}{c}\mathrm{N}-\mathrm{m} \\
71-10=\end{array}$ & 61 & $8,33 \mathrm{E}+04$ & $1,36 \mathrm{E}+03$ & & & \\
\hline $\begin{array}{l}\text { variação } \\
\text { total }\end{array}$ & $\begin{array}{c}N-1 \\
(2 * 36-1)=\end{array}$ & 71 & SQtotal $=1,08 E+05$ & & & & \\
\hline
\end{tabular}

Tabela F.21 - Tabela da análise de variância do módulo de fluência após recuperação (MPa), realizada com nível de significância de 0,05 , ou seja, confiança de $95 \%$, considerando-se o fator $A$ qualitativo, representando o volume de vazios

\begin{tabular}{|c|c|c|c|c|c|c|c|}
\hline $\begin{array}{c}\text { fonte de } \\
\text { variação }\end{array}$ & $\begin{array}{l}\text { graus de } \\
\text { liberdade } \\
\text { (GL) }\end{array}$ & & $\begin{array}{l}\text { soma de quadrados } \\
\qquad S Q=r L^{2} / 2^{n}\end{array}$ & $\begin{array}{c}\text { quadrado } \\
\text { médio } \\
\mathrm{QM}=\mathrm{SQ} / \mathrm{GL}\end{array}$ & $F_{0}=\frac{Q M \text { trat }}{\text { QMerro }}$ & $F_{0,05}$ & $\begin{array}{c}\text { significativo } \\
?\end{array}$ \\
\hline $\mathrm{a} 1$ & 1 & & $5,46 \mathrm{E}+04$ & $5,46 \mathrm{E}+04$ & 2,04 & 4,00 & não \\
\hline a2 & 1 & & $4,11 \mathrm{E}+04$ & $4,11 E+04$ & 1,53 & 4,00 & não \\
\hline B & 1 & & $1,61 E+03$ & $1,61 \mathrm{E}+03$ & 0,06 & 4,00 & não \\
\hline C & 1 & & $6,00 E+04$ & $6,00 \mathrm{E}+04$ & 2,24 & 4,00 & não \\
\hline X7 & 1 & & $3,42 E+03$ & $3,42 E+03$ & 0,13 & 4,00 & não \\
\hline X8 & 1 & & $1,55 E+05$ & $1,55 \mathrm{E}+05$ & 5,78 & 4,00 & $\operatorname{sim}$ \\
\hline a1C & 1 & & $\mathrm{SQ}$ a1C = & $7,79 \mathrm{E}+03$ & 0,29 & 4,00 & não \\
\hline a2C & 1 & & $\mathrm{SQ}$ a2C = & $5,92 E+03$ & 0,22 & 4,00 & não \\
\hline a1X8 & 1 & & $S Q$ a $1 \times 8=$ & 7,93E+04 & 2,96 & 4,00 & não \\
\hline a2X8 & 1 & & $\mathrm{SQ}$ a2X8 $=1,68 \mathrm{E}+04$ & $1,68 \mathrm{E}+04$ & 0,63 & 4,00 & não \\
\hline erro & $\begin{array}{c}\mathrm{N}-\mathrm{m} \\
71-10=\end{array}$ & 61 & SQerro $=1,63 \mathrm{E}+06$ & $2,68 \mathrm{E}+04$ & & & \\
\hline $\begin{array}{l}\text { variação } \\
\text { total }\end{array}$ & $\begin{array}{c}N-1 \\
(2 * 36-1)=\end{array}$ & 71 & SQtotal $=2,07 E+06$ & & & & \\
\hline
\end{tabular}

Tabela F.22 - Tabela da análise de variância da inclinação da curva de fluência, realizada com nível de significância de 0,05 , ou seja, confiança de $95 \%$, considerando-se o fator $A$ qualitativo, representando o volume de vazios

\begin{tabular}{|c|c|c|c|c|c|c|c|}
\hline $\begin{array}{l}\text { fonte de } \\
\text { variação }\end{array}$ & $\begin{array}{l}\text { graus de } \\
\text { liberdade } \\
\text { (GL) }\end{array}$ & & $\begin{array}{l}\text { soma de quadrados } \\
\qquad S Q=r L^{2} / 2^{n}\end{array}$ & $\begin{array}{c}\text { quadrado } \\
\text { médio } \\
\mathrm{QM}=\mathrm{SQ} / \mathrm{GL}\end{array}$ & $F_{0}=\frac{Q M \text { trat }}{\text { QMerro }}$ & $F_{0,05}$ & $\begin{array}{c}\text { significativo } \\
?\end{array}$ \\
\hline a1 & 1 & & $7,78 \mathrm{E}-03$ & $7,78 \mathrm{E}-03$ & 8,95 & 4,00 & $\operatorname{sim}$ \\
\hline a2 & 1 & & 2,84E-03 & 2,84E-03 & 3,27 & 4,00 & não \\
\hline B & 1 & & 1,89E-03 & 1,89E-03 & 2,18 & 4,00 & não \\
\hline C & 1 & & 2,20E-02 & 2,20E-02 & 25,37 & 4,00 & $\operatorname{sim}$ \\
\hline $\mathrm{X} 7$ & 1 & & 5,96E-04 & 5,96E-04 & 0,69 & 4,00 & não \\
\hline X8 & 1 & & 8,48E-04 & 8,48E-04 & 0,98 & 4,00 & não \\
\hline a1C & 1 & & $S Q$ a $1 C=$ & 1,42E-03 & 1,63 & 4,00 & não \\
\hline $\mathrm{a} 2 \mathrm{C}$ & 1 & & $\mathrm{SQ}$ a2C $=$ & 1,67E-03 & 1,93 & 4,00 & não \\
\hline a1X8 & 1 & & $S Q$ a $1 \times 8=$ & 4,52E-04 & 0,52 & 4,00 & não \\
\hline $\mathrm{a} 2 \times 8$ & 1 & & $\mathrm{SQ}$ a $2 \times 8=$ & $1,58 \mathrm{E}-03$ & 1,82 & 4,00 & não \\
\hline erro & $\begin{array}{c}N-m \\
71-10=\end{array}$ & 61 & SQerro = & 8,69E-04 & & & \\
\hline $\begin{array}{l}\text { variação } \\
\text { total }\end{array}$ & $\begin{array}{c}\mathrm{N}-1 \\
(2 * 36-1)=\end{array}$ & 71 & SQtotal $=9,43 \mathrm{E}-02$ & & & & \\
\hline
\end{tabular}


Tabelas da análise de variância (ANOVA) realizada com os resultados do ensaio de creep dinâmico

Tabela F.23 - Tabela da análise de variância da deformação total, realizada com nível de significância de 0,01 , ou seja, confiança de $99 \%$, considerando-se o fator $A$ quantitativo, representando o teor de ligante

\begin{tabular}{|c|c|c|c|c|c|c|c|}
\hline $\begin{array}{l}\text { fonte de } \\
\text { variação }\end{array}$ & $\begin{array}{l}\text { graus de } \\
\text { liberdade } \\
(\mathrm{GL})\end{array}$ & & $\begin{array}{l}\text { soma de quadrados } \\
\qquad S Q=r L^{2} / 2^{n}\end{array}$ & $\begin{array}{c}\text { quadrado } \\
\text { médio } \\
\mathrm{QM}=\mathrm{SQ} / \mathrm{GL}\end{array}$ & $F_{0}=\frac{Q M \text { trat }}{\text { QMerro }}$ & $F_{0,01}$ & $\begin{array}{c}\text { significativo } \\
?\end{array}$ \\
\hline$\overline{\mathrm{Al}}$ & 1 & & $\overline{\mathrm{SQ} A \mathrm{Al}}=7,01 \mathrm{E}-06$ & 7,01E-06 & 8,28 & 7,08 & $\operatorname{sim}$ \\
\hline $\mathrm{Aq}$ & 1 & & $S Q A q=5,43 E-08$ & $5,43 E-08$ & 0,06 & 7,08 & não \\
\hline$B$ & 1 & & $S Q B=2,28 E-05$ & 2,28E-05 & 26,93 & 7,08 & $\operatorname{sim}$ \\
\hline $\mathrm{C}$ & 1 & & $S Q C=1,56 E-05$ & $1,56 \mathrm{E}-05$ & 18,43 & 7,08 & sim \\
\hline X7 & 1 & & $S Q \times 7=1,10 E-05$ & $1,10 \mathrm{E}-05$ & 12,99 & 7,08 & $\operatorname{sim}$ \\
\hline $\mathrm{X} 8$ & 1 & & $S Q \times 8=9,49 E-06$ & $9,49 E-06$ & 11,21 & 7,08 & $\operatorname{sim}$ \\
\hline AIC & 1 & & $\mathrm{SQ} A I C=2,40 \mathrm{E}-06$ & $2,40 \mathrm{E}-06$ & 2,84 & 7,08 & não \\
\hline $\mathrm{AqC}$ & 1 & & $S Q A q C=1,34 \mathrm{E}-06$ & 1,34E-06 & 1,58 & 7,08 & não \\
\hline AIX8 & 1 & & $\mathrm{SQ}$ AIX $8=3,12 \mathrm{E}-06$ & $3,12 \mathrm{E}-06$ & 3,69 & 7,08 & não \\
\hline $\mathrm{Ag} \times 8$ & 1 & & $\mathrm{SQ} A q \times 8=1,23 \mathrm{E}-06$ & $1,23 E-06$ & 1,45 & 7,08 & não \\
\hline erro & $\begin{array}{c}\mathrm{N}-\mathrm{m} \\
71-10=\end{array}$ & 61 & SQerro $=5,16 \mathrm{E}-05$ & $8,47 E-07$ & & & \\
\hline $\begin{array}{l}\text { variação } \\
\text { total }\end{array}$ & $\begin{array}{c}\mathrm{N}-1 \\
(2 * 36-1)=\end{array}$ & 71 & SQtotal $=1,26 \mathrm{E}-04$ & 1,77E-06 & & & \\
\hline
\end{tabular}

Tabela F.24 - Tabela da análise de variância da deformação total, realizada com nível de significância de 0,05 , ou seja, confiança de $95 \%$, considerando-se o fator $A$ quantitativo, representando o teor de ligante

\begin{tabular}{|c|c|c|c|c|c|c|c|}
\hline $\begin{array}{l}\text { fonte de } \\
\text { variação }\end{array}$ & $\begin{array}{l}\text { graus de } \\
\text { liberdade } \\
\text { (GL) }\end{array}$ & & $\begin{array}{l}\text { soma de quadrados } \\
\qquad S Q=r L^{2} / 2^{n}\end{array}$ & $\begin{array}{c}\text { quadrado } \\
\text { médio } \\
\mathrm{QM}=\mathrm{SQ} / \mathrm{GL}\end{array}$ & $F_{0}=\frac{Q M \text { trat }}{\text { QMerro }}$ & $F_{0,05}$ & $\begin{array}{c}\text { significativo } \\
?\end{array}$ \\
\hline$\overline{\mathrm{Al}}$ & 1 & & $\mathrm{SQ} A \mathrm{Al}=7,01 \mathrm{E}-06$ & $7,01 \mathrm{E}-06$ & 8,28 & 4,00 & $\operatorname{sim}$ \\
\hline $\mathrm{Aq}$ & 1 & & $S Q A q=5,43 E-08$ & $5,43 E-08$ & 0,06 & 4,00 & não \\
\hline B & 1 & & $S Q B=2,28 E-05$ & 2,28E-05 & 26,93 & 4,00 & $\operatorname{sim}$ \\
\hline $\mathrm{C}$ & 1 & & $S Q C=1,56 E-05$ & 1,56E-05 & 18,43 & 4,00 & $\operatorname{sim}$ \\
\hline $\mathrm{X} 7$ & 1 & & $S Q \times 7=1,10 E-05$ & $1,10 \mathrm{E}-05$ & 12,99 & 4,00 & $\operatorname{sim}$ \\
\hline X8 & 1 & & $\mathrm{SQ} \times 8=9,49 \mathrm{E}-06$ & $9,49 E-06$ & 11,21 & 4,00 & $\operatorname{sim}$ \\
\hline $\mathrm{AIC}$ & 1 & & $\mathrm{SQ} A I C=2,40 \mathrm{E}-06$ & 2,40E-06 & 2,84 & 4,00 & não \\
\hline $\mathrm{AqC}$ & 1 & & $S Q A q C=1,34 \mathrm{E}-06$ & $1,34 \mathrm{E}-06$ & 1,58 & 4,00 & não \\
\hline AIX8 & 1 & & $\mathrm{SQ}$ AIX $8=3,12 \mathrm{E}-06$ & $3,12 \mathrm{E}-06$ & 3,69 & 4,00 & não \\
\hline $\mathrm{AqX8}$ & 1 & & $\mathrm{SQ} A q \times 8=1,23 \mathrm{E}-06$ & $1,23 \mathrm{E}-06$ & 1,45 & 4,00 & não \\
\hline$\overline{\text { erro }}$ & $\begin{array}{c}\mathrm{N}-\mathrm{m} \\
71-10=\end{array}$ & 61 & SQerro $=5,16 \mathrm{E}-05$ & $8,47 \mathrm{E}-07$ & & & \\
\hline $\begin{array}{l}\text { variação } \\
\text { total }\end{array}$ & $\begin{array}{c}N-1 \\
(2 * 36-1)=\end{array}$ & 71 & SQtotal $=1,26 \mathrm{E}-04$ & 1,77E-06 & & & \\
\hline
\end{tabular}


Tabela F.25 - Tabela da análise de variância do módulo de fluência, realizada com nível de significância de 0,01 , ou seja, confiança de $99 \%$, considerando-se o fator $A$ quantitativo, representando o teor de ligante

\begin{tabular}{|c|c|c|c|c|c|c|}
\hline $\begin{array}{l}\text { fonte de } \\
\text { variação }\end{array}$ & $\begin{array}{l}\text { graus de } \\
\text { liberdade } \\
\text { (GL) }\end{array}$ & $\begin{array}{l}\text { soma de quadrados } \\
\qquad S Q=r L^{2} / 2^{n}\end{array}$ & $\begin{array}{c}\text { quadrado } \\
\text { médio } \\
\mathrm{QM}=\mathrm{SQ} / \mathrm{GL}\end{array}$ & $F_{0}=\frac{Q M \text { trat }}{\text { QMerro }}$ & $F_{0,01}$ & $\begin{array}{c}\text { significativo } \\
?\end{array}$ \\
\hline$\overline{\mathrm{Al}}$ & 1 & $\mathrm{SQ} \mathrm{Al}=2,08 \mathrm{E}+03$ & $2,08 \mathrm{E}+03$ & 1,75 & 7,08 & não \\
\hline $\mathrm{Aq}$ & 1 & $\mathrm{SQAq}=1,97 \mathrm{E}+03$ & 1,97E+03 & 1,66 & 7,08 & não \\
\hline B & 1 & $S Q B=6,83 E+04$ & $6,83 E+04$ & 57,60 & 7,08 & $\operatorname{sim}$ \\
\hline C & 1 & $S Q C=3,24 E+04$ & $3,24 \mathrm{E}+04$ & 27,32 & 7,08 & $\operatorname{sim}$ \\
\hline$X 7$ & 1 & $\mathrm{SQ} \times 7=1,48 \mathrm{E}+04$ & $1,48 E+04$ & 12,53 & 7,08 & $\operatorname{sim}$ \\
\hline X8 & 1 & $\mathrm{SQ} \times 8=1,25 \mathrm{E}+03$ & $1,25 E+03$ & 1,05 & 7,08 & não \\
\hline AIC & 1 & $\mathrm{SQ} A I C=1,37 \mathrm{E}+03$ & 1,37E+03 & 1,16 & 7,08 & não \\
\hline $\mathrm{AqC}$ & 1 & $S Q A q C=3,26 E+03$ & $3,26 E+03$ & 2,75 & 7,08 & não \\
\hline AIX8 & 1 & $\mathrm{SQ}$ AIX8 = 7,47E+02 & $7,47 E+02$ & 0,63 & 7,08 & não \\
\hline $\mathrm{Aq} \times 8$ & 1 & $\mathrm{SQ} A q \times 8=2,06 \mathrm{E}+02$ & $2,06 \mathrm{E}+02$ & 0,17 & 7,08 & não \\
\hline erro & $\begin{array}{c}\mathrm{N}-\mathrm{m} \\
71-10=\end{array}$ & SQerro = 7,23E +04 & $1,19 E+03$ & & & \\
\hline $\begin{array}{l}\text { variação } \\
\text { total }\end{array}$ & $\begin{array}{c}\mathrm{N}-1 \\
(2 * 36-1)=\end{array}$ & SQtotal $=1,99 \mathrm{E}+05$ & $2,80 \mathrm{E}+03$ & & & \\
\hline
\end{tabular}

Tabela F.26 - Tabela da análise de variância do módulo de fluência, realizada com nível de significância de 0,05 , ou seja, confiança de $95 \%$, considerando-se o fator $A$ quantitativo, representando o teor de ligante

\begin{tabular}{|c|c|c|c|c|c|c|c|}
\hline $\begin{array}{l}\text { fonte de } \\
\text { variação }\end{array}$ & $\begin{array}{l}\text { graus de } \\
\text { liberdade } \\
(\mathrm{GL})\end{array}$ & & $\begin{array}{c}\text { soma de quadrados } \\
S Q=r L^{2} / 2^{n}\end{array}$ & $\begin{array}{c}\text { quadrado } \\
\text { médio } \\
Q M=S Q / G L\end{array}$ & $F_{0}=\frac{\text { QMtrat }}{\text { QMerro }}$ & $F_{0,05}$ & $\begin{array}{c}\text { significativo } \\
?\end{array}$ \\
\hline$\overline{\mathrm{Al}}$ & 1 & & $\mathrm{SQAI}=2,08 \mathrm{E}+03$ & $2,08 \mathrm{E}+03$ & 1,75 & 4,00 & não \\
\hline $\mathrm{Aq}$ & 1 & & $\mathrm{SQAq}=1,97 \mathrm{E}+03$ & $1,97 \mathrm{E}+03$ & 1,66 & 4,00 & não \\
\hline$B$ & 1 & & $S Q B=6,83 E+04$ & $6,83 E+04$ & 57,60 & 4,00 & $\operatorname{sim}$ \\
\hline C & 1 & & $S Q C=3,24 E+04$ & $3,24 \mathrm{E}+04$ & 27,32 & 4,00 & $\operatorname{sim}$ \\
\hline $\mathrm{X} 7$ & 1 & & $\mathrm{SQ} \times 7=1,48 \mathrm{E}+04$ & $1,48 \mathrm{E}+04$ & 12,53 & 4,00 & $\operatorname{sim}$ \\
\hline X8 & 1 & & $\mathrm{SQ} \times 8=1,25 \mathrm{E}+03$ & $1,25 E+03$ & 1,05 & 4,00 & não \\
\hline AIC & 1 & & $\mathrm{SQ} A I C=1,37 \mathrm{E}+03$ & $1,37 \mathrm{E}+03$ & 1,16 & 4,00 & não \\
\hline $\mathrm{AqC}$ & 1 & & $S Q A q C=3,26 E+03$ & $3,26 \mathrm{E}+03$ & 2,75 & 4,00 & não \\
\hline AIX8 & 1 & & $\mathrm{SQ}$ AIX8 $=7,47 \mathrm{E}+02$ & $7,47 \mathrm{E}+02$ & 0,63 & 4,00 & não \\
\hline $\mathrm{Ag} \times 8$ & 1 & & $S Q A q X 8=2,06 E+02$ & $2,06 \mathrm{E}+02$ & 0,17 & 4,00 & não \\
\hline erro & $\begin{array}{c}\mathrm{N}-\mathrm{m} \\
71-10=\end{array}$ & 61 & SQerro $=7,23 \mathrm{E}+04$ & $1,19 \mathrm{E}+03$ & & & \\
\hline $\begin{array}{l}\text { variação } \\
\text { total }\end{array}$ & $\begin{array}{c}N-1 \\
(2 * 36-1)=\end{array}$ & 71 & SQtotal $=1,99 \mathrm{E}+05$ & $2,80 \mathrm{E}+03$ & & & \\
\hline
\end{tabular}

Tabela F.27 - Tabela da análise de variância da inclinação, realizada com nível de significância de 0,01 , ou seja, confiança de $99 \%$, considerando-se o fator $A$ quantitativo, representando o teor de ligante

\begin{tabular}{|c|c|c|c|c|c|c|c|}
\hline $\begin{array}{l}\text { fonte de } \\
\text { variação }\end{array}$ & $\begin{array}{l}\text { graus de } \\
\text { liberdade } \\
\text { (GL) }\end{array}$ & & $\begin{array}{l}\text { soma de quadrados } \\
\qquad S Q=r L^{2} / 2^{n}\end{array}$ & $\begin{array}{c}\text { quadrado } \\
\text { médio } \\
\mathrm{QM}=\mathrm{SQ} / \mathrm{GL}\end{array}$ & $F_{0}=\frac{Q M \text { trat }}{\text { QMerro }}$ & $F_{0,01}$ & $\begin{array}{c}\text { significativo } \\
?\end{array}$ \\
\hline $\mathrm{Al}$ & 1 & & 1,20E-02 & 1,20E-02 & 6,40 & 7,08 & não \\
\hline $\mathrm{Aq}$ & 1 & & $\mathrm{SQAq}=6,90 \mathrm{E}-03$ & 6,90E-03 & 3,68 & 7,08 & não \\
\hline B & 1 & & $S Q B=2,90 E-03$ & 2,90E-03 & 1,55 & 7,08 & não \\
\hline $\mathrm{C}$ & 1 & & $\mathrm{SQ} C=3,82 \mathrm{E}-02$ & 3,82E-02 & 20,38 & 7,08 & $\operatorname{sim}$ \\
\hline$X 7$ & 1 & & $\mathrm{SQ} \times 7=1,37 \mathrm{E}-02$ & 1,37E-02 & 7,31 & 7,08 & $\operatorname{sim}$ \\
\hline X8 & 1 & & $\mathrm{SQ} \times 8=1,51 \mathrm{E}-02$ & 1,51E-02 & 8,06 & 7,08 & $\operatorname{sim}$ \\
\hline AIC & 1 & & $\mathrm{SQ} A I C=5,17 \mathrm{E}-04$ & 5,17E-04 & 0,28 & 7,08 & não \\
\hline $\mathrm{AqC}$ & 1 & & $\mathrm{SQ} A q C=8,19 \mathrm{E}-04$ & 8,19E-04 & 0,44 & 7,08 & não \\
\hline AIX8 & 1 & & SQ AIX8 = 2,22E-04 & 2,22E-04 & 0,12 & 7,08 & não \\
\hline $\mathrm{Aq} \times 8$ & 1 & & $\mathrm{SQ} A q \times 8=1,67 \mathrm{E}-03$ & 1,67E-03 & 0,89 & 7,08 & não \\
\hline erro & $\begin{array}{c}\mathrm{N}-\mathrm{m} \\
71-10=\end{array}$ & 61 & SQerro = 1,14E-01 & 1,87E-03 & & & \\
\hline $\begin{array}{l}\text { variação } \\
\text { total }\end{array}$ & $\begin{array}{c}N-1 \\
(2 * 36-1)=\end{array}$ & 71 & SQtotal $=2,06 \mathrm{E}-01$ & 2,91E-03 & & & \\
\hline
\end{tabular}


Tabela F.28 - Tabela da análise de variância da inclinação, realizada com nível de significância de 0,05 , ou seja, confiança de $95 \%$, considerando-se o fator $A$ quantitativo, representando o teor de ligante

\begin{tabular}{|c|c|c|c|c|c|c|c|}
\hline $\begin{array}{l}\text { fonte de } \\
\text { variação }\end{array}$ & $\begin{array}{l}\text { graus de } \\
\text { liberdade } \\
\text { (GL) }\end{array}$ & & $\begin{array}{l}\text { soma de quadrados } \\
\qquad S Q=r L^{2} / 2^{n}\end{array}$ & $\begin{array}{c}\text { quadrado } \\
\text { médio } \\
\mathrm{QM}=\mathrm{SQ} / \mathrm{GL}\end{array}$ & $F_{0}=\frac{Q M \text { trat }}{\text { QMerro }}$ & $F_{0,05}$ & $\begin{array}{c}\text { significativo } \\
?\end{array}$ \\
\hline$\overline{\mathrm{Al}}$ & 1 & & $\mathrm{SQ} A \mathrm{~A}=1,20 \mathrm{E}-02$ & $1,20 \mathrm{E}-02$ & 6,40 & 4,00 & $\operatorname{sim}$ \\
\hline $\mathrm{Aq}$ & 1 & & $S Q A q=6,90 E-03$ & $6,90 \mathrm{E}-03$ & 3,68 & 4,00 & não \\
\hline B & 1 & & $S Q B=2,90 E-03$ & $2,90 \mathrm{E}-03$ & 1,55 & 4,00 & não \\
\hline C & 1 & & $S Q C=3,82 E-02$ & $3,82 \mathrm{E}-02$ & 20,38 & 4,00 & $\operatorname{sim}$ \\
\hline $\mathrm{X} 7$ & 1 & & $S Q \times 7=1,37 E-02$ & 1,37E-02 & 7,31 & 4,00 & $\operatorname{sim}$ \\
\hline $\mathrm{x} 8$ & 1 & & $S Q \times 8=1,51 E-02$ & $1,51 \mathrm{E}-02$ & 8,06 & 4,00 & $\operatorname{sim}$ \\
\hline AIC & 1 & & $S Q A I C=5,17 E-04$ & 5,17E-04 & 0,28 & 4,00 & não \\
\hline $\mathrm{AqC}$ & 1 & & $S Q A q C=8,19 E-04$ & $8,19 E-04$ & 0,44 & 4,00 & não \\
\hline AIX8 & 1 & & $\mathrm{SQ}$ AIX8 $=2,22 \mathrm{E}-04$ & 2,22E-04 & 0,12 & 4,00 & não \\
\hline $\mathrm{Aq} \times 8$ & 1 & & $\mathrm{SQ} A q \times 8=1,67 \mathrm{E}-03$ & 1,67E-03 & 0,89 & 4,00 & não \\
\hline erro & $\begin{array}{c}\mathrm{N}-\mathrm{m} \\
71-10=\end{array}$ & 61 & SQerro $=1,14 \mathrm{E}-01$ & 1,87E-03 & & & \\
\hline $\begin{array}{l}\text { variação } \\
\text { total }\end{array}$ & $\begin{array}{c}N-1 \\
(2 * 36-1)=\end{array}$ & 71 & SQtotal $=2,06 \mathrm{E}-01$ & $2,91 \mathrm{E}-03$ & & & \\
\hline
\end{tabular}

Tabela F.29 - Tabela da análise de variância da deformação total, realizada com níveis de significância de 0,01 ou 0,05 , ou seja, graus de confiança de $99 \%$ ou $95 \%$, considerando-se o fator $A$ qualitativo, representando o volume de vazios

\begin{tabular}{|c|c|c|c|c|c|c|c|}
\hline $\begin{array}{l}\text { fonte de } \\
\text { variação }\end{array}$ & $\begin{array}{c}\text { graus de } \\
\text { liberdade } \\
(G L)\end{array}$ & & $\begin{array}{l}\text { soma de quadrados } \\
\qquad S Q=r L^{2} / 2^{n}\end{array}$ & $\begin{array}{c}\text { quadrado } \\
\text { médio } \\
\mathrm{QM}=\mathrm{SQ} / \mathrm{GL}\end{array}$ & $F_{0}=\frac{Q M \text { trat }}{\text { QMerro }}$ & $F_{0,05}$ & $\begin{array}{c}\text { significativo } \\
?\end{array}$ \\
\hline a1 & 1 & & $3,41 \mathrm{E}-07$ & $3,41 \mathrm{E}-07$ & 0,41 & 4,00 & não \\
\hline a2 & 1 & & 7,01E-06 & 7,01E-06 & 8,48 & 4,00 & $\operatorname{sim}$ \\
\hline$B$ & 1 & & $2,28 E-05$ & $2,28 \mathrm{E}-05$ & 27,54 & 4,00 & $\operatorname{sim}$ \\
\hline $\mathrm{C}$ & 1 & & $1,56 \mathrm{E}-05$ & $1,56 \mathrm{E}-05$ & 18,90 & 4,00 & $\operatorname{sim}$ \\
\hline X7 & 1 & & $1,29 E-05$ & $1,29 E-05$ & 15,66 & 4,00 & $\operatorname{sim}$ \\
\hline X8 & 1 & & 9,49E-06 & 9,49E-06 & 11,48 & 4,00 & $\operatorname{sim}$ \\
\hline a1C & 1 & & $S Q$ a $1 C=$ & $1,45 E-08$ & 0,02 & 4,00 & não \\
\hline a2C & 1 & & $\mathrm{SQ}$ a2C $=$ & $3,01 \mathrm{E}-06$ & 3,64 & 4,00 & não \\
\hline a1X8 & 1 & & $\mathrm{SQ}$ a $1 \times 8=$ & $3,12 \mathrm{E}-06$ & 3,78 & 4,00 & não \\
\hline a2X8 & 1 & & $\mathrm{SQ}$ a $2 \times 8=$ & $1,23 E-06$ & 1,48 & 4,00 & não \\
\hline erro & $\begin{array}{c}\mathrm{N}-\mathrm{m} \\
71-10=\end{array}$ & 61 & SQerro = & $8,27 E-07$ & & & \\
\hline $\begin{array}{l}\text { variação } \\
\text { total }\end{array}$ & $\begin{array}{c}N-1 \\
(2 * 36-1)=\end{array}$ & 71 & SQtotal $=1,26 \mathrm{E}-04$ & 1,77E-06 & & & \\
\hline
\end{tabular}

Tabela F.30 - Tabela da análise de variância do módulo de fluência, realizada com níveis de significância de 0,01 ou 0,05 , ou seja, graus de confiança de $99 \%$ ou $95 \%$, considerando-se o fator $A$ qualitativo, representando o volume de vazios

\begin{tabular}{|c|c|c|c|c|c|c|c|}
\hline $\begin{array}{l}\text { fonte de } \\
\text { variação }\end{array}$ & $\begin{array}{l}\text { graus de } \\
\text { liberdade } \\
\text { (GL) }\end{array}$ & & $\begin{array}{l}\text { soma de quadrados } \\
\qquad S Q=r L^{2} / 2^{n}\end{array}$ & $\begin{array}{c}\text { quadrado } \\
\text { médio } \\
\mathrm{QM}=\mathrm{SQ} / \mathrm{GL}\end{array}$ & $F_{0}=\frac{Q M \text { trat }}{\text { QMerro }}$ & $F_{0,05}$ & $\begin{array}{c}\text { significativo } \\
?\end{array}$ \\
\hline$\overline{a 1}$ & 1 & & $2,48 \mathrm{E}+01$ & $2,48 \mathrm{E}+01$ & 0,01 & 4,00 & não \\
\hline a2 & 1 & & $3,28 \mathrm{E}+03$ & $3,28 E+03$ & 1,69 & 4,00 & não \\
\hline B & 1 & & $3,27 E+04$ & $3,27 \mathrm{E}+04$ & 16,83 & 4,00 & $\operatorname{sim}$ \\
\hline C & 1 & & $1,95 E+04$ & $1,95 \mathrm{E}+04$ & 10,01 & 4,00 & $\operatorname{sim}$ \\
\hline X7 & 1 & & $1,44 \mathrm{E}+04$ & $1,44 \mathrm{E}+04$ & 7,43 & 4,00 & sim \\
\hline X8 & 1 & & $3,46 \mathrm{E}+03$ & $3,46 \mathrm{E}+03$ & 1,78 & 4,00 & não \\
\hline a1C & 1 & & $S Q$ a $1 \mathrm{C}=$ & $1,37 E+03$ & 0,70 & 4,00 & não \\
\hline a2C & 1 & & $\mathrm{SQ}$ a2C $=$ & $3,26 \mathrm{E}+03$ & 1,68 & 4,00 & não \\
\hline a1X8 & 1 & & $\mathrm{SQ}$ a $1 \times 8=$ & $1,92 E+03$ & 0,99 & 4,00 & não \\
\hline a2X8 & 1 & & $S Q$ a $2 \times 8=$ & $7,61 \mathrm{E}+01$ & 0,04 & 4,00 & não \\
\hline erro & $\begin{array}{c}\mathrm{N}-\mathrm{m} \\
71-10=\end{array}$ & 61 & SQerro $=1,19 \mathrm{E}+05$ & $1,94 \mathrm{E}+03$ & & & \\
\hline $\begin{array}{l}\text { variação } \\
\text { total }\end{array}$ & $\begin{array}{c}N-1 \\
(2 * 36-1)=\end{array}$ & 71 & SQtotal $=1,99 \mathrm{E}+05$ & $2,80 \mathrm{E}+03$ & & & \\
\hline
\end{tabular}


Tabela F.31 - Tabela da análise de variância da inclinação, realizada com níveis de significância de 0,01 ou 0,05 , ou seja, graus de confiança de $99 \%$ ou $95 \%$, considerando-se o fator $A$ qualitativo, representando o volume de vazios

\begin{tabular}{|c|c|c|c|c|c|c|c|}
\hline $\begin{array}{l}\text { fonte de } \\
\text { variação }\end{array}$ & $\begin{array}{l}\text { graus de } \\
\text { liberdade } \\
\text { (GL) }\end{array}$ & & $\begin{array}{l}\text { soma de quadrados } \\
\qquad S Q=r L^{2} / 2^{n}\end{array}$ & $\begin{array}{c}\text { quadrado } \\
\text { médio } \\
\mathrm{QM}=\mathrm{SQ} / \mathrm{GL}\end{array}$ & $F_{0}=\frac{\text { QMtrat }}{\text { QMerro }}$ & $F_{0,05}$ & $\begin{array}{c}\text { significativo } \\
?\end{array}$ \\
\hline a1 & 1 & & $1,32 \mathrm{E}-02$ & 1,32E-02 & 8,46 & 4,00 & $\operatorname{sim}$ \\
\hline a2 & 1 & & 1,80E-02 & $1,80 \mathrm{E}-02$ & 11,48 & 4,00 & $\operatorname{sim}$ \\
\hline$B$ & 1 & & $6,22 E-03$ & $6,22 \mathrm{E}-03$ & 3,98 & 4,00 & não \\
\hline C & 1 & & 2,60E-02 & $2,60 \mathrm{E}-02$ & 16,65 & 4,00 & $\operatorname{sim}$ \\
\hline X7 & 1 & & 2,36E-02 & 2,36E-02 & 15,08 & 4,00 & $\operatorname{sim}$ \\
\hline X8 & 1 & & $1,51 \mathrm{E}-02$ & $1,51 \mathrm{E}-02$ & 9,67 & 4,00 & $\operatorname{sim}$ \\
\hline a1C & 1 & & $\mathrm{SQ}$ a $1 \mathrm{C}=$ & 3,83E-03 & 2,45 & 4,00 & não \\
\hline a2C & 1 & & $\mathrm{SQ}$ a2C = & 6,39E-04 & 0,41 & 4,00 & não \\
\hline a1X8 & 1 & & $\mathrm{SQ}$ a $1 \times 8=$ & $2,38 \mathrm{E}-03$ & 1,52 & 4,00 & não \\
\hline a2X8 & 1 & & $\mathrm{SQ}$ a $2 \times 8=$ & 1,27E-03 & 0,81 & 4,00 & não \\
\hline erro & $\begin{array}{c}N-m \\
71-10=\end{array}$ & 61 & SQerro = & $1,56 \mathrm{E}-03$ & & & \\
\hline $\begin{array}{l}\text { variação } \\
\text { total }\end{array}$ & $\begin{array}{c}N-1 \\
(2 * 36-1)=\end{array}$ & 71 & $2,06 \mathrm{E}-01$ & $2,91 \mathrm{E}-03$ & & & \\
\hline
\end{tabular}

